\section{НОВАЯ НАУКА}

Международный центр научного партнерства
NEW SCIENCE

International Center for Scientific Partnership

\title{
ЧЕЛОВЕК И СОВРЕМЕННОЕ ОБЩЕСТВО В СОЦИАЛЬНОМ, ПРАВОВОМ, ЭКОНОМИЧЕСКОМ РАКУРСАХ
}

Монография

г. Петрозаводск

МЦНП «Новая наука»

2022 
УДК 001.12

ББК 70

Ч39

Рекомендовано к публикации редакционной коллегией МЦНП «Новая наука»

\section{Рецензенты :}

Ершова Л. В.

доктор педагогических наук

ФГБОУ ВО «Ивановский государственный университет»

Панков Д. А.

доктор экономических наук

Белорусский государственный экономический университет

\section{Коллектив авторов:}

Адмаев О.В., Арсеньев Ю.Н., Барцаева Е.В., Березина Е.С., Богданов И.В., Большаков С.Н., Гидзинский Е.В., Горшкова В.В., Грязнова Е.Р., Давыдова Т.Ю., Иванов И.В., Катаева Л.Ю., Киворкова А.Ю., Ким О.Л., Корзун О.О., Миляева Л.Г., Неволина В.В., Низамбиева И.И., Осокина Ю.Ю., Разумовская Т.И., Рябышева В.В., Сабитова А.М., Савкина Е.А., Скорев В.А., Скорева В.В., Соловьев А.Г., Сухарева Е.В., Талалаева Г.В., Ушакова Н.В.

ЧЕЛОВЕК И СОВРЕМЕННОЕ ОБЩЕСТВО В СОЦИАЛЬНОМ, ПРАВОВОМ, ЭКОНОМИЧЕСКОМ РАКУРСАХ : монография / [Адмаев О. В. и др.]. - Петрозаводск : МЦНП «Новая наука», 2022. - 492 с. : ил. - Коллектив авторов.

ISBN 978-5-00174-447-4

В монографии рассматриваются актуальные вопросы, стоящие перед современными исследователями, предлагаются оригинальные решения научно-методических, технологических и практических вопросов. Издание может быть полезно научным работникам, специалистам-практикам, преподавателям всех уровней образования, интересующимся проблемами развития современной науки и образования.

Авторы публикуемых материалов несут ответственность за содержание своих работ, точность цитат, легитимность использования иллюстраций, приведенных цифр, фактов, названий, персональных данных и иной информации, а также за соблюдение законодательства Российской Федерации и сам факт публикации.

Полные тексты статей в открытом доступе размещены в Научной электронной библиотеке Elibrary.ru в соответствии с Договором № 467-03/2018K от 19.03.2018 г.

ISBN 978-5-00174-447-4 


\section{ОГЛАВЛЕНИЕ}

\section{РАЗДЕЛ І. ТЕНДЕНЦИИ РАЗВИТИЯ}

СОВРЕМЕННОГО ОБРАЗОВАНИЯ.

ГЛава 1. ЦИФРОВИЗАЦИЯ ОБУЧЕНИЯ: РИСКИ,

ПРОБЛЕМЫ, ТЕНДЕНЦИИ

Ушакова Надежда Владимировна

ГЛава 2. СТАНОВЛЕНИЕ ПРОФЕССИОНАЛЬНОЙ

ПОЗИЦИИ СТУДЕНТА

Неволина Виктория Васильевна

ГЛава 3. ИНТЕГРАЦИЯ ПЕДАГОГИЧЕСКОГО И КАДРОВОГО АУДИТА

ПРИ ОЦЕНКЕ УРОВНЯ ПРОФЕССИОНАЛИЗМА ПЕДАГОГОВ 48

Березина Екатерина Сергеевна, Грязнова Елена Роландовна

ГЛава 4. ОСОБЕННОСТИ ПРЕПОДАВАНИЯ ПРЕДМЕТА

«МАТЕМАТИЧЕСКОЕ МОДЕЛИРОВАНИЕ» В ТРАНСПОРТНОМ ВУЗЕ .... 65

Катаева Лилия Юрьевна

ГЛава 5. ФОРМИРОВАНИЕ ИССЛЕДОВАТЕЛЬСКОЙ КОМПЕТЕНЦИИ

СТУДЕНТОВ - БУДУЩИХ УЧИТЕЛЕЙ АНГЛИЙСКОГО ЯЗЫКА:

ОТ ТЕОРИИ К ПРАКТИКЕ

Корзун Оксана Олеговна, Савкина Екатерина Александровна

ГЛава 6. ОСОБЕННОСТИ ПСИХОФИЗИЧЕСКОГО СОСТОЯНИЯ

СОВРЕМЕННОЙ МОЛОДЁЖИ В УСЛОВИЯХ СЕВЕРНЫХ

ШИРОТ РОССИИ

Богданов Иван Викторович, Горшкова Валентина Владимировна

ГЛава 7. ОСОБЕННОСТИ РАЗВИТИЯ ЗВУКОПРОИЗНОСИТЕЛЬНЫХ

УМЕНИЙ У МЛАДШИХ ШКОЛЬНИКОВ С ОБЩИМ

НЕДОРАЗВИТИЕМ РЕЧИ.

Бариаева Елена Васильевна, Рябышева Валерия Вячеславовна

ГЛава 8. ТРАДИЦИОННЫЕ И ИННОВАЦИОННЫЕ СПОСОБЫ

ЯЗЫКОВОЙ ОЦЕНКИ В ПРОИЗВЕДЕНИЯХ ДЕТСКИХ

ПИСАТЕЛЕЙ НА УРОКАХ ЛИТЕРАТУРЫ

Сабитова А.М., Низамбиева И.И.

РАЗДЕЛ ІІ. ЧЕЛОВЕК И СОВРЕМЕННОЕ ОБЩЕСТВО

В ЭКОНОМИЧЕСКОМ РАКУРСЕ

Глава 9. КОНКУРЕНТОСПОСОБНОСТЬ ЭКОНОМИКИ И АНАЛИЗ

ТОРГОВОЙ ПОЛИТИКИ В РЕГИОНАХ СЕВЕРО-ЗАПАДНОГО

ФЕДЕРАЛЬНОГО ОКРУГА

Большаков Сергей Николаевич

ГЛава 10. АНАЛИЗ КОНКУРЕНТОСПОСОБНОСТИ ЭКОНОМИКИ И ДИНАМИКИ ЦЕН НА РЕГИОНАЛЬНЫХ РЫНКАХ.

Ким Ольга Леонидовна 
ГЛАВа 11. ТЕОРЕТИЧЕСКИЕ И ПРИКЛАДНЫЕ АСПЕКТЫ РАЗРАБОТКИ И ВНЕДРЕНИЯ МОТИВАЦИОННОЙ МОДЕЛИ УПРАВЛЕНИЯ ПОВЕДЕНИЕМ ПЕРСОНАЛА ПРЕДПРИЯТИЯ 271

Миляева Лариса Григорьевна

ГЛава 12. УПРАВЛЕНИЕ ДЕЯТЕЛЬНОСТЬЮ СУБЬЕКТА С УЧЕТОМ ФУНКЦИОНАЛЬНЫХ И СТРУКТУРНЫХ КРИТЕРИЕВ . 292

Арсеньев Юрий Николаевич, Разумовская Татьяна Ивановна,

Давыдова Татьяна Юрьевна

ГЛава 13. МЕТОДЫ АНАЛИЗА ФИНАНСОВО-ХОЗЯЙСТВЕННОЙ ДЕЯТЕЛЬНОСТИ КОМПАНИИ.

Сухарева Евгения Викторовна

Глава 14. ЭКОНОМИЧЕСКОЕ ОБОСНОВАНИЕ

СОЦИАЛЬНОГО ПРОЕКТА «ПЛАТНЫЕ ПАРКОВКИ»

Адмаев Олег Васильевич, Гидзинский Евгений Витальевич

РАЗДЕЛ ІІІ. АКТУАЛЬНЫЕ ВОПРОСЫ ВЗАИМОДЕЙСТВИЯ ЧЕЛОВЕКА, ОБЩЕСТВА И ГОСУДАРСТВА

ГЛава 15. ПРОГРАММА ПЕРСОНИФИЦИРОВАННОГО

МЕНЕДЖМЕНТА В ПСИХОЛОГИЧЕСКОЙ РЕАБИЛИТАЦИИ

ЧЛЕНОВ СЕМЕЙ ЛИЦ ОПАСНЫХ ПРОФЕССИЙ 362

Киворкова Александра Юрьевна, Соловьев Андрей Горгоньевич

ГЛава 16. АКТУАЛЬНЫЕ ВОПРОСЫ СОЗДАНИЯ БАЗ ДАННЫХ

О БЕЗОПАСНОМ ПОВЕДЕНИИ ЛЮДЕЙ В ЭКСТРЕМАЛЬНЫХ

УСЛОВИЯХ И ЧРЕЗВЫЧАЙНЫХ СИТУАЦИЯХ.

Талалаева Галина Владленовна, Иванов Игорь Владимирович

ГЛава 17. НАПРАВЛЕНИЯ ОБЕСПЕЧЕНИЯ КОНСТИТУЦИОННЫХ

ПРАВ ГРАЖДАН ПРИ ПРИМЕНЕНИИ ИНСТИТУТА

АДМИНИСТРАТИВНОЙ ПРЕЮДИЦИИ 462

Скорев Василий Александрович, Скорева Валерия Васильевна

ГЛава 18. СОВЕТСКАЯ МОДЕЛЬ СОЦИАЛЬНОГО ГОСУДАРСТВА:

СУЩНОСТЬ, ОСНОВНЫЕ ЭТАПЫ СТАНОВЛЕНИЯ 478

Осокина Юлия Юрьевна 
РАЗДЕЛ I.

ТЕНДЕНЦИИ РАЗВИТИЯ СОВРЕМЕННОГО ОБРАЗОВАНИЯ

УДК 37.091:004

\title{
Глава 1.
}

ЦИФРОВИЗАЦИЯ ОБУЧЕНИЯ: РИСКИ, ПРОБЛЕМЫ, ТЕНДЕНЦИИ

\section{Ушакова Надежда Владимировна}

к.э.н., доцент

\begin{abstract}
Аннотация: В статье изучены изменения, произошедшие в отношении к дистанционному обучению в среде преподавателей, исследовано современное состояние рынка дистанционных образовательных услуг. Разработана концепция дальнейшего развития цифровизации обучения в Тульском госуниверситете с предоставлением студентам возможности получения дополнительной профессиональной квалификации «Цифровой куратор».

Ключевые слова: онлайн-образование, цифровизация, онлайн-курс, дистанционное обучение, пандемия коронавируса.
\end{abstract}

\section{PROSPECTS AND RISKS OF DIGITALIZATION OF EDUCATION}

\section{Ushakova Nadezhda Vladimirovna}

Abstract: The changes that have occurred in relation to distance learning among teachers have been studied, the current state of the market of distance education services has been investigated. The concept of further development of digitalization of education at Tula State University with the provision of students 
with the opportunity to obtain additional professional qualifications "Digital curator" has been developed.

Key words: online education, digitalization, online course, distance learning, coronavirus pandemic.

\section{1 Обзор рынка дистанционного обучения}

Новые информационные технологии активно проникают во все сферы деятельности, в том числе в сферу образования. Причем трансформируются не только его технологии, но и содержание обучения, поскольку общей и новой задачей всех форм обучения является подготовка населения к жизни и профессиональной деятельности в цифровой среде.

Онлайн-образование в России является активно развивающимся рынком с прогнозируемым ростом в 15-20\% в год. Ведущие IT-компании вкладывают миллионные инвестиции в данную сферу.

В 2001 году Массачусетский технологический институт выложил часть своих учебных курсов в открытый доступ. Его примеру последовало множество других высших учебных заведений, обозначив тренд на развитие онлайн образования. В 2008 году появился термин MOOC (Massive open online course), обозначающий онлайн курс с возможностью бесплатной и открытой регистрации. МООС основаны на вовлечении учащихся, предпочитающих самостоятельно организовывать свой учебный процесс в соответствии с целями обучения, знаниями, навыками и интересами [1, с. 4]. На сегодняшний день наиболее развитой международной платформой, предоставляющей онлайн-курсы, является Coursera, она сотрудничает со 149 известными мировыми университетами.

По итогам 2019 года мировой рынок онлайн-образования оценивался в \$205 млрд, согласно Global Market Insights. По прогнозам разных 
исследовательских агентств, к 2023 году он достигнет \$282,62 млрд при ожидаемом среднегодовом темпе прироста 7-10\%.

Российский рынок онлайн образования сравнительно молод, однако в темпах роста не уступает мировому и даже обгоняет его. Его представляют как коммерчески ориентированные компании, поставщики онлайн-услуг, так и платформы МООС. Согласно исследованию сервиса CourseBurg, в 2017 году Россия вошла в пятёрку стран, активно использующих онлайн-платформы как форму обучения. Однако явным лидером оказались США, существенно обгоняя все страны мира [2, с. 93]. По оценкам EdMarket.Digital, «по итогам 2019 года объём российского b2c-рынка онлайн-образования достиг 38,5 млрд руб. при среднегодовых темпах роста на уровне 20\%» [3, с. 40].

В России лидирующие позиции среди МООС платформ также занимает Coursera, задающая тренды онлайн-самообразования для всего мира. На данную платформу приходится более половины трафика среди МООС. К другим крупным МООС в России относятся платформы «Открытое образование», «Лекториум», «ЕdX», «Универсариум».

В последние годы среди IT-компании явно заметен тренд на вложение средств в EdTech-проекты. К 2020 году наиболее развитые из них уже обзавелись своими онлайн-школами, направленными в основном на получение актуальных digital-профессий (веб-разработка, веб-дизайн, интернет-маркетинг и др). В 2019 году Mail group, владеющая образовательным порталом Geekbrains, купила контрольный пакет акций Skillbox. Яндекс, в структуру которого входят Яндекс.Практикум и Яндекс.Школа, объявил о том, что в период с 2020 по 2023 годы планирует вложить в EdTech-проекты до 5 млрд руб [4]. А фонд Skolkovo Digital совместно с другими инвесторами вложили в платформу Maximum Education 390 млн руб. 


\section{ЧЕЛОВЕК И СОВРЕМЕННОЕ ОБЩЕСТВО В СОЦИАЛЬНОМ, ПРАВОВОМ, ЭКОНОМИЧЕСКОМ РАКУРСАХ}

Большие сдвиги в технологическом процессе происходят во время серьезных социальных, экономических, политических, экологических потрясений, когда возрастает необходимость в технологических изменениях. В 2020 году пандемия коронавируса стала серьёзным вызовом для всех сфер общественной жизни, особенно для образования, которое было вынуждено быстро переходить на онлайн-формат. Рынок образовательных онлайн-услуг один из немногих, который только выиграл от введения карантинных мер весной 2020 года. Из-за карантина произошло возрастание спроса на образовательные онлайн-курсы, что объясняется увеличением свободного времени у населения и вынужденным проведением учебы и досуга в домашних условиях. Среди онлайн-платформ обострилась конкуренция за аудиторию, в основном компании привлекали клиентов бесплатным контентом. После прохождения временно открытых курсов новые пользователи успешно конвертировались в постоянных покупателей.

Названы топ-50 крупнейших игроков на российском рынке онлайнобразования в 2020 году [4]. Суммарная выручка EdTech-компаний в 2020 году выросла почти в два раза по сравнению с аналогичным периодом прошлого года. В 2020 г. компании из списка топ-50 заработали примерно 25 млрд руб. Исходя из прогнозируемой оценки в 55-60 млрд руб., топ-50 занимает около половины EdTech-рынка. Быстрее остальных растут ресурсы, обучающие цифровым профессиям. Первые два места занимают Skillbox и Geekbrains. На третьем месте SkyEng, на четвертом — «Нетология-групп».

Несмотря на то, что большая часть образовательного контента направлена на взрослую аудиторию (45\% по данным опроса «Барометр онлайн-образования» $[1, \mathrm{c.18}])$, доля поставщиков онлайн-услуг для школьников в 2020 г. увеличилась в 2 раза по сравнению с 2019 годом. Увеличение предложения онлайн-курсов для школьников связано с 
возрастанием спроса. Например, школьная аудитория Puzzle English после карантина увеличилась на $30 \%$.

Крупнейший и один из лучших образовательных сервисов для детей «Учи.ру»в процессе опроса своих пользователей называет своих лучших коллег и конкурентов (рис. 1). К ним следует добавить новый многофункциональный сервис «Сферум», который в 2021 г. начали активно использовать школьные учителя.

\section{1. Какие детские образовательные сервисы вы знаете?}

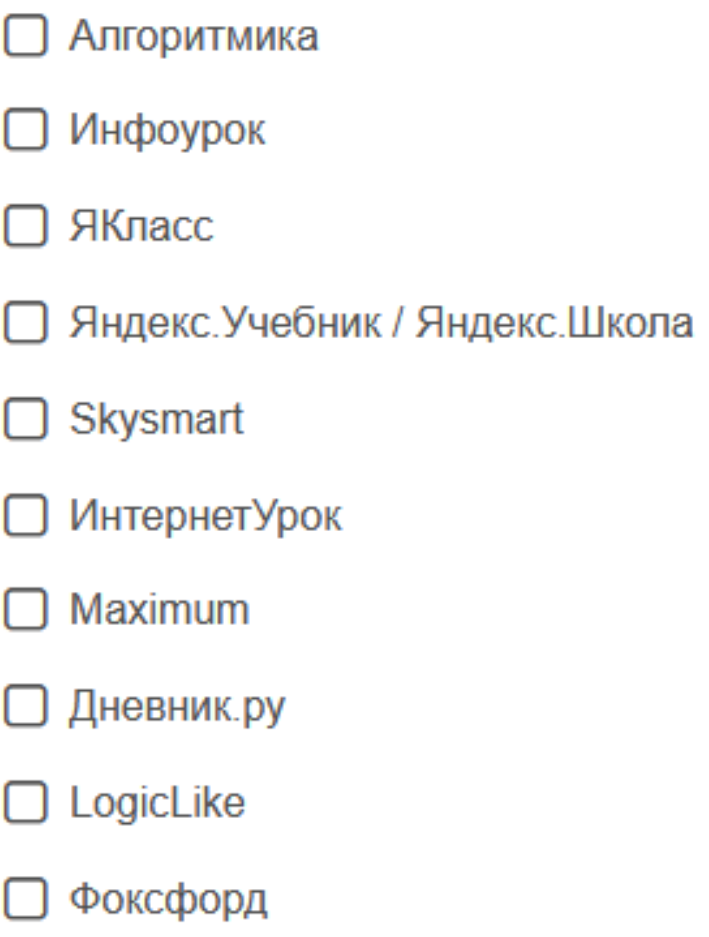

\section{Рис. 1. Детские образовательные сервисы, работающие в России}

Из собственного опыта можем подтвердить, что школьники пользуются сервисами «Учи.ру», «LogicLike», «Lingualeo», «Яндекс-учебник» и др. охотно, с пользой и с удовольствием, благодаря разнообразию заданий, прекрасной форме подачи материала, быстрой обратной связи и удачной, 
изобретательной и по-настоящему вовлекающей геймификации. Вместе с тем создатели этих платформ позаботились о том, чтобы дети не засиживались за компьютером сверх меры. Например, на «Учи.ру» каждый день любому ученику доступны 20 бесплатных заданий - вполне достаточно для интеллектуальной разминки и повторения учебного материала. Причем ребенок может сам выбирать, каким предметом он сейчас будет заниматься. Как известно, свобода выбора - это уже сам по себе фактор мотивации. А внутри предмета задания идут строго последовательно, в соответствии с учебной программой и методикой преподавания. Здесь же есть задания от учителя, соревнования между классами, индивидуальные рейтинги. Именно в процессе таких соревнований внуки уговорили меня купить им безлимитный доступ к нескольким предметам. Однако оказалось, что и при безлимитном доступе здоровью детей ничего не угрожает. Программа отслеживает общее время, проведенное ребенком за компьютером, и сообщает, что «на сегодня достаточно, пора отдохнуть».

Но не все новые образовательные сервисы столь удачны. Например, «Знайка.ру» (финансируемый из госбюджета) старомоден по форме и содержанию, уроков там мало, не всю программу они охватывают, стиль удручающе однообразен. Это не «говорящая голова», а учитель, стоящий у доски, который что-то рассказывает рядом с демонстрируемой картинкой. Съемка в профессиональной студии, но результат хуже, чем, если бы учитель рисовал свои объяснения на доске, потому что получается скучно, не интересно, наукообразно. Это результат плохого взаимодействия в команде, когда содержание урока готовят учителя, без сомнения, прекрасно знающие свой предмет, но не представляющие себе полных возможностей и особенностей дистанционного обучения, а техническое оформление урока делают узкие специалисты, не имеющие ни опыта дистанционного обучения, ни полноценной связи с учителями-предметниками. 


\section{2 Технологии дистанционного обучения, их достоинства и} недостатки

В области цифровизации образования в данный момент имеются следующие вызовы и угрозы:

- co стороны преподавателей недостаточное владение навыками применения цифровых сервисов;

- со стороны обучающихся слабая мотивация, навыки самоорганизации, самоконтроля, планирования личного времени;

- со стороны администрации недооценка трудоемкости переработки курсов под дистанционные формы обучения, слабое внимание к качеству контента;

- внешнеполитическая угроза чрезмерной зависимости от иностранных платформ для дистанционного обучения.

Не везде есть достаточно устойчивый и быстродействующий интернет. Не у всех школьников есть домашний компьютер. Не у всех есть современные модели телефонов, на которых можно смотреть дистанционные уроки. Текстовые файлы на телефоне раскрывать или неудобно, или невозможно. Вебинар смотреть и слушать с телефона можно, но писать в чате, отвечать на вопросы ведущего голосом, рисовать на общей доске и участвовать в командной работе на уроке невозможно или затруднительно.

«Глюки», зависание, обрыв связи, «выпадение» из процесса, необходимость перезагрузить страницу или перезагрузить компьютер (а за это время часть занятия уже пройдет) и войти заново - это обычные явления во время синхронных онлайн-занятий.

Асинхронные занятия (просмотр видеозаписи занятия, изучение рекомендованных текстов и видео, обсуждения в учебном форуме, выполнение заданий и тестов) имеет свои особенности и недостатки. 
В видеозаписи трудно найти нужное место, чтобы что-нибудь уточнить или вспомнить. Особенно если это запись целиком полуторачасовой лекции. Обсуждения и групповая работа в асинхронном форуме занимают гораздо больше времени. По рекомендациям МИМ ЛИНК (пионера дистанционного обучения в России, опыт работы с 1992 г.) и Открытого университета Великобритании (с 1969 г.) асинхронные занятия требуют времени в 7 раз больше, чем синхронные.

Контрольные мероприятия в дистанционном формате не дают гарантии того, что студент выполнил задание самостоятельно. Прокторинг не работает, т.к. у студентов нет достаточного количества видеокамер. Часто задания упрощены, чтобы их можно было втиснуть в формат теста. Тест с вариантами ответов - самый «тупой» метод контроля, который годится только для уровня «знать». Умения и понимание с помощью тестов не определить. То, что опытный преподаватель легко определяет при живом общении со студентом, при дистанционном обучении вырастает в проблему. Сложнее выявить ошибки в рассуждениях, причины затруднений, глубину понимания.

В целом у преподавателя уходит намного больше времени на подготовку к занятию (тоже примерно с коэффициентом 1 к 7), на проведение, на объяснение, на проверку. При очном обучении «рот закрыл - домой пошел», а при дистанционном, хотя и сэкономил время на дорогу от дома до работы, но зато дома целый день «включен в процесс» - проверяешь, отвечаешь на звонки и сообщения, вывешиваешь, перевешиваешь, даешь студентам допуск в группу, к определенным материалам, к следующему этапу занятий, фиксируешь результаты в своих записях и в той системе, которая принята в данном учебном заведении.

Bce перечисленное можно делать и автоматически или полуавтоматически, но далеко не все СДО и не все преподаватели к этому готовы. 
Со всеми этими проблемами система образования постепенно справляется. Преподавателей обучают за счет бюджета, они учатся сами с оплатой за свой счет или «методом тыка», используя ресурсы того же интернета, делятся опытом в профессиональных группах в соцсетях, привлекают студентов к созданию учебных материалов новых форм.

Учебные видео, сделанные во время первого локдауна 2020 года, пригодились и в дальнейшем, в том числе и для студентов очного обучения (рис. 2).
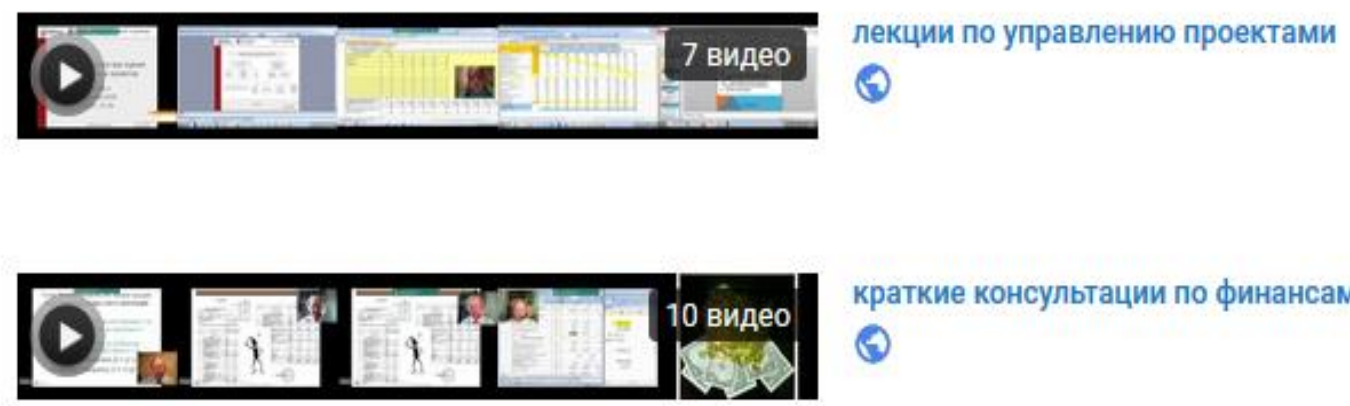

краткие консультации по финансам

\section{Рис. 2. Пример тематических видео, собранных в плейлисты по предметам}

Эксперты по развитию утверждают, что никакую компетенцию нельзя развить быстрым наскоком. Длительные обучающие марафоны изматывают, и очень часто студент теряет интерес. Потому любое обучение будет более эффективным, если оно разбито на небольшие кванты знаний - промежутки времени, в которых чередуется обучение и практика.

Важное место в развитии технологий дистанционного обучения занимает дружественность интерфейса и бесперебойная работа техподдержки. Причем бесперебойная означает не только мгновенный отклик чатбота, но и работа 24/7 живого компетентного оператора. Если к онлайн-курсу 
подключилось много участников, то процесс могут застопорить оргвопросы: кто-то не так заполнил поля или не разобрался, куда нажимать. Поэтому важно, чтобы на связи была оперативная заботливая техподдержка.

Рассмотрим 3 платформы дистанционного обучения с этой точки зрения: частная «Тичбейз», локальная «Личный кабинет студента/преподавателя ТулГУ» и федеральная «ODIN».

Лучшая техподдержка - на «Тичбейз». Эта платформа выдержала увеличение числа участников одного мероприятия (посвященного космической тематике) с 200 до 2000, всех успели обслужить, зарегистрировать, допустить, проконсультировать.

Второе место можно отвести системе, действующей в Тульском госуниверситете. Здесь есть подробные общедоступные инструкции для пользователей, в техподдержку можно написать в любое время, причем уже на стадии отправки письма пользователи сами сортируют их по тематике (хороший ход!). Ответ приходит быстро и всегда по делу. Запросы и пожелания пользователей «берут на карандаш» и постепенно улучшают систему. Например, появились возможность копировать методические материалы для разных групп, вести поиск нужной группы в списке, предусмотрен показ виртуальных аудиторий, в которых преподавателя ждут новые сообщения. Минус этой системы в том, что нет возможности поговорить с живым оператором, но плюс в том, что обратная связь четко налажена, и даже если сейчас какая-то возможность отсутствует, Вам честно скажут об этом и учтут на будущее.

А самая плохая техподдержка - на государственном, федеральном сайте «ODIN». Томский госуниверситет, получив статус опорного ВУЗа в этом направлении и немалое государственное финансирование, не вполне справился с возложенными на него задачами. Сайт разработан, он бедноват функционально, но все-таки существует. Стремление к универсальности 


\section{ЧЕЛОВЕК И СОВРЕМЕННОЕ ОБЩЕСТВО В СОЦИАЛЬНОМ, ПРАВОВОМ, ЭКОНОМИЧЕСКОМ РАКУРСАХ}

конфликтует с ограничениями на типы файлов, совместимость с другими платформами и т.п. А техподдержка - это вообще полный позор и провал, можно сказать, что её вообще не существует. Инструкций для пользователей нет (хотя есть кнопка «Знакомимся с ОДИНом», но там всего одно короткое видео «как войти в систему» и ничего о том, как ею пользоваться). Кнопка «Техподдержка» тоже присутствует, но нет никого по ту сторону дисплея. В техподдержку можно написать, но ответа Вы не получите или получите не скоро. По всем телефонам, которые мы смогли найти, отвечали работники, не имеющие понятия о работе системы, вместо содержательных ответов были переадресации «а попробуйте позвонить еще...». Но по замыслу этот сайт гораздо глубже, предусматривает формирование библиотеки и даже биржу дистанционных курсов и рассчитан на очень большое число, как студентов, так и преподавателей по всей территории РФ. Непонятно поэтому, как можно было такое огромное по замыслу начинание оставить практически без техподдержки.

В ходе карантинного 2020 года сформировались общие правила дистанционного урока - как для учеников, так и для учителей. Они настолько универсальны, что могут быть записаны как заповеди. Одна скрижаль - для школьников: «Не рисуй на чужой презентации!», «Не флуди в общем чате!», «Не держи микрофон включенным, если не отвечаешь!», и т.д. Вторая скрижаль - для педагогов: «Не проводи урока в онлайне без презентации!», «Не выключай свою камеру во время лекции!», «Помни о тех, кто всегда молчит!». Педагоги, работающие онлайн, составили примерный список правил проведения онлайн-урока и работают над его расширением [5]. В начале урока выбирается «дежурный» из числа учеников, присутствовавших на предыдущем занятии. Дежурный кратко, в течение 1-2 минут, пересказывает содержание предыдущего урока, формулирует главную мысль. Остальные участники могут задать отвечающему вопросы, 
если дежурный затрудняется с ответом, он «берет помощь» аудитории или учителя.

Современный этап цифровизации обучения в ВУЗах характеризуется параллельным ведением очного и онлайн-обучения. Во-первых, мы постоянно готовы к краткосрочным локдаунам. Во-вторых, время от времени возникает необходимость перевести на дистант одну-две группы из потока, если в ней вдруг обнаружатся заболевшие. В-третьих, наработки 2020 года и в части методического, и в части технического обеспечения сделали и студентов, и преподавателей более подготовленными и более гибкими в этой области.

В 2020-21 годах всё больше школ и университетов переходят на HyFlex. Это такой формат, когда занятия ведутся в аудитории, а часть учеников и студентов присоединяются к занятию удалённо. Очень удобно для тех случаев, когда часть слушателей может присутствовать в школе и университете, а часть работает дистанционно [6].

Некоторые проблемы возникают лишь в части состыковки результатов смешанного обучения. Все еще высока трудоемкость перенесения оценок из одной учетной системы в другую, проверки дистанционно представленных работ. Но это проблемы чисто технические, которые будут разрешены по мере дальнейшего обучения и совершенствования

\section{3 Отношение преподавателей к дистанционному обучению}

Ковидные ограничения дали толчок к развитию дистанционного обучения, способствуя появлению новых технологий и форматов обучения, массовому вовлечению преподавателей в дистанционные формы общения с учениками и студентами. Степень их готовности оказалась весьма различной. Легче было тем, кто уже имел какой-то опыт и наработки в области 
дистанционного обучения, труднее тем, кто оказался перед этой проблемой впервые.

Исследование В.С. Лихтовникова (зам. директора по IT института непрерывного образования БашГУ) в 2020 г. выявило следующие группы педагогов по их отношению к дистанционному обучению (рис. 3):

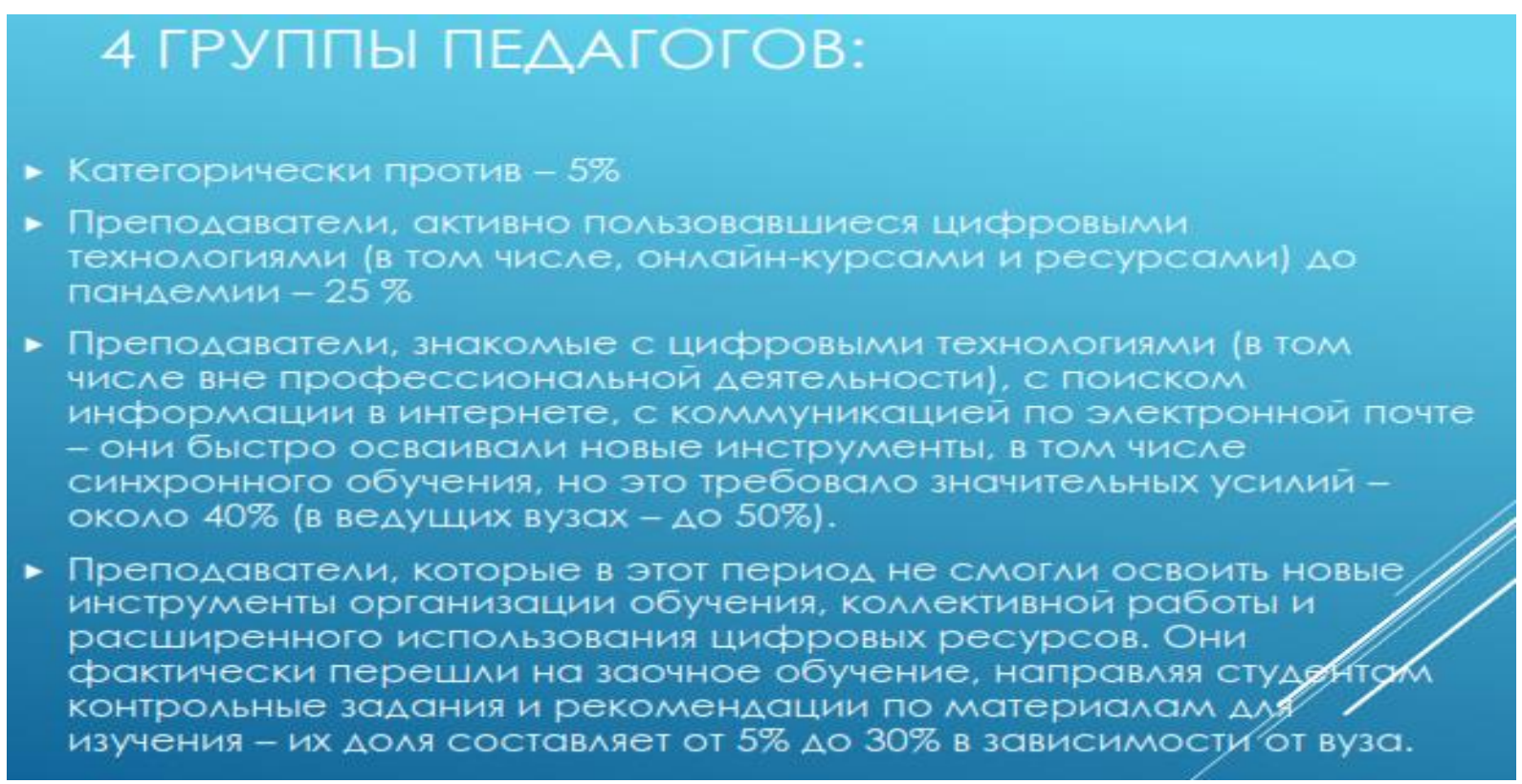

\section{Рис. 3. Отношение преподавателей к дистанционному обучению}

(по данным В.С. Лихтовникова, 2020 г., материальв вебинара)

В 2021 г. мы повторили опрос по тем же позициям и увидели, что ситуация претерпела некоторые изменения (рис. 4). Мы отдаем себе отчет, что эти различия могут быть обусловлены разницей в числе опрошенных, региональными особенностями, ситуацией в конкретных ВУЗах. Тем не менее следует отметить положительные сдвиги: увеличение доли преподавателей, успешно освоивших и применяющих новые технологии (с 30 до 48\%) и уменьшение (с 40 до 21\%) доли тех, кто не смог или не захотел учиться новому и по-прежнему ограничивается использованием электронной почты и переписыванием файлов на флешки. 


\section{ЧЕЛОВЕК И СОВРЕМЕННОЕ ОБЩЕСТВО \\ В СОЦИАЛЬНОМ, ПРАВОВОМ, ЭКОНОМИЧЕСКОМ РАКУРСАХ}

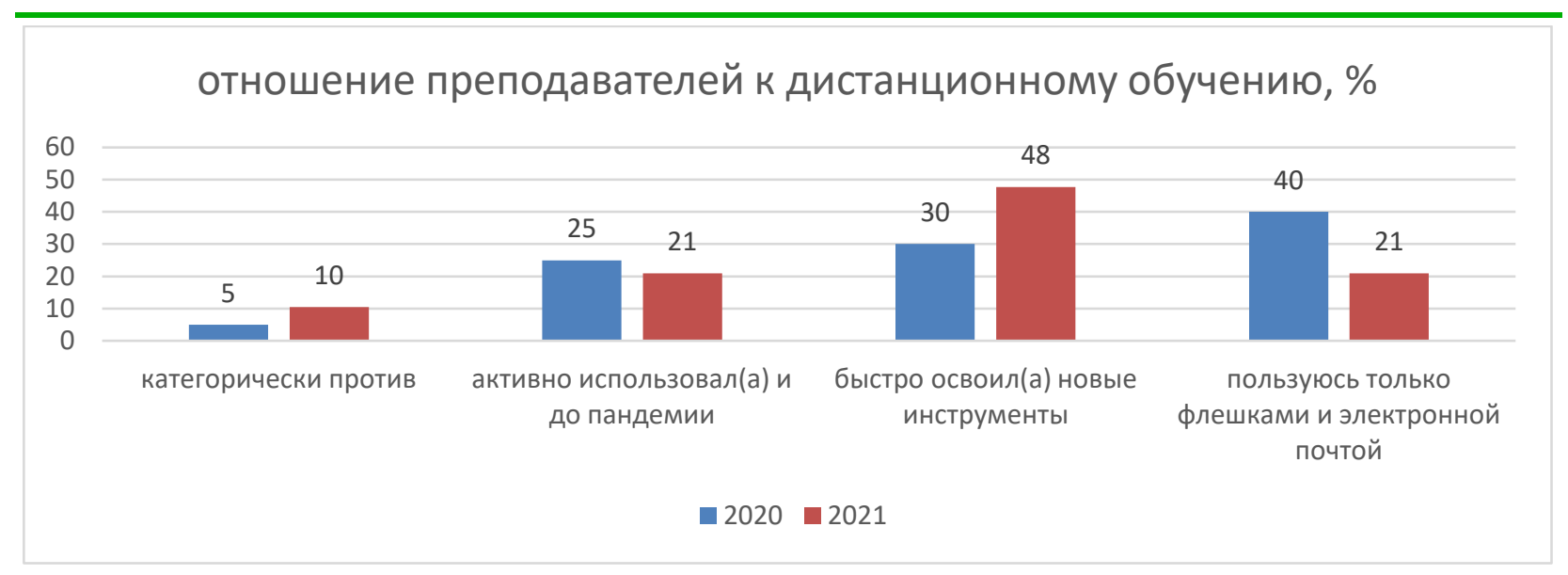

\section{Рис. 4. Изменения в отношении преподавателей к дистанционному обучению}

Вместе с тем, настораживает тот факт, что вдвое увеличилась доля преподавателей, которые высказываются категорически против дистанционного обучения. На наш взгляд, это произошло потому, что более тесное соприкосновение с дистанционным обучением ярче выявило его проблемы и недостатки. Заявив свое категорическое «нет», участники опроса на этом не останавливались, много говорили о том, что невозможно убедиться в степени самостоятельности выполнения задания студентом, прокторинг не работает или работает плохо по техническим причинам, невозможно выявить причину затруднений студента, проверка занимает намного больше времени, чем в очном варианте. Последнее, скорее всего, связано именно с тем, что многие преподаватели научились предоставлять контент студентам в форме текстового файла, презентации или видеозаписи лекции, но не овладели современными формами обратной связи в дистанционном обучении, навыками составления и использования автоматических онлайн-тестов на различных платформах, автоматической проверки и фиксации их результатов, проведения активных форм вебинаров, ведения асинхронных учебных форумов и т.п. Неправильное, не профессиональное использование средств 
дистанционного обучения ведет к резкому росту трудоемкости у преподавателей и провоцирует негативные высказывания о дистанте.

Оптимистический взгляд на проблему роста трудоемкости в период массового перехода на дистанционные формы обучения состоит в том, что это проблема временная, связанная именно с процессом перехода. По мере освоения дистанционных технологий преподаватели будут все больше освобождаться от рутинных операций транслирования информации и механического контроля действий обучаемых, перемещая свое внимание на разработку качественного контента и новых форм донесения материала и проверки его усвоения.

Дистант - это будущее, которое надо просто принять. Восставать против него - это значит уподобиться луддитам, громившим прядильные станки, или проявщикам фотопленок, которые до последнего не верили в тотальный переход человечества на цифровые фотокамеры.

Преподаватели вузов могут пройти повышение квалификации в рамках федерального проекта «Кадры для цифровой экономики». Казанский университет «Инноолис» бесплатно (за счет бюджета) обучает преподавателей тому, как актуализировать свои учебные программы и адаптировать их к условиям цифровой экономики. По окончании обучения все слушатели остаются в базе данных университета и регулярно получают приглашения на митапы с ведущими специалистами в области цифровизации.

\section{4 Индивидуализация в дистанционном обучении}

Преимуществом дистанционного обучения, особенно его асинхронных форм, является выстраивание индивидуальных образовательных траекторий для каждого студента, в зависимости от того, в формировании каких именно навыков он более всего нуждается. Преподаватель перестает быть 
транслятором знаний, превращается в тьютора-наставника, который должен учить навыкам.

Этим вопросом «Как можно, изучая одно и то же, научиться разному?» преподавательское сообщество задавалось задолго до пандемических вызовов, и даже до формирования каких-либо систем управления дистанционным обучением. Это были просто вдумчивые преподаватели, которые анализировали типичные ошибки, выделяли ошибки специфические, доискивались их причин, определяли «слабые места» каждого ученика и подбирали им задания по силам, вели шаг за шагом по ступеням развития, каждого своим темпом и своим путем. Не всегда это совмещалось со временем обучения, предусмотренным программой, с работой в большой аудитории или переполненном классе, но это именно то, к чему настоящие педагоги всегда стремились, в чем видели смысл своей работы. Сейчас именно дистанционные технологии позволяют систематизировать и оцифровать опыт таких преподавателей при построении ветвящихся сценариев обучения в современных LMS.

В адаптивном обучении образовательный контент и задания подбираются индивидуально каждому учащемуся, основываясь на его уровне знаний и подготовке, поэтому к создаваемым урокам предъявляют особые требования:

- в одном уроке нужно собрать задачи одной сложности, минимум одна задача в одном уроке;

- $\quad$ все уроки должны были быть независимы друг от друга, чтобы каждый из них можно было посоветовать учащимся на разных стадиях обучения.

Примером такой платформы является платформа Stepik.org, ориентированная в основном на преподавание естественнонаучных дисциплин, математики и программирования. Впрочем, на ней вполне 
успешно реализованы и многие гуманитарные курсы, например, китайский язык или история западноевропейской гравюры. На рис. 5 показан пример уроков по финансовой тематике, которые могут быть использованы в разных курсах.

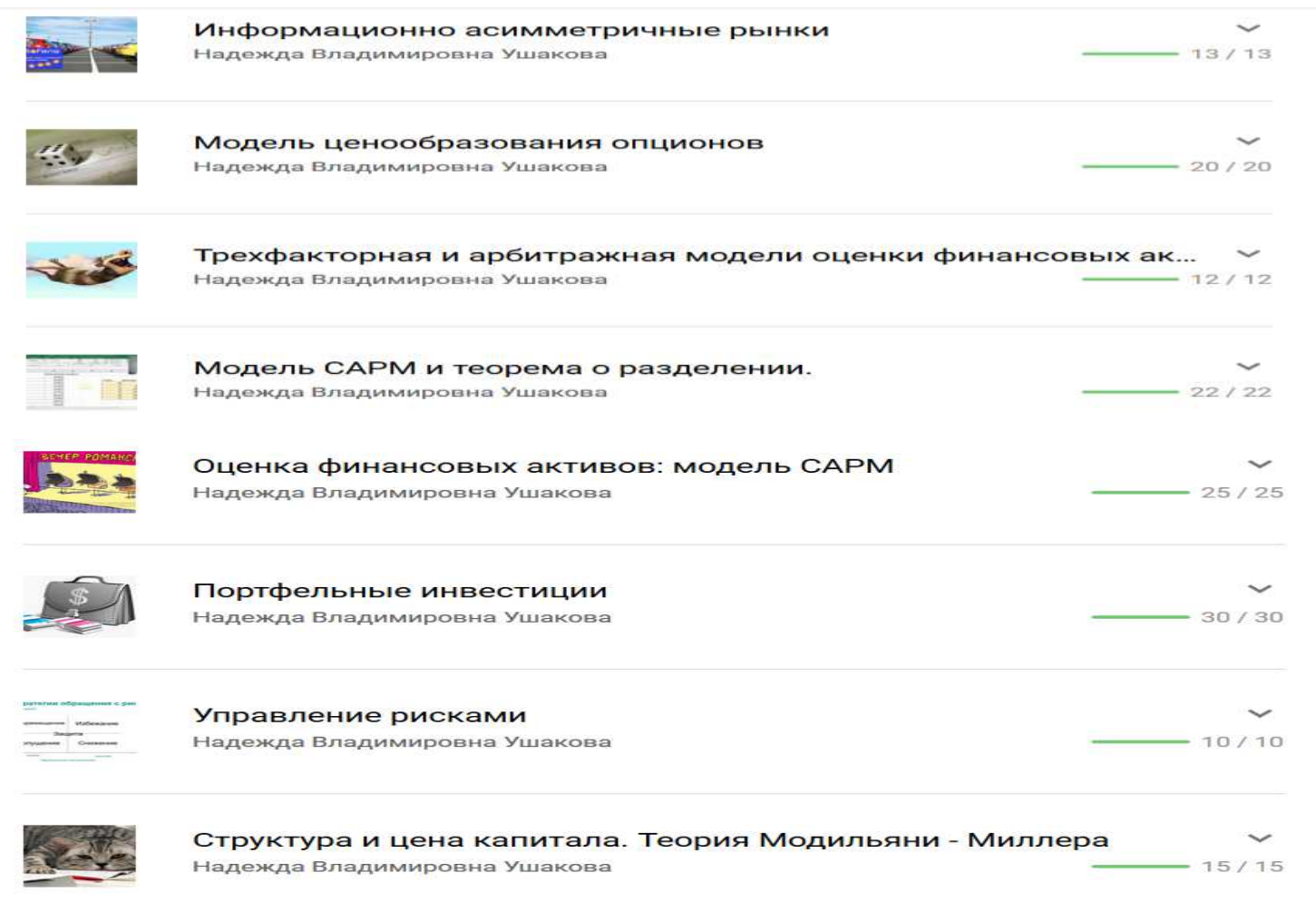

\section{Рис. 5. Пример отдельных уроков, объединяемых в различные по} тематике и уровню сложности курсы по модульному принципу

Например, урок «Портфельные инвестиции» входит в курсы «Рынок ценных бумаг», «Финансовые рынки и финансово-кредитные институты», «Теоретические основы финансового менеджмента», урок «Дивидендная политика» - в курс финансового менеджмента и курс «Рынок ценных бумаг», урок «Управление рисками» - в курс «Управление проектами», «Финансовый менеджмент», «Финансовые и предпринимательские риски». Также они могут быть рекомендованы разным студентам в зависимости от уровня их подготовки и успехов в изучении предыдущих тем. Например, если студент на 


\section{ЧЕЛОВЕК И СОВРЕМЕННОЕ ОБЩЕСТВО В СОЦИАЛЬНОМ, ПРАВОВОМ, ЭКОНОМИЧЕСКОМ РАКУРСАХ}

отлично завершил урок «Методы оценки инвестиционных проектов - расчет NPV», то он переходит дальше, к уроку «Методы оценки инвестиционных проектов - расчет IRR», затем к методу реальных опционов, и затем к использованию модели САРМ (Capital Assets Price Model), 3-х факторной модели Фама-Френча и т.д. Хуже успевающий студент может остановиться на первых 2-3 шагах (и получит соответственно более низкую, но удовлетворительную оценку). Это пример индивидуализации обучения по содержанию.

Пример индивидуализации «по навыкам» основан на внимании преподавателя к развитию когнитивных способностей. Проверяя обычные курсовые работы, преподаватель может заметить, что студент недостаточно хорошо делает таблицы, диаграммы, выводы, обобщения и т.п. На развитие каждого навыка у преподавателя есть набор упражнений на материале своего курса. В зависимости от того, какому студенту чего не хватает, он получает направление на соответствующую ветку заданий. Чтобы подготовить такую «умную» систему, преподавателю надо накопить банк заданий, разметить их индикаторами не только учебных тем, но и навыков, и сформулировать тригеры, переключатели, т.е. признаки, по которым система поймет, в какую сторону направить данного студента. Одну и ту же задачу можно сформулировать по-разному, так, чтобы в процессе её решения и формулировки ответа студент развивал разные когнитивные навыки (кому что нужнее) одновременно с усвоением материала по изучаемой теме. Например, изучаем тему «Доходность векселей», уровень «уметь», решаем задачу. Каждый студент, для самостоятельности решения, получает индивидуальный набор исходных данных, одинаковых по структуре. Задание и формулы вычислений для всех одинаковые. Однако требования к представлению конечного результата различны: представьте диаграмму изменения доходности векселя, составьте таблицу, в которой была бы отражена 
зависимость доходности векселя от сроков предъявления, сделайте выводы о влиянии срока предъявления векселя на его доходность.

Индивидуальные образовательные траектории (ИОТ) в Тюменском госуниверситете развиваются через систему элективных курсов. В 2017 году проект запустили в тестовом режиме, в нем участвовало около 800 студентов. Сейчас число тех, кто учится по новой системе, более 8000 (всего в ТюмГУ учится 15200 человек). На первом курсе студенты изучают общеобразовательные дисциплины («ядро»), профессиональные (мейджор) и выбирают по два дополнительных курса (элективы). «Ядру» отводится примерно 4/5 всего учебного времени.

Независимо от выбранного факультета студенты каждые полгода выбирают по два электива и сдают по ним зачеты. У обладателей хороших зачеток есть преимущество: они могут первыми выбирать самые популярные элективы (сейчас их около 600). Электив - это разработанный преподавателем или сторонним специалистом (инженером, врачом, режиссером) курс из лекций, семинаров или лабораторных занятий, посвященный одной теме. Каждый преподаватель может вести по два таких курса в год (дополнительно к основной нагрузке).

Список самых популярных элективов в ТюмГУ:

- Фото- и видеоискусство

- Психология общения

- Психика и мозг

- Кинотекст: от сериала к артхаусу

- Основы токсикологии и химическая криминалистика

- Instagram: основы продвижения в цифровом пространстве

Преподаватели рассматривают формирование элективных курсов как возможность личного профессионального роста. У студентов укрепляется 


\section{ЧЕЛОВЕК И СОВРЕМЕННОЕ ОБЩЕСТВО В СОЦИАЛЬНОМ, ПРАВОВОМ, ЭКОНОМИЧЕСКОМ РАКУРСАХ}

мотивация к обучению, расширяется кругозор, формируется широкая платформа междисциплинарных связей.

Хотя в Тульском госуниверситете тоже существуют «курсы по выбору», система в целом в Тюмени работает гораздо эффективнее.

Индивидуализация обучения, помимо индивидуальных образовательных траекторий, включает также «поштучное» зачисление, на дистанционные курсы, которое есть, например, в Центре повышения квалификации Тульского госуниверситета. Есть условия и для общения студентов курса, но не хватает навыков тьюторства у преподавателей и число студентов слишком мало для полноценной работы учебных форумов. Некоторые проблемы создают также требования учебной части закончить обучение в срок, обозначенный рабочей программой, что противоречит идее индивидуального темпа обучения, сообразно возможностям и способностям студента.

\section{5 Большие данные и искусственный интеллект в сфере образования}

Руслан Енсебаев, председатель Правления АО "Национальные Информационные Технологии", предлагает использовать большие данные в образовании. Пользователи интернет-магазинов хорошо знают, что система запоминает, что мы искали, и сразу предлагает нам товары, которые могут нас заинтересовать. Большие данные, собранные в процессе обучения, - что смотрит ребенок, как читает текст, на каких моментах задерживается, какой материал не понимает, а также тесты в конце каждого курса позволят составить индивидуальные программы для обучения каждого ребенка.

С помощью цифровых следов школьников «ВКонтакте» ВУЗ может анализировать интересы и круг общения, находить потенциальных студентов, отправляя им персонализированные приглашения к обучению. 


\section{ЧЕЛОВЕК И СОВРЕМЕННОЕ ОБЩЕСТВО В СОЦИАЛЬНОМ, ПРАВОВОМ, ЭКОНОМИЧЕСКОМ РАКУРСАХ}

Необходимое бизнесу накопление сведений о выпускниках - какими компетенциями и на каком уровне он владеет - достигается через грамотное построение и применение ФОС, которые предназначены для оценки уровня владения теми или иными компетенциями.

Цифровая трансформация университетов идет в направлении объединения сведений за все время обучения, создания экосистем, в которых накапливались бы сведения о всех видах учебной и общественной активности студентов, превращаясь затем в цифровой портрет выпускника, на который будет ориентироваться работодатель.

Искусственный интеллект может использоваться в анализе метрик образования для формирования индивидуальных образовательных траекторий студентов. Опыт преподавателей при этом важен как для «обучения» программ искусственного интеллекта, так и для создания новых и верификации ранее созданных образовательных метрик. Формальный и неквалифицированный подход к созданию ФОС может загубить эту хорошую идею на корню, не дать ей воплотиться в реальные достижения, дискредитирует сам замысел измерения компетенций.

К сожалению, административная практика в ВУЗах провоцирует именно такой, сугубо формальный подход к составлению ФОС. Их разработка никак не поощряется и не оплачивается, хотя это очень трудоемкая и ответственная работа, если делать ее по-настоящему. А в рамках «второй половины дня», т.е. за тот же оклад или даже часть оклада, ФОС делают из старых экзаменационных билетов, весьма приблизительно придерживаясь привязки к требуемым компетенциям. Контроль за составлением ФОС ведется по сугубо формальным признакам, автоматически (есть/нет) или вручную (номер протокола об утверждении, идентификационный номер, перечень компетенций). При этом содержанию ФОС не уделяют никакого внимания. Методический отдел ВУЗа не обладает знаниями спецдисциплин и не имеет 


\section{ЧЕЛОВЕК И СОВРЕМЕННОЕ ОБЩЕСТВО В СОЦИАЛЬНОМ, ПРАВОВОМ, ЭКОНОМИЧЕСКОМ РАКУРСАХ}

такого количества работников, чтобы проверить еще и содержание, а кафедры, вынужденные утвердить от 100 до 1000 рабочих программ и ФОСов на одном заседании, и вовсе не рассматривают их содержание, голосуют списком и утверждают, не глядя дальше титульного листа. А посему прекрасный замысел измерения уровня овладения компетенциями пока остается недостижимым. Даже если удастся объединить сведения об успеваемости каждого студента по всем курсам за все время обучения и создать его цифровой профиль, доверия этому профилю со стороны работодателей не будет до тех пор, пока в саму основу оценивания будут положены малопригодные для этого средства измерения [8, с. 272].

Учебным заведениям следует более подробно консультироваться с работодателями при составлении матрицы компетенций. Насколько учтены пожелания работодателей при формировании образовательных стандартов, не ясно. Поэтому логичен переход от образовательных (ФГОС $3+$ ) к профессиональным стандартам (ФГОС $3++)$ в в которых пожелания работодателей уж точно учтены составителями и соответствуют составу работ, которые предстоит выполнять выпускникам.

\section{6 Формирование цифровых навыков}

Цифровая трансформация образования не противоречит, а поддерживает основные цели в области образования, такие как обеспечение доступности образования, его глобальной конкурентоспособности. Современное образование как в очной, так и в дистанционной форме, должно способствовать формированию не только чисто профессиональных, но и цифровых навыков, которые становятся важной составной частью многих профессий. В число таких навыков входит умение найти нужную информацию, установить контакт с людьми, которые могут помочь её найти 
или пояснить, умение самостоятельно определить, какие данные Вам нужны, а какие нет, умение безопасно и эффективно собирать и хранить данные, умение обработать данные и извлечь из них ценную информацию, критически оценивать достоверность и полезность информации, в изобилии доступной благодаря существованию сетей.

Кафедрой «Финансы и менеджмент» Тульского госуниверситета сформирована концепция дальнейшего участия университета в программе повышения цифровой грамотности населения [8, с. 475]. В соответствии с этой концепцией учебные материалы программы повышения квалификации по цифровизации экономики будут использованы в качестве первого (вводного) блока программы профессиональной переподготовки для получения студентами ТулГУ дополнительной специальности «Цифровой куратор». Второй блок этой программы «Общие цифровые компетенции» будет одинаковым для всех студентов, третий - «Цифровые компетенции в сфере профессиональной деятельности» - будет дифференцирован по факультетам. При подготовке этой программы потребуется широкое участие преподавателей специальных дисциплин ТулГУ, для чего им будет предложено пройти программу «Трансформация бизнеса и общества в условиях цифровой экономики», выполнив в качестве зачетного задания исследование на тему применения цифровых технологий в преподаваемой ими дисциплине и эссе «Профессии будущего». Студенты старших курсов с дипломами профессиональных цифровых кураторов будут выполнять задания с широким охватом населения по месту жительства и в местах прохождения практик.

Мы провели исследование каналов связи преподавателей со студентами, в котором приняли участие более 400 человек (рис. 6,7). Эти результаты можно использовать для того, чтобы правильно выбрать канал оперативной связи со студентами, место для учебного форума, опросов, обсуждений и т.П. 
Например, ясно, что группу для дискуссий лучше делать Вконтакте, а не в Фейсбуке.

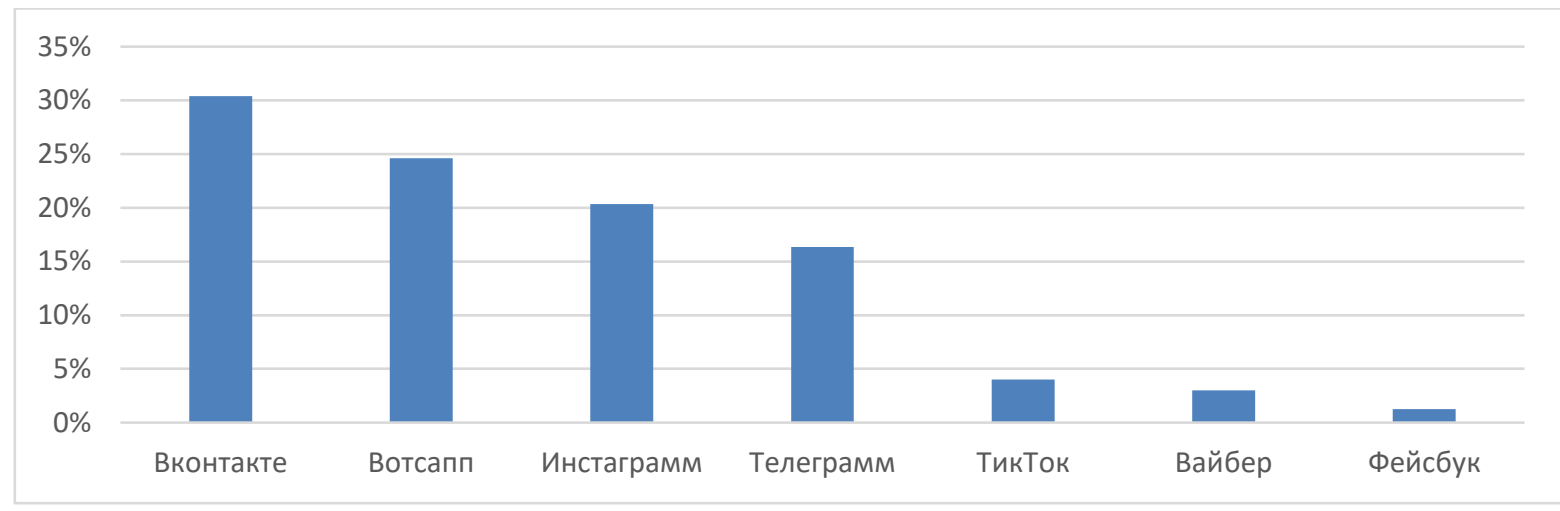

Рис. 6. Какие каналы связи используют студенты для общения

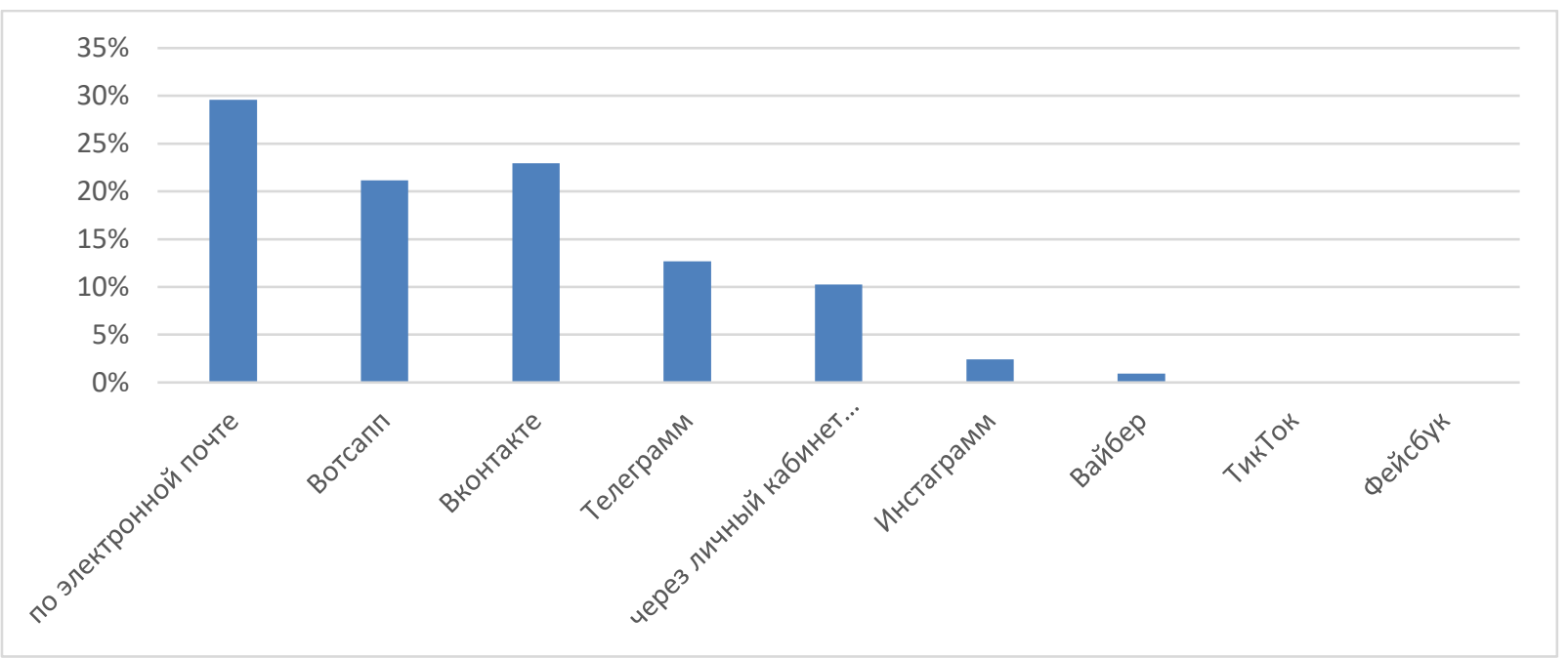

\section{Рис. 7. Какие каналы связи студенты предпочитают}

\section{для получения учебной информации}

Цифровизация обучения должна повысить доступность высококачественного учебного контента широким слоям населения, создавая возможность непрерывного обучения, повышения квалификации и смены профессий. Ведущую роль при этом будут играть крупные университеты. Они могут и должны обеспечить цифровизацию преподавания базовых и профильных дисциплин, использовать технологию «больших данных» и 
искусственного интеллекта для формирования индивидуальных

образовательных траекторий, профессионального портфолио выпускника, соответствующего требованиям работодателя, привлечения наиболее перспективных абитуриентов, поддержания мотивации и «удержания» обучающихся, что важно с финансовой точки зрения.

\section{Список литературы}

1. Как живут МООС платформы в российских реалиях URL: https://courseburg.ru/analytics/Issledovanie_MOOC_platform.pdf -73 c.

2. Зотова В.Н., Першина Т.А. Анализ рынка онлайн-образования до и после пандемии коронавируса // в сб. «Студент года» - МЦНП «Новая наука», 2021. - c. 84-95

3. Исследование российского рынка онлайн-образования» URL: http://research.edmarket.ru/ -40 c.

4. Исследование рынка онлайн-образования в России URL: https://drive.google.com/file/d/1LWKKJVpUTYZCFF9xOs_hzGW7KNmEn WR1/view -c. 18

5. Кутузова А. 18 тезисов о дистанте, https://trizway.com/.../pedteh.../18tezisov-o-distante.html

6. Григорьева И.В. Развитие и внедрение технологии смешанного обучения и онлайн-обучения, как важной составляющей цифровизации образования . // Вестник Университета Российской академии образования. 2021. № 3. C. 34-45.

7. Ушакова Н.В. Перспективы и риски цифровизации образования // Сборник статей II Международного профессионально-исследовательского конкурса Преподаватель года 2021 Часть 1 Петрозаводск 14 декабря 2021 г. 398 c. - c.268-278 https://www.sciencen.org/assets/Kontent/Konkursy/Arhivkonkursov/NIK-151.-CHast-1.pdf 
8. Ушакова Н.В. Формы участия университета в повышении цифровой грамотности населения〉// Цифровая экономика: проблемы и перспективы развития. Сборник научных статей Межрегиональной научно-практической конференции. 2019. С. 472-478. 


\title{
Глава 2.
}

\section{СТАНОВЛЕНИЕ ПРОФЕССИОНАЛЬНОЙ ПОЗИЦИИ СТУДЕНТА}

\section{Неволина Виктория Васильевна}

д.П.н., доцент

Аннотация: Профессиональное развитие представляет процесс становления и дальнейшего совершенствования профессионала. Профессиональное становление человека осуществляется в профессиональных учебных заведениях в процессе систематического обучения. Профессиональная деятельность изменяется в процессе развития субъекта труда, которое стимулирует качественное изменение учебнопрофессиональной деятельности и, как следствие, становление профессиональной позиции будущего специалиста. Профессиональное развитие предполагает устойчивую мотивацию, приобретение новых знаний и умений, определенных результатов деятельности и достижения. На разных этапах жизнедеятельности человека становление профессиональной позиции является и результатом, и средством развития личности.

Ключевые слова: профессиональная позиция, профессиональное саморазвитие, профессиональная подготовка студента.

\section{FORMATION OF A STUDENT'S PROFESSIONAL POSITION}

\section{Nevolina Victoria Vasilyevna}

\begin{abstract}
Professional development represents the process of formation and further improvement of a professional. The professional formation of a person is carried out in professional educational institutions in the process of systematic


training. Professional activity changes in the process of development of the subject of labor, which stimulates a qualitative change in professional activity and, as a result, professional self-development. Professional development involves sustained motivation, the acquisition of new knowledge and skills, certain performance results and achievements. At different stages of a person's life, the formation of a professional position is both a result and a means of personal development.

Key words: professional position, professional self-development, professional training of the student.

При изучении особенностей становления профессиональной позиции студента представляется важным учитывать контекст, в рамках которого оно происходит:

- социальный (изучение интеграции студента в систему социальнопрофессиональных отношений);

- образовательный (рассмотрение студента в системе непрерывного образования, подготовка компетентных, ответственных специалистов, способных к постоянному профессиональному росту);

- личностный (изучение саморазвития личности, развитие профессионально-личностных качеств студента, самосознания, формирование системы ценностных ориентаций).

Становление профессиональной позиции студента в системе социальнопрофессиональных отношений требует устойчивой мотивации, учебной успешности, освоения профессии в процессе подготовки, адаптации на рабочем месте, формирования индивидуального профессионального стиля, поиска путей профессионального роста, стремления к постоянному самосовершенствованию. Особо следует выделить этап профессиональной подготовки, поскольку именно в этот период определяются основы становления профессиональной позиции студента. 


\section{ЧЕЛОВЕК И СОВРЕМЕННОЕ ОБЩЕСТВО В СОЦИАЛЬНОМ, ПРАВОВОМ, ЭКОНОМИЧЕСКОМ РАКУРСАХ}

В профессиограмме качествами субъекта труда, желательными для успешного выполнения профессиональной деятельности и профессионального роста, выступают: характеристики эмоционально-волевой сферы (мотивы, ценностные ориентации, потребности, интересы, профессиональные притязания и самооценка, профессиональное самосознание), операциональной сферы (знания о профессии, профессиональные способности, обучаемость, профессиональное мышление, профессиональное саморазвитие, умение реализовывать стратегию профессионального роста).

Стадии профессионального становления личности позволяют говорить о «жизненном пути» профессионала (Э.Ф. Зеер, Е.А. Климов):

1. Оптация (выбор профессии с учетом индивидуальных особенностей). На этой стадии происходит формирование самосознания, самооценки, осознание собственных возможностей.

2. Профессиональная подготовка (приобретение профессиональных знаний и умений). На данном этапе происходит развитие самосознания, рефлексивных и эмпатийных способностей, креативности, критичности и навыков саморегуляции, актуализация интереса к общепрофессиональным дисциплинам, профессиональной интерпретации и моделированию, а также формирование профессиональных намерений, системы знаний о профессиональном саморазвитии и стремление к самосовершенствованию.

3. Профессиональная адаптация (освоение социально-профессиональной роли, самоопределение в профессии, формирование профессиональных качеств и опыта). Актуализируется потребность в профессиональной самореализации, соотношение усвоенных знаний с профессиональной деятельностью; способность к постановке и решению профессиональных задач, профессиональная компетентность, создание моделей профессионального поведения.

4. Профессионализация (интеграция личностных и профессиональных 


\section{ЧЕЛОВЕК И СОВРЕМЕННОЕ ОБЩЕСТВО В СОЦИАЛЬНОМ, ПРАВОВОМ, ЭКОНОМИЧЕСКОМ РАКУРСАХ}

качеств, выполнение обязанностей). На этом этапе происходит формирование профессиональной позиции и индивидуального стиля деятельности, высокого уровня самоорганизации и самоуправления.

5. Профессиональное мастерство (самореализация в профессии). Этот этап представляет собой высокую и постоянно совершенствуемую степень овладения профессиональной деятельностью.

Наряду с прогрессивными тенденциями саморазвития, каждый из данных этапов профессионального становления может сопровождаться и затруднениями, периодами стагнации. Профессиональное становление включает профессиональное развитие, стимулируемое внешними факторами, и профессиональное саморазвитие, обусловленное интеграцией внешних и внутренних факторов.

Этап становления профессиональной позиции студента связан с профессиональным образованием, которое представляет собой процесс и результат профессионального становления личности, сопровождается овладением установленными знаниями, умениями и компетенциями по конкретным специальностям. На современном этапе профессиональное образование не только выполняет функцию насыщения рынка труда компетентными специалистами, но и создает возможности для профессионального роста и развития личности. Согласно Федеральному закону «Об образовании в Российской Федерации» № 273-Ф3 от 29 декабря 2012 г. с изменениями 2017-2018 гг., профессиональное образование направлено на приобретение обучающимися знаний, умений и компетенций в процессе освоения основных образовательных программ, что позволяет осуществлять определенную профессиональную деятельность и выполнять работу по конкретной специальности.

Итак, рассматриваем профессиональную позицию студента как профессионально-личностный феномен, обеспечивающий готовность 
студента к осознанию социальной значимости профессиональной деятельности, ее приоритетов, профессиональных ценностей в динамике социальных отношений, к постоянному самосовершенствованию и освоению новых достижений профессии, разработке проектов профессионального роста.

Теоретические основы исследования становления профессиональной позиции обучающихся базируются на гносеологических предпосылках, как объективно существующих обстоятельствах, отражающих научные представления о данном феномене:

- характеристики общественно-экономической ситуации, которые определяют потребности и возможности их удовлетворения, мировоззрение, общекультурные ценности; социальный заказ на решение исследуемой проблемы; результаты теоретического изучения исследуемой проблемы, которые позволяют проследить эволюцию представлений и оценить их значение для перспективы; способы решения исследуемой проблемы в образовательной практике;

- поиск путей воплощения идей гуманистической психологии о саморазвитии, самоактуализации; выявление специфики профессионального обучения с опорой на самостоятельность, самопознание и саморегуляцию;

- основой идей педагогического сопровождения стала педагогика самовоспитания и личностного саморазвития, актуализация проблемы субъектности в профессиональном образовании;

- интенсивная разработка и внедрение идей педагогического управления, тьюторства саморазвития в деятельности субъектов взаимодействия в аспекте педагогического сопровождения;

- идеи ресурсологии об обусловленности саморазвития личности, заложенным в ней потенциалом (ресурсом развития);

- идеи педагогической прогностики в конструировании и прогнозировании профессионально-личностных перспектив в ответ на вызовы 
современного социума;

- катализатором выступает проникновение дискурса синергетики в педагогику о моделировании, самоорганизации и достижении синергетического эффекта в процессе становления профессиональной позиции;

- доминантой в исследовании становления профессиональной позиции является активная разработка теории человеческого капитала, ядром которой выступает образованный и инициативный человек - профессионал;

- идеи профессиональной социализации, инструментальнотехнологической инноватики в системе высшего образования;

- новые возможности для исследования открывает активное внедрение современных форм организации образования - сетевое взаимодействие, интернет-платформа, социальное партнерство, обусловливающие активный обмен культурно-образовательными инициативами.

В исследовании становления профессиональной позиции студентов университета выявляем инвариантные гносеологические предпосылки (установление приоритетов самости, мотивации и нравственных ориентиров обучающихся как базиса профессиональной педагогики; идеи проектирования профессионального будущего в условиях информационно-сетевых связей) и специцфические (развитие теории человеческого капитала как ориентира в повышении значимости здоровья человечества; ведущая роль профессионального этоса как морально-нравственного регулятива; процессы взаимодействия потенциалов субъектов образования).

Профессиональная позиция студента университета представляет профессионально-личностный феномен, обеспечивающий готовность студента к осознанию социальной значимости профессиональной деятельности, ее приоритетов, профессиональных ценностей в динамике 
социальных отношений, к постоянному самосовершенствованию и освоению новых достижений профессии, разработке проектов профессионального роста.

В соответствии с законом «Об образовании в РФ» профессиональное образование должно быть направлено на создание условий для самореализации и саморазвития личности выпускника образовательной организации, выступая тем самым фактором социально-экономического фактора развития социума.

Интерес к проблеме становления профессиональной позиции студента обусловлен развитием современного студенчества как социокультурного феномена. Составляющей студенческой жизни является активное самопознание и самоопределение в личной и профессиональной жизни. Студенческий возраст является началом реализации жизненных стратегий, активного освоения профессиональной деятельности, интенсивной профессиональной социализации в образовательной среде и во взаимодействии с преподавателями и однокурсниками в контексте приобретаемой профессии. Значимость контекстов профессии в педагогическом сопровождении изучаемого феномена подчеркивают многочисленные исследования. Так, в процессе профессиональной подготовки под руководством или при участии преподавателей происходит освоение традиционных и новых норм, образцов и правил деятельности, присвоение ценностей профессии.

Выделим структурные компоненты профессиональной позиции студента:

- мотивационно-цуенностного (развитие познавательной мотивации и ценностного отношения к проектированию стратегий с нравственными доминантами здоровья);

- информационно-гностического (обогащение знаний о способах и приемах саморазвития в профессии, новых достижениях современной науки и техники); 


\section{ЧЕЛОВЕК И СОВРЕМЕННОЕ ОБЩЕСТВО В СОЦИАЛЬНОМ, ПРАВОВОМ, ЭКОНОМИЧЕСКОМ РАКУРСАХ}

- деятельностного (развитие способности к целеполаганию, планированию, применение способов и приемов саморазвития; умение реализовывать стратегии с учетом инновационных тенденций);

- рефлексивно-регулятивного (развитие навыков саморегуляции, самоорганизации и оценки результатов учебно-профессиональной деятельности, осознание ответственности, ориентация на профессиональный рост).

Востребованным и конкурентоспособным становится специалист, чей профессиональный рост детерминирован стремлением к саморазвитию. Утверждение проекта нового образовательного стандарта влечет за собой ряд изменений в структуре, содержании и условиях реализации основной образовательной программы, что влияет на качество подготовки выпускников. Повышение качества и уровня преподавания за счет использования инновационных форм обучения увеличивает требования к обучающимся и в результате выводит учебный процесс на качественно новый уровень.

Анализ изменений образовательных стандартов показал усиление внимания к становлению профессиональной позиции студента университета, которая позволяет выстраивать непрерывное образование, начало которого закладывается на этапе вузовской подготовки. Образовательные стандарты, уделяя основное внимание формированию профессиональных компетенций будущего специалиста, не меньшее значение придают общекультурному совершенствованию личности студента. Профессиональное образование направлено на подготовку высокообразованного специалиста с широким кругозором, высокой степенью инфокоммуникативности в разных языковых сферах, владеющего современными технологиями.

Анализ образовательных стандартов позволяет отметить активизацию самостоятельной работы студентов в процессе обучения, а дефиниции «способность», «готовность» предполагают необходимость формирования у 
студента активной жизненной и профессиональной позиции, обеспечение субъектного взаимодействия в учебном процессе. Обязательным является участие студентов в научно-исследовательской работе.

Структурные компоненты профессиональной позиции студентов университета соотносятся с компетенциями в соответствии с федеральными государственными образовательными стандартами высшего образования.

Так, мотивационно-иенностный компонент профессиональной позиции студента охватывает компетенции, связанные с ценностями здоровья, здорового образа жизни, ценности профессии, выражает стремление студента к саморазвитию в рамках различных видов профессиональной деятельности.

Информационно-гностический компонент включает когнитивную составляющую на уровне знаний, которые выступают в роли не только конечного результата образовательного процесса, а также в качестве базиса становления профессиональной позиции.

Деятельностный компонент профессиональной позиции студента интегрирует категории способности и готовности, умения студента.

Рефлексивно-регулятивный компонент охватывает умения саморегуляции, самоконтроля и самоорганизации.

Ключевыми особенностями ФГОС $\mathrm{BO}, \quad$ способствующими профессиональному саморазвитию студента, выступают новые возможности реализации образовательных программ (дистанционные образовательные технологии), требования к оценке качества освоения ОП (студенты, работодатели, профессиональные стандарты, профессионально-общественная аккредитация). В ФГОС ВО особо выделены сетевые формы организации учебно-воспитательного процесса, электронное обучение и дистанционные образовательные технологии.

Профессиональная компетентность включает совершенствование знаний и умений, применение в своей деятельности профилактические, 


\section{ЧЕЛОВЕК И СОВРЕМЕННОЕ ОБЩЕСТВО В СОЦИАЛЬНОМ, ПРАВОВОМ, ЭКОНОМИЧЕСКОМ РАКУРСАХ}

реабилитационные мероприятия, постоянно и мотивированно совершенствоваться, быть коммуникабельным, уметь работать в команде, быть способным к инновациям и использованию их в своей повседневной практике.

В соответствии с приказом от 12 апреля 2013 г. № $148 \mathrm{H}$ «Об утверждении уровней квалификации в целях разработки проектов профессиональных стандартов» утверждены уровни квалификации, которые применяются для описания требований к образованию и обучению специалистов и их трудовых функций. Единые требования к уровням квалификации работников расширяются с учетом специфики видов профессиональной деятельности, знаний, умений, уровня квалификации, полномочий и ответственности.

В данном нормативном документе начиная с 6-го уровня квалификации требованиями к работнику являются: обучение по образовательным программам высшего образования, определенные полномочия и ответственность (самостоятельная деятельность, предполагающая определение задач собственной работы, обеспечение взаимодействия, ответственность за результат выполнения деятельности), характер знаний (применение профессиональных знаний, самостоятельный поиск, анализ и оценка информации для решения профессиональных задач) и умений (решение различных типов задач с элементами проектирования, выбор способов решения в изменяющихся условиях, контроль и оценка результатов). Повышение уровня квалификации работников характеризуется обогащением знаний, умений, полномочий и ответственности, заключающихся в определении стратегии, создании новых знаний, принятии ответственных решений, использовании инновационных методов и технологий. Начиная с 8-го уровня квалификации работников, требованием для их подготовки выступает: обучение по программам подготовки кадров, создание новых 


\section{ЧЕЛОВЕК И СОВРЕМЕННОЕ ОБЩЕСТВО В СОЦИАЛЬНОМ, ПРАВОВОМ, ЭКОНОМИЧЕСКОМ РАКУРСАХ}

знаний межотраслевого характера, оценка и отбор информации, решение задач исследовательского и проектного характера, направленных на повышение эффективности деятельности.

Основные характеристики квалификации, необходимой работникам для осуществления их профессиональной деятельности, закладываются профессиональными стандартами. В профессиональном стандарте рассматриваются трудовые функции, функциональная карта вида профессиональной деятельности, необходимые знания и умения. Детальный анализ профессиональных стандартов различных наименований специальностей показал наличие общих требований к образованию специалиста (высшее образование) и другие характеристики с целью профессионального роста и присвоения квалификационных категорий (повышение квалификации и профессиональная переподготовка, формирование профессиональных навыков посредством наставничества, стажировок, использования современных дистанционных образовательных технологий, тренингов, участия в конференциях, мастер-классах; соблюдения принципов профессиональной этики и деонтологии; соблюдения законодательства).

Педагогическое сопровождение становления профессиональной позиции обучающихся обусловлено развитием современного общества, нарастанием роли человеческого капитала, ответственностью, возлагаемой на профессию, высоким уровнем инструментально-технической оснащенности, развитием новых научных исследований, интеллектуализацией труда.

Потенциал образования ориентирован на глобальные тенденции и закономерности их реализации в ходе педагогических процессов. В результате анализа современных педагогических исследований к тенденциям гуманитарного знания о педагогическом сопровождении становления профессиональной позиции относим приоритеты самости, теорию 


\section{ЧЕЛОВЕК И СОВРЕМЕННОЕ ОБЩЕСТВО В СОЦИАЛЬНОМ, ПРАВОВОМ, ЭКОНОМИЧЕСКОМ РАКУРСАХ}

человеческого капитала, интегративный подход к идеям становление профессиональной позиции, приоритетность информационно-сетевых взаимосвязей.

\section{Список литературы}

1. Абакумова, И.В. Развитие представлений о смыслообразующих стратегиях личности в современном обществе [Электронный ресурс] / И.В. Абакумова, М.В. Годунов, Е.В. Белова // Гуманитарные, социальноэкономические и общественные науки. - 2017. - № 5. - С. 13-16. - Режим доступа: https://DIO 10.23672/SAE.2017.5.6050 (дата обращения: 25.05.2017).

2. Абульханова-Славская, К.А. Стратегия жизни [Текст] / К.А. Абульханова-Славская. - М. : Мысль, 1991. - 299 с.

3. Аверин, В.А. Психология личности : учебное пособие [Текст] / В.А. Аверин. - СПб. : Издательство В. А. Михайлова, 2001. - 192 с.

4. Алисов, Е.А. Стратегии проектирования образовательной среды [Текст] / Е.А. Алисов // Вестник университета (государственный университет управления). - 2008. - № 1 (22). - С. 200-204.

5. Амиров, А.Ф. Активизация личностно-развивающего потенциала самостоятельной работы студентов вуза как условие развития их субъектной позиции [Текст] / А.Ф. Амиров, Р.М. Гаранина, А.А. Гаранин. - Самара : Офорт, 2014. - $516 \mathrm{c}$.

6. Амиров, А.Ф. Трехпарадигмальная основа системы профессиональной социализации студентов в высшей школе [Текст] / А.Ф. Амиров, Л.А. Амирова // Вестник КГУ им. Н.А. Некрасова. - 2014. T. 20. - C. 108-113.

7. Ананьев, Б.Г. О проблемах современного человекознания [Текст] / Б.Г. Ананьев. - М. : Наука, 1977. - 379 с. 
8. Андреев, В.И. Концептуальная педагогическая прогностика [Текст] / В.И. Андреев. - Казань : Центр инновационных технологий, 2010. - 220 с.

9. Асмолов, А.Г. Вызовы современности и перспективы профессионального роста в мире образования [Текст] / А.Г. Асмолов // Образовательная панорама. - 2016. - № 1. - С. 6-8.

10. Асташова, Н.А. Аксиологическое образование современного учителя: методология, концепция, модели и технологии развития : автореферат дис. ... доктора педагогических наук : 13.00.01 / Н.А. Асташова ; Брян. гос. пед. ун-т им. И.Г. Петровского. - Брянск, 2001. - 52 с.

11. Бабина, С.В. Формирование компетенции профессионального саморазвития студентов вуза : автореферат дис. ... канд. пед. наук : 13.00 .08 / С. В. Бабина. - М., 2009. - 23 с.

12. Бакшаева, Н.А. Развитие познавательной и профессиональной мотивации студентов педагогического вуза в контекстном обучении : автореферат дис. ... кандидата психологических наук : 19.00 .07 / Н.А. Бакшаева // Исслед. центр проблем качества подготовки специалистов. Москва, 1997. -23 с.

13. Барабанщиков, В.А. Системный подход в структуре психологического познания [Текст] / В.А. Барабанщиков // Методология и история психологии. - 2007. - Т. 2, вып. 1. - С. 86-99.

14. Баранов, В.В. Факторный анализ как инструментарий педагогического знания о процессах саморазвития студента университетского комплекса [Текст] / В.В. Баранов, И.Д. Белоновская, В.И. Чепасов // Вестник Оренбургского государственного университета. - 2012. - № 2 (138). C. 21-27.

15. Баранов, В.В. Формирование конкурентного ресурса личности студента в условиях университетского комплекса : автореферат дис. ... д-ра пед. наук : 13.00.01 / В.В. Баранов. - Оренбург, 2013. - 44 с. 
16.Бездухов, В.П. Морально-этическая рефлексия учащегося [Электронный ресурс] / В.П. Бездухов, О.К. Позднякова // Известия Самарского научного центра РАН. - 2010. - № 3-3. - Режим доступа: https://cyberleninka.ru/ article/n/moralno-eticheskaya-refleksiya-uchaschegosya (дата обращения: 06.08.2021).

17. Безрукова, В.С. Интеграционные процессы в педагогической теории и практике [Текст] / В.С. Безрукова. - Екатеринбург : Издательство Гос. ин.проект. ин-та, 1994. - 152 с.

18. Белоновская, И.Д. Роль самоуправляемого обучения студентов в университетском образовании [Текст] / И.Д. Белоновская, Т.Б. Серебровская // Научные труды SWorld. - 2012. - Т. 12, № 2. - С. 85-88.

19. Белоновская, И.Д. Формирование профессиональной компетентности специалиста: региональный опыт : монография [Текст] / И.Д. Белоновская. - М. : Ин-т развития проф. образования, 2005. - 351 с.

20. Богуславский, М.В. Научные основы историко-педагогической экспертизы инноваций в образовании [Электронный ресурс] / М.В. Богуславский // Отечественная и зарубежная педагогика. - 2016. - № 1 (28). - Режим доступа: http://cyberleninka.ru/article/n/nauchnye-osnovy-istorikopedagogicheskoy-ekspertizy-innovatsiy-v-obrazovanii (дата обращения: 20.02.2021).

21. Бодров, В.А. Психология профессиональной пригодности : учебное пособие для вузов [Текст] / В.А. Бодров. - М. : ПЕР СЭ, 2001. - 511 с.

22. Божович, Л.И. Проблемы формирования личности [Текст] / Л.И. Божович ; под редакцией Д.И. Фельдштейна ; вступительная статья Д.И. Фельдштейна. 2-е изд. - М. : Издательство «Институт практической психологии»; Воронеж : НПО «МОДЭК», 1997. - 352 с. 
23. Бозиев, Р.С. Отечественная педагогика и образование: между прошлым и будущим [Текст] / Р.С. Бозиев, А.И. Донцов // Педагогика. - 2016. - № 1. - С. 3-11.

24. Болотов, В.А. Компетентностная модель: от идеи к образовательной программе [Текст] / В.А. Болотов, В.В. Сериков // Педагогика. - 2003. - № 10. - C. 8-14.

25. Бордовская, H.В. Деятельностный подход к изучению исследовательского потенциала студента [Электронный ресурс] / Н.В. Бордовская, С.Н. Костромина, С.И. Розум, Н.Л. Москвичева // Международный журнал экспериментального образования. - 2012. - № 1. C. 81-87. - Режим доступа: http://expeducation.ru/ru/article/view?id=2577 (дата обращения: 06.01.2021).

26. Ваганова, Н.О. Системные эффекты университетских комплексов [Электронный ресурс] / Н.О. Ваганова, В.М. Лопаткин // Образование и наука. - 2017. - № 2. - Режим доступа: http://cyberleninka.ru/article/n/sistemnyeeffekty-universitetskih-kompleksov (дата обращения: 22.04.2021).

27. Вазина, К.Я. Рефлексивная технология саморазвития человека [Текст] / К.Я. Вазина. - Н. Новгород : ВГИПУ, 2009. - 166 с.

28. Валеева, Р.А. Учебно-исследовательская работа студентов средство самореализации личности [Текст] / Р.А. Валеева, С.В. Усова // Высшее образование в России. - 2013. - № 9. - С. 91.

29. Валицкая, А.П. Аксиосфера: содержание понятия и его инструментальный статус : коллективная монография [Текст] / А.П. Валицкая [и др.] // В кн. Аксиосфера современности: философско-эстетический анализ и нравственное обоснование социокультурных практик. - СПб. : Астерион, 2013. $-251 \mathrm{c}$.

30. Васильева, Т.В. Проблема формирования ценностных ориентаций студентов [Электронный ресурс] / Т.В. Васильева // Вестник КемГУ. - 2014. - 
№ 2 (58). - Режим доступа: https://cyberleninka.ru/article/n/problemaformirovaniya-tsennostnyh-orientatsiy-studentov (дата обращения: 11.08.2021).

31. Вековцева, Т.А. Основные направления саморазвития преподавателя вуза в профессиональной деятельности [Текст] / Т.А. Вековцева // Фундаментальные исследования. - 2012. - № 11 (2). - С. 326-330.

32. Веракса, Н.Е. Социальная психология : учебник [Текст] / Н.Е. Веракса, А.Н. Веракса. - М. : Академия, 2011. - 228 с.

33. Вербицкий, А.А. Теория и технологии контекстного образования : учебное пособие [Текст] / А.А. Вербицкий. - М. : МПГУ, 2017. - 268 с.

34. Веселов, И.Н. Система управления кластером практикоориентированных научно-технических клубов творческого развития студентов и школьников вуза на базе краудсорсинговой онлайн-платформы [Электронный ресурс] / И.Н. Веселов, А.А. Мальцева, И.Д. Лельчицкий // ОTO. - 2017. - № 2. - Режим доступа: http://cyberleninka.ru/article/n/sistemaupravleniya-klasterom-praktiko-orientirovannyh-nauchno-tehnicheskih-klubovtvorcheskogo-razvitiya-studentov-i-shkolnikov-vuza (дата обращения: 10.01.2021).

35. Витвицкая, Л.А. Развитие взаимодействия субъектов образовательного процесса университета : автореферат дис. ... д-ра пед. наук / Л.А. Витвицкая. - Оренбург, 2012. - 42 с.

36. Витковская, И.Н. Философско-мировоззренческие ориентиры современного образовательного процесса [Текст] / И.Н. Витковская, Е.У.Байдаров // Информационно-образовательные и воспитательные стратегии в современном обществе: национальный и глобальный контекст ; Материалы международной научной конференции. - Минск : Право и экономика, 2010. - 762 с.

37. Габдрахмановна, Р.Г. Об академической мобильности студентов в условиях сетевого взаимодействия [Текст] / Р.Г. Габдрахманова, 
Р.М. Хусаинова, С.Е. Чиркина // Образование и саморазвитие. - 2016. - № 1 (47). - C. 58-64.

38. Галицких, Е.О. Интегративный подход как теоретическая основа профессионально-личностного становления будущего педагога в университете : автореферат дис. ... д-ра пед. наук : 13.00.08 / Е.О. Галицких. Рос. гос. пед. ун-т им. А. И. Герцена. - СПб., 2002. - 43 с.

39. Гапоненко, А.В. Концепция саморазвития личности в современных социально-экономических и природных условиях [Текст] / А.В. Гапоненко. Краснодар : Просвещение-Юг, 2005. - 147 с.

40. Гершунский, Б.С. Образовательно-педагогическая прогностика. Теория, методология, практика [Текст] / Б.С. Гершунский. - Москва : Наука, 2003. -765 c.

41. Гидденс, Э. Последствия современности [Электронный ресурс] / Э. Гидденс // Мониторинг. - 2010. - № 6 (100). - Режим доступа: https://cyberleninka.ru/article/n/posledstviya-sovremennosti (дата обращения: 30.05.2021). 
УДК 371.124 (021)

\title{
Глава 3.
}

ИНТЕГРАЦИЯ ПЕДАГОГИЧЕСКОГО И КАДРОВОГО АУДИТА ПРИ ОЦЕНКЕ УРОВНЯ ПРОФЕССИОНАЛИЗМА ПЕДАГОГОВ

\section{Березина Екатерина Сергеевна}

к.э.н., доцент кафедры управления персоналом

Грязнова Елена Роландовна

к.с.н., доцент, доцент кафедры управления персоналом

\begin{abstract}
Аннотация: Авторы фокусируют внимание на трактовке понятий «образовательный аудит», «педагогический аудит», «кадровый аудит». В ходе исследования был проведен анализ педагогического состава образовательных учреждений, выявлены основные формы и методы повышения уровня профессионализма. Представлены результаты оценки уровня профессионализма педагогов сельских школ, в которых были реализованы программы кадрового аудита.

Ключевые слова: образовательный аудит, педагогический аудит, кадровый аудит, объекты аудита, качество образования, педагогическая деятельность, уровень профессионализма педагога.
\end{abstract}

\section{INTEGRATION OF PEDAGOGICAL AND PERSONNEL AUDIT WHEN ASSESSING THE LEVEL OF PROFESSIONALISM OF TEACHERS}

Berezina Ekaterina Sergeevna Gryaznova Elena Rolandovna 


\section{ЧЕЛОВЕК И СОВРЕМЕННОЕ ОБЩЕСТВО В СОЦИАЛЬНОМ, ПРАВОВОМ, ЭКОНОМИЧЕСКОМ РАКУРСАХ}

Abstract: The authors focus on the interpretation of the concepts of "educational audit", "pedagogical audit", "personnel audit". In the course of the study, the analysis of the teaching staff of educational institutions was carried out, the main forms and methods of increasing the level of professionalism were identified. The results of the assessment of the level of professionalism of teachers of rural schools in which personnel audit programs were implemented are presented.

Key words: educational audit, pedagogical audit, personnel audit, audit objects, quality of education, pedagogical activity, the level of professionalism of the teacher.

Научный интерес к оценке уровня профессионализма педагогов не ослабевает, о чем свидетельствуют многочисленные публикации проектных разработок, результатов педагогических и управленческих исследований.

Вниманию научного сообщества и практикам представлены различные точки зрения на методы оценки уровня профессионализма современного педагога. Среди современных методов признание получил «педагогический аудит». Апробация и адаптация данного метода направлены на оценку работы педагога, повышение его педагогической культуры, выявление проблемных зон при мониторинге педагогической деятельности и их коррекцию. Выполнение оценки профессиональной деятельности в процессе аудита подразумевает, в первую очередь, анализ качества решения различных функциональных задач педагогом. Успешность решения соответствующих функциональных задач обусловливается компетенциями педагога.

Как отмечают авторы, педагогическая деятельность имеет «полифункциональный характер». Ее основные функции характеризуют грани реализации профессии. Педагог опирается на концептуальную функцию при выборе парадигмы, подходов, теорий, методов и образовательных технологий. Конструктивная функция позволяет проводить отбор содержания 


\section{ЧЕЛОВЕК И СОВРЕМЕННОЕ ОБЩЕСТВО В СОЦИАЛЬНОМ, ПРАВОВОМ, ЭКОНОМИЧЕСКОМ РАКУРСАХ}

учебной информации, создавать условия для развития обучающихся. Педагогическая деятельность невозможна без реализации организаторской и коммуникативной функций.

В данной работе внимание сфокусировано на контрольно-оценочной, диагностической и аналитико-рефлексивной функциях педагога. Эффективная реализация обозначенных функций может быть обеспечена применением методов педагогического и кадрового аудита, что в целом направлено на формирование высокого уровня профессионализма педагога. Мы согласимся с позицией Хафизовой Н.Ю., что «профессионализм педагога рассматривается как системное образование, проявляющееся в уровне владения профессиональной деятельностью, который отражает степень сформированности профессиональной компетентности как интегративного личностного ресурса педагога и составляющих ее компетенций» [1, с. 22] .

Многие исследователи склонны считать, что под воздействием изменений, происходящих в обществе и экономике, трансформируются «классические» концепции аудиторского контроля. Возрастание роли человеческих ресурсов в организациях «позитивно влияет на практики аудиторского контроля, который рассматривается как эффективный оценочный метод» [2, с. 164].

В публикациях прослеживаются различные взгляды при определении содержания понятий «образовательный аудит», «педагогический аудит», «кадровый аудит». Единая терминологическая база находится в стадии формирования. Интеграционный характер всех видов аудита в значительной степени зависит от реализуемой программы исследования.

Обзор литературы показал, что образовательный аудит рассматривается «как независимая оценка результатов учебной деятельности специальными аттестационными службами, имеющими сертификат на проведение контрольно-оценочных процедур стандартизированными педагогическими 


\section{ЧЕЛОВЕК И СОВРЕМЕННОЕ ОБЩЕСТВО В СОЦИАЛЬНОМ, ПРАВОВОМ, ЭКОНОМИЧЕСКОМ РАКУРСАХ}

измерителями при соблюдении правил, установленных Законом РФ «Об образовании» или другими нормативными документами» [3, с. 279]. Автор отмечает, что «глубинный смысл объективного контроля в форме аудита заключается не в одноразовых процедурах, а в создании целостной системы обучения и развития на основе самоконтроля, мониторинга, анализа и интерпретации результатов для оценки качества образования и совершенствования образовательной деятельности» [3, с. 282]. В частности Файзуллина Г.З., включает в объекты образовательного аудита «содержание, технологии обучения, организацию управления образовательным процессом, научную и методическую деятельность, системы управления персоналом» $[4$, c. 38$]$.

В целом, современные исследования убеждают, что «обучение и развитие играют ключевую роль в сегодняшней организации рабочего процесса» $[5$, с. 24]. Это в полной мере относится и к обучению методам аудиторского контроля.

По мнению Чикуровой М.В., педагогический аудит - это «экспертиза, характеризующаяся процессом исследования образовательной организации, вынесением оценочных суждений и прогнозом взаимодействий, оказанием методического сервиса по совершенствованию деятельности» [6, с. 204]

В научной литературе существуют и иные подходы к определению педагогического аудита как способа создания ситуации успеха в профессиональном и личностном становлении и развитии учителя. Акцентируется внимание на сложностях выявления проблем аналитикорефлексивного плана опытными педагогами. Авторы связывают объективную необходимость применения методов педагогического аудита с трансформацией концепции управления персоналом и переходом образовательных учреждений к концепции управления человеческими ресурсами [7, с. 146]. 


\section{ЧЕЛОВЕК И СОВРЕМЕННОЕ ОБЩЕСТВО В СОЦИАЛЬНОМ, ПРАВОВОМ, ЭКОНОМИЧЕСКОМ РАКУРСАХ}

Российские исследователи трактуют кадровый аудит как «систему консультационной поддержки, аналитической оценки и независимой экспертизы эффективности деятельности организации по управлению персоналом и регулированию социально-трудовых отношений, которая позволяет выявить соответствие кадрового потенциала организации ее целям и стратегии развития; соответствие деятельности персонала и структурных подразделений управления организацией, существующей нормативноправовой базе; эффективность системы управления персоналом с точки зрения решения задач, стоящих перед персоналом организации, еe руководством, отдельными структурными подразделениями; причины возникающих в организации социальных проблем (рисков) и возможные пути их разрешения или снижения негативного воздействия» $[8$, с. 6$]$.

Обзор теоретических подходов показал, что педагогический и кадровый аудит имеют как общие, так и особенные характеристики. Интеграция методов, на наш взгляд, состоит в направленности диагностических процедур на достижения личности (в контексте нашего рассуждения - уровня профессионализма конкретного педагога). На результаты деятельности оказывает влияние, как образовательная среда, так и реализуемая кадровая политика учреждения.

На наш взгляд, заслуживает внимания опыт проведения кадрового аудита оценки уровня профессионализма педагогов в учреждениях образования Саратовской области. Программы кадрового аудита разработаны под руководством авторов настоящей публикации.

Впервые консультативно-диагностические процедуры были осуществлены в 2015 году в МБОУ «Средняя общеобразовательная школа села Большая Дмитровка Лысогорского района Саратовской области» при поддержке руководства школы. Территориально учреждение образования удалено от райцентра на расстояние 57 км. Микрорайон школы включает в 
себя несколько населенных пунктов. Вся работа с детьми направлена на сохранение здоровья, эмоционального благополучия и развития индивидуальности каждого ребенка. В течение многих лет успешно работают творческое объединение «Аюшка» (сольное пение), «Затейница» (прикладное искусство), «Друг природы» (экологическое направление), «Юный механизатор» (техническое направление), кружки «Умелые руки», «Цветиксемицветик» (ИЗО), «Теремок» (театральное направление), «Исток» (краеведение).

Для организации характерны признаки малокомплектной школы: отсутствие параллельных классов; недостаточное оснащение школы современным оборудованием; малочисленность учительского состава; малочисленность родительского коллектива; низкий образовательный ценз родителей; «педагогическое одиночество» - ситуация, когда при недостаточно развитой сети дорог и транспортных трудностях учителя крайне редко посещают уроки по своей специальности в других школах, а значит, не имеют возможности изучения опыта своих коллег.

При проведении кадрового аудита использованы следующие методы: анализ документов, интервью, анкетирование.

В организации численность педагогических работников составляла на начало 2016 год 15 человек. В динамике за три года отмечалось незначительное увеличение числа педагогов. На 01.01.16 года школа была укомплектована педагогическими кадрами на 100\%. При проведении кадрового аудита был осуществлен анализ педагогического состава по гендерному признаку, возрасту, уровню образования и стажу работы. Большая часть персонала работает в учреждении свыше 10 лет. Это во многом объясняется отсутствием других образовательных учреждений и рабочих мест. В динамике за три года отмечалось старение кадрового состава. Выявлена характерная особенность - наличие персонала, относящегося 
к категории «пожилые лица». Населенные пункты развиваются слабо, отсутствует инфраструктура, которая привлекала бы молодых специалистов. В штате работали педагоги в возрастной категории 60-70 лет. Их доля составляла практически $25 \%$ от общей численности педагогического состава. Только 60\% педагогов имели высшее образование.

В школе организована работа методического объединений: естественноматематического цикла, гуманитарного цикла, классных руководителей; разработана система внутришкольного контроля, предусматривающая систематическое проведение различного вида контроля, мониторинговых мероприятий по учебно-воспитательной работе, образовательных достижений обучающихся. Справки по итогам ВШК рассматривались на заседаниях педагогического совета, методического совета, совещаниях при администрации, заседаниях творческих объединений учителей, проходящих регулярно по плану.

На период проведения кадрового аудита в образовательном учреждении была разработана «Программа повышения профессионального мастерства учителя». Каждый педагог разработал собственный образовательный маршрут. Были организованы выезды учителей на проблемные курсы (1 человек) и участие в работе районных предметных методических объединений. Проведены 2 семинара по обмену опытом. Один учитель прошел аттестацию, ему была присвоена 1 квалификационная категория. Данные приведены на начало 2016 года.

Оценка уровня профессионализма педагогических работников школы проводилась с использованием таких методов как самообследование, оценка результатов обучающихся, оценка родителями, то есть методов, которые можно отнести к методам педагогического аудита. При проведении аудита были изучены публичные отчеты директора школы. По итогам предыдущего 2014-2015 учебного года состояние качества образовательных услуг данной 
школы следующее: все выпускники 9 класса сдали ОГЭ; наличие высоких тестовых баллов по результатам ЕГЭ по обществознанию; наличие большого количества элективных курсов: по 8 курсов в 10 и 11 классах. Выделены проблемные зоны: невысокое качество знаний по русскому языку, демонстрируемое на административных контрольных работах и ГИА; не все выпускники 11-х классов сдали ЕГЭ и получили аттестаты; отсутствие аттестатов с отличием; результаты ГИА по всем предметам, кроме обществознания и химии в 11 классе ниже региональных результатов; снижение показателей качества знаний по результатам ЕГЭ по математике и русскому языку.

Эффективность работы образовательного учреждения по результатам анкетирования родителей представлена на рис 1.

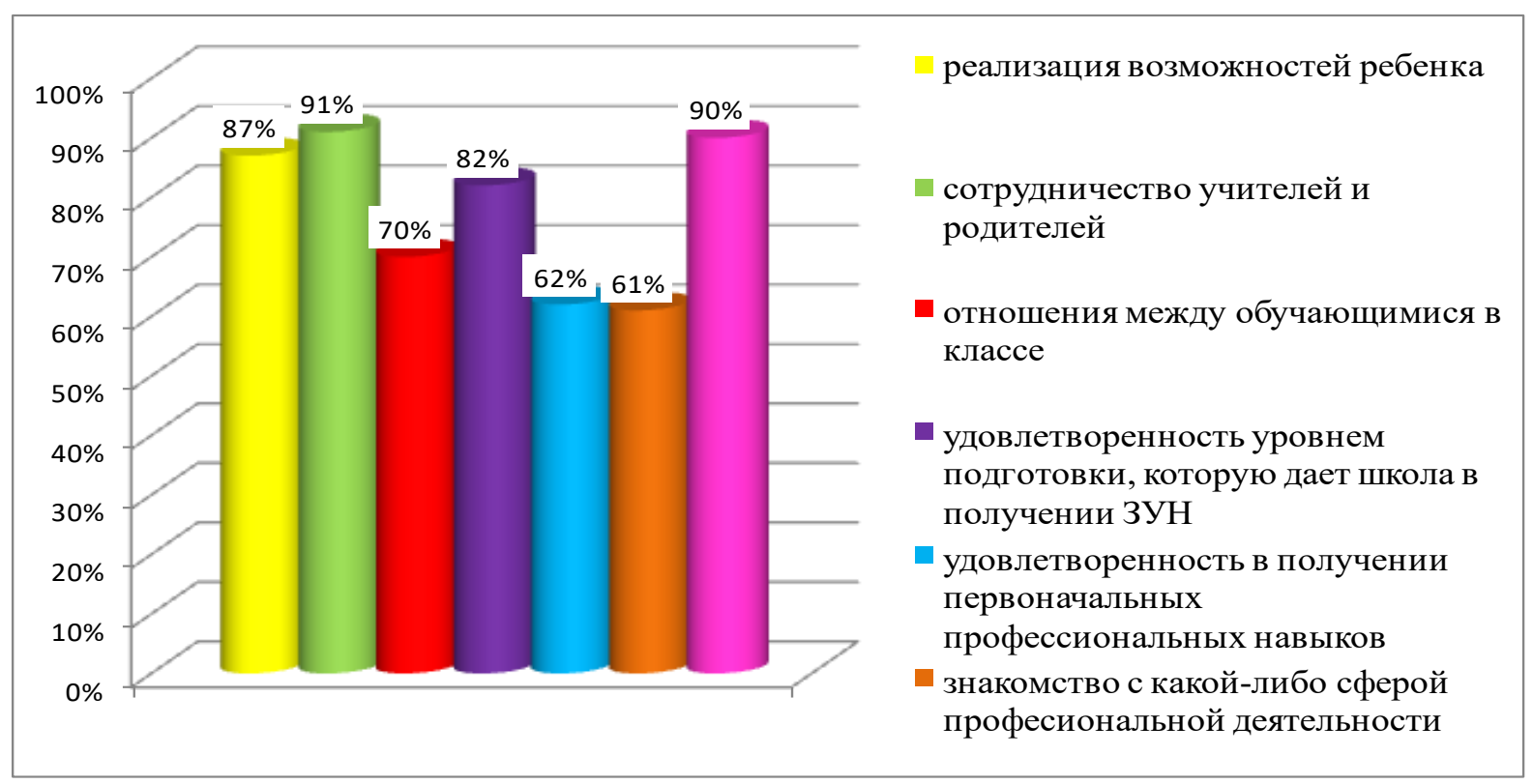

Рис. 1. Результаты анкетирования родителей (\%)

Большинство респондентов-родителей считает, что в школе созданы хорошие условия для реализации возможностей ребенка, его интересов; комфортная, безопасная, миролюбивая обстановка; высокий уровень 
сотрудничества учителей и родителей; высокий уровень проведения общешкольных мероприятий.

Проведено интервью с директором школы, в котором отмечено, что молодые педагоги не приезжают в село, ставку можно делать только на выпускников школы, но это сложно. Работа педагогов за многие годы отмечена высокими наградами, мотивация к овладению новыми компетенциями и педагогическими технологиями снижена. Директор отметил неэффективное использование возможностей онлайн-обучения.

Были опрошены учителя (выборка 100\%). Было предложено выделить по значимости факторы, которые будут способствовать повышению профессионализма. Основные результаты представлены на рис. 2.

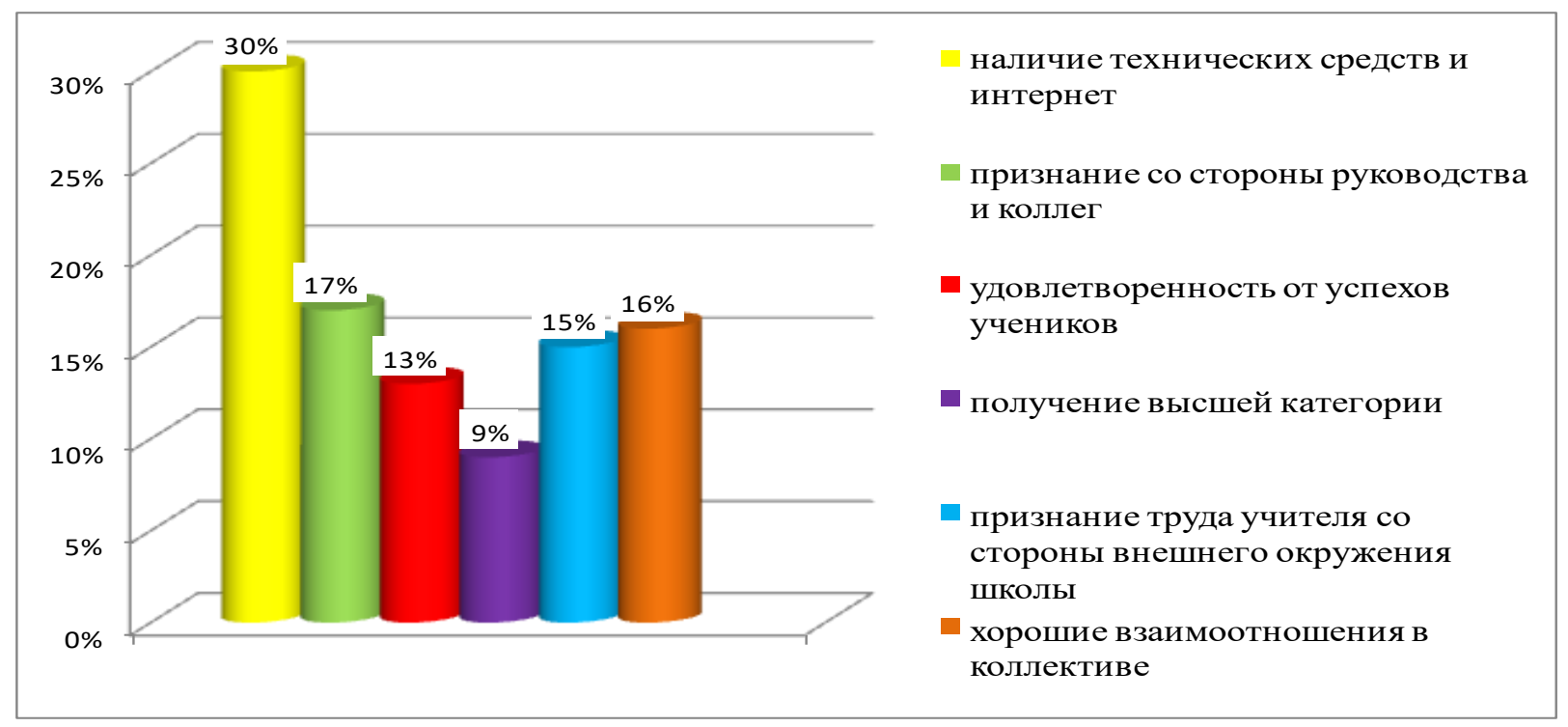

Рис. 2. Факторы, способствующие повышению уровня профессионализма педагогов школы (\%)

Из распределения следует, что большая часть респондентов связывает повышение уровня профессионализма с организационной составляющей, а именно наличием доступа к техническим средствам и интернет. Только 9\% респондентов хотели бы получить высшую квалификационную категорию. 
Среди сильных сторон, выявленных в ходе кадрового аудита, были отмечены: стабильность кадрового состава, большой стаж работы в данном образовательном учреждении, представление Портфолио учителей на сайте школы.

За высокий профессионализм педагоги отмечены наградами. На период проведения исследования педагоги имели следующие награды и звания: звание Заслуженный учитель РФ - 1 чел., награждены значком «Отличник народного образования» - 2 чел., звание «Почетный работник общего образования РФ» - 3 чел., награждены Почетной грамотой министерства образования и науки РФ - 3, награждены Почетной грамотой министерства образования Саратовской области - 2 учителя.

Минусом в работе педагогов отмечена тенденция снижения за три года представления «своего» опыта на муниципальном уровне (73\% учителей школы), сократилось количество публикаций педагогов, представляющих опыт профессиональной деятельности; все педагогические работники готовят для проведения занятий презентационные материалы, но их качество не на высоком уровне. Характерным для исследуемого периода был факт создания «очередности» при заполнении электронного дневника ввиду ограниченности доступа к интернет.

В МБОУ СОШ «Село Большая Дмитровка» проблему повышения уровня квалификации и профессиональной компетенции педагогических работников было предложено решить посредством более широкого применения таких методов повышения квалификации как дистанционное обучение и подготовки публикаций по предметному направлению. Был проведен однодневный обучающий семинар для всех педагогических работников на тему «Мировые библиотечные ресурсы и мой авторский профиль». При участии учителя информатики организован и проведен мастеркласс «Презентация как средство визуализации». 
Следует сказать, что в последующие годы осуществлялась обратная связь с руководством школы. В период пандемии большая часть педагогов осуществляла проведение занятий в режиме онлайн. Произошла сменяемость кадров и кадровый состав пополнился тремя молодыми педагогами, активизировалась работа по адаптации молодых специалистов.

В 2021 году при поддержке руководства школы проведен кадровый аудит в МБОУ «Средняя общеобразовательная школа с. Озерки Калининского района Саратовской области». Образовательная организация реализует программы начального общего, основного общего и среднего общего образования.

За период 2018-2020 численность персонала постепенно возросла и составила 28 человек. Добавились новые штатные единицы в связи с внедрением центров образования цифрового и гуманитарного профилей «Точка роста» в рамках нацпроекта «Образование» в сельских школах и образовательных организациях. Для реализации данного проекта потребовалось привлечение новых специалистов.

Было проведен анализ наличия у педагогов квалификационных категорий (рис. 3)

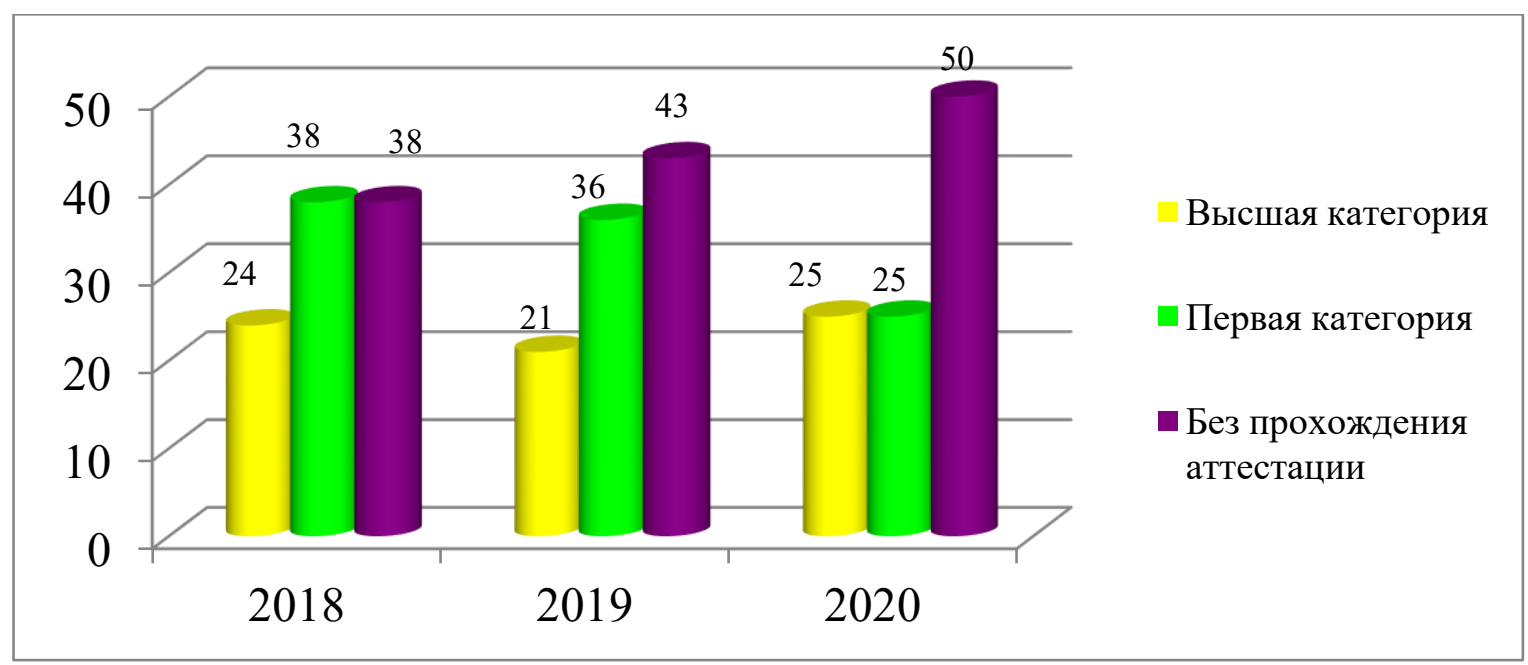

Рис. 3. Наличие у педагогов квалификационных категорий (\%) 


\section{ЧЕЛОВЕК И СОВРЕМЕННОЕ ОБЩЕСТВО В СОЦИАЛЬНОМ, ПРАВОВОМ, ЭКОНОМИЧЕСКОМ РАКУРСАХ}

Наблюдается тенденция к росту количества педагогических сотрудников без прохождения аттестации для получения квалификационной категории. Снижение тенденции педагогов с высшей и первой категории говорит о том, что педагогические кадры слабо мотивированы в повышении профессионализма. В 2020 году 8 педагогов (50\%) имели: первую квалификационную категорию - 4 человека, высшую - 4 человека. 88\% педагогов прошли за последние 2 года курсы повышения квалификации.

Анализ педагогов по возрасту показал, что доля молодых педагогов в категории от 21 года до 30 лет составляют 7\%. Преобладает персонал в возрастной категории от 51 года до 60 лет, что составляет на данный момент $57 \%$ от общей численности. Текучесть в организации довольно низкая и притока молодых специалистов практически нет, что в целом характерно для сельских школ.

В организации преобладают педагоги со стажем более 15 лет, что составляет около 40\% от всех сотрудников. Из этого следует, что коллектив опытный, который стабильно и слажено функционирует. Также в организации наблюдается благоприятный социально-психологический климат. Однако, как было сказано выше, очень мало молодых специалистов, которые смогли бы привнести новые идеи в образовательный процесс, активизировать разработку и апробацию авторских образовательных методик.

Основные формы повышения профессионализма педагогов: методические советы, проблемные семинары, научные конференции, самообразование, аттестация, курсы повышения квалификации.

Было проведено анкетирование педагогов. Выборка сплошная. $57 \%$ респондентов отметили, что повышают свой профессионализм раз в год или чаще, это в основном более молодые сотрудники с небольшим стажем работы в организации. У них довольно высокая мотивация и стремление к профессиональному развитию. Менее половины сотрудников отметили, что 


\section{ЧЕЛОВЕК И СОВРЕМЕННОЕ ОБЩЕСТВО В СОЦИАЛЬНОМ, ПРАВОВОМ, ЭКОНОМИЧЕСКОМ РАКУРСАХ}

повышают свой профессионализм раз в несколько лет, это в основном опытные сотрудники с высоким стажем работы, которым присвоена первая или высшая квалификационная категория.

12\% опрашиваемых отметили, что им не предоставлялась возможность для повышения их профессионализма, это новые сотрудники, которые работают в организации менее 1 года. За последние 3 года в организации курсы повышения квалификации прошли 88\% педагогов. Это необходимая процедура, которая регламентирована Ф3 «Об образовании».

62\% педагогов не нацелены на повышение уровня профессионализма, прохождение курсов повышения квалификации носит для них больше «принудительный характер». К данной категории относятся сотрудники старшей возрастной категории, у них отсутствует мотивация для дальнейшего профессионального роста.

За последние два года педагогами были пройдены следующие курсы: «Традиции и новаторство в преподавании русского языка»; «Преподавание истории в рамках ФГОС»; «Работа с одаренными детьми в начальной школе в соответствии с ФГОС»; «Проектирование деятельности учителя второго иностранного языка в условиях реализации ФГОС»; «Теория и методика преподавания истории и обществознания» и другие.

Пандемия коронавируса 2020 года активизировала развитие цифрового образования, цифровых ресурсов и цифровых технологий. Педагоги в активном режиме перешли на проведение занятий в дистанционном формате. Из-за проблем с техническим оснащением было сложно «влиться» в данный формат.

Во время пандемии дистанционно были пройдены следующие курсы: «Безопасное использование сайтов в сети «Интернет» в образовательном процессе в целях обучения и воспитания обучающихся в образовательной организации»; «Основы обеспечения информационной безопасности детей» и 
«Профилактика короновируса, гриппа и других острых респираторных вирусных инфекций в образовательном учреждении».

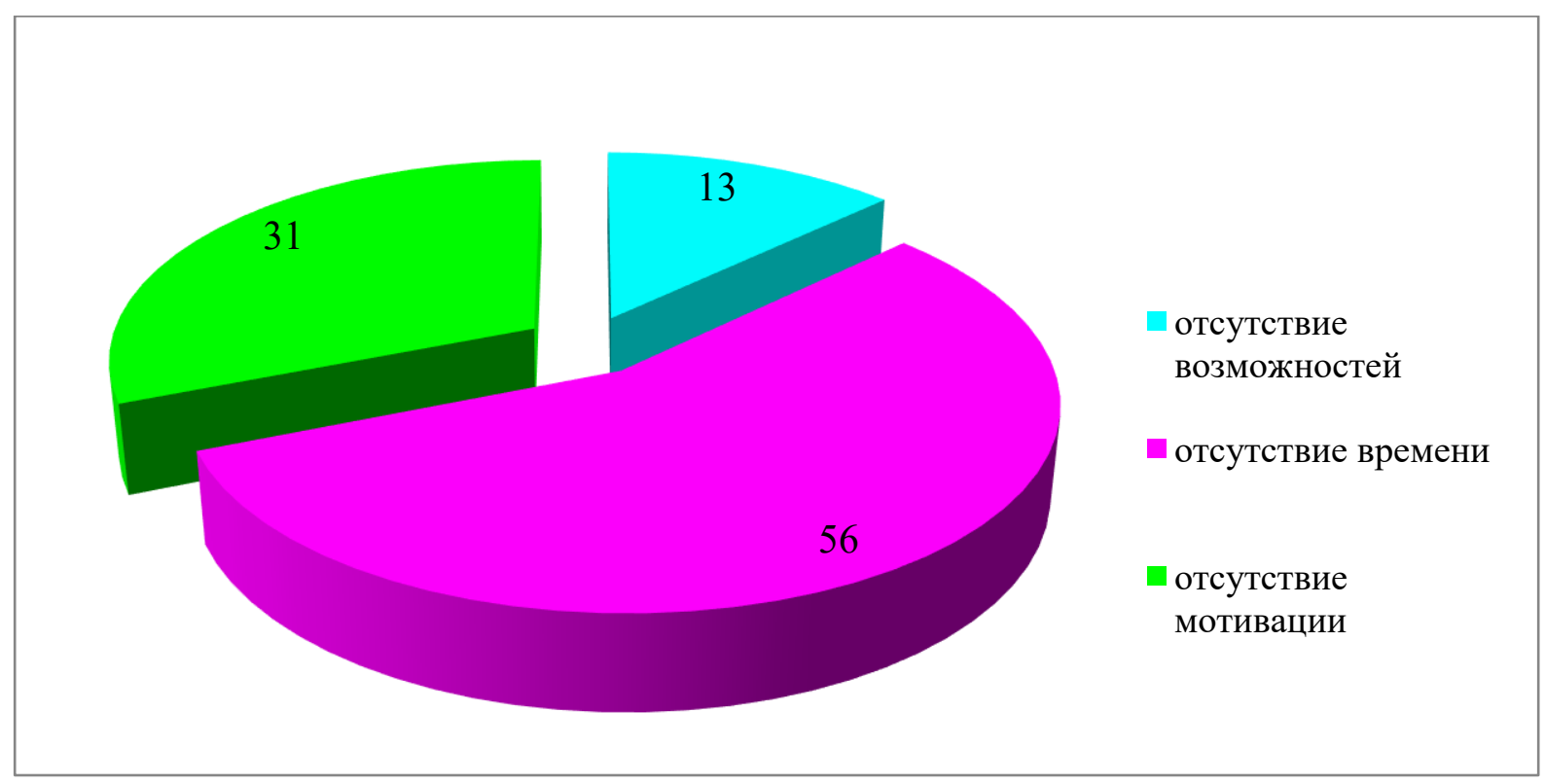

Рис. 4. Факторы, препятствующие повышению уровня профессионализма (\%)

Среди факторов, препятствующих повышению профессионализма более половины - 56\% сотрудников отметили такой фактор, как отсутствие времени. Они объясняют это тем, что увеличилось время подготовки к занятиям, в том числе с введением онлайн-формата. Сложно в этот график добавить еще и повышение уровня профессионализма. 31\% респондентов отметили, что снижена мотивация, так как индивидуальные карьерные траектории реализованы в связи с возрастными критериями.

На наш взгляд, интересны ответы о влиянии пандемии на повышение уровня профессионализма. Во время пандемии дистанционно были пройдены следующие курсы: «Безопасное использование сайтов в сети «Интернет» в образовательном процессе в целях обучения и воспитания обучающихся в образовательной организации»; «Основы обеспечения информационной 


\section{ЧЕЛОВЕК И СОВРЕМЕННОЕ ОБЩЕСТВО В СОЦИАЛЬНОМ, ПРАВОВОМ, ЭКОНОМИЧЕСКОМ РАКУРСАХ}

безопасности детей» и «Профилактика короновируса, гриппа и других острых респираторных вирусных инфекций в образовательном учреждении».

$28 \%$ сотрудников отмечает, что пандемия открыла новые возможности для повышения их профессионализма. Она подтолкнула к освоению цифрового пространства, пришлось учиться осваивать новые форматы преподавания с помощью различных систем. Также у преподавателей появилась возможность проходить разнообразные курсы дистанционно, без отрыва от дома. Большая часть респондентов считает, что пандемия затруднила процесс повышения их профессионализма, так как они столкнулись с техническими проблемами: отсутствие достаточного количества техники; часть имеющейся техники устарела; отсутствие знаний для работы с необходимыми информационными системами.

Опираясь на результаты кадрового аудита, было предложено провести для педагогов тренинг по тайм-менеджменту с использованием видео и аудио материалов. Тренинг по тайм-менеджменту позволит педагогам научиться грамотно управлять своим временем. Целесообразно организовать бесплатные курсы для педагогов по обучению методам подачи материалов с помощью различных онлайн-платформ с выдачей сертификатов государственного образца о пройденном обучении.

Приведенные примеры отражают в динамике проблемы повышения уровня профессионализма в сельских школах, выявленные методами кадрового и педагогического аудита, но не претендуют на их полный охват. Опыт показал, что имеют место факторы старения кадрового состава, отсутствуют или недостаточно развиты инструменты поддержки молодых педагогов. С 2020 года объективным фактором активизации цифрового образовательного пространства признана пандемия короновируса. Не все сельские школы оказались готовы к работе в онлайн-формате. Положительной тенденцией является готовность педагогов обучаться, накапливать и 
передавать опыт и максимально использовать технические возможности сельских образовательных учреждений.

Таким образом, на сегодняшний день положительный эффект от применения кадрового и педагогического аудита очевиден. Его результаты находят понимание как у руководителей, так и непосредственно у педагогов. С позиции управления, внедрение методов педагогического и кадрового аудита имеет большое значение, так как расширяются возможности адресного создания условий для саморазвития учителя, повышения уровня его профессионализма, мобильности его индивидуальной траектории развития при реализации кадровой политики.

\section{Список литературы}

1. Хафизова Н.Ю. Диагностика уровня профессионализма педагога образовательной организации // Инновационные проекты и программы в образовании.-2019.- №3.-с.20-24

2. Грязнова Е.Р., Синчугова А.В. Использование кадрового аудита как технологии внутренней оценки системы управления персоналом производственного предприятия: практический ракурс // Социальноэкономические процессы в условиях модернизации экономики: современные вызовы, глобальные трансформации и стратегические ориентиры развития / Под ред. Подкопаева О.А. - Самара: ООО НИЦ «ПНК», 2021. - с. 164-177

3. Ефремова Н.Ф. Образовательный аудит как форма педагогической поддержки // Сборник научных трудов НПК с международным участием «Социокультурные проблемы развития образования в условиях проектного управления (22-23 марта 2018)» / Под общей ред. Абакумовой И.В., Елагиной М.Ю., Чумак И.В. - М.: КРЕДО, 2018.- с. 275-290 
4. Файзуллина Г.З. Образовательный аудит как способ обеспечения гарантий качества образовательного учреждения // Вестник КИГИТ.-2012.№11 (29).- c.34-39

5. Андрющенко О.В., Березина Е.С. Эффективная система обучения и развития персонала как фактор конкурентоспособности современной организации. // Инновационное развитие как фактор конкурентоспособности национальной экономики: монография [под ред. А.А. Сукиасян] - Уфа: Аэтерна, 2021. С. 4-24.

6. Чикурова М.В.Педагогический аудит как функция управления образовательной организацией // Инновационные процессы в образовании: стратегия, теория и практика развития. Материалы VI Всероссийской научнопрактической конференции. Научные редакторы: Е.М. Дорожкин, В.А. Федоров.- Издательство РГППУ, Екатеринбург.-2013.-с.204-205

7. Иванова А.П. Аудит как способ реализации личностного и профессионального роста учителя в современной школе // Ученые записки ЗабГГПУ.-2010.-№5 (34).- c.144-149

8. Софиенко А.В. Аудит и контроллинг системы управления персоналом: учебное пособие / А.В. Софиенко.- Москва: ФГБОУ ВПО «РЭУ им Г.В. Плеханова».-2015.-100 с.

(C) Березина Е.С., Грязнова Е.Р., 2022 
УДК 378

Глава 4.

ОСОБЕННОСТИ ПРЕПОДАВАНИЯ ПРЕДМЕТА

«МАТЕМАТИЧЕСКОЕ МОДЕЛИРОВАНИЕ»

В ТРАНСПОРТНОМ ВУЗЕ

\begin{abstract}
Катаева Лилия Юрьевна
д.ф.-м.н., профессор

Самарский государственный университет путей сообщения

(филиал СамГУПС в г. Нижнем Новгороде)
\end{abstract}

\begin{abstract}
Аннотация: Внедрение бережливых технологий на транспорте вовлекает в процесс принятия решений все уровни планирования. Это приводит к необходимости повышать степень согласованности принимаемых решений с целью оптимизации работы всей транспортной сети и снижения нагрузки на нее, но при этом важной целевой составляющей остается доступность перевозок на железнодорожном транспорте. В работе показано, что большая востребованность инженерных кадров и оказываемое ими влияние на развитие производства, а также многовариантность решаемых задач определили повышение требований к их профессиональной подготовке, знаниям и владению не только информационными технологиями, но и умению решать профессиональные задачи на основе математического моделирования с привлечением методов оптимизации и численных методов. Показано, что в рамках данного предмета необходимо научить будущего инженера осуществлять декомпозицию задачи управления, формулированию их с точки зрения математики и формированию целевой функции. С точки зрения методологии преподавания данной дисциплины и формирования
\end{abstract}


заинтересованности студента необходимо учитывать специфику решаемых на производстве задач.

Ключевые слова: высшее профессиональное образование, математическое моделирование, транспортный унаверситет.

\title{
PECULIARITIES OF TEACHING THE SUBJECT OF MATHEMATICAL MODELING IN TRANSPORT UNIVERSITIES
}

\section{Kataeva Liliya Yurievna}

\begin{abstract}
The introduction of lean technologies in transportation involves all levels of planning in the decision-making process. This leads to the need to increase the consistency of decisions made in order to optimize the operation of the entire transport network and reduce the load on it, but at the same time an important target component remains the availability of transportation on the railway transport. The paper shows that the high demand for engineering personnel and the impact they have on the development of production, as well as the multivariate nature of the tasks to be solved determined the increased requirements for their professional training, knowledge and possession not only of information technology, but also the ability to solve professional problems based on mathematical modeling with the involvement of optimization methods and numerical methods. It is shown that within the framework of this subject it is necessary to teach the future engineer to carry out decomposition of control problems, formulating them in terms of mathematics and formation of the target function. From the point of view of the methodology of teaching this discipline and the formation of the student's interest it is necessary to take into account the specifics of the problems to be solved in production.
\end{abstract}




\section{ЧЕЛОВЕК И СОВРЕМЕННОЕ ОБЩЕСТВО \\ В СОЦИАЛЬНОМ, ПРАВОВОМ, ЭКОНОМИЧЕСКОМ РАКУРСАХ}

Key words: higher professional education, mathematical modeling, university of transport.

\section{Значение математического моделирования при подготовке бакалавров в транспортном вузе}

В условиях сформированного информационного и технологизированного общества и в условиях требований развития личности, предмет математическое моделирование становится неотъемлемой связующей частью образовательного процесса при подготовке бакалавров в транспортном вузе. Именно данный предмет объединяет в себе возможности комплексного формирования интереса и мотивации обучающихся, т.к. позволяет показать наглядно студенту аспекты практической применимости полученных навыков на таких предметах как математика и информатика к решению профессиональных задач обеспечения работы железнодорожного транспорта. Особенно это актуально на фоне общего падения интереса студентов, рассматривающих математику как формально-логическую и теоретическую науку.

Именно данный предмет позволяет систематизировать знания и возможности наглядно показать весь процесс моделирования, начиная от анализа словесной формулировки задачи к математической ее интерпретации, дальнейшем ее решение с применением различных методов ее решения. Обладая большим потенциалом с точки зрения формирования мотивации к учебно-познавательной деятельности данный предмет выходит на первый план при формировании профессиональных компетенций и умений применять на практике полученные знания [1-3].

Следует отметить, что сам метод математического моделирования не нов и имеет богатую историю его использования в педагогике. 


\section{ЧЕЛОВЕК И СОВРЕМЕННОЕ ОБЩЕСТВО В СОЦИАЛЬНОМ, ПРАВОВОМ, ЭКОНОМИЧЕСКОМ РАКУРСАХ}

Математическое моделирование является инструментом познавательной, научной и практической деятельности человека [4-6]. Еще в школе учащиеся сталкиваются с элементами математического моделирования при решении задач на составление уравнений. Однако выделение данного метода в самостоятельную дисциплину произошло лишь с возможностью широкого применения компьютерной техники.

Особенно актуально использование математического моделирования на практике стало в современных условиях конкуренции. Использование навыков полученных при изучении математического моделирования позволяет современному инженеру осуществлять поиски оптимальных решений в своей профессиональной деятельности для более рационального использования ресурсов или организации производственных и технологических процессов на железнодорожном транспорте.

Данный предмет ориентирован на системное изучение профессиональных задач с помощью математических моделей микро- и макроуровней, а также в разрезе решения профессиональных задач. Преимущества математического моделирования в том, что изучаемый объект интерпретируется моделью, которую затем можно изучать и анализировать с помощью инструментария математики, вычислительной техники с привлечением методов оптимизации и численных методов. Практическая ценность математического моделирования как раз в том, что при изучении модели формулируются выводы относительно самого исследуемого объекта. Все это позволяет решить одну из важнейших проблем педагогики и психологии - проблему мотивации интереса и познавательной активности студента. Следует отметить, что именно мотивы - главная движущая сила учебного процесса [7 - Error! Reference source not found.].

Высокого уровня мотивации у студента к образовательному процессу можно достичь только в условиях правильно сформированного образа его 
будущей профессиональной деятельности и личной заинтересованности в изучении математического моделирования, поэтому при изучении данного предмета важно наглядно показать применимость к конкретной профессиональной деятельности [7]. Важно сформировать целую логическую цепочку профессиональной подготовки, где математическое моделирование становится важным инструментом при решении конкретных, связанных с будущей профессией задач и придающий образовательному процессу личностный смысл с одной стороны, но при этом важно не упускать обобщение моделей на более общие случаи. В этом случае студент будет мотивирован на глубокое изучение материала в сулее того, что у него будет понимание, как изучаемый материал может ему помочь при решении профессиональных задач, характерных для инженера железнодорожного транспорта. Предмет математическое моделирование имеет тесную связь со всеми предметами, изучаемыми в вузе (математика, физика, химия и другие), а также с профессиональными, изучаемыми на старших курсах. Все это определяет важнейшее место данного предмета в системе подготовки бакалавров транспортных вузов.

\section{Мировые тенденции современности высшего образование и усиление} важности изучения предмета «Математическое моделирование» в транспортном вузе

Ускорение процессов глобализации и мобильности стали отличительной чертой общества и высшего образования после 1995 года. В результате этих процессов произошли структурные изменения на рынке труда и вырос интерес к получению высшего образования. Экспоненциально выросший спрос на высшее профессиональное образование, наличие ограничивающих составляющих: технологического фактора и ресурсов привели к дисгармонии 
в высшем образовании. Выросла потребность в улучшении качества образования возникла острая необходимость в высококвалифицированных кадрах, способных оптимизировать и совершенствовать все технологические процессы, в том числе на железнодорожном транспорте [8-10]. Основным тормозящим звеном при переходе к массовому высококачественному дистанционному образованию стало отсутствие технических возможностей [11] при этом в России остается высокое качество подготовки специалистов при использовании контактных методов обучения.

Однако условия пандемии 2019 года внесли свои коррективы и в развитие новых тенденций высшего образования. Внедрение технологий дистанционного образования уже стали неотъемлемой частью современного высшего образования. В этот период стали более активно использоваться возможности дистанционного образования с элементами интерактивности на основе методов моделирования [12-14]. При этом кардинально стали меняться и мировые тенденции в высшем образовании. Главным и определяющим фактором успешного развития страны и ее безопасности становится высшее образование $[15,16]$.

Происходящие трансформации современности привели к возрастающей сложности самой системы образования и изменению условий труда и требований к профессиональной деятельности самих преподавателей. На фоне создания новых технологий происходит постоянная модернизация производства, и формируются требования к специалистам нового поколения.

Сегодня уже требуются не просто высоко квалифицированные специалисты способные решать типовые задачи, а наиболее востребованными становятся специалисты способные на поиск новых творческих нестандартных решений. При усилении спроса на высшее образование происходит повышение его стоимости. Если образование имеет государственное финансирование, то оно тоже растет, а в странах без 


\section{ЧЕЛОВЕК И СОВРЕМЕННОЕ ОБЩЕСТВО В СОЦИАЛЬНОМ, ПРАВОВОМ, ЭКОНОМИЧЕСКОМ РАКУРСАХ}

бюджетного финансирования расширяются программы его кредитования. Одной из таких стран является США с задолженностью по этим программам более одного трлн. долларов. При повышении издержек на получение высшего образования возникли новые тенденции по их сокращению при создании новых образовательных платформ на базе объединения крупных вузов [11] и формированию сетевого образования по всему миру, но при этом сохраняется дефицит на качественное образование. Огромным преимуществом развитых стран возможности по расширению виртуальных университетов и привлечению к обучению потока желающих из развивающихся стран, что существенно снижает издержки на образование.

К сожалению, Россия пока не является мировым лидером в высшем образовании. Большой перечень проблем образования сформировался в результате непонимания со стороны государства степени важности высшего образования. Процесс самовыживания государственных вузов и целевое обогащения негосударственных, перераспределение финансовых ресурсов не в пользу государственных нанесло огромный ущерб системе образования Росси в целом. Данные процессы сопровождались резким падением престижа и заработных плат работников образования, что в свою очередь привело к ее разрушению, потере кадрового потенциала и спровоцировало кризис в Российском образовании. 90-е годы стали самыми тяжелыми для высшего образования. Отсутствие полноценного финансирования привело к старению оборудования Вузов, отсутствию возможности полноценного поддержания образовательного процесса и активному поиску новых источников финансирования в виде легальных платных образовательных услуг [11].

Другим негативным аспектом, отразившимся на высшем образовании стало нарастание кадрового дефицита в средней школе. Он привел к увеличению наполняемости классов и существенному снижению качества среднего образования и сейчас это отражается на высшем образовании. 
Непропорциональный рост зарплат в сфере образования привел к оттоку талантливых молодых педагогов из школы и вузов в более привлекательные отрасли. Сформировавшаяся демографическая яма только усугубила ситуацию и привела к существенному уменьшению Вузов. Явное отставание России на фоне глобальной трансформации высшего образования привело к пониманию того, что существует диалектическая связь развития и высшего образования. Невозможно развивать страну при отсутствии системы качественного высшего образования. Формируется новая архитектура системы высшего образования, включающая в себя национальноисследовательские, национальные и опорные университеты. Для увеличения доли участия в мировом сегменте реализуется проект «5-100». Предпринимаемые усилия со стороны государства конечно благотворно сказываются на развитии системы образования, но Россия до сих пор существенно отстает от мировых лидеров в создании виртуальных университетов, а приоритетной остается традиционная система образования, а показатель индекса человеческого развития остается низким и сейчас.

Как показал анализ общемировых и внутригосударствененых тенденций [11] именно высшее профессиональное образование играет ключевую роль и способствует формированию его кадрового потенциала. В работах [11-16] показано, что для обеспечения прогресса, независимости и обеспечения экономической безопасности необходима хорошо сбалансированная и динамично развивающаяся системы образования, позволяющая готовить современных инженеров железнодорожного транспорта высокого уровня.

Сегодня железнодорожный транспорт как никогда нуждается в новом поколении талантливых инженеров, способных решать локальные и глобальные профессиональные задачи. Особенно это важно в условиях конкурентной борьбы, требующей изыскивать внутренние резервы для внедрения бережливых технологий на транспорте, и, вовлекает в процесс 
принятия решений все уровни планирования. Осуществление оптимизации работы всей транспортной сети требует от инженеров железнодорожного транспорта всех уровней поиска нестандартных и инновационных решения для снижения нагрузки на нее и сохранением доступности перевозок.

Для подготовки таких инженерных кадров необходимо не только показать современному студенту возможности использования математического моделирования для решения профессиональных задач, но и научить такие задачи формулировать, перводить их на формальный язык математики и решать с использованием современных средств. Поэтому прикладная направленность становится не просто важным аспектом в обучении, а жизненно необходимой реальностью $[11,14]$ в преподавании такой дисциплины как математическое моделирование. При обучении математическому моделированию необходимо формировать навыков решения профессиональных задач по конкретным направлениям и специальностям. Необходимо создавать и использовать методические разработки, включающие решение задач, характерных для этих специальностей по математике, численным методам, математическому моделированию и других [19-22], а для технических специальностей необходимо делать упор на задачи, характерные для соответствующего направления подготовки по математике, численным методам и методам решения задач естествознания $[19,22]$ и включать задачи характерные для железнодорожного транспорта [18].

Как отмечалось в работе [14] для устранения перекоса в сторону изучения абстрактных задач, возникающего при изучении математики необходимо при изучении предмета математическое моделирование показать связь абстрактных задач с прикладными и профессиональными задачами. Выделены процессы и компоненты математического моделирования, а также авторы сформулировали дидактические функции и акцентировали внимание на практическую направленность преподавания математики. 


\begin{abstract}
Именно прикладная направленность в обучении предмета математическое моделирование позволяет развивать у студента математической культуры в целом и позволяет осознать взаимосвязи с другими предметами. Необходимо делать акценты при решении практических задач на правдоподобность и логические аспекты решения.

Методологическая проблема практической направленности не является новой. Она детально изучена в работах В.М. Монахова, В.В. Фирсова, А.В. Усовой и другими авторами, а проблемы прикладной ориентированности математики были рассмотрены в работах В.А. Стукалова, С.С. Варданяна, Г. Трелиньски и других.
\end{abstract}

Механизмы реализации прикладной направленности с точки зрения психологии изучены в работах Н.А. Мечинской, Н.Ф. Талызиной, П.Я. Гальперина и других.

Но не смотря на большое количество проводимых исследований проблемы практической направленности не нашла должного теоретического и практического решения. До сих пор не существует единого мнения по проблеме прикладной направленности предмета. Наиболее полно на современном этапе развития разработан только этап математического решения, но этого не достаточно, т.к. предмет математическое моделирование должен включать в себя все этапы начиная от словесной формулировки, формализации ее записи на языке математики, обоснованного выбора средств и инструментов ее решения, реализация самого решения и анализ полученных результатов. Для осуществления преподавания такой сложной дисциплины необходимо привлекать высококвалифицированные кадры - хорошо знающие математику, суть и особенности профессиональных задач, возникающих на железнодорожном транспорте с учетом специализации, умеющих осуществлять формализация задач, а также знающие инструменты для их решения. 


\section{ЧЕЛОВЕК И СОВРЕМЕННОЕ ОБЩЕСТВО В СОЦИАЛЬНОМ, ПРАВОВОМ, ЭКОНОМИЧЕСКОМ РАКУРСАХ}

Как показано в работе [14] математическое моделирование выполняет такие дидактические функции, как познавательную, управление деятельностью обучающегося, интерпретационную, эстетическую и функцию моделирования. На основе проведенного эксперимента авторы показали, что включение взаимосвязей между предметами математика и математическое моделирование оказало существенное влияние на эффективность усвоения материала.

Таким образом, при изучении дисциплины «Математическое моделирование» студенты не только должны овладеть теоретическими и практическими навыками анализа профессиональных задач, связанных с совершенствованием систем и процессов на железнодорожном транспорте, но и научиться самостоятельно, изучать литературу по математическому моделированию и практическому использованию полученных знаний.

Учебно-методический комплекс, реализуемый через интерактивные и анимационные модели учебной деятельности, использующий информационно-коммуникационные технологии, учитывающие вариативность и индивидуализацию профессионального образования, имеет блочную структуру и включает в себя:

- лекционно-теоретический блок, содержащий электронный учебник «Математическое моделирование систем и процессов» с иллюстрациями, рисунками, схемами, а также комплексом анимационных и интерактивных моделей с учетом направлений подготовки бакалавров;

- практически-тренирующий блок, имеющий примеры решения профессиональных задач с учетом направлений подготовки бакалавров;

- тестирующий блок, интегрированный с базой задач, содержащий тесты и типовые задачи;

- справочно-информационный блок, содержащий список основных формул, используемых в расчетах, постоянных и глоссарий терминов; 
- профессиональный блок, включающий примеры выполнения исследовательских работ с учетом специальности, а также комплекс анимационных и интерактивных моделей;

- телекоммуникационный блок, содержащий предметный поиск по ключевым словам, систему помощи с путеводителем по курсу и инструкциями по работе;

- блок информационной безопасности;

- блок методической поддержки курса, включающий комплекс методических разработок, рекомендуемый список литературы по различным темам курса.

Начиная осуществлять моделирование простых задач оптимизации с использованием таких пакетов прикладных программ как Excel и MathCad позволяет студенту освоить сами принципы моделирования и наглядно увидеть весь процесс начиная от словесной формулировки задачи и ее ограничений, формализации записи ее на языке математики до реализации в пакетах прикладных программ. Однако, для решения более сложных профессионально ориентированных задаче необходимо создание интерактивных моделей.

Использование профессионально ориентированных интерактивных моделей, позволяет студенту, варьируя заданные параметры, изучать процессы в системах. Приведем один из примеров такой модели для моделирования, изучения и анализа переходных процессов в электрической цепи. Студент может изменяя параметры задачи и методы ее решения осуществлять наблюдения за изменением возникающих в цепи силы тока и напряжения, а также определять количество теплоты, выделяемой на определенном резисторе за указанный промежуток времени. Такая интерактивная модель позволяет выполнить численные расчеты на любом изучаемом языке программирования. 


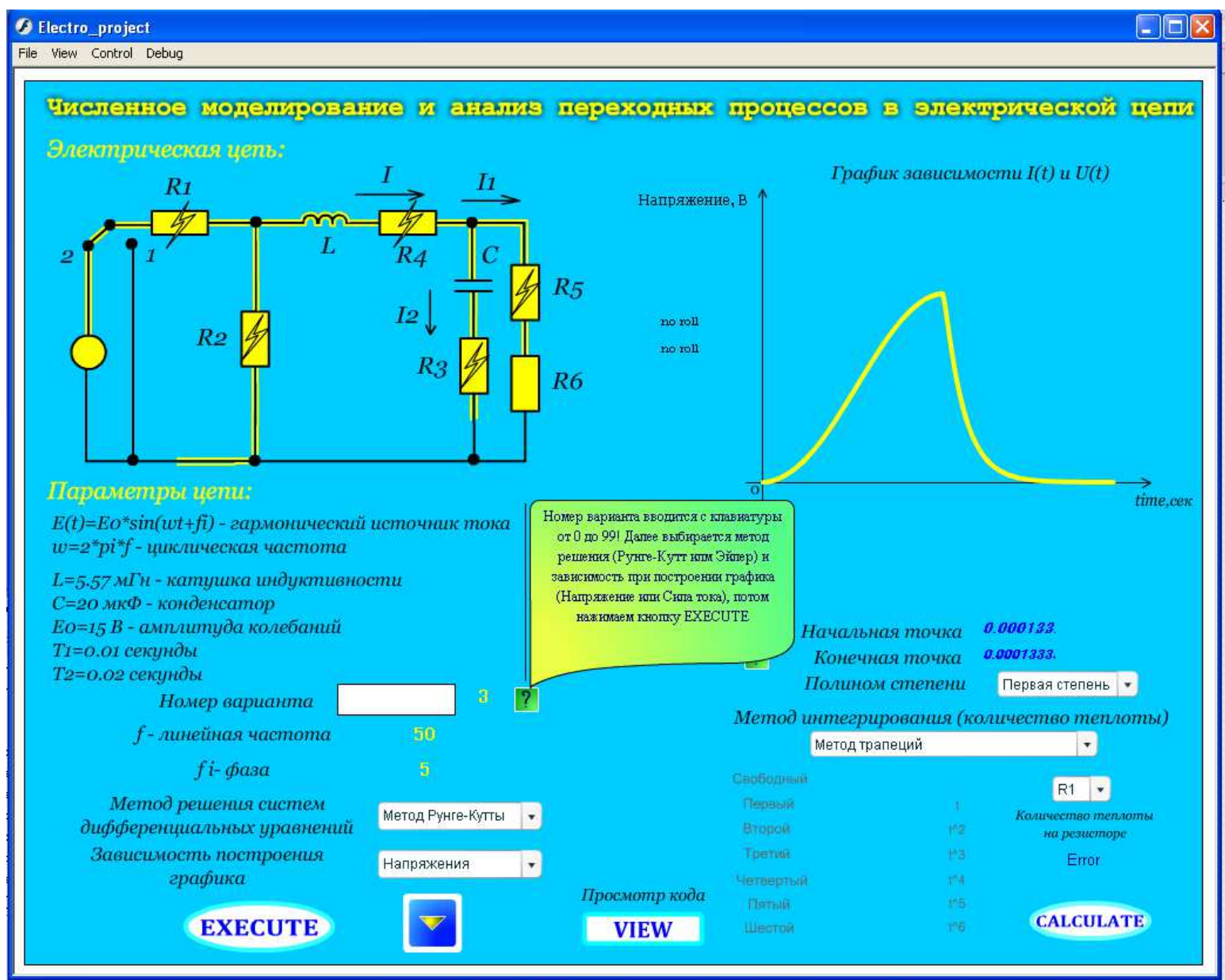

\section{Рис. 1. Интерактивная модель анализ переходных процессов в электрической цепи}

Используя такой набор интерактивных моделей, позволяет студенту наглядно осуществлять процесс моделирования. Использование таких комплексов позволяет выстроить индивидуальную траекторию обучения студента, мотивируя на изучение и совершенствование своей профессиональной подготовки. 


\section{Список литературы}

1. Маслоу А.Г. Мотивация и личность / пер. с англ. - 3-е изд. - СПб.: Питер., 2003. - 392 с.

2. Медведева Т.Н., Пешкина Е. Особенности учебной мотивации у студентов ВУЗа // Научно-методический электронный журнал «Концепт». 2015. - T. 36. - C. 16 - 20. - URL:http://e-koncept.ru/2015/95595.htm.

3. Петунин О.В., Мамонова Л.И., Профессиональная направленность физико-математической подготовки инженеров// Высшее образование сегодня. - No10, - 2007, - C.21 - 22.

4. Самарский А.А. Математическое моделирование: идеи, методы, примеры [Текст] / А.А. Самарский, А.П. Михайлов. - М.: Физматлит, 2001. $320 \mathrm{c}$.

5. Штофф В.А. Моделирование и познание / Под ред. В.А. Штофф. Минск: Наука и техника, 1974. - 211с.

6. Kent P. Mathematics in the University Education of Engineers. A Report to the Ove Arup Foundation/P.Kent. R.Noss.-London: London Knowledge Lab. 2003.-Retrieved 25/10/2014. from http://www.lkl.ac. uk/research/REMIT/KentNoss-report-Engineering-Maths.pdf

7. Ильин Е. П. Мотивация и мотивы. - СПб.: Питер, 2000. - 342 с.

8. Высшее образование в XXI веке. Подходы и практические меры. Всемирный статистический обзор по высшему образованию. Рабочий документ. ЮНЕСКО. Париж, 1998 г.

9. Высшее образование в XXI веке. Подходы и практические меры. Заключительный доклад. ЮНЕСКО. Париж, 1998 г.

10. Всемирный доклад по образованию. Учителя, практическая деятельность и новые технологии. ЮНЕСКО. 1998 г.

11. Катаева, Л.Ю. О трансформации высшего профессионального образования в современных условиях / Л.Ю. Катаева // Анализ состояния, проблем и перспектив развития современного образования: Монография. - 
Петрозаводск: Международный центр научного партнерства «Новая Наука» (ИП Ивановская Ирина Игоревна), 2021. - С. 116-129.

12. Клячко Т.Л. Образование в России и мире. Основные тенденции // Образовательная политика. Российская академия народного хозяйства и государственной службы при Президенте РФ. Москва. 2020. №1 (81) С. 26-42.

13. Зеленков Г.А., Каратаева Н.Г., Латун В.В. Математическое моделирование как метод активизации исследовательской деятельности студентов // Интернет-журнал «Мир науки» 2016, Том 4, номер 5 http://mirnauki.com/PDF/12PDMN516.pdf.

14. Архаров, Е.В. О некоторых теоретических аспектах прикладной направленности обучения высшей математике студентов / Е.В. Архаров, Л.Ю. Катаева // Современные проблемы науки и образования. - 2019. - № 6. C. 78. - DOI 10.17513/spno.29433.

15. Устойчивое развитие и угрозы экономической безопасности / С.Н. Митяков, Д.Н. Лапаев, Л.Ю. Катаева, С.А. Рамазанов // Экономика и предпринимательство. - 2019. - № 10(111). - С. 111-114.

16. Оперативный мониторинг экономической безопасности России / С.Н. Митяков, Л.Ю. Катаева, Е.С. Митяков, С.А. Рамазанов // Инновационное развитие экономики. - 2019. - № 5-2(53). - С. 213-223.

17. Катаева, Л.Ю. Постановка и проведение вычислительного эксперимента по исследованию аэро- и гидродинамических процессов в аварийных ситуациях природного и техногенного характера / Л.Ю. Катаева ; Российский государственный открытый технический университет путей сообщения. - Москва : Российский государственный открытый технический университет путей сообщения, 2007. - 218 с. - ISBN 978-5-7473-0347-8.

18. Четверов, Д.А. Применение динамического статистического анализа для определения сроков службы и оптимизации систем железнодорожного транспорта / Д.А. Четверов, Л.Ю. Катаева // Техника и технология наземного транспорта : Материалы международной студенческой научно-практической 
конференции. В 2-х частях, Нижний Новгород, 18 декабря 2019 года / Науч. редактор Н.В. Пшениснов, сост. А.Н. Сидоров. - Нижний Новгород: Общество с ограниченной ответственностью "Научно-издательский центр "XXI век", 2020. - С. 568-570.

19. Катаева Л.Ю., Ильичева М.Н., Федосеева Т.А., Масленников Д.А. Численное решение задач экономики с использованием Excel, C++ и MatLab - учебное пособие / Нижний Новгород, 2020.

20. Алексеенко С.Н., Катаева Л.Ю. Поверхностные интегралы. Теория: учебно-методическое пособие для студентов всех специальностей и всех форм обучения - Нижегород. гос. техн. ун-т им. Р.Е. Алексеева. - Нижний Новгород, 2011. 23 с.

21. Катаева Л.Ю., Масленников Д.А., Лощилова Н.А., Белоцерковская И.Е., Галина Н.В., Федосеева Т.А., Ильичева М.Н. Численные методы решения прикладных задач - учеб. пособие / Нижний Новгород, 2014.

22. Катаева Л.Ю., Крайзлер М.Б., Савченко А.В. Методы решения задач естествознания - учебное пособие для студентов технических специальностей / Л.Ю. Катаева, М.Б. Крайзлер, А.В. Савченко; Федеральное агентство по образованию, Государственное образовательное учреждение высшего профессионального образования Нижегородский государственный технический университет им. Р.Е. Алексеева. Нижний Новгород, 2007.

(с) Л.Ю. Катаева, 2022 


\title{
Глава 5.
}

ФОРМИРОВАНИЕ ИССЛЕДОВАТЕЛЬСКОЙ КОМПЕТЕНЦИИ СТУДЕНТОВ - БУДУЩИХ УЧИТЕЛЕЙ АНГЛИЙСКОГО ЯЗЫКА: ОТ ТЕОРИИ К ПРАКТИКЕ

\author{
Корзун Оксана Олеговна \\ к.пед.н., доцент \\ Савкина Екатерина Александровна \\ ассистент \\ Московский городской педагогический университет, \\ институт иностранных языков
}

Аннотация: Данное исследование посвящено вопросу формирования исследовательской компетенции будущих учителей английского языка (бакалавриат). Рассматриваются особенности организации профессиональнометодической подготовки, конкретизируется понятие «профессиональнометодическая компетенция», дается ее компонентный состав на основе анализа работ исследователей данного вопроса. Представляется описание содержательно-целевого компонента системы формирования исследовательской компетенции (6 блоков). Авторы определяют специфику исследовательской компетенции учителя английского языка и разрабатывают компоненты данной компетенции. В практической части дается технология формирования исследовательской компетенции.

Ключевые слова: профессиональная подготовка учителя, профессионально-методическая компетентность, исследовательская компетенция, исследовательская деятельность. 


\title{
DEVELOPING FUTURE ENGLISH TEACHERS' \\ RESEARCH COMPETENCE: FROM THEORY TO PRACTICE
}

\section{Korzun Oksana Olegovna \\ Savkina Ekaterina Aleksandrovna}

\begin{abstract}
This study is devoted to the formation of intending English teachers' research competence. The features of the organization of professional and methodological training are considered, the concept of "professional and methodological competence" is specified, its component composition is given based on the analysis of the work of researchers on this issue. The description of the content-target component of the system of formation of research competence (6 blocks) is presented. The authors define the peculiarities of the English teachers' research competence and introduce the components of this competence. In the practical part, the technology of formation of research competence is given.
\end{abstract}

Key words: professional teacher training, professional and methodological competence, research competence, research activity.

Необходимость разработки системы формирования исследовательской компетенции студентов - будущих учителей английского языка - обусловлена требованиями Федерального государственного образовательного стандарта высшего образования (далее ФГОС ВО) по направлению подготовки 44.03.01 «Педагогическое образование» (уровень бакалавриата), профиль «Иностранный язык». В настоящее время учитель иностранного языка должен быть готов к проведению как собственного исследования, так и руководить исследовательской деятельностью студентов.

Несмотря на то, что в теории проблема формирования исследовательской компетенции исследована подробно, на практике, к 
сожалению, наблюдается низкий уровень сформированности данной компетенции у студентов.

Авторы выражают надежду на то, что работа окажется полезной преподавателям языковых вузов и исследователям в области педагогики и методики обучения иностранным языкам.

\section{1. Исследовательская компетенция}

\section{как цель профессионально-методической подготовки студентов}

Многочисленные социальные изменения, вхождение России в мировое образовательное пространство, переосмысление целевых образовательных ориентиров обусловили выдвижение ряда новых требований к профессиональной подготовке будущих специалистов, в том числе учителей иностранного языка. В данном ключе на смену знаниево-ориентированному подходу в образовании пришёл компетентностный подход, нацеленный на обеспечение нового качества профессиональной подготовки, оптимальной и результативной с точки зрения современной объективной реальности.

Данные изменения также коснулись системы подготовки студентов бакалавриата, будущих учителей английского языка. Английский язык давно приобрел статус международного языка. Он является самым распространенным среди изучаемых языков в школах и в ВУЗах России. Следовательно, возникает потребность в подготовке грамотных специалистов, которые будут способны обучать английскому языку следующие поколения, которые смогут в дальнейшем представлять свою страну на мировой арене. В связи с этим все чаще меняется перечень требований, выдвигаемый перед педагогом. В своей профессии современный учитель выступает в качестве исследователя, методиста-технолога и учителя практика.

Изменения в подготовке учителя находят отражение в Федеральном государственном образовательном стандарте высшего образования по 
направлению подготовки 44.03.01 Педагогическое образование (уровень бакалавриата), принятого 22 февраля 2018 года (далее ФГОС ВО), который регулярно обновляется и модернизируется. Обратимся к документам с целью выявления места исследовательской компетенции в структуре результатов образовательной подготовки будущих учителей ИЯ. ФГОС ВО среди требований к результатам освоения программы бакалавриата выделяет сформированность у выпускников универсальных, общепрофессиональных и профессиональных компетенций.

Исследовательская компетенция напрямую связана со следующими группами универсальных компетенций: системное и критическое мышление (УК-1. Способен осуществлять поиск, критический анализ и синтез информации, применять системный подход для решения поставленных задач); разработка и реализация проектов (УК-2. Способен определять круг задач в рамках поставленной цели и выбирать оптимальные способы их решения, исходя из действующих правовых норм, имеющихся ресурсов и ограничений); коммуникация (УК-4. Способен осуществлять деловую коммуникацию в устной и письменной формах на государственном языке Российской Федерации и иностранном(ых) языке(ax)); межкультурное взаимодействие (УК-5. Способен воспринимать межкультурное разнообразие общества в социально-историческом, этическом о философском контекстах); самоорганизация и саморазвитие (УК-6. Способен управлять своим временем, выстраивать и реализовывать траекторию саморазвития на основе принципов образования в течение всей жизни).

Системное и критическое мышление напрямую связано с исследовательской компетенцией, наличие данных компонентов является необходимостью формирования исследовательской компетенции.

Среди общепрофессиональных компетенций стоит обратить внимание на следующие компетенции: разработка основных и дополнительных 


\section{ЧЕЛОВЕК И СОВРЕМЕННОЕ ОБЩЕСТВО В СОЦИАЛЬНОМ, ПРАВОВОМ, ЭКОНОМИЧЕСКОМ РАКУРСАХ}

образовательных программ (ОПК-2. Способен участвовать в разработке основных и дополнительных образовательных программ, разрабатывать отдельные их компоненты); контроль и оценка формирования результатов образования (ОПК-5. Способен осуществлять контроль и оценку формирования образовательных результатов обучающихся, выявлять и корректировать трудности в обучении); научные основы педагогической деятельности (ОПК-8. Способен осуществлять педагогическую деятельность на основе специальных научных знаний) [1].

Педагогическая деятельность предполагает, что учитель должен постоянно модернизировать существующий учебно-воспитательный процесс, дополняя его разными новыми компонентами, ведь именно эта деятельность требует проведения исследования.

Подводя итог всему вышесказанному, можно сделать вывод, что в действующем ФГОСе отмечается необходимость исследовательской деятельности обучающихся, которая тесно связана с другими видами деятельности. Следовательно, итоговый портрет выпускника бакалавра включает в себя такой компонент как исследовательская компетенция, которая позволит специалисту выполнять работу на более продуктивном и эффективном уровне.

Продолжая наши рассуждения о значимости исследовательской компетенции в структуре профессионально-методической компетентности выпускника бакалавриата по направлению 44.03.01 «Педагогическое образование» обратимся к ключевому для нашего исследования понятию «профессионально-методическая компетентность». Остановимся на рассмотрении сущностно-структурных характеристиках профессиональнометодической компетентности будущего учителя английского языка, акцентируем внимание на исследовательской компетенции как необходимой ее составляющей. 


\section{ЧЕЛОВЕК И СОВРЕМЕННОЕ ОБЩЕСТВО В СОЦИАЛЬНОМ, ПРАВОВОМ, ЭКОНОМИЧЕСКОМ РАКУРСАХ}

Необходимо уточнить, что в последнее время в научной литературе заметны терминологические расхождения в трактовке понятий «компетенция» и «компетентность». Возможно, возникшие расхождения в трактовке получили широкое распространение из-за двусмысленности перевода английского слова 'competence', что привело к тому, что в современных научно-педагогических и методических исследованиях рассматриваются общие и частные вопросы формирования как методической компетенции, так и компетентности учителя иностранного языка (Н.В. Языкова 1994, 2015; О.Н. Игна, 2010; С.Н. Макеева, 2010, 2015; Е.Ю. Никитина, О.Ю. Афанасьева М.Г. Федотова, 2013; А.В. Дубаков, 2015; О.О. Корзун, Е.А. Савкина, 2018 и др.).

Несмотря на то, что в методической литературе встречаются мнения, что возникшие расхождения в трактовке понятий не представляют принципиальной значимости для практики, отметим, что понятия «компетенция» и «компетентность» ошибочно воспринимать синонимами.

Не прибегая к научной полемике, в своем исследовании мы опираемся на мнение одного из ведущих деятелей компетентностного подхода в нашей стране А.В. Хуторского. Под понятием «компетентность» ученый понимает «владение, обладание обучающимся соответствующей компетенцией, подразумевающее его отношение к ней и предмету деятельности, т.е. совокупность личных качеств обучаемого, необходимых и достаточных для осуществления продуктивной деятельности по отношению к определенному объекту» [2, с. 86]. Под понятием «компетенция» А.В. Хуторской понимает «нормативное требование к образовательной подготовке обучаемого, необходимой для его эффективной и продуктивной деятельности в определенной сфере [там же].

Из этого вытекает вывод, что компетентность более широкое понятие, чем компетенция. Компетенция - это внешне заданная норма, а 
компетентность является личностным качеством, определяемым данной нормой. Если про человека говорят, что он компетентен в своей профессии, то это означает, что у человека сформированы нужные компетенции (имеются знания, умения, навыки и личностное отношение) для успешного осуществления своей профессиональной деятельности. Применительно к будущему учителю ИЯ, то компетентный специалист, тот, кто готов использовать сформированные компетенции для осуществления следующих видов деятельности: педагогической; проектной; методической; организационно-управленческой; культурно-просветительской; сопровождения.

Основываясь на вышесказанном, в монографии мы оперируем понятием «профессионально-методическая компетентность» (далее ПМК). Несмотря на существующий плюрализм во взглядах все исследователи единогласно сходятся во мнении, что данная компетенция / компетентность выступает в качестве важнейшего показателя и результата профессиональной подготовки учителей английского языка.

Несмотря на достаточно большое количество имеющихся работ, касающихся разнообразных аспектов методической подготовки учителя английского языка, можно отметить лишь немногочисленное количество исследований, раскрывающих характеристики непосредственно профессионально-методической компетентности будущего учителя иностранного языка, а не других вариаций этого названия. Остановимся на обзоре и анализе некоторых исследований.

В ходе анализа имеющихся работ было обнаружено, что каждый автор определяет профессионально-методическую компетентность по-своему и, соответственно, выделяет отличный от своих коллег компонентный состав данной компетентности. Анализ определений и компонентного состава профессионально-методической компетентности позволит выявить общие черты, которые выделяют исследователи. Важно отметить, что определения авторов так же разнятся, поэтому будут рассмотрены такие понятия как: 


«профессиональная деятельность», «профессиональная компетентность»,
«профессиональная $\quad$ компетенция», «методическая $\quad$ компетенция» и
«профессионально-методическая компетентность».

Таблица 1

\section{Обзор определений понятия «профессионально-методическая}

компетенция/компетентность»

\begin{tabular}{|c|c|}
\hline Термин & Определение \\
\hline $\begin{array}{l}\text { профессиональная } \\
\text { компетенция }\end{array}$ & $\begin{array}{l}\text { «синтез, неразрывное единство содержательного и структурного компонентов, } \\
\text { совокупность знаний, умений, навыков и способностей, реализуемых через } \\
\text { психолого - педагогическую, методическую, коммуникативную, филологическую, } \\
\text { общекультурную, информационную, социальную и управленческую компетенции» } \\
\text { [3, с. } 72-79]\end{array}$ \\
\hline $\begin{array}{l}\text { методическая } \\
\text { компетентность }\end{array}$ & $\begin{array}{l}\text { результат психолого-педагогической, методической, предметной подготовки, } \\
\text { личного научно-исследовательского и профессионального опыта }[4, \text { с. } 91]\end{array}$ \\
\hline $\begin{array}{l}\text { профессиональная } \\
\text { компетентность }\end{array}$ & $\begin{array}{l}\text { интегративную профессионально-личностную характеристику специалиста, } \\
\text { определяющую его способность и готовность осуществлять профессиональную } \\
\text { деятельность посредством сформированных компетенций, где готовность не } \\
\text { статичное состояние, а готовность меняться и развиваться с появлением новых } \\
\text { образовательных технологий [5, с. } 119]\end{array}$ \\
\hline $\begin{array}{l}\text { методическая } \\
\text { компетентность }\end{array}$ & $\begin{array}{l}\text { интегративное свойство личности учителя ИЯ, предполагающее его готовность и } \\
\text { способность эффективно решать методические задачи в процессе реализации } \\
\text { целей обучения иностранным языкам }[6, \text { с. } 95]\end{array}$ \\
\hline $\begin{array}{l}\text { методическая } \\
\text { компетенция }\end{array}$ & $\begin{array}{l}\text { совокупность знаний о сущностных характеристиках процесса обучения ИЯ и } \\
\text { практических умений, заключающихся в его эффективной организации } \\
{[7, \text { с. } 2578]}\end{array}$ \\
\hline $\begin{array}{l}\text { профессиональная } \\
\text { компетентность }\end{array}$ & $\begin{array}{l}\text { «информационный багаж», психологическое новообразование личности и } \\
\text { включает совокупность знаний, умений и компетенций, присвоенных им личный } \\
\text { опыт [8, c. 102]. }\end{array}$ \\
\hline
\end{tabular}

В представленной таблице (табл. 1) можно сопоставить мнение ученых о сущности исследовательской компетенции. Мнения авторов разделяются: часть ученых (Махмурян, 2006), (Колесникова, Тамашевич, 2007), (Дубаков, 2015), (Гальскова, 2018) определяют ПМК как совокупность полученных компетенций, в то время как другие ученые (Игна, 2010), 
(Надточева, 2011), (Макеева, 2012) как интегративную личностную характеристику специалиста. Обобщив выше представленные точки зрения, под профессионально-методической компетентностью учителя ИЯ» в работе авторы понимают: владение совокупностью специфических компетенций, необходимых учителю иностранного языка, которые позволяют решать педагогические, проектные, исследовательские, культурнопросветительские и методические задачи, возникающие в организации иноязычного учебно-образовательного процесса [9, с. 422].

Перейдем к выявлению компонентного состава ПМК. Это позволит нам установить значимость исследовательской компетенции среди всех компонентов ПМК.

Ситуация с компонентным составом ПМК сложилась точно такая же как с определениями данного термина. Исследователи выделяют различный перечень компетенций, исходя из специфики собственных наблюдений.

В качестве основных структурных элементов профессиональнометодической деятельности учителя ИЯ в монографии Н.В. Языковой выделяются профессиональные знания, умения, навыки и профессиональнопедагогическая направленность личности учителя, которая образует статическую модель процесса преподавания. В знания учителя ИЯ включаются предметные методические знания, методологические знания и знания обобщенных способов решения методологических задач. Процесс выработки, принятия и реализации методических решений является ключевым звеном этой деятельности, которые представляет собой сложный и многоуровневый процесс, что способствуют становлению личности учителя [10].

Модель профессионально-методической подготовки учителя ИЯ, исходя из поставленной цели, включает: теоретическое обучение; практическое обучение; научно-исследовательскую работу. 
Во время своей работы учителю ИЯ приходится решать целый ряд определенных задач: исследовательские, технологические и практические, что позволяет выявить, какие роли выполняет современный учитель ИЯ во время своей работы: исследователь, методист-технолог и учитель практик. Подводя итог данной работе, стоит отметить, что профессионально-методическая деятельность учителя ИЯ является детерминантом не только целей, но и содержания методической подготовки [там же].

Проанализированный компонентный состав ПМК, который выделяют разные исследователи, обобщим в Таблице 2.

Таблица 2

\section{Обзор компонентного состава ПМК}

\begin{tabular}{|c|c|}
\hline Понятие & Компонентный состав \\
\hline $\begin{array}{c}\text { Методическая } \\
\text { компетенция }\end{array}$ & $\begin{array}{l}\text { - гностическая компетенция; } \\
\text { - аналитическая компетенция; } \\
\text { - проектировочная компетенция; } \\
\text {-профессионально-коммуникативная компетенция; } \\
\text {-информационно-коммуникативная компетенция; } \\
\text { - инновационная компетенция; } \\
\text {-научно-исследовательская компетенция; } \\
\text {-рефлексивная компетенция [7, с. 2578] }\end{array}$ \\
\hline $\begin{array}{c}\text { Профессиональная } \\
\text { компетентность }\end{array}$ & $\begin{array}{l}\text {-коммуникативно-культурологическая компетенция; } \\
\text {-общенаучная компетенция: (субкомпетенция- исследовательская } \\
\text { компетенция); } \\
\text {-психолого-педагогическая; } \\
\text {-личностная; } \\
\text {-самообразовательная [11] }\end{array}$ \\
\hline $\begin{array}{c}\text { Профессиональная } \\
\text { компетентность }\end{array}$ & $\begin{array}{l}\text {-предметная компетентность: общекультурные компетенции; } \\
\text { общепрофессиональные компетенции; профессиональные компетенции. } \\
\text { - социальная компетентность; } \\
\text { - мотивационная компетентность: } \\
\text { учебно-мотивационная компетенциия; профессионально-мотивационная } \\
\text { компетенция; } \\
\text {-функциональная компетентность: } \\
\text {-научно-исследовательская компетенщия; } \\
\text {-информационно-когнитивная компетенщия; } \\
\text {-педагогические компетенции [12, с. 85]. }\end{array}$ \\
\hline $\begin{array}{c}\text { Профессиональная } \\
\text { компетентность }\end{array}$ & $\begin{array}{l}\text {-психолого-педагогическая; } \\
\text {-предметная лингвистическая и филологическая: } \\
\text {-методическая; } \\
\text {-иноязычно-коммуникативная; } \\
\text {-профессионально-коммуникативная [8, с. 105-106] }\end{array}$ \\
\hline
\end{tabular}


После детального изучения компонентного состава (табл. 2), предлагаемым представленными исследователями, становится возможным прийти к некоторым умозаключениям:

- не все исследователи выделяют исследовательскую компетенцию как самостоятельную компетенцию, зачастую исследовательская компетенция входит в состав более общей компетенции, что приводит к тому, что ее роль становится менее значительна и, следовательно, ей уделяется меньшее внимание;

- исследовательская компетенция тесно связана с другими компетенциями, поэтому формирование и развитие исследовательской компетенции будет способствовать повышению уровня остальных компетенций.

Представим компонентный состав ПМК в виде рисунка:

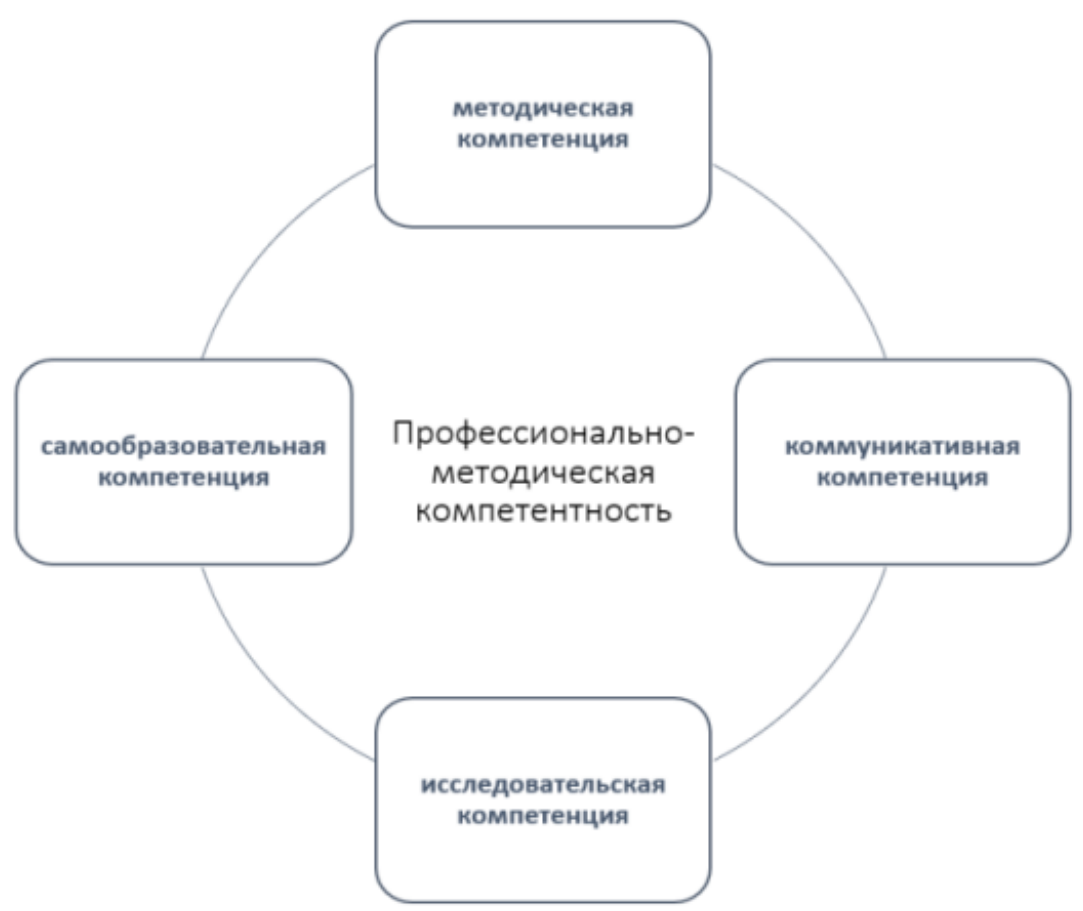

Рис. 1. Структура ПМК педагога ИЯ 
Данная структура соотносится с требованием ФГОС ВО: по окончанию обучения выпускник должен быть готов к осуществлению различных видов деятельности. Исследовательская компетенция является немаловажной компетенцией в структуре профессионально-методической компетентности учителя ИЯ, т.к. исследовательская деятельность пронизывает каждый аспект деятельности учителя. Отличительная особенность подготовки учителей иностранного языка от учителя любого другого предмета - это свободное владение иностранным языком, поэтому в данном контексте представляется возможным говорить об иноязычной исследовательской компетенции помимо исследовательской компетенции только на родном языке.

На основе анализа определений и структуры исследовательской компетенции учителя ИЯ, нами было выработано рабочее определение понятия, которое наиболее полно раскрывает его сущность: «исследовательская компетенция учителя иностранного языка - готовность и способность педагога осуществлять исследовательскую деятельность на родном и иностранном языках самостоятельно (или в процессе взаимодействия с научным руководителем); обладать знаниями, умениями и навыками вести научный диалог и делиться результатами исследованиями в устном или письменном виде с соотечественниками $и$ зарубежными коллегами; использовать исследовательскую компетенцию как инструмент совершенствования межкультурной коммуникативной компетенции с иелью собственного профессионального роста.

\section{2. Содержательно-целевой компонент системы формирования исследовательской компетенции будущего учителя}

Перед тем как приступить к описанию содержательно-целевого компонента, необходимо акцентировать внимание на том, что в данный момент «содержание фокусируется на личном опыте обучающегося, а не на 


\section{ЧЕЛОВЕК И СОВРЕМЕННОЕ ОБЩЕСТВО В СОЦИАЛЬНОМ, ПРАВОВОМ, ЭКОНОМИЧЕСКОМ РАКУРСАХ}

внешних учебных целях» [13 с. 281]. Поэтому данная система должна быть прежде всего личностно-ориентированной. Под системой формирования исследовательской компетенции понимается совокупность необходимых компонентов, выстроенных в определенной иерархии, которые способствуют эффективному формированию исследовательской компетенции начинающего исследователя.

В основу разрабатываемой системы была положена система исследовательской деятельности Л.А. Одинцовой (2014). Автор выделяет следующие блоки, входящие в данную систему, и дает им детальное описание:

- целевой блок (генеральной целью системы является подготовка к организации и проведению исследовательской деятельности);

- мотивационный блок (описание дидактических средств и приемов, позволяющих мотивировать включение студентов в исследовательскую деятельность. Мотивация, осуществляемая преподавателем, должна быть убедительной, обеспечивать развитие у студентов интереса и внутренней мотивации к занятию исследовательской деятельностью);

- содержательный блок (подробное описание теоретических знаний и практических умений исследовательской деятельности, подлежащих усвоению, служащих основой для ее осуществления);

- процессуальный блок (описание содержания работы кафедры, отвечающей за подготовку бакалавров соответствующего профиля, по формированию исследовательской деятельности студентов);

- технологический блок (описание форм, методов и средств реализации содержания формирования исследовательской деятельности будущего бакалавра педагогического образования); 


\section{ЧЕЛОВЕК И СОВРЕМЕННОЕ ОБЩЕСТВО В СОЦИАЛЬНОМ, ПРАВОВОМ, ЭКОНОМИЧЕСКОМ РАКУРСАХ}

- результативный блок (описание критериев, по которым можно судить о сформированности исследовательской деятельности студентов $[14$, c. 688$]$.

Данная система была адаптирована к условиям проведения учебной (ознакомительной) практики и дополнена дополнительными компонентами необходимыми для организации эффективного процесса формирования исследовательской компетенции.

Для того чтобы определить целевой блок системы формирования ИК будущих учителей АЯ, обратимся к философскому энциклопедическому словарю, где «цель» трактуется как один из результатов поведения сознательной деятельности человека, который характеризует предвосхищение в мышлении результата деятельности и пути его реализации с помощью определенных свойств. Цель выступает как способ интеграции различных действий человека в некоторую последовательность или систему [15].

Обобщая данное определение, отмечаем, что цель - это желаемый результат. Для того, чтобы достичь поставленной цели необходима разработка определенной последовательности действий, которая образует систему. Говоря о цели формирования исследовательской компетенции будущих учителей английского языка, в качестве главного результата мы видим сформированность данной компетенции. Иначе говоря, цель системы формирования исследовательской компетенции - это сама исследовательская компетенция, сформированная до определенного уровня.

Какой уровень исследовательской компетенции будет достигнут студентом-бакалавром зависит от: 1) его индивидуальных способностей; 2) стиля когнитивной деятельности, так как каждый обучающий неповторимая личность. Одним из условий формирования исследовательской компетенции должно считаться сохранение индивидуальных особенностей обучающихся. 


\section{ЧЕЛОВЕК И СОВРЕМЕННОЕ ОБЩЕСТВО В СОЦИАЛЬНОМ, ПРАВОВОМ, ЭКОНОМИЧЕСКОМ РАКУРСАХ}

В.В. Краевский к основным элементам индивидуальной образовательной деятельности относит: смысл деятельности (зачем я это делаю); постановка личной цели (предвосхищающей результат); план деятельности; реализация плана; рефлексия (осознание собственной деятельности); оценка; корректировка или переопределение целей [16, с. 233].

В связи с этим стоит говорить о принципе личностного целеполагания. Согласно данному принципу, образование каждого обучающего происходит на основе и с учетом его личных учебных целей. Данный принцип опирается на такое качество человека как - способность постановки целей своей деятельности [там же]. Уровень компетенции измерить довольно трудно, можно проверить некоторые умения и знания, но, например, личностный компонент никак нельзя измерить у каждого конкретного студента, поэтому можно лишь говорить об определенном уровне исследовательской компетенции в качестве ведущей цели системы формирования исследовательской компетенции и у каждого обучающегося эта цель своя. На протяжении всего учебно-образовательного процесса, занимаясь одинаковыми видами деятельности, каждый студент достигает того уровня исследовательской компетенции, которого он сам себе позволяет в связи с его личностными особенностями, поэтому необходимо учитывать этот фактор при постановке целей системы и оценке конечного результата, который демонстрируют обучающиеся.

Мотивационный компонент системы является немаловажным элементом, так как именно он зависит от обучающегося и руководит всей его деятельностью. Традиционно выделяют различные виды мотивации: экстринсивная (внешняя) обуславливается внешними факторами и обстоятельствами; интринсивная (внутренняя) связана с личными потребностями, установками, желаниями субъекта, все действия и поступки совершаются по «доброй воле» студента; положительная/отрицательная 
мотивация основана на положительных/отрицательных стимулах; устойчивая мотивация, та мотивация, в основе которой лежат нужды человека, она не требует дополнительного подкрепления [17, с. 205]. В нашем исследовании мы постарались представить средства, которые позволяют формировать учебную мотивацию. Наиболее важной является для нас формирование внутренней и положительной мотивации, которые тесно связаны между собой. Необходимо создать положительный образ процесса прохождения практики в сознании студента и объяснить для чего нужна данная практика и как впоследствии она пригодится для будущей профессии. Все это создаст правильную мотивационную установку, и внутренняя мотивация приобретет устойчивый характер.

\section{Таблица 3}

\section{Виды мотиваций студентов, проходящих учебную практику}

\begin{tabular}{|l|l|}
\hline $\begin{array}{l}\text { Внешняя } \\
\text { мотивация }\end{array}$ & $\begin{array}{l}\text { Высокая отметка за практику, место в балльной-рейтинговой системе, получение } \\
\text { похвалы, дух соперничества. }\end{array}$ \\
\hline Внутренняя & $\begin{array}{l}\text { Интересы студентов, любознательность, стремление познать новое, осознание } \\
\text { необходимости исследовательской компетенции для дальнейшей успешной учебы и } \\
\text { повышения уровня общего профессионализма, стремление добиться успеха, открыть } \\
\text { новый талант, движение к личностному благополучию. }\end{array}$ \\
\hline $\begin{array}{l}\text { Положительная } \\
\text { мотивация }\end{array}$ & $\begin{array}{l}\text { Эмоциональное включение в изучаемый материал, осознание практической и } \\
\text { теоретической значимости формируемой компетенции, ожидание успеха. }\end{array}$ \\
\hline Отрицательная & $\begin{array}{l}\text { Неодобрение преподавателя/ одногруппников/ родителей, страх отчисления/пересдачи, } \\
\text { собственный провал. }\end{array}$ \\
\hline $\begin{array}{l}\text { Устойчивая } \\
\text { мотивация }\end{array}$ & \begin{tabular}{l} 
Непрерывное повышение профессионально-методической компетентности \\
\hline
\end{tabular} \\
\hline
\end{tabular}

В случаях слабой внутренней мотивации необходимо отталкиваться от внешней мотивации, с помощью которой можно формировать внутреннюю систему мотивов, которая является по своей природе более надежной и устойчивой (табл.3). Отрицательную мотивацию необходимо применять лишь 


\section{ЧЕЛОВЕК И СОВРЕМЕННОЕ ОБЩЕСТВО В СОЦИАЛЬНОМ, ПРАВОВОМ, ЭКОНОМИЧЕСКОМ РАКУРСАХ}

в самых крайних случаях, когда все остальные способы не работают. Данная мотивация, как правило, не имеет такого эффекта как положительная и внутренняя мотивация, она, наоборот, отпугивает студента от исследовательской деятельности и прививает негативное отношение к ней.

Большую роль в мотивировании студентов, безусловно, играет преподаватель. Особенно если это первичное введение в исследовательскую деятельность будущего учителя, то очень важно создать необходимые условия для привлечения студентов в исследовательскую деятельность. Предварительно перед началом прохождения практики студенту необходимо заполнять индивидуальный образовательный маршрут начинающего исследователя отвечать для себя на вопросы: «Для чего я это делаю?», «Что я научусь делать?», «Как я смогу применить это в дальнейшем?». Ответив для себя на эти вопросы, возникает осмысленная потребность, которая становится мотивом студента для развития необходимых умений, которые требуются для проведения собственного исследования.

Студенту необходимо понимать цель, которая преследуется в процессе обучения, возвращаясь к размышлениям в целевом блоке, необходимо говорить о собственной индивидуальной цели студента. Немаловажно, чтобы студент мог строить собственный маршрут развития исследовательской компетенции. Овладение исследовательской компетенцией может способствовать повышению общего уровня профессионально-методической компетентности, поскольку исследовательская компетенция является универсальной компетенцией и затрагивает все сферы деятельности учителя. Это положительно скажется в дальнейшем на карьере будущего учителя.

В данный блок также можно отнести личные интересы обучающихся, которые могут оказывать положительное влияние на процесс формирования исследовательской компетенции, если тема исследования совпадает со сферой 


\section{ЧЕЛОВЕК И СОВРЕМЕННОЕ ОБЩЕСТВО В СОЦИАЛЬНОМ, ПРАВОВОМ, ЭКОНОМИЧЕСКОМ РАКУРСАХ}

интересов студента. Для этого преподавателю необходимо учитывать круг научных интересов студентов или в процессе беседы направить студента и совместно определить для него перспективное направление деятельности.

С целью отбора компонентов, необходимых для содержательного блока, мы обратились к работам ученых, направленных на изучение специфики исследовательской деятельности будущих педагогов. В результате компиляции работ ученых (Г.В. Рогова, 1984; Н.В. Языкова, 1994; А.С. Обухов, 2003; Н.В. Языкова, С.Н. Макеева, 2015; Елагина, Кутепова, 2016; С.П. Фирсова, Т.В. Голикова, 2017) нам удалось выявить структуру исследовательской компетенции учителя ИЯ и, как следствие, выявить необходимые знания, навыки и умения для исследовательской деятельности учителей английского языка. При составлении таблицы мы руководствовались определениями понятий «навык» и «умение» из методического словаря Э.Г. Азимова и А.Н. Щукина, чтобы распределить необходимые исследовательские действия среди данных категорий. Словарь определяет навык как действие, достигшее уровня автоматизма и характеризующееся цельностью, отсутствием поэлементного осознания. Функционирует в речевой деятельности, включающей речевые действия и речевые операции [18, с. 150-151]. Умение это усвоенный субъектом способ выполнения действий, обеспечиваемый совокупностью приобретенных знаний и навыков. Способность осознанно совершать действие, опираясь на сформированные навыки и приобретенные знания. Создает возможность выполнения определенных действий не только в привычных, но и в изменяющихся условиях [18, с. 320].

Компонентный состав представим в виде Таблицы 4. 


\section{Таблица 4}

\section{Содержание исследовательской компетенции будущего учителя ИЯ}

\begin{tabular}{|c|c|}
\hline Знания & Умения \\
\hline $\begin{array}{l}\text { 1. Информационные ресурсы и } \\
\text { базы необходимые для решения } \\
\text { исследовательских задач; } \\
\text { 2. Методы педагогического } \\
\text { исследования; } \\
\text { 3. Способы организации } \\
\text { научной деятельности; } \\
\text { 4. Специфику требований } \\
\text { оформления научных трудов; } \\
\text { 5. Понятийного аппарата } \\
\text { проводимого исследования (на } \\
\text { родном и иностранном языке); } \\
\text { 6. Знание научного дискурса; } \\
\text { 7. Знание особенностей } \\
\text { оформления научной работы; }\end{array}$ & $\begin{array}{l}\text { 1. Формулировать тему, выявлять объект, предмет, ставить цель } \\
\text { и задачи исследования; } \\
\text { 2. Адекватно отбирать методы, необходимые для проведения } \\
\text { исследования; } \\
\text { 3. Обобщать степень изученности какой-либо проблемы в научной } \\
\text { литературе; } \\
\text { 4. Оформлять результаты изучения научной литературы в виде } \\
\text { монореферата и обзорного реферата; } \\
\text { 5. Написания аннотации к научной статье; } \\
\text { 6. Составлять библиографический список литературы; } \\
\text { 7. Написания методической статьи; } \\
\text { 8. Участвовать в круглых столах/семинарах по теме исследования, } \\
\text { защита выдвигаемых гипотез; } \\
\text { 9. Проектировать исследовательскую деятельность школьников; } \\
\text { 10. Проводить эксперименты/опытное обучение; } \\
\text { 11. Ориентироваться в зарубежных источниках, извлекать полезную } \\
\text { информацию для собственного исследования. } \\
\text { 12. Вести научный разговор о собственной теме исследования } \\
\text { (на родном и иностранном языке). } \\
\text { 13. Умение проводить анализ УМК для общеобразовательных школ } \\
\text { с позиции заданной проблемы; } \\
\text { 14. Умение осуществлять поиск научной литературы при помощи } \\
\text { разнообразных электронных ресурсов и библиотек; } \\
\text { 15. Уметь ориентироваться в научных источниках информации; } \\
\text { 16. Уметь использовать основные методы обработки информации; }\end{array}$ \\
\hline Навыки & Отношение \\
\hline $\begin{array}{l}\text { 1. Презентационные навыки: } \\
\text { • составление текста } \\
\text { выступления к презентации; } \\
\text { • логично выстраивать } \\
\text { выступление; } \\
\text { • представление собственного } \\
\text { исследования; } \\
\text { • взаимодействие с } \\
\text { партнерами по исследованию; } \\
\text { • графическое оформление } \\
\text { электронной презентации. }\end{array}$ & $\begin{array}{l}\text { 1.Саморефлексией собственного исследования; } \\
\text { 2.Личностной направленностью личности исследователя: творческий } \\
\text { оригинальный подход к исследованию, готовность к изучению что-то } \\
\text { нового, создание собственной мотивации и заинтересованность } \\
\text { в проводимой исследовательской деятельности, увеличение качества } \\
\text { проделанной работы; } \\
\text { 3.Обладать гибкостью мышления и способностью менять } \\
\text { исследовательский маршрут в связи с окружающими } \\
\text { обстоятельствами. } \\
\text { 4.Способностью самореализовываться как специалист в собственном } \\
\text { исследовании. }\end{array}$ \\
\hline
\end{tabular}




\section{ЧЕЛОВЕК И СОВРЕМЕННОЕ ОБЩЕСТВО В СОЦИАЛЬНОМ, ПРАВОВОМ, ЭКОНОМИЧЕСКОМ РАКУРСАХ}

Отличительной особенностью этой структуры (табл. 4) от рассмотренных работ известных исследователей заключается в том, что в данной структуре уделяется внимание иностранному языку (английскому), так как необходимо учитывать специфику деятельности будущего учителя и профиль его подготовки. Привлечение иностранного языка в исследовательскую деятельность расширяет направления для проведения исследования, так как можно обращаться к иноязычным источникам, анализировать их и заключать на основании этого собственные выводы. Помимо это, будущий специалист сможет делиться своими выводами как в устной, так и письменной форме на нескольких языках.

В результативном блоке представляются уровни оценивания сформированности исследовательской компетенции студентов.

В настоящее время существует уровневое описание владения иностранным языком, которое зафиксировано в Общеевропейских компетенциях владения иностранным языком (Common European Framework of Reference, CEFR). CEFR используется для создания национальных систем оценки языковой компетенции. В данной системе компетенция учащихся состоит из трех крупных категорий, которые далее делятся на 6 уровней:

- А - Элементарное владение

○ А1 Уровень выживания;

○ А2 Предпороговый уровень.

- В - Самодостаточное владение

○ В1 Пороговый уровень;

○ В2 Пороговый продвинутый уровень.

- $\mathrm{C}$ - Свободное владение

○ С1 Уровень профессионального владения;

○ С2 Уровень владения в совершенстве. 
Каждый уровень имеет детальное описание того перечня способностей, который необходим для владения указанного уровня. Данная система позволяет с высокой точностью определить уровень владения языком [19].

В нашем исследовании нам кажется целесообразным сделать попытку перенести модель уровневого владения языком в систему формирования исследовательской компетенции и представить владение исследовательской компетенции по уровням [20]. Данные уровни будут опираться на специфику содержательного компонента системы формирования исследовательской компетенции и особенности процесса формирования данной компетенции в ВУЗе. Количество уровней владения исследовательской компетенции предлагается соотнести с уровнем бакалавриата, магистратуры и аспирантуры. Следовательно, получается 3 уровня владения исследовательской компетенцией:

Таблица 5

\section{Уровни владения исследовательской компетенции учителей}

\section{иностранного языка}

\begin{tabular}{|c|c|}
\hline уровень & характеристика \\
\hline $\begin{array}{l}\text { Высокий (Свободное } \\
\text { владение) } \\
\text { аспирантура }\end{array}$ & $\begin{array}{l}\text { Готовность автономно проводить собственное исследование, опираясь на } \\
\text { имеющиеся знания специфики проведения исследований и оформлений их } \\
\text { результатов, используя умения организации исследования и его дальнейшее } \\
\text { проведение. Быть способным ориентироваться в современных отечественных } \\
\text { и зарубежных информационных ресурсах. Быть осведомленным в сфере } \\
\text { современных трендов методики обучения ИЯ и способным к определению } \\
\text { векторов собственного исследования, адаптируясь к изменениям } \\
\text { окружающего мира. Быть готовым к представлению результатов } \\
\text { исследования в устной и письменной форме на АЯ и РЯ. } \\
\text { Возможность организации исследовательской деятельности своих } \\
\text { подопечных и сопровождение до получения результатов, т.е. способствовать } \\
\text { формированию исследовательской компетенции обучающихся. Обладать } \\
\text { собственной мотивацией к проведению исследования. Способность к } \\
\text { проведению рефлексии собственной исследовательской деятельности и ее } \\
\text { результатов. }\end{array}$ \\
\hline
\end{tabular}




\section{Продолжение Таблицы 5}

\begin{tabular}{|c|c|}
\hline $\begin{array}{l}\text { Базовый (Достаточное } \\
\text { владение) } \\
\text { магистратура }\end{array}$ & $\begin{array}{l}\text { Готовность совместно с научным руководителем проводить исследование } \\
\text { заданной проблематики в процессе совершенствуя знания специфики } \\
\text { проведения исследований и оформлений их результатов, приобретая умения } \\
\text { самостоятельной работы над исследованием. Быть способным } \\
\text { ориентироваться в современных отечественных информационных ресурсах. } \\
\text { Быть готовым к представлению результатов исследования в устной форме на } \\
\text { АЯ и РЯ и письменной форме на РЯ. Проявление интереса к } \\
\text { исследовательской деятельности. Начало процесса формирования } \\
\text { исследовательской саморефлексии. }\end{array}$ \\
\hline $\begin{array}{l}\text { Минимальный } \\
\text { (Элементарное владение) } \\
\text { бакалавриат }\end{array}$ & 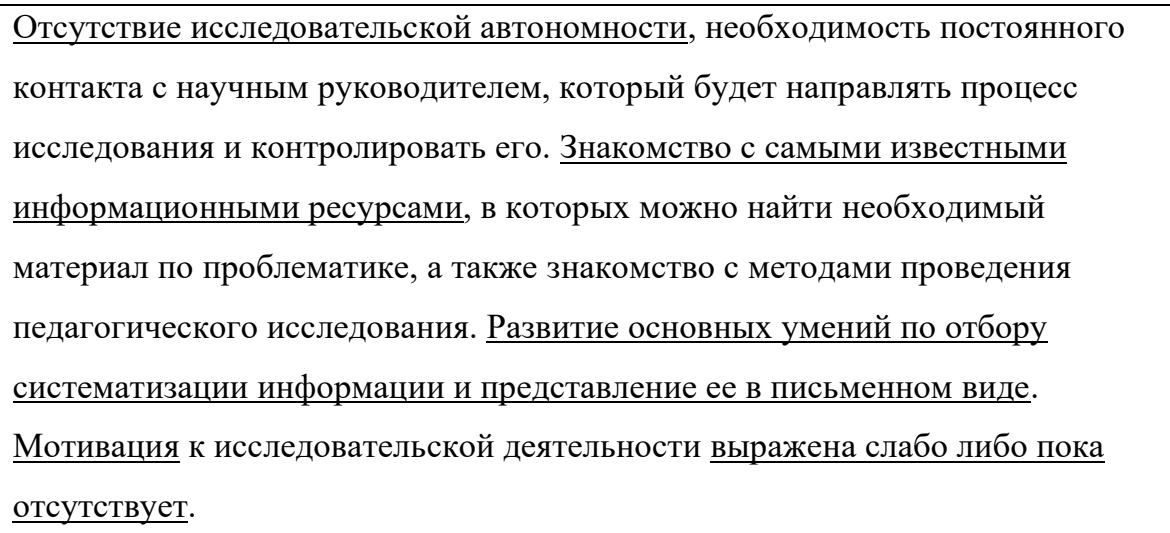 \\
\hline
\end{tabular}

Во время начала исследовательской практики на 2 курсе студенты находятся на минимальном уровне владения исследовательской компетенцией, оперируя исследовательскими навыками и умениями, которые были развиты в школе и на 1 курсе ВУЗа, достаточные для подготовки небольших сообщений и выступлений. Во время прохождения учебной практики происходит переход от минимального уровня к базовому уровню. Студенты учатся оформлять список научной литературы, монореферат, обзорный реферат, аннотацию статьи, используя различные информационные ресурсы. Постепенно формируется автономность обучающего, его способность проведения исследования под руководством научного руководителя. На данном этапе студентам предлагается участвовать в конференциях для студентов (например, в МГПУ ежегодно проводится Научный старт), где они учатся делиться результатами своего исследования в устной форме. 
Отметим, что представленные нами уровни формирования исследовательской компетенции (табл. 5), закрепленные за тем или иным этапом обучения (бакалавриат - магистратура - аспирантура) условны и не являются строгими. В отдельных случаях по окончанию бакалавриата, выпускник может демонстрировать владение видами исследовательской деятельности, которые мы отнесли к последующим уровням владения исследовательской компетенции. Также необходимо заметить, что название «минимальный уровень» не несет в себе негативной коннотации. Это значит, что студент сделал первый шаг для формирования исследовательской компетенции.

\section{1. Принципы, методы и средства формирования исследовательской компетенции}

Система формирования исследовательской компетенции студентов требует рассмотрения ряда важных с точки зрения организации этой работы компонентов, к которым мы относим следующее:

1) принципы обучения, определяющие специфику формирования исследовательской компетенции студентов;

2) методы, используемые преподавателем и студентом;

3) средства формирования исследовательской компетенции студентов.

Рассмотрим последовательно данные компоненты в заданной логике их изложения.

При выборе принципов - «нормативных требований к организации и осуществлению образовательного процесса» [16, с. 233], мы, прежде всего, ориентировались на общедидактические принципы, актуальные с позиций современной образовательной парадигмы - с точки зрения личностно ориентированного обучения. Их совокупность и специфика полностью соотносятся с особенностями формирования исследовательской компетенции 
студентов. К этим принципам мы относим: 1) принцип личностного полагания; 2) принцип выбора индивидуальной образовательной траектории, 3) принцип продуктивности, 4) принцип образовательной рефлексии, 5) принцип единства учебной и исследовательской работы студентов, 6) принцип конструктивного сотрудничества преподавателя со студентами. Рассмотрим специфику реализации каждого из принципов с точки зрения их значимости для организации работы по формированию исследовательской компетенции студентов.

\section{Согласно принципам личностного целеполагания и выбора} индивидуальной образовательной траектории образование каждого обучающегося происходит на основе и с учетом его личных учебных целей. Принцип личностного целеполагания предусматривает необходимость осознания целей обучения самим обучающимся (или совместно с преподавателем). Данный принцип опирается на глубинное чувство человека - способность постановки целей своей деятельности [16, с. 234].

Принцип выбора индивидуальной образовательной траектории базируется на возможности выбора способов достижения поставленных целей. Этот принцип устанавливает соответствие формируемого учеником личностного содержания образования задаваемому ему содержанию, имеющему характер образовательных стандартов [16, с. 235]. Раскроем, как мы видим реализацию данных принципов в системе формирования исследовательской компетенции. Принцип личностного целеполагания предполагает, что студент в процессе взаимодействия с научным руководителем определяет для себя цель прохождения учебной практики, а также учится соотносить свои желания с реальными возможностями. Благодаря принципу выбора индивидуальной образовательной траектории студент имеет возможность выбора способов достижения поставленной цели. Именно данный принцип будет учить студента самоорганизации и 
соблюдению поставленных «дедлайнов», если студент сам будет строить свой исследовательский маршрут.

Согласно принципу продуктивности обучения, главным ориентиром обучения является личное образовательное приращение обучающегося, складывающееся из его внутренних и внешних образовательных продуктов учебной деятельности [16, с. 236]. В ходе учебной практики студенты выполняют определенный перечень заданий, который в конце представляет из себя портфолио результатов прохождения учебной практики. Все это в совокупности представляет из себя готовый продукт образовательной деятельности студентов (в нашем случае, продукт его исследовательской деятельности).

Принцип образовательной рефлексии означает, что образовательный процесс сопровождается его рефлексивным осознанием субъектами образования. Отмечается, что рефлексия - это осознание способов деятельности, обнаружение еe смысловых особенностей, выявление образовательных приращений обучающегося. Обучающийся должен осознавать не только сделанное, но и способы деятельности, каким образом оно было сделано [16, с. 236]. По завершению учебной практики необходимо организовать встречу (итоговая конференция), на которой студенты смогли бы подвести итоги собственной деятельности, подчеркнуть, что получилось, а над чем необходимо поработать. Преподавателю рекомендуется проводить анкетирование студентов с целью выявления существующих проблем и сложностей, которые возникают у студентов, чтобы впоследствии найти эффективный способ снятия данных трудностей. Мнение студентов является не маловажным фактором при организации образовательного процесса, поэтому очень важно научить студентов рефлексии на данном этапе.

Помимо принципов личностно ориентированного обучения, выделяемых В.В. Краевским и А.В. Хуторским, стоит отметить принцип 
единства учебной и исследовательской работы студентов. Данный

принцип предполагает в качестве требований системный и непрерывный характер учебной исследовательской работы и творческое сотрудничество преподавателей и студентов. Непрерывность учебной исследовательской работы обеспечивает привлечение студентов к исследовательской работе [10, с. 54]. Данный принцип находит свое проявление в том, что полученные умения в ходе учебной практики легко применимы в учебной деятельности. Помимо учебной практики, стоит отметить, что исследовательский характер деятельности должен преобладать на многих дисциплинах, особенно связанных с методикой обучения иностранному языку.

Принцип конструктивного сотрудничества преподавателя со студентами в научно-исследовательской работе предполагает в качестве ведущего исследовательский тип взаимодействий, где студент выступает как соисполнитель в разработке определенной научной проблемы, а научный руководитель выполняет роль наставника и консультанта [10, с. 200]. Принцип реализуется при работе научного руководителя со своими обучающимися. Рассматриваемый принцип играет важную роль, так как именно научный руководитель первой исследовательской деятельности создает «фундамент», на котором будущий учитель английского языка формирует базовый уровень исследовательской компетенции.

Рассмотрев принципы, необходимые для организации исследовательской работы студентов, перейдем к следующему компоненту «методы обучения». Традиционно методы обучения делятся на следующие две большие категории: методы преподавания (показ, объяснение, организация тренировки, организация практики, коррекция, оценка) и методы учения (ознакомление, осмысление, участие в тренировке, практика, самооценка, самоконтроль) [18, с. 137]. Данные методы актуальны при 


\section{ЧЕЛОВЕК И СОВРЕМЕННОЕ ОБЩЕСТВО В СОЦИАЛЬНОМ, ПРАВОВОМ, ЭКОНОМИЧЕСКОМ РАКУРСАХ}

организации выполнения письменных видов деятельности, включенных в перечень заданий учебной практики.

Говоря о формировании исследовательской компетенции нельзя не упомянуть такой метод как исследовательский метод обучения. Данный метод предусматривает организацию поисковой творческой деятельности учащихся путем постановки новых проблем и проблемных задач [18, с. 91]. Данный метод пронизывает всю учебную практику по формированию первичных навыков научно-исследовательской работы. Благодаря исследовательскому методу организуется применение полученных знаний во время решения поставленных задач, требующих творческого решения. При исследовательском методе обучения студент овладевает методами научного познания в процессе поиска решения.

Далее представим технологический компонент системы формирования исследовательской компетенции будущих учителей английского языка, который представляет из себя те формы, средства и стратегии, которые используются для формирования искомой компетенции у студентов. Основным способом организации развития исследовательской компетенции выступает научно-исследовательская работа студентов (НИРС). Под данной работой понимается совокупность мероприятий, направленных на освоение методов приема и навыков выполнения научных работ, развитие способности, самостоятельности инициативности. Исследовательская компетенция должна формироваться в условиях системности и непрерывности образовательного процесса и ориентированности на индивидуальный потенциал студента [21, с. 38].

Для того, чтобы ввести будущих педагогов в научно-исследовательскую работу используют учебную практику, о которой мы неоднократно говорили ранее. По мнению Н.С. Стародубцевой учебная практика обладает потенциалом к выполнению следующих задач: 
- закрепить и углубить теоретические знания по общепрофессиональным и специальным дисциплинам, помочь овладеть способами применения полученных знаний в практической деятельности;

• приобрести практические умения и навыки по специальности;

- сформировать профессиональную гибкость;

- отработать умения правильно строить взаимоотношения с коллегами;

- развить личностно-профессиональные качества, создавать условия для формирования индивидуального стиля деятельности;

- создать условия для самопознания, самоопределения студентов в различных профессиональных ролях, вызывать потребности самосовершенствования личности в профессиональной деятельности;

- сформировать профессиональную направленность;

- сформировать профессиональное самосознание (адекватную самооценку себя как профессионала и знание путей и способов саморазвития, и самосовершенствования)

- выработать профессиональный оптимизм - убежденность в достижении профессионального успеха в будущем [22, с. 92].

В рамках учебной практики используются такие формы работы как: аудиторная и самостоятельная работа. В качестве аудиторной работы студенты участвуют в установочной конференции, посещают библиотечное занятие, являются на консультации с научным руководителем практики, участвуют в итоговой конференции по представлению результатов исследовательской деятельности и по подведению итогов прохождения учебной практики. Однако большая часть работы отводится студентам для самостоятельной организации собственной деятельности, что обучает студентов ответственности и самоорганизации. 


\section{ЧЕЛОВЕК И СОВРЕМЕННОЕ ОБЩЕСТВО В СОЦИАЛЬНОМ, ПРАВОВОМ, ЭКОНОМИЧЕСКОМ РАКУРСАХ}

Те виды деятельности, которыми необходимо овладеть студентам являются средствами формирования исследовательской компетенции. В рамках учебной практики мы предлагаем следующие виды деятельности:

- составление библиографического списка литературы по избранной проблеме;

• написание реферата научной статьи по избранной проблеме;

- написание аннотации научной статьи;

- написание обзорного реферата по 2-3 научным статьям по избранной проблеме;

• подготовка устного выступления по проблеме исследования

- создание презентации к устному выступлению;

- написание тезисов устного выступления.

Составление библиографического списка литературы является первой ступенью, первым видом деятельности предлагаемой системы формирования исследовательской компетенции. Необходимо уточнить, что список литературы студенты-будущие учителя английского языка составляют по проблемам иноязычного образования. Студенту необходимо понимать, какие источники литературы существуют, где их можно найти. Здесь поднимается вопрос об обучении будущих учителей английского языка умению ориентироваться в электронных библиотеках, а также разъяснению, где и как можно найти необходимые ресурсы по заданной теме. Студенты должны уметь оформлять необходимую для их исследования литературу в соответствии с последними правилами ГОСТа. Обучающиеся должны научиться оформлять разные виды источников (статьи, монографии, учебные пособия и др.), а также уметь оформлять англоязычные источники по проблеме.

Написание монореферата учит студентов анализировать мысли автора статьи. Обучающиеся знакомятся со статьей, с позицией автора по той или 


\section{ЧЕЛОВЕК И СОВРЕМЕННОЕ ОБЩЕСТВО В СОЦИАЛЬНОМ, ПРАВОВОМ, ЭКОНОМИЧЕСКОМ РАКУРСАХ}

иной проблеме иноязычного образования. Студенты изучают структуру реферата, знакомятся с устойчивыми фразами, свойственными научному письменному дискурсу. Студенты учатся цитировать ученых и правильно оформлять ссылки на их цитаты. Данные умения будут полезны для выполнения реферата, курсовой и выпускной квалификационной работы. Написание монореферата должно отражать теоретический аспект темы, вводя студента в проблему исследования и подготавливая его для написания обзорного реферата.

При написании аннотации к статье обучающийся пробует свои способности обобщать изученную информацию. Для этого руководитель учебной практики знакомит студентов со структурой аннотации к научной статье, объясняет особенности ее написания. Исходя из этого, обучающиеся начинают процесс осмысления статьи и представляют аннотацию. Данный вид деятельности необходим, так как студент должен осознавать необходимость своего собственного профессионального развития. Стоит отметить, что не все учителя в школе посвящают свое время написанию статей, некоторые заканчивают свою исследовательскую деятельность после написания ВКР на 4 курсе, однако необходимо сформировать у обучающихся стойкую мотивацию к продолжению личностного роста. Для повышения профессиональной категории учителю необходимо писать методические статьи, в которых, как правило, требуется представлять аннотацию.

Написание обзорного реферата в отличие от написания монореферата учит студентов сопоставлять мнения нескольких авторов, выделять общее и различное. При сопоставлении разных точек зрения у обучающего начинает формироваться собственное видение данной проблемы, развивается собственная позиция. Неотъемлемая часть обзорного реферата - это написание собственного мнения и его аргументация. Помимо этого, студент учить формулировать цели и задачи собственного «мини» исследования. 
Здесь начинаются первые шаги по проектированию собственного исследовательского маршрута. Выявление объекта и предмета исследования подготавливает к написанию курсовой и ВКР, так как очень важно на ранних стадиях научить студентов видеть разницу между данными понятиями и уметь выделять это в собственном исследовании. Обзорный реферат в отличие от монореферата направлен на практическое решение проблемы и рассматривает разные способы решения заданной проблемы.

Так или иначе, в своей профессиональной деятельности каждому учителю когда-нибудь приходится выступать перед аудиторией. С данной целью необходимо познакомить студентов со структурой устного выступления на научной конференции.

Для создания успешного устного выступления необходима грамотно сделанная презентация. Презентация происходит от латинского слова «praesento», что переводится как «представление». В качестве основной цели презентации выделяется донесение до аудитории информации об объекте презентации. Презентация, как правило, это сочетание текста, графических изображений, видео ряда, звукового сопровождения и т.д. Презентация должна иметь строгую структуру и запланированный сюжет. Однако отличительной особенностью презентации является ее интерактивность, как в техническом плане, так и в плане взаимодействия с аудиторией. На протяжении всего процесса обучения практически на каждой дисциплине сталкиваются с заданием «подготовить презентацию», поэтому именно на учебной практике необходимо научить студентов это делать, иначе от курса к курсу студенты будут накапливать «багаж» проблем при составлении презентации. Умение выступать с презентацией можно назвать современным умением, без которого учителю 21 века уже не обойтись.

Продолжая тему выступления перед аудиторией, акцентируем внимание на необходимости научиться писать тезисы собственного выступления. 


\section{ЧЕЛОВЕК И СОВРЕМЕННОЕ ОБЩЕСТВО В СОЦИАЛЬНОМ, ПРАВОВОМ, ЭКОНОМИЧЕСКОМ РАКУРСАХ}

Тезисы значительно упрощают выступление и помогают докладчику донести мысли до аудитории. В широком смысле тезисы это основные положения научного исследования, сформулированные в краткой форме. Студентам предлагается написать тезисы к своему выступлению, который обобщает проблему его исследования.

Как показали результаты анкетирования студентов 2 курса, будущих учителей английского языка, то необходимо в перечень заданий по учебной практике включить виды деятельности, связанные с английским языком. Студенты выражают заинтересованность в привлечении английского языка в свою исследовательскую деятельность, поэтому такие виды деятельности как написание аннотации и составление устного выступления с презентацией можно осуществлять сразу на двух языках (на русском и английском).

Мы полагаем, что в содержание дополнительного модуля, который студенты могут выбрать по желанию, мы можем включить написание аннотации на английском языке по требованиям международных публикаций, а также перевод аннотации русскоязычной статьи на английский, так как в настоящее время во многих российских журналах требуется аннотация и ключевые слова на русском и английском языках.

Данные средства формирования исследовательской компетенции отобраны на основе анализов рабочих программ учебных практик разных вузов, результатах анкетирования студентов и преподавателей, а также базируются на современных вызовах, которые стоят перед современным учителем английского языка. Таким образом, мы подробно рассмотрели средства формирования исследовательской компетенции в рамках учебной практики.

Благодаря рассмотренным блокам в данном параграфе: «методы формирования ИК», «принципы формирования ИК» и технологическому блоку можно собрать воедино всю систему формирования исследовательской 
компетенции, которой посвящена данная глава 2. Для наглядности представим данную систему в виде следующей схемы (табл. 6) в необходимом порядке:

\section{Таблица 6}

\section{Система формирования исследовательской компетенции}

\begin{tabular}{|c|c|}
\hline Целевой блок & - формирование исследовательской компетенции до определенного уровня \\
\hline $\begin{array}{l}\text { Мотивационный } \\
\text { блок }\end{array}$ & $\begin{array}{l}\text { - потребность в осуществлении исследовательской деятельности; } \\
\text { - мотив к развитию личности начинающего исследователя; } \\
\text { - интересы к проведению собственного исследования; } \\
\text { - осознание ИК как способ совершенствования ПМК. }\end{array}$ \\
\hline $\begin{array}{l}\text { Содержательный } \\
\text { блок }\end{array}$ & $\begin{array}{l}\text { - знания; } \\
\text { - навыки; } \\
\text { - умения; } \\
\text { - отношения (см. таблица 5) }\end{array}$ \\
\hline $\begin{array}{l}\text { Блок «принципы } \\
\text { формирования ИК» }\end{array}$ & $\begin{array}{l}\text {-принцип личностного полагания; } \\
\text {-принцип выбора индивидуальной образовательной траектории; } \\
\text {-принцип продуктивности; } \\
\text {-принцип образовательной рефлексии; } \\
\text {-принцип единства учебной и исследовательской работы студентов; } \\
\text {-принцип конструктивного сотрудничества преподавателя со студентами. }\end{array}$ \\
\hline $\begin{array}{l}\text { Блок } \\
\text { «методы } \\
\text { формирования ИК» }\end{array}$ & $\begin{array}{l}\text { - методы преподавания } \\
\text { - методы учения } \\
\text { - инновационно-деятельностные методы (исследовательский метод обучения) }\end{array}$ \\
\hline $\begin{array}{l}\text { Технологический } \\
\text { блок }\end{array}$ & $\begin{array}{l}\text { - учебная практика (виды деятельности: составление библиографического списка, } \\
\text { написание аннотации, написание тезисов, монореферата и обзорного реферата, } \\
\text { подготовка презентации и устного выступления). }\end{array}$ \\
\hline $\begin{array}{l}\text { Результативный } \\
\text { блок }\end{array}$ & $\begin{array}{l}\text { - минимальный уровень (Элементарное владение); } \\
\text { - базовый уровень (Достаточное владение); } \\
\text { - высокий уровень (Свободное владение). }\end{array}$ \\
\hline
\end{tabular}

Далее раскроем технологию формирования исследовательской компетенции студентов-бакалавров. 


\section{3. Технология формирования исследовательской компетенции студентов}

\section{В процессе учебной практики}

Каждый из указанных видов деятельности в рабочей программе должен сопровождаться определенными рекомендациями, которые призваны облегчить процесс прохождения учебной практики. Данный параграф представит стратегии выполнения каждого вида деятельности и критерии его оценивания.

Традиционно, задания идут по порядку от более простого к более сложному, постепенно подводя студента к новому уровню. Рекомендуемая последовательность выглядит следующим образом: 1) библиографический список; 2) монореферат; 3) аннотация; 4) обзорный реферат; 5) устное выступление с презентацией; 6) тезисы выступления.

Однако подготовка к выполнению каждого вида деятельности должна проходить через определенные этапы. В данном исследовании на основе анализа научной литературы и результатов опытного обучения предлагается определенная последовательность действий, призванная облегчить понимание студентов сущности выполнения каждого вида работ. Всего представляется 4 этапа [23]:

$>1$ этап - ознакомление. На данном этапе студенты знакомятся с предлагаемым видом работы в общем плане и осознают значимость данного умения для дальнейшего профессионального становления. Уделяется внимание формированию мотивации у студента к выполнению предлагаемого вида деятельности и привлечение внимания обучающегося. Определяются сроки выполнения данного вида работ и заполняется индивидуальный образовательный маршрут начинающего исследователя пункты 1-3;

2 этап - погружение. Студенты изучают образцы и пытаются выявить структуру и алгоритм действий с предлагаемым видом работы. Происходит знакомство с памятками и снятие возможных трудностей. 
На данном этапе необходимо ознакомить студентов с требованиями по оформлению конкретного документа;

3 этап - исполнительский. Студенты первый раз пробуют себя в выполнении данного вида работы и в соответствии с дедлайном сдают работу своему руководителю. Преподаватель активно взаимодействует со студентами на данном этапе, направляя студентов в нужном направлении. Студенты заполняют в маршруте пункты 4-9;

$>4$ этап - демонстрационно-рефлексивный. Данный этап предлагает защиту выполненного задания и рефлексию проведенной деятельности. Преподаватель оценивает работу студента по выполнению данного задания. Задача студента состоит в проведении подробной рефлексии собственных действий и выявлению трудностей и возможных причин их возникновения. Студенты заканчивают заполнение исследовательского маршрута и проверяют документацию.

Данная стратегия используется для каждого вида деятельности, перечисленного выше, и представляет из себя непрерывный цикл (рис. 2). При завершении одного цикла сразу же начинается новый. Пропускать один из этапов представляется невозможным, также, как и менять их местами, так как нарушится логика выполнения заданий, что может привести к неполноценному формированию исследовательских действий.

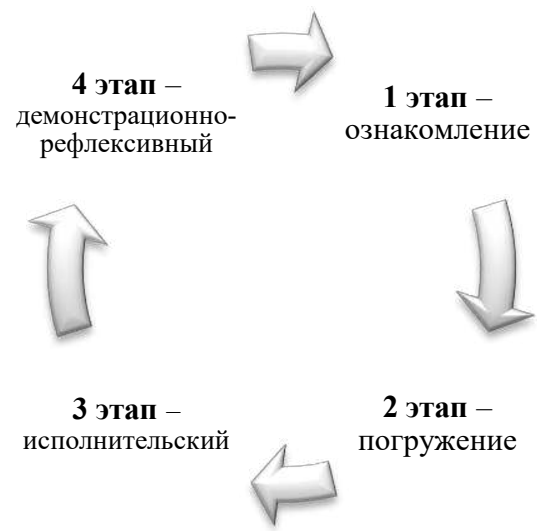

Рис. 2. Этапы выполнения заданий учебной практики 115 


\section{ЧЕЛОВЕК И СОВРЕМЕННОЕ ОБЩЕСТВО В СОЦИАЛЬНОМ, ПРАВОВОМ, ЭКОНОМИЧЕСКОМ РАКУРСАХ}

Самым первым видом деятельности выступает составление библиографического списка. На первом этапе студенты посещают библиотечное занятие, знакомятся с электронными библиотеками и заводят личный кабинет читателя. На втором этапе студенты погружаются в данную деятельность и знакомятся с образцами библиографического описания, а также с образцом оформления данного списка и рекомендациями по выполнению данной деятельности (табл. 7).

\section{Таблица 7}

\section{Рекомендации по составлению библиографического списка}

1. Найти подходящий материал, используя ресурсы, которые были представлены на библиотечном занятии;

2. Определить вид источника (журнальная статья/монография/ автореферат/ диссертация/ материалы конференций/ учебник/ учебное пособие/ словарь/ электронный источник и т.п.);

3. Обратиться к нужной форме описания, используя образцы библиографического описания.

4. Составить библиографическое описание найденного источника, обращая внимание на особенности оформления конкретного источника.

5. Добавить все найденные источники и распределить их по алфавиту.

6. Проверить весь документ на соответствие требованиям к оформлению (шрифт, размер, интервал и Т.П.).

7. Распечатать файл и вложить в папку портфолио по учебной практике.

Рекомендуемая последовательность этапов систематизирует в понимании студентов правильную последовательность действий, доводя их до автоматизма. В каждом последующем виде деятельности студентам придется указывать использованный список литературы, именно поэтому он идет первым в перечне. На 3 этапе студенты выполняют библиографический список и сдают своему руководителю. Важно также чтобы источники были не только русскоязычные, но и англоязычные тоже, так как английский язык это профиль подготовки студентов. В своих дальнейших исследованиях студентам будет необходимо обращаться к англоязычным источникам и правильно их оформлять. 


\section{ЧЕЛОВЕК И СОВРЕМЕННОЕ ОБЩЕСТВО В СОЦИАЛЬНОМ, ПРАВОВОМ, ЭКОНОМИЧЕСКОМ РАКУРСАХ}

На 4 этапе происходит рефлексия собственной деятельности и оценивание результатов детальности согласно следующим критериям: разнообразие источников; правила оформления; дедлайн; количество попыток.

Следующий вид деятельности - это написание монореферата. В начале необходимо пояснить студентам, что монореферат не копирует дословно источник. Цель данной работы заключается в обучении студентов систематизировать и обобщать точку зрения одного автора, а также научить правильно оформлять ссылку на цитируемую работу. На данном этапе важно ознакомить студентов со всеми вводными конструкциями, благодаря которым студент может формировать свою точку зрения. Помимо этого, студенты заполняют индивидуальный образовательный маршрут начинающего исследователя. Кроме того, студенты точно должны осознавать структуру монореферата (табл. 8):

\section{Таблица 8}

\section{Компоненты монореферата (реферат по 1 статье)}

\begin{tabular}{|l|l|}
\hline \multicolumn{1}{|c|}{$\begin{array}{c}\text { Компонент } \\
\text { монореферата }\end{array}$} & \multicolumn{1}{c|}{ Описание } \\
\hline Представление статьи (1) & $\begin{array}{l}\text { Кратко представляете название статьи, автора и журнал. Чему посвящена } \\
\text { статья? }\end{array}$ \\
\hline Актуальность (2) & $\begin{array}{l}\text { Несколько предложений об актуальности данной проблемы для современной } \\
\text { методики обучения иностранным языкам. }\end{array}$ \\
\hline Пбъект (3) & $\begin{array}{l}\text { Пространство, в рамках которого ведется исследование, процесс, } \\
\text { порождающий проблемную ситуацию, который взят исследователем для } \\
\text { изучения. Часть научного знания, с которой исследователь имеет дело. Чаще } \\
\text { всего формулируется через слово «процесс» }\end{array}$ \\
\hline Предмет (4) & $\begin{array}{l}\text { Тот аспект проблемы, исследуя который, студент познает целостный объект, } \\
\text { выделяя его главные наиболее существенные признаки. Предмет находится в } \\
\text { рамках объекта. }\end{array}$ \\
\hline Цель (5) & Основная цель, которую преследовал автор при написании статьи. \\
\hline Основная часть (6) & $\begin{array}{l}\text { Выделение смысловых частей статьи и грамотное раскрытие основных } \\
\text { вопросов каждой смысловой части. Здесь необходимо использование клише, } \\
\text { данные в образцах и дополнительных памятках. }\end{array}$ \\
\hline Подведение итогов (7) & Краткое обобщение результатов проведенного исследования в статье. \\
\hline Адресованность (8) & Для кого реферируемая статья представит интерес? \\
\hline
\end{tabular}


Ознакомив студентов со структурой монореферата, необходимо порекомендовать ту последовательность действий при написании монореферата, которая будет способствовать получению наиболее успешного результата и сократить количество попыток студентов написать верный вариант монореферата. Также студентам демонстрируется готовый образец монореферата с целью ознакомления графического оформления.

Таблица 9

\section{Рекомендации по написанию монореферата}

1. Сформулировать тему исследования (провести самостоятельный поиск круга проблем, которые
представляют интерес и проконсультироваться с научным руководителем для утверждения темы);
2. С помощью различных ресурсов отобрать необходимый источник для монореферата;
3. Ознакомиться с выбранным источником;
4. Приступить к систематизации изученной информации, следуя структуре монореферата (табл. 8).
Соблюдать правила цитирования источника в тексте и использовать клише для обобщения мыслей
автора;
5. Оформить конечный вариант монореферата (сверить все требования по оформлению,
пронумеровать страницы и т.п.).

Монореферат, как неотъемлемый вид деятельности, включенный в перечень учебной практики, необходимо оценивать по следующим критериям: соблюдение структуры монореферата; уровень обобщенности мыслей автора; логика; использование клише; дедлайн; попытка; оформление.

Аннотацию будет целесообразно писать по статье после того, как студент детально изучит статью в процессе написания монореферата. Благодаря этому студенту будет легче кратко изложить основное содержание статьи. Студенты изучают образец аннотации. А после этого студентов необходимо ознакомить со структурой аннотации (табл. 10). 
Таблица 10

\section{Основные компоненты аннотации}

\begin{tabular}{|c|c|}
\hline $\begin{array}{l}\text { Компонент } \\
\text { аннотации }\end{array}$ & Описание \\
\hline $\begin{array}{l}\text { Актуальность } \\
\text { (1) }\end{array}$ & $\begin{array}{l}\text { С самого начала необходимо показать важность изучаемой исследовательской проблемы } \\
\text { или предлагаемого проекта. У читателей сразу должно сформироваться представление, } \\
\text { почему обсуждаемая проблема требует внимания, изучения. }\end{array}$ \\
\hline $\begin{array}{l}\text { Постановка } \\
\text { проблемы (2) }\end{array}$ & $\begin{array}{l}\text { После раскрытия актуальности необходимо обозначить существующую проблему, на } \\
\text { решение которой и будет направлено исследование (статья). }\end{array}$ \\
\hline $\begin{array}{l}\text { Пути решения } \\
\text { проблемы (3) }\end{array}$ & $\begin{array}{l}\text { В данном разделе аннотации необходимо перечислить конкретные шаги, направленные } \\
\text { на решение существующей проблемы. В теоретических исследованиях (в которых нет } \\
\text { описания эксперимента и анализа его результата) может быть перечисление } \\
\text { исследуемых теоретических вопросов. В экспериментальных исследованиях (если в } \\
\text { работах имеются статические данные эксперимента) в этом разделе аннотации } \\
\text { перечисляются методики проведения экспериментальной работы, исследуемые } \\
\text { переменные. }\end{array}$ \\
\hline Результаты (4) & $\begin{array}{l}\text { В данном разделе представляется количественные или качественные результаты } \\
\text { исследования. Рекомендуется использовать общие слова типа «доказала } \\
\text { эффективность», «оказалась неэффективной», не упоминая конкретные цифры, которые } \\
\text { могут быть неверно интерпретированы. }\end{array}$ \\
\hline \multirow[t]{2}{*}{$\begin{array}{l}\text { Выводы }+ \\
\text { Адресованность } \\
\text { (5) }\end{array}$} & $\begin{array}{l}\text { В заключение необходимо обозначить сферу внедрения результатов исследования, } \\
\text { насколько проделанная работы расширила существующие представления об изучаемом } \\
\text { вопросе или предложила новое решение существующей проблемы. }\end{array}$ \\
\hline & $\begin{array}{l}\text { Кому предназначена данная статья, возможный круг читателей, который может } \\
\text { заинтересоваться данной тематикой. }\end{array}$ \\
\hline
\end{tabular}

После ознакомления студентов с компонентами аннотации должен происходить инструктаж студентов о том, какую последовательность действий необходимо соблюдать, чтобы процесс написания аннотации был посильным студенту (табл. 11). 
Таблица 11

\section{Рекомендации по написанию аннотации}

1. Прочитайте статью и постарайтесь разбить текст на смысловые части;

2. В каждой смысловой части выделите основную идею;

3. Передайте основные идеи по порядку, используя перифраз, чтобы не повторять текст статьи;

4. Приступайте к написанию текста аннотации. Сначала в 1-2 предложениях сформулируйте актуальность затронутой темы;

5. Представьте основную проблему и мысли, на которых акцентирует внимание автор.

6. Перечислите основные шаги, которые осуществляет автор для решения поставленных проблем;

7. Кратко, без подробностей, перечислите к чему приходит автор в своем исследовании;

8. Проанализируйте, какой аудитории подойдет данная статья и почему.

При написании аннотации к собственной статье необходимо выделять ключевые слова статьи, поэтому предлагается студентам попробовать определить ключевые слова для реферируемой статьи.

Ключевые слова - это теги, по которым можно искать статью в интернете. Правильно выбранные слова помогают исследователям необходимые статьи находить в интернете.

Аннотацию следует оценивать по следующим критериям, которые затрагивают разные аспекты: актуальность и соответствие теме; структура; обобщенность информации; ключевые слова; дедлайн; попытка; оформление.

Обзорный реферат является самым сложным из представленных ранее видов деятельности. Все предыдущие виды деятельности подготавливали студентов к написанию данного реферата. Как и ранее на 2 этапе сначала студентов необходимо ознакомить с компонентами обзорного реферата (табл. 12): 
Таблица 12

Компоненты обзорного реферата

\begin{tabular}{|c|c|}
\hline Компонент реферата & Описание \\
\hline Актуальность (1) & $\begin{array}{l}\text { Небольшой параграф, доказывающий актуальность вопроса, затронутого в } \\
\text { реферате. В конце Вы подводите читателя к теме своего исследования. } \\
\text { Рекомендуется использовать фразу (... это и обусловило выбор темы } \\
\text { настоящего реферата «Название темыл). }\end{array}$ \\
\hline Объект исследования (2) & $\begin{array}{l}\text { Пространство, в рамках которого ведется исследование, процесс, } \\
\text { порождающий проблемную ситуацию, который взят исследователем для } \\
\text { изучения. Часть научного знания, с которой исследователь имеет дело. Чаще } \\
\text { всего формулируется через слово «процесс» }\end{array}$ \\
\hline Предмет исследования (3) & $\begin{array}{l}\text { Тот аспект проблемы, исследуя который, студент познает целостный объект, } \\
\text { выделяя его главные наиболее существенные признаки. Предмет находится в } \\
\text { рамках объекта. }\end{array}$ \\
\hline Цель реферата (4) & Формулируете главную цель своего реферата. Звучит широко и масштабно. \\
\hline Задачи рефер: & $\begin{array}{l}\text { Из сформулированной цели вытекает решение нескольких задач (3-4 задачи). } \\
\text { Задачи звучат более конкретно в отличие от цели. В основном содержании } \\
\text { впоследствии необходимо предоставить решение каждой поставленной } \\
\text { задачи. }\end{array}$ \\
\hline $\begin{array}{l}\text { Какие статьи } \\
\text { рассматриваются? (6) }\end{array}$ & Представляете труды, которые подвергаются реферированию. \\
\hline Основная часть (7) & $\begin{array}{l}\text { Обобщаете позиции авторов по указанной проблеме, сопоставляете, } \\
\text { отмечаете их основные мысли и т.п. Представляете решение поставленных } \\
\text { задач к данному реферату в указанном порядке (см. пункт задачи реферата). } \\
\text { Не забывайте использовать специальные клише, представленные в памятках. }\end{array}$ \\
\hline Собственная позиция (8) & $\begin{array}{l}\text { На основе изучения мнений исследователей приходите к собственному } \\
\text { умозаключению и аргументируете его. }\end{array}$ \\
\hline Выводы (9) & $\begin{array}{l}\text { Подводите итог проделанной работы, обращаете внимание на главные } \\
\text { моменты своего реферата. }\end{array}$ \\
\hline Список литературы (10) & Оформляется строго по правилам оформления. \\
\hline
\end{tabular}

Неотъемлемой частью этапа погружения являются рекомендации по выполнения данного задания и знакомство с клише. После ознакомления со структурой обзорного реферата обучающимся предлагается следующая последовательность действий (табл. 13): 
Таблица 13

Рекомендации по написанию обзорного реферата

1. Сформулировать тему исследования (провести самостоятельный поиск круга проблем, которые представляют интерес и проконсультироваться с научным руководителем для утверждения темы);

2. Составить список литературы, который необходим по этой теме.

3. Изучить составленный список и отобрать необходимое для реферата.

4. Составление плана реферата.

5. Приступить к систематизации изученной информации.

6. Следовать структуре написания обзорного реферата, соблюдая все правила цитирования.

7. Оформить правильно конечный вариант реферата, который включает всю структуру: (сверить все требования по оформлению, пронумеровать страницы и т. п.).

Студентам также предлагается образец выполненного задания с целью демонстраций требований оформления и соблюдение структуры. Критерии, которые необходимо положить в основу оценивания на 4 этапе представляем следующие: соответствие содержания заданной теме; структура реферата (актуальность, объект, предмет, цель, задачи, описание статей, основная часть, собственная позиция, выводы; список использованной литературы); логика; оформление; ссылки; клише; попытка; дедлайн.

Следующие виды деятельности связаны с устными видами деятельности: устное выступление с презентацией и тезисы выступления. Устное выступление с презентацией студентам необходимо во время защиты своего обзорного реферата (индивидуально) и при подведении итоговой учебной практики (групповое задание) на итоговой конференции.

На первом этапе целесообразно провести лекцию для студентов о том, как нужно делать презентацию. Необходимо продемонстрировать примеры разных уровней презентаций и осудить их ошибки со студентами в процессе беседы.

Научно-исследовательская презентация, которая интересует нас на данном этапе профессионального становления, является по природе своей 
линейной презентацией. У научно-исследовательской презентации 2 основные функции: быть планом-опорой для выступающего; быть визуализацией информации для аудитории. Структура научно-исследовательской презентации должна иметь следующий вид (табл. 14):

Таблица 14

Структура научно-исследовательской презентации

\begin{tabular}{|c|c|}
\hline Слайд & Содержимое \\
\hline 1.Титульный слайд & $\begin{array}{l}\text { - тема исследования } \\
\text { - кто выполнил } \\
\text { - научный руководитель }\end{array}$ \\
\hline 2.План & Представить логику выступления \\
\hline 3.Основная часть & $\begin{array}{l}\text {-обобщение степени изученности } \\
\text { - собственные мысли }\end{array}$ \\
\hline 4.Выводы & Список умозаключений \\
\hline 5.Список использованной литературы & Перечень основных трудов, использованных в работе \\
\hline 6.Титульный лист & См. пункт 1 \\
\hline
\end{tabular}

Студентов необходимо ознакомить со следующими этапами процесса подготовки презентации и речи:

$>1$ эman. Формулировка цели презентации. Перед созданием презентации всегда необходимо ответить на вопросы: «Зачем? Что я хочу добиться своей презентацией?» Для того, чтобы добиться от показа презентации максимальной пользы, цель должна быть реалистичной и выражена одним предложением.

$>2$ эman. Сбор и систематизация материала. На этом этапе важно отобрать материал для выступления. Материала должно быть достаточно для выступления, но на слайдах все должно быть представлено в графиках, таблицах, схемах и т.п. Следует помнить, что на слайдах должна быть представлена только самая важная информация. Рекомендуется при подборе материала сразу формулировать те слова или фразы, которые будут вынесены 
на слайды. Это легко реализовать в виде таблицы, где в левом столбце будет информация, которая будет донесена до зрителей в устной форме, а в правом - материалы для слайдов (тексты, иллюстрации, схемы и проч.).

$>3$ эman. Разработка концепции презентации. В соответствии с задачами исследования постепенно раскрывать материал, не забывая о логике выступления;

> 4 эman. Создание дизайна презентации. При создании презентаций можно ограничиться выбором готовых шаблонов, позже необходимо придумать свой стиль для презентаций. На этом этапе необходимо решить, какие цвета будут преобладать в презентации, какими будут переходы между слайдами и т.п. Обычно визуально выделяют: титульный, основной/контентный, слайд-разделитель (используется для визуального отделения блоков презентации) и заключительный слайды. Дизайн презентации тоже не так прост, как кажется. Здесь необходимо следовать следующим правилам (на слайдах): использовать грамотное сочетание цветов; соблюдать контрастность текста и фона; текст и картинки должны быть выровнены; наличие минимум текста, правило предпочтений на слайде: схема, рисунок, график, таблица, текст; выделять важные моменты другим цветом;

> 5 эman. Наполнение презентации. Необходимо перенести на слайды материалы из второго столбца таблицы (см. 2 этап). Следует учитывать, что помимо основного материала, у слайдов должны быть заголовки.

> 6 эman. Оптимизация текстов и графики. Важно решить, какие из текстовых материалов можно заменить иллюстрациями или схемами. Если текст необходимо оставить, то нужно придерживаться следующих правил: большие абзацы текста попробовать сократить или разбить на несколько слайдов; не использовать выравнивание по центру для больших блоков текста (читать такой материал очень трудно); перечисления лучше представить в 


\section{ЧЕЛОВЕК И СОВРЕМЕННОЕ ОБЩЕСТВО В СОЦИАЛЬНОМ, ПРАВОВОМ, ЭКОНОМИЧЕСКОМ РАКУРСАХ}

виде списков; не использовать эффекты анимации к текстам. количественные данные можно визуализировать с помощью диаграмм - это добавит наглядности излагаемому материалу.

> 7 этап. Вёрстка слайдов. Текстам присваиваются единые виды шрифтов и цветов. Заголовки и тексты выравниваются по направляющим или сетке (чтобы при переходе от одного слайда к другому тексты не «прыгали», меняя свои позиции). При необходимости к элементам презентации добавляются эффекты анимации (они должны быть оправданы - например, постепенный показ схемы или этапов). От звуковых эффектов при переходе от слайда к слайду лучше отказаться.

$>8$ эman. Тестирование презентации. На этом этапе необходимо соотнести текст выступления со слайдами. Проверка презентации в режиме демонстрации позволит проверить удобство работы со слайдами, эффектами анимации [24].

К презентации и устному выступлению выдвигаем следующие критерии оценивания необходимые для 4 этапа: соблюдение структуры презентации и логика выступления; аргументация собственных суждений; раскрытие темы (соответствие названия презентации ее содержанию); интеракция с аудиторией; умение соблюдать регламент выступления; графическое оформление презентации; умение отвечать на вопросы после выступления; умение взаимодействовать с напарником (при парной или групповой форме работы).

Тезисы связаны с выступлением непосредственно прямым образом связаны. Тезисы представляют из себя основные моменты устного выступления и служат помочь аудитории понять суть выступления. Студенты знакомятся с образцом тезисов выступления. Рекомендации по написанию тезисов для студентов необходимые для 2 этапа предлагаются следующие (табл. 5): 
Таблица 15

\title{
Рекомендации по написанию тезисов выступления
}

\begin{abstract}
1. Дайте название тезисам в соответствии с содержанием выступления;
2. Из текста выступления из каждого параграфа одним предложением сформулируйте ключевую мысль (Убедитесь, что Ваши тезисы выступления отвечают на следующие вопросы: что изучалось (формулировка проблемы, актуальность в настоящее время)? как проводилось исследование (обзор и анализ научной литературы)? в чем результаты исследования? (собственные умозаключения и выводы);

3. Перечитайте написанное, определите все ли ключевые мысли раскрыты в тезисах, при необходимости дополните;

4. Проверьте тезисы на требования к оформлению.
\end{abstract}

Во время подведения итогов выполненного задания на 4 этапе помимо рефлексии студентов, предлагаются следующие критерии оценивания необходимые для преподавателей: соответствие названию тезисов основному содержанию; умение обобщить основные мысли выступления в сжатом виде для тезисов; графические требования оформления тезисов; использование клише; попытка; дедлайн.

В качестве развития иноязычной исследовательской компетенции предлагается в рамках дополнительного модуля учебной практики включить виды деятельности на английском языке [25]. Данные задания будут представлять интерес для мотивированных студентов, которые считают, что им будет интересно и полезно освоить данные виды деятельности для их будущей профессии. Стоит отметить, что данный модуль не является обязательным и является осознанным выбором самих студентов.

В данном модуле студентам предлагается ознакомиться со структурой написания аннотации на английском языке. Если студент заинтересован в дальнейшей публикации результатов собственного исследования, то он осознает для себя потребность научиться писать аннотацию. Многие журналы помимо русского текста аннотации требуют название, ключевые слова и аннотацию на английском языке. Журналы могут требовать как обычный 
перевод аннотации с русского на английский, так и аннотацию со структурой, принятой в англоязычном научном мире (все зависит от выбранного журнала). Представляется целесообразным ознакомить студентов с двумя вариантами аннотации. Рассмотрим первый вариант написания аннотации, когда автору необходимо перевести уже готовый русский текст на английский язык. В данной диссертации для этого мы предлагаем следующую последовательность действий, которая опирается на ранее данные рекомендации по написанию аннотации на русском языке (табл.16):

Таблица 16

\section{Рекомендации по написанию аннотации на английском языке} (1 вариант)

\footnotetext{
1. Прочитайте статью и постарайтесь разбить текст на смысловые части;

2. В каждой смысловой части выделите основную идею;

3. Выделите для себя ключевые слова статьи и найдите с помощью словарей их подходящий английский эквивалент;

4. Составьте список ключевых слов статьи на английском языке (4-5 слов);

5. Аккуратно переведите русскую аннотацию, соблюдая особенности англоязычного научного дискурса (используйте клише, ключевые слова, поищите в англоязычной методической литературе необходимые термины);

6. Внимательно перечитайте полученный текст и проверьте его на наличие ошибок.
}

В качестве критериев оценки переведенной аннотации на английский язык выдвигаются следующие критерии оценивания: уровень обобщенности мыслей автора; способность передать мысли автора на английском языке, сохраняя основную суть; английский язык; дедлайн; попытка; оформление.

Помимо простого перевода аннотации на английский язык может потребоваться написание аннотации с соблюдение английской структуры [корзун, савкина]. В структуру аннотации на английском языке входят следующие компоненты: 


\section{ЧЕЛОВЕК И СОВРЕМЕННОЕ ОБЩЕСТВО \\ В СОЦИАЛЬНОМ, ПРАВОВОМ, ЭКОНОМИЧЕСКОМ РАКУРСАХ}

- background (то что уже известно об изучаемом вопросе в краткой форме 2-3 предложения, самая маленькая секция аннотации);

- methods (описание того, что было сделано для того, чтобы получить собственные умозаключения, описание анализа литературы, описание проведенных опросов, экспериментов, если таковые имеются);

- results (на основе описанных ранее методов вывести основные результаты продленной работы, самая большая часть аннотации);

- conclusions (подведение итогов исследования, кратко что было сделано и перспективы дальнейшего исследования).

Рекомендации по написанию аннотации данного типа могут выглядеть следующим образом (табл. 17):

Таблица 17

\section{Рекомендации по написанию аннотации на английском языке}

(2 вариант)

1. Прочитайте текст статьи и выделите основные мысли автора;

2.Соотнесите содержание статьи с компонентами аннотации, определите, где какая информация дана;

3.Начнайте составлять текст аннотации на английском языке;

4.Проверьте все ли компоненты аннотации раскрыты у Вас;

5.Перечитайте текст на наличие ошибок;

6.Проверьте все требования по оформлению.

Исходя из выше сказанного критерии по оценке данного вида аннотации выглядят следующим образом: соблюдение структуры аннотации; раскрытие основных смыслов; английский язык; дедлайн; попытка; оформление. Нарушение структуры аннотации или выбор неправильного регистра могут стать причиной социолингвистических различий исследований на русском и английском языках. При написании аннотации обучающийся может не задумывать о том, что у представителя другого научного сообщества может 
быть «своя индивидуально сформированная (пропущенная сквозь собственный опыт) картина мира, отличная от общепринятой в его стране)» $[26$, с. 110]. В рамках осуществления исследовательской деятельности на неродном языке эти факторы необходимо принимать во внимание.

Перечисленные виды работы ранее призваны способствовать развитию исследовательской компетенции студентов - будущих учителей английского языка. Балльная система оценки каждого критерия должна быть прописана в рабочей программе исходя из общего количества баллов отведенного для каждого вида задания. Предложенные технологии были апробированы в ходе опытного обучения и доказали свою эффективность. Представленные виды деятельности и технологии позволят представить рабочую программу практики по формированию первичных навыков и умений научноисследовательской работы.

\section{Список литературы}

1. Приказ Минобрнауки России от 4 декабря 2015 г. № 1426 «Об утверждении федерального государственного образовательного стандарта высшего образования по направлению подготовки 44.03.01 Педагогическое образование (уровень бакалавриата)» [Электронный ресурс]. URL: https://минобрнауки.рф/документы/7995 (дата обращения 10.02. 2018).

2. Хуторской, А.В. Методологические основания применения компетентностного подхода к проектированию образования // Высшее образование в России. - 2017. - № 12 (218). - С. 85-91.

3. Махмурян, К.С. Структура, содержание и уровни профессиональной компетентности учителя иностранного языка [Текст] / К.С. Махмурян // Сборник статей МГПУ, МИОО. - М., 2006. - С.72-79. 
4. Игна, О.Н. Структура и содержание методической компетентности учителя иностранного языка // ГОУ ВПО «Томский государственный педагогический университет». - 2010. - №1. - С.90-94.

5. Надточева, Е.С. Профессионально-методическая компетенция как приоритетная цель подготовки будущих учителей второго иностранного языка // Языковое образование сегодня -векторы развития: материалы II Международной научно-практической конференции-форума. Екатеринбург, 2011. - С. 117-129.

6. Макеева, С.Н. К разграничению понятий «лингводидактическая компетенция» и «методическая компетенция» учителя иностранного языка//Вестник Московского городского педагогического университета. Серия: Филология. Теория языка. Языковое образование. - 2012. - № 1 (9). C. 91-96.

7. Дубаков, А.В. Формирование методической компетенции будущего учителя иностранного языка: содержательные и организационнотехнологические аспекты // Научно-методический электронный журнал «Концепт», 2015. - Т. 13. - С. 2576-2580.

8. Гальскова, Н.Д. Основы методики обучения иностранным языкам: учебное пособие / Н.Д. Гальскова, А.П. Василевич, Н.Ф. Коряковцева, Н.В. Акимова. - М.: Кнорус, 2018. - 390 с.

9. Корзун О.О. Роль исследовательской компетенции в структуре профессионально-методической компетентности будущих учителей иностранного языка / О.О. Корзун, Е.А. Савкина // Филологические науки. Вопросы теории и практики. - 2018. - № 6-2(84). - С. 420-424. - DOI 10.30853/filnauki.2018-6-2.50.

10. Языкова, Н.В. Формирование профессионально-методической деятельности студентов педагогических факультетов иностранных языков. Улан-Удэ: Бурятское книжное издательство, 1994. 238 с. 
11. Бредихина И.А. Особенности структуры профессиональной компетентности преподавателя иностранного языка // Педагогическое образование в России. - 2015. - №9. URL: https://cyberleninka.ru/article/n/ osobennosti-struktury-professionalnoy-kompetentnosti-prepodavatelyainostrannogo-yazyka (дата обращения: 02.03.2018).

12. Каменский А.И. Структура профессиональной компетентности учителя иностранного языка // Компетентностная модель филолога. Симферополь, 2017. - С 61-96.

13. Тарева, Е.Г. Языковое образование в эпоху постмодернизма: кризис системности или новая системность? / Е.Г. Тарева // Язык и культура. - 2021. - № 53. - C. 270-289. - DOI 10.17223/19996195/53/17.

14. Одинцова, Л.А. Основные принципы и факторы формирования исследовательской деятельности будущих бакалавров педагогического образования // Современные проблемы науки и образования. - 2014. - №6. C. 688 .

15. Ильичев, Л.Ф., Федосеев, П.Н. Философский энциклопедический словарь. - М.: Советская энциклопедия, 1983. - 840 с.

16. Краевский, В.В. Основы обучения. Дидактика и методика: учебное посбие для студентов высш. учеб. Заведений / В.В. Краевский, А.В. Хуторской. - М.: Издательский центр «Академия», 2007. - 352 с.

17. Ильин, Е.П. Мотивация и мотивы. / Е.П. Ильин. - СПб.: Питер, 2011. $512 \mathrm{c}$.

18. Азимов, Э.Г., Щукин, А.Н. Новый словарь методических терминов и понятия (теория и практика обучения языкам). - М.: Издательство ИКАР, 2009. -448 c.

19. Common European Framework of Reference for Languages: learning, teaching, assessment. Companion volume with new descriptors. Council of Europe, Strasbourg, 2020 [Электронный pecypc] URL: https://rm.coe.int/common- 
european-framework-of-reference-for-languages-learning-teaching/16809ea0d4 (дата обращения 17.09.2021).

20. Корзун, О.О. Формирование исследовательской компетенции студентов - будущих учителей английского языка / О.О. Корзун, Е.А. Савкина // Среднее профессиональное образование. - 2019. - № 3. - С. 32-35.

21. Мацевич, С.Ф. К вопросу о формировании исследовательской компетенции студентов нелингвистических направлений подготовки средствами дисциплины «иностранный язык» // Иностранный язык и культура в контексте образования для устойчивого развития. Международный сборник научно-методических статей. - 2017. - С. 37-47.

22. Стародубцева, Н.С. Формирование основ профессиональной успешности у студентов вузов в условиях учебных практик: диссертация ... кандидата педагогических наук: 13.00.08. - Биробиджан, 2006. - 230 с.

23. Корзун, О.О. Технология формирования исследовательской компетенции студентов - будущих учителей английского языка в условиях учебной практики / О.О. Корзун, Е.А. Савкина // Среднее профессиональное образование. - 2019. - № 9. - С. 36-41.

24. Грибан, О.Н. Мастер презентаций / О.Н. Грибан. - Екатеринбург: Уральский государственный педагогический университет, 2016. - 268 с. ISBN 978-5-4474-4829-5.

25. Корзун, О.О. К вопросу подготовки будущих учителей английского языка к реализации исследовательской деятельности / О.О. Корзун, Е.А. Савкина // Среднее профессиональное образование. - 2021. - № 1(305). C. 62-66.

26. Савкина, Е.А. Параметры социолингвистической компетенции участника межкультурной коммуникации / Е.А. Савкина // Общество. Коммуникация. Образование. - 2020. - Т. 11. - № 3. - С. 108-120. - DOI 10.18721/JHSS.11309. 
Глава 6.

ОСОБЕННОСТИ ПСИХОФИЗИЧЕСКОГО СОСТОЯНИЯ

СОВРЕМЕННОЙ МОЛОДЁЖИ В УСЛОВИЯХ

СЕВЕРНЫХ ШИРОТ РОССИИ

\author{
Богданов Иван Викторович \\ к.п.н., доцент кафедры общегуманитарных \\ и естественнонаучных дисциплин \\ Северо-Западный институт (филиал) \\ АНО ВО «Московский гуманитарно- \\ экономический университет» \\ Горшкова Валентина Владимировна \\ д.п.н., профессор, \\ заслуженный работник высшей школы РФ, \\ действительный член (академик) \\ Академии гуманитарных наук, \\ профессор Института специальной педагогики \\ и психологии имени Рауля Валленберга
}

Аннотация: Представленная научная статья посвящена раскрытию основных особенностей психофизического состояния молодого поколения, проживающего в условиях Северных широт. На основании результатов диагностических исследований раскрыты причины крайне недостаточной физической подготовленности современных молодых людей. При общей характеристике природно-климатических факторов, влияющих на здоровье человека, представлен сравнительный анализ физического состояния человека 


\title{
ЧЕЛОВЕК И СОВРЕМЕННОЕ ОБЩЕСТВО В СОЦИАЛЬНОМ, ПРАВОВОМ, ЭКОНОМИЧЕСКОМ РАКУРСАХ
}

в зоне благоприятного и неблагоприятного климата для укрепления организма человека в процессе его жизнедеятельности.

В контексте изучения и раскрытия факторов, характеризующих организацию жизни молодёжи на Севере, в статье предлагается проводить современный мониторинг физического, нравственного и социального здоровья современной молодёжи. На основании его результатов в условиях высших учебных заведений предлагаются некоторые рекомендации для более эффективной организации образовательного процесса в преподавании физической культуры и создании условий для здорового образа жизни и психофизического саморазвития молодых людей.

Ключевые слова: физическое воспитание молодёжи, психофизическая неустойчивость человека, условия Северных широт, психофизическое состояние молодёжи, феномен холода, природно-климатические факторы.

\section{FEATURES OF THE PSYCHOPHYSICAL STATE OF MODERN YOUTH IN THE CONDITIONS OF THE NORTHERN LATITUDES OF RUSSIA}

\section{Bogdanov Ivan Viktorovich \\ Gorshkova Valentina Vladimirovna}

\begin{abstract}
The presented scientific article is devoted to the disclosure of the main features of the psychophysical state of the young generation living in the northern latitudes. Based on the results of diagnostic studies, the reasons for the extremely insufficient physical fitness of modern young people are revealed. With a general description of natural and climatic factors affecting human health, a comparative analysis of the physical condition of a person in the zone of favorable and unfavorable climate is presented to strengthen the human body in the course of its life.
\end{abstract}


In the context of studying and revealing the factors that characterize the organization and life of young people in the North, the article proposes to conduct modern monitoring of the physical, moral and social health of modern youth. Based on its results in the conditions of higher educational institutions, some recommendations are made for a more effective organization of the educational process in teaching physical culture and creating conditions for a healthy lifestyle and psychophysical self-development of young people.

Key words: physical education of youth, psychophysical instability of a person, conditions of the Northern latitudes, psychophysical state of youth, the phenomenon of cold, natural and climatic factors.

На современном этапе развития психофизической и педагогической науки одной из наиболее актуальных является проблема возвращения к человеку как психологическому портрету, так и стремления к физическому совершенству, актуализации его подлинной сущности, особенно когда речь идёт о молодёжи - ценнейшем антропологическом потенциале для развития социума. Задача молодого поколения - не пройти по тривиальному пути, а сделать нечто такое, чего раньше не делал никто, создавать что-то самобытное, собственное и уникальное. Считается, что у каждого человека есть возможность на своем уровне ставить сверхзадачи, то есть хотеть невозможного, чтобы достигать желаемого, то есть превзойти себя, чтобы добраться до себя подлинного. Новое поколение молодёжи в чем-то не оправдывает социальных ожиданий, а в чем-то вызывает почтительное удивление. Однако задача современной молодёжи состоит в том, чтобы они сохраняли мир, уважали высокие цели и понимали то, что было утрачено в период жёсткой прагматики, когда надо было отвечать на вопросы «что это даёт человеку», «как из этого извлечь выгоду», «как можно удовлетворить 


\section{ЧЕЛОВЕК И СОВРЕМЕННОЕ ОБЩЕСТВО В СОЦИАЛЬНОМ, ПРАВОВОМ, ЭКОНОМИЧЕСКОМ РАКУРСАХ}

свои материальные потребности». Сегодня это не работает, поскольку от человека, находящегося и развивающегося в субъектном пространстве, свободном от «социальных внушений», требуется другой уровень мышления, иной масштаб перспектив, трансцедентальная широта взглядов и самоуправляемая мотивация, не обусловленная только материальной пользой [1, c. 130].

Согласно мнению А. Маслоу, необходим «новый тип человека», который не чувствовал бы себя потерянным в быстро меняющимся современном мире, человека, готового к импровизации и способного «радостно встретить неожиданную, новую для него ситуацию». Но для этого, по его мнению, должна быть выращена «новая порода людей», способных принимать «молниеносные творческие решения» и снимать встающие перед ними проблемами «без подоверительней подготовки» [2]. Все это в прямом смысле относится и к психофизическому совершенствованию молодёжи.

В свою очередь ставка на решение этой задачи предполагает радикальную перестройку системы образования и моложёной политики в Российской Федерации.

Соответственно, 30 декабря 2020 г. за № 489-Ф3 принят Федеральный закон от «О молодежной политике в Российской Федерации» [3]. Настоящий Федеральный закон регулирует отношения, возникающие между субъектами, осуществляющими деятельность в сфере молодежной политики, при формировании и реализации молодежной политики в Российской Федерации, определяет цели, принципы, основные направления и формы реализации молодежной политики в Российской Федерации. Законом закреплен статус молодежи к ней будут относиться российские граждане в возрасте от 14 до 35 лет включительно. 
Правительство Российской Федерации создало распоряжение от 29 ноября 2014 № 2403-р «Об утверждении Основ государственной молодежной политики Российской Федерации на период до 2025 года», где указано, что эффективная реализация государственной молодежной политики должна обеспечивать устойчивый рост числа молодых людей, мотивированных на позитивные действия, разделяющих общечеловеческие и национальные духовные ценности, обладающих хорошим физическим здоровьем, занимающихся физической культурой и спортом, не имеющих вредных привычек, работающих над своим личностным и профессиональным развитием, любящих свое Отечество и готовых защищать его интересы, прилагающих усилия для динамичного развития сильной и независимой Российской Федерации [4].

Российская Федерация является одной из самых холодных стран в мире, поскольку около 70\% её территории представлено зоной вечной мерзлоты. Более 7 миллионов человек проживает в чрезвычайно холодных регионах, классифицируемых Российским законодательством как «Крайний Север и приравненные к нему районы», где все постоянные жители, а также лица, временно работающие на местных предприятиях, имеют право на компенсацию в связи с суровыми климатическими условиями. Очевидно, очевидно, что в условиях Российской действительности существуют веские основания рассматривать феномен холод как национальную проблему, что в той или иной степени отражено в работах определенного числа авторов (Бочаров М.И., Евдокимов В.Г., Рощевский М.П., Чащин В.П. и др).

Так, «климат Мурманской области относится к субарктическому, для которого характерны ярко выраженные атмосферные явления и усиленная циклоническая деятельность, резкие колебания (в течение коротких промежутков времени) температуры и влажности воздуха, атмосферного 


\section{ЧЕЛОВЕК И СОВРЕМЕННОЕ ОБЩЕСТВО В СОЦИАЛЬНОМ, ПРАВОВОМ, ЭКОНОМИЧЕСКОМ РАКУРСАХ}

давления и скорости ветра, наличие своеобразной фотопериодичности (полярный день - полярная ночь), выраженные космические и геомагнитные возмущения. Весь год типично пасмурная, неустойчивая погода. Среднегодовое количество осадков 600-750 мм. Дней с осадками около 240, со снежным покровом 199-216. На побережье, вследствие сильного сдувания, высота снежного покрова невелика (15-28 см), на подветренных склонах холмов и гор 200-300 см и держится до 260-300 дней. Окончательно снег сходит к третьей декаде мая с отклонениями в ту или иную сторону на 14-20 дней, а на побережье до 26 дней. Туманы характерны для тёплого периода, всего в году насчитывается до 40 дней с туманами. Ветры летом преобладают северные и северо-восточные, зимой южные и юго-западные. Зимой с сильными ветрами связаны метели и ураганы. Помимо чисто климатических условий на Севере своеобразный микро-макро элементарный состав воды и почвы, характеризующийся недостатком биологически активных веществ или нарушением их баланса. Кроме того, отмечается недостаточная насыщенность воздуха кислородом. Имеется и ряд других негативных для организма человека обстоятельств». При этом уточняется, что человек страдает не только от фактора холода, но и от частых и резких перепадов температуры; постоянной погодная «чехарда», атмосферное давление, к примеру, может значительно колебаться не по дням, а по часам. Это и есть своеобразное «суперненастье» которое гигиенисты называют «раздражающим» в отличие от «щадящего» - мягкого и относительно постоянного климата средней полосы.

В табл. 1 приведены основные природно-климатические факторы, влияющие на здоровье проживающих в умеренном (комфортном) климате и в условиях Северных широт (Е.Н. Арсеньев) [5]. 
Таблица 1

Основные природно-климатические факторы, влияющие на здоровье проживающих в умеренном (комфортном) климате и в условиях Северных широт (по Е.Н. Арсеньеву)

\begin{tabular}{|c|c|}
\hline $\begin{array}{c}\text { Зона умеренного (комфортного) } \\
\text { климата (благоприятного } \\
\text { для организма) }\end{array}$ & $\begin{array}{c}\text { Зона полярного климата } \\
\text { (неблагоприятного для организма) }\end{array}$ \\
\hline $\begin{array}{l}\text { - Ритмичная смена сезонных периодов, } \\
\text { нормальная суточная светопериодичность } \\
\text { - } \text { Постоянное атмосферное давление } \\
\text { воздуха в приделах нормы } \\
\text { - } \text { Умеренная температура воздуха летом } \\
\text { (17-25 градусов выше нуля) и зимой } \\
\text { (5-12 градусов мороза) } \\
\text { - } \text { Низкая относительная влажность } \\
\text { воздуха. Маловетреная погода. Малая } \\
\text { облачность (обеспечивается достаточное } \\
\text { облучение кожи ультрафиолетовыми } \\
\text { лучами) } \\
\text { - Слабо выраженные геомагнитные } \\
\text { и гелиофизические возмущения }\end{array}$ & $\begin{array}{l}\text { - } \text { Продолжительная полярная зима, } \\
\text { полярная ночь (59 дней) с периодом } \\
\text { биологической тьмы } \\
\text { - } \quad \text { Резкая динамика атмосферного } \\
\text { давления (так называемые } \\
\text { барометрические «ямы» и } \\
\text { барометрические «кризы») } \\
\text { - } \quad \text { Прохладная температура летом } \\
\text { (8-14 градусов выше нуля) и холодная } \\
\text { зимой (15-32 градуса мороза) с широкими } \\
\text { колебаниями среднесуточной температуры } \\
\text { - Высокая влажность воздуха в течение } \\
\text { всего года (в отдельные дни до } 100 \%) \\
\text { - } \quad \text { Частые сильные ветры: до } 70 \% \text { дней } \\
\text { зимой и до } 25 \% \text { летом } \\
\text { - Сильная облачность: до } 82 \% \\
\text { пасмурных дней в году } \\
\text { - Использование годичного баланса } \\
\text { ультрафиолета - } 20 \% \text { от биологической } \\
\text { потребности } \\
\text { - Сильно выраженные геомагнитные } \\
\text { и гелиофизические возмущения }\end{array}$ \\
\hline
\end{tabular}

Таким образом, человек, проживая в высоких широтах, должен бороться с целым комплексом сопровождающих его факторов: холодом, ветрами, 139 


\section{ЧЕЛОВЕК И СОВРЕМЕННОЕ ОБЩЕСТВО В СОЦИАЛЬНОМ, ПРАВОВОМ, ЭКОНОМИЧЕСКОМ РАКУРСАХ}

полярной ночью, магнитными бурями и авитаминозами. Естественно, что такая постоянная борьба за «выживаемость» отрицательно сказывается на его организме. Отсюда возникает предположение, что исходный фон психофизиологических показателей организма у жителей северных регионов может отличаться от общепринятого. Это, в свою очередь, даёт основание полагать, что границы нормы здоровья и точки отсчёта отклонения от этой нормы должны быть иными, региональными.

Накопленные к настоящему времени научные данные убедительно констатируют изменения в структуре здоровья людей Северных широт. Другими словами, в показателях их здоровья заметно прослеживается чёткий региональный оттенок, а именно: согласно классификации А.В. Ткачёва, группу условно достоверных (то есть подкрепленных неполными, отрывочными научными данными) фактов, характеризующих жизнедеятельность человека на Севере, составляют следующие:

- психофизиологическая неустойчивость организма.

- снижение сопротивляемости организма, как правило тяжёлое течение воспалительных процессов с тенденцией перехода их в хронические заболевания;

- изменение многих видов обменных процессов в организме и, вероятно, связанное с этим широкое распространение определённых расстройств;

В связи с этим возникают несколько обстоятельств, которые подтверждают выдвинутые научных гипотезы: региональный характер физиологического статуса организма северян; зависимость функциональных показателей от сезонности, фотопериодичности, «жёсткости» метеорологических факторов; общее снижение резервных возможностей организма, то есть уменьшение «запасов здоровья».

Влияние вышеперечисленных факторов, характерных для Северных широт России, проявляется в снижении потенциальных возможностей 


\section{ЧЕЛОВЕК И СОВРЕМЕННОЕ ОБЩЕСТВО В СОЦИАЛЬНОМ, ПРАВОВОМ, ЭКОНОМИЧЕСКОМ РАКУРСАХ}

системы энергообеспечения, вследствие чего вся деятельность (умственная и двигательная) осуществляется за счёт высокой степени напряжения адаптивных механизмов и превосходит «физиологическую стоимость» подобной работы в других регионах. Значительная общая нагрузка на фоне годичных сезонных периодов, испытываемая человеческим организмом, находит своё отражение в его повышенной реактивности, усугубляясь в период выхода из полярной ночи и быстрого перехода к полярному дню. Низкий уровень двигательной активности в осенне-зимний период на фоне общей эстенизации человеческого организма в этот период также негативно влияет на состояние здоровья.

Известны результаты проведенных исследований Российскими учёными о комплексном влиянии природных факторов на динамику физического и психомоторного развития обучающейся молодёжи, проживающей в Северных широтах России. Были проведены исследования по сравнению уровня физической подготовленности студентов двух групп: первая группа включала молодёжь, прожившую в Северных широтах более 10 лет; вторая группа состояла из молодёжи, которая проживала в более благоприятных климатических регионах России.

Эти исследования показали, что студенческая молодёжь, проживающая на Северных широтах более 10 лет, хуже выполняли нормативы «бег на 100 м» и «бег на 3000 м», иллюстрирующие проявление быстроты и выносливости, и упражнения на гибкость. Вместе с тем студенты Северных широт выполнили упражнение «Прыжок в длину» (показатель взрывной силы ног) и упражнение «Подтягивание на перекладине» (показатель силовой выносливости) не хуже, а даже лучше, чем молодые люди из более благоприятных регионов России. Этот факт говорит о том, что проживание на Севере не влияет на силу человека и лишь частично негативно влияет на физическую подготовленность молодёжи. Для нашего исследования это 


\section{ЧЕЛОВЕК И СОВРЕМЕННОЕ ОБЩЕСТВО В СОЦИАЛЬНОМ, ПРАВОВОМ, ЭКОНОМИЧЕСКОМ РАКУРСАХ}

означает, что акцент в физической подготовке молодёжи с Севера следует делать на развитие общей и скоростной выносливости, повышение уровня функционального состояния кардиореспираторной и нервной системы, а также на формирование специальных навыков в том числе военноприкладного спорта.

Таким образом становится определенно ясно, что в условиях Севера без занятий физическими упражнениями и спортом здоровье студенческой молодёжи всё более может ухудшаться и поэтому необходимы комплекс программ и методик психофизической подготовки, реализованных в рамках образовательного процесса, которые позволяют нивелировать отрицательное воздействие комплекса погодных факторов Северных широт [6].

Отдельные ученые (А.А. Баранов, В.Р. Кучма и др.) указывают, что особенности физического развития современной молодёжи кроется в социально-экономических условиях жизни населения и условиях организованной образовательной среды. Как правило, высокая учебная нагрузка и низкая мотивация здорового образа жизни приводят к развитию гипокинезии на фоне нарушений в режиме питания, следствием чего оказываются избыточная масса тела и ожирение, а также развитие синдрома вегетативной дисфункции.

Известно, что в системе нормативных документов представлены материалы по каждому из федеральных округов страны и показано существенное влияние климатогеографического фактора на физическое развитие молодёжи, а также фактора проживания в мегаполисе, городе и сельской местности. Процесс увеличения веса приобретает столь глобальный характер, что многие исследователи говорят об «эпидемии ожирения». Другая тенденция, которая обнаруживается у молодёжи нашей страны, противоположна - когда при стабилизации продольного роста происходит снижение показателей веса, меняется форма тела в сторону астенизации и 
лептосомизации телосложения. Об этом свидетельствуют данные обследования молодёжи и подростков Москвы, Санкт-Петербурга, Саратова, Мурманска и ряда других крупных городов России, полученные на разных временных срезах. При этом, и в том, и в другом случае происходят отчётливые негативные сдвиги в физическом развитии организма человека [7].

Современные исследования физического состояния молодёжи Северных широт (Е.М. Лапицкая, В.И. Лях, Ф.А. Щербина) показали, что молодёжь весьма легкомысленно, индифферентно относится к своему здоровью и своему физическому развитию. Развитие себя как физически и духовно полноценного человека не является для современного молодого человека приоритетным и усугубляется негативным отношением к себе как психически и физически здоровому человеку ввиду повсеместной цифровизация всех сфер жизни человека. До 37\% молодёжи в возрасте от 15 до 18 лет употребляют алкогольные напитки. До 35\% молодёжи употребляют наркотические средства [8]. Современный мониторинг физического состояния молодёжи показывает, что по данным показателям наблюдается тенденция ухудшения [9]. Такое состояние здоровья молодёжи вызывает тревогу в обществе и заявляет о необходимости активизации внимания к физической культуре, в основу которой при осуществлении образовательного процесса должен быть положен приоритет физического, нравственного и социального здоровья.

В последнее время проводилось исследование по здоровьесбережению студентов вуза средствами физического воспитания и оценивания физического состояния молодёжи Мурманской области. Результаты исследования показали достаточно низкий уровень состояния здоровья и физического развития студентов, что требует проведения необходимых специальных мероприятий по их здоровьесбережению [10]. Констатируется, 
что здоровье молодёжи находится на среднем и удовлетворительном уровне, чего нельзя сказать о физической подготовке, в частности наблюдаются низкие показатели в результатах упражнений на выносливость и силу. Поэтому рекомендуется при планировании физических занятий с молодёжью учитывать факторы отклонения в здоровье с низким уровнем развитием выносливости и силы.

Повышение частоты возникновения сдвигов в состоянии здоровья молодёжи именно в период обучения в образовательных организациях позволяет предположить наличие связи между указанными явлениями и учебном процессе и определять учебную нагрузку в качестве пропедевтического фактора в появлении таких патологий, как нарушение осанки, нервно-психические расстройства, близорукость и т.д.

Многочисленные данные свидетельствуют о том, что в образовательных организациях психофизиологическое здоровье молодёжи ухудшается, здоровью наносится явный вред в процессе образования. В этой связи формирование основ здорового образа жизни и занятия физическими упражнениями и спортом в молодом возрасте становятся определяющими для всей последующей жизни человека.

Если рассмотреть материалы официального статистического наблюдения и результатов многолетней работы по изучению состояния здоровья молодёжи, то видно, что в первую очередь подвергается патологическим изменениям вследствие неблагоприятного воздействия средовых факторов Северных широт сердечно-сосудистая система. Отмечается рост числа молодых людей, имеющих пограничную артериальную гипертензию и даже гипертоническую болезнь. Распространение патологии органов кровообращения наблюдается в промышленных городах Северных широт и также наблюдается у молодёжи нарушения в костно-мышечной и опорно-двигательных системах. Отмечается большое количество молодёжи, 


\section{ЧЕЛОВЕК И СОВРЕМЕННОЕ ОБЩЕСТВО В СОЦИАЛЬНОМ, ПРАВОВОМ, ЭКОНОМИЧЕСКОМ РАКУРСАХ}

имеющей заболевания органов дыхания. Также имеет широкое распространение среди молодёжи патология системы аккомодации глаз. Нарушение зрения в районах Северных широт значительно выше, чем в центральной России. На Севере процент таких нарушений может достигать значений в 25-28\% от общего количества обследуемых.

Поэтому ученые утверждают (Ф.А. Щербина) что в условиях Северных широт сложно говорить о реальном повышении результатов у большинства, занимающихся спортом. Однако, занятия физическими упражнениями и спортом необходимы для поддержания здоровья молодёжи, проживающей в условиях Северных широт. В связи с этим отмечена тенденция повышения уровня эмоционального и физического состояния, а также уровня тренированности у занимающихся в периоды благоприятных погодных условий (в летний, осенний период). Вместе с тем в зимнем и весеннем периодах, особенно в моментах выхода из полярной ночи и ранней весны рекомендуется снизить физическую нагрузку молодёжи и уделить внимание здоровому образу жизни.

В Стратегии развития физической культуры и спорта в Мурманской области на период до 2020 года указано, что «в условиях Кольского Заполярья одной из главных проблем является ухудшение здоровья, физического развития и физической подготовленности населения. Экстремальные климатические факторы северных территорий - низкая температура, напряжённость геомагнитного поля, выраженные колебания атмосферного давления, синдром полярного напряжения (полярная ночь и полярный день) приводят к крайне неблагоприятным последствиям для здоровья северян. Эффект внешних факторов проявляется в виде сокращения резервного потенциала организма, более раннего истощения жизненно важных функций, и, как следствие, более высокого уровня заболеваемости, ухудшения качества здоровья» [11]. 


\section{ЧЕЛОВЕК И СОВРЕМЕННОЕ ОБЩЕСТВО В СОЦИАЛЬНОМ, ПРАВОВОМ, ЭКОНОМИЧЕСКОМ РАКУРСАХ}

«По данным статистического отчёта в 2020 году в Мурманской области только $23,5 \%$ от общего числа жителей систематически занимались физической культурой и спортом, что явно недостаточно для тяжёлых климатических условий Крайнего Севера. Вместе с тем, по сравнению с 2015 годом численность населения региона, систематически занимающегося физической культурой и спортом, увеличилась на 41 тысячу 492 человека. Следует отметить, что за последние годы наблюдается устойчивая положительная динамика изменения данного показателя (2010 г. - 11,0\%, 2015 г. $-11,4 \%, 2020$ г. - 12,0\%) [12].

Но, несмотря на приведённые выше факты о пагубном влиянии климатических условий Крайнего Севера на здоровье человека, авторы Сысоев Ю.В., Жеребёнков В.А., Сысоева Е.Ю. в работе «Воспитание готовности к труду и обороне от Древней Греции до современной России» [13] раскрывают роль физической подготовленности и положительное влияние занятий на открытых площадках на готовность граждан России к труду и обороне: «Велика роль подготовленности граждан нашей страны и для обороноспособности страны. Современная воинская деятельность связана с большими физическими и психическими нагрузками. Многие воинские специальности предъявляют повышенные требования к умственной работоспособности, к быстрой и точной реакции на множество сигналов, к точной координации движений на фоне нарастающего утомления и стрессовой ситуации. В то же время ведущая роль в военном деле в современных условиях принадлежит преимущественно коллективным видам оружия, эффективность которого зависит от таких личностных качеств воина, как коллективизм и высокое чувство долга перед Родиной. Всё это меняет аспекты физической подготовки будущих воинов, делая её более разнообразной по целям. На первое место выдвигается воспитание патриота, готового в любую минуту встать на защиту Родины от внешних и внутренних 
врагов, обладающего отличной общей физической и психической выносливостью, устойчивого к самым неблагоприятным факторам окружающей среды. Вполне понятно, что эти качества к молодым людям сами собой не приходят, а формируются и воспитываются в процессе многолетней регулярной подготовки на занятиях по физической культуре в школе, вузе, в свободное время при посещении спортивных секций. Опыт показал, что если занятия регулярно проводятся на открытых площадках при различных метеоусловиях (жара, холод, дождь, снег и т.п.), то это позволяет юношам и девушкам развить у себя необходимые двигательные навыки, физические и волевые качества, помогают формировать у школьников и студентов умение проявлять физическую и психическую выносливость в сложных условиях, адаптируют их организм к неблагоприятным факторам внешней среды, знакомят с организацией здорового стиля жизни [14].

Основываясь на вышеизложенном, резюмируем, что в настоящее время уровень физической подготовленности молодёжи Северных широт по данным исследований оцениваются, как сниженный. В различных регионах разрабатываются комплексы мер для выхода из сложившейся ситуации, однако статистические данные за последние пять лет констатируют лишь небольшой прирост в уровне физической подготовленности молодёжи. В то же время налицо отсутствие чёткой нормативной базы, регламентирующей процесс физического воспитания молодёжи. До сих пор не получили своего должного научно-практического обоснования вопросы организации и содержания физической подготовки молодёжи в условиях взаимодействия гражданских и воинских организаций в специфических и суровых условиях Северных широт. 


\section{Список литературы}

1. Горшкова В.В. Феномен образования человека: избранные научные труды / В.В. Горшкова. - СПб. : Астерион, 2020. - 490 с.

2. Маслоу А.Х. Мотивация и личность / под ред Ильина, Е.П. - СПб. : Питер, 2019. - 400 с.

3. О молодежной политике в Российской Федерации: Федеральный закон № 489-Ф3 от 30.12.2020 [Электронный ресурс]. - Режим доступа: https://rg.ru/2021/01/11/molodez-dok.html (дата обращения: 14.01.2022).

4. Об утверждении Основ государственной молодежной политики Российской Федерации на период до 2025 года: распоряжение Правительства Российской федерации № 2403-р от 29.11.2014 [Электронный ресурс]. Режим доступа:http://www.consultant.ru/document/cons_doc_LAW_171835/5416 a7ecef3afe3ff052deb74264bbf282e889ef/ (дата обращения: 14.01.2022).

5. Арсеньев, Е.Н. Работоспособность и здоровье человека на Севере / Е.Н. Арсеньев. - Мурманск: Север, 1993. - 87 с.

6. Мухаметгалиева, С.Х. Комплексное влияние природных факторов на динамику физического и психомоторного развития учащейся молодёжи, проживающей на территории крайнего Севера / C.X. Мухаметгалиева, В.И. Кузьменко, Н.Л. Иванова // Теория и практика физической культуры. 2018. - № 6. - С. 50-52.

7. Баранов, А.А. Физическое развитие детей и подростков Российской Федерации / А.А. Баранов, В.Р. Кучма, Н.А. Скоблина, Л.М. Сухарева и др. М.: ПедиатрЂ, 2013. - 192 с.

8. Щербина, А.Ф. Дыхание человека в Арктике в сезоны световой апериодичности: монография / Ф.А. Щербина, А.Ф. Щербина, Ю.Ф. Щербина. - Архангельск: Мурманский государственный технический университет, 2018. $-134 \mathrm{c}$. 
9. Лапицкая, Е.М. Анализ физкультурно-оздоровительной работы, двигательной активности и двигательной подготовленности школьников / Е.М. Лапицкая // Организация и оценка здоровьесберегающей деятельности образовательных учреждений: Руководство для работников системы общего образования / сост. М.М. Безруких, В.Д. Сонькина. - М.: Московский городской фонд поддержки школьного книгоиздания, 2004. - С. 130-139.

10. Лях, В.И. Мониторинг физического и моторного развития детей, подростков и молодёжи Кольского Заполярья / В.И. Лях, Е.М. Лапицкая. - М.: ТИВФ РАО, 2008. - 47 c.

11. Ткачёв, А.В. Некоторые показатели здоровья в высоких широтах: Доклад на заседании Президиума Коми научного центра Уральского отделения Российской академии наук / А.В. Ткачёв, Е.Р. Бойко, Е.Б. Раменская и др. - Сыктывкар: Коми науч. центр УрО РАН, 1993. - 24 с.

12. О стратегии развития физической культуры и спорта в Мурманской области на период до 2020 года: Постановление правительства Мурманской области № 284-ПП/8 от 02.06.2014 [Электронный ресурс]. - Режим доступа: http://demo.garant.ru/\#/document/16991239/paragraph/1:0 (дата обращения: 13.01.2022).

13. Сысоев, Ю.В. Воспитание готовности к труду и обороне от древней Греции до современной России: Учебно-методическое пособие / Ю.В. Сысоев, В.А. Жеребёнков, Е.Ю. Сысоева. - Смоленск: Смядынь, 2018. - 112 с.

14. Богданов И.В. Физическое воспитание допризывной молодёжи Арктического региона Кольского Заполярья в условиях взаимодействия гражданских и воинских организаций: монография / И.В. Богданов, О.Н. Степанова. - СПб. : Моя строка, 2021. - 244 с. 


\title{
Глава 7.
}

\section{ОСОБЕННОСТИ РАЗВИТИЯ ЗВУКОПРОИЗНОСИТЕЛЬНЫХ \\ УМЕНИЙ У МЛАДШИХ ШКОЛЬНИКОВ С ОБЩИМ \\ НЕДОРАЗВИТИЕМ РЕЧИ}

\begin{abstract}
Барцаева Елена Васильевна старший преподаватель ФГБОУ ВО «Мордовский государственный педагогический университет им. М.Е. Евсевьева»

Рябышева Валерия Вячеславовна МАДОУ «Центр развития ребенка - Детский сад № 9»
\end{abstract}

Аннотация: В статье представлены результаты исследования уровня сформированности звукопроизносительных умений у младших школьников с общим недоразвитием речи.

Ключевые слова: звукопроизносительные умения, младшие школьники, общее недоразвитие речи, особенности развития, уровень сформированности звукопроизносительных умений.

\section{FEATURES OF THE DEVELOPMENT OF SOUND-SPEAKING SKILLS \\ IN YOUNGER SCHOOLCHILDREN WITH GENERAL SPEECH UNDERDEVELOPMENT}

Barcaeva Elena Vasilyevna Ryabisheva Ekaterina Viacheslavovna

\begin{abstract}
The article presents the results of a study of the level of formation of sound-speaking skills in younger schoolchildren with general speech underdevelopment.
\end{abstract}


Key words: sound-speaking skills, younger schoolchildren, general underdevelopment of speech, features of development, the level of formation of sound-speaking skills.

В современных условиях наблюдается огромный рост речевой патологии, в частности нарушения звукопроизносительных умений. В последние десятилетия положение дел в этом отношении резко ухудшилось, о чем свидетельствуют статистические данные. Вопросами развития звукопроизносительных умений у детей младшего школьного возраста занимались многие отечественные ученые, среди них можно отметить А.М. Бородич, А.Н. Гвоздева, И.Е. Тихееву, А.В. Миртова, М.Ф. Фомичева и др.

В то же время процент детей с общим недоразвитием речи (ОНР) растет, речевые нарушения комбинируются, формируя множественные недостатки в речевом развитии детей. Вопрос о систематической специальной работе над обучением детей с ОНР правильному произношению звуков стал одним из приоритетных. Современные направления логопедической работы по развитию звукопроизносительных умений у младших школьников с общим недоразвитием речи раскрыты в исследованиях Е.М. Мастюкова, Р.Е. Левиной, Е.Ф. Архиповой, В.А. Киселевой и др. Таким образом, анализ исследований по развитию звукопроизносительных умений у младших школьников с OHP на логопедических занятиях свидетельствует о необходимости проведения целенаправленной коррекционной поэтапной работы.

В настоящее время в начальных школах увеличилось количество младших школьников с ОНР. Такая группа детей, обладая, в целом, полноценными предпосылками для овладения мыслительными операциями, доступными их возрасту, отстают в развитии словесно-логического 
мышления, без специального обучения с трудом овладевают анализом и синтезом, сравнением и обобщением. Речевое развитие таких младших школьников протекает замедленно, различные звенья речевой системы долгое время остаются несформированными. А это отрицательно сказывается на дальнейшем развитии и обучении младших школьников: достижение планируемых результатов обучения, определенных ФГОС НОО, неизбежно вызывает у обучающихся с ОНР серьезные затруднения. Без оказания своевременной помощи по преодолению речевых нарушений такие младшие школьники будут испытывать сложности в процессе обучения и могут оказаться в числе стойко не успевающих учащихся. Выстраивание стратегии и содержания коррекционно-развивающей работы с младшими школьниками обсуждаемой группы предполагает осмысление и учет природы общего недоразвития речи, его уровней, проявлений ОНР у младших школьников $[1$, c. 86$]$.

В специальных исследованиях под общим недоразвитием речи у младших школьников с нормальным слухом и первично сохранным интеллектом понимается такая форма аномалии речи, при которой нарушено формирование всех структурных компонентов речевой системы, непосредственно относящихся как к звуковой, так и к смысловой частям речи. В многоаспектных исследованиях младших школьников с разными речевыми нарушениями P.Е. Левиной и сотрудниками НИИ дефектологии еще в 50-60 годах прошлого столетия была раскрыта сущность общего недоразвития речи: различные речевые отклонения стали соотноситься с недоразвитием в системе высших психических функций при развитии младшего школьника. На прикладном уровне общее недоразвитие речи может выражаться и в качестве самостоятельного нарушения, и как только лишь сопутствующее в общей системе различных речевых нарушений. При этом заслуживает внимания тот факт, что практически у всех младших школьников 
с общим недоразвитием речи выражен важный общий критерий - это отстроченное по отношению ко времени появление собственной речи, в сравнении с нормой [2, с. 167].

Следует подчеркнуть, что у младших школьников с ОНР речевое развитие не соответствует критериям возрастной нормы. В данной связи исследователь М.Е. Меднова обращает внимание на то, что механизм, который отвечает за декодирование речевого сообщения, у младших школьников, слабо сформирован [3, с. 36]. Базальные компоненты при этом не анализируют сложный состав компонентов речи. Иначе говоря, понижение уровня речевого восприятия, которое относится к фонематическому слуху и фонематическому восприятию, в существенной степени замедляет процессы усвоения и анализа акустической информации.

При этом было установлено, что в ходе выполнения заданий по распознаванию звуковых компонентов при учащенном темпе (интервал уменьшался между звуками), когда особенно необходимо различение, дифференцированное восприятие, младшие школьники с ОНР испытывают существенные сложности. В научных исследованиях было выявлено, что и общее двигательное развитие анализируемой категории детей отстает от возрастной нормы. Младшие школьники ориентируются в пространстве не в полной мере; у них понижена быстрота и точность, четкость движений. Кроме этого, они не способны сразу воспроизвести ритмические движения под музыку.

Не подлежит сомнению то положение, что логопедическая помощь должна оказываться младшим школьникам на систематической основе, т.к. с возрастом дети с общим недоразвитием речи начинают осознавать свой дефект и переживать собственную неполноценность, что неблагоприятно отражается на всем развитии младшего школьника. В последующем подобные проблемы могут весьма неблагоприятно отразиться как на личностном и 
профессиональном развитии, так и на процессах социализации младших школьников, в общем.

Отечественный исследователь Р.Е. Левина подвергла анализу критерии для определения состояния аномального развития языковой системы у младших школьников с общим недоразвитием речи, и на этой основе разработала уровни ОНР, проявления ОНР на каждом уровне: от полного отсутствия речевого взаимодействия до проявления развернутых форм связной речи с компонентами фонетико-фонетического и лексикограмматического недоразвития [2, с. 168]. Следует отметить, что сам первичный дефект, находящийся в основе обсуждаемого речевого нарушения, значительно тормозит развитие коммуникативных процессов; обусловливает нарушение речевого развития. Переход же на иной уровень определяется проявлением в речи новых языковых способностей. В этой связи Р.Е. Левина предложила выделять четыре уровня развития речи, в зависимости от того, в какой именно мере выражена речевая аномалия [2, с. 169]. Рассмотрим эти уровни более подробно.

Первый уровень является самым низким. На этом уровне младшие школьники не применяют вовсе фразовую речь, уровень их коммуникации ограничен минимальным числом используемых слов, похожих больше на звуковое подражание. Очень часто младшие школьники в общении прибегают к использованию невербальных средств коммуникации, для того чтобы их лучше поняли. Пассивный словарь у младших школьников с первым уровнем речевого развития существенно больше активного, в повседневном общении такие дети в основном ориентируются на уже знакомую ситуацию, по этой причине у их родителей часто складывается впечатление, что их дети гораздо больше понимают, чем это кажется окружающим. Однако при целенаправленном исследовании у таких детей фиксируется незнание многих предметов окружающего мира, признаков и действий, из чего можно сделать 


\section{ЧЕЛОВЕК И СОВРЕМЕННОЕ ОБЩЕСТВО В СОЦИАЛЬНОМ, ПРАВОВОМ, ЭКОНОМИЧЕСКОМ РАКУРСАХ}

вывод о том, что у этих детей словарь импрессивной речи в значительной степени является ограниченным [4, с. 109].

Второй уровень развития речи определяется как более благоприятный. На данном уровне у младшего школьника появляются новые речевые возможности, он все чаще применяет различные паралингвистические средства. Такой младший школьник уже без особого труда способен назвать какие-то любимые предметы, определить у них значимые признаки и отличительные характеристики. Несмотря на выраженный конструктивный фактор, дефицит речевого развития у таких младших школьников выражен явно. Ограниченный словарный запас, который не соответствует возрасту, на практическом уровне не дает возможности младшему школьнику, верно назвать некоторые части тела, правильно перечислить виды животных, предметы одежды, мебели.

Следует обратить внимание на то, что у младших школьников на данном уровне по-прежнему остаются сложности в назывании различных форм и размеров, цветов и оттенков, они довольно часто могут заменять слова с подобной смысловой нагрузкой. Эти младшие школьники в речи используют имена существительные только в именительном падеже, при этом у них нет согласования со сказуемыми в числе и роде. Зачастую они смешивают и взаимозаменяют глаголы настоящего и прошедшего времени. В основном в речи младший школьник использует только лишь существительные и глаголы, прилагательные практически не применяются им в активном словаре. Для полноценного постижения словаря и грамматики младшему школьнику указанного уровня речевого развития надо верно освоить звуковой состав слов, в противном случае такие дети без специализированной коррекционной работы не будут способны овладеть письмом и чтением [5, с. 215]. Итак, у младших школьников второго уровня речевого развития можно выделить такие ведущие характеристики речевого 


\section{ЧЕЛОВЕК И СОВРЕМЕННОЕ ОБЩЕСТВО В СОЦИАЛЬНОМ, ПРАВОВОМ, ЭКОНОМИЧЕСКОМ РАКУРСАХ}

развития: в речи таких детей, кроме главных членов предложения, постепенно появляются качественные прилагательные и незначительное количество наречий; дети уже способны выделять из предложенных предметов необходимый предмет, оценивать его назначение и определять наиболее характерные его признаки и черты. Таким образом, младшим школьникам со вторым уровнем речевого развития для совершенствования речи необходимо на практике обучение по адаптированным программам с применением индивидуального подхода и использованием специфических коррекционных методик и технологий.

Третий уровень развития речи характеризуется тем, что младшие школьники данной группы используют развернутые по содержанию предложения, явно грубые речевые нарушения практически уже не обнаруживают себя, но в произношении все же остаются определенные трудности, не сформирован грамматический и лексический строй. Так, в речи младших школьников можно услышать неверно построенные простые фразы, но при этом неверно произнесенных звуков становится все меньше и меньше.

У детей с ОНР четвёртого уровня возникают трудности в звукопроизношении и повторении слов со сложным слоговым составом, наблюдается низкий уровень фонематического восприятия. Они допускают ошибки в словоизменении и словообразовании. Словарный запас детей с ОНР четвёртого уровня уже достаточно разнообразен, но не всегда присутствует точное знание и понимание значения употребляемых слов, антонимов и синонимов, поговорок, пословиц. Кроме этого, такие дети не могут логично излагать события в самостоятельной речи, часто делают акцент на второстепенных деталях, упуская главное, и повторяют ранее сказанное.

На основе рассмотренных выше положений о речевом развитии детей младшего школьного возраста с общим недоразвитием речи необходимо сделать вывод о том, что, в работе с такими детьми, несмотря на 


\section{ЧЕЛОВЕК И СОВРЕМЕННОЕ ОБЩЕСТВО В СОЦИАЛЬНОМ, ПРАВОВОМ, ЭКОНОМИЧЕСКОМ РАКУРСАХ}

относительное недоразвитие лексико-грамматических и фонематических средств, в логопедической деятельности на систематической основе следует уделять особое внимание верному произношению слов со сложной звуковой наполняемостью, развитию и совершенствованию слоговой структуры и формированию навыка звукового анализа и синтеза у анализируемой категории детей.

Итак, в настоящее время достаточно часто встречаются младшие школьники, имеющие нормальный слух и интеллект, но недостаточно сформированный лексический и грамматический строй речи и еe фонетической стороны. Практика показывает, что речевые нарушения отражаются на формировании всей психической жизни младших школьников, поскольку могут усложнять правильное формирование познавательных процессов, оказывают влияние на эмоционально-волевую сферу и, как следствие, вызывают затруднения в общении с окружающими. Наиболее распространенным речевым нарушением на сегодняшний день является общее недоразвитие речи. У младших школьников, имеющих данное нарушение, может возникнуть ряд вторичных отклонений, образующих картину аномального развития младших школьников в целом. Преодоление и предупреждение речевых нарушений обеспечивает становление творческих сил личности младших школьников, устраняет препятствия для реализации ее общественной направленности, получения новых знаний, гармоническому развитию личности в целом. Значимой стороной речи, составляющей основу речевого процесса, принято считать звукопроизносительные умения [5, с. 215$]$.

Механизм звукопроизносительных умений принято рассматривать с двух позиций - перцептивной и артикуляционной. Перцептивная позиция предусматривает восприятие фонетических единиц, сравнение их с эталонами и дифференциация. Под артикуляционной базой понимается готовность 
артикуляционного аппарата реализовать тонкие дифференцированные движения, играющие большую роль в произнесении звуков.

Дети овладевают артикуляцией (то есть движением и позицией речевых органов, требуемых для произнесения звуков) и наряду с этим - системой дифференциальных признаков, важных для их распознавания. Формирование восприятия речевых звуков осуществляется в ходе активного артикуляторного опыта, начиная с младшего школьного возраста и приобретая незаконченный характер. Процесс правильного формирования звукопроизносительных умений у младших школьников - это достаточно сложный и трудоемкий процесс. Младшие школьники с ОНР чаще всего имеют нарушения звукопроизносительных умений, которые сами по себе не устраняются, но их можно преодолеть, если правильно организовать логопедическую работу, направленную на коррекцию звукопроизносительных умений.

Важнейшая цель логопедической работы при коррекции звукопроизносительных умений заключается в формировании умений и навыков правильного воспроизведения звуков речи [6, с. 200].

Формирование звукопроизносительных умений у младших школьников с общим недоразвитием речи невозможно без проведения диагностики. Для нашего исследования основным диагностическим методом стала методика «Тестовая методика диагностики устной речи младших школьников» Т.А. Фотековой. Эта методика является часто используемой у логопедов, имеет балльную систему оценивания, возможность многократного использования. В исследовании приняли участие 10 детей младшего школьного возраста с ОНР III уровня, обучающиеся в МОУ «СОШ № 8» г. о. Саранск. Для нашего исследования значимыми являются показатели сформированности фонематического восприятия, артикуляционной моторики, звукопроизношения, состояния звуко-слоговой структуры слова. 
В результате исследования звукопроизносительной стороны речи младших школьников с ОНР мы выявили, что отмечаются затруднения в формировании фонематического восприятия, артикуляционной моторики и звукопроизношения. Преобладает средний уровень сформированности звукопроизносительной стороны речи, что говорит о необходимости специальной работы с детьми указанной категории.

Данные исследования звукопроизносительной стороны речи представлены на рисунке 1.

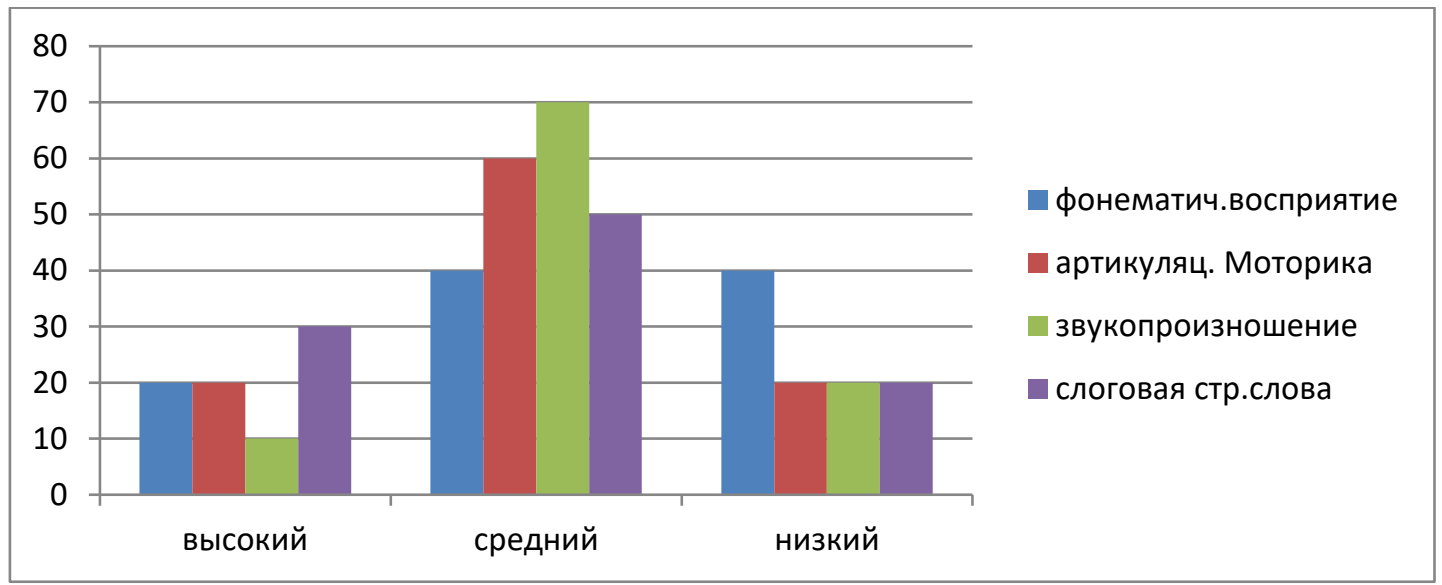

\section{Рис. 1. Уровни сформированности звукопроизносительной стороны речи у детей младшего школьного возраста с ОНР при первичном исследовании}

Полученные результаты показывают необходимость развития звукопроизносительной стороны речи у младших школьников. Данную задачу мы попытались решить с применением здоровьесберегающих технологий.

Мы разработали комплекс занятий по формированию звукопроизносительной стороны речи у младших школьников с ОНР. Он состоял из систематических, учитывающих индивидуальные особенности детей занятий, проводимых в течение учебного года. Проводились подгрупповые и индивидуальные занятия 2 раза в неделю. Для каждого 
занятия был составлен конспект, имеющий последовательную структуру и разное содержание, а также учитывались возрастные особенности детей. Каждое занятие состояло из нескольких этапов: подготовительный, основной, итоговый.

При разработке содержания логопедической работы по развитию звукопроизносительных умений у младших школьников с ОНР мы опирались на рекомендации Н.С. Попковой, Т.Ю. Ковыляевой, С.Н. Назаровой, М.Е. Медновой и др.

Содержание работы было построено по двум направлениям:

Первое направление логопедической работы было организовано для младших школьников с низким уровнем.

Оно делилось на 2 блока: постановка нарушенных звуков, проводилась учителем логопедом; автоматизация поставленных звуков, реализовывалась поэтапно. Нами были разработаны индивидуальные логопедические задания по развитию звукопроизносительных умений у младших школьников с ОНР.

Задание 1. Повтори чистоговорки и подбери к ним подходящие картинки. Например: Са-са-са - у норы сидит лиса; Сё-сё-сё - молоко прилили всё; За-за-за - здесь привязанная коза; Зя-зя-зя - детям спички брать нельзя.

Задание 2. Доскажи слово и нарисуй нужный предмет. Например: В зоопарке, к клетке Яна увидела ... (обезьяну). Извиваясь и шипя по земле ползет ... (змея). Са-са-са - в лесу бегает ...(лиса). Усь-усь-усь - на лугу пасется... (гусь).

Задание 3. Назови картинки со звуком [c], [3], [c'], [3'] и раскрась их.

Задание 4. Рассмотри картинки и раскрась только те, в названиях которых есть звук [c], [3], [c'], [3'].

Задание 5. Где находится звук [c], [3], [c'], [3’] в этих словах? Нарисуй сам картинки, в названиях которых звук [c'] в начале, конце, середине слова. 
Задание 6. Где находится звук [c], [3], [c'], [3'] в названиях картинок: в начале, в середине или в конце? Соедини линиями картинки и схемы.

Задание 7. В каких словах звук [c], [3], звучит твёрдо, а в каких мягко? Покажи при помощи стрелок.

Задание 8. Произнеси слова со звуком [c], [3], [c’], [3’]. Обведи букву с, 3. Где она находится (в начале, в середине, в слова конце)?

Задание 9. Ответь на вопросы. Покажи подходящие картинки.

Например, на звуки [c] и [c']. Ответь на вопросы. Покажи подходящие картинки: Что у Серёжи? (Самосвал); Что у Насти? (Коляска); Что у Светы? (Кастрюля); Что у Семёна? (Самолёт); Что у Славы? (Самокат); Что у Алисы? (Сумка).

Задание 10. Произнеси слова, чётко выговаривая все звуки. Какой слог в этих словах общий?

Итак, с каждым младшим школьником были проведены задания на каждый звук, который отрабатывался поэтапно: автоматизация изолированного звука, затем в слогах, словах, словосочетаниях, фразах, в стихах, в текстах, рассказах, самостоятельной речи. При подборе содержание учитывали и подбирали: открытый слог, закрытый слог, со стечением согласных и в интервокальной позиции.

Дыхательным упражнениям необходимо уделять особое внимание. Правильное речевое дыхание - основа для нормального звукопроизношения, речи в целом. Некоторые звуки требуют энергичного сильного выдоха, сильной воздушной струи.

Неотъемлемой и очень важной частью работы по коррекции звукопроизношения является артикуляционная гимнастика. Она необходима для нормального звукопроизношения, а также для укрепления мышц лица, языка, губ, мягкого нёба. Для достижения лучших результатов в работе над развитием артикуляционной моторики, применяются элементы такого метода как биоэнергопластика - соединение движений артикуляционного аппарата с 


\section{ЧЕЛОВЕК И СОВРЕМЕННОЕ ОБЩЕСТВО В СОЦИАЛЬНОМ, ПРАВОВОМ, ЭКОНОМИЧЕСКОМ РАКУРСАХ}

движениями руки. Этот метод эффективно ускоряет исправление дефектных звуков, так как работающая ладонь многократно усиливает импульсы, идущие к коре головного мозга от языка. В результате регулярного выполнения артикуляционной гимнастики с элементами биоэнергопластики, улучшается кровоснабжение артикуляционных органов, развивается подвижность, укрепляется мышечная система языка, губ, щёк, улучшается внимание, память, мышление, речь.

Биоэнергопластика - это сопряженная гимнастика для языка и кистей рук под сопровождение стихотворного текста или упражнения объединены в единый сюжет.

Постановка звуков осуществляется при максимальном использовании всех анализаторов: зрительного, тактильного, слухового и двигательного. На этапе закрепления изолированного произношения звука, применяются фонопедические упражнения (метод В. Емельянова). Дети с большим интересом выполняют упражнения, в процессе которых тренируются дыхательные мышцы, укрепляется голосовой аппарат, развивается голос. Фонетическая ритмика - обозначение звуков речи при помощи движения тела, тело нам подсказывает само и помогает произносить и закреплять звук. А также выполняет функцию формирования правильного речевого дыхания, с продолжительным выдохом.

Фонетическая ритмика представлена в виде таких упражнений: звук А разводим руки в стороны, рисуя большой круг, рот широко открыт; звук У губы вытягивает в трубочку, руки вместе и тянем из вперед, кисти на себя. Звук O - чуть присели, руки подняли к верху и соединили, в овал, губы округлены. Звук И - губы в улыбке, руки от груди тянем плавно в стороны. Звук Э - высовываем язык вперед и грозим пальчиком. Звук К - руки перед собой в кулачках, резко опускаем их вниз и произносим К. Звук С - насосы, накачиваем шину. Звук Ш - развели руки в стороны и с длительным выдохом, произносим звук Ш, обхватываем себя руками за плечи. С помощью данных 
упражнений мы еще и выполняем функцию развития звукового анализа и обучения чтению слогов при помощи тела.

Обязательно на занятии присутствовала физминутка, тесно связанная с темой занятия и являющаяся как бы переходным мостиком к следующей части занятия.

В работе мы пользовались тренажерами Ковалева для снятия усталости с глаз и развития глазодвигательных мыщц. Так же влияние на организм ребенка оказывает цветотерапия, мы тоже пользовались ее средствами в работе над звукопроизношением.

Так, зеленый цвет настраивает ребенка на работу. Рекомендуется его использование после эмоционального возбуждения и двигательной активности, создает настроение. Красный цвет - использовали для активизации физиологических процессов. Желтый цвет - центр наибольшей светимости в спектре, тем самым стимулирует зрение, снимает нервное напряжение, успокаивает. Релаксационная гимнастика, кинезиологическая гимнастика оказывают большое влияние на развитее детей в целом, а так же помогают в постановке и автоматизации звуков.

Для улучшения мыслительной деятельности, расширения границ возможностей мозга применялись кинезиологические упражнения (Методика Сиротюк). Под влиянием кинезиологических тренировок в организме происходят положительные структурные изменения, дети активнее включаются в деятельность, с удовольствием выполняют комплексы упражнений «Колечко», «Кулак-ладонь-ребро», «Лягушка» и др.

Кинезиологическая гимнастика представлена несколькими блоками упражнений, которые синхронизируют работу полушарий, способствуют улучшению запоминания, повышают устойчивость внимания, облегчают процессы письма. 
Чтобы настроить ребёнка на восприятие материала, снять напряжение, восстановить ослабленные мышцы, активизировать работу головного мозга мы пользовались самомассажем с речевым сопровождением.

По итогам контрольного исследования выявился преимущественно высокий уровень сформированности звукопроизносительной стороны речи у детей младшего школьного возраста с ОНР. В обеих группах полностью исключился низкий уровень, что позволяет говорить об эффективности работы над звукопроизносительной стороной речи. Данные по итоговому исследованию представлены на рисунке 2.

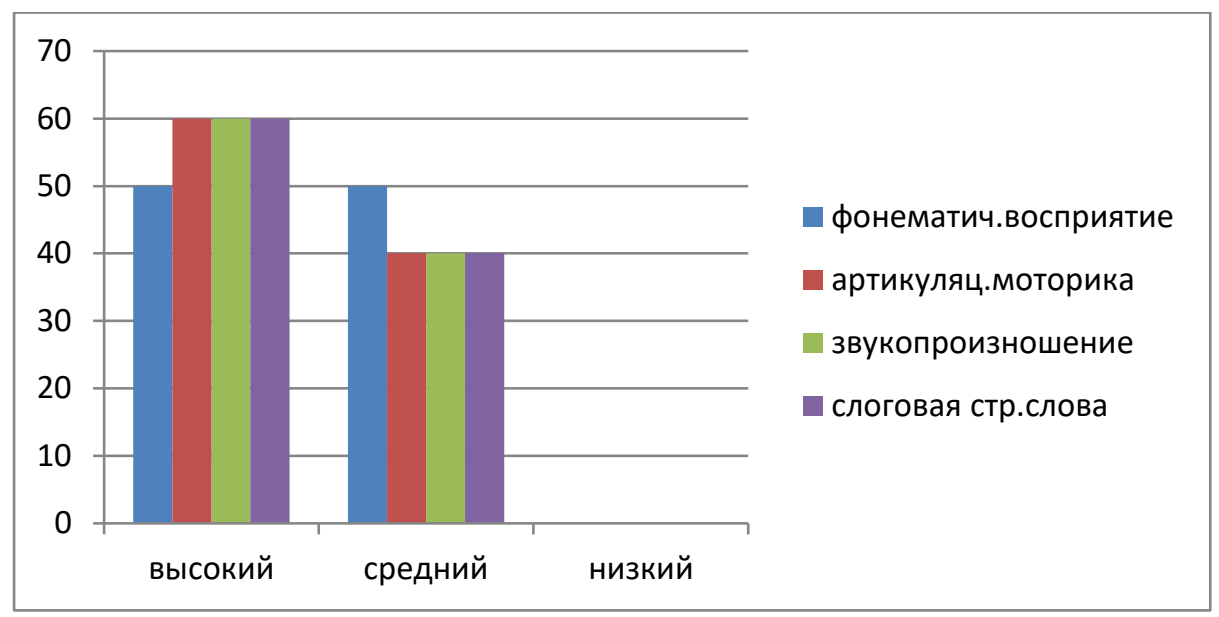

Рис. 2. Уровни сформированности звукопроизносительной стороны речи у детей младшего школьного возраста с ОНР в результате итогового исследования

Итак, своевременная коррекция звукопроизносительных умений у детей младшего школьного возраста будет залогом успешного обучения детей. Важность оказания помощи младшим школьникам с речевыми недостатками постоянно подчеркивается в научно-методической литературе, документации по организации логопедической работы. Младший школьный возраст является периодом для всестороннего развития детей, поэтому систематическая работа 
по коррекции звукопроизносительных умений у младших школьников с ОНР является актуальной и необходимой на сегодняшний день.

Таким образом, в результате работы по формированию звукопроизносительной стороны речи мы выявили, что использование биоэнергопластики, кинезиологических и фонопедических упражнений в дополнение к основным приемам работы по формированию навыков правильного звукопроизношения у детей младшего школьного возраста с ОНР обеспечивает разнообразную, учитывающую цели и задачи коррекции, работу.

\section{Список литературы}

1. Задумова, Н.П. Механизмы нарушений звукопроизношения у детей 7-8 лет с общим недоразвитием речи / Н.П. Задумова. - Текст : непосредственный // Азимут научных исследований: педагогика и психология. - 2019. - № 2 (27). - С. 85-88.

2. Левина, Р.Е. Нарушения речи и письма у детей: избранные труды / Р.Е. Левина. - Москва : АРКТИ, 2005. - 224 с. - ISBN 978-5-534-06067-6. Текст : непосредственный.

3. Меднова, М.Е. Изучение звукопроизносительной стороны речи у младших школьников со сложным дефектом / М.Е. Меднова. - Текст : непосредственный // Коррекционная педагогика: теория и практика. - 2017. № 4 (74). - С. 35-41.

4. Иванова, Н.В. Особенности звукопроизношения при общем недоразвитии речи / Н.В. Иванова. - Текст : непосредственный // Символ науки: международный научный журнал. - 2017. - № 3. - С. 108-111.

5. Карлова, М.А. Особенности звукопроизношения у детей с ОНР / М.А. Карлова. - Текст : непосредственный // В сборнике: Современные 
тенденции развития системы образования. сборник статей. Чебоксары. - 2019. - № 1. - C. 214-217.

6. Нефедова, М.В. Коррекция нарушений звукопроизношения школьников с ОНР III уровня как основа их успешной инклюзии / М.В. Нефедова. - Текст : непосредственный // В сборнике: Инклюзивное образование. Индивидуализация сопровождения детей с ограниченными возможностями здоровья. материалы Всероссийской научно-практической конференции. Ответственные за выпуск: Л.Б. Осипова, Е.В. Плотникова. 2016. - № 1. - C. 197-201.

(C) Е.В. Барцаева, В.В. Рябышева, 2022 
Глава 8.

ТРАДИЦИОННЫЕ И ИННОВАЦИОННЫЕ СПОСОБЫ ЯЗЫКОВОЙ ОЦЕНКИ В ПРОИЗВЕДЕНИЯХ ДЕТСКИХ ПИСАТЕЛЕЙ

НА УРОКАХ ЛИТЕРАТУРЫ

Сабитова А.М. кандидат филологических наук, старший преподаватель Казанский федеральный университет Низамбиева И.И. старший преподаватель Казанский федеральный университет

Аннотация: В главе рассматриваются традиционные и инновационные способы языковой оценки в произведениях детских писателей на уроках литературы.

Ключевые слова: традиционные и инновационные способы, языковая оценка, литература, художественные произведения.

TRADITIONAL AND INNOVATIVE WAYS OF LANGUAGE ASSESSMENT IN THE WORKS OF CHILDREN'S WRITERS IN LITERATURE LESSONS

Sabitova A.M.

Nizambieva I.I. 
Abstract: The article discusses traditional and innovative ways of language assessment in the works of children's writers in literature lessons.

Keywords: traditional and innovative methods, language assessment, literature, works of art.

\section{Предисловие}

Процесс преподавания русского языка и литературы в современной школе носит гибкий и подвижный характер и отражает все изменения, происходящие как в профессиональной, так и в социальной среде. Как никакой другой предмет, русский язык оказался в эпицентре начавшегося в нашей стране в конце 80-х годов так называемого «четвертого информационного взрыва», следствием которого стало бурное развитие информационных технологий, всеобщая компьютеризация, сделавшая возможным приобщение широких слоев населения, начиная от школьников и заканчивая людьми пенсионного возраста, к всемирной информационной сети. Вследствие этого методика преподавания русского языка в современных отечественных школах претерпевает в последние два десятилетия значительные изменения.

Технологии развивающего обучения, интерактивные формы обучения заставляют искать новые подходы к преподаванию, как отдельных разделов школьного курса русского языка, так и всего курса в целом. В настоящее время все больше уделяется внимание обучению методике анализа художественного текста, вводятся инновационные формы лингвистического и филологического анализа, при сохранении традиционных. На данном этапе развития русской лингвистики изучение лексических единиц в функционально-стилистическом аспекте в различных сферах художественной коммуникации является одним из перспективных направлений. 
Также возникает вполне предсказуемая проблема обучения школьников методике языковой оценки на уроках русского языка и литературы. Для еe решения в процессе нашей деятельности привлекаются произведения современных отечественных детских писателей В. Драгунского, А. Алексина, Ю. Коваля, большая часть работ которых входит в школьную программу младшего и среднего школьного звена.

Этим определяется цель исследования - выявить и описать средства и способы выражения языковой оценки в произведениях детских писателей на уроках русской литературы.

В исследовании поставлены и находят разрешение следующие задачи:

1. Определение понятия языковая оценка в современной лингвистике и методике преподавания русского языка;

2. Уточнение понятия языковая норма;

- языковая норма и основные типологические случаи ее преднамеренного или непреднамеренного нарушения в художественном тексте;

3. Выделение форм и способов выражения традиционной и инновационной речевой оценки художественного текста;

4. Анализ существующих классификаций речевой оценки в работах отечественных лингвистов и методистов;

5. Классификация языковой игры по типам и функциям;

6. Дифференциация и интеграция понятий «языковая норма» и «языковая игра» в художественном тексте на примере анализа произведений детских писателей: В. Драгунского, Ю. Коваля, А. Алексина.

Вопросы, касающиеся понятия «языковая оценка», затрагивали многие исследователи в своих трудах, посвящённых:

- выявлению связи между языковой оценкой и отличительными чертами личности (психологическими, гендерными, национальными); 
- анализу процесса формирования экспрессивного и оценочного значения на разных уровнях языка;

- функционированию экспрессивно-оценочных единиц в тексте и дискурсе и т.д.

Огромную роль в изучении языковой оценки имеет деятельность таких выдающихся лингвистов, как Н.Д. Арутюновой [1988], Е.М. Вольф [1985], Н.А. Лукьяновой $[1976,1980,1986,1991]$. В последние годы на способы и средства выражения языковой оценки в художественном тексте были нацелены труды Е.В. Кочетковой [2004], Т.В. Латкиной [2006], Н.Н. Кузнецовой [2011].

Таким образом, наша монография посвящена исследованию способов выражения языковой оценки в произведениях детских писателей на уроках русского языка и литературы.

Объектом исследования выступили средства выражения языковой оценки в прозаических текстах детской литературы таких авторов, как В.Драгунский, Ю. Коваль и А. Алексин.

Предмет исследования - семантические, структурные и функциональные характеристики оценочных единиц в восприятии текста.

Материалом послужили оценочные единицы, извлеченные методом сплошной выборки из ряда рассказов вышеупомянутых авторов.

В сферу наших интересов вошли, прежде всего, те произведения указанных авторов, которые включены в основную образовательную программу, предназначенные не только для изучения на уроке, но и выведенные на самостоятельное изучение (внеклассное чтение).

Теоретическая значимость исследования состоит в разработке новых подходов обучению методике анализа текста, в частности, методике языковой оценки; в выявлении способов выражения и функций оценочных единиц в произведениях детских писателей. 


\section{ЧЕЛОВЕК И СОВРЕМЕННОЕ ОБЩЕСТВО В СОЦИАЛЬНОМ, ПРАВОВОМ, ЭКОНОМИЧЕСКОМ РАКУРСАХ}

Практическая значимость работы заключается в выявлении фонда языковых оценочных единиц в текстах В. Драгунского, Ю. Коваля, А. Алексина; в возможности использования результатов работы при дальнейшем изучении особенностей выражения языковой оценки и художественных приёмов иных авторов. Материалы и результаты исследования могут быть использованы учителями начальных и средних классов на уроках русского языка и литературы, студентами филологических факультетов, а также всеми, кому интересны категориальные способы языковой оценки литературных произведений известных писателей.

\section{ЧАСТЬ І. ТЕОРЕТИЧЕСКИЕ АСПЕКТЫ ИЗУЧЕНИЯ КАТЕГОРИИ ОЦЕНКИ В СОВРЕМЕННОЙ ФИЛОЛОГИИ}

\section{1. Понятие языковой оценки. Её структура}

Этимология слова «оценка» указывает на исходное - «ценности», исходя из которой, можно определить цель всякой оценки, заключающуюся в определении ценности явления или предмета. Это в полной мере относится и к языковым явлениям. Языковая оценка неразрывно связана с самим языком, независимо от того, какой это язык конкретно, и тем самым носит универсальный характер. При языковой оценке должна присутствовать та или иная классификация языковых явлений и шкала их ценности. В области языка шкала ценностей связана с объективной оценкой:

1. Разнообразия, богатства языковых средств в тексте;

2. Правильности и уместности их применения данным автором.

Вследствие этого устная или письменная речевая ситуация, предлагаемая к оценке, требует применения определенных языковых средств для выражения и характеристики оценочного значения, которые могут быть сформулированы на различных языковых уровнях: морфологическом, синтаксическом, лексическом. 
Проблема языковой оценки находится в центре внимания отечественных лингвистов и методистов, поэтому к настоящему времени изучена достаточно подробно. В разное время К ней обращаются известные лингвисты Н.Д. Арутюнова, Е.М. Вольф, А.А. Ивин, Т.В. Маркелова, Т.А. Трипольская, Ю.А. Фомина и другие; методисты Т.А. Ладыженская, Л.П. Федоренко, Е.И. Литневская, В.А. Багрянцева, О.В. Кукушкина, М.Р. Львов.

Несмотря на достаточную изученность проблемы языковой оценки в современном языкознании и методике преподавания языков, в ней все еще остается ряд непроясненных до конца вопросов. К их числу, в частности, относится отсутствие единой, универсальной классификации языковых оценок. Каждый исследователь предлагает собственный вариант. В то же время стоит отметить, что на данном этапе развития лингвистики можно указать на некоторые (особенно важные и единые) критерии языковой оценки, которые неизменно присутствуют в различных классификациях исследователей. Тем самым у каждого практика (преподавателя, школьного учителя, работника сферы коммуникаций) появляется возможность с достаточной степенью объективности произвести анализ художественного текста и прийти к выводам по поводу его языковой ценности, опираясь при работе на систематизированную организацию способов языковой оценки. Рассмотрим их подробнее.

Первым и самым важным критерием, на наш взгляд, является аксиологическая (в переводе с греческого axios- «ценный») интерпретация, которая основана на двух самостоятельно доминирующих значениях описываемого явления, стоящих в оппозиции: хорошо (+) / плохо (-). Из этого следует, что в тексте имеется возможность использования двух типов оценок: положительной (мелиоративной) и отрицательной (дерогативной). Например: «Красотка» (+) и «Дура» (-). 
Данная классификация позволяет судить об отношении автора к тому или иному объекту реального мира: признает ли он или отрицает его ценность.

Следующий, немаловажный критерий - наличие эмотивного компонента. Эмотивность характеризуется сильной реакцией и чувствительностью. Следовательно, соответствующая явлению оценка может быть рациональной (интеллектуальной, логической) или эмоциональной. Например, факт повышения расценок на коммунальные услуги с рациональной позиции может быть представлен так: «Данный жилищностроительный кооператив, как было выяснено, намеренно завысил расценки». Эмоциональная оценка происходящего может быть более непосредственной и выразится в одном слове: «Воры!».

И заключительным критерием выступает соотношение объективных и субъективных оценочных факторов.

Взаимодействие объективных и субъективных свойств объекта позволяет выделить его дескриптивные (собственные) свойства (белокурая, худая, голубоглазая) и оценочные свойства (привлекательная, красивая, способная).

Важным показателем языковой оценки является наличие изначального положительного или отрицательного значения слова. Например, слова «добрый», «скромный», «красивый» имеют положительную изначальную семантику. При их использовании возникают определенные ассоциации, которые формируют наше представление о новом предмете или человеке, получившем эти определения. И наоборот: слова с отрицательной изначальной семантикой формируют представление о новом предмете или человеке - тоже отрицательное: «глупый», «злой», «уродливый».

Таким образом, языковые оценки могут характеризоваться совершенно разнообразно, вследствие чего могут подразделяться на: 
- положительные;

- отрицательные;

- одобрительные;

- неодобрительные;

- нейтральные.

Рассмотрим пример. В предложении «Сегодня чудесная тёплая погода» содержится положительная оценка, хотя прямого указания на это нет. Здесь важны ассоциации, которые у нас связаны с солнечным днем, и сама коннотация этого слова. Понятия «теплый» и «чудесный» вызывают у нас положительные ассоциации, в отличие от их антонимов: «холодный», «ужасный».

Таким образом, на положительную или отрицательную языковую оценку влияет изначальная ассоциация, возникающая в процессе формирования предшествующего языкового опыта у каждого человека. Стоит отметить, что оценочная функция прилагательных зависит, помимо прочего, и от языкового контекста. Так, например, слово «темный» в словосочетании «темный шоколад» не имеет отрицательной коннотации. В словосочетании «темный (непросвещенный) субъект» отрицательная коннотация выражена отчетливо.

Из всех частей речи прилагательные («странный», «бирюзовый», «мягкий») и наречия («грязновато», «сверхточно», «прекрасно») обладают наибольшей частотностью отражения оценочной функции. Также вышеупомянутые части речи являются основными способами выражения оценки в русском языке. Обратите внимание, к примеру, прилагательное «красивый» трудно сделать отрицательным без частицы не. В то же время, допустим, слово «лёгкий» будет положительным в сочетании типа «лёгкое прикосновение» и отрицательным - в сочетании «лёгкое поведение». 
Что же касается наречий, то они могут быть не только частью предложения, но и являться полноценными предложениями самостоятельно, обладая способностью давать оценку. В высказывании «Посмотри сюда. Это изумительно!» наречие является восклицанием и употребляется с восклицательным знаком и выражает положительную оценку (восхищение чем-то).

Как известно, наречия и прилагательные к тому же обладают и степенями сравнения. Например, наречия: плохо - хуже; прилагательные: красивый - красивейший - самый красивый. Оценочную функцию могут выполнять и краткие прилагательные. Они тоже несут свою оценочную функцию. Например, «Он определенно умен» (положительная характеристика).

Из служебных частей речи оценочную функцию могут выполнять междометия: «тьфу!»; «увы!»; «вах!» и т. д. Это так называемые восклицания. Обычно это моментальная, сиюминутная реакция на какое-либо действие. Причем в процессе восклицания и удивления у нас возникают совершенно определенные ассоциации. Мы не скажем «Увы! Как прекрасно!» Это уже момент стилистики и закрепления некоторых слов за определенными понятиями.

Оценку предмета могут содержать и имена существительные. Чаще всего это существительные с уменьшительно-ласкательными суффиксами, такие как глазки, ушки, ножки и т.д. Обычно они содержат положительную коннотацию, которая относится к предмету. Но слова с уменьшительноласкательными суффиксами могут быть и с отрицательной коннотацией, когда это насмешка: домишко, ножонка.

В целом, категория языковой оценки обладает уникальным содержанием, общим для всех входящих в её состав единиц, многочленной 


\section{ЧЕЛОВЕК И СОВРЕМЕННОЕ ОБЩЕСТВО В СОЦИАЛЬНОМ, ПРАВОВОМ, ЭКОНОМИЧЕСКОМ РАКУРСАХ}

структурой. Языковая оценка также связана с категориями модальности, эмотивности и реализуется разноуровневыми средствами.

Оценочная единица играет бесценную роль в семантике различных составляющих языка. Стилистический энциклопедический словарь русского языка дает следующее определение оценки: категория оценки совокупность разноуровневых языковых единиц, объединенных оценочной семантикой и выражающих положительное или отрицательное отношение автора к содержанию речи [50;139].

Оценочность характерна для нашего языка в совокупности мыслительного акта с процессом познания. Как утверждает доктор философских наук, профессор Александр Архипович Ивин, языковая категория оценки является отражением логической категории, мыслительных процессов, которые ведут к установлению ценности объектов [19; 35].

По мнению выдающегося советского и российского лингвиста Нины Давидовны Арутюновой, оценка не только представляет собой результат логической операции, но и является наиболее ярким представителем прагматического значения, то есть значения, приобретаемого языковыми единицами в определенной речевой ситуации [1; 5]. Оценочное значение модифицируется за счёт различий категорий описываемых предметов, со временем, в момент которого осуществляется оценка, в большой степени подчинено как говорящему субъекту, так и адресату речи. К тому же, оценочное значение социально обусловлено.

Доктор филологических наук, профессор Елена Михайловна Вольф подчёркивает, что в общеязыковом плане оценка подразумевает ценностный аспект значения языковых выражений и всегда включает субъективный фактор, взаимодействующий с объективным. Оценочное высказывание отражает ценностное отношение между субъектом и объектом, даже если субъект прямо не выражен. Субъективный компонент связан с возможностью 
положительного или отрицательного отношения субъекта к объекту, в то время как объективный компонент ориентирован на собственные свойства предметов или явлений, являющихся основанием для вынесения оценки $[7 ; 24-33]$.

Для наиболее полного изучения языковой оценки необходим анализ (применительно к ней) всех трех аспектов функционирования языковых средств - семантического, грамматического и прагматического.

Оценочное изречение предопределяется особой структурой - модальной рамкой, накладывающейся на высказывание и не соотносящейся ни с логикосемантической, ни с синтаксической его составляющей.

Обратимся к структуре модальной рамки. Она представляет собой синтез субъекта и объекта, связанных между собой оценочным предикатом. Субъектом оценки (эксплицитный (материально выраженный) или имплицитный (скрытый) является лицо или социум, с точки зрения которого дается оценка. Объектом оценки выступает лицо, предмет, событие или ситуация, к которым относится оценка. Следует отметить, что модальная рамка включает в себя, как правило, имплицитный субъект оценки, шкалу оценок и стереотипы, на которые ориентирована оценка, то есть непосредственно то, что составляет основание оценки.

В посвящённых языковой оценочности работах, внимание исследователей при разборе языковых явлений в зависимости от поля научных интересов обращено к различным критериям, опираясь на которые можно обозначить типы оценок. Обратимся к некоторым основным классификациям.

Е.М. Вольф в своём труде «Функциональная семантика оценки» подчёркивает разделение оценки, в зависимости от построения оценочного высказывания, на абсолютные (в случае, если речь идёт об одном объекте оценки) и сравнительные (если в языковой единице присутствуют минимум 
два объекта или состояния одного и того же объекта; и производится их сопоставление) [7; 15]. Подобная классификация позволяет говорить о конструктивно различных оценочных высказываниях, а также о различии в семантике, поскольку в абсолютной оценке присутствует имплицитное сравнение и предполагается наличие некоторой пресуппозиции, связанной с объектом оценки, определенного заранее сформированного представления о нем.

Кроме того, на основе аксиологического критерия оценочные значения подразделяются на положительные (мелиоративные) и отрицательные (пейоративные) [Там же]. Эта классификация носит больше обобщенный, суммированный характер. В ней мы можем найти ответ только на один вопрос: положительно или отрицательно отношение автора к объекту. Стоит отметить, что именно биполярное соотношение оценки является одним из важнейших этапов при анализе, систематизации материала. В результате, мы приобретаем возможность трактовать различные деформации системного определения оценочной единицы в изложении речи, а также предоставляется возможность реализации первичного представления о ценностной картине мира субъекта высказывания.

Основываясь на взаимодействии объективных и субъективных факторов, и исходя от природы оценочного признака, выделяют два типа оценочных единиц:

1) Общзая оценка («хорошо/плохо»);

2) Частная оцуенка (со стороны определенного признака).

Данная классификация используется такими исследователями, как Г. фон Вригт, Н.Д. Арутюнова, Е.М. Вольф, А.А. Карамова. Стоит отметить, что знаменитый финский философ и логик Георг Хенрих фон Вригт выделяет общие и частные типы оценочных значений, основываясь на концептах «добра» (опираясь на анализ прилагательного good - хороший). 
Н.Д. Арутюнова, в свою очередь, критикует классификацию оценок Г. фон Вригта, указывая на такой недостаток, как недопустимая замена общей оценки частной. Нина Давидовна выдвигает на первый план критерий деления по характеру основания оценки, и выводит свою классификацию частнооценочных значений $[1 ; 64-77]$, которую мы представили в виде схемы.

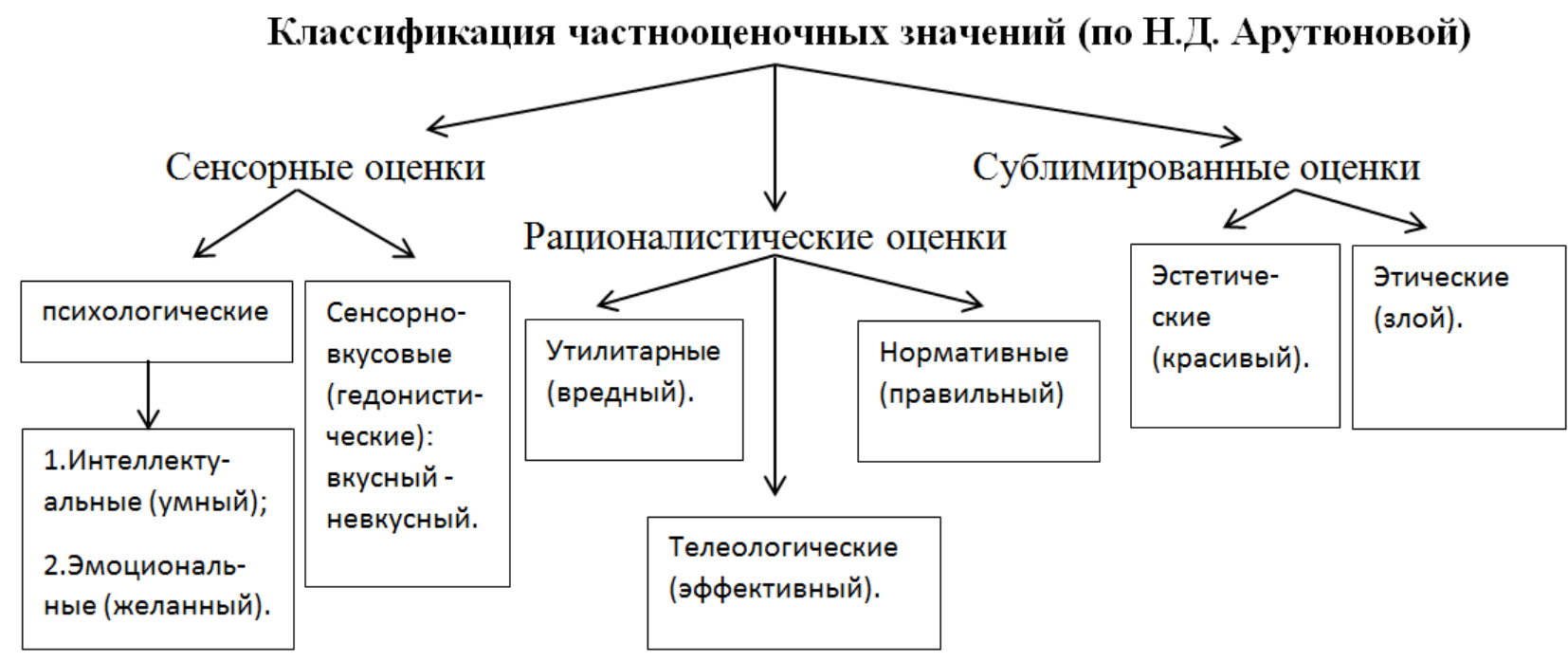

Ещё один исследователь - Е.А. Чернявская, в своей кандидатской работе, которая посвящена анализу оценки и оценочности в языке и художественной речи (на материале наследия А.С. Пушкина), даёт классификацию объектов оценки. Лингвист считает, что объекты (взяв во внимание их «глубинную природу») можно разделить на:

- вещественные (предметные);

- невещественные (непредметные).

Из чего следует, что вещественные - это все «живые» объекты (представители живой природы, включая человека), а все «неживые» существующие независимо. Таким образом, невещественные объекты события и факты, связующие объекты реального и вещественного мира $[9 ; 16]$. 
Е.А. Чернявская выдвигает также и классификацию объектов. Суть ее теории заключается в том, что при классификации основное внимание обращается на отношение объектов к источнику оценочных единиц, то есть к человеку.

В свою очередь, абсолютно все оцениваемые объекты исследователь разделяет на три тематических ряда:

1) «Человек» - объекты, отражающие человека;

2) «Артефрактыл» - объекты, созданные человеком;

3) «Внешний мир» - объекты самостоятельные, независимые от человека [Там же].

Идентичную классификацию использует, например, Т.В. Латкина при исследовании оценочности в идиостиле И.А. Бунина.

Последняя (из представленных в нашей работе) классификаций, на наш взгляд, наиболее ёмко, лаконично и точно раскрывает природу оценочных единиц, учитывает влияние контекста на реализацию семантики оценочных выражений. В ней различают два типа оценок:

1) Ингерентная (языковая, узуальная) оценка;

2) Адгерентная (речевая, окказиональная) оценка.

Данная классификация раскрывает максимальные возможности перед исследователем языковых оценочных единиц.

\section{2. Выражение языковой оценки в разных стилях речи}

Отличительными признаками отображения языковой оценки выступают процессы интенсификации и деинтенсификации. Если первый процесс представляет собой усиление признака («хорошо»/ «плохо»), то второй, в свою очередь, характеризуется ослаблением признака. При истечении любого из вышеупомянутых процессов наблюдается движение по оценочной шкале (как с отметкой « - », так и с «+»). 
Рассмотрим пример: красивый, очень красивый, необыкновенно красивый, не очень красивый, довольно красивый. Обратите внимание, что интенсификация языковой оценки не предоставляет возможности установить расстояние между «красивым» и «необыкновенно красивым». Она также не ограничена количеством вариаций, как, например, в степенях сравнения. Здесь к месту определение Елены Михайловны Вольф о том, что «Интенсификаторы составляют длинные, слабо организованные ряды из единиц, соотнесенных друг с другом неопределенным образом» [7; 45].

Стоит отметить, в тексте оценочная единица в основном не будет являться независимой, а, скорее всего, будет представлять составную часть общего изложения. Нина Давидовна Арутюнова считает, что средства языковой оценки информативно недостаточны, поэтому в тексте, так или иначе, возмещается их смысловая недостаточность и неоднозначность. Оценочные отношения (предикаты) обладают сильной валентностью на смысловое развертывание, которая составляет одно из основных свойств практического значения оценочных единиц. Прагматическое значение восполняется общими для собеседников знаниями и нормами, так как тесно переплетается с ситуацией общения. Однако если наблюдается отсутствие такого рода общих норм и знаний, то говорящий дополняет языковую оценку дескриптивными характеристиками объекта или приводит фактические данные [1;215-218].

Всякая записанная речь, как правило, выражается комбинированно - как собственно языковыми, так и текстовыми средствами. Однако способы выражения языковой оценки в текстовых произведениях различаются в зависимости от стиля и содержания. Рассмотрим эти примеры подробнее.

Научный стиль. В тексте, соответствующем данному стилю, языковая оценка несёт ценностную ориентацию создателя в имеющемся к этому моменту багажу знаний и в приобретаемых впоследствии новых. Языковая 
оценка в данном случае может служить в роли регулятора процесса познания, систематизации и преобразования в представлении читателя прошлого научного опыта. Немалую роль играет оценка и при реализации новых научных идей, положений. Таким образом, языковая оценка сопровождает научные знания с самого его возникновения до развития и реализации в текстовом виде.

К тому же «каждый класс теоретических объектов и ментальных операций имеет свои критерии оценки: выводное знание - гипотезы, подходы, методики и пр. - квалифицируются по их обоснованности, обобщения теории, концепции и пр. - по объяснительной силе, классификации - по основаниям, события - по вероятности, законы - по области действия, построения - по сложности, рассуждение и изложение - по непротиворечивости, непредвзятости, глубине, понятности, полноте, результаты - по значимости, новизне и т.п.» [54; 26].

В реализации языковой оценки в научных текстах принимает участие многочисленный состав синтаксических, лексико-грамматических единиц. Особую значимость приобретают слова, выражающие оценочность, которые по своему значению приближены к центральным понятиям «положительный» - «отрицательный». В данном стиле существует негласная закономерность: положительно оцениваются новые, актуальные, достоверные, доказанные практическим путём знания и научные факты, а отрицательно - не нашедшие качественных, весомых оснований.

Состав оценочных единиц в научном произведении разнообразен, но в то же время систематизирован и стандартизирован. Например, читатель может с легкостью определить наиболее частотные и уже клишированные оценочные выражения. Это такие как «оптимальный вариант», «значительный труд», «авторитетное решение», «существенный вклад», «яркий пример». К тому же оценки отрицательного характера встречаются в научном тексте 
намного реже положительных. К числу таких можно отнести такие прилагательные, выражающие оценку, как «неприемлемый», «неудачный», «некорректный».

Исследователь Л.В. Красильникова предлагает свою классификацию оценок научного текста, в которой выделяет четыре типа:

1) общая аксиологическая оценка (высокий уровень, удачнылй пример, блестящзая идея);

2) ментальная оценка, включающая в себя психолого-интеллектуальную (важный вклад, основополагающий метод, серьезная попьтка) и эмоционально-интеллектуальную (остроумная идея, рациональный подход, тонкий анализ) оценку;

3) практическая оценка, основывающаяся на отношении к норме, стандарту, актуальности, эффективности (идеальная классификация, академический труд);

4) эмоциональная оценка, обозначающая различные психологические состояния и реакции (сильное впечатление, неожиданные выводы, поразительнье результать).

Оценочная единица, касающаяся конкретного лица, упоминаемого в научном тексте (чаще всего в рецензиях), включает в себя общую оценку мастерства (знаменитый профессор), профессиональную оценку (высококвалифицированнылй спещчиалист), этико-психологическую оценку (смелое решение) $[55 ; 21]$.

Научный стиль, как правило, служит для выражения результатов конкретного исследования, для реализации которого используются различные термины, сложные синтаксические конструкции. Слова, в основном, употребляются в прямом значении. Следовательно, применение эмоционально-экспрессивной лексики сведено до минимума. Таким образом, в научном тексте, с точки зрения оценочности, доминирующий состав 
представлен рациональной оценкой, как правило, служащей текстообразующим, связующим средством. В подобных текстах языковые оценочные единицы распределены неравномерно, что, несомненно, связано с композиционной структурой произведения.

Обратимся к официально-деловому стилю. По наблюдениям доктора филологических наук, профессора Тамары Вячеславовны Матвеевой, которая занималась исследованием категории языковой оценки во всех функциональных стилях литературного русского языка, в официальноделовом тексте основными (составляющими) единицами языковой оценки выступают глагол «улучшить» и девербатив (отглагольное существительное) «улучшение». Эти слова являются наиболее важными средствами выражения оценочности в произведениях данного стиля.

Если в мотивирующей части делового текста присутствует критическая констатация первоначальной выдвинутой ситуации, то в этом случае будет реализовываться отрицательная языковая оценка. Текстовое ядро, вместе с базовыми единицами, составляют как «положительные» (благоприятный, эффективность, прогресс), так и «отрицательные» (неоправданный, негативный) языковые оценочные выражения. Также велика вероятность обнаружить в текстах данного стиля лексику с рационально-оценочной коннотацией (планомерное развитие, сбалансированная система, гибкая структура).

Подобно научному, в официально-деловом стиле также многие из языковых оценочных единиц образуют «клишированные союзы». Примерами могут служить такие сочетания, как «полное удовлетворение», «непомерно высокие иеныл», «крайне неудовлетворительно».

В целом, явлению оценочности в официально-деловом стиле принадлежит функция подготовки читателя (адресата) к восприятию и 
анализу главной мысли текста. То есть для таких текстов характерна открытая оценочность.

Главной отличительной чертой оценочности в данном случае, если сравнивать с другими стилями русского литературного языка, является модальная окраска обязанности. Например: Организацияя обязуется систематично обеспечивать воспроизводство материально-технической базы на прогрессивной основе.

Публиц̧истический стиль. В этом случае языковая оценка выступает специфической стилевой чертой. Это объясняется тем, что оценочные единицы (в частности, социальная оценка) преобразуются в принцип создания текста. Оценочность речи, в частности, раскрывается при полемике, при критике противоположного мнения, а также при различных оценках освещаемых событий. Огромное количество фразеологических оборотов, экспрессивного синтаксиса, качественно-оценочных прилагательных и существительных служат средствами выражения языковой оценки в данном жанре. Вот несколько примеров: гениальное творение, погреть руки, показуха. К тому же такая способность является отличительной чертой данного стиля при сопоставлении с остальными.

Часто при реализации оценочного содержания в тексте используется и нейтральная лексика при условии, что в ней отражается рациональнооценочная коннотация, исходя, например, из опыта конкретного этноса. Оценочные единицы в данном случае могут нести как положительный (трудолюбие, честь, демократия), так и отрицательный (фашизм, трусость, терроризм) характер.

Отметим двоякий характер авторских оценок. С одной стороны, языковая оценка может являться рациональной по смыслу и развёрнутой по форме. В этом случае языковые оценочные единицы составляют отдельные логические тезисы в составе текста. С другой стороны, языковая оценка 


\section{ЧЕЛОВЕК И СОВРЕМЕННОЕ ОБЩЕСТВО В СОЦИАЛЬНОМ, ПРАВОВОМ, ЭКОНОМИЧЕСКОМ РАКУРСАХ}

может оказаться распространённой во всём представленном тексте. В этом случае главная функция оценочных единиц - оценочное окрашивание всего произведения.

В публицистике последних лет приобретают актуальность тексты практически лишённые знаков оценочности. Смысловая структура данных текстов строится на основе объективно-логического характера фрагментов произведения. Стоит отметить, что немаловажна в подобных текстах роль автора: он систематизирует данные фрагменты таким образом, что по контексту появляется возможность определить социальную оценку предмета речи. Читателю при этом предстоит самостоятельно вычленить оценочность из контекста, опираясь на общее содержание произведения. Следует подчеркнуть, что публицистика на современном этапе развития старается избегать прямых, абсолютных оценочных выводов.

Самый интересный состав языковых оценок представлен, несомненно, в разговорном стиле. Вполне логично утверждать, что разговорному тексту не характерна объективно-логическая, рациональная оценки. Как правило, языковая единица, отражающая прямую рациональную шкалу оценки, расширяется дополнительным эмоциональным значением. Этому способствуют, например, эмоционально-экспрессивная лексика, интонация.

К классическим оценочным средствам текста разговорного стиля относят:

1) сочетания рационально-оценочного слова с наречиями меры и степени, указывающими на крайнюю степень языковой оценки (ужасно, здорово, безумно хорошо);

2) сочетания рационально-оценочной единицы со словами «так» и «такой», отражающими необходимую говорящему интонацию (так нравится, такой красавец, он так плохо учится); 
3) субъективно-модальные синтаксические конструкции с оценочной семантикой (Мало ли! Больно надо! Ага, щас!);

4) жаргонизмы, имеющие единое оценочное значение (Концерт такой ужасный был вообще! Смотри, какая крутая у меня кожа после маски! Ну что там, вчера кайфовая была вечеринка?).

Преобладание количества оценочных единиц, распределяющихся в тексте без какой-либо систематизации, упорядоченности - отличительная черта оценочности в разговорной речи.

Подобно разговорному, художественному стилю не характерна рациональная оценка. Авторы, при создании текстов в данном стиле, также стараются исключать употребление открытых обобщённо-логических оценочных единиц. В свою очередь, их периодическое использование в авторской речи предопределяет публицистическое начало. Что касается рациональной оценки, то такие единицы в тексте наделяются автором экспрессивно-эмоциональными тонами. Типичным является сочетание оценочного слова с прямым или непрямым сигналом эмоциональности: Легко на сердие от песни весёлой (В. Лебедев-Кумач).

Отличительная черта оценочности в художественном стиле заключается в том, что в произведении текстовое оценочное содержание может не совпадать с языковым (иногда и противоречить ему). Определить оценочное значение языковой единицы в произведении возможно, лишь опираясь на контекст. В качестве примера можно привести результаты исследования T.В. Матвеевой рассказа В. Шукшина «Вянет-пропадает». В данном произведении, как выводит исследователь, оценочная единица «хороший» систематично проявляется в параллели с сюжетной линией дяди Володи, в его прямой речи (хоромее дело... очень хоромее дело; мне и так хорошо; завтра хороший день будет). Данная языковая оценка накладывает отпечаток на соседние конкретно-предметные реалии, так что «хорошими» становятся и 


\section{ЧЕЛОВЕК И СОВРЕМЕННОЕ ОБЩЕСТВО В СОЦИАЛЬНОМ, ПРАВОВОМ, ЭКОНОМИЧЕСКОМ РАКУРСАХ}

комната, и сервант. Однако чем лучше все обстоит у этого персонажа, тем больше читательское раздражение по его поводу. Этот эффект достигается через восприятие других персонажей и автора. И напротив, отрицательнооценочная фраза «проломиться с молотком к Игорю» (с целью убийства) в рассказе В. Шукшина «Обида» имеет совершенно иное текстовое наполнение - вызывает читательское сочувствие, сострадание к герою [29; 27$].$

Наблюдается ещё один интересный момент, касающийся оценочности в художественном тексте. Он связано с тем, что один и тот же текст может содержать в себе и совмещать абсолютно противоположные оценки, которые принадлежат разным субъектам. Это помогает реализовать многоаспектность мировоззрения, в котором параллельно сосуществуют разные ценностные стереотипы. Именно в оценочности в художественном тексте часто проявляется полифония, многоголосие, о которых не раз говорили исследователи языка данного стиля (М.М. Бахтин, Б.А. Успенский). Перед нами пример, который приводит М.М. Бахтин, анализируя соотношение монологического слова героя и слова рассказчика у Достоевского: «Я живу в кухне, или гораздо правильнее будет сказать вот так: тут подле кухни есть одна комната (а у нас, нужно вам заметить, кухня чистая, светлая, очень хоромая), комнатка небольщая, уголок такой скромный, то есть, или ещуе лучше сказать, кухня большая в три окна, так у меня вдоль поперечной стень перегородка, так что и выходит как бы ещуе комната, нумер сверхштатный, все просторное, удобное, и окно есть, и все, одним словом, все удобное» («Бедные люди»). Комментируя данный отрывок, Е.М. Вольф пишет: «Здесь серия оценочных слов (субъект оценки - говорящий) со знаком «+» (кухня чистая, светлая, очень хорошая, уголок такой скромный, кухня большая, все просторное, удобное), контрастирует с описанием кухни, которая на основании общепринятых стереотипов оценки скорее характеризуется знаком «-» (в кухне за перегородкой жить плохо). Но при этом оба стереотипа 


\section{ЧЕЛОВЕК И СОВРЕМЕННОЕ ОБЩЕСТВО В СОЦИАЛЬНОМ, ПРАВОВОМ, ЭКОНОМИЧЕСКОМ РАКУРСАХ}

совмещаются в изложении рассказчика» [7; 209]. Подлинное понимание оценочного значения той или иной языковой оценочной единицы в тексте рассматриваемого стиля возможно только опираясь на контекст художественного целого.

Языковая оценка, таким образом, присутствует в любых типах текстов, даже если она не выражена эксплицитно (открыто). Оценочная позиция субъекта речи детерминируется канонами, выработанными соответствующей эпохой, поэтому изучение оценки позволяет понять обобщенную ценностную ориентацию социума в определенный период его развития.

\section{3. Способы и средства выражения языковой оценки}

Работы таких исследователей, как О.И. Усминский, С.Г. Шейдаева, Л.М. Васильев, Н.Д. Арутюнова и др. доказывают, что оценка проявляется на всех уровнях языка и обладает широким арсеналом средств выражения фонетических, морфологических, словообразовательных, лексических и синтаксических.

На фонетическом уровне оценка может оформляться звукоподражаниями, звуко-ритмоподражаниями, фонетическими и семантикофонетическими каламбурами, а также аллитерацией и/или ассонансом, которые создают нужный психоэмоциональный фон высказывания [56; 18$]$.

Однако, как отмечает Е.В. Кочеткова, фонетические единицы языка не содержат оценки как таковой. Они, как и синтаксические конструкции, могут только усиливать положительное или отрицательное восприятие адресатом отношения субъекта речи к ее предмету [57].

По мнению Т.В. Кочетковой, «в первую очередь оценка актуализируется лексико-семантическими средствами языка, выражающими ее эксплицитно и имплицитно, денотативно и/или коннотативно, прямыми номинациями, определениями-характеристиками и через характер совершаемых действий 


\section{ЧЕЛОВЕК И СОВРЕМЕННОЕ ОБЩЕСТВО В СОЦИАЛЬНОМ, ПРАВОВОМ, ЭКОНОМИЧЕСКОМ РАКУРСАХ}

(глагол-сказуемое)» [там же]. Оценочное значение может также усиливаться при помощи использования явлений синонимии и антонимии.

Кроме того, оценочные значения реализуются в словобразовании, как правило, при помощи суффиксов субъективной оценки. Как считает С.Г. Шейдаева, это средство выражения оценки наиболее ярко проявляется в художественном тексте, где отражено все богатство субъективно-оценочной лексики [58]. Существуют разнообразные аффиксы, способные передавать оценочное значение: помимо усилительных и уменьшительно-ласкательных суффиксов, к ним также относятся некоторые приставки.

На морфологическом уровне основным средством выражения оценки являются формы сравнительной степени наречий, формы сравнительной и превосходной степени имен прилагательных, а также их элятивные формы, которые обозначают безотносительно высокую степень качества.

В полном объеме оценочная семантика реализуется только в высказываниях. К синтаксическим средствам, выражающим оценку, можно отнести некоторые именные предикаты (Hе утешенье mbl, не украменье, я у тебя в пожизненном долгу (М.Ю. Лермонтов)), инфинитивные конструкции (Странно и сладко жить настоящим (В.Я. Брюсов)) и т.П., а также нечленные конструкции, состоящие из междометий, и односоставные предложения, включающие слова категории состояния (Замечательно! Ужасно!). Для усиления оценочного значения могут использоваться, например, риторические вопросы и сравнительные обороты.

В перечисленных случаях на оценочное значение влияет не только лексическое наполнение, но и в значительной степени сама структура высказывания. Тем не менее, синтаксические средства, по-видимому, не могут выражать оценку самостоятельно. По мнению Т.В. Маркеловой, «основное место в репертуаре оценочных структур занимают высказывания типа «Жизнь есть жизнь», «Учеба есть учеба», в которых констатируется соответствие 
объекта оценки некоторой известной норме, существующему стереотипу $[60 ; 94]$. Однако и в этих высказываниях важно лексическое наполнение.

Таким образом, лексические, морфологические и словообразовательные средства в тексте могут выражать оценку эксплицитно и имплицитно, самостоятельно, а фонетические и синтаксические средства являются для них вспомогательными.

В письменной речи можно выделить еще один способ выражения оценки - графический. К его средствам относятся различные шрифты и начертания, знаки пунктуации, повторение графем и все, что позволяет выделить часть текста, привлечь к ней внимание читающего, отразить состояние субъекта речи.

\section{ЧАСТЬ ІІ.ТРАДИЦИОННЫЕ И ИННОВАЦИОННЫЕ СПОСОБЫ ЯЗЫКОВОЙ ОЦЕНКИ В ПРОИЗВЕДЕНИЯХ ДЕТСКИХ ПИСАТЕЛЕЙ НА УРОКАХ ЛИТЕРАТУРЫ}

\section{1. Понятие языковой нормы в художественном тексте.}

\section{Способы её оценки}

В современной лингвистике понятие языковая норма тесно перекликается с визуализацией литературно грамотной, правильной речи, которая является одним из самых важных показателей уровня общей культуры человека. Как правило, нормы имеют биполярную природу. Если, с одной стороны, в ней заключены объективные свойства развивающегося языка, то, с другой - общественные вкусовые оценки.

Норма, как явление социально-историческое и глубоко национальное, характеризует, прежде всего, литературный язык - признанный в качестве образцовой формы национального языка. Из чего следует, что понятия «языковая норма» и «литературная норма» часто оказываются синонимичными, особенно в применении к современному русскому языку. Не 
стоит упускать из внимания, что исторически это не тождественные определения.

Норма как система, включающая в себя унифицированные и фиксированные лингвистические средства (в параллели с правилами их употребления), закреплённые в словарях, а также в учебной литературе, выражает уникальный признак литературного языка на всех этапах его развития. Выявлением нормы литературного языка, опираясь на анализ устной и письменной речи в различных условиях коммуникативного акта, занимаются специалисты соответствующего профиля. Норма представляется в изданиях как научных, так и массовых, предназначенных широкому кругу читателей разной возрастной категории. Владение литературной нормой родного языка и языка страны проживания является одним из важнейших показателей образованности. Фиксированность и традиционность нормы выступают, в некоторой степени, показателем ретроспективности нормы. Несмотря на свою принципиальную подвижность и изменчивость, норма предельно осторожно открывает свои границы для инноваций, оставляя их до поры до времени на периферии языка. Стоит отметить, что само определение нормы в применении к языку раскрывает два ключевых значения.

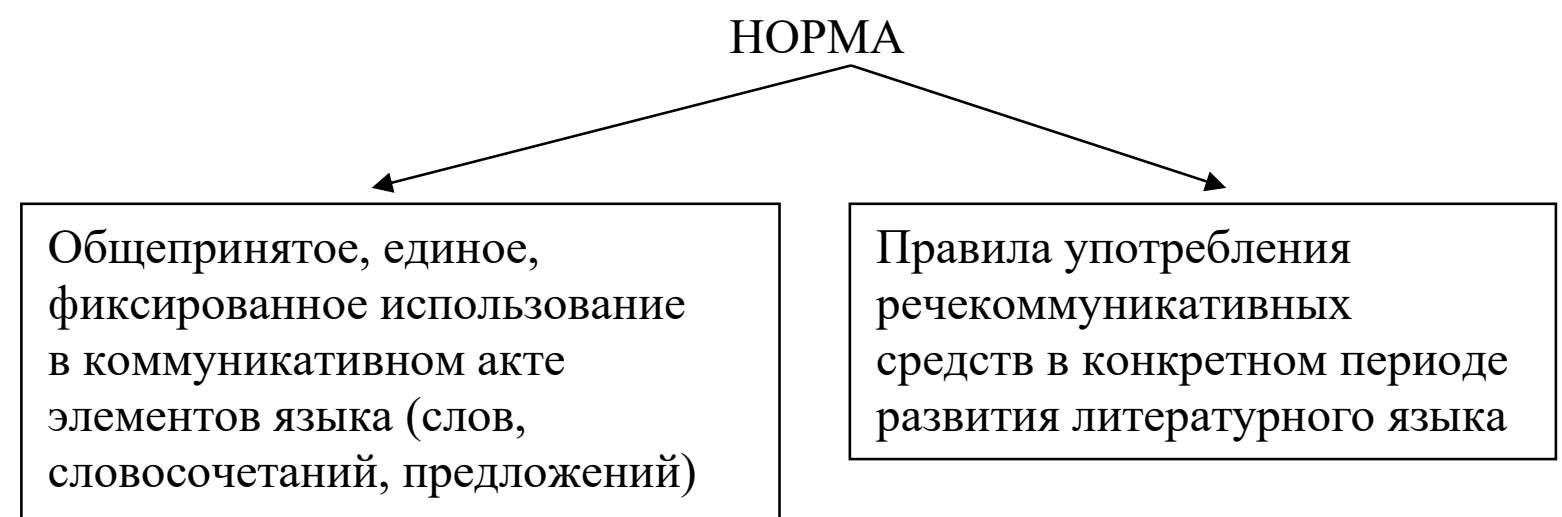

Норма является всеобъемлющим показателем структурного содержания языка, она обязательна как для устной, так и для письменной речи. Языковые нормы, в свою очередь, представляют явление историческое: если часть из 
них выработана давно, зафиксирована и сохраняется в языке вплоть до современного этапа развития языка, то другая - характеризуется видоизменённостью.

В основе возникновения объективной нормы лежит конкуренция вариантов языковых знаков. Долгое время более предпочтительным источником литературной нормы являлась классическая художественная литература. В настоящее время центр образования норм смещён в средства массовой информации (радио, телевидение, интернет, периодическая печать). Следовательно, с этим меняется и языковой вкус эпохи, который способствует изменению и самого статуса литературного языка. Тем самым норма демократизируется, открывается путь для ранее нелитературных языковых средств. При этом коренным образом может измениться семантика слова.

Финальному изменению норм предшествует появление их вариантов, реально существующих в языке на определенном этапе его развития и активно используемых его носителями, которые представлены на всех уровнях языка:

\begin{tabular}{|l|l|}
\hline \multicolumn{1}{|c|}{ Уровень } & \multicolumn{1}{c|}{ Варианты } \\
\hline Фонетический & папоротник - папортник \\
\hline Словообразовательный & слесарничать - слесарить \\
& геройски - по-геройски \\
\hline Морфологический & кофе готов - кофе готово \\
& поезжай - езжай - съезди \\
\hline Синтаксический & купить хлеба - купить хлеб \\
& ехать на поезде - ехать в поезде \\
\hline Фразеологический & языком трепать - языком чесать \\
& - болтать - молоть \\
\hline
\end{tabular}




\section{ЧЕЛОВЕК И СОВРЕМЕННОЕ ОБЩЕСТВО В СОЦИАЛЬНОМ, ПРАВОВОМ, ЭКОНОМИЧЕСКОМ РАКУРСАХ}

Вариантов различных типов языковой нормы очень много в русском языке, что свидетельствует о его богатстве. Однако для выборки правильного варианта, необходимо знать, какова его характеристика, его стилистическая окраска. Информация о вариантах содержится в толковых словарях и в словарях, созданных как результат исследования употребления различных вариантов в речи как письменной, так и устной.

В понятие идеала, образцовости нормативного языкового средства всё более отчётливо включается значение целесообразности, удобности. Норма обладает некоторым набором признаков, которые должны присутствовать в ней в определённой комбинации. Подробно о признаках нормы пишет известный лингвист Кирилл Сергеевич Горбачевич в книге «Вариантность слова и языковая норма». В своей работе исследователь выделяет три основных признака: 1) устойчивость нормы, консерватизм; 2) распространенность языкового явления; 3) авторитет источника. Каждый из признаков по отдельности может присутствовать в том или ином языковом явлении, однако для того, чтобы языковое средство было признано нормативным, необходимо сочетание признаков [13; 7-19].

Языковая норма образуется в процессе речевого общения, отрабатывается и фиксируется в общественном употреблении как узус (лат. usus - пользование, употребление, обыкновение). Литературная норма, безусловно, основывается на узусе, однако, также намеренно кодифицируется - закрепляется в словарях, в сводах правил, в учебниках.

Правила словоупотребления, произношения, использования стилистических и грамматических языковых средств, которые зафиксированы в общественно-языковой практике, называются литературной нормой. Норма исторически подвижна, но вместе с тем устойчива и традиционна, она обладает такими качествами, как привычность и общеупотребительность.

Лингвистические нормы отражают закономерные процессы и явления, 
которые происходят в языке, и поддерживаются речевой практикой. К основным источникам установления языковой нормы относятся:

1. Произведения писателей-классиков и современных писателей,

2. Анализ языка средств массовой информации,

3. Общепринятое современное употребление,

4. Данные живого и анкетного опросов,

5. Научные исследования ученых-языковедов.

Понятие языковой нормы находится в фокусе внимания современных ученых-лингвистов и методистов, при этом аспекты изучения этого определения существенно различаются. В методике преподавания русского языка выражен практический аспект, который заключается в том, что учащимся следует знать нормы языка для полноценного языкового образования. Разумеется, их, в первую очередь, должны хорошо знать на теоретическом и практическом уровнях сами школьные преподаватели. Только при таком условии за годы изучения языка можно сформировать правильные речевые навыки, предотвратить деформацию языкового процесса.

Таким образом, понятие языковой нормы - одно из фундаментальных, ключевых в школьном базовом курсе русского языка на всем протяжении его изучения. Известный отечественный методист Елена Ивановна Литневская дает следующее определение языковой нормы в своем учебнике: «Норма - это сложившийся в языковом, групповом или индивидуальном сознании образ результата определенного речемыслительного действия. Большинство норм речи носит подсознательный характер: их психологический механизм аналогия, действие по образцу. Носитель языка усваивает сами тексты и при накоплении вычленяет из них стандарт, то есть модель, образец» [23; 552].

Только зная и хорошо понимая языковую норму, можно заметить отступления от нее или, наоборот, наблюдать полное ей следование в той или иной языковой деятельности: анализ, пересказ, письменная работа различного 
типа. В современной методике преподавания русского языка в настоящее время создана классификация речевых отклонений от нормы, которые называются по-разному: отклонения от нормы, речевые ошибки. Е.И. Литневская деликатно определяет их как «речевые неудачи». В своей классификации типов речевых неудач она опирается на работу Ольги Владимировны Кукушкиной «Основные типы речевых неудач в русских письменных текстах». Согласно этой классификации выделяются следующие основные виды нарушения речевой нормы:

1. Неудачи качественной организации смысловой структуры, которые подразделяются на несколько категорий:

1) Недостаточное расчленение на этапе осмысления, когда «целое» берется вместо «части целого»;

2) Включение «ложного участника»;

3) Ложная принадлежность;

4) Присвоение «чужого» обстоятельства;

5) Неточное установление связей между смысловыми единицами;

2. Недостаточная детализация (или избыточная расчлененность) на уровне языковой номинации;

3. Неудачное определение отношений между «предметом» и его «признаком»;

4. Неудачная квалификация положения дел;

5. Неудачная ментальная или языковая номинация;

6. Неудачное референционное определение категорий;

7. Неудачный выбор и воспроизведение означающего.

По данной классификации несоответствия норме языка подразделяются на три типа:

- нарушение;

- неудача; 
- ошибка.

Обратимся к значениям каждого из вышеупомянутых понятий. Любое, в том числе и намеренное, оправданное отступление от языкового стандарта, то есть стилистический прием, языковая игра представляет собой нарушение.

Неоправданное отступление от языкового стандарта, вызывающее негативную реакцию адресата, - это речевая неудача. В свою очередь, речевые неудачи, при которых отклонение от стандарта носит грубый характер, вызывая однозначно негативную реакцию слушающего, являются языковыми ошибками [23; 552].

Данная классификация отличается достаточной полнотой и дает, как мы полагаем, возможность анализа языковых нарушений в конкретном художественном тексте, предлагаемом для изучения в школе. Формы работы над текстом могут быть различны, интерактивные формы сегодня наиболее востребованы. Порядок изучения текста на уроках словесности предполагает:

1. Ознакомление с его содержанием и языковым составом;

2. Выявление нарушений речи, их классификацию;

3. Определение правильной языковой нормы;

4. Ответ на вопрос, являются ли те или иные отступления от нормы намеренными или нет;

5. Ответ на вопрос, с какой целью и по какой причине они допущены в тексте автором.

Исходя из вышесказанного, можно сделать вывод о том, что последовательный ответ на эти вопросы подводит к выявлению авторского замысла, мировоззренческой позиции писателя, идеи произведения и его образной системы.

Показатели различных нормативных словарей дают основание говорить о трех степенях нормативности:

Норма 1-й степени - строгая, жесткая, не допускающая вариантов; 
норма 2-йстепени - нейтральная, допускает равнозначные варианты;

норма 3-й степени - более подвижная, допускает использование разговорных, а также устаревших форм.

Нормы помогают литературному языку сохранять свою целостную структуру и понятность для всех слоёв населения. Они защищают литературный язык от потока диалектной речи, социальных и профессиональных жаргонов, просторечия. Это позволяет литературному языку выполнять свою основную функцию - культурную.

Стоит также отметить, что историческое видоизменение норм литературного языка - закономерное, объективное явление. Оно не зависит от воли и желания отдельных носителей языка. Развитие общества, изменения социальных условий жизни, возникновение новых традиций, совершенствование взаимоотношений между людьми, функционирование литературы, искусства приводят к постоянному обновлению литературного языка и его норм.

Таким образом, систематизация нормы есть результат нормализаторской деятельности, а кодификаторы, наблюдая за речевой практикой, фиксируют норму, сложившуюся в самом языке, отдавая предпочтение тому из вариантов, который оказывается наиболее актуальным в конкретный период времени.

\section{2. Мотивированные отклонения от языковой нормы} в художественных текстах

В процессе устной и письменной речевой деятельности нередко можно заметить отклонения от нормы. Они проявляются в произношении, в постановке ударений в слове, в употреблении определённых грамматических форм, в словоупотреблении. Эти нарушения способны иметь различный характер. Если, с одной стороны, они могут довольно незатейливо 


\section{ЧЕЛОВЕК И СОВРЕМЕННОЕ ОБЩЕСТВО В СОЦИАЛЬНОМ, ПРАВОВОМ, ЭКОНОМИЧЕСКОМ РАКУРСАХ}

свидетельствовать о неграмотности, неразвитой речевой культуре, то с другой, могут быть осознанными, специально запланированными, подчёркивающими и раскрывающими определенный замысел. Во втором случае нарушения кроют в себе вторичный характер. При таком раскладе они рассчитаны на понимание смысла и представляют собой особый литературный прием. Осмысленное, намеренное употребление речевых «ошибок», поясняющих, раскрывающих определённую речевую ситуацию, допустимо в образовательной среде профессионально связанных людей, когда ошибочность высказываний привносит элемент непринужденности, обычно ироничности, в общение хорошо понимающих друг друга собеседников. Так возникает своеобразная игра с легко воспринимаемым подтекстом. Великолепно сказал об этом Л.В. Щерба: «Только безупречное знание языка, грамматики дает возможность почувствовать всю прелесть отклонения от правил. Эти отклонения становятся средством тонких и метких характеристик» $[37 ; 13]$.

Художественную значимость нарушение языковой нормы приобретает в публицистике, в художественной литературе. Такие отклонения от нормы становятся словесным образом, средством передачи специального, характерологического смысла.

В художественной литературе нарушения нормы представляют собой некий приём речевых характеристик. Эти приёмы подчинены говорящему, пишущему. Отчего следует их зависящая от исполнителя природа. Они выполняют художественную функцию. Часто случается, что великие художники слова, такие как Л.Н. Толстой, Ф.М. Достоевский допускают такие погрешности в языке, какие не дозволены рядовому носителю языка. Подобное можно встретить и у А. Блока - в орфографии, в акцентном оформлении слова, в грамматике: «по вечерам над ресторанами» из стихотворения «Незнакомка» (неправильное употребление предлога), 
«в соседнем доме окна жолты» из «Фабрики» (вместо «жЁлты»). Блок настойчиво охранял свои грамматические оплошности от издателей, поскольку они для него имели цену образно-эстетическую.

Звуковые и словесные повторы, алогизмы при сочетании однородных членов предложения, нарушение управления и согласования - эти элементарные просчеты, нарушающие правила практической стилистики, могут служить целям особого плана. Словесная или грамматическая игра, тонко проведенная, заставляет почувствовать оригинальность слога, умение свободно и легко обращаться с тем неистощимым богатством, которое предоставляет нам язык. И отклонения от нормы в создании такого слога занимают свое особое место.

В противопоставление «норме» выступает понятие «антинорма». Репрезентация нормы делает текст стандартным, а производство антинормы сообщает ему индивидуальность, уникальность. Исходя из вышесказанного, можно сделать вывод, что норма всегда воспроизводится, а антинорма создаётся.

На базе сопоставления взаимоотношений нормы и антинормы, можно сформулировать критерии их разграничения:

1. Статистический (чем чаще употребляется, тем более приближена к статусу общепринятой нормы);

2. Деривационный (все производные формы языка тяготеют к не нормативности, все производящие - к нормативности);

3. Логический (нормативны те формы, которым соответствуют логические структуры - так, прямой порядок слов носит более нормативный характер, чем обратный);

4. Психологический (чем нейтральнее языковая форма, тем она нормативнее, так как привычнее отмеченной; последние попадают в фокус внимания). 
Норма - понятие биполярное. Она может быть императивной (всеобщей, обязательной) и диспозитивной (допускающей выбор, вариантной). К примеру, обязательными для всех являются ударения в словах аллея, средства, досуг, телефон, каталог, тогда как в словах творог, одновременный, по средам допускается вариантность.

Кроме того, норма также бывает общеязыковой (с вариантами или без них) и ситуативной (стилистической). Последняя характеризует, в частности, речь профессиональную, например, общеязыковая литературная норма требует окончания -и, -ы во множественном числе существительных мужского рода типа отщы, лётчики, бухгалтеры. Профессиональная и разговорная речь допускает варианты с окончаниями -а, -я (инженера, бухгалтера, итурмана).

Как уже нами упоминалось, понятие норма теснейшим образом связано с термином «языковая оценка». Так же, как и норма, языковая оценка, эволюционируя, претерпевала некоторые изменения.

Стоит отметить, оценочность является одной из сложнейших языковых категорий. Она формируется, прежде всего, под влиянием, экстралингвистических факторов: культурных, психологических, социальных и, безусловно, под действием оценочной системы конкретной исторической эпохи. Лингвистическая составляющая данного вопроса специфична, что объясняется не просто изучением оценки, закреплённой в слове, но и выявлением способов еe реализации. В течение длительного времени изучение языковой оценки ограничивалось рамками логики, философии, аксиологии, теологии, этики. Переломным моментом в развитии оценочности становится вторая половина XX века, когда оценка оказывается в центре внимания лингвистов, которые рассматривают ее как феномен, без которого не обходится ни один язык мира (Арутюнова, Вольф, Галкина-Федорук, Маркелова, Сковородников, Худяков, Шаховский). Именно этот период 


\section{ЧЕЛОВЕК И СОВРЕМЕННОЕ ОБЩЕСТВО В СОЦИАЛЬНОМ, ПРАВОВОМ, ЭКОНОМИЧЕСКОМ РАКУРСАХ}

можно назвать «золотым веком» оценочности, так как качественное и количественное соотношение новых приёмов, способов, средств достигает своего пика. Если до этого языковая оценка была, в основном, биполярна (то есть закрепляла за словом либо отрицательный оттенок, либо положительный), то к середине XX века она расширяет свои границы и становится одним из основных характеризующих факторов явлений, образов, лиц.

Для сравнения приведем примеры:

Скотинин (протянув руку). Ну, сестрица, скоряй же по рукам.

Г-жа Простакова (тихо Скотинину). Постой, братец. Сперва надобно спросить ее, хочет ли еще она за тебя вытти?

Скотинин. Как! Что за вопрос! Неужто ты ей докладываться станешь?» [46].

Указанный пример из известного произведения, созданного в XVIII веке, даёт конкретную отрицательную оценку героям через соответствующий окрас лексического состава диалога.

А теперь обратимся к литературе XX века. Например, небольшой отрывок из рассказа Людмилы Петрушевской «Свой круг»:

«- Я устраиваю его в детдом, вот анкета, - сказала я и, не вставая, достала из-за стекла книжной полки анкету и заполненные бланки.

Коля их взял посмотреть и порвал.

- Наглая же дура, - сказал Андрей» [47].

Читатель, опираясь на вполне естественные человеческие факторы, может сделать досрочный вывод о том, что «сухая», безэмоциональная лексика героини характеризует её лишь с отрицательной стороны, представляя её эгоисткой, готовой бросить своего ребёнка. Лишь к концу произведения становится известно о тяжёлой болезни женщины и о том, что она досрочно позаботилась о будущем своего ребёнка (не в детском доме, а в 
полноценной семье). Таким образом, мы видим, что сугубо эмоциональная окрашенность слов не является фактором отрицательности.

В заключение можно сказать, что развитие языковой оценки делится на два периода: 1) период до середины XX века; 2) период со второй половины $\mathrm{XX}$ века - по настоящее время. Если на 1 этапе основными, традиционными способами выражения языковой оценки выступали лексические, грамматические и синтаксические (точнее, их неусложнённые формы), то во втором периоде данные способы сохраняются и модифицируются. Также появляется абсолютно новый приём выражения оценочности - языковая игра, которая значительно расширяет всю палитру способов описания языковой оценки.

\section{3. Классификация авторских отступлений от языковой нормы в произведениях детских писателей \\ (В. Драгунский, Ю. Коваль, А. Алексин)}

Языковая оценка тесно связана с языковой нормой, что объясняется неограниченным количеством утверждающих это факторов. Во-первых, излюбленным способом выражения языковой оценки у авторов художественных произведений (в данном случае ряда детских писателей) становится мотивированное нарушение языковой нормы. Под влиянием этой тенденции зародились инновационные способы для описания оценочности: выведение неологизмов и, одно из самых важных, использование приёма языковой игры.

Во-вторых, именно отступления от языковой нормы послужили для закрепления традиционных способов выражения языковой оценки (грамматических, лексических, синтаксических, морфологических) и стали опорной точкой для создание инновационных (языковой игры, неологизмов, окказионализмов). 


\section{ЧЕЛОВЕК И СОВРЕМЕННОЕ ОБЩЕСТВО В СОЦИАЛЬНОМ, ПРАВОВОМ, ЭКОНОМИЧЕСКОМ РАКУРСАХ}

Особое внимание нужно обратить на единичные авторские неологизмы - окказионализмы. Особую роль это явление играет в детской речи, соответственно, и в речи героев детской литературы, являясь одним из средств их характеристики. Примеры окказиональных словообразований можно найти во многих произведениях детских писателей (почайпил = попил чай, пропо-ви-сание = правописание - В.Ю. Драгунский; рыбоуды, рыбоудский = от «удить рыбу», ножевик = от «нож», квасовары = от «варить квас» - Ю. Коваль).

Однако перед тем как перейти к подробному описанию вышеописанных способов оценочности и к их выявлению, стоит обратиться к раскрытию понятия языковой нормы.

В современной лингвистике понятие языковая норма тесно перекликается с визуализацией литературно грамотной, правильной речи (так как определяет устойчивые, единые правила употребления), которая является одним из самых важных показателей уровня общей культуры человека. Невероятно объёмный пласт составляют грамматические нормы, которые определяют правила использования морфологических форм разных частей речи и синтаксических конструкций. В частности, грамматическая норма русского языка сохраняет свою устойчивость. Несмотря на некоторое размывание границы между нормативными и ненормативными явлениями, понятие нормы русского языка продолжает существовать. Однако не следует забывать о существовании вариантов нормы, которые могут употребляться в языке либо как равноправные, либо как относящиеся к строго нормированному литературному языку, либо к разговорной, профессиональной или жаргонной речи. Стоит также отметить, что по истечении времени ситуация с нормативными и ненормативными вариантами может изменяться. Впоследствии, вариант, который был ненормативным, может стать единственно возможным. 
Грамматические нормы, в свою очередь, делятся на две равноправные категории: морфологические и синтаксические. Морфологические нормы несут ответственность за выбор нужной словоформы из ряда вариантных форм слов разных частей речи (существительных, прилагательных, глаголов). Грамматические нормы связаны с выбором формы рода имен существительных (банкнот - банкнота, плацкарт - плаикарта, туфель туфля), некоторых падежных форм имен существительных (договоры договора, лекторы - лектора, слесари - слесаря), форм глаголов (махает машет, cblnem - сыплет), деепричастий (ведя, неся).

Синтаксические нормы определяют правильное употребление синтаксических конструкций: словосочетаний и предложений. К этой классификации норм относятся правила согласования прилагательных и существительных $\mathrm{c}$ некоторыми формами существительных (билет $c$ плачкартой, новая туфля), нормы управления глаголов (оплатить чтолибо, уверенность в чем-либо), правила использования причастных и деепричастных оборотов. Стоит отметить, что синтаксические нормы также выражают систематизацию построения предложений в соответствии с особенностями порядка слов в русском языке и правилами построения сложных предложений.

Особую группу представляют собой стилистические нормы русского языка, определяющие особенности употребления в речи стилистически окрашенных языковых единиц - единиц, обладающих стилистической окраской книжности или разговорности. Стилистическая окраска отдельных языковых элементов должна соответствовать стилистической окраске всего текста. Нарушение стилистических норм приводит к стилевому разнобою, стилистически неоправданному комизму, стилистическим ошибкам.

В целом, литературно-языковую норму можно рассматривать как одну из важнейших условий стабильности, единства и самобытности 
национального языка, его успешного функционирования в качестве важнейшего средства общения людей и хранителя богатств русской духовной культуры.

Грамматические нарушения языковой нормы были обнаружены нами методом сплошной выборки в следующих произведениях детских писателей: А. Алексин «Безумная Евдокия», Ю. Коваль «Шесть рассказов» («Капитан Клюквин», «Крахмальная собака» «Ножевик», «Белозубка» «Нулевой класс», «Чайник»), В. Драгунский «Денискины рассказы».

\section{Грамматические отступления от языковой нормы}

Ю. Коваль «Шесть рассказов».

1. «Капитан Клюквин»

\begin{tabular}{|l|l|}
\hline $\begin{array}{l}\text { Солнечных дней выпадало немного, и в } \\
\text { комнате было тускло }\end{array}$ & $=$ темно \\
\hline $\begin{array}{l}\text { На спине цвет перьев вдруг становился } \\
\text { зеленый, лесной, моховой }\end{array}$ & $\begin{array}{l}\text { = каким? (Т. п.) - зеленым } \\
\text { лесным моховым }\end{array}$ \\
\hline $\begin{array}{l}\text { Корявая игра на гитаре сопровождалась } \\
\text { кривоносым пением }\end{array}$ & языковая игра \\
\hline $\begin{array}{l}\text { Я кормил его семечками с руки } \\
\text { Капитан Клюквин украшает мою игру } \\
\text { таинственными хвойными лесными звуками }\end{array}$ & $\begin{array}{l}\text { языковая игра } \\
\text { предлиогоён неверный }\end{array}$ \\
\hline $\begin{array}{l}\text { Даже шишки долбал он теперь не с таким } \\
\text { яростным интересом }\end{array}$ & $=$ не так яростно \\
\hline Еле бредущие последним снегом & $=$ по последнему снегу \\
\hline
\end{tabular}


2. «Картофельная собака»

\begin{tabular}{|c|c|}
\hline По своей картофельной должности & $\begin{array}{l}=\text { по причине или вследствие } \\
\text { своей должности } \\
\text { Употреблён неверный предлог }\end{array}$ \\
\hline Брал кого-нибудь из своих сторожей на шнурок & = брал на поводок \\
\hline Ноздреватый холст (о мешке) & $\begin{array}{l}\text { по аналогии с ноздреватый сыр, т. } \\
\text { е. с дырками } \\
\text { Языковая игра }\end{array}$ \\
\hline Черная и лохматая собачья рожа & $\begin{array}{l}\text { = морда } \\
\text { Здесь мотивированное } \\
\text { отступление, является средством } \\
\text { характеристики персонажа - умен } \\
\text { как человек. }\end{array}$ \\
\hline $\begin{array}{l}\text { Крахмальный сок струился по его кавалерийским } \\
\text { усам (используется как повтор несколько раз) } \\
\text { Старушка - бабушка } \\
\text { в платочке, расписанном огурцами }\end{array}$ & $\begin{array}{l}\text { Мотивированное отступление как } \\
\text { средство характеристики } \\
\text { персонажа } \\
\text { инверсия } \\
\text { = узорами в форме огурцов } \\
\text { Лексическая ошибка; }\end{array}$ \\
\hline Курица, абсолютно мертвая & $\begin{array}{l}\text { избыточная лексика } \\
\text { Мотивированное отступление от } \\
\text { нормы - выражает иронию автора. }\end{array}$ \\
\hline Грянул курицей Тузика по ушам & $\begin{array}{l}=\text { ударил } \\
\text { Лексическое просторечие }\end{array}$ \\
\hline Солнце, клонящееся к обеду & $\begin{array}{l}=\text { к полдню } \\
\text { Мотивированное отступление от } \\
\text { нормы, создает подтекст }\end{array}$ \\
\hline Отобедать & $\begin{array}{l}\text { = пообедать } \\
\text { Лексическое нарушение }\end{array}$ \\
\hline
\end{tabular}


Продолжение таблицы

\begin{tabular}{|c|c|}
\hline $\begin{array}{l}\text { «Я с этой картошкой совсем измучился»,- } \\
\text { сказал хозяин курицы. -Такая мелкая, что } \\
\text { сам не кушаю } \\
\text { курям варю } \\
\text { А сам все макароны, макароны }\end{array}$ & $\begin{array}{l}=\text { не ем } \\
=\text { курам } \\
\text { (пропуск сказуемого) Мотивированное } \\
\text { отступление от языковой нормы, служит } \\
\text { характеристикой героя. }\end{array}$ \\
\hline Подошел месяц август & $\begin{array}{l}\text { =наступил август или подошел август } \\
\text { Избыточная лексика }\end{array}$ \\
\hline $\begin{array}{l}\text { Сержант достал записную книжечку, что-то } \\
\text { цикнул в ней карандашиком }\end{array}$ & $\begin{array}{l}\text { = написал, черкнул } \\
\text { Неологизм }\end{array}$ \\
\hline $\begin{array}{l}\text { Полубледный Растрепин отскочил в } \\
\text { сторону }\end{array}$ & $\begin{array}{l}\text { по аналогии с «полумертвый от страха» } \\
\text { Мотивированное отступление, выражает } \\
\text { иронию автора. }\end{array}$ \\
\hline $\begin{array}{l}\text { Я собирал чернушки, которых высыпало в } \\
\text { этом году очень много }\end{array}$ & = которых было много \\
\hline $\begin{array}{l}\text { Голос у него был очень громкий, красивый, } \\
\text { деревенский }\end{array}$ & $\begin{array}{l}=\text { неоднородные определения } \\
\text { Лексическое нарушение }\end{array}$ \\
\hline $\begin{array}{l}\text { Сады, набитые яблоками, золотыми } \\
\text { шарами }\end{array}$ & = полные яблок \\
\hline
\end{tabular}

\section{3. Чайник}

\begin{tabular}{|l|l|}
\hline Неуплатеж, - говорит Петрович & не уплатили или неплатеж \\
\hline Нрышепота, ни бульканья не доносится из-под & Лексическое нарушение \\
\hline Он - беспредельник & $\begin{array}{l}\text { Неологизм с использованием } \\
\text { суффикса основного } \\
\text { существительного: чайник }\end{array}$ \\
\hline Раскаленные ошметки пара, осколки кипятка & $\begin{array}{l}\text { Намеренное отступление от } \\
\text { лексической языковой нормы, } \\
\text { служит для передачи } \\
\text { ирреальности происходящего. }\end{array}$ \\
\hline
\end{tabular}




\section{4. Белозубка}

\begin{tabular}{|l|l|}
\hline $\begin{array}{l}\text { Тем временем из щели у порога высунулась новая } \\
\text { лопаточка }\end{array}$ & мордочка мыши \\
\hline Залез с ногами на нары и чагу пьет & =чай из чаги \\
\hline Эй, квасовары, квасу! & $\begin{array}{l}\text { неологизм } \\
\text { Языковая игра }\end{array}$ \\
\hline
\end{tabular}

\section{5. Ножевик}

\begin{tabular}{|c|c|}
\hline Картошечки пекете & $\begin{array}{l}\text { = картошечку печете (лексическое } \\
\text { просторечие) } \\
\text { Мотивированное нарушение } \\
\text { языковой нормы. Служит для } \\
\text { характеристики персонажа. }\end{array}$ \\
\hline Рыбоуды... Такой дым у костра - рыбоудский & $\begin{array}{l}\text { Неологизм, от «удит рыбу» } \\
=\text { рыболовы } \\
\text { языковая игра }\end{array}$ \\
\hline Навязчивый очень к ночи & $\begin{array}{l}\text { не к ночи будь сказано - } \\
\text { интертекст. } \\
\text { Перекличка с пословицей }\end{array}$ \\
\hline Что бродит он по чужим кострам & = по стоянкам \\
\hline Финка.. вострая & $\begin{array}{l}=\text { острая } \\
\text { Лексическое просторечие }\end{array}$ \\
\hline $\begin{array}{l}\text { Положь на место } \\
\text { Он у нас вообще....ножевик }\end{array}$ & $\begin{array}{l}=\text { положи } \\
\text { Лексическое просторечие } \\
\text { неологизм от нож+ начальник, } \\
\text { лесовик }\end{array}$ \\
\hline
\end{tabular}


6. Нулевой класс

\begin{tabular}{|l|l|}
\hline Дружили так с неделю, а потом рассорились & =поссорились \\
\hline $\begin{array}{l}\text { А Ваня стал рисовать букву за буквой и до того } \\
\text { зарисовался, что запруду снова прорвало }\end{array}$ & = дорисовался \\
\hline $\begin{array}{l}\text { Не знал он, конечно, что здесь происходят занятия } \\
\text { нулевого класса }\end{array}$ & = проходят \\
\hline
\end{tabular}

\section{А. Алексин}

\section{Безумная Евдокия}

\begin{tabular}{|c|c|}
\hline $\begin{array}{l}\text { Это, я думаю, еще не стало болезнью, оно стало } \\
\text { моей бессонницей, неотступностью }\end{array}$ & Избыточная лексика \\
\hline $\begin{array}{l}\text { Встречаясь, мы говорили друг другу «здрасьте», не } \\
\text { называя имен, потому что не знали их. }\end{array}$ & $\begin{array}{l}\text { Разговорный стиль, } \\
\text { редукция = здравствуйте }\end{array}$ \\
\hline У вас нет платка? Мой абсолютно промок & Избыточная лексика \\
\hline $\begin{array}{l}\text { Хрупкая Люся тоже пряталась за громоздкой, но } \\
\text { очень подвижной фигурой своей классной } \\
\text { руководительницы. }\end{array}$ & $\begin{array}{l}\text { Лексические } \\
\text { взаимоисключающие определения }\end{array}$ \\
\hline $\begin{array}{l}\text { Евдокия Савельевна была в брюках, старомодной } \\
\text { шляпе с обвислыми полями }\end{array}$ & $\begin{array}{l}\text { от «обвисать»- обвисший } \\
\text { Морфологическое нарушение }\end{array}$ \\
\hline $\begin{array}{l}\text { И ночью Оленьки не было? Полушепотом - } \\
\text { полукриком спросил я. }\end{array}$ & $\begin{array}{l}\text { Избыточное лексическое } \\
\text { сочетание несочетаемых слов }\end{array}$ \\
\hline $\begin{array}{l}\text { А упиваясь собственным горем, не мешает } \\
\text { подумать, что у кого-то в душе праздник }\end{array}$ & $\begin{array}{l}\text { стиль: упиваться счастьем } \\
\text { Языковая игра }\end{array}$ \\
\hline Продолжая борьбу за прекрасное & $\begin{array}{l}\text { = против чего, с чем? } \\
\text { Морфологически неверный выбор } \\
\text { предлога }\end{array}$ \\
\hline $\begin{array}{l}\text { Характер у нее был вулканического } \\
\text { происхождения }\end{array}$ & $\begin{array}{l}=\text { порода вулканического } \\
\text { происхождения) подмена объекта. } \\
\text { Мотивированное: средство } \\
\text { характеристики, выражение } \\
\text { иронии. }\end{array}$ \\
\hline
\end{tabular}


Продолжение таблицы

\begin{tabular}{|c|c|}
\hline $\begin{array}{l}\text { На всех бывших учеников у нее была } \\
\text { заведена картотека. Как в читальнях и } \\
\text { библиотеках на книги. В карточках, помимо } \\
\text { адресов, телефонов и библиографических } \\
\text { сведений, было отмечено, когда проведена } \\
\text { встреча... }\end{array}$ & Языковая игра \\
\hline $\begin{array}{l}\text { Евдокия Семеновна обожала выставки и } \\
\text { вернисажи. }\end{array}$ & $\begin{array}{l}\text { избыточная лексика: вернисаж входит в } \\
\text { общее понятие «выставка» }\end{array}$ \\
\hline $\begin{array}{l}\text { В } 9 \text { «б» замыслили разыграть на } \\
\text { английском языке сцену из Шекспировской } \\
\text { «Двенадцатой ночи» }\end{array}$ & $=$ сыграть \\
\hline $\begin{array}{l}\text { За моей спиной была Надя с ее больным } \\
\text { сердцем }\end{array}$ & $\begin{array}{l}\text { Лексическая неточность, отделение части } \\
\text { от целого }\end{array}$ \\
\hline $\begin{array}{l}\text { Кокетничала она очень громоздко и } \\
\text { неуклюже }\end{array}$ & $\begin{array}{l}\text { Избыточная лексика } \\
\text { Мотивированное отступление: служит } \\
\text { средством характеристики персонажа, } \\
\text { который проявляет избыточную } \\
\text { деятельность, суетливость. }\end{array}$ \\
\hline $\begin{array}{l}\text { Наш адрес она помнила наизусть, хотя дома } \\
\text { у нас никогда не бывала }\end{array}$ & стиль: =никогда не была \\
\hline Школу ты скоро кончаешь & лекс.=заканчиваешь \\
\hline $\begin{array}{l}\text { Женщина, у которой нет личной жизни, } \\
\text { часто с утроенной энергией бросается в } \\
\text { жизнь общественную. }\end{array}$ & $\begin{array}{l}\text { = бросаться в реку } \\
\text { Языковая игра, служит для характеристики } \\
\text { персонажа. Мотивированное отступление - } \\
\text { средство характеристики персонажа. }\end{array}$ \\
\hline $\begin{array}{l}\text { Но они втроем учинили что-то такое, что } \\
\text { она не выдержала, не стерпела }\end{array}$ & $\begin{array}{l}\text { лекс. = совершили. Учинить можно } \\
\text { расправу. } \\
\text { Мотивированное отступление от нормы, } \\
\text { создает подтекст }\end{array}$ \\
\hline Надо сообщить всюду & = сообщить повсюду \\
\hline
\end{tabular}


Продолжение таблицы

\begin{tabular}{|c|c|}
\hline Голос оставался неколебимо спокойным & =непоколебимо \\
\hline Водил по лицу ладонью, прикрывая его & $\begin{array}{l}\text { избыточная лексика = прикрывал лицо } \\
\text { ладонью }\end{array}$ \\
\hline Чтобы о нем позабыли & = забыли \\
\hline $\begin{array}{l}\text { Приглушая голос, сказал Антохин } \\
\text { Вернулись с кухни }\end{array}$ & $\begin{array}{l}=\text { негромко сказал, избыточная лексика } \\
=\text { из кухни } \\
\text { Морфологически неверное употребление } \\
\text { предлога }\end{array}$ \\
\hline $\begin{array}{l}\text { Только глаза, которые из-за припухлости } \\
\text { век становились по утрам вроде бы меньше } \\
\text { и уже, напоминали о том, что порок сердца } \\
\text { все-таки есть. }\end{array}$ & $\begin{array}{l}=\text { меньше } \\
\text { Избыточность определений }\end{array}$ \\
\hline Эстафета увлечений & $\begin{array}{l}\text { эстафета поколений } \\
\text { Языковая игра }\end{array}$ \\
\hline $\begin{array}{l}\text { Несколько раз, когда Оля заболевала, он } \\
\text { приходил к нам домой. }\end{array}$ & = болела \\
\hline $\begin{array}{l}\text { Иногда у него возникали и свои } \\
\text { собственные предложения. }\end{array}$ & $\begin{array}{l}=\text { собственные } \\
\text { Избыточная лексика }\end{array}$ \\
\hline $\begin{array}{l}\text { Из многих дорог он выбрал самую } \\
\text { короткую и ту, на которой его не } \\
\text { подстерегала встреча с врагами. }\end{array}$ & $\begin{array}{l}\text { сколько было дорог? } \\
\text { Лексическая неточность }\end{array}$ \\
\hline
\end{tabular}

Опираясь на созданную нами таблицу, можно сделать следующие выводы:

1. Во всех проанализированных рассказах детских писателей обнаруживаются грамматические отступления от языковой нормы двух видов: морфологические и синтаксические. Помимо этого встречаются лексические и стилистические неточности;

2. В ряде случав в рассказах используется прием языковой игры; 
3. Нарушения языковой нормы носят в ряде случаев намеренный мотивированный характер, используются как средство характеристики персонажей или средство выражения авторской интенции.

Стоит отметить, что существуют различные классификации языковых игр в художественных текстах. Однако все они касаются двух сторон этого явления: языковой формы и художественной функции в тексте. Анализ форм языковых игр в рассказах В.Е. Драгунского, А. Алексина, Ю.И. Коваля позволил нам составить следующую классификацию:

1. Приемы использования синтаксического и лексического повтора.

Повтор - один из наиболее распространенных приемов создания речевой игры. Это может быть повтор определенного слова или сочетания слов в одинаковой форме (лексический повтор). Повтор также может использоваться в качестве повторяющегося эпитета. Повтор может сочетаться с функцией подражания звукам (звукозапись).

2. Использование в языковой игре расширения лексического значения слов и их необычных сочетаний. Этот прием может рождать неологизмы, нетипичные формы слов.

Например, «ноздреватый холст» (о мешке) из произведения Ю.Коваля «Картофельная собака».

Словосочетание «ноздреватый холст» необычно и является неологизмом. Подобные сочетания слов могут рождать комический эффект шока. У детей, которые сами любят создавать необычные сочетания слов, использование такой словесной игры развивает чувство юмора и вкус к слову, они начинают понимать лексическую многозначность слов (полисемию).

3. Метафоры различного вида - один из наиболее излюбленных приемов в языковых играх. Метафорическая речь - основана на употреблении слов в переносном смысле, на основе ассощиации, аналогии, подобия. 
Например, «колючее такси» (о еже, который «перевозит на иголках яблоки») или «бюро кошачьих прогнозов» (об умении кошек чувствовать перемену погоды).

4. Использование графических игровых приемов при оформлении текста (фигурные стихи). Прием часто используется в детских журналах. Например, стихотворение о кошке в форме кошачьего абриса («Кошка на крыше», Качалова Л.В.):

Кошке приятны

Лунные пятна:

В них она ловит мышей...

Всюду маячит

Абрис комачий -

Хвостик да пара ушей.

5. Использование звукозаписи или звукоподражания.

Следующим этапом нашей деятельности стало выявление новой классификации для проведения анализа языковой игры в художественных текстах по функииональной характеристике:

1. Функиия дискредитации описываемого явления: используется разрушительная сила смеха.

2. Обучающая функция, которую можно сравнить с игрой в мячик: «Напав на какое-либо слово, играю им, как мячиком».

3. Языкотворческая функиия, когда языковая игра создает новые слова с новым семантическим смыслом.

4. Развлекательная функиия, заключающаяся в том, что языковая игра развлекает как автора, так и его собеседников (читателей). Эта функция присуща практически всем видам языковых игр.

5. Маскировочная функция, когда языковая игра позволяет «скрыть» сообщение, но при этом выразить те оттенки смысла, которые по различным причинам находятся под запретом. 
Bсе перечисленные языковые приемы как самостоятельные, так и в сочетаниях можно встретить в ситуациях языковой игры в рассказах В.Ю. Драгунского, А. Алексина, Ю. Коваля. При анализе мы использовали методику сплошной выборки. Эмпирическим материалом послужили: «Денискины рассказы» В. Драгунского, «Шесть рассказов» Ю. Коваля, «Безумная Евдокия» А. Алексина.

Обучающая и развлекательная функции находят выражение в языковой игре в рассказе В. Драгунского «Заколдованная буква».

Рассказ «Заколдованная буква» основан на словесной игре с одним единственным словом «шишки», которое трое невольных «участников» (Аленка, Мишка и Денис) не могут произнести в соответствии с фонетической нормой. В игре использован прием звукоподражания, а цель ее - создание комической ситуации, которая вызывает добрый смех.

«... Потом Аленка взялась за одну веточку и сказала: «Смотрите, а на елке сыски висят».

Двое других осмеивают девочку и веселятся на ее счет:

«Ой, умру от смеха! Сыски! Пять лет девчонке, а говорит сыски!»

Девочка оправдывается тем, что у нее зуб выпал, но в ответ слышит:

«Эка невидаль! У нее зуб вывалился! У меня целых три вывалилось, да два шатаются. А я все равно говорю правильно. Вот слушай: «Xыхки».

Резюме подводит главный герой: «Никакие не сыскки. Никакие не $x b l x к и$, а коротко и ясно: фылфки. Вот и все» [38; 98].

Сыски, хыхки, фылфки - составляющчие фонетической языковой игры. При этом правильная форма слова «шишки» известна как участникам игры, так и читателям или слушателям. Но дети по причине утраты молочных зубов выговорить ее не могут. Добрый юмор и определенная педагогическая задача (осмеять самонадеянность и заносчивость) сочетаются в рассказе - и эта воспитательная цель достигается с помощью фонетической языковой игры.

Развлекательная и языкотворческая функции присутствуют в языковой игре в рассказе В. Драгунского «Друг детства», которая основана на звуковой 
омонимии слов. Омонимы - слова с одинаковым звучанием, но различные по смыслу:

«- Папа, купи мне грушу!

-Сейчас январь, груш нет. Съешь пока морковку.

Я рассмеялся:

- Нет, папа, не такую! Не съедобную грушу!

Ты, пожалуйста, купи мне обыкновенную кожаную боксерскую грушу...» [39; электронный ресурс].

Прием звукоподражания (звукозаписи) использован в языковой игре в рассказе В. Драгунского «Смерть шпиона Гадюкина». Игра выполняет развлекательную и языкотворческую функции. Денис должен позвонить в звонок по ходу действия спектакля, но теряет звонок. И выходит из ситуации, воспроизведя его звук:

«Звонок куда-то исчез.

- И тут меня осенило. Я высунул голову на сцену и быстро сказал:

«Динь, динь, динь» [40].

Особенно часто звукоподражание используется в рассказах о животных и птицах, обычно сочетаясь с приемом олицетворения: звери и птицы «говорят» и «понимают», и выражают это с помощью свойственных каждому из них звуков, которые «переводятся» писателем на человеческий язык.

С такой целью звукоподражание используется в языковой игре в рассказе Ю. Коваля «Белозубка»: «Пи-пи-пи, - закричала Белозубка».

В рассказе Ю. Коваля «Капитан Клюквин» звукоподражательная игра используется неоднократно, так как писатель говорит о певчей птице-клесте. Игра выполняет развлекательную и языкотворческую функции:

«Цык», - услышал я.

Потом еще:

Цык, Цык... 
Убогая песня, - думал я, - «Цык» и все. Маловато» [41; 16].

Или:

«Капитан помолчал, поглядел задумчиво в окно и запел. Песня началась глухо, незаметно. Послышался глухой и печальный звук, что-то вроде «тиууу» - «лиуу» [41;17].

В рассказе В. Драгунского «Мотогонки по отвесной стене» используются два вида языковой игры. В первом случае - лексическая игра, когда один не слышит другого - вертящегося по двору на чужом велосипеде, который он не может остановить, и озвучивает свою мысль вместо ответа на его крик, подменяя слово «пьет» на «убьет», что создает комический эффект, следовательно, присутствует развлекательная функция:

«Я кричу этому дуралею: Сбегай за вашим Федькой!

- Он чай пьет, - кричит Мишка.

- Потом допьет, - ору я.

А он не дослышал и соглашается со мной:

- Убьет, обязательно убьет!» [42].

Во втором случае языковая игра основана на создании неологизма. Игра выполняет развлекательную и языкотворческую функции: «Но в это время кто-то сильно схватил машину, она перестала трещать, и меня довольно крепко хлопнули по затылку. Я сообразил, что это Мишкин брат Федька наконец почайпил ...» [42].

Детский «неологизм» создается и в языковой игре в рассказе В.Драгунского «Англичанин Павля», где игра также выполняет развлекательную и языкотворческую функции.

«-Вот ты арбуз поел. Почему не сказал «спасибо»?

- Я сказал, - сказал Павел.

- Ну, да, по-русски -то ты сказал, а по-английски? 
- Мы до «спасибо» еще не дошли. Очень трудное пропо-ви-сание» $[38 ; 119]$.

В рассказе В. Драгунского «Белая лошадь» функция языковой игры маскировочная, так как она призвана скрыть подлинный смысл сообщения. Дежурный на пограничной заставе по уставу не может сообщать ничего личного. Поэтому он сообщает не о появлении белой лошади на границе, а об обстановке на границе, где «все тихо», вот только откуда-то появилась и бродит у ручья отбившаяся от табуна белая лошадь. В подтексте этого сообщения - беспокойство не только по поводу обстановки, но и по поводу жизни животного, однако сказать прямо об этом нельзя. Языковая игра скрывает этот смысл и в то же время позволяет сделать сообщение о происходящем с лошадью. Дежурный видит, как лошадь пересекает границу, оказывается на чужой территории, наблюдает драматическую картину нападения на нее волков и наблюдает поведение пограничников, спасавших животное. По уставу нельзя вторгаться на чужую территорию, поэтому говорить о подлинном смысле происходящего дежурный и его начальник не имеют права, но языковая игра маскирует, с одной стороны, подлинный смысл высказывания, с другой - помогает выразить истинный его смысл: лошадь спасена. Композиционно получается рассказ в рассказе: внутри сообщения дежурного «спрятан » рассказ о спасении животного и гуманности пограничников. Дважды - в начале и в конце рассказа - приводится диалог, основанный на языковой игре:

«- Все тихо, - докладывает пограничник с вышки по телефону,- все тихо, товарищ капитан. Только возле ручья бродит белая лошадь.

- Белая лошадь?

- Белая лошадь.

- Продолжайте наблюдение». 
В рассказе В. Драгунского «Одна капля убивает лошадь» также применен прием скрытого повествования, рассказа в рассказе, который создан с помощью «маскировочной » языковой игры. Герой переживает из-за курения отца, услышав о том, что одна капля никотина убивает лошадь. Появление гостей, среди которых тетя Тамара, начавшая проявлять излишнее внимание к отцу - усиливает его переживания. Денис не может выразить свое отношение к неприятной и враждебной даме, но выражает его внутренний монолог, ведущийся параллельно внешнему. При этом создается комический эффект. Два параллельных потока речи- внутренний и внешний монологи ребенка создают подтекст.

Внутренний монолог: «Вы дура, тетя Тамара! Чтоб вы лопнули! И вообще вон из моего дома. Чтоб ноги вашей толстой больше здесь не было» [43].

В этом же рассказе использована языковая игра в форме диалога отца и матери, встревоженной «шумами» в сердце мужа, основанная на лексическом повторе, рождающем ряд однокоренных слов - неологизмов. Ее основная функция - языкотворческая. И когда он (врач) ушел, мама сказала:

«- Как это все-таки глупо - доводить себя до болезней этими проклятыми папиросами. Ты еще такой молодой, а вот уже в сердце у тебя шумы и хрипь.

Ну, - сказал папа, - ты преувеличиваешь! У меня нет никаких особенных шумов, а тем более хрипов. Есть всего-навсего один маленький шумишко. Это не счет.

- Нет, в счет, - воскликнула мама. - Тебе, конечно, нужен не шумишко. Тебя бы больше устроил скрип, лязг и скрежет. Я тебя знаю.

- Во всяком случае, мне не нужен звук пильы, - перебил ее папа»[43].

В рассказе В. Драгунского «Кот в сапогах» языковая игра основана на словесном недоразумении, вызванном употреблением контекстного слова 
«Хвост» в прямом и условном значении, что создает комический эффект. Использована преимущественно развлекательная и отчасти языкотворческая функции. Ребенок спрашивает об одном, а собеседница, не поняв смысла его вопроса, говорит о другом. Слово «хвост» употреблено в языковой игре в прямом и в переносном смыслах слова: мальчик имеет в виду деталь костюма, соседка говорит о настоящем хвосте. Рассмотрим отрывок произведения:

«Я вышел в коридор. А там стояла наша соседка, Вера Сергеевна. Она как увидела меня, всплеснула рукам и говорит:

- Ох, настоящий Кот в сапогах!

Я сразу догадался, что значит мой костюм. Я - «Кот в сапогах!» Только жалко, хвоста нет! Я спрашиваю:

Вера Сергеевна, у вас есть хвост?

А Вера Сергеевна говорит:

- Разве я очень похожа на черта?

- Нет, не очень,- говорю. Но не в том дело. Вот вы сказали, что этот костюм значит «Кот в сапогах», а какой же кот может быть без хвоста? Нужен какой-нибудь хвост! Вера Сергеевна, помогите, а?

Тогда Вера Сергеевна сказала:

- Одну минуточку!

И вынесла мне довольно драненький хвостик с черными пятнами.

- Вот, - говорит, - это хвост от старой горжетки. Я в последнее время прочищаю им керогаз, но думаю, тебе он вполне подойдет...» [44].

В этом же рассказе использована лексическая языковая игра, основанная на повторе однокоренных слов, в ходе которой появляется новое слово в гнезде однокоренных - «коль» (от «колоть»). Функции игры развлекательная и языкотворческая:

«Он (Мишка) шил довольно ловко, но потом вдруг как уколет меня!

- Это я немножко не рассчитал. И опять как кольнет! 


\section{A оH:}

Это я в первый раз в жизни шью

И опять - коль!» [44].

Языковая игра в рассказе А. Алексина «Безумная Евдокия» имеет однотипный характер и одинаковую форму, повторяется на протяжении всего рассказа, основана преимущественно на рифмовке слов. Игра выражает иронию героини по отношению к окружающим - учительнице, одноклассникам, что позволяет ей в центр внимания поставить собственную личность, продемонстрировав свои способности и неординарность. В результате языковой игры достигается характеристика персонажей - самой Оленьки и осмеиваемых ею людей. Игра выполняет отчасти развлекательную функцию, так как Оля метко высмеивает окружающих. Но основная ее функция - маскировочная. С помощью игры девочка скрывает свое чувство неприязни и превосходства:

«Никогда нас не катали на груженом самосвале...

Прошел путь от водителя до руководителя...

О ком я говорю, спроси? И я отвечу: о Люси...

Вырос Боря нам на горе...

Ну, и мерси, дорогая Люси...»[45].

Опираясь на полученные результаты, мы можем подвести итоги нашего исследования о том, что языковые игры активно используются детскими писателями в своих художественных произведениях. Понятие является определенным авторским знаком, элементом писательского стиля. Так, юмористические рассказы В. Драгунского насыщены комическими диалогами, основанными на языковой игре, и это - отличительная черта его авторской индивидуальности. У других писателей языковая игра используется в тексте как художественный прием, по мере необходимости - для звукоподражания у Ю. Коваля, например, или для характеристики героини у 
А. Алексина. Авторы используют данный приём для того, чтобы сделать акцент на конкретном факте, выделить его для лучшего запоминания читателем.

Наличие языковых игр нами было установлено во всех трех группах проанализированных текстов различных писателей: в рассказах В. Драгунского, Ю. Коваля, А. Алексина. Стоит отметить, что они бывают различных типов, встречаются в произведениях каждого писателя. Однако при этом можно заметить, что писатель выбирает из них какие-то излюбленные, соответствующие его авторскому идиостилю. Например, в рассказах Ю. Коваля преобладают звукоподражательные языковые игры; в рассказах А. Алексина - рифмованные; в рассказах В.Драгунского встречаются практически все типы языковых игр.

Практическое использование языковых игр является определенным намеренным авторским отступлением от языковой нормы, имеющим характерную функцию в тексте - смыслообразующую, дидактическую, образную и другие.

Отметим, что языковая игра не служит средством нарушения сложившихся языковых норм, а, наоборот, способствует их закреплению. Она реализуется по уже существующим моделям языка. Языковая игра изначально заложена в человеческое сознание вместе с языковыми умениями и навыками.

\section{ЗАКЛЮЧЕНИЕ}

Наше исследование посвящено актуальной проблеме обучения школьников методике языковой оценки, поскольку именно в школьный период формируется фундамент будущей интеллектуальной, эрудированной личности. Для решения этого вопроса в ходе нашей работы к анализу были привлечены произведения современных отечественных детских писателей В. Драгунского, А. Алексина и Ю. Коваля. 


\section{ЧЕЛОВЕК И СОВРЕМЕННОЕ ОБЩЕСТВО \\ В СОЦИАЛЬНОМ, ПРАВОВОМ, ЭКОНОМИЧЕСКОМ РАКУРСАХ}

Стоит отметить, что на данном этапе развития русской лингвистики изучение лексических единиц в функционально-стилистическом аспекте в различных сферах художественной коммуникации является одним из перспективных направлений.

Необходимо обратить внимание на тот факт, что восприятие художественного текста опирается, первооочередно, на буквальное понимание текста. Так возникает потребность внедрения в образовательный процесс обучающихся утверждения, что текст допускает множественность интерпретаций, использование разнообразных языковых средств, отражает многие аспекты, как внешнего мира, так и человеческого сознания.

Нами была достигнута поставленная цель - выявить и описать средства и способы выражения языковой оценки в произведениях детских писателей на уроках русской литературы. Стоит отметить, что в процессе подготовки к уроку учителю необходимо изучить и сопоставить большой объем теоретического материала для того, чтобы отобрать (при необходимости, выявить) определенную классификацию способов и приемов языковой оценки, учитывающую особенности класса, поскольку в настоящий момент отсутствует единая общая классификация этого филологического явления.

Выбор произведений детских писателей в качестве объекта исследования - не случаен. Тексты детских писателей являются важной составляющей большой литературы. Язык этих произведений даёт возможность судить о современных языковых процессах в целом. Несложно заметить существование двух параллельных процессов в языкознании: если с одной стороны, литературная и языковая норма сохраняются в языке в определенной мере стабильно, то с другой, наблюдается рождение новых словоформ. Наиболее ярким показателем рождения нового в области языка становится намеренное отступление авторов от языковой нормы с целью поиска новых средств выражения языковой оценки, что, в свою очередь, обогащает словарный запас читателей. Часто эти отступления выражаются в форме языковой игры - одного из наиболее важных и сравнительно молодых 
приёмов выражения языковой оценки, который был внедрён в филологическую науку лишь во II половине XX века.

В поисках определённых способов выражения языковой оценки каждый художник слова выражает свою творческую индивидуальность. Например, мы отметили преобладание языковых игр различного типа и различной функциональности в рассказах Виктора Юзефовича Драгунского. Использование просторечной лексики - особенность рассказов Юрия Иосифовича Коваля. А избыточное употребление лексических сравнений, достаточно большое количество морфологических отступлений от нормы отличительная черта повести Анатолия Георгиевича Алексина «Безумная Евдокия».

Проделанный нами глубокий языковой анализ может быть перенесен в школьную практику. Учащиеся, используя методику определения нормированности языка, могут самостоятельно узнать и проанализировать идейно-художественное и лингвистическое своеобразие произведений, и это будет способствовать усовершенствованию их навыков анализа художественного текста. Благодаря освоению методики языковой оценки художественных текстов, школьники обогатят не только свой словарный запас, но и подготовят солидную базу знаний для успешного выполнения различных блоков ЕГЭ (в том числе, части «Сочинение») по русскому языку и литературе, а также по остальным предметам гуманитарного цикла.

\section{Список литературы}

1. Арутюнова Н.Д. Типы языковых значений: Оценка. Событие. Факт / Н. Д. Арутюнова. - М.: 1988-339с.

2. Баранов М.Т. Методика преподавания русского языка / М.Т.Баранова, Т.А.Ладыженская, М.Р.Львов. - М.: 2001.-368c. 
3. Булыгина Т.В. Аномалии в тексте: проблемы интерпретации. Логический анализ языка: Противоречивость и аномальность текста / Т.В.Булыгина, А.Д.Шмелёв. - М.: 1990.-278с.

4. Введенская Л.А., Павлова Л.Г., Кашаева Е.Ю. Русский язык и культура речи / Ростов-на Дону, 2003.-189с.

5. Вежбицкая А. Прототипы и инварианты // Вежбицкая А. Язык, Культура. Познание. М., изд. «Русские словари»,1997.- 231с.

6. Витгенштейн Л. Философские исследования // Новое в зарубежно й лингвистике. Вып. XVI. - M., 1985. - 320с.

7. Вольф Т.М. Функциональная семантика оценки/ Вступ.ст. Н.Д.Арутюновой, И.И.Челышевой. Изд. 3-е стереотип. М., 2006.-280с.

8. Выготский Л.С.Игра и ее роль в психическом развитии ребенка// Вопросы психологии. №6 - 1966.- 74c.

9. Чернявская, 2001г. -54c.

10. Гаранина Е.А. Языковые средства выражения комического в детской литературе. Дис.канд.филол. наук. Самара, 1998.-189с.

11. Гибатова Г.Ф. Семантические категории оценки и средства ее выражения в современном русском языке.: Автореф. дис.канд.филол.наук. Уфа, БашГУ, 1996.-15с.

12. Голуб И. Б. Стилистика русского языка. Уч. пособие. М., МГУ,2010.-448c.

13. Горбачевич К.С. Нормы современного русского литературного языка. 3-изд. испр. М., Просвещение,1989.-208c.

14. Донгак С. Языковая игра и обманутое ожидание // Критика и семиотика. Вып. 3/4. Новосибирск, 2001. - с. 78-86.

15. Драгунский В.Ю.Денискины рассказы. Астрель, М., 2012. - 639с. 
16. Гридина Т.А., Боровикова Т.П. Языковая игра в детской речи// Актуальные проблемы лингвистики. 5-е февральские лингвистические чтения. Екатеринбург, 1992.- с.83-90.

17. Гридина Т.А. Языковая игра в детской речи// Русский язык в школе №4, 1993. - с.61-65.

18. Земская Е.А., Китайгородская М.А., Розанова Н.Н. Языковая игра // Русская разговорная речь: Фонетика. Морфология. Лексика. Жест. М., 1983. - c. $172-214$.

19. Ивин А.А. Основания логики оценок. М., 1970. - 230с.

20. Каган М.С. Философская теория ценностей. СПб, 1997.-205c.

21. Карамова А.А. Категория оценки в современном русском языке: учебное пособие. Уфа, РИО БАШГУ,2003. - 52с.

22. Коновалова Ю.О. Языковая игра в современной русской разговорной речи. Владивосток, изд. ВГУЭС, 2008. - 196с.

23. Кукушкина О.В. Основные типы речевых неудач в русских письменных текстах. М., МГУ,1998.-173с.

24. Литневская Е.И., Багрянцева В.А. Методика преподавания русского языка в средней школе. Учебное пособие для студентов высших учебных заведений. М., Академический проект, 2006.-590с.

25. Львов М.Р. Риторика. Культура речи. Уч. пособие. М., изд.центр Академия,2004.-272c.

26. Максимов В.И. Стилистика и литературное редактирование. М., 2007.-653c.

27. Маркелова Т.В. Семантика оценки и средства ее выражения в рус.яз.: автореф. дис.док.наук.-М., 1996.-47с.

28. Никаноров С.А. Приемы словообразовательной игры в повестисказке Э. Успенского «Меховой интеркот» // Язык, система, личности. Екатеринбург, 1999. -с.89-94. 
29. Нухов С.Ж. Языковая игра в словообразовании: автореф. дис. на соиск. учен. степени док. филол. наук. М, 1997. -39с.

30. Санников В.З. Русский язык в зеркале языковой игры. М., 1999.$541 \mathrm{c}$.

31. Усолкина А.В. Языковая игра как текстообразующий фактор: Автореф. дис. на соиск. учен. степени канд. филол. наук. М, 1997. -39с.

32. Темиргазина 3.К. Оценочные высказывания в русском языке. Монография. Павлодар, ЭКО, 1999.-272с.

33. Трипольская Т.А. Языковые механизмы эмоциональной и оценочной интерпретации действительности // Проблемы интерпрет. лингвистики: межвуз. сб. научн.тр. Новосибирск, 2000.- с.14-27.

34. Федоренко Л.П. Принципы обучения русскому языку. Пособие для учителей. М., Просвещение, 1973. - 159с.

35. Фомина Ю.А. Функциональный потенциал номинативных оценочных высказываний в современном русском языке. Дис.канд.фил.н. Нижний Тагил, Уральский гос. пед ун-т, 2009.-203c.

36. Хейзинга Е. Опыт исследования игрового элемента в культурологии// Самосознание европейской культуры ХХ века. М., 1991.- 69c.

37. Зверева Е.И. Основы культуры речи. Теоретический курс. М., 2008. $-34 \mathrm{c}$.

38. Юдаева М.В. Внеклассное чтение (для 2-го класса). - М., Самовар, 2005.- $128 \mathrm{c}$.

39. Драгунский В. Ю. Друг детства: [Электронный ресурс]. URL: https://deti-online.com/skazki/rasskazy-dragunskogo/drug-detstva/.

(Дата обращения: 12.05.2017).

40. Драгунский В. Ю. Смерть шпиона Гадюкина: [Электронный pecypc]. URL: https://deti-online.com/skazki/rasskazy-dragunskogo/smertshpiona-gadyukina/. (Дата обращения: 12.05.2017). 
41. Коваль Ю.И. Чистый Дор. Рассказы. - М.: Детская литература, 1991. $-64 \mathrm{c}$.

42. Драгунский В. Ю. Мотогонки по отвесной стене: [Электронный pecypc]. URL: https://deti-online.com/skazki/rasskazy-dragunskogo/motogonki-pootvesnoy-stene/. (Дата обращения: 15.06.2017).

43. Драгунский В. Ю. Одна капля убивает лошадь: [Электронный pecypc]. URL: https://deti-online.com/skazki/rasskazy-dragunskogo/odna-kaplyaubivaet-loshad/. (Дата обращения: 15.06.2017).

44. Драгунский В. Ю. Кот в сапогах: [Электронный ресурс]. URL: http://www.razumniki.ru/kot_v_sapogah_dragunskiy.html. (Дата обращения: 15.06.2017).

45. Алексин А. Г. Безумная Евдокия: [Электронный ресурс]. URL: http://lib.ru/PROZA/ALEKSIN/ewdokia.txt. (Дата обращения: 15.06.2017).

46. Фонвизин Д. И. Недоросль: [Электронный ресурс]. URL: http://www.ilibrary.ru/text/1098/p.1/index.html. (Дата обращения: 15.06.2017).

47. Петрушевская Л. С. Свой круг: [Электронный ресурс]. URL:http://www.lib.ru/PROZA/PETRUSHEWSKAYA/swoj_krug.txt_with-bigpictures.html. (Дата обращения: 15.06.2017).

48. Сухомлинский В.А. Сердце отдаю детям. Киев, 1973 - 542с.

49. Программа общеобразовательных учреждений: Русский язык: 5-9 класс /М.Т.Баранов, Т.А. Ладыженская, Н.М.Шанский.- М., 2002.

50. Лингвистический энциклопедический словарь. М., Советская энциклопедия, 1990.-685c.

51. Соболева О.А. Полный справочник по орфографии и пунктуации / О.А. Соболева - М.: 1999 - 267c.

52. Словарь русского языка. В 4-х т. Изд. второе, испр. и доп. М., Изд. «Русский язык», 1981. 
53. Ушаков Д.Н. Школьный орфографический словарь русского языка. 5-11 кл / Д.Н.Ушаков, С.Е.Крючков - М.: 2000. - 697с.

54. Рябцева Н.К. Коммуникативный модус и метаречь. Логический анализ языка: Культурные концепты / Н.К.Рябцева. - М.:1996. - 98с.

55. Красильникова Л.В. Жанр научной рецензии: сенмантика и прагматика / Л.В. Красильникова. - М.: 1999. - 50с.

56. Усминский О.И. Сенсорно-прагматические и типологические аспекты русских тропов / О.И.Усминский. - Екатеринбург: 1997.- 363с.

57. Кочеткова Е. В. Синтаксические средства выражения негативной оценки в поэзии И. Северянина: дис. канд. филол. наук: [Электронный pecypc]. URL: http://www.poet-severyanin.ru/library/yazikovie-sredstvavirazheniya8.html. (Дата обращения: 07.10.2016).

58. Шейдаева С. Г. Категория субъективной оценки в русском языке: автореф. дис. доктора филол. наук: [Электронный ресурс]. URL: http://cheloveknauka.com/kategoriya-subektivnoy-otsenki-v-russkom-yazyke. (Дата обращения: 08.10.2016).

59. Маркелова Т. В. Семантика оценки и средства ее выражения в русском языке. - М.:МПУ, 1993. - 341 с.

60. Федеральный государственный образовательный стандарт начального общего образования (1 - 4 классы): [Электронный ресурс]. URL: минобрнауки.рф/документы/922. (Дата обращения: 17.06.2017).

61. Климанова Л.Ф. Литературное чтение. 2 класс / Л.Ф.Климанова, В.Г. Горецкий, М.В. Голованова. - М.: 2012 - 224c.

62. Образовательная система «Школа 2100»: [Электронный ресурс]. URL: http://school2100.com/. (Дата обращения: 17.06.2017).

63. УМК «Перспективная начальная школа»: [Электронный ресурс]. URL: http://www.akademkniga.ru/projects/prospective-primary-school/ . (Дата обращения: 17.06.2017). 
РАЗДЕЛ ІІ.

\title{
ЧЕЛОВЕК И СОВРЕМЕННОЕ ОБЩЕСТВО \\ В ЭКОНОМИЧЕСКОМ РАКУРСЕ
}

\section{УДК 338.5}

\author{
Глава 9.
}

КОНКУРЕНТОСПОСОБНОСТЬ ЭКОНОМИКИ И АНАЛИЗ

ТОРГОВОЙ ПОЛИТИКИ В РЕГИОНАХ СЕВЕРО-ЗАПАДНОГО

ФЕДЕРАЛЬНОГО ОКРУГА

\author{
Болышаков Сергей Николаевич \\ д.э.н., профессор \\ ГАО ВО ЛО «Ленинградский государственный \\ университет имени А.С. Пушкина»
}

\begin{abstract}
Аннотация: Анализ конкурентоспособности экономики региона определяется необходимостью стимулирования производителей региона, структурой экономики региона, высоким уровнем добавленной стоимости. Анализ показывает рост спроса на рынках продовольствия как в РФ, так и за рубежом, снижение предложения, урожайности многих сельскохозяйственных культур, рост инфляции. Исследование показывает необходимость совершенствования мер государственной поддержки товаропроизводителей, регулирования торговой политики.
\end{abstract}

Ключевые слова: экономика региона, торговая политика, инфляция, продовольствие. 


\section{ECONOMIC COMPETITIVENESS AND ANALYSIS OF TRADE POLICY IN THE REGIONS OF THE NORTHWESTERN FEDERAL DISTRICT}

\section{Bolshakov Sergey Nikolaevich}

Abstract: The analysis of the competitiveness of the region's economy is determined by the need to stimulate regional producers, the structure of the region's economy, and a high level of added value. The analysis shows an increase in demand on food markets both in the Russian Federation and abroad, a decrease in supply, yields of many agricultural crops, and an increase in inflation. The study shows the need to improve measures of state support for producers, regulation of trade policy.

Key words: regional economy, trade policy, inflation, food.

Актуальность исследования определяется важность стратегических задач поставленных Президентов РФ по повышению уровня жизни населения, необходимости выполнения задач заложенных в стратегических приоритетах и национальных программах по восстановлению допандемийного уровня экономики. Исследования показывают рост уровня цен на товары народного потребления и продовольствия в 2020-2021 гг., что вызвано значительным ростом цен на товары и продукты на мировых рынках продовольствия. Активность используемых мероприятий и мер государственного регулирования по контролю инфляции сопровождается мерами по стимулированию товаропроизводителей. В 2021 году в рамках договора о Союзном государстве с Республикой Беларусь согласованы объемы взаимных поставок продовольствия на 2022 год.

Продовольственное и сельскохозяйственное агентство ООН зафиксировало в 2021 году самые высокие темпы роста цен на продовольствие при сокращении урожая в сельскохозяйственных отраслях в таких странах как Канада, США, Россия (что например способствовало росту цен на пшеницу в 2021 году на 5\%). ООН также отмечает, что ежемесячный рост цен на пшеницу в 2021 году являлся самым длительным периодом роста 
цена с 2007 года. Пандемия и экономическая рецессия во многих странах мира позволяет отметить повышенный рост цен на мировых рынках продовольствия, что способствовало росту цен при ограниченности предложения на $32,8 \%$. Росту цен способствовало восстановление потребительского спроса в условиях ограниченности предложения [1, с. 9].

По данным Правительства РФ рост цен на плодоовощную продукцию и мяса вносит существенный вклад в общий высокий уровень инфляции. Этому способствует недостаток предложения на рынке, на фоне низкого урожая 2021 года. К 1.10.2021 году картофеля собрано на 19\% меньше чем в 2020 году, овощей на 7\% меньше чем в 2020 году.

Правительство РФ продлило эмбарго на некоторые виды продовольствия до конца 2022 года, запретила импорт отдельных видов сельскохозяйственной продукции и продовольствия из таких стран как США, Канада, Австралия, страны ЕС. В санкционный список традиционно попали такие товары как мясо и рыба, морепродукты, колбасы, овощи, молочная продукция, фрукты.

Ниже проанализирована динамика цен на социально-значимые товары по регионам Северо-Запада РФ. Сложившаяся в 2021 году. В таблице 1 представлена динамика цен на основные виды продовольствия регионах Северо-Запада России.

В период с января по ноябрь 2021 г. самый низкий уровень цен на рынке говядины, сформировался в Санкт-Петербурге, Вологодской и Новгородской областях (по состоянию на январь 2021 г. цена составляла 393,35 руб., 406,67 и 395,16 руб. соответственно). Самый высокий уровень цен наблюдался в Республике Карелия (по состоянию на январь 2021 г. цена составляла 469,73 руб.) в ноябре цена соответственно по республике составила 486,36 руб. за кг. Таким образом, разница между самым низким и самым высоким уровнем цен в отдельные периоды составляла 19,3\%. Кроме того, цены на товар в Мурманской области и Республика Карелия сложились выше цен в Ленинградской области на 3,6-6,4\%. 
Таблица 1

\section{Динамика цен на продовольственные товары}

по РФ и субъектам Северо-Западного Федерального округа

(по данным Росстата, составлено автором)

\begin{tabular}{|c|c|c|c|c|c|c|c|c|c|}
\hline $\begin{array}{lll} & 0 \\
0\end{array}$ & 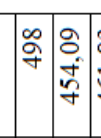 & 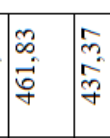 & 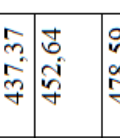 & 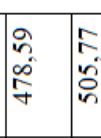 & 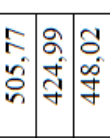 & 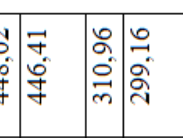 & 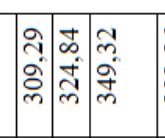 & 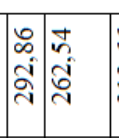 & 兽 \\
\hline 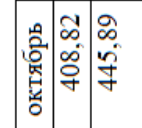 & 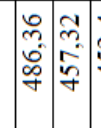 & & 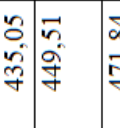 & 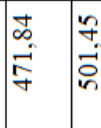 & 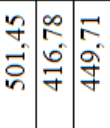 & 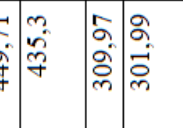 & 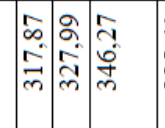 & 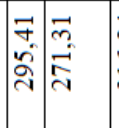 & 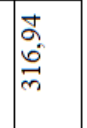 \\
\hline 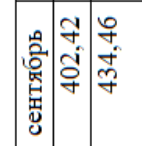 & 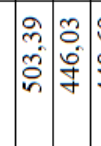 & & 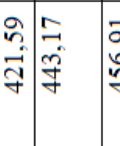 & 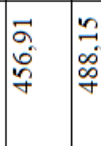 & 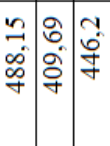 & 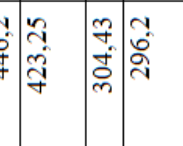 & 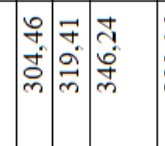 & 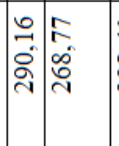 & $\begin{array}{l}7 \\
7 \\
0 \\
0 \\
0\end{array}$ \\
\hline 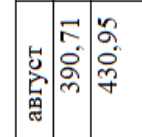 & 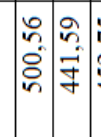 & & 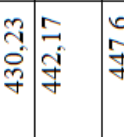 & \begin{tabular}{|l|l|}
0 \\
\hdashline \\
\hdashline \\
\hdashline
\end{tabular} & 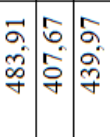 & 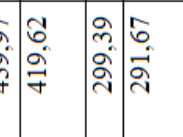 & 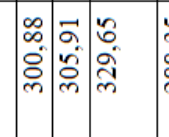 & 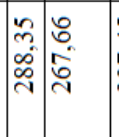 & 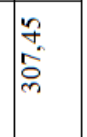 \\
\hline 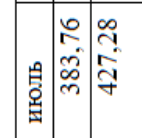 & 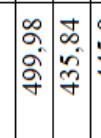 & 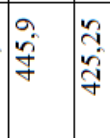 & 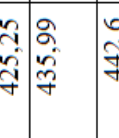 & 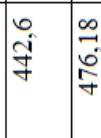 & 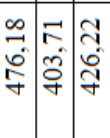 & 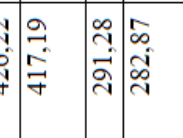 & 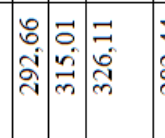 & 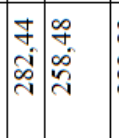 & 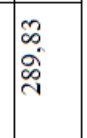 \\
\hline 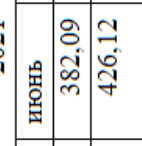 & 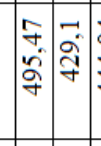 & & 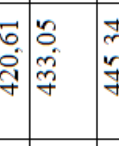 & 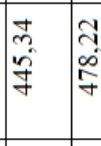 & 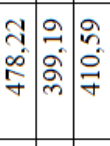 & 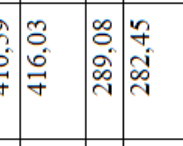 & 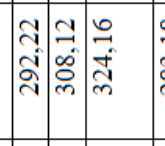 & 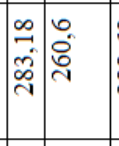 & 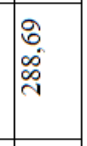 \\
\hline & 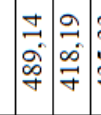 & & 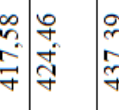 & & 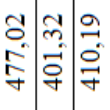 & 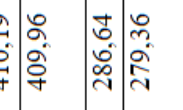 & 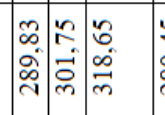 & & 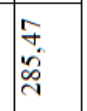 \\
\hline 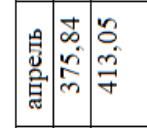 & 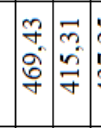 & & 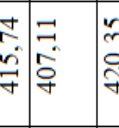 & 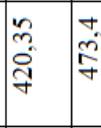 & 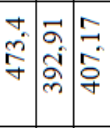 & 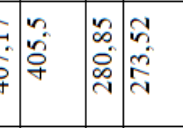 & 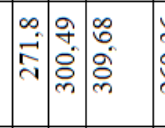 & & 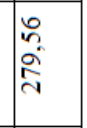 \\
\hline 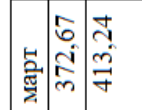 & 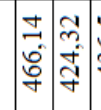 & 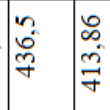 & 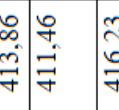 & 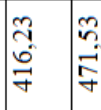 & 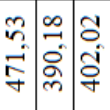 & 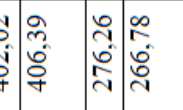 & 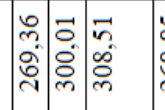 & 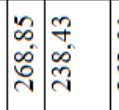 & 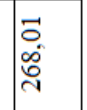 \\
\hline 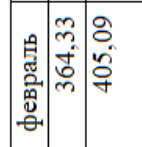 & 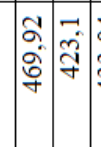 & & 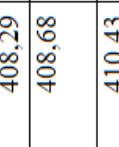 & 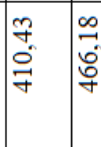 & 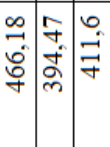 & 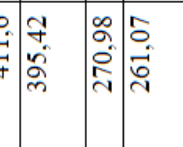 & 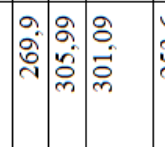 & 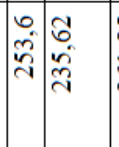 & 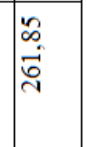 \\
\hline 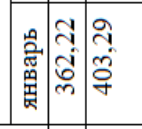 & 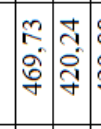 & 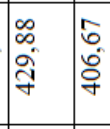 & 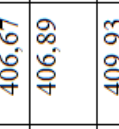 & 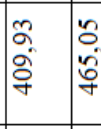 & 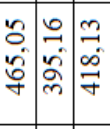 & 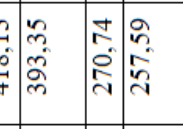 & 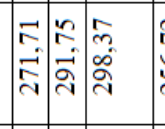 & 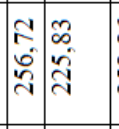 & 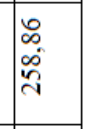 \\
\hline 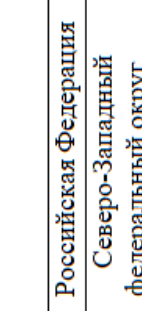 & 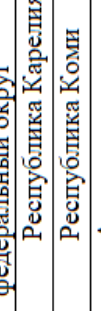 & 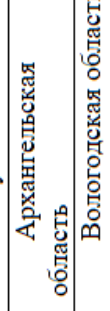 & 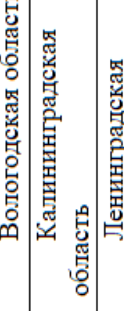 & 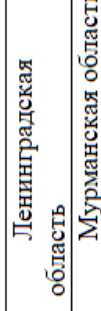 & 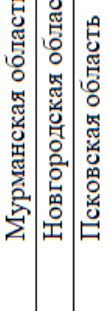 & 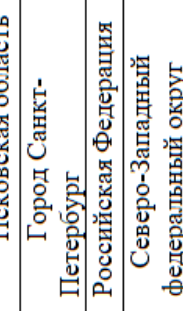 & 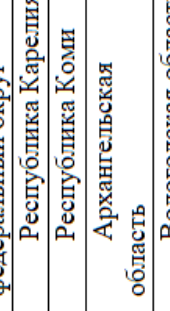 & 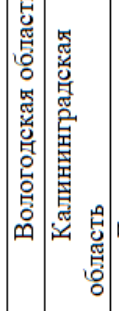 & 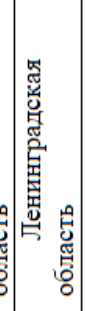 \\
\hline 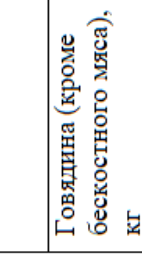 & & & & & & 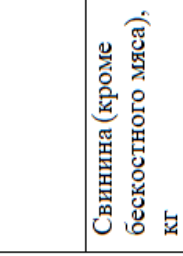 & & & \\
\hline
\end{tabular}




\section{Продолжение Таблицы 1}

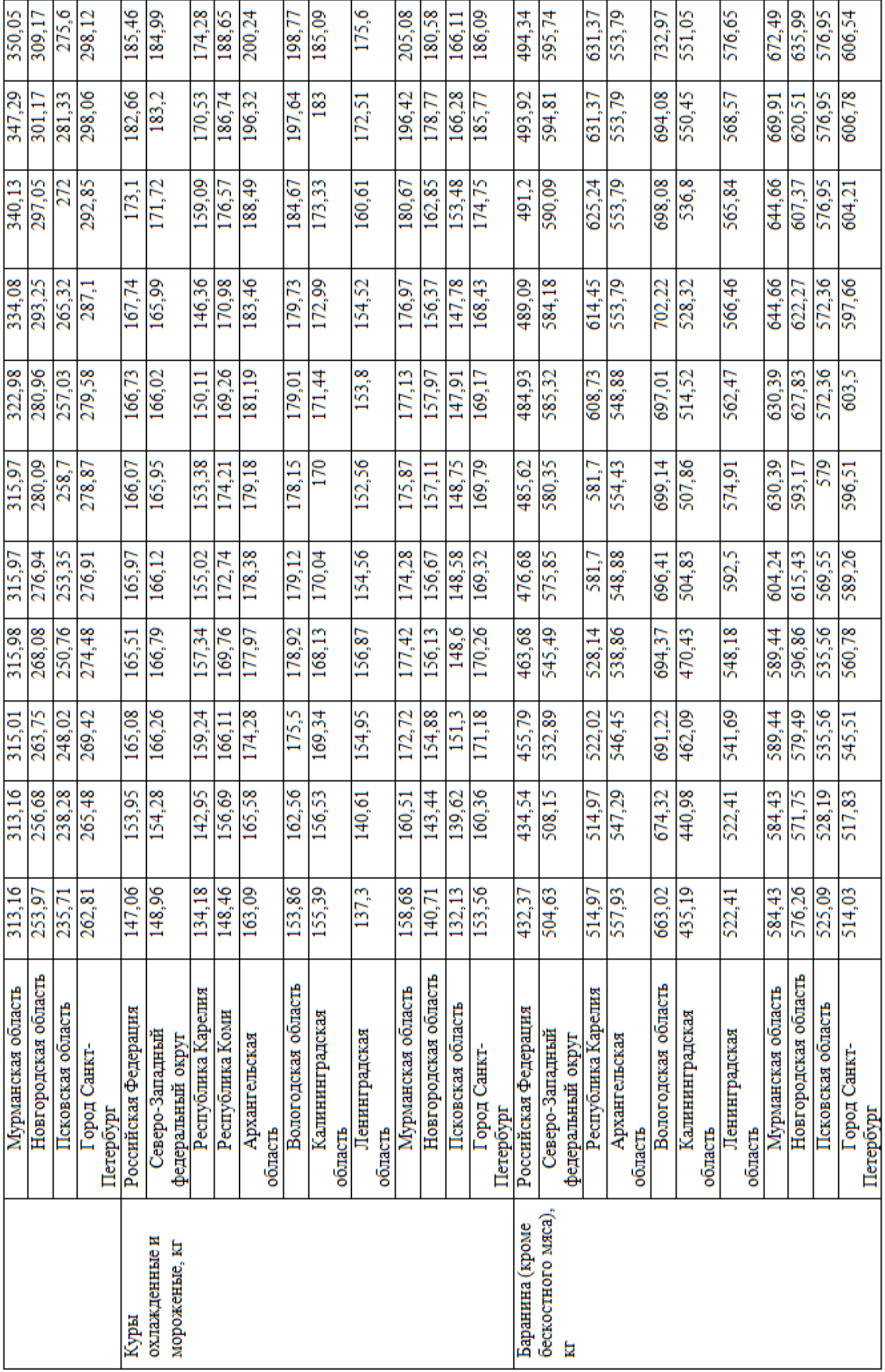




\section{Продолжение Таблицы 1}

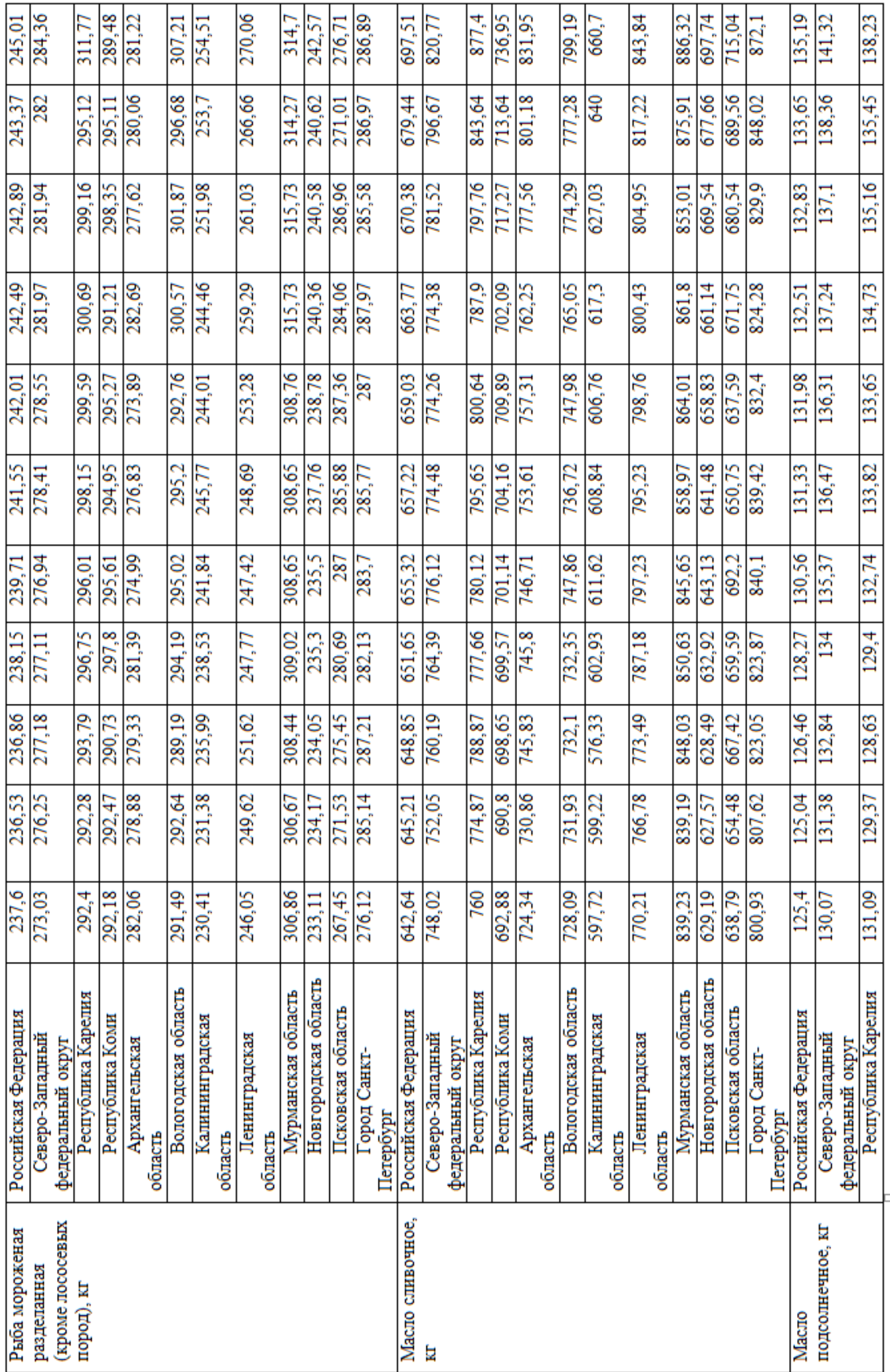




\section{Продолжение Таблицы 1}

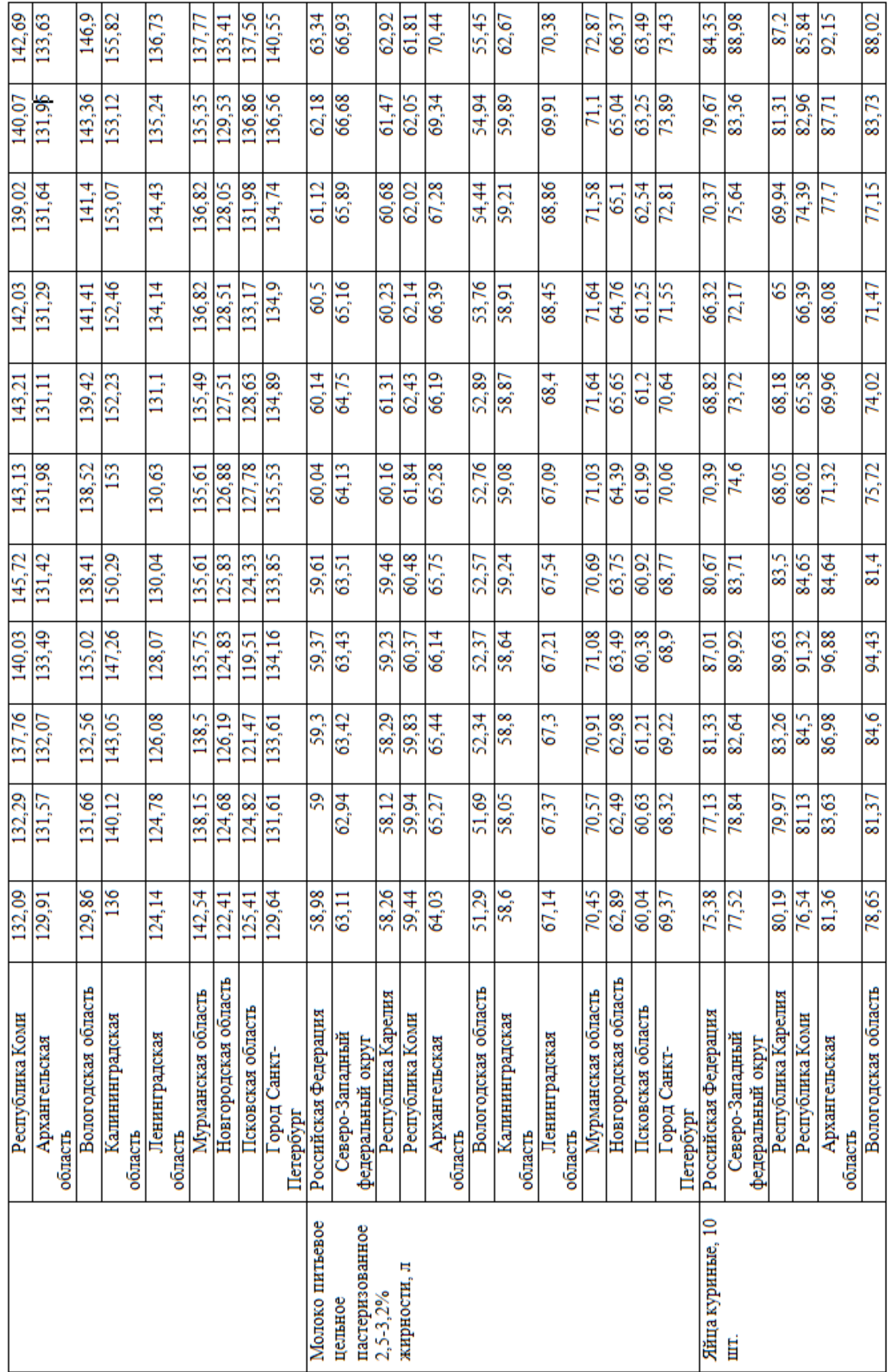




\section{Продолжение Таблицы 1}

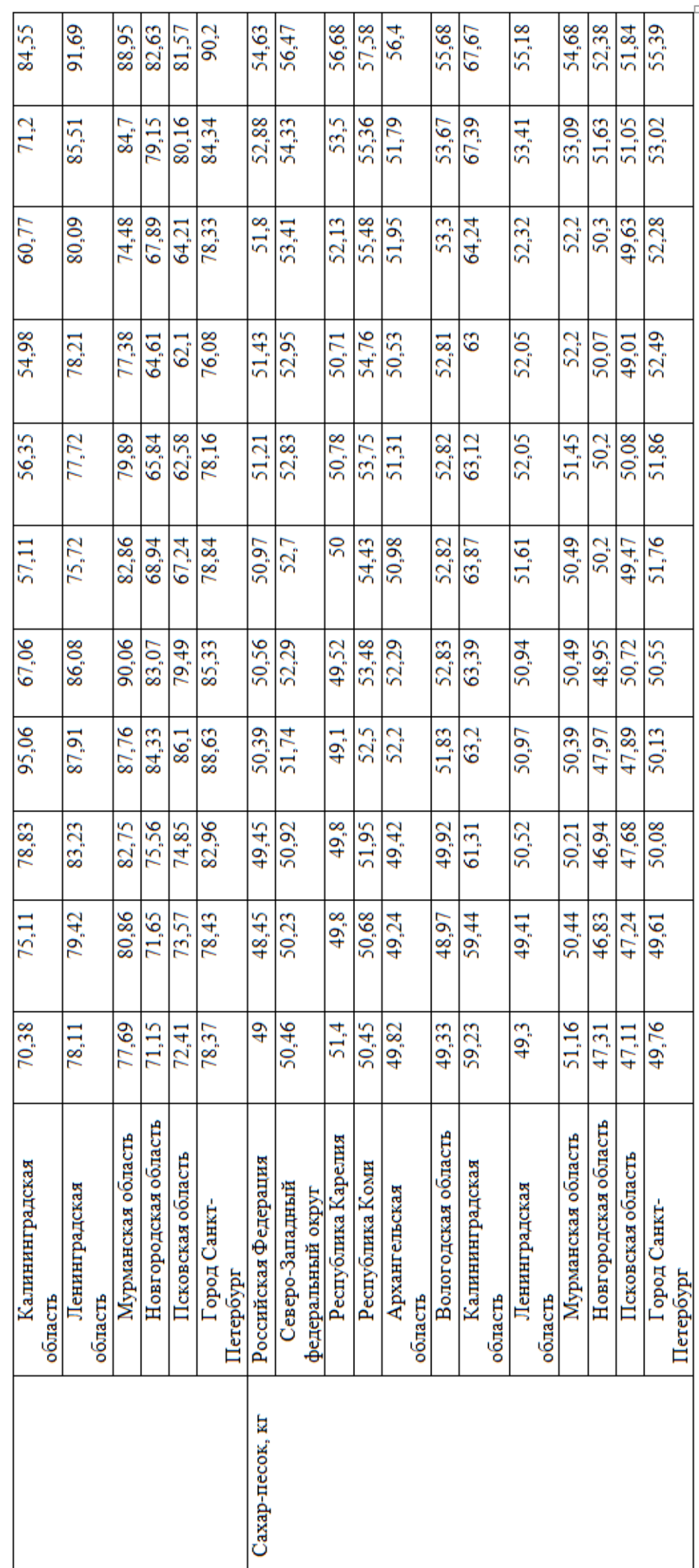


Следует отметить, что в 2021 году в остальных регионах на данный товар не наблюдался ярко выраженный тренд снижения цен в течение всего периода наблюдения, поскольку цены в одном регионе в определенный период времени пересекали уровень цен, сложившихся в иных регионах. Так, например, в период с января по май 2021 г. на втором месте по динамике снижения уровня цен после уровня цен, сформировавшихся в Российской Федерации, сложился уровень цен в Новгородской и Псковской областях. В июле 2021 г., наблюдался прирост цен выше чем по СЗФО в регионах Республика Карелия, Республика Коми, Мурманская и Калининградская области.

Самый высокий уровень цен на рынке свинины в 2021 году преобладал в Мурманской области (по состоянию на ноябрь 2021 г. цена составляла 347,29 руб.). Разница между самым низким и самым высоким уровнем цен в отдельные периоды составляла $21,8 \%$. Кроме того, цены на свинину в Ленинградской области, по сравнению с максимальными ценами, которые сложились на такой товар в Мурманской области, сформировались ниже на $9,8 \%$.

В октябре 2021 г. на второй позиции по уровню увеличения цен, то есть после минимальных цен в Псковской области (265,32 руб.), сложились цены в Калининградской области и Санкт-Петербурге. Цены на товар в таких регионах, как Ленинградской области, Республике Карелия и Санкт-Петербурге не только не отличались значительно друг от друга, но и в отдельные периоды, в зависимости от движения цены в ту или иную сторону постоянно пересекали друг друга.

Более ярко выраженный уровень цен сложился в Ленинградской области, который занимал вторую позицию по динамике прироста цен из десяти исследуемых территорий. Несколько выше расположился уровень цен 
в Российской Федерации, за которым следовал максимальный уровень цен в Новгородской области (+37\%) и Вологодской области $(+35 \%)$.

Следует отметить, что общая тенденция цен на свинину во всех исследуемых регионах, в том числе в Российской Федерации, в течение года сформировалась в сторону увеличения вследствие роста цен на корма, топливо, горюче-смазочные материалы.

В 2021 г. самый низкий уровень цен на куры, как и годом ранее, сформировался в Псковской области и Республике Карелия (по состоянию на ноябрь 2021 г. цена составляла 166,28 руб., и 170,53 руб. соответственно), для сравнения цена в Ленинградской области составляла 172,51 руб.).

Самый высокий уровень цен преобладал в Вологодской области (197,64 руб.) Архангельской области (195,15 руб.), в Мурманской области (по состоянию на январь 2021 г. цена составляла 158,68 руб., для сравнения, в Ленинградской области цена составляла 137,3 руб.). Таким образом, разница между самым низким и самым высоким уровнем цен в отдельные периоды составляла 10,4\%. Кроме того, цены на товар в Ленинградской области, по сравнению с максимальными ценами, которые образовались на данный товар в Мурманской области, сформировались ниже на 17,1\%.

Первую позицию в ранге территорий по степени увеличения цен на куры, после минимальных цен, которые сложились в Псковской области, занимает Вологодская область, второе место по уровню цен на товар занимает Мурманская область, третью позицию по уровню цен заняла Архангельская область, по цене на данный товар Ленинградская область занимает 3 место среди регионов СЗФО, дешевле данный товар только в Республике Карелия и Псковской области (11 место и 12 место соответственно с ценами на данный товар 174,2 и 166,1 руб. за кг.).

Проведенный анализ показывает, что рост цен обусловлен дефицитом инкубационного яйца в первой половине 2021 года, рост стоимости 


\section{ЧЕЛОВЕК И СОВРЕМЕННОЕ ОБЩЕСТВО В СОЦИАЛЬНОМ, ПРАВОВОМ, ЭКОНОМИЧЕСКОМ РАКУРСАХ}

производства за счет упаковки, кормов, витаминных добавок птицы, транспортировка, логистика и хранение. Подорожание и рост цена на мясо говядины и свинины привело к росту спроса на куриное мясо как основной источник недорого белка для населения. В 1 полугодии 2021 года рост спроса на мясо кур не совпал со снижением производственных показателей на 2\% в среднем по России.

В период с января по ноябрь 2021 г. самый низкий уровень цен на рыбу сформировался в Новгородской области (по состоянию на август 2021 г. цена составляла 240,36 руб.).

Самый высокий уровень цен преобладал в Мурманской области (по состоянию на ноябрь 2021 г. цена составляла 314,7 руб., для сравнения цена в Ленинградской области была ниже на 16,2\% и составляла 270,0 руб.). Таким образом, разница между самым низким и самым высоким уровнем цен в отдельные периоды составляла $26 \%$.

Следует отметить, что ближе к минимальному уровню цен, который сформировался в Новгородской области (233,62 руб.) сложился уровень цен в Калининградской области, который в марте - апреле 2021 г. был самым минимальным. Третье место в ранге регионов по росту цен занимает Вологодская область (296,68 руб.). На некотором удалении от рассмотренных регионов, сформировался уровень цен в Российской Федерации (243,77 руб.), за которым сразу следовал уровень цен, сформировавшийся в Новгородской области и Ленинградской области, который из-за тенденции роста цен в ноябре 2021 г. пересек уровень Российской Федерации и стал выше среднероссийского уровня. 8-е место из десяти регионов СЗФО ранжированных по убыванию цены занимает Ленинградская область (266,66 руб.), 9-е место остается за Калининградской областью (253,7 руб.), на 10-е месте с самой низкой ценой на товар разместилась Новгородская область (240,62 руб. за кг). В первую тройку регионов по СЗФО с самой высокой 
ценой на товар входят - Мурманская область, Вологодская область, Республика Карелия.

За период с января по ноябрь 2021 г. стоимость масла сливочного в Ленинградской области была выше стоимости масла в Российской Федерации на 16\%. При этом так же как и цена на товар в Ленинградской области (843,84 руб.), цена, сложившаяся в Российской Федерации в течение всего периода наблюдения увеличивалась.

Следует отметить, что ближе к минимальному уровню цен, который сформировался в Калининградской области (597 руб.) сложился уровень цен в Новгородской (629,6 руб.) и Псковской (638,56 руб.) областях, которые в наблюдаемый период 2021 г. были минимальными. Третье место в ранге регионов по увеличению цен занимает Республика Карелия (877 руб.). На некотором удалении от рассмотренных регионов СЗФО сформировался уровень цен в Мурманской области, за которым сразу следовал уровень цен, сформировавшийся в Санкт-Петербурге, который из-за тенденции роста цен в августе-ноябре 2021 г. пересек уровень Российской Федерации и стал выше, заняв тем самым второе место.

В период с января по ноябрь 2021 г., также как и годом ранее, на масло подсолнечное не сформировался ярко выраженный минимальный уровень цен в каком-либо одном регионе. Так, в январе 2021 самые низкие цены сложились в Российской Федерации (125,4 руб.), но уже в феврале 2021 г. минимальные цены преобладали в Ленинградской, Мурманской и Новгородской областях (по 124 руб.). Таким образом, в течение наблюдаемого периода цены в указанных регионах постоянно пересекались друг с другом в связи с ростом и падением цен в отдельные периоды. Ближе к минимальному уровню цен также сформировались цены в Архангельской области $(129,49$ руб.). 
За период с января по ноябрь 2021 г. тенденция по уровню максимальных цен на масло подсолнечное несколько изменилась. Если в начале года максимальные цены на товар сложились в г. Санкт-Петербурге, то уже в августе 2021 г. уровень максимальных цен сформировался в Республике Коми и Калининградской области. Разница между самым минимальным и самым максимальным уровнем цен достигала $18,7 \%$.

Общая тенденция цен на масло подсолнечное во всех исследуемых регионах, в том числе в Российской Федерации, в 2021 году по сравнению с прошлым годом поменялась и сформировалась в сторону повышения. В период с января по ноябрь 2021 г. меньше всего цены на масло подсолнечное увеличились в Санкт-Петербурге (увеличение 8,4\%). Далее по степени увеличения цен, территории распределились следующим образом: Республика Карелия (увеличение 5,5\%), Ленинградская область (увеличение $10,1)$, Псковская область (увеличение 9,6\%), Новгородская область $(8,9 \%)$. Максимальное увеличение цены на данный товар произошло в Калининградской области - 12,6\%.

В период с января по ноябрь 2021 г. минимальный уровень цен на молоко, как и годом ранее удерживала Вологодская область (по состоянию на ноябрь 2021 г. цена составляла 55,41 руб.). Самый высокий уровень цен, как и год ранее, преобладал в Санкт-Петербурге (73,43 руб.) и Мурманской области (по состоянию на ноябрь 2021 г. цена составляла 71,1 руб. Таким образом, разница между самым низким и самым высоким уровнем цен в отдельные периоды составляла от 37\% (январь, 2021 г.) до 32,5\% (ноябрь, 2021 г.).

Второе место в ранге территорий по степени увеличения цен на молоко, после минимальных цен, которые сложились в Вологодской области, занимает уровень цен, сформировавшийся в Калининградской области. В 2021 году цены в Псковской области и Республики Коми сформировались ближе к уровню средних цен по России. 


\section{ЧЕЛОВЕК И СОВРЕМЕННОЕ ОБЩЕСТВО В СОЦИАЛЬНОМ, ПРАВОВОМ, ЭКОНОМИЧЕСКОМ РАКУРСАХ}

В период с января по ноябрь 2021 г. цены на продукцию повысились во всех наблюдаемых регионах - в Ленинградской области (рост на 4,8\%), далее по степени уменьшения регионы расположились следующим образом: Санкт-Петербург (рост 5,8\%), Республика Карелия (рост 7,9\%), Новгородская область (рост 5,5\%). Увеличение цен произошло в Псковской области (увеличение 5,8\%), Вологодской области (увеличение 8,1\%).

Как показывает проведенный анализ причины роста цен на молоко кроются в увеличении цены на составляющие производственной упаковки, удорожанием ветеринарных препаратов для животных (которые в основном носят импортный характер), ростом цен на горючее и электро-энергию. Также в последнее время наблюдается снижение урожайности кормов, что повлияло на рост цен на молоко.

В период с января по март 2021 г. самый низкий уровень цен на яйца сформировался в Новгородской области (82,63 руб.). Впоследствии первенство по самому низкому уровню цен переходило к Калининградской области (по состоянию на ноябрь 2021 г. цена составляла 84,55 руб.). Следует отметить, что на данный товар в течение 2021 года во многих регионах наблюдался явно выраженный уровень роста цен.

Самый высокий уровень цен преобладал в Архангельской области (92,15 руб.) и Ленинградской области (по состоянию на ноябрь 2021 г. цена составляла 91,69 руб. Таким образом, разница между самым низким и самым высоким уровнем цен в отдельные периоды составляла 12,9\%.

Общая тенденция цен на яйца во всех исследуемых регионах, в том числе в Российской Федерации, в 2021 году по сравнению с прошлым годом не изменилась, то есть сформировалась в сторону роста. В период с января по ноябрь 2021 г. меньше всего цены на яйца выросли в Республика Карелия (увеличение 8,7\%), Псковская область (увеличение на 12,6\%), Мурманская область (увеличение на 14,4\%). Далее по степени роста цен, территории 
распределились следующим образом: Новгородской области (увеличение на $16,1 \%$ ), Санкт-Петербург (увеличение на 15,0\%), Ленинградская область увеличение цены на продукцию на $17,4 \%$, Калининградская область (увеличение на 20,1\%).

В период с января по сентябрь 2021 г. самый низкий уровень цен на сахар-песок, как и годом ранее, сформировался в Псковской области (по состоянию на август 2021 г. цена составляла 49 руб.).

Самый высокий уровень цен преобладал в Калининградской области (по состоянию на август 2021 г. цена составляла 63 руб., для сравнения, в Ленинградской области цена составляла 52,02 руб.). Таким образом, разница между самым низким и самым высоким уровнем цен в отдельные периоды составляла $32,4 \%$. Кроме того, цены на товар в Ленинградской области сформировались на 26,1\% ниже максимальных цен, которые сложились на такой товар в Калининградской области.

Вторую позицию в ранге территорий по степени увеличения цен на сахар-песок, после минимальных цен, которые сложились в Псковской области, в период с января по май 2021 г. занимал уровень цен, сформировавшийся в Ленинградской области. Третье место среди регионов занимал уровень цен Новгородской области, который после апреля 2021 г. занял второе место.

Следует отметить, что общая тенденция цен на сахар-песок во всех исследуемых регионах, в том числе в Российской Федерации, в 2021 году по сравнению с прошлым годом сформировалась в сторону повышения. В период с января по ноябрь 2021 г. меньше всего цены на сахар-песок увеличились в Мурманской области (увеличение 7\%), Республика Карелия (увеличение составило 10,3\%). Далее по степени увеличения цен, территории распределились следующим образом: Новгородская область (увеличение 10,7 \%). Псковская область (увеличение 10,0\%), Санкт-Петербург (увеличение 
11,3\%), Ленинградская область (увеличение 11,9\%), Российская Федерация (увеличение 11,9\%). Вологодская область (увеличение 12,8\%), Республика Коми (увеличение 14,1\%).

В период с января по сентябрь 2021 г. самый низкий уровень цен на чай, как и годом ранее, сформировался в Новгородской области (по состоянию на август 2021 г. цена составляла 833 руб., для сравнения, цена в Ленинградской области составляла 1123,94 руб.).

Не изменился тренд на увеличение цен на чай в период с января по ноябрь 2021 г. Так, в 2021 г. второе и третье место в ранге территорий по уровню цен вышли регионы: Калининградская область (снижение $-0,5 \%$ ) и незначительное повышение цен в Архангельской области (увеличение на 5,9\%). По сравнению с прошлым годом цены в Республике Карелия сформировались ниже прошлого уровня, что позволило Карелии занять в начале года четвертое место среди регионов. Цены в Архангельской и Калининградской, Мурманской области и Санкт-Петербург образовали верхний потолок и в течение года пересекали друг друга.

Таким образом, разница между минимальным и максимальным коридором цен составила 44,2\%.

Следует отметить, что общая тенденция цен на чай во всех исследуемых регионах, в том числе в Российской Федерации, в 2021 году продолжила повышательную тенденцию прошлого года. Только в Псковской области наметилось снижение цены на 2,01\%.

В период с января по сентябрь 2021 г. меньше всего цены на чай увеличились в Вологодской области (увеличение 1,0\%). Далее по степени увеличения цен на чай распределились следующим образом: Ленинградская область (увеличение 4,4\%), Российская Федерация (увеличение 2,9\%), Санкт-Петербург (увеличение 3,8\%), Республика Карелия (увеличение 1,6\%), Мурманская область (увеличение 4,3\%). 


\section{ЧЕЛОВЕК И СОВРЕМЕННОЕ ОБЩЕСТВО В СОЦИАЛЬНОМ, ПРАВОВОМ, ЭКОНОМИЧЕСКОМ РАКУРСАХ}

В период с января по апрель 2021 г. самый низкий уровень цен на соль, как и годом ранее, наблюдался в Санкт-Петербурге (цена на товар в январе 2021 г. составляла 13,71 руб.). На втором месте сложился уровень цен в Российской Федерации. Ленинградская область в начале года занимает вторую позицию по уровню цены на соль в 2021 г., - 14,8 руб.

Максимальные цены на соль во всем периоде наблюдения, как и в предыдущем 2020 г. сложились в Республике Коми - 19,84 руб., и Вологодской области - 19,29 руб. (в сентябре 2021). Разница между минимальным и максимальным уровнем в 2020 г. составляла 44,7\%. Кроме того, цены на товар в Ленинградской области сформировались на $41 \%$ ниже максимальных цен, которые сложились на такой товар в Вологодской области.

Следует отметить, что общая тенденция цен на соль во всех исследуемых регионах, в том числе в Российской Федерации, в 2021 году продолжалась в сторону увеличения. В период с января по ноябрь 2021 г. меньше всего цены на соль увеличились в Санкт-Петербурге (увеличение $4,2 \%$ ). Более всего рост цена на товар составил в Ленинградской области (увеличение 37,1\%), Новгородская область (увеличение 24,2\%). По степени увеличения цен, территории распределились следующим образом: Республика Карелия (увеличение 11,7\%), Республика Коми (увеличение 10,3\%), Псковская область (увеличение 10,8\%). На товар в ряде регионов наблюдается снижение: Мурманская область (снижение - 10,7\%), Вологодская область (снижение $-5,8 \%$ ), Калининградская область (снижение -2,1\%).

В период с января по ноябрь 2021 г. самый низкий уровень цен на муку пшеничную, как и годом ранее, сформировался в Российской Федерации (по состоянию на сентябрь 2021 г. цена составляла 49,73 руб.) и в Псковской области (по состоянию на ноябрь 2021 г. цена составляла 48,28 руб.). При этом в Ленинградской области цена в этот же период составляла 53,04 руб., что на 6,64 руб. выше минимальных цен в Российской Федерации (превышение 12,0\%). 
Самый высокий уровень цен в 2021 году делили между собой два региона (в прошлом году - три региона): Калининградская область и Мурманская область (по состоянию на сентябрь 2021 г. цена составляла 58,12 и 56,64 руб. соответственно).

Цены в Ленинградской области в определенный период сформировались ближе к максимальному уровню, но не пересекали его. Таким образом, разница между самым низким и самым высоким уровнем цен в отдельные периоды составляла 25,8\%. Кроме того, разница между максимальным уровнем цен и ценами в Ленинградской области достигала 4,9\%.

Второе место в рейтинге регионов по темпу увеличения цен уверенно занимала Калининградская область и Мурманская область (увеличение 9,0\%). Третье и четвертое место в рейтинге регионов поделили между собой Вологодская и Ленинградская области уровни цен на товар в которых на протяжении года несколько раз пересекались.

Следует отметить, что не сложилось общей тенденции цен на муку в исследуемых регионах, в том числе в Российской Федерации, в 2021 г. В некоторых регионах цена сформировалась в сторону повышения, в некоторых снизилась по итогам года. В период с января по ноябрь 2021 г. цены на муку пшеничную снизились в Калининградской области (снижение $6,7)$ и Мурманской области (снижение $-4,0)$. Рост цены на муку отмечается в Новгородской области (увеличение $33,4 \%$ ) и Ленинградской области (увеличение 24,4\%), Вологодская область (увеличение 21,2\%). Далее по степени увеличения цен, территории распределились следующим образом: Республике Карелия (увеличение 6,9\%), Мурманская область (увеличение 2,6\%), Псковская область (увеличение 1,3\%).

В период с января по сентябрь 2021 г. самый низкий уровень цен на хлеб ржаной сформировался в Республике Коми - 69,76 руб. а в Российской Федерации (по состоянию на ноябрь цена составляла 61,51 руб.). При этом в 
Ленинградской области цена в этот же период составляла 82.62 руб. и регион занимал 5-е место из 10 регионов СЗФО по цене на данный товар. Превышение цен над минимальной по СЗФО в Ленинградской области в этот период составило 13,26 руб. или $8,4 \%$.

Как было отмечено выше, самый высокий уровень цен в период с января по март 2021 г., а также в июле-августе 2021 г. сформировался в Мурманской, Архангельской и г. Санкт-Петербурге. Таким образом, уровень самых высоких цен в отдельные периоды сформировался в двух регионах: Мурманской области и Архангельской области. Разница между самым низким и самым высоким уровнем цен в отдельные периоды составляла 23,25\%. Максимальное увеличение цен состоялось в Калининградская области (13\%).

Если второе место в рейтинге регионов в 2021 г. уверенно занимала Архангельская область, то третье и четвертое место в рейтинге регионов по уровню увеличения цен занимали регионы: Архангельская область (89,53 руб.), Калининградская область (86,91 руб.), Ленинградская область (82,62 руб.).

Следует отметить, что общая тенденция цен на хлеб ржаной в 10 исследуемых регионах, в том числе в Российской Федерации, как и годом ранее, в течение 2021 года сформировалась в сторону повышения. В 2021 г. меньше всего цены на хлеб ржаной увеличились в Псковской области $(0,7 \%)$. Далее по степени увеличения цен, территории распределились следующим образом: Республика Коми (увеличение 1,1\%), Мурманская область (увеличение 1,6\%), Псковская область (увеличение 2,3\%). Существенно выросли цены на товар в регионах: Санкт-Петербург (увеличение 8,5\%), Новгородская область (увеличение 8,2\%), Республика Карелия (увеличение $6,3 \%)$.

Уровень цен на хлеб из пшеничной муки, установившийся в 2021 г., прослеживался и в период с января по сентябрь 2021 г. Низкие цены были в 


\section{ЧЕЛОВЕК И СОВРЕМЕННОЕ ОБЩЕСТВО В СОЦИАЛЬНОМ, ПРАВОВОМ, ЭКОНОМИЧЕСКОМ РАКУРСАХ}

Вологодской области - 111,2 руб., а в Российской Федерации (цена составляла 135,51 руб.), затем по степени увеличения ценовых уровней регионы расположились в следующем порядке: Республика Коми - 112,9 руб., Новгородская область - 117,47 руб., Псковская область - 118,64 руб., Наиболее высокие цены на данный отвар отмечены на рынках следующих регионов: Архангельская область - 154,23 руб., Санкт-Петербург -154,29 руб., Республика Карелия -138,87 руб., Ленинградская область - 137,77 руб.. Единственное отличие по уровням цен в 2021 г. заключается в том, что уровень цен в Псковской области был ближе к ценам, сформировавшимся в Вологодской и Мурманской областях, т.е. к минимальным ценам на товар, тогда как в 2020 г. цены в Псковской области были ближе к ценам Республики Карелия.

Разница между самым низким и самым высоким уровнем цен в отдельные периоды составляла $38,6 \%$. Разница между максимальными ценами Санкт-Петербурга и ценами Ленинградской области составила 11,2\%.

Общая тенденция цен на хлеб из пшеничной муки в 10 исследуемых регионах СЗФО, в том числе в Российской Федерации, как и год ранее, сформировалась в сторону повышения. В период с января по сентябрь 2021 г. меньше всего цены на хлеб из пшеничной муки увеличились в Псковской области (увеличение на 2,9\%). Далее по степени увеличения цен, территории распределились следующим образом: Архангельская область (увеличение 7,1\%), Республика Карелия (увеличение 9,9\%), Вологодская область (увеличение 7,7\%), Российская Федерация (увеличение 6,3\%), Новгородская область (увеличение 6,3\%). В Санкт-Петербурге цены показали максимальный результат роста по регионам СЗФО (увеличение 11,3\%).

В период с января по ноябрь 2021 г., как и годом ранее, самый низкий уровень цен на рис сформировался в Российской Федерации (по состоянию на январь 2021 г. цена составляла 100,53 руб.). При этом в Ленинградской 
области цена в этот же период составляла 104,52 руб., что на 4,0 руб. выше зафиксированных цен в Российской Федерации (превышение 3,9\%).

Самый высокий уровень цен в январе-феврале 2021 г. сформировался в Мурманской и Ленинградской областях, цена в сентябре 2021 г. составила 112,39 руб. и 108,7 руб. соответственно, этот уровень в 2021 г. смогли преодолеть цены Ленинградской области, которые выросли к ноябрю 2021 г. Таким образом, разница между самым низким и самым высоким уровнем цен в отдельные периоды составляла 22,8 \%.

В 2021 году, как и годом ранее, второе и третье место в рейтинге регионов по уровню увеличения цен занимали Ленинградская область и Республика Карелия соответственно. В 2021 г. по сравнению с прошлым периодом поменялись местами Республика Карелия и Вологодская область. В рассматриваемый период цены Вологодской области стали выше уровня цен Псковской, Новгородской и Калининградской областей, Республики Коми.

Следует отметить, что общая тенденция цен на рис во всех исследуемых регионах, в том числе в Российской Федерации, в 2021 году, как и год ранее, сформировалась в сторону увеличения. В период с января по ноябрь 2021 г. меньше всего цены на рис увеличились в Вологодской области (увеличение составило 0,9\%). Далее по степени увеличения цен на рис территории распределились следующим образом: Республика Карелия (увеличение $12,6 \%$ ), Санкт-Петербурге (увеличение на 10,5\%), Мурманской области (увеличение 10,2\%), Ленинградская область (увеличение 8,9\%), Архангельская область (увеличение 8,7\%), Новгородская область (увеличение $7,6 \%)$.

В 2021 году несколько изменились минимальные и максимальные уровни по регионам на социально-значимый и популярный среди населения товар - крупа гречневая. 
Так, в период с января по сентябрь 2021 г. самый низкий уровень цен на крупу гречневую, сформировался в Новгородской области (по состоянию на январь 2021 г. цена составляла 102,5 руб.). При этом в Ленинградской области цена в этот же период составляла 125,24 руб., что на 21,18 руб. выше минимальных цен в Новгородской области (превышение 22,1\%).

Самый высокий уровень цен в начале 2021 г. сформировался в Мурманской области (по состоянию на ноябрь 2021 г. цена составляла 138,8 руб.) Республике Карелия (по состоянию на август 2021 г. цена составляла 140,63). Таким образом, максимальные цены в 2021 г. наблюдались в трех регионах: Мурманской области, Республика Карелия, Республика Коми, Санкт-Петербург. Разница между самым низким и самым высоким уровнем цен в отдельные периоды составляла 41,5\%. Кроме того, разница между максимальными ценами и ценами, сформировавшимися в Ленинградской области достигала 22,1\%.

Второе место по уровню цен заняла третье - Республика Коми, четвертое Республика Карелия, пятое место - Вологодская область.

Следует отметить, что общая тенденция к росту цен на крупу гречневую сохраняется во всех исследуемых регионах, в том числе в Российской Федерации, в 2021 г., как и годом ранее. В период с января по ноябрь 2021 г. меньше всего цены на крупу гречневую увеличились в Мурманской области (увеличение 9,2\%), Санкт-Петербурге (увеличение на 14,4\%), Республике Коми (увеличение на 14,2\%). Далее по степени увеличения цен, территории распределились следующим образом: Калининградская область (увеличение на 30,9\%), Вологодская область (увеличение 22,2\%), Республика Карелия (увеличение 19,1\%), Псковская область (увеличение 20,6\%), Ленинградская область (увеличение 15,4\%).

В 2021 году, также как и годом ранее, во всех регионах на картофель не наблюдался ярко выраженный уровень в течение года, поскольку цены в 


\section{ЧЕЛОВЕК И СОВРЕМЕННОЕ ОБЩЕСТВО В СОЦИАЛЬНОМ, ПРАВОВОМ, ЭКОНОМИЧЕСКОМ РАКУРСАХ}

одном регионе в определенный период времени пересекали уровень цен, сложившихся в иных регионах. Так, например, в период с февраля по апрель 2021 г. самые низкие цены на картофель наблюдались в Вологодской, Новгородской, Псковской, Ленинградской областях, однако с ростом цен, который произошел в мае 2021 г. самые минимальные цены сформировались в Псковской области. Разница между максимальными и минимальными ценами на картофель достигала 30\%. Тенденция изменения цен во всех субъектах была одинаковой: в первом полугодии прослеживался значительный рост, а затем снижение цены на товар.

В 2021 г. меньше всего цены на картофель увеличились в СанктПетербург (увеличение 43,4\%), Ленинградской области (45,6\%). Далее по степени увеличения цен, территории распределились следующим образом: Калининградская область (увеличение 74,5\%), Российская Федерация (увеличение 27,12\%), Псковская область (увеличение 62,2\%), Вологодская область (увеличение 40\%), Республика Карелия (увеличение 38,5\%), Новгородская область (увеличение 29,4\%).

По мнению специалиста рост цен на картофель обусловлен сокращением посевных площадей под данную культуру, рост доли импортозамещаемой продукции, рост производства зерновых (в условиях роста цен на импорт зерна), рост затрат на хранение продукции, рост транспортных расходов.

\section{Список литературы}

1. FAO Statistical Yearbook - World Food and Agriculture. 2021. World Food and Agriculture - Statistical Yearbook 2021 (fao.org) (дата посещения 06.01.2021) 
УДК 338.5

Глава 10.

АНАЛИЗ КОНКУРЕНТОСПОСОБНОСТИ ЭКОНОМИКИ

И ДИНАМИКИ ЦЕН НА РЕГИОНАЛЬНЫХ РЫНКАХ

Ким Ольга Леонидовна

д.э.н., профессор

ГАОУ ВО ЛО «Ленинградский государственный университет имени А.С. Пушкина»

Аннотация: Анализируются проблемы ценовой политики на региональных рынках. На примере регионального рынка продовольствия Ленинградской области анализируются проблемы роста цен на всех рынках товарных групп. В статье анализируется ценовая политика, рост цен и влияние инфляционных факторов на региональным рынке. Дается сравнительный анализ данных по ценам на социально-значимые продукты питания, делается вывод о росте цен на все анализируемые продукты питания (за исключением рынка пшена). В статье делается вывод о значительном росте в 2021 году цен на молоко и молочные продукты, мясо свинины и говядины, овощи.

Ключевые слова: экономика региона, конкурентоспособность, ценовая политика, инфляция.

\section{ANALYSIS OF ECONOMIC COMPETITIVENESS AND PRICE \\ DYNAMICS IN REGIONAL MARKETS}

Kim Olga Leonidovna 
Abstract: The problems of pricing policy in regional markets are analyzed. On the example of the regional food market of the Leningrad region, the problems of price growth in all markets of commodity groups are analyzed. The article analyzes the pricing policy, price increases and the impact of inflationary factors on the regional market. A comparative analysis of data on prices for socially significant food products is given, and a conclusion is made about the rise in prices for all analyzed food products (except for the millet market). The article concludes that there has been a significant rise in prices for milk and dairy products, pork and beef, vegetables.

Key words: regional economy, competitiveness, pricing policy, inflation.

Актуальность исследования ценовой политики и динамики цен основывается на влиянии инфляционных факторов на потребительское поведение потребителей, показатели товарной политики субъектов предприримательства.

В 2020-2021 гг. по всем товарным рынкам прослеживается рост цен выше официального уровня инфляции, что является досточно чуствительным фактором для потрнбителей. Проведенное автором статьи исследование цен на рынках потребительских товаров Ленинградской области и сравнительный анализ рынков России в целом показали опережающий рост цен на рынках регионов, именно поэтому акцент в экономическом регулировании министерство экономики делает на стимулировании производства и предложения продовольствия на рынках регионов России.

Важным представляется то что наблюдается на всех мировых рынках продовольствия рост цен в пределах 23-25\%. На региональных рынках стран 
Северной Америки и Азии наблюдается рост цен на товары народного потребления и продовольствия.

Представители отраслевых объединений производителей продовольствия и продуктов питания в РФ отмечают готовность увеличивать производство продуктов питания в целях повышения доступности товаров, удовлетворения спроса населения на товары, но делают акцент на необходимость адресной поддержки производителей продуктов питания со стороны государства.

По признанию министерства сельского хозяйства РФ мировой рынок продовольствия находится в фазе кризиса, важно отвязать цены внуреннего рынка продовольствия от растущих цен на мировых рынках.

Конкурентоспособность экономики региона во многмо зависит от сложившейся структуры предложения, производственных возможностей экономики региона, логистического потенциала региона.

Анализ данных показывае, что в Ленинградской области преобладает динамика повышения цен ввиду ускорения темпа инфляционных процессов.

Так, к ноябрю 2021 года она составила 7,69\% (см. рис. 1), причем по группе продовольственных товаров инфляция составила 11,55 п.П., наибольший рост продемонстрировали цены Ленинградской области по группе плодоовощная продукция $35,73 \%$. По непродовольственным товарам и услугам инфляция и динамика прироста цена осталась в пределах прогнозируемых параметров инфляции на начало года. 


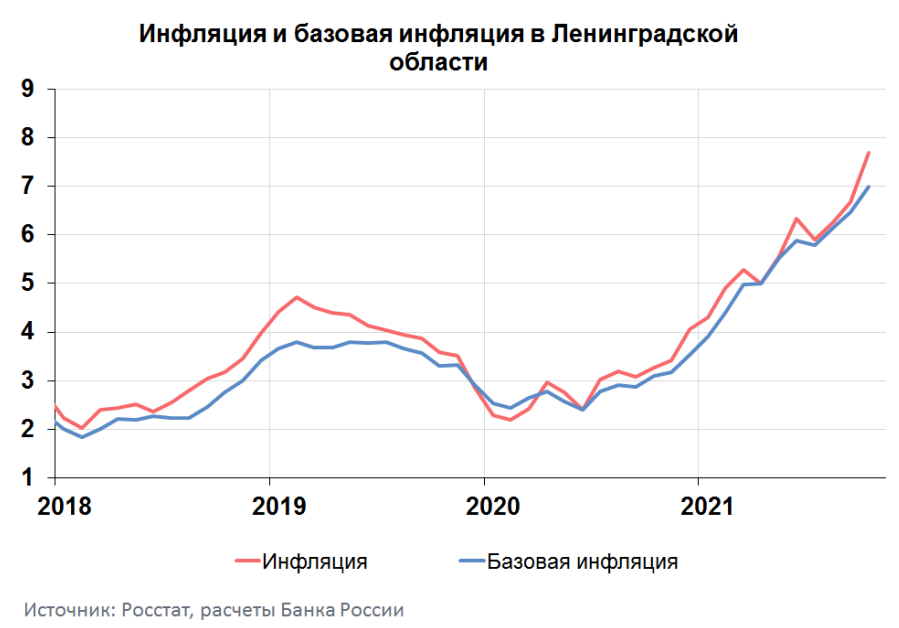

\section{Рис. 1. Инфляция в Ленинградской области, составлено автором по данным Росстата и Центробанка}

Ниже анализируется состояние динамики цен и ценовой политики на рынках продовольствия Ленинградской области, дается оценка состояния цен на основные виды социально-значимых продуктов питания определенные постановлением Правительства РФ.

За период с января по сентябрь 2021 г. цены на говядину в Ленинградской области выросли на 3,0%. В январе 2021 г. стоимость 1 кг продукта составляла 409,93 руб., в декабре 2020 г. - 383,47 руб. (рост в денежном выражении составил 26,46 руб.) (см. данные таблицы 1).

Цена на товар увеличивалась в течение всего периода наблюдения с небольшим снижением в июле 2021 г. Соответственно, первая значительная волна увеличения цены продукта произошла в период с марта по июнь 2021 г. В этот период стоимость товара увеличилась с 409,93 руб. до 445,34 руб. (рост цен составил 2,5\%). В летний период 2021 г. наблюдался рост цены на говядину с 445,34 рубля за 1 кг., до 447,6 руб., и в ноябре наблюдался рост цен до отметки 478,59 руб. за 1 кг. Таким образом, цена на говядину в Ленинградской области за год выросли на 11,6\%. 
Таблица 1

Динамика цен на продукты питания по РФ и Ленинградской области (составлено автором по данным Россстата)

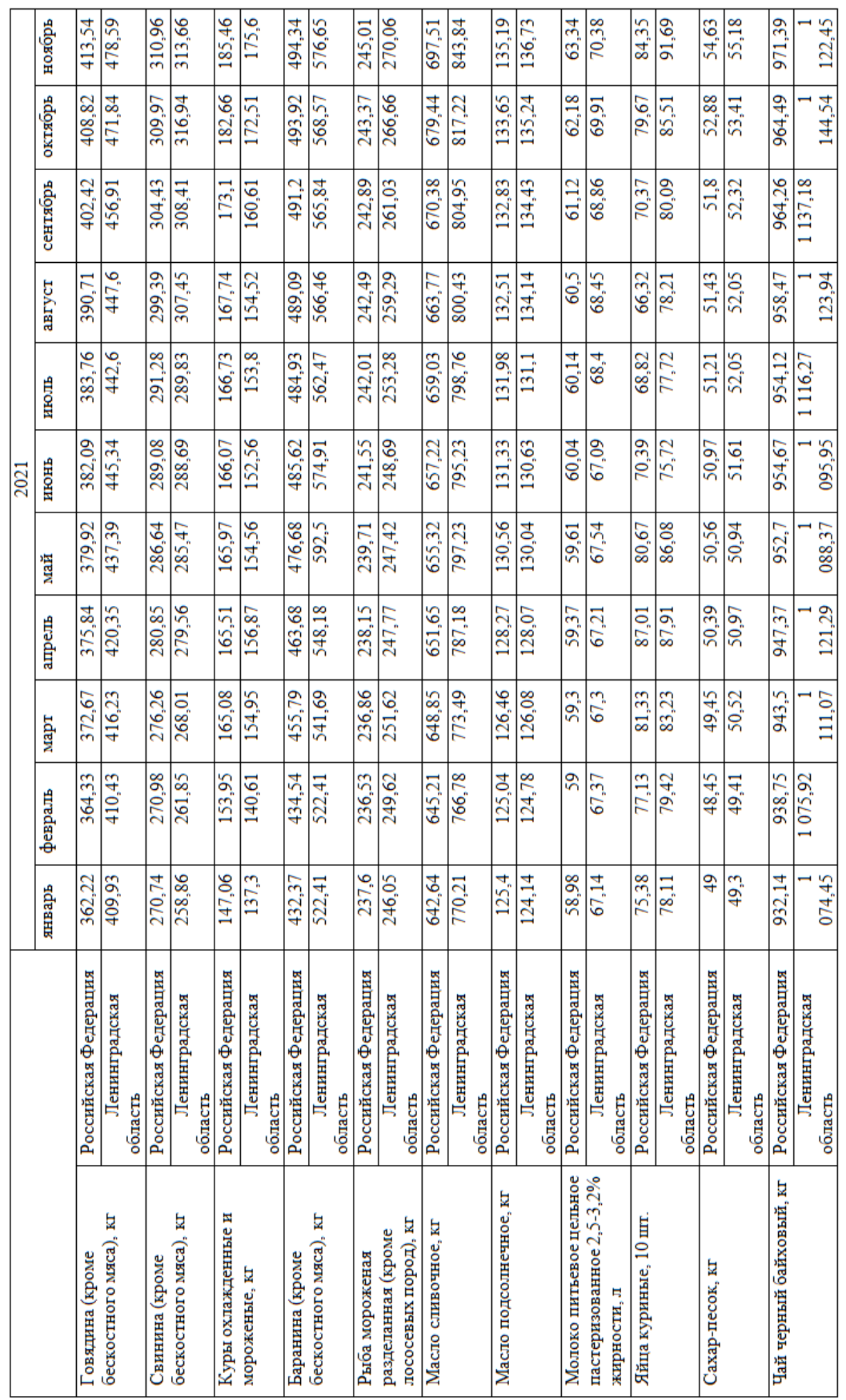




\section{Продолжение Таблицы 1}

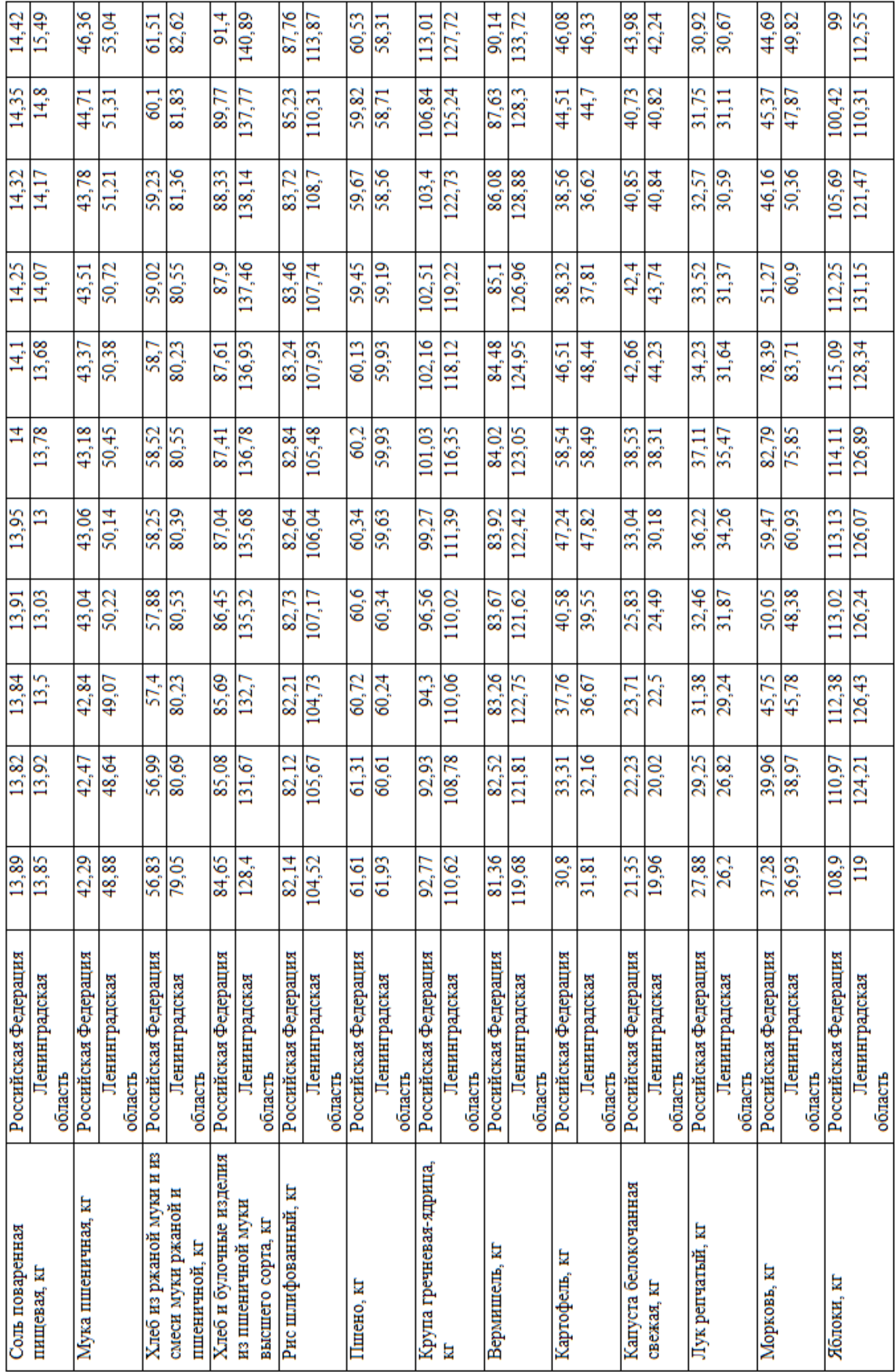


Уровень цен на говядину, сложившийся в Российской Федерации, за весь наблюдаемый период 2021 г., был ниже уровня цен на такой товар в Ленинградской области. Так, в январе 2021 г. цена на товар в целом по Российской Федерации составила 362,22 руб. против 409,93 руб. в Ленинградской области. Разница между ценами в отдельные периоды составляла 8,5-11,6\%. При этом цена на товар, сложившаяся в целом по Российской Федерации, за наблюдаемый период январь-ноябрь 2021 г. постепенно увеличивалась без особых снижений, поднявшись с 362,22 руб. (январь 2021) до 390,71 руб. (сентябрь 2021 г.). В ноябре 2021 года цены на товар выросли как по региону, так и по РФ в целом, причем цена в Ленинградской области составила 478,59 руб., за кг., что выше чем по РФ на 63,02 рубля. Таким образом, увеличение цены на товар по Российской Федерации за год составило 10,4 \%, в Ленинградской области, цена на говядину выросла на $11,5 \%$.

Уровень цен на свинину в сложившейся в Ленинградской области период с января по апреля 2021 года был ниже уровня цены на данный товар в Российской Федерации. Рост цен на свинину в апреле составил 8\%, в мае наблюдалось корректировка цены с движения до 9\%, в период с июня по август месяц цена на свинину достигла своего пика в 307,45 в рублей за килограмм, с последующим ростом до 309,97 руб. в ноябре месяце (прирост в $+3,4 \%$ к сентябрю 2021 г.).

При этом динамика изменения цен в Ленинградской области и Российской Федерации в ключевые моменты были схожими (например, первая волна падения цен до апреля 2021, увеличение цены в августе 2021, и дальнейшее снижение цены в остальной период), а сложившаяся в целом по Российской Федерации тенденция изменения цен наблюдалась в сторону снижения. Снижение цены на свинину в 2021 г. по Российской Федерации и Ленинградской области было одинаковым и составило 3,9\%. 
Уровень цен на свинину, сложившийся в Ленинградской области, в период с января по сентябрь 2021 г., был аналогичен уровню цен на такой товар в целом по Российской Федерации. Так, в январе 2021 г. цена на товар в Ленинградской области составила 258,86 руб. против 264,738 руб. в Российской Федерации. Разница между ценами в отдельные периоды составляла $4,5-2,3 \%$.

Цены, сложившиеся в Российской Федерации и в Ленинградской области синхронно росли за весь период 2021 г., с июня цены на обоих территориях развернулись в сторону увеличения и повышательная тенденция продолжалась до ноября 2021, по РФ цена на единицу товара составила $309,97 \%$, а по Ленинградской области - 316,94 руб., что больше на 2,2\% среднероссийских значений.

Стоимость свинины в Российской Федерации в январе 2021 г. составляла 270,74 руб., в августе 2021 г. - 299,39 руб. Таким образом, увеличение цены на товар по Российской Федерации за год составило 10,5\%, в то время как, по Ленинградской области, увеличение цены составило 5,0\%.

В 2021 году изменения цены на куру определяется стабильностью, с небольшой корректировкой и ростом цены за период с января по апрель 156,8 за кг (+19 руб. или 18\%), средняя цена на куру охлажденную характеризуется сезонным снижением до 131 руб. за кг., и стабилизацией ценового уровня в летний период. В октябре 2021 наблюдается незначительное снижение цены на куру до 138,14 руб., к уровню цены января 2021, в ноябре декабре цены на товар выросли до 140,89 руб за кг., или на $+9,7 \%$ к январю 2021.

В 2021 г. динамика изменения цены на рыбу в Ленинградской области была не равномерной. Так, в марте 2021 г. цена на товар вновь увеличилась на 2,0\% по сравнению с январем 2021 г. достигнув значения 251,62 руб., а уже в апреле 2021 г. снизилась до отметки 247,77 руб. В мае месяце цена на товар 
достигла пикового значения в 262,5 руб за кг., с последующей корректировкой до 247,42 руб., за период с июня 2021 г. прослеживалась тенденция увеличения с 248,6 руб. до 270,06 руб., к ноябрю 2021года. Таким образом, цена на рыбу в Ленинградской области за период с января по сентябрь 2021 г. выросла на 9,7\%.

Цена на рыбу в Ленинградской области в 2021 г. была выше цены по Российской Федерации в течение всего рассматриваемого периода. Отклонения цены составило от 7,1\% до 10,2\%. На протяжении всего периода 2021 г. цены на товар в Ленинградской области поднимались выше средних цен на данный товар по Российской Федерации и сохраняли такую тенденцию до ноября 2021 г. Цена на рыбу в Ленинградской области за период с января по ноябрь 2021 г. выросла на 10,2\%, в то время, как цена в Российской Федерации выросла на 3,3\%. В феврале -апреле месяце наблюдалось кратковременное снижение цен на -1,6\% по Ленинградской области. В целом цена на товар в ленобласти значительно выше чем в среднем по РФ, на 10,2\% (на ноябрь 2021).

Тенденция увеличения стоимости масла сливочного в Ленинградской области продолжилась и в 2021 г. В первом квартале 2021 года цена на товар увеличилась до 787,1 руб, или на 2,2\% к явнварю месяцу. За период с января по сентябрь 2021 г. стоимость товара выросла на 3,9 \%, за летний период до 800,43 руб. за кг., в августе месяце, достигнуув своего пика, выросла до 843,84 руб. за кг. в ноябре. Цена на товар увеличивалась под влиянием сезонного фактора каждый месяц, за исключением февраля месяца.

В 2021 г. динамика изменения цены на масло подсолнечное в Ленинградской области была более плавная. Так, тенденция роста цены наблюдалась в 1 квартале 2021 года до 128 руб. в апреле, что выше на 4 руб., или $+3,2 \%$ чем в январе. В мае месяце наблюдалось снижение цены, с 
минимальной ценой на товар 115,28 руб. В летние месяцы 2021 г. цена на товар стала увеличиваться и рост продолжился вплоть до ноября 2021 г.

В 2021 г. динамика изменения цены на масло подсолнечное в Ленинградской области была более плавная. Так тенденция роста цены наблюдалась в 1 квартале 2021 года до 128 руб. в апреле, что выше на 4 руб., или $+3,2 \%$ чем в январе. В мае месяце наблюдалось снижение цены, с минимальной ценой на товар 115,28 руб. В летние месяцы 2021 г. цена на товар стала увеличиваться и рост продолжился вплоть до ноября 2021 г.

В 2021 году цены на яйца куриные были достаточно стабильными по сравнению с предыдущим годом, пиковое значения цены было достигнуто в апреле 87,91 руб., в июне месяце цена за рассматриваемый период снизилась до 75,72 руб. С августа по ноябрь 2021 года наблюдался рост цены, если в августе цена на товар составила 77,72 руб. то в ноябре цена составила 91,69 руб. рост составил 21 пп., по отношению к январю 2021 года прирост цен составил 17,4\%. Наименьшая цена на товар наблюдалась в Ленинградской области в июне месяце и составила 75,71 что меньше на 21,0\% чем в ноябре.

Практически выровнявшийся уровень цен на яйца в прошлом году вновь приобрел тенденцию к росту в январе 2021 г., и такая тенденция сохранилась до конца наблюдаемого периода. Минимальный уровень цен сформировался в Российской Федерации в летний период 2021 года. Разница между ценами по РФ и Ленобласти составляла $14,7 \%$ в августе месяце. Но общая тенденция осталась неизменной, то есть, цены как в Ленинградской области, так и в Российской Федерации по сравнению с началом 2021 г. выросли на 17,4\% и $12.0 \%$ соответственно.

Тенденция по стабилизацию цен на сахар в Ленинградской области, которая началась в прошлом году г. продолжилась до апреля 2021 г., затем цена на товар развернулась с 49,03 руб. и до октября 2021 г. постепенно росла достигнув отметки 52,05 руб., в ноябре цена составила 55,18 руб. Таким 
образом, за период с января по октябрь 2021 г. цена на сахар-песок в Ленинградской области выросла на $8,3 \%$.

В период с января по ноябрь 2021 г. цена на сахар-песок, сложившаяся в Ленинградской области была ниже цены, сложившейся в Российской Федерации. Разница в ценах была незначительна и составила от 1,2 до $0,8 \%$. Однако общая тенденция изменения цены была в сторону увеличения. Цена на сахар-песок в РФ увеличилась на 11,2\%, в Ленинградской области также выросли за рассматриваемый период на 11,9\%.

Сложившаяся в прошлом году в Ленинградской области тенденция повышения цен на чай, продолжилась в 2021 г. Увеличение цен на чай в период с января по апрель 2021 г. в Ленинградской области составило +4,3\%. Цена поднялась с 1074,45 руб. до 1121,2 руб. Повышение цен происходило каждый месяц. В мае было зафиксировано кратковременное снижение цены на чай до 1088,37 руб., с последующим ростом до 1122,45 руб. до конца периода наблюдения (ноябрь 2021) наблюдалось повышение цен на данный товар, к октябрю 2021 года цена на товар составила 1144,54 руб. что составило увеличение на 6,5\% к началу 2021 года к декабрю стоимость товара снизилась до 1122,45 руб. за кг.

В январе и феврале 2021 г. цена на муку в Ленинградской области несколько снизилась с 44,58 руб. до 48,64 руб., но уже в марте 2021 г. начался рост, который продолжился до ноября 2021 г (53,04 руб.). Цена на муку в рассматриваемый период увеличилась на 8,5 \% (в денежном выражении рост составил 4,12 руб.), к декабрю цена на товар продолжила свой рост и составила 53,04 руб. за кг. в Ленинградской области.

В период с января по ноябрь 2021 г. цена на муку в Ленинградской области была выше цены, сформированной в Российской Федерации. Разница в отдельные периоды составляла 12,86\%-14,7\%. В целом цена на муку в Российской Федерации увеличилась за год на 9,6\% (цена поднялась 
с 42,29 руб. до 44,71 руб.), в Ленинградской области выросла - на 8,5\% до 53,04 руб. на кг к ноябрю 2021.

Начавшаяся в прошлом году тенденция роста цен на хлеб ржаной в Ленинградской области продолжилась в период с января по ноябрь 2021 г. с небольшим снижением таких цен в период марта, мая, июля месяца 2021г. (снижение на 0,44\%). Таким образом, цена на товар сначала поднялась с 79,05 руб. до 80,55 руб., затем, опустилась до 80,23 руб., (в августе) впоследствии снова стала повышать до 81,36 руб. в сентябре 2021 г. цена на хлеб ржаной, ржано-пшеничный отметились небольшим снижением в июле 2021 г. Таким образом, цена на хлеб ржаной в Ленинградской области в 2021 г. увеличилась на 4,5\%.

Уровень цен на хлеб ржаной, сложившийся в Российской Федерации, в период с января по сентябрь 2021 г., был ниже уровня цен на такой товар в Ленинградской области. Так, в январе 2021 г. цена на товар в целом по Российской Федерации составила 56,83 руб. против 79,05 руб. в Ленинградской области. Разница между ценами в отдельные периоды составляла 31\%. При этом цена на товар, сложившаяся в целом по Российской Федерации, за наблюдаемый период январь-ноябрь 2021 г. постепенно увеличивалась без особых снижений, поднявшись с 56,83 руб. (январь 2021) до 61,51 руб. (ноябрь 2021 г.). Таким образом, увеличение цены на товар по Российской Федерации за год составило $8,2 \%$, в то время как, по Ленинградской области, цена выросла меньшими темпами, рост на наблюдаемый период составил 4,5\%, и равняется 82,62 руб.

Начавшаяся в сентябре 2020 г. тенденция снижения цены на хлеб из пшеничной муки в Ленинградской области продолжилась до января 2021 г. В этот период цена достигла отметки 128,4 руб. В 1 квартале 2021 г. цены на хлеб из пшеничной муки вновь развернулись в сторону увеличения и повышательная тенденция продолжилась весь период наблюдения 2021 г., 
достигнув цены 140,89 руб., против 128,4 в январе 2021 г. В августе-сентябре 2021 г. наблюдался рост цены на товар до 137,77 руб. (рост составил 7,3\%). В целом за период с января по ноябрь 2021 г. цена на хлеб из пшеничной муки в Ленинградской области выросла на 9,7\%.

Уровень цен на хлеб из пшеничной муки, сложившийся в Российской Федерации, в период с января по ноябрь 2021 г., был ниже уровня цен на такой товар в Ленинградской области. Так, в январе 2021 г. цена на товар в целом по Российской Федерации составила 84,65 руб. против 128,4 руб. в Ленинградской области. Разница между ценами в отдельные периоды составляла 44,9\%-36,5\%. При этом цена на товар, сложившаяся в целом по Российской Федерации, за наблюдаемый период январь-ноябрь 2021 г. постепенно увеличивалась без особых снижений, поднявшись с 84,65 руб. (январь 2021) до 91,4 руб. (ноябрь 2021г.). Таким образом, увеличение цены на товар по Российской Федерации за год составило 7,9\%, в то время как, по Ленинградской области, наблюдается более высокий рост цены в 9,7\%.

В период с января по сентябрь 2021 г. динамика цены на рис в Ленинградской области не отличалась большей стабильностью. В январе стоимость товара составляла 104,52 руб., которая каждый месяц увеличивалась, достигнув к июлю 2021 года отметки 107,93 руб., и к ноябрю 2021 г. достигла пиковой отметки в 110,31 руб. Таким образом, цена на товар за период с января по сентябрь 2021 г. увеличилась на 5,5\%., последующее увеличение цены ы декабре составило 113,87 руб. за кг.

Уровень цен на рис, сложившийся в Российской Федерации, в период с января по ноябрь 2021 г., был ниже уровня цен на такой товар в Ленинградской области. Так, в январе 2021 г. цена на товар в целом по Российской Федерации составила 82,14 руб. против 104,52 руб. в Ленинградской области. Разница между ценами в отдельные периоды составляла 23,2-23,5\%. При этом цена на товар, сложившаяся в целом по 


\section{ЧЕЛОВЕК И СОВРЕМЕННОЕ ОБЩЕСТВО В СОЦИАЛЬНОМ, ПРАВОВОМ, ЭКОНОМИЧЕСКОМ РАКУРСАХ}

Ленинградской области, за наблюдаемый период январь-ноябрь 2021 г. постепенно увеличивалась без особых падений, поднявшись с 104,52 руб. (январь 2021) до 113, 87 руб. (ноябрь 2021 г.). Следовательно, динамика изменения цен на обоих территориях, как и год ранее, прослеживалась в сторону увеличения. Таким образом, увеличение цены на товар по Российской Федерации за год составило $6,8 \%$, в то время как, по Ленинградской области, увеличение цены составило 8,9\%.

В сентябре - ноябре 2021г. в Ленинградской области началась тенденция снижения цены на пшено, которая продолжалась весь рассматриваемый период. Цена в рассматриваемый период упала с 61,93 руб. до 58,71 руб., то есть на 5,2\%. В мае-июне 2021 г. цена на товар в Ленинградской области снова увеличилась достигнув максимальной отметки 59,93 руб., а затем снова стала снижаться, достигнув в ноябре 2021 г. цены в 58,31 руб. Таким образом, в период с января по ноябрь 2021г. на данный товар прослеживалась тенденция колебаний и незначительного снижения цены, которая составила $5,2 \%$.

Уровень цен на пшено, сложившийся в Российской Федерации, в период с января по ноябрь 2021 г., как и год ранее, был выше уровня цен на такой товар в Ленинградской области. Так, в январе 2021 г. цена на товар в целом по Российской Федерации составила 61,61 руб. против 61,93 руб. в Ленинградской области. Разница между ценами в отдельные периоды достигала 6-11\%. При этом цена на товар, сложившаяся в целом по Российской Федерации, за наблюдаемый период январь-ноябрь 2021 г. постепенно снижалась. Первая волна снижения произошла в период с января по май 2021 г., а вторая - с июля по сентябрь 2021 г. Таким образом, снижение цены на товар по Российской Федерации за год составил $3,0 \%$, в то время как, по Ленинградской области, снижение цены составило 10,9\%. 
Тенденция относительной стабилизации цена на товар в Ленинградской области наблюдался в январе - апреле месяце 2021г. В мае месяце наблюдалось снижение цены до 101,38 руб. (что на $8,3 \%$ ниже чем в январе). Летнее повышения цены на крупу гречневую-ядрицу, которая началась в июне 2021 г. в Ленинградской области продолжилась в период с июня по август 2021 г. Цена на товар в Ленинградской области в этот период увеличилась на 2,4\%, со 116,35 до 125,24 руб. В сентябре наблюдается рост цены до 125,24 руб., что означает тенденцию роста годовых значений цены на товар в 2021 году со 110,62 руб. до 125 руб. за кг. крупы гречневой-ядрицы.

Уровень цен на крупу гречневую, сложившийся в Российской Федерации, в период с января по ноябрь 2021 г., как и год ранее, сформировался ниже уровня цен на такой товар в Ленинградской области. Так, в январе 2021 г. цена на товар в целом по Российской Федерации составила 92,77 руб. против 110,62 руб. в Ленинградской области. Разница между ценами в отдельные периоды составляла 16,2\%-15,3\%. При этом цена на товар, сложившаяся в целом по Российской Федерации, за наблюдаемый период январь-ноябрь 2021 г. увеличилась, поднявшись с 92,77 руб. (январь 2021 ) до 106,84 руб. (ноябрь 2021 г.), со значительной тенденцией роста в период июня по ноябрь 2021 г (увеличение составило 7,1\%). В Ленинградской области уровень цен на крупу гречневую вырос с 110,62 в январе 2021 года до 125,24 руб. в ноябре 2021. Таким образом, увеличение цены на товар по Российской Федерации за год составило $15,1 \%$, в то время как, по Ленинградской области, наблюдается рост цены на 13,2\%.

В период с января по апрель 2021 г. цены на картофель в Ленинградской области увеличивались постепенно с 31,81 руб. за 1 кг. До 39,55 руб. достигнув максимального снижения в мае месяце, но, уже, в июне 2021 г. рост цен на новый урожай картофеля был значительным. Достигнув максимальной цены в июне 2021 г. (58,49 руб.) цена в августе и сентябре стала снижаться до 
26,63 руб., далее в октябре 2021 года наметился рост до 44,7 руб. за кг. Таким образом, за рассматриваемый период цена на товар в Ленинградской области вырос на 18,23\%, цена на товар в декабре месяце составила 46,33 руб. за кг.

Несколько изменился уровень цен на картофель в 2021 г. Так, в период с января по апрель 2021 г. низкие цены преобладали в Ленинградской области, в июне-августе 2021г. в Российской Федерации. Так, в январе 2021 г. цена на товар в целом по Российской Федерации составила 22,32 руб. против 37,81 руб. в Ленинградской области. Разница между ценами в отдельные периоды составляла 0,1-29,3\%. При этом цена на товар, сложившаяся в целом по Российской Федерации, за наблюдаемый период январь-сентябрь 2021 г. постепенно увеличивалась, поднявшись с 32,43 руб. (январь 2021) до 41,22 руб. (сентябрь 2021 г.). Таким образом, увеличение цены на товар по Российской Федерации рассматриваемый период составило 44,5\%, в то время как, по Ленинградской области, цены выросли с 31,81 руб. до 46,33 руб., или увеличение составило $45,6 \%$.

В период с января по июль 2021 г. цена на капусту в Ленинградской области сначала увеличилась на $221 \%$ под воздействием сезонных факторов, а затем вновь стала снижаться, достигнув к сентябрю 2021 г. отметки 20,78 руб. В целом, стоимость капусты за рассматриваемый период увеличилась в 2,0 раза. Вместе с тем стоит отметить, что уровень цен, сложившийся в 2021 г., выше уровня рыночных цен, сформированный годом ранее. В октябре месяце сезонные цены повлияли на рынок, и цена снизилась по сравнению с июлем на 7,8\%.

В период с января по май 2021 г. тренд на низкие цены на капусту сформировались в Ленинградской области. В связи с тем, что в июне 2021 г. в Ленинградской области еще прослеживалась тенденция повышения цены, а в Российской Федерации в этот период началось уже снижение, уровень цен, сложившийся в Российской Федерации на данный товар во втором полугодии 
2021 г. стал минимальным. Несмотря на то, что общая тенденция движения цены была одинаковой, в целом за рассматриваемый период цена на капусту в РФ выросла практически в 2,2 раза (с 21,35 руб. за 1 кг. до 42,4 руб. в августе 2021), и снизилась под воздействием сезонных факторов в ноябре месяце до 40,82 руб. за кг. или на 4,5\%, а в Ленинградской области цены на данный товар увеличились в 2,1 раза.

Динамика цен на лук репчатый в Ленинградской области и Российской Федерации была практически синхронной. В период с января по март 2021 г. низкие цены на лук сформировались в Российской Федерации, в апреле месяце разница в цене достигла $28 \%$. С мая по август месяц начался процесс снижения цена на товар, в Ленинградской области с 34,26 руб. до 31,37 руб. в сентябре 2021. В целом тенденции изменения цен были схожими: в период с января по май 2021 г. - рост цены на товар, а затем снижение под влиянием сезонного фактора, нового урожая. Цена на товар по РФ выросли на 12\%, в Ленинградской области поднялись на $25 \%$.

В период с января по май 2021 г. в Ленинградской области наблюдалась тенденция повышения цены на морковь. В этот период цена увеличилась с 36,93 руб. до 48,38 руб. В августе - сентябре 2021 г. цена двигалась в сторону уменьшения, достигнув отметки 33,16 руб. Однако тенденция, в целом, сформировалась в сторону снижения цены на товар. Цена на товар в Ленинградской области за этот период снизились на 29,6\%.

В период с мая по июнь 2021 г. низкие цены на морковь сформировались в Ленинградской области, затем в Российской Федерации. Так, в январе 2021 г. цена на товар в целом по Российской Федерации составила 37,28 руб. против 36,93 руб. в Ленинградской области. Разница между ценами в отдельные периоды составляла 1,8-54,2\%. При этом динамика изменения цены на товар, сложившаяся в целом по Российской Федерации, за наблюдаемый период была схожей с динамикой изменения цены в 
Ленинградской области: до мая 2021 г. преобладал рост цены, август-сентябрь 2021 характеризовался снижением цены. Однако в целом цена в Российской Федерации, в течение года цена двигалась в сторону увеличения, повышение составило $37,8 \%$ в РФ, и в Ленинградской области снижение цены на морковь составило 10,1\%. К ноябрю 2021 года цена на данный товар снизилась. 45,37 руб. в Российской Федерации и до 47,87 руб. в Ленинградской области, т.е. снижение к ценам июня месяца составило 67\%, на снижение цены повлияли факторы сезонности, сбора нового урожая.

Таким образом, следует отметить, что на региональных рынках сложилась тенденция к дальнейшему повышению цен на продукты питания, в том числе социально-значимые. Данный рост цен, в том числе выше уровня инфляции вызывает у потребителей чувство недовольства и разочарования действиями органов регионального управления в сфере цен и тарифов, федеральных органов антимонопольного регулирования. Рост цен на мировых рынках продовольствия отозвался соответствующим ростом цен, как на федеральных, так и региональных рынках продовольствия, товаров и услуг. 
УДК 331.101.3

Глава 11.

ТЕОРЕТИЧЕСКИЕ И ПРИКЛАДНЫЕ АСПЕКТЫ РАЗРАБОТКИ

И ВНЕДРЕНИЯ МОТИВАЦИОННОЙ МОДЕЛИ УПРАВЛЕНИЯ

ПОВЕДЕНИЕМ ПЕРСОНАЛА ПРЕДПРИЯТИЯ

\section{Миляева Лариса Григорьевна}

д.э.н., профессор, заведующая кафедрой экономики предпринимательства

Бийский технологический институт (филиал) ФГБОУ ВО «Алтайский государственный технический университет им. И.И. Ползунова» (БТИ АлтГТУ)

Аннотация: В работе проведен сравнительный критический анализ традиционной (классической) и мотивационной концепций управления поведением персонала; акцентированы плюсовые особенности мотивационной модели управления поведением персонала (ММУПП); обоснованы сущностно-содержательные аспекты, формирующие методологию разработки и внедрения ММУПП. Предложен опросник, аккумулирующий профильные вопросы-утверждения, предназначенный для выявления мотивационного профиля респондента. Представлен и проиллюстрирован на условном (модельном) примере оригинальный инструментарий обеспечения методического сопровождения ММУПП, ключевыми элементами которого являются: обоснование аспектноиндикаторный структуры мотивов труда; построение индивидуальных мотивограмм; выделение мотивационных единиц; формирование Паспорта мотивационной модели управления поведением персонала; оценка 
управленческого потенциала мотивационных рычагов; разработкой целевой программы, ориентированной на определенный «управленческий мотивационный эффект».

Ключевые слова: мотивационная модель управления поведением персонала (ММУПП), аспектно-индикаторная структура мотивов труда, мотивационный профиль, мотивограмма, мотивационная единица, Паспорт ММУПП, управленческий потенциал мотивационного рычага, методический инструментарий.

\title{
THEORETICAL AND APPLIED ASPECTS OF DEVELOPMENT AND IMPLEMENTATION OF MOTIVATIONAL MODEL OF ENTERPRISE PERSONNEL BEHAVIOR MANAGEMENT
}

\section{Milyaeva Larisa Grigoryevna}

\begin{abstract}
Comparative critical analysis of traditional (classical) and motivational concepts of personnel behavior management is carried out; positive features of the motivational model of personnel behavior management (MMUPP) are emphasized; Substantive aspects that form the methodology for the development and implementation of ISMP are justified. A questionnaire is proposed, which accumulates profile questions-approvals, designed to identify the motivational profile of the respondent. Presented and illustrated on a conditional (model) example is the original instrumentation for providing methodological support to MMUPP, the key elements of which are: substantiation of the aspect-indicator structure of labor motives; construction of individual motivograms; allocation of motivational units; creation of a passport of motivational model of personnel behavior management; assessment of management potential of motivational levers;
\end{abstract}


the development of a targeted program focused on a certain «management motivational effect».

Key words: motivational model of personnel behavior management (MMUPP), aspect-indicator structure of labour motifs, motivational profile, motivation chart, motivational unit, MMUPP Passport, management potential of motivational lever, methodological toolkit.

Одной из важнейших составляющих персонал-менеджмента является управление поведением, позиционируемое как совокупность определенных действий и средств, предназначенных для целенаправленного изменения поведения наемных работников, преобразования его в необходимые модели и формы [1].

Как известно, классическая концепция управления поведением персонала организации характеризуется следующими параметрами [2, с. 4-5]:

1. Носителем поведения является исполнитель трудовых функций и/или трудовых действий, закрепленных («привязанных») за конкретным рабочим местом.

2. Поведение рассматривается в узком смысле (только как совокупность рабочих действий, сопряженных с выполнением функционала), то есть, без учета социально-психологических и мотивационных аспектов.

3. Поведение проявляется через иерархические (разноуровневые) связи.

4. Целевая модель поведения обеспечивается жестским регулированием, сопряженным с четким адресным распределением задач, распространением информации, разграничением компетенций, полномочий и ответственности.

5. Всем наемным работникам руководством организации (предприятия) задаются общие правила (формы, модели) поведения, не учитывающие индивидуальных особенностей, интересов, целеполаганий.

6. Управление поведением персонала ассоциируется с рационализацией структуры предприятия и трудового процесса. 
7. Основной целью управления поведением наемных работников является максимизация прибыли, сопряженная с оптимизацией затрат (в том числе, трудовых) и повышением эффективности производства.

В условиях социально-ориентированной экономики все большее распространение в управлении поведением персонала предприятий (организаций) получает нетрадиционная концепция, характерными особенностями которой выступают:

1. Во-первых, расширенная трактовка ключевой дефиниции, согласно которой поведение - это не только рабочие действия, связанные с реализацией трудового функционала, но и опосредованная совокупность социальнопсихологических особенностей персонала, обусловливающих различную степень их активности и результативности.

2. Во-вторых, проявление поведения через взаимодействия относительно независимых специалистов и рабочих групп.

3. В-третьих, обеспечение целевой модели поведения правилами, выработанными в процессе совместных действий и согласования интересов наемных работников.

4. В-четвертых, управление поведением, нацеленное, прежде всего, на развитие персонала, на повышение его конкурентоспособности и профессиональной компетентности.

5. В-пятых, управление поведением базирующееся на изучении, анализе и корректировке системы трудовой мотивации персонала организации.

В контексте с последним из отмеченных обстоятельств нетрадиционную концепцию управления поведением персонала принято называть мотивационной (МКУПП - мотивационная концепция управления поведением персонала).

Справедливости ради необходимо подчеркнуть, что первоначальный интерес российских ученых к анализируемой проблематике возник в начале 
90-х годов минувшего столетия [3-4]. Поступательно развиваясь, мотивационная концепция управления поведением персонала организаций на протяжении последних 10-15 лет обогащалась новыми аспектами и методическими наработками [5-9].

Сущностную (концептуальную, методологическую) основу разработки мотивационной модели управления поведением персонала (ММУПП) предприятия (организации) формируют следующие моменты:

1. Разграничение персонала, не зависимо от трудового функционала (принадлежности к определенной функциональной категории), на мотивационные единицы (ME) - группы наемных работников, имеющих схожую (однотипную) структуру трудовых мотивов.

2. Формирование по аспектно-индикаторному принципу (табл. 1) перечня анализируемых мотивов труда.

Таблица 1

Анализируемая аспектно-индикаторная структура мотивов труда (условный пример)

\begin{tabular}{|c|c|}
\hline $\begin{array}{c}\text { Аспект трудовой мотивации } \\
\text { (классификационный признак) }\end{array}$ & Индикаторы аспекта трудовой мотивации \\
\hline Стимулирующий аспект (CA) & $\begin{array}{l}И_{1}^{C A}-\text { достойный уровень заработной платы; } \\
И_{2}^{C A}-\text { справедливый уровень заработной платы; } \\
И_{3}^{C A}-\text { обоснованность премиального положения }\end{array}$ \\
\hline $\begin{array}{l}\text { Карьерно-профессиональный } \\
\text { аспект (КПА) }\end{array}$ & 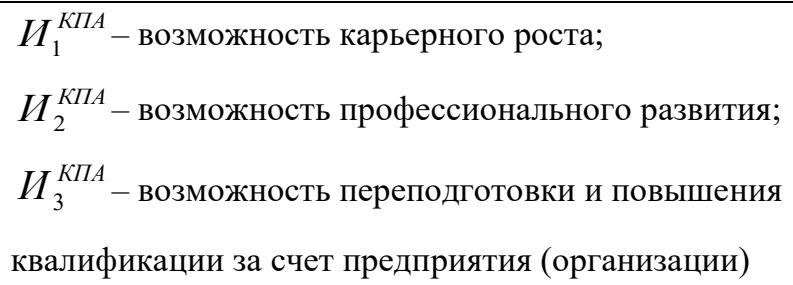 \\
\hline Социально-психологический аспект (СПА) & $\begin{array}{l}И_{1}^{C П А} \text { - нормальный социально-психологический } \\
\text { климат в коллективе; } \\
И_{2}^{C П А} \text { - развитые социально-трудовые отношения; } \\
И_{3}^{C П А} \text { - доверительные отношения с руководством }\end{array}$ \\
\hline
\end{tabular}


Продолжение Таблицы 1

\begin{tabular}{|c|c|}
\hline Функциональный аспект (ФА) & $\begin{array}{l}И_{1}^{\Phi A}-\text { инновационный характер труда; } \\
И_{2}^{\Phi A}-\text { творческий характер труда; } \\
И_{3}^{\Phi A}-\text { адекватный полученному образованию и } \\
\text { занимаемой должности характер труда }\end{array}$ \\
\hline Организационный аспект (OA) & $\begin{array}{l}И_{1}^{O A}-\text { хорошие (комфортные) условия труда; } \\
И_{2}^{O A}-\text { своевременная аттестация рабочих мест; } \\
И_{3}^{O A}-\text { рациональная (научно-обоснованная) } \\
\text { организация рабочих мест }\end{array}$ \\
\hline Моральный аспект (МА) & $\begin{array}{l}И_{1}^{M A}-\text { публичное объявление благодарности; } \\
И_{2}^{M A}-\text { занесение фото работника на доску почета; } \\
И_{3}^{M A}-\text { награждение почетной грамотой }\end{array}$ \\
\hline
\end{tabular}

Очевидно, что представленный перечень (табл. 1), аккумулирующий 18 индикаторов (профильных трудовых мотивов) является условным. В зависимости от сложившейся ситуации (конкретных условий апробации) он может быть откорректирован, как в сторону удлинения за счет расширения анализируемых аспектов и/или индикаторов, так и в сторону их сокращения.

3. Использование для идентификации выделенных мотивационных единиц так называемых мотивограмм - иллюстраторов структуры трудовых мотивов (МИ - мотивоиллюстраторов), представленных профильными индикаторами.

4. Применение для выявления структуры анализируемых трудовых мотивов идеи $[10$, c. 16-26], положенной в основу построения «мотивационного профиля».

Инструментом сбора анализируемой информации в предлагаемой методике служит Анкета респондента (работника предприятия), объединяющая 12 вопросов-утверждений, каждое из которых содержит 3 варианта ответа, идентичных индикаторам трудовой мотивации, оцениваемых 
в баллах. Количество анализируемых параметров, как правило, составляет 10-12. Для иллюстрации инструментария, предназначенного для выявления «мотивационного профиля», предположим, что анализируемый перечень формируют по два индикатора ( $h_{1}$ и $\left.h_{2}\right)$, отражающих все обозначенные аспекты трудовой мотивации (табл. 1):

- стимулирующий аспект (CA);

- карьерно-профессиональный аспект (КПА);

- социально-психологический аспект (СПА);

- функциональный аспект (ФА);

- организационный аспект (OA);

- моральный аспект (MA).

Заполнение Анкеты проводится в соответствии со следующей инструкцией: «Вам нужно распределить 10 баллов между тремя вариантами каждого из утверждений, обозначенных буквами: X, У, Z. Если Вам кажется, что один из вариантов наиболее важен для вас, оцените его в 10 баллов; если вы полагаете его вовсе не существенным, не присуждайте ему ни одного балла; в остальных случаях постарайтесь по собственному усмотрению распределить все 10 баллов между тремя предложенными в каждом утверждении вариантами. Для получения наилучших результатов на вопросы следует отвечать быстро, не раздумывая подолгу».

\section{Анкета респондента (фрагмент)}

\section{1. Абсолютно приоритетным считаю предприятие, на котором:}

$\mathrm{X}$. Есть возможность для карьерного роста.

У. Уровень заработной платы обеспечивает достойное качество жизни.

Z. Созданы хорошие (комфортные) условия труда.

2. Для меня принципиально, чтобы на предприятии:

Х. Регулярно и своевременно проводилась аттестация рабочих мест по условиям труда. 
У. Была возможность для профессионального развития.

Z. Систематически внедрялись инновации в сфере производства и организации труда.

3. Значимыми критериями эффективной мотивационной системы для меня являются:

$\mathrm{X}$. Нормальный социально-психологический климат в коллективе.

У. Моральное поощрение, сопряженное с публичным объявлением благодарности за высокие результаты профессиональной деятельности.

Z. Уровень заработной платы работника, полностью адекватный результативности его труда.

4. Никогда не устроюсь на предприятие, на котором:

Х. Отсутствует творческий характер труда.

У. Отсутствуют развитые социально-трудовые отношения.

Z. Не реализуется такая форма морального поощрения работников, как размещение их фото на доске почета.

\section{5. Критериями успешного трудоустройства считаю:}

$\mathrm{X}$. Развитые социально-трудовые отношения, способствующие полному использованию образовательно-квалификационного потенциала работника.

У. Возможность для профессионального развития.

Z. Уровень заработной платы, обеспечиваемый полной реализацией ее стимулирующей функции.

6. Желательно, чтобы на моем рабочем месте:

Х. Применялись инновационные формы организации труда.

У. Проводилась своевременная аттестация рабочих мест.

Z. Де-факто имелась возможность для карьерного роста.

7. Мне бы очень хотелось, чтобы на предприятии:

X. Реализовывалась такая форма морального поощрения, как публичное объявление благодарности отличившемуся работнику. 
У. Были созданы условия труда, полностью соответствующие действующим нормативам по охране труда и технике безопасности.

$\mathrm{Z}$. Был нормальный социально-психологический климат в коллективе.

8. Считаю социально-ориентированным предприятие, на котором:

Х. Уровень заработной платы соответствует социальноориентированным нормативам.

У. Практикуется такая форма морального поощрения, как занесение персональных данных работника на доску почета.

Z. Действующая система премирования была ориентирована на поощрение творческих инициатив работника.

9. Считаю серьезным недостатком кадровой политики предприятия отсутствие возможностей для:

Х. Обоснованного карьерного роста.

У. Своевременной аттестации рабочих мест.

Z. Обеспечения достойного уровня жизни работникам предприятия и членам их семей.

10. Считаю, что эффективность труда повышается, если:

Х. Есть возможность для профессионального развития персонала.

У. Обеспечена взаимосвязь между уровнем заработной платы и результатами труда.

Z. Созданы условия труда, полностью соответствующие профильным нормативам.

11. Мне бы очень хотелось, чтобы на «моем» предприятии:

Х. Был нормальный социально-психологический климат в коллективе.

У. Регулярно и целенаправленно внедрялись инновационные формы организации, стимулирования и оценки персонала.

Z. Реализовывалась такая форма морального поощрения работников, как публичное объявление благодарности отличившимся работникам. 


\section{2. Для меня важнейшие критерии эффективной системы} организации труда:

$\mathrm{X}$. Возможность для проявления творческих инициатив.

У. Размещение фото эффективно работающих сотрудников на доске почета.

Z. Социально-трудовые отношения, способствующие повышению эффективности и результативности производства.

Безусловно, исследователь может сформировать опросник, используя другие (на его взгляд, более обоснованные утверждения) и, соответственно, иной шаблон сводных результатов опроса респондентов (табл. 2).

Каждый из анализируемых трудовых мотивов (индикаторов) может набрать от 30 (максимум) до 0 (минимум) баллов (табл. 3). Переведя набранные баллы в относительные величины (проценты от общей суммы баллов, равной в представляемом варианте 120), получим профиль приоритетности, отражающий долевую структуру трудовой мотивации персонала. Поэтому максимальная доля (доля индикатора-лидера) в мотивационном профиле может достигать $\left(\frac{30 \times 100}{120}\right) 25 \%$. Если допустить, что все индикаторы, формирующие мотивационный профиль работника, равноценны $\left(\frac{10 \times 100}{120}=8,3 \%\right)$, это будет означать, что поведение индивида не поддается мотивационному управлению по причине отсутствия явных управленческих рычагов (мотивов-лидеров). 
Таблица 2

Шаблон сводных результатов опроса респондентов

\begin{tabular}{|c|c|c|c|c|c|c|c|c|c|c|c|c|}
\hline \multirow{3}{*}{$\begin{array}{l}\text { № } \\
\Pi / \Pi\end{array}$} & \multicolumn{12}{|c|}{ Трудовые мотивы (индикаторы системы трудовой мотивации) } \\
\hline & $U_{1}^{C A}$ & $U_{2}^{C A}$ & $U_{1}^{K \Pi A}$ & $U_{2}^{K \Pi A}$ & $U_{1}^{C I A}$ & $U_{2}^{C \Pi A}$ & $U_{1}^{\Phi A}$ & $U_{2}^{\Phi A}$ & $H_{1}^{O A}$ & $U_{2}^{O A}$ & $U_{1}^{M A}$ & $U_{2}^{M A}$ \\
\hline & 1 & 2 & 3 & 4 & 5 & 6 & 7 & 8 & 9 & 10 & 11 & 12 \\
\hline 1 & $\mathrm{y}$ & & $X$ & & & & & & $\mathrm{Z}$ & & & \\
\hline 2 & & & & $\mathrm{y}$ & & & $\mathrm{Z}$ & & & $\mathrm{X}$ & & \\
\hline 3 & & $\mathrm{Z}$ & & & $\mathrm{X}$ & & & & & & $\mathrm{y}$ & \\
\hline 4 & & & & & & $\mathrm{y}$ & & $\mathrm{X}$ & & & & $\mathrm{Z}$ \\
\hline 5 & & Z & & $\mathrm{y}$ & & $X$ & & & & & & \\
\hline 6 & & & $\mathrm{Z}$ & & & & $\mathrm{X}$ & & & $\mathrm{y}$ & & \\
\hline 7 & & & & & $\mathrm{Z}$ & & & & $\mathrm{y}$ & & $\mathrm{X}$ & \\
\hline 8 & $X$ & & & & & & & $Z$ & & & & $\mathrm{y}$ \\
\hline 9 & $\mathrm{Z}$ & & $\mathrm{X}$ & & & & & & & $\mathrm{y}$ & & \\
\hline 10 & & $\mathrm{y}$ & & $X$ & & & & & $Z$ & & & \\
\hline 11 & & & & & $\mathrm{X}$ & & $\mathrm{y}$ & & & & $Z$ & \\
\hline 12 & & & & & & $\mathrm{Z}$ & & $\mathrm{X}$ & & & & $\mathrm{y}$ \\
\hline $\begin{array}{c}\text { Итог } \\
\text { о }\end{array}$ & $\ldots$ & $\ldots$ & $\ldots$ & $\ldots$ & $\ldots$ & $\ldots$ & $\ldots$ & $\ldots$ & $\ldots$ & $\ldots$ & $\ldots$ & $\ldots$ \\
\hline
\end{tabular}

Реализация мотивационной модели управления поведением персонала опирается на выявление и анализ индивидуальных мотивационных профилей.

Обработка материалов опросной статистики респондентов - работников предприятия, анкетируемых в соответствии с обоснованной выборкой, предполагает:

1. Анализ структуры мотивов труда и типа мотивационного профиля.

2. Ранжирование трудовых мотивов (индикаторов) - разграничение их на три условных типа:

ВЗМ - высокозначимые мотивы, оказывающие управленческое воздействие на поведение работника (персонала);

СЗМ - среднезначимые мотивы, оказывающие корректирующее воздействие на поведение работника (персонала); 
НЗМ - низкозначимые мотивы, не влияющие на поведение работника (персонала).

3. Формирование (обоснование) мотивограмм респондентов (табл. 4), иллюстрирующих выявленный мотивационный профиль в разрезе относительной значимости и анализируемой аспектности индикаторов. Принципиально, что состав мотивограмм (мотивоиллюстраторов) формируют только высокозначимые мотивы, оказывающие управленческое воздействие на поведение работника (персонала) и обоснованно позиционируемые как «мотивационные рычаги» (по сути, рычаги управления поведением).

Представляется, что различают:

- одноаспектный состав В3М, включающий один или несколько однотипных индикаторов-лидеров, например, стимулирующих (табл. 4);

- многоаспектный состав ВЗМ (табл. 5), когда «мотивационными рычагами», де-факто управляющими поведением работника (персонала), являются разноаспектные индикаторы. Не секрет, что именно схожесть состава высокозначимых мотивов (по сути, однотипность мотивограмм) является основанием для объединения работников разных функциональных категорий (профессий, должностей) в условные мотивационные единицы.

Таблица 3

Матрица мотивационного профиля респондента (условный пример)

\begin{tabular}{|c|c|c|c|c|c|c|c|c|c|c|c|c|}
\hline \multirow{3}{*}{$\begin{array}{l}\text { № } \\
\text { П/П }\end{array}$} & \multicolumn{12}{|c|}{ Трудовые мотивы (индикаторы системы трудовой мотивации) } \\
\hline & $H_{1}^{C A}$ & $H_{2}^{C A}$ & $И_{1}^{K \Pi A}$ & $U_{2}^{K \Pi A}$ & $H_{1}^{C \Pi A}$ & $U_{2}^{C I I A}$ & $U_{1}^{\Phi_{i}}$ & $U_{2}^{\Phi A}$ & $H_{1}^{O A}$ & $H_{2}^{O A}$ & $h_{1}^{M A}$ & $H_{2}^{M A}$ \\
\hline & 1 & 2 & 3 & 4 & 5 & 6 & 7 & 8 & 9 & 10 & 11 & 12 \\
\hline 1 & 8 & & 2 & & & & & & 0 & & & \\
\hline 2 & & & & 6 & & & 2 & & & 2 & & \\
\hline 3 & & 8 & & & 2 & & & & & & 0 & \\
\hline 4 & & & & & & 3 & & 5 & & & & 2 \\
\hline 5 & & 7 & & 2 & & 1 & & & & & & \\
\hline
\end{tabular}


Продолжение Таблицы 3

\begin{tabular}{|c|c|c|c|c|c|c|c|c|c|c|c|c|}
\hline 6 & & & 5 & & & & 3 & & & 2 & & \\
\hline 7 & & & & & 4 & & & & 4 & & 2 & \\
\hline 8 & 10 & & & & & & & 0 & & & & 0 \\
\hline 9 & 7 & & 2 & & & & & & & 1 & & \\
\hline 10 & & 8 & & 1 & & & & & 1 & & & \\
\hline 11 & & & & & 3 & & 4 & & & & 3 & \\
\hline 12 & & & & & & 6 & & 4 & & & & 0 \\
\hline $\begin{array}{c}\text { Итого } \\
\text { (баллы) }\end{array}$ & 25 & 23 & 9 & 9 & 9 & 10 & 9 & 9 & 5 & 5 & 5 & 2 \\
\hline
\end{tabular}

Таблица 4

\section{Одноаспектная мотивограмма условного (модельного) респондента}

\begin{tabular}{|c|c|c|c|c|c|c|}
\hline \multirow[t]{2}{*}{$\begin{array}{c}\text { Мотивы } \\
\text { (индикаторы) }\end{array}$} & \multirow[t]{2}{*}{$\begin{array}{l}\text { Оценка, } \\
\text { быллы }\end{array}$} & \multirow[t]{2}{*}{$\begin{array}{c}\text { Структура, } \\
\%\end{array}$} & \multicolumn{3}{|c|}{$\begin{array}{l}\text { Ранжирование } \\
\text { мотивов труда }\end{array}$} & \multirow[t]{2}{*}{$\begin{array}{c}\text { Мотивограмма } \\
\text { респондента }\end{array}$} \\
\hline & & & B3M & C3M & H3M & \\
\hline$U_{1}^{C A}$ & 25 & 20,8 & + & & & \multirow[t]{12}{*}{$M \Gamma_{i}=B 3 M\left(U_{1}^{C A} ; И_{2}^{C A}\right.$} \\
\hline$U_{2}^{C A}$ & 23 & 19,2 & + & & & \\
\hline$U_{1}^{K \Pi A}$ & 9 & 7,5 & & + & & \\
\hline$И_{2}^{K \Pi A}$ & 9 & 7,5 & & + & & \\
\hline$U_{1}^{C П A}$ & 9 & 7,5 & & + & & \\
\hline$И_{2}^{C \Pi A}$ & 10 & 8,3 & & + & & \\
\hline$U_{1}^{\Phi A}$ & 9 & 7,5 & & + & & \\
\hline$U_{2}^{\Phi A}$ & 9 & 7,5 & & + & & \\
\hline$U_{1}^{O A}$ & 5 & 4,2 & & & + & \\
\hline$U_{2}^{O A}$ & 5 & 4,2 & & & + & \\
\hline$U_{1}^{M A}$ & 5 & 4,2 & & & + & \\
\hline$И_{2}^{M A}$ & 2 & 1,6 & & & + & \\
\hline Итого & 120 & 100 & - & - & - & - \\
\hline
\end{tabular}


Таблица 5

\section{Многоаспектная мотивограмма условного (модельного) респондента}

\begin{tabular}{|c|c|c|c|c|c|c|}
\hline \multirow[t]{2}{*}{$\begin{array}{c}\text { Мотивы } \\
\text { (индикаторы) }\end{array}$} & \multirow[t]{2}{*}{$\begin{array}{c}\text { Оценка, } \\
\text { баллы }\end{array}$} & \multirow[t]{2}{*}{$\begin{array}{c}\text { Структура, } \\
\%\end{array}$} & \multicolumn{3}{|c|}{$\begin{array}{l}\text { Ранжирование } \\
\text { мотивов труда }\end{array}$} & \multirow[t]{2}{*}{$\begin{array}{c}\text { Мотивограмма } \\
\text { респондента }\end{array}$} \\
\hline & & & B3M & C3M & H3M & \\
\hline$U_{1}^{C A}$ & 11 & 9,2 & & + & & \multirow{12}{*}{$\begin{array}{l}M \Gamma_{i}=B 3 M\left(И_{2}^{C A}\right. \\
\left.И_{1}^{K \Pi A} ; И_{2}^{K \Pi A} ; И_{2}^{\Phi A}\right)\end{array}$} \\
\hline$U_{2}^{C A}$ & 20 & 16,7 & + & & & \\
\hline$И_{1}^{K \Pi A}$ & 18 & 15,0 & + & & & \\
\hline$И_{2}^{K \Pi A}$ & 17 & 14,2 & + & & & \\
\hline$И_{1}^{C П A}$ & 5 & 4,2 & & & + & \\
\hline$И_{2}^{C П A}$ & 4 & 3,3 & & & + & \\
\hline$U_{1}^{\Phi A}$ & 9 & 7,5 & & + & & \\
\hline$U_{2}^{\Phi A}$ & 16 & 13,3 & + & & & \\
\hline$U_{1}^{O A}$ & 9 & 7,5 & & + & & \\
\hline$U_{2}^{O A}$ & 4 & 3,3 & & & + & \\
\hline$U_{1}^{M A}$ & 4 & 3,3 & & & + & \\
\hline$U_{2}^{M A}$ & 3 & 2,5 & & & + & \\
\hline Итого & 120 & 100 & - & - & - & - \\
\hline
\end{tabular}

Накопленный опыт [2, 5] указывает на целесообразность первоначального внедрения мотивационной модели управления поведением персонала (ММУПП) на локальном уровне, то есть, на уровне конкретного структурного подразделения предприятия, выбранного для пилотной апробации предлагаемой методики, которое условимся называть объектом базового эксперимента.

Основополагающими при выборе объекта базового эксперимента являются следующие критерии: 
1. Соотнесение закрепленного за ним функционала с основным (профильным) видом деятельности предприятия, зафиксированным в его учредительных документах.

2. Экономическая благополучность и финансовая устойчивость, обеспечиваемые высокой результативностью производственно-хозяйственной деятельности анализируемого структурного подразделения (то есть, объектом базового эксперимента не может быть подразделение-аутсайдер).

3. Относительная немногочисленность (до 100 человек) персонала, поскольку ММУПП основывается на анализе индивидуальных мотивационных профилей (табл. 3) и разработке персональных мотивограмм (табл. 4-5).

4. Высокая (по меньшей мере, достаточная для адекватного восприятия проводимого эксперимента) лояльность персонала.

5. Диверсифицированность профессионально-категориальной структуры работников.

Алгоритм методического сопровождения внедрения на локальном уровне мотивационной модели управления поведением персоналом (ММУПП) предполагает последовательное выполнение следующих 12 этапов:

1. Первый этап - обоснование выбора объекта базового эксперимента в соответствии с обозначенными критериями.

2. Второй этап - анализ профессионально-категориального состава и структуры персонала, сопряженый с разграничением работников по профессиям и/или должностям в разрезе профильных функциональных категорий (в частности, для промышленного предприятия таких, как «руководители», «специалисты», «рабочие», «служащие»).

3. Третий этап - экспресс-диагностика системы трудовой мотивации [2], проводимая с помощью выборочного анкетирования и/или 
интервьюрования респондентов, нацеленная на уточнение наиболее значимых аспектов и профильных индикаторов.

4. Четвертый этап - обоснование по результатам экспресс-диагностики аспектно-индикаторной структуры мотивов труда (табл. 1).

5. Пятыцй этап - разработка Анкеты респондента, аккумулирующей вопросы-утверждения, предназначенные для формирования матрицы индивидуального мотивационного профиля (табл. 3).

6. Шестой этап - сплошное (полное, стопроцентное) анкетирование персонала объекта базового эксперимента.

7. Седьмой этап - анализ и обработка материалов опросной статистики, нацеленные на составление индивидуальных мотивограмм (табл. 4-5) работников анализируемого структурного подразделения.

8. Восьмой этап - систематизация результатов опросной статистики формирование так называемого реестра мотивограмм $\left(M \Gamma_{i}\right)$ и обоснование количества выделяемых мотивационных единиц ( $M E)$. Допустим, на основании анализа состава высокозначимых мотивов (ВЗМ) было выделено 7 вариантов мотивограмм $\left(M \Gamma_{1}, M \Gamma_{2}, \ldots, M \Gamma_{7}\right)$ и 7 типов соответствующих им мотивационных единиц $\left(M E_{1}, M E_{2}, \ldots, M E_{7}\right)$.

9. Девятый этап - составление Карты категориально-мотивационного состава и структуры персонала объекта базового эксперимента (табл. 6).

Для идентификации работников целесообразно использовать буквенную символику (А - Андреев, Б - Борисов, В - Васильев и т.д.). Для обозначения функциональных категорий (ФК) персонала логично применить типовые сокращения (руководитель - «рук»; рабочий - «раб»; специалист - «сп»). Для идентификации должностей (Д) руководителей $\quad$ (ДР), должностей специалистов (ДС) и профессий рабочих (ПР) допустимо использовать цифровую символику. 
Таблица 6

Фрагмент Карты категориально-мотивационного состава и структуры персонала (условный пример)

\begin{tabular}{|c|c|c|c|c|c|c|c|c|c|}
\hline \multirow{2}{*}{$\begin{array}{c}\text { ФИО } \\
\text { работника }\end{array}$} & \multirow[t]{2}{*}{ ФК } & \multirow[t]{2}{*}{ Д/П } & \multicolumn{7}{|c|}{ Мотивационные единицы (мотивограммы) } \\
\hline & & & $\begin{array}{c}1 \\
\left(M \Gamma_{1}\right)\end{array}$ & $\begin{array}{c}2 \\
\left(M \Gamma_{2}\right)\end{array}$ & $\begin{array}{c}3 \\
\left(M \Gamma_{3}\right)\end{array}$ & $\begin{array}{c}4 \\
\left(M \Gamma_{4}\right)\end{array}$ & $\begin{array}{c}5 \\
\left(M \Gamma_{5}\right)\end{array}$ & $\begin{array}{c}6 \\
\left(M \Gamma_{6}\right)\end{array}$ & $\begin{array}{c}7 \\
\left(M \Gamma_{7}\right)\end{array}$ \\
\hline A & Рук & ДР 1 & $\mathrm{X}$ & & & & & & \\
\hline Б & Раб & $\mathrm{CP}_{1}$ & & $\mathrm{X}$ & & & & & \\
\hline B & Раб & $\Pi \mathrm{P}_{1}$ & & & $\mathrm{X}$ & & & & \\
\hline$\Gamma$ & Раб & $\Pi^{\prime} P_{2}$ & $\mathrm{X}$ & & & & & & \\
\hline Д & Сп & ДС ${ }_{1}$ & & & & & & $\mathrm{X}$ & \\
\hline$E$ & Раб & $\Pi \mathrm{P}_{3}$ & & & & $X$ & & & \\
\hline Ж & Рук & $\mathrm{LP}_{2}$ & & X & & & & & \\
\hline 3 & Сп & ДС 2 & & & & & $\mathrm{X}$ & & \\
\hline И & Раб & $\Pi \mathrm{P}_{4}$ & & & $\mathrm{X}$ & & & & \\
\hline K & Раб & $\Pi \mathrm{P}_{5}$ & & & & & & & \\
\hline Л & Сп & ДС & & $\mathrm{X}$ & & & & & \\
\hline $\mathrm{M}$ & Раб & $\Pi \mathrm{P}_{3}$ & & & & & & & $\mathrm{X}$ \\
\hline$\ldots$ & $\ldots$ & $\ldots$ & $\ldots$ & $\ldots$ & $\ldots$ & $\ldots$ & $\ldots$ & $\ldots$ & $\ldots$ \\
\hline Итого & - & - & $\sum X_{1}$ & $\sum X_{2}$ & $\sum X_{3}$ & $\sum X_{4}$ & $\sum X_{5}$ & $\sum X_{6}$ & $\sum X_{7}$ \\
\hline Структура & - & - & $d X_{1}$ & $d X_{2}$ & $d X_{3}$ & $d X_{4}$ & $d X_{5}$ & $d X_{6}$ & $d X_{7}$ \\
\hline
\end{tabular}

Очевидно (табл. 6), что каждую мотивационную единицу могут формировать представители как одной, так и нескольких функциональных категорий, имеющие (занимающие) схожие или разные профессии (должности), но обладающие идентичным составом высокозначимых мотивов («мотивационных рычагов» или рычагов управления их поведением).

10. Десятый этап - составление Паспорта мотивационной модели управления поведением персонала анализируемого структурного подразделения - объекта базового эксперимерта (табл. 7).

Подчеркнем, что реализация данного этапа предполагает:

- расчет численности персонала мотивационных единиц ( $\left.\sum X_{1} \ldots \sum X_{7}\right)$; 
- расчет долевой структуры мотивационных единиц $\left(d X_{1} \ldots d X_{7}\right)$;

- обоснование управленческих рычагов в разрезе выявленных мотивационных единиц (табл. 6);

- диагностику типа мотивограмм (состава индикаторов ВЗМ).

Таблица 7

Паспорт мотивационной модели управления поведением персонала (условный пример)

\begin{tabular}{|c|c|c|c|c|}
\hline \multirow{2}{*}{$\begin{array}{c}\text { Мотивационные } \\
\text { единицы (ME) }\end{array}$} & \multicolumn{2}{|c|}{ Персонал МЕ } & \multirow{2}{*}{$\begin{array}{c}\text { Управленческие рычаги } \\
\text { (индикаторы В3М) }\end{array}$} & \multirow{2}{*}{$\begin{array}{c}\text { Тип мотивограмм (состав } \\
\text { индикаторов ВЗМ) }\end{array}$} \\
\hline & чел. & $\%$ & & \\
\hline $\mathrm{ME}_{1}$ & 15 & 15,8 & $U_{1}^{C A} ; U_{2}^{C A}$ & одноаспектный \\
\hline $\mathrm{ME}_{2}$ & 25 & 26,3 & $И_{1}^{C A} ; И_{1}^{K \Pi A}$ & двухаспектный \\
\hline $\mathrm{ME}_{3}$ & 19 & 20,0 & $И_{2}^{C A} ; И_{2}^{K \Pi A} ; И_{1}^{C \Pi A}$ & трехаспектный \\
\hline $\mathrm{ME}_{4}$ & 12 & 12,6 & $U_{2}^{C A} ; И_{2}^{\Phi A}$ & двухаспектный \\
\hline $\mathrm{ME}_{5}$ & 10 & 10,5 & ${ }_{1}^{C A} ; И_{2}^{C A} ; И_{1}^{O A}$ & двухаспектный \\
\hline $\mathrm{ME}_{6}$ & 8 & 8,4 & $И_{2}^{K \Pi A} ; И_{1}^{\Phi A} ; И_{1}^{C \Pi A}$ & трехаспектный \\
\hline $\mathrm{ME}_{7}$ & 6 & 6,4 & $И_{1}^{C I I A} ; И_{1}^{O A} ; И_{2}^{\Phi A}$ & трехаспектный \\
\hline Итого & 95 & 100,0 & - & - \\
\hline
\end{tabular}

Представляется (табл. 7), что ряд индикаторов - развитые социальнотрудовые отношения ( $\left.U_{2}^{\text {СпA }}\right)$, своевременная аттестация рабочих мест $\left(U_{2}^{\text {OA }}\right)$, публичное объявление благодарности $\left(U_{1}^{M A}\right)$, занесение фото работника на доску почета $\left(U_{2}^{M A}\right)$, не были включены в Паспорт ММУПП, поскольку не получили по результатам анкетирования респодентов статус ВЗМ.

11. Одиннадцатый этап - выявление сферы управления индикатора В3М и оценка его управленческого потенциала - численности работников, для которых анализируемый индикатор является высокозначимым (табл. 8). 
Индикаторы ВЗМ (рычаги управления поведением персонала), проранжированные по величине управленческого потенциала (табл. 8), образуют следующую вертикаль значимости:

1) справедливый уровень заработной платы $\left(U_{2}^{C A}\right)$;

2) достойный уровень заработной платы $\left(U_{1}^{C A}\right)$;

3) нормальный социально-психологический климат в коллективе ( $\left.U_{1}^{\text {CПA }}\right)$;

4) возможность профессионального развития $\left(U_{2}^{\text {KПА }}\right)$;

5) возможность карьерного роста $\left(U_{1}^{\text {KПА }}\right)$;

6) творческий характер труда $\left(U_{2}^{\phi_{A}}\right)$;

7) хорошие (комфортные) условия труда $\left(U_{1}^{O A}\right)$;

8) инновационный характер труда $\left(U_{1}^{\Phi A}\right)$.

Таблица 8

Управленческий потенциал высокозначимых мотивов труда

\begin{tabular}{|c|c|c|c|}
\hline $\begin{array}{l}\text { Индикаторы } \\
\text { ВЗМ (табл.7) }\end{array}$ & Сфера управления & $\begin{array}{l}\text { Управленческий } \\
\text { потенциал, чел. }\end{array}$ & $\begin{array}{c}\text { Ранг } \\
\text { индикатора }\end{array}$ \\
\hline$U_{1}^{C A}$ & $\mathrm{ME}_{1} ; \mathrm{ME}_{2} ; \mathrm{ME}_{5}$ & $15+25+10=50$ & 2 \\
\hline$U_{2}^{C A}$ & $\mathrm{ME}_{1} ; \mathrm{ME}_{3} ; \mathrm{ME}_{4} ; \mathrm{ME}_{5}$ & $15+19+12+10=56$ & 1 \\
\hline$И_{1}^{\kappa \Pi A}$ & $\mathrm{ME}_{2}$ & 25 & 5 \\
\hline$И_{2}^{\kappa \Pi A}$ & $\mathrm{ME}_{3} ; \mathrm{ME}_{6}$ & $19+8=27$ & 4 \\
\hline$U_{1}^{C \Pi A}$ & $\mathrm{ME}_{3} ; \mathrm{ME}_{6} ; \mathrm{ME}_{7}$ & $19+8+6=33$ & 3 \\
\hline$U_{1}^{\Phi A}$ & $\mathrm{ME}_{6}$ & 8 & 8 \\
\hline$U_{2}^{\Phi A}$ & $\mathrm{ME}_{4} ; \mathrm{ME}_{7}$ & $12+6=18$ & 6 \\
\hline$U_{1}^{O A}$ & $\mathrm{ME}_{5} ; \mathrm{ME}_{7}$ & $10+6=16$ & 7 \\
\hline
\end{tabular}

12. Двенадиатый этап - разработка программы мотивационного управления поведением персонала, ориентированной на «управленческий мотивационный эффект» индикаторов ВЗМ с учетом выявленных рангов. 289 


\section{ЧЕЛОВЕК И СОВРЕМЕННОЕ ОБЩЕСТВО В СОЦИАЛЬНОМ, ПРАВОВОМ, ЭКОНОМИЧЕСКОМ РАКУРСАХ}

Безусловно, центральное место в программе условного (модельного) объекта (табл. 8) должно быть отведено совершенствованию системы оплаты труда, направленному на усиление стимулирующей и воспроизводственной функций заработной платы, а, соответственно, на обеспечение ее справедливого и достойного уровня (например, за счет внедрения на предприятии гибкой системы оплаты труда).

В заключение подчеркнем, что механизм мотивационного управления поведением персонала предприятия (организации) может дать значительный эффект, величина которого зависит от правильности постановки цели, ее согласованности с интересами работников и степени осознания ими мотивирующих воздействий, а главное - от наличия и адекватности предъяляемым требованиям методического инструментария, обеспечивающего внедрение и успешное функционирование ММУПП. Последнее из отмеченных обстоятельств является дополнительным весомым аргументом, обосновывающим правомерность тиражирования представленного теоретико-методического материала в профильных изданиях.

\section{Список литературы}

1. Апенько С.Н. Поведение в организации: учебное пособие. - Омск: ОмГУ, 2002. - 330 с.

2. Миляева Л.Г. Мотивация, оценка и стимулирование труда персонала организаций: монография. - Барнаул: Изд-во Алт. гос. тех. ун-та, 2005. $190 \mathrm{c}$.

3. Русинов Ф., Петросян Д. Теория современного менеджмента и экономика России // Проблемы теории и практики управления. - 1993. - № 6. - C. 64-69.

4. Шрайэгг Г., Носс К. Изжила ли себя организационная структура // Проблемы теории и практики управления. - 1994. - № 4. - С. 78-82. 
5. Миляева Л.Г., Леонова С.Г. Мотивационная модель управления научно-педагогическим персоналом вуза: монография. - Бийск: Изд-во Алт. гос. тех. ун-та, 2008. -98 с.

6. Удалов Ф.Е., Алехина О.Ф., Воронов Н.А. Управление поведением персонала на промышленных предприятиях // ЭКО. - 2010. - № 4. - С. 128 136.

7. Горшенин В.П., Резанович И.В. Управление ресурсосберегающим поведением персонала промышленного предприятия // Современные проблемы науки и образования. - 2014. - № 5. - С. 424.

8. Овсянникова Т.С., Алямкина Е.А., Бурыкин Е.С. Типология личностей и ее практическое применение в условиях развития инновационной экономики // Вестник Московского университета им. С.Ю. Витте. Серия 1: Экономика и управление. - 2015. - № 1 (12). - С. 120-125.

9. Миляева Л.Г. Трансформационно-структурный анализ трудовой мотивации персонала организаций // Вестник Томского государственного университета. - 2015. - № 398. - С. 68-72.

10. Ричи Ш., Мартин П. Управление мотивацией: учеб. пособие для вузов / Пер. с англ. под ред. проф. Е.А. Климова. - М.: ЮНИТИ-ДАНА, 2004. $-399 \mathrm{c}$.

(C) Л.Г. Миляева, 2022 
УДК 338

Глава 12.

УПРАВЛЕНИЕ ДЕЯТЕЛЬНОСТЬЮ СУБЬЕКТА С УЧЕТОМ ФУНКЦИОНАЛЬНЫХ И СТРУКТУРНЫХ КРИТЕРИЕВ

Арсеньев Юрий Николаевич д.т.н., профессор, акад. АНЗ, АИО, МАОП Разумовская Татьяна Ивановна канд. соц. наук, доцент, директор филиала Тульский филиал РАНХиГС при Президенте РФ Давыдова Татьяна Юрьевна канд. пед. наук, доцент Тульский государственный педагогический университет

Аннотация: В статье исследуется специфика управления деятельностью живого организма человека по структурным и функциональным критериям.

Ключевые слова: этапы развития точных и философских наук, развития личности, модели управления жизнью субъекта, показатели, критерии.

\title{
MANAGEMENT OF THE ENTITY'S ACTIVITIES TAKING INTO ACCOUNT FUNCTIONAL AND STRUCTURAL CRITERIA
}

\author{
Arsenyev Yuri Nikolaevich \\ Razumovskaya Tatyana Ivanovna \\ Davydova Tatyana Yuryevna
}

\begin{abstract}
The specifics of managing the activity of a living human organism according to structural and functional criteria are investigated.
\end{abstract}


Key words: stages of development of exact and philosophical sciences, personality development, models of managing the life of the subject, indicators, criteria.

Жизнь разумного творческого человека хранит еще массу тайн и загадок. Одна из них - кто такой человек, каковы законы и принципы его жизнедеятельности, каков механизм управления заложен в его структуру, как в совокупности они проявляются в масштабе личности и Вселенной. Одна часть ученых стоит на позиции материализма, считая человека творцом себя на основе его разума, чувств и мыслей, другая - пытается совместить современные достижения прогресса в исследовании человека, интегрирующего в себе тело, разум, чувства и мысли, найти сочетание материального и идеального [1-15]. Такой подход к деятельности человека, как субъекта управления, с учетом прогресса предложил Карманов К.Ю. [16]. Рассмотрим его как интересный проект с позиции [17-21].

С понятием идеального человек знакомится в раннем возрасте: это реальность, непохожая на материю, о которой нельзя уверенно сказать, тождественна ли ее глубинная природа материи или нет. Попытка поиска ответа в точных науках и физике бесполезна: физика проблемой природы мысли не занимается, и мысль количественно не измерима. Это можно исследовать на основе философии, систем спекулятивного знания, в частности, метода рассуждений. Под «человеком», как «Я», понимают именно субъекта, а не его тело (тело и «Я» различны: тело - объект или то, на что направлено действие, к чему «Я» приложен, как некоторая сила). Если «Я» захотелось пошевелить рукой, то можно увидеть, как тело придет в движение. Однако того, кто отдал приказ на исполнение, субъекта, инициатора действия, не видно (этот субъект и есть «Я»). Отсюда следует первый вывод: меня, человека, увидеть нельзя (это порождает массу вопросов, новую цепочку 
рассуждений, ибо «Я» посредством управления соотнесен со своим телом, но в то же время «Я» не в теле и не поддаюсь обнаружению; нельзя указать мои координаты, мой размер или как-то определить меня в пространстве). «Я» просто соотнесен с материей тела как некоторая управленческая реальность, как поток мыслей, вдруг обнаружив, что это тело следует считать своим, потому что «Я» связан с ним от рождения, и не в силах от него оторваться. Но если «Я» лишь поток соображений, иначе говоря, поток мысли, то становится понятно, что меня нельзя видеть. Мы не более чем сопричастны своему телу, мы - лишь свидетели процессов, происходящих с ним. Однако нам присуща важная функция: пробуждаясь по утрам, мы организуем процесс взаимодействия тела со средой обитания, выступая субъектами, организаторами своего поведения. Чувства задают нам вектор поведения и фактически управляют нами. Посредством актов поведения мы исполняем задачи, задаваемые чувством, ибо ни на что иное мы не «запрограммированы». Как способность управлять, мы нужны именно для этой цели.

Возникает вопрос: если «Я» не тело, то кто тогда «Я»? Точные науки не дают на это ответа. Попытаемся вывести природу «Я» человека через функцию, которую мы реально выполняем в организме: нас «включают» для осуществления серии актов управления. Тогда человек - «включаемый» по утрам, в период бодрствования, управленческий процесс, имеющий свое собственное активное начало. В частных случаях мысль выступает источником движения материи. Если нечто работает в единичном случае, то оно может быть справедливо и в общем. Факт, что «Я» могу управлять движением материи, позволяет создать методологию, базирующуюся на ряде следующих фактологических данных.

1. Фундаментальные свойства материи таковы, что позволяют ей соприкасаться с субъектом, организовать узел их стыка, специфичный 


\section{ЧЕЛОВЕК И СОВРЕМЕННОЕ ОБЩЕСТВО В СОЦИАЛЬНОМ, ПРАВОВОМ, ЭКОНОМИЧЕСКОМ РАКУРСАХ}

интерфейс, где две среды (материя и мысль) осуществляют передачу друг другу своей специфичности. Материя тела - среда, находящаяся под управлением мысли. Со всей материей Вселенной должна быть соотнесена некоторая незримая мысль или среда по типу мысли (то, что она недоступна взору и не фиксируется приборами, - не основание отрицания ее реальности: ни один из субъектов не обнаруживается физическими методами, но в их существовании сомнения нет; физическим аспектом бытия все многообразие мира не исчерпано, ему присущи реальности по типу способности управлять. Тем, кто занят фундаментальным изучением материи, выдается пожелание: ищите материю, и вы найдете субъекта!

2. Двигая рукой, «Я» - источник побудительного импульса, направленного на тело (в этом качестве «Я» - приложенная к телу способность управлять, выбора оптимальной формы поведения, инициации действия из себя; «Я» - приложенный к телу невидимого человека управленческий процесс (термин применим в иерархических системах, интересен как феномен функционального действия в серии актов управления). Как субъект, «Я»-сочетание силь (способность инициировать действие из себя) и свободы (никто не ограничивает меня в выборе формы действия, никакими законами физики специфичность моего выбора не определяется, в ней сугубо мое усмотрение, мой произвол). «Я» - сам себе есть закон, и сам для себя закон вырабатываю. Я есть сила в сочетании со свободой.

3. Для движения рукой «Я» генерирую побудительный импульс, собственную энергию субъекта, по которому материя приходит в движение (направления своего действия «Я» могу произвольно менять; мое поведение можно описать в терминах теории вероятности; такова специфика силы по типу произвола, но физики не включают силу по типу произвола в модель Вселенной). Все ненаблюдаемое - предмет философии, но мир - не только физические компоненты. 
4. Энергия $(E)$ есть специфическое выражение массы $(m)$, а масса специфическое выражение энергии по закону А. Эйнштейна: $E=m c^{2}$, где $c$ скорость света. Расход энергии неизбежно сопровождается потерей массы. «Я» тоже должен быть «скрытой массой» своего тела (при биологическом отказе человека обнаружена потеря массы тела в 30 г; исчезнувшую энергию обнаружить не удалось, форма, в которую она переходила, осталась неизвестной; но эти 30 г обеспечивали процесс жизни на уровне организма, а не на уровне отдельных клеток). Это энергия некоего надклеточного управленческого процесса, координирующего согласованную деятельность всех тканей организма (в теле насчитывается 100 трлн. клеток, которому необходим «дирижер», «субъект-координатор совокупной физиологии организма»; мы исчезаем вместе с тем процессом, в совокупности обеспечивающим наше тело живым).

5. Среда по типу энергии или силь специфична в свободе выбора (соотнесенность невидимого фактора «био» с определенным материальным субстратом делает і-ю порцию материи живым («Я» есть материя в виде тела, с одной стороны, и субъект, способный материей управлять, с другой). Глобальный управленческий процесс, безусловно, обладает энергией, позволяет ей играть роль силы, но энергией какой-то иной, отличной от материи природы; астрофизики, изучая структуры и типы вращения галактик, обнаружили, что их собственной гравитационной энергии совсем недостаточно, нужна дополнительная энергия, во много раз большая; дефицит по энергии составляет минимум 20, максимум 100 раз; мир на 95-99\% состоит из «скрытой массы» Вселенной, как средой существования материи, задающей формы организации, специфические формы движения; субъекты, выступающие в роли «скрытой массы» своего тела, - единичные проявления этой среды. «Скрытая масса» Вселенной везде присутствует и незримо стоит за материей. Факт, что масса глобального управленческого процесса в 20-100 
раз больше массы материи делает количественное сравнение этих сред материя в среде мысли, или наоборот, несоизмеримым; мир есть, в первую очередь, среда по типу мысли («произвола»), сочетающей в себе силу и свободу. В условиях абсолютного дефицита материи ее порций может попросту на всех не хватать. В итоге субъекты смогут присоединять себя к материи периодически (погружая в состояние сна, нас в момент засыпания «выключают»).

7. Параметрами порций поля являются скорость, координаты, момент углового вращения (спин), а также странное явление, обнаруженное физиками, названное ими «памятью». Побывавшие в одном и том же процессе частицы сохраняют некую память о нем, а в дальнейшем ведут себя согласованно. Так, физические эксперименты 1982 г. обнаружили следующее:

а) два фотона, рожденные в одном и том же процессе, начинали свой разлет в вакууме в противоположные стороны. Ученые измеряли параметры либо координат, либо скорости (их всегда удавалось провести разрозненно, но никогда по обоим критериям сразу). Как только одну из частиц измеряли по критерию координат, параметр скорости «схлопывался» как у нее, так и ее напарницы на расстоянии 13 м; никакого временного интервала засечь не удавалось: он равнялся нулю, либо лежал ниже границы возможного измерения);

б) частицы «не позволяют» знать о себе все, что-то всегда должно оставаться неизвестным (абсолютная синхронность «схлопывания» означала координацию и наличие незримой связи между ними, а отсутствие какоголибо временного интервала указывало, что скорость их коммуникации многократно превышала скорость света и практически равнялась бесконечности, указывая на выход в иной, отличный от материи диапазон бытия, получившим специальное название - «среда нелокального 
взаимодействия» (это - один из главных парадоксов квантовой механики, назван «принциип неопределенности» Гейзенберга;

в) на квантовом уровне материя начинает демонстрировать свойства субъектности, обнаруживает, что ею управляют. Фотоны разлетались по среде, которая одновременно управляла их поведением и была способна передавать им свой побудительный импульс. В итоге ученые выяснили: «скрытая масса» Вселенной, «среда нелокального взаимодействия» и «субъект» по своей фундаментальной природе есть одно и то же; это - разные формы проявления глобального управленческого прочесса. Кванты поля являются пограничным состоянием материи, они соприкасаются со средой, которая управляет их поведением;

г) взаимодействие материи и мысли происходит на квантовом уровне, а «среда нелокального взаимодействия» - типичная сигналопередающая среда. Это объясняет, каким образом наши зрительные ощущения, обусловленные специфическим распределением электромагнитного поля в мозге, субъективно воспринимаются нами на большом удалении от мозга, проецируются на обусловившие их предметы, «очерчивая» их. Пространство вакуума и мысль тождественны. Способность пространства вакуума манипулировать материей - на самом деле мысль, имеющая силовую природу, тождественная глобальному управленческому процессу, энергия которого больше энергии материи в 20-100 раз.

8. Быть материей означает быть квантом поля. Никакого другого способа бытия материя не знает. Таков уровень ее реальности в отличие от того, чем материя нам представляется, что зависит лишь от способа показа мира, за который отвечают автономные слои нашей психики, вырабатывающие содержание восприятия. На практике под квантом поля понимают некий локальный концентрат колебаний среды. Эти единичные порции энергии лучше всего можно описать как способность становления, 
обретения то одного, то другого дискретного набора параметров. Они могут существовать только в «квантовых» состояниях и не имеют формы существования в промежутке (отсюда понятие «квантовый скачок»). Каждый субъект представляет собой единичную порцию энергии. Мириады единичных субъектов демонстрируют идентичный принцип бытия. Они все проявления глобального управленческого процесса, который должен быть средой квантованного типа, образованного всей совокупностью субъектов мира, суммарная энергия которых превосходит энергию материи в 20-100 раз.

Физики показали, что способом бытия материи является существование в виде дискретных порций энергии. Кванты поля - единственное, что реально определяет определенность материи и глобального управленческого процесса. Кванты поля разные и образуют множество их видов. Кварков, например, всего 6, но они имеют разные показатели энергии в диапазоне $0,3-175,6 \mathrm{GeV}$ (гигаэлектронвольт),но столь большие различия не мешают всем кваркам быть фундаментальными. Не исключено, как субъекты бодрствования, мы лишь один из возможных типов, и что есть иные виды субъектности, энергетически гораздо мощнее нас. Субъектов можно объединять в разные конфигурации - семьи, общества, народы, но каких-либо изменений от этого не происходит. Наш мир - двуединый феномен. Мы выводим мир из себя самих, трактуя себя как типичное проявление мира. Как носители бытия, мы образуем часть общей цепи закономерностей, и с этой позиции не более случайны, чем мир в целом. Самопознание, глубокое познание самого себя открывает нам путь к познанию мира.

Разум субъекта. Ответить на вопрос, откуда появился и почему существует мир в границах нашего разума невозможно, а длительный поиск ответа может вызвать внутренний дискомфорт, болезненное чувство, предупреждая нас о применении разума не по назначению (разум - чисто земной инструмент, его цель - подчинение чувствам, помощь жизни 


\section{ЧЕЛОВЕК И СОВРЕМЕННОЕ ОБЩЕСТВО В СОЦИАЛЬНОМ, ПРАВОВОМ, ЭКОНОМИЧЕСКОМ РАКУРСАХ}

организма, осмысление мира через восприятие, создание серий абстрактных моделей в раскрытии специфики реальности. Понимать - значит описать исследуемый объект абстрактной моделью, но не все в мире можно смоделировать; бесконечности мира в пространстве и времени не свести к чему-то меньшему, превратить в модель (разум при попытке это осмыслить, «спотыкается»; при всей своей непостижимости мир в определенных пределах, конечно, постижим, что указывает научно-технический прогресс, стремление расширения границ познаваемого, концентрации на аспектах продуктивного применения разума человечества.

Философия как компонент научного познания вносит свой вклад в общий прогресс. Законы физиологии едины для всех живых организмов, спящее животное сходно со спящим человеком, но различно техникой мышления в период бодрствования. Мы управляем своим поведением разумом, а животные - элементарной сообразительностью; люди выстраивают суждения в словах, мыслят абстрактно, животные этого не умеют. Феномен бодрствования повторяется изо дня в день в миллиардах живых организмов. Материя нашего тела типична, на 70\% состоит из воды. Сухое вещество клеток сложено из органических молекул, основа которых - атом углерода, четырехвалентная природа которого совместно с другими свойствами делает его удобным «строительным» материалом выстраивания тканей тела. Другой потенциально пригодный элемент - кремний, но он химически менее удобен. В организме широко присутствуют азот, кислород, сера, металлы натрий, калий и др., причем все химические элементы поступают к нам с пищей. Организм распознает их по каким-то своим критериям, транспортирует их в нужные места, используя по назначению. Тело же представляет собой самую обычную порцию материи Вселенной. Будучи типичными, мы вправе выводить из характера своего бытия закономерности и свойства мира в целом. 


\section{ЧЕЛОВЕК И СОВРЕМЕННОЕ ОБЩЕСТВО В СОЦИАЛЬНОМ, ПРАВОВОМ, ЭКОНОМИЧЕСКОМ РАКУРСАХ}

Бодрствующий субъект - реальность, действующая примерно 16 ч в сутки и прерываемая на время сна, тогда мы переходим в некоторое потенциальное состояние, характеризуемое полной потерей функциональности и существующее без всякой помощи с нашей стороны. Во сне решаются задачи восстановления и отладки физиологии организма, а для способности управлять мы ему не нужны. Во время сна способность восприятия окружающего мира исчезает, накопление памяти прекращается с момента засыпания. Между тем с организмом продолжает оставаться соотнесенным некий процесс возможного «включения» бодрствования. Проснувшись спустя несколько часов, возможно и лет, человек замечает вокруг себя перемены. Причем он не сам себя «включил», переведя из потенциального состояния в активное, a в организме действует управленческий процесс, периодически обеспечивающий наше «включение». Запуск бодрствующего субъекта происходит целиком без его воли (нас генерирует на 16 ч в сутки как вспомогательную управленческую реальность надклеточный управленческий процесс, соотнесенный с организмом человека до момента его гибели.

Потребность в бодрствующем субъекте возникает в связи с необходимостью организации взаимодействия организма со средой обитания, как способностью воспринимать, делать выбор и инициировать определенные действия из себя. Когда надобность в нашей функции отпадает, нас «отключают», когда организм закончит исполнение своих генетических программ нас «отключают» окончательно, вернее, перестают производить, и живой организм прекращает существовать (жизнь в нем сохраняется еще некоторое время на уровне клеток отдельных тканей). То, что невидимый человек - часть надклеточного управленческого процесса, связано с функцией управления (желая пошевелить рукой, в движение сразу приходят многие 
миллионы клеток, мы манипулируем организмом надклеточно, мы - часть надклеточного управленческого процесса).

Генерация нас, как вспомогательного субъекта, требует расхода энергии, а так как лишней энергии в организме нет, ее нужно взять из какихто других процессов, что невозможно бесконечно долго (длительное бодрствование способно истощать организм, ибо все тонкие физиологические балансы нарушаются, нервная система истощается, что может закончиться смертью). Управление физиологией требует всей энергии субъектакоординатора, вынужденного до 8 ч в сутки обращать свою энергию вовнутрь (на генерацию бодрствующего субъекта энергии не остается). Энергия, выделяемая на нас, дается лишь на время (к вечеру в организме начинается дисбаланс, субъект бодрствования надо «отключать» для восстановления физиологии: пока это не реализовано, бодрствование закрыто).

Аналогичная ситуация возникает при тяжелых травмах. Сознание человека исчезает, ибо вся энергия нужна для срочной переналадки физиологических процессов. Субъект-координатор лихорадочно пытается спасти пострадавший организм: бодрствующий субъект, требующий для себя части энергии, был бы здесь помехой; решив задачу реорганизации физиологии и обеспечив выживание организма, можно «включить» этого субъекта вновь (тогда говорят, что он очнулся, «пришел» в сознание, хотя, конечно, он это сделал не сам и не собственными силами, а его вновь стали вырабатывать).

В процессе генерации нам достается лишь малая часть энергии от субъекта-координатора. В обычных условиях ее выдается немного, но бывают «пиковые» периоды, моменты эмоционального подъема, когда такой энергии действительно выдается больше обычного, при этом мы чувствуем необыкновенный прилив сил, чувств и готовы на многое. Но так как общие 
энергетические ресурсы организма ограничены, длительность этих «пиковых» периодов невелика.

В [16] субъект-координатор, функционально нам предшествующий, назван субъектностью первичного, а мы - субъектностью вторичного типа (согласно очередности стоящих перед организмом задач: физиология первична, поведение вторично, ибо оно нужно для обслуживания физиологии и бессмысленно включать поведение, пока в физиологии не наведен хотя бы элементарный порядок). Во сне, когда нас функционально нет, субъектность первичного типа полностью руководит организмом. Вероятно, субъекткоординатор никогда не отключен, ибо управленческий процесс делает тело живым, а его «отключение» адекватно летальному исходу, а нас же можно многократно «включать» и «отключать». Мы появляемся как подспорье процессу жизни, начатому до нас, и в этом процессе нам отводится хотя и важная, но вторичная роль (бытие бодрствующего субъекта «запускают» по мере надобности и прерывают совершенно безболезненно).

Проведенные рассуждения позволяют сделать ряд важных выводов:

1) «Я» не один в организме (Я не один ассоциирован с этим организмом);

2) метафизическое способно существовать в двух видах: источник и продукт, имеющие разные задачи и, вероятно, совершенно разные энергетические возможности: одно - лишь часть другого; продукт находится в полной зависимости от источника, которому другое обязано своим функциональным бытием (прекращая перераспределять энергию в нашу пользу, мы мгновенно исчезаем, но утром нас могут «запустить» вновь или сделать это через много лет);

3) субъект бодрствования есть метафизическое-вторичное, метафизическое-продукт, превращенная форма первичных метафизических процессов. При всей значимости бодрствующего субъекта для организма 
ключевую роль в нем играет субъектность первичного типа, которая может нас из себя генерировать (мы сами себя генерировать не можем, ибо не владеем технологией своего бытия, не посвящены в его тайну; наше бытие технологически обеспечивает процесс, предшествующий нам в организме, вырабатывающий нас как свое временное продолжение, используя временно высвобождаемую часть энергии, а остальную часть продолжая расходовать на нужды координации физиологии);

4) указав на возможный источник своего бытия, перед нами вновь встает проблема древних философов-греков: «Познай самого себя!» (при этом субъектность первичного типа предоставляет нам направление поиска);

5) бодрствующий субъект - это продукт генерации с ее неизвестной технологией; чтобы существовать, нужно быть единичной порцией энергии, иначе бытие не обрести. При генерации нас неизбежно должны вырабатывать по принципу кванта поля, в виде дискретной порции энергии (дискретность означает замкнутость на себя, пребывание в неких собственных границах; причем этим требованиям мы полностью удовлетворяем). Mbl реально есть: а) энергия (мы способны инициировать действия из себя); б) субъект единичный (субъект реального тела) и дискретный (внутренне обособленный от других субъектов, без сливания с ними); в) наше бытие - некая временная концеентрация энергии (в процессе выработки нам отдается лишь часть энергии субъекта-координатора, который также единичен и дискретен, являясь субъектом конкретного тела, поэтому нас логично назвать квантом поля «малого» типа). Субъект-координатор намного превосходит нас, хотя его масса в 30 г - гигантская величина по сравнению с массой квантов физического поля - электронов, кварков и др.; огромные различия в энергии дают представление о сравнительной силе физического и идеального: если масса частей метафизического диапазона бытия может достигать 30 г, то 
совокупная энергия этого диапазона превосходит энергию материи в 20-100 раз).

6) Генерируя нас в качестве субъекта бодрствования, субъекткоординатор поставляет нам энергии не только мало, но еще и в превращенной форме (мы можем воспринимать мир, быть источником побудительного импульса, направленного на тело, но мы не способны оживлять материю, наши свойства существенно отличаются от свойств субъекта-координатора физиологии. Как субъект бодрствования, в реальности мы есть: а) временная концеентраџия энергии; б) квант поля «малого» типа; в) превращченная форма первичных энергетических процессов. Хотя эти суждения по характеру спекулятивны, их трудно подтвердить экспериментом, но их логику можно проверить по аналогии с реальными фактами. Так, кванты поля, как элементарный способ существования материи, весьма отличны друг от друга (энергия электрона значительно превосходит энергию нейтрино, хотя эти частицы являются фундаментальными; упоминавшиеся кварки также фундаментальные частицы без составных частей, но с диапазоном энергии $0,3-17,5 \mathrm{GeV}$. И чем они не являются аналогами квантов «малого» поля?

7) По временной концентрации энергии примеров масса: это реальные тайфуны, сели, ураганы, штормы, турбулентные выбросы солнечной энергии, a разрушения, причиняемые ими, нас поражают. Наше тело - типичный аналог локального «сгущения» поля, временная концентрация электромагнитной энергии в ограниченном объеме. Пример превращенной формы первичных энергетических процессов - электрический свет в комнате путем поворота выключателя (это аналогия с субъектом бодрствования: нас «включают» по утрам, как некий «свет», когда с нашей помощью нужно «осветить» окружающий мир, и «выключают» при достижении цели бытия). В живом теле источник энергии - органические молекулы, получаемые с 


\section{ЧЕЛОВЕК И СОВРЕМЕННОЕ ОБЩЕСТВО В СОЦИАЛЬНОМ, ПРАВОВОМ, ЭКОНОМИЧЕСКОМ РАКУРСАХ}

пищей (их распад обеспечивает протекание физиологических процессов, включая генерацию сознания; при истощении организма и дефиците энергии происходит периодическое отключение сознания в виде голодных обмороков; не следует иметь постоянно «включенный» бодрствующий субъект, если иные жизненно важные процессы снабжены слабо).

8) В целом субъект бодрствования - продукт надклеточного управленческого процесса, в нем субъект-координатор либо питает бодрствующий субъект своей собственной энергией в 30 г, либо берет ее откуда-то извне. Неясно, как субъект-координатор пополняет эти свои 30 г, откуда берет энергию (для современных знаний эти вопросы пока запредельны, а их моделирование недоступно).

Пытаясь объяснить материю, мы знаем, что вся пищевая цепь основана на энергии Солнца: клетки зеленого листа захватывают фотоны солнечного света, синтезируя с их помощью органические молекулы из углекислого газа и воды. Энергия фотонов становится энергией химических связей. Полученными молекулами углеводородов питаются травоядные животные, становящиеся пищей других животных. Человек - полноправный участник этого процесса, питаясь захваченным солнечным светом, Источник энергии Солнца - термоядерные процессы (ядра водорода сливаются в ядра гелия, а далее в ядра все более и более тяжелых химических элементов, что сопровождается выделением огромного количества энергии в виде фотонов). Вся материя в ее нынешнем виде образовалась из предшествующего состояния, называемого сингулярностью, характеризуемого бесконечно малыми размерами и бесконечно большой плотностью. 15 млрд. лет спустя в результате «Большого взрыва» появились элементарные частицы, произошел последующий разлет Вселенной. После остывания Вселенной кванты поля смогли образовать газообразные облака, при определенной концентрации в которых возникают термоядерные реакции, а облака стали звездой. Однако не 


\section{ЧЕЛОВЕК И СОВРЕМЕННОЕ ОБЩЕСТВО В СОЦИАЛЬНОМ, ПРАВОВОМ, ЭКОНОМИЧЕСКОМ РАКУРСАХ}

ясно: а) что такое сингулярность; б) откуда взялась ее гигантская энергия; в) как ведется подпитка субъекта-координатора, чтобы его масса в 30 г сохранялась в течение жизни? Эти вопросы открыты, и ответы на них частичны.

9) Более надежны рассуждения о мире - всеобщий закон сохранения $и$ превращения энергии: меняются лишь формы мира, временные концентрации энергии появляются и исчезают, но не энергия и не сам мир вообще. Что может являться абсолютным носителем бытия в метафизической части мира? Субъект бодрствования возникает лишь на время, а вот субъект-координатор с массой в 30 г - подходящий претендент (указанные 30 г массы, как реальная составляющая мира, просто так исчезнуть не может по закону сохранения и превращения энергии; ей дозволено лишь изменять статус своего бытия: переходить от активной функиии в некое потенцииальное состояние, и обратно. Невидимая масса в 30 г должна существовать и сохраняться до того, как наш организм стал развиваться как живое. Когда нас прекращают вырабатывать, никаких реальных потерь для мира не происходит: общее количество энергии в нем остается постоянным).

10) Измененный декартовский тезис таков [16]: «Мыслю - значит существую, но условно, как периодически возникающцая управленческая реальность» (метафизический диапазон бытия - среда по типу мысли, сила и мысль одновременно: мир на 95-99\% состоит именно из нее, а не из материи).

Взаимодействие частей нашего «Я». Любое движение живого тела сложный физиологический процесс, реализуемый на уровне клеток (миллионы клеток мозга должны сбросить сигналы клеткам мышцы, которые, синхронно сокращаясь, стягивают свои стенки, обеспечивая нужное движение рукой). Но от клеток своего тела, как и от физиологии вообще, мы отрезаны. Наша задача - удовлетворить потребности, о которых физиология сообщает нам с помощью наших органов чувств. Субъект-координатор - единственный 
подходящий кандидат для принятия нашего приказа к исполнению и обеспечения его реализации физиологически. Не владея техникой работы с клетками и отсутствия возможности доведения побудительного импульса до нужных из них, нам совершенно необходима промежуточная инстанция. Нам дозволяется управлять работой рук, ног, мышцами языка, гортани, - всем тем, что связано с функцией организатора поведения. Но в свои внутренние процессы мы вмешиваться не в состоянии, в регулирование тонких физиологических процессов, работу почек, костного мозга, сердца и др. Единственно жизненно важная функция, которую нам разрешено контролировать, - дыхание, осуществляемое в целом лишь автономно.

Как же взаимодействуют субъектности первичного и вторичного видов? Субъектность первичного вида создает нас как свое служебное средство, поэтому мы и появляемся, как субъект бодрствования, возникающий как продолжение процесса в организме, в совокупности делающего данное тело живым. Так как делать тело живым - задача субъекта-координатора физиологии, то мы помогаем ему достичь целей, ибо собственных целей у бодрствующего субъекта нет. Мы приходим в мир помимо своей воли, без понятия, как все происходит, сразу обнаруживая себя в привязке к телу, от которого не можем оторваться.

На нас давят чувства, сообщающие о конкретных потребностях тела и заставляющие их реализовывать. Чувства наши - язык, на котором субъекткоординатор через коммуникацию отдает нам свои приказы, манипулируя нами изнутри. Нам задан вектор поведения и разъяснено, какие задачи следует исполнять в первую очередь. Все поведение человека связано с уступкой чувству. Даже в ситуации чисто рассудочного усилия мы всегда ориентируемся на долгосрочные выгоды, поощряемые чувством (без этого даже не реализуется то или иное действие). Давление чувств на бодрствующего субъекта составляет мотиващию, заставляющую его 
действовать (оно порой бывает невыносимо, но поддерживает нас в жизни; без чувств мы не понятен смысл действий, своего бытия, ибо особые собственные цели у нас отсутствуют, а наше бытие носит подчиненный характер: существование живого организма - цель субъектности первичного типа, стремящейся продолжать начатый процесс эволюции; то, что мы сопричастны к этому процессу не означает нашей ревностной ему службы). Субъекту-координатору просто нужно, чтобы мы жили, и по отношению к нам чувства исполняют роль «кнута и пряника» (за удачные действия, утверждающие организм, мы испытываем приятные эмоции, радость, удовлетворение, за проигрыш - досаду, разочарование, депрессию.

Субъект-координатор должен завершить то, ради чего он выстроил живой организм, а любую мысль о самоубийстве им встречается негативно: он явно не желает преждевременно прервать работу, не ожидает этого от бодрствующего субъекта, изначально созданного им как подспорье. Все наше бытие - создание субъектом-координатором иллюзии нашей реальности при усердной работе в достижении чьих-то целей. В ответах на ряд вопросов: а) как бодрствующий субъект обретает функциональное бытие; б) как субъект-координатор становится сопричастным конкретному телу; в) что он делал и в каком состоянии пребывал до появления тела; г) как далеко в ретроспективе (год, два или более) мы можем проследить свою жизнь, - мы крайне затруднены, но сейчас мы реально вполне успешно взаимодействуем с нашим телом. Тогда можно считать себя реальностью, возникающей из ничего и появляющейся ниоткуда. Так как разум - единственно доступный нам инструмент мышления, и мы не подозреваем его в порочности, то остается предположить, что эти формулировки вопросов неверны.

Глаголы «появляться», «возникать» указывают на мгновенный переход из одной формы существования в другую (возник из чего-то или это «скрытое» существование субъектов без их связи с конкретным телом). 


\section{ЧЕЛОВЕК И СОВРЕМЕННОЕ ОБЩЕСТВО В СОЦИАЛЬНОМ, ПРАВОВОМ, ЭКОНОМИЧЕСКОМ РАКУРСАХ}

Концепция потенциальности содержит такое состояние, когда субъекты не имеют конкретной управленческой функции, и им лишь предстоит стать субъектами конкретного тела (о состоянии потенциальности говорит наш собственный опыт погружения в это состояние (наше «выключение» фактически равнозначно утрате бытия, а для субъекта-координатора изменение статуса его существования; реальные элементы мира исчезнуть не могут, но им временно запрещена управленческая функция, они как бы «отключены» от конкретной порции материи).

Отсюда сформулируем ряд следующих выводов:

а) будущий субъект-координатор переходит из потенциальной в активную форму существования;

б) если субъектности первого типа в мире в 20-100 раз больше, чем материи, то какая-то ее часть должна становиться в очередь;

в) ее присоединение к материи возникает крайне редко (должно произойти слияние молекул родительских ДНК, при этом возникает информационная программа с инструкциями о создании нового организма;

г) субъект-координатор получает поле деятельности (однако одним лишь физическим диапазоном бытия все многообразие мира не исчерпывается);

д) становясь субъектом конкретного тела, субъект-координатор физиологии присоединяет себя к растущему конгломерату клеток, заставляя его функционировать согласованно, как единый организм;

е) из биологии известно: развитие любых макроорганизмов начинается с фазы одной единственной клетки; 36 ч оплодотворенная клетка находится в относительном покое, потом начинает делиться; продуктом ее последующего деления становится гигантский многоклеточный организм; при наличии материи с подходящим комплексом физико-химических условий и алгоритма информационной программы всегда найдется субъект, стоящий в очереди; 


\section{ЧЕЛОВЕК И СОВРЕМЕННОЕ ОБЩЕСТВО В СОЦИАЛЬНОМ, ПРАВОВОМ, ЭКОНОМИЧЕСКОМ РАКУРСАХ}

ж) эксперименты с клонированием показали следующее: позволив оплодотворенной клетке разделиться, а затем поместив две полученные клетки в организмы приемных матерей, из каждой разовьются однояйцевые близнецы и с каждой далее будет соотнесен свой субъект-координатор; между третьим и четвертым делением клетки происходит явление: 16 клеток порознь вырасти не смогут; они либо все погибают, либо выживает одна (в этот момент к ним присоединяется субъект-координатор физиологии, благодаря чему конгломерат клеток превращается в единый организм;

3) бодрствующие субъекты (люди, животные) обретают бытие через механизм пробуждения и удовлетворение своих потребностей. Для этого нам показывают мир через восприятие чувств. предоставляя необходимую энергию для действий. Кроме сенсорных образов, чувств и эмоций, людям дополнительно присущ вид психической продукции - мысли в словах, отсутствующий у животных. Философы объясняют, что мышление животных всегда конкретно, оно привязано к текущей ситуации, в которой животное находится, и не может за нее выйти. Своим психическим аппаратом животное обрабатывает то, что открывается в данный момент восприятию, и ничего более. В сочетании с хорошо развитым набором телесных инструментов (клыки, крылья, когти, быстрые ноги) сообразительности животным вполне хватает, даже в окружении хищников они успевают вырасти и оставить потомство. Иная ситуация с человеком: его тело беспомощно, практически не защищено, обречено на вымирание, но мощная избыточная мыслительная способность, разум, поставила нас над животными;

и) с помощью техники мышления мы можем: переноситься в воображении из одной точки в другую; из настоящего в прошлое и будущее; сравнивать, анализировать и планировать свои действия, делать предметом своего анализа что угодно; осуществлять выбор оптимальной формы поведения; мысленно моделировать возможную ситуацию и заранее 
готовиться к ней; создавать абстрактные модели, с ними удобно оперировать, манипулировать, адаптировать к своим целям; эволюция обеспечила выживание людей, постоянный прогресс технологий;

к) разум дан людям от рождения, но его важно развивать через социализацию (пребывание в специфически человеческой среде; без прямого непрерывного контакта с другими разумное мышление не разовьется; причем первые годы жизни критические; однако разум, как специфическая техника мышления, теряется при тяжелых психических заболеваниях (шизофрения, деменция и др.).

Мысли всегда приходят нам в готовом законченном виде, целостной формулировке, составленной из слов. Выработка мысли - целиком автономный психический процесс, параллельный нашему сознанию. Каждую секунду нам открывается одна конкретная мысль, через секунду ее сменяет другая, и так без конца. Человек есть череда мыслей, законченных дискретных состояний, способ существования субъекта в каждый данный момент времени. Бодрствующего субъекта можно определить, как способность непрерывного становления, типичный способ нашего бытия. В этом видна параллель с поведением квантов поля, поведением порций энергии в физическом мире. Отсюда сформулируем ряд выводов:

1) мыслящего субъекта вырабатывают по законам кванта поля, а его бытие реализуется через череду дискретных состояний, сложенных из «параметров» слов. Каждое из таких состояний - информационная модель реальности, отражающая либо фактические детали мира, либо схему, по которой можно построить мир, и тогда человек - череда информациинных моделей действительности. Будучи видом силы, модели способны задавать миру формы организации, по которым происходит глобальное упорядочение материи на всех уровнях Вселенной; 
2) человеческая мысль вырабатывается автономно, как продукт всего накопленного содержания личности. «Нижние слои» психики, направляющие нам свою продукцию, вырабатывают ее, исходя из совокупности критериев, имеющихся у нее. Чем больше объем знаний личности, чем с большим количеством жизненных ситуаций она сталкивалась, тем более интересным, богатым и глубоким является стихийно вырабатываемое суждение. Человек не мудрее совокупности «базы данных», знаний и опыта, которыми он обладает, но, когда некая мысль приходит нам в голову, часто происходит его озарение. Знание представляет некоторое отражение реальности в словах, еe информационную модель. Все получаемое нами знание поступает к нам изнутри, неожиданно, создается впечатление, что знание мира мы изначально носим в себе, но не знаем, как из себя извлечь; человек - единичный, замкнутый на себя поток соображений, с состояния невежества за время жизни может продвинуться на ряд шагов вперед;

3) в реализации призыва древних «Познай самого себя!», в познании тела далеко продвинулись анатомия и медицина, но древние предлагали познать совокупность психического в организме, продуктом и продолжение которого мы являемся; себя, как части мира, вывести из этого закономерности и свойства мира в целом (наибольший интерес вызывает узел стыка, интерфейс двух сред - материи и мысли, механизм передачи друг другу своей специфичности). Свойства материи предъявляют конкретные требования к идеальному, осуществляющему такое взаимодействие, через задание ему области допустимых значений.

Ясно одно: феномен сознания ассоциирован с живой материей мозга, гибель тканей мозга ведет к исчезновению сознания в известных нам формах. Бодрствующий субъект - продолжение процесса жизни, начавшегося задолго до того, как он обрел управленческую функцию и изначально ассоциирован в организме. 


\section{ЧЕЛОВЕК И СОВРЕМЕННОЕ ОБЩЕСТВО В СОЦИАЛЬНОМ, ПРАВОВОМ, ЭКОНОМИЧЕСКОМ РАКУРСАХ}

В процессах познания логическими методами применим ряд правил. Одно из них - принцип «бритвы Оккамыl»: а) везде, где только возможно, снижай спекулятивность рассуждений; б) из всех вариантов объяснений выбирай минимально необходимое; в) чем проще получается логическая схема, тем лучше. Минимально необходимое объяснение состоит в следующем: бодрствующее сознание - продукт процесса фундаментально одной с ним природы. Этот первичный психический процесс, так же, как и мы, ассоциирован с данным организмом, продолжая сохранять с ним связь по ночам, когда нас нет. Благодаря такой соотнесенности, нас можно «запускать» тогда, когда нужно организму.

Что делает клетку живой? Это - фундаментальный вопрос биологии, на который она не отвечает, ибо свои исследования начинает с момента, когда клетка уже стала живой. Биофизика сосредоточена лишь на материальных аспектах живых тел, игнорируя феномен субъектности. Молекулярная биология столкнулась с аналогичными трудностями (ей нужно объяснить феномен считывания информации с молекул ДНК; субъект, как реальность, для нее не существует, и она не отвечает, кто автор генетической информации). Однако нам известно, информация: а) считывается субъектом; б) всегда мысль или набор мыслей; в) специфическое состояние субъекта (передавая информацию, мы посылаем свое специфическое состояние другому субъекту; посредники в этом - колебания воздуха в устной речи, совокупность знаков на бумаге, экране в речи письменной).

Живой клетку делает соотнесенность с ней управляющего субъекта, ибо:

1) субъекты существуют, являясь частью феномена живого, участвуя в любых рассуждениях о живом; субъект, как фактор силы, соотносится с феноменом живого, образуя наше самое достоверное, глубокое фундаментальное знание о живом, вытекающее не из наблюдения, а из 


\section{ЧЕЛОВЕК И СОВРЕМЕННОЕ ОБЩЕСТВО В СОЦИАЛЬНОМ, ПРАВОВОМ, ЭКОНОМИЧЕСКОМ РАКУРСАХ}

собственного опыта, где мы - прямые активные участники процесса. Имеющиеся у нас сведения о живом (движение, размножение, потребление пищи) вторичны и отражают внешние проявления феномена, глубинная природа которого скрыта от наблюдения;

2) источник специфичности движения материи живого тела как вспомогательных субъектов бодрствования: а) на макроуровне - роль субъекта в организации движения тела; б) на микроуровне «самодвижущаяся» материя; в) феномен живого подчинен единым принципам, регулирующим бытие одной клетки, группы клеток и многоклеточного организма на всем их периоде жизни;

3) любой макроорганизм схож с клеткой (если с конгломератом соотнесен фактор субъектности, он аналогичен единичной клетке, с которой его развитие началось; опыт показывает, что субъектность - атрибут и условие живого; без нас, организатора поведения, организм погибнет). Субъект клетки, обеспечивая ее взаимодействие со средой обитания, позволяет клетке быть живой; наличие субъекта превращает клетку в узел стыка, интерфейс двух сред - область взаимодействия материи и идеального, передающих друг другу свою специфичность;

4) субъект клетки приложен к материи клетки как порция силы, обладающая радиусом действия и контроля, благодаря присутствию субъекта конгломерат молекул превращается из физического в биофизический; все реакции в клетке обретают направленность, избирательность, биохимизм (разрыв связи между субъектом и материей клетки в момент смерти ведет к исчезновению аспекта «био»); самые большие размеры клеток - 200 микрон (0,2 мм), а максимальный радиус действия субъекта по контролю материи 100 микрон (0,1 мм). Таковы же размеры материи типичной клетки человеческого организма, имеющей в диаметре 0,02 мм и состоящей из $10^{15}$ элементарных частиц (для управления ими нужен всего один лишь субъект; 


\section{ЧЕЛОВЕК И СОВРЕМЕННОЕ ОБЩЕСТВО В СОЦИАЛЬНОМ, ПРАВОВОМ, ЭКОНОМИЧЕСКОМ РАКУРСАХ}

одна единственная порция метафизического держит под контролем $10^{15}$ порций физического, подчеркивая сравнительную силу материи и идеального);

5) имея гигантскую силу к материи, возможности субъекта ограничены радиусом действия (0,1 мм), количеством квантов поля, удерживаемых под контролем (если материи становится много, на помощь приходит дополнительный субъект, клетка делится, очередной субъект из потенциального состояния переходит в активное, присоединяя к себе разросшуюся порцию материи);

6) субъект, давая начало новой порции живого, присоединяет себя не столько к материи, сколько к определенной информационной программе. Отсюда - формула живого сводится к субъекту, как порции силь,, и информационной молекуле, задающей ему программу действий;

7) в своей деятельности субъект клетки учитывает инструкции, записанные на молекулах ДНК, считывает генетическую информацию и далее исполняет, записывая информацию на ДНК в четырехзначной системе (всего четыре нуклеотида), что математически удобно и эффективно. Сравнение любой цепочки знаков при записи информации имеет смысл, если в их соприкосновении есть специфическая модель, а в итоге - определенная мысль. Для считывания информации с цепи ДНК субъект клетки должен как-то приложить себя к этой молекуле, а после соприкосновения стать специфической моделью. Если это инструкция, он сможет реализовать ее в действии;

8) генетическая программа разъясняет субъекту клетки, какие манипуляции следует провести с материей. Инструкции на ДНК задают субъекту направление приложения себя к материи как силы. В процессе жизни клетки субъект непрерывно соотносит себя с инструкциями, руководствуясь ими; 
9) для создания каждой новой порции живого в делении клетки очередной субъект переходит из потенциального состояния в активное и получает информационный «справочник». Копирование генетической информации таково: двойная спираль ДНК разворачивается, и по каждому ее тяжу, как по шаблону, синтезируются две совершенно идентичные молекулы, причем одна остается в материнской клетке, а другая готова перейти в дочернюю. Это сигнал очередному субъекту для перехода из потенциального в активное состояние: новый субъект присоединяет себя к генетической программе, забирает на себя часть материальной среды клетки, далее клетка делится, и обе полученные клетки повторяют цикл развития до наступления очередного цикла деления;

10) информационная программа копируется субъектом перед каждым актом деления (без набора инструкций субъект - слепая сила, вносящая в мир хаос); массив генетической информации придает смысл объединению материи и субъекта, точнее, определенной информационной программы и субъекта. Аналог этого - работа архитектора над проектом, итогом которого служит накопление опыта для движения вперед, разработки более интересных технических решений, развития своего творчества;

11) «проект» на основе перестановки нуклеотидов очередной субъект должен реализовать на практике (он присоединяет себя к материи, берет ее часть под свой контроль, «прогоняет» во взаимодействии с окружающей средой, приобретает адаптационный опыт, как базу в эволюции информационной модели построения клетки и изменений в ее генетической записи); итог деятельности субъекта - эволюция мысли, получение более совершенных информационных программ, как аналога части информационных программ Вселенной; через эволюцию информационных моделей мысль первичного типа совершенствует себя. 


\section{Относительно сути субъекта клетки сформулируем следующие} выводы:

1) это замкнутый на себя поток соображений, обладающий силой по типу мысли; это сила и мысль одновременно; это узел возникновения специфической мысли на микроуровне;

2) субъект клетки единичен (его можно назвать единичной порцией или квантом поля метафизического типа); способ бытия всякого кванта дискретные состояния (в отношении субъекта - «мысли»; он постоянно действует, становится чем-то, превращается в модель);

3) мысли субъекта клетки вырабатываются и существуют на языке, отличном от нашего, представляя способ выражения, систему кодов, в рамках которых возможна запись информации на материальном носителе - молекуле ДНК; как тип мысли субъект клетки непосредственно соприкасается с материей, может приложить себя к ней как силу, взаимодействовать с материей и улавливать специфику электромагнитных колебаний, задавать им желаемую специфичность, позволяя воспринимать материю и целенаправленно манипулировать ею;

4) объединяя поток соображений, обладающий силой, и мысль, существующую на определенном языке, можно получить язык, на котором существует субъект, являющийся одновременно способом существования силы. Язык есть способ выработки мысли, система кодов или правил, с их помощью образуются целостные модели реальности. Вне языка мысли не бывает (язык - не просто способ существования мысли, но и условие самой ее возможности). Язык есть способ существования субъекта;

5) энергия, материя и сила, по сути, - одно и то же. Коды выработки кванта поля, отвечающие на вопрос «как?» предществуют его фактическому бытию; как система принципов или кодов, язык предшествует бытию элементарной частицы, делает ее бытие в определенной форме возможным; 
6) кванты поля - способ существования энергии или силы в физическом мире (если способ их выработки - язык, то язык - способ существования силы и в физическом диапазоне бытия; отсюда язык есть способ существования (uль). Для считывания информации с цепочки ДНК напрямую, как это делает субъект клетки, надо перейти в другие коды, стать другим типом мысли, перейти на язык, отличный от человеческого. Этого генетики пока не достигли, хотя рост прогресса в мире поразителен. Можно скоро стать «сверхчеловеком», познать тайну своего бытия, затем - тайну мира, что дерзко для того, кто не более чем сопричастен бытию, являясь временным продуктом. Для целенаправленной манипуляции с электромагнитной средой клетки обязательно надо соотнести субъект;

7) наши трудности во взаимодействии с процессом, из которого мы проистекаем, - трудности языка. Нельзя коммуницировать с субъектностью первичного типа на ее языке. Все, что нам доступно, - надавить на нее своим усилием; в ответ на усилие, особенно при напряженной работе субъекткоординатор сопротивляется встречным чувством (мы тогда не хотим чтолибо делать, ощущаем лень, апатию, паралич энергии, нужна настойчивость рассудка в преодолении этого внутреннего сопротивления). Если субъектность первичного типа коммуницирует при помощи органов чувств, то, может, она сама и есть чувство?

8) Бодрствующего субъекта генерируют как получателя чувств. Мы способны быть адресатом чувств, понимать их смысл, но сами не можем их вырабатывать даже по заказу. Чувства - целиком автономный процесс, объективное в психике, отражающий объективную реакцию психики на происходящее. Под воздействием чувств происходит выброс гормонов в кровь, учащение дыхания, сердцебиения, изменение электропроводности кожи. На фиксации этих процессов строятся «детекторы лжи»: через контроль физиологических параметров позволяющие установить, какой вопрос к 
проверяемому вызывает максимальный выброс чувств (способность вмешаться в физиологию, может служить инструментом управления физиологией, a норма на детекторе чувств означает спокойное уравновешенное расположение духа, являющееся чувством, хотя и нейтральным, но у этого эмоционального фона есть физиологический коррелят).

В заключение сформулируем следующие важные для практики выlвoдbl:

1. Субъектность первичного типа есть субъектность по типу чувства. В момент обострения чувств биохимический фактор начинает работать немного по-другому, активизируя одни процессы и притормаживая другие. Так, страх вызывает усиленный распад АТФ, повышение мышечного тонуса и одновременное замедление пищеварения (организм мгновенно мобилизуется для отчаянной схватки или бегства). В целом фактор «био» и чувства взаимосвязаны (фактор «био» тождественен по своей природе чувству). Если это верно, то тогда чувство - вид идеального, превращающий химию в биохимию, делающий материю живым, а биохимия, по сути, - это химия, к которой добавлено чувство, или химия, специфически модулированная чувством.

2. Одним из важных физиологических показателей, быстро меняющимся вслед за изменением эмоционального фона, является электропроводность кожи. Ее изменение говорит, что чувство способно напрямую реализовывать себя электромагнитно. Чувство становится типом идеального, который способен работать с материей на уровне ее реальности. Тогда образуется система тандема, где каждому чувству соответствует определенная электромагнитная картина, и наоборот. Две среды - материя и чувство - как бы зеркальное отражение друг друга. Граница двух сред (материя - мысли) проходит в организме по чувству. Из себя мы можем генерировать лишь усилие, но не чувство (усилие - форма нашей коммуникации с первичным субъектом). 
3. Эксперименты ученых в 1982 г. показали следующее:

a) «среда нелокального взаимодействия» или метафизическая реальность является сигналопередающей средой, по которой информация передается с бесконечной скоростью, и любой приказ доходит до получателя мгновенно (получатель нематериального сигнала, посланного нематериальной структурой нематериальными средствами, должен быть чем-то нематериальным; это метафизический аспект клеток мозга, соотнесенный с ними субъект, и именно ему открывается субъект-координатор своим специфическим состоянием);

б) получив сигнал в метафизическом диапазоне бытия, субъекты нейронов должны реализовать его электромагнитно, превратив в набор электрических импульсов, для чего используется механизм распада АТФ, дающий свободные кванты энергии для совершения работы (каждая клетка мозга - миниатюрный генератор электрического тока, непрерывно возбуждающая потоки импульсов; процесс распада АТФ весьма тонко управляется для получения нужного количества квантов в нужный момент, и без присутствия субъекта-координатора такая деятельность немыслима);

в) полученному от субъекта-координатора приказу в виде мысли субъекты клеток мозга вырабатывают определенный набор электромагнитных колебаний, которые как бы переводят мысль в материальные коды (в таком виде сигнал уже можно отправить по нервным волокнам внутри тела; когда этот сигнал достигает клеток мышцы, они стягивают свои стенки, вызывая эффект сокращения, и повторенный синхронно миллионы раз этот эффект дает нам нужное движение руки). Такова общая схема приведения материи в движение;

г) мозгу человека, как управляющему органу организма, присуща чрезвычайная электромагнитная активность. Он генерирует непрерывные потоки импульсов, адресованные всем частям тела. Чтобы выработать такое 
количество тока, мозгу требуется огромный объем питательных веществ и кислорода, поступающих к нему с кровью. В результате мозг забирает себе непропорционально большой ее объем - до 40\% от общего объема в организме;

д) клетки мозга - своеобразныле телеграфисты в в организме (к ним пришел сигнал в одном диапазоне бытия, а вышел в другом: поступил сигнал в виде мысли, вышел набор колебаний материи; отличие нервных волокон от медного кабеля в том, что в кабеле применен метод электронной проводимости, в нервном волокне - метод ионной проводимости напряжением 80 мВ (в конце волокна есть полость шириной 0,08 мм, в нее вбрасываются молекулы особых веществ - нейротрансмиттеров, и сигнал передается уже не ионным, а химическим путем).

4. Детализируя роль чувства в процессе приведения материи в движение, получим следующее. Уровень чувства начинается с субъектакоординатора физиологии и субъектов клеток мозга, существующих в иных кодах, чем мы, и способных свободно коммуницировать друг с другом. Полученный от нас приказ в виде волевого усилия субъект-координатор должен сначала перевести в коды чувства, чтобы в таком виде довести до субъектов клеток мозга. Роль субъекта-координатора, как промежуточной инстанции, состоит в осуществлении этого перевода, а затем в его распределении между нужными клетками.

Получив приказ в кодах чувств, субъекты клеток мозга ставят ему в соответствие определенный набор колебаний материи, возбуждают и сбрасывают по нервным волокнам специфически модулированную волну, зеркально отражающую чувства в другом диапазоне бытия, его коррелят. Так любую нашу мысль или волевое усилие можно закодировать электромагнитным способом. 
5. Коммуникации между клетками в теле происходят в материальном диапазоне бытия с применением химических методов, выделением в кровь особых веществ, играющих роль сигналов. Для отправки информации могут использоваться чисто электрические методы, возбуждающие колебания поля.

6. Заметим, что коммуницируют между собой не столько клетки, сколько соотнесенные с ними субъекты (сама по себе клетка - груда кирпичей, не способная коммуницировать). Обмен информацией бесспорный признак деятельности субъекта. В процессе обмена сигналами субъекты клеток адресуют друг другу свое специфическое состояние, свою мысль. Электромагнитная волна при этом играет роль лишь посредника. Субъект-отправитель возбуждает колебания поля и специфически модулирует их в соответствии с той мыслью, которую он хотел передать (это превращает волну в носителя информации). При поступлении импульсов в клеткуполучатель ее субъект может непосредственно приложить себя к ним и «считать» с них мысль. От соприкосновения с ними он становится специфической мыслью, той самой, какая была у отправителя сигнала. В итоге в разных точках организма «вспыхивает» тождественная мысль, что является актом коммуникации.

\section{Список литературы}

1. Ackerman D.A. Natural of the Senses. Phoenix. London, 1996.

2. Brown T.A. Genetics: A molecular approach. Chapman\& Hall. London, 1996.

3. Davies P. God and New Physics. Penguin. New York, 1983.

4. Horgan J. The End of Science. Abacus. London, 1998.

5. Gribbin J. Almost Everyone's Guide to Science. Phoenix. London, 1998.

6. Guth A.H. The Inflational Universe/ Vintage. GB, 1998.

7. Herbert N. Elemental Mind. Penguin, New York, 1994. 
8. Kalat J.W. Biological Psycology, Brooks/cole. London, 1995.

9. Martin P. The Sickening Mind. Flamingo. London, 1997.

10. Maturana H.R., Varela F.J. The Tree of Knowledge: The Biological Roots of Understanding. Shambhala. Boston \& London, 1998.

11. Murphy M.P. \& O’Neils A.J. (eds.) What is Life? The Next Fifty Years. Cambridge University Press, Cambridge, 1997.

12. Peck M.S. Denial of the Soul. Simon \& Schuster. Sydney, 1997.

13. Rifkin J. The Biotech Century. Tarcher/Putnam. New York, 1998.

14. Smolin L. The Life of Cosmos. Phoenix. London, 1987.

15. Wolf F.A. The Dreaming Universe. Simon \& Schuster. New York, 1994.

16. Карманов К.Ю. Логика идеального. Книга 1. Введение в проблематику. Амстердам, 2000. 265 с.

17. Арсеньев Ю.Н., Давыдова Т.Ю. Управление проектами, программами. В 2-х т. М. - Берлин: Изд-во Директ-Медиа, 2021.

18. Арсеньев Ю.Н., Давыдова Т.Ю. Инновации, инвестиции, интеллект: потенциал, капитал, модели: монография. М.-Тула: Изд-во ТулГУ, 2013. 447 с.

19. Арсеньев Ю.Н., Давыдова Т.Ю., Разумовская Т.И. Государственное и административное управление и право, государственная деятельность: теория и практика / под науч. ред. д.т.н., проф. Ю.Н. Арсеньева. М.-Тула: Издво ТулГУ, 2018. 317 с.

20. Арсеньев Ю.Н., Давыдова Т.Ю. Системы «государство - общество семья - человек»: политика, культура, религия, бизнес, право, образование: монография / под науч. ред. д.т.н., проф. Ю.Н. Арсеньева. М. - Берлин: Изд-во «Директ-Медиа», 2022. 540 с.

21. Арсеньев Ю.Н., Давыдова Т.Ю., Сычугов А.А. Управление проектами и принятие решений: эффективность, надежность, качество, безопасность, риски / под науч. ред. д.т.н., проф. Ю.Н. Арсеньева. Тула: Издво ТулГУ, 2018. 360 с.

(C) Ю.Н. Арсеньев, Т.И. Разумовская, Т.Ю. Давыдова, 2022 
УДК 338

Глава 13.

МЕТОДЫ АНАЛИЗА ФИНАНСОВО-ХОЗЯЙСТВЕННОЙ ДЕЯТЕЛЬНОСТИ КОМПАНИИ

\section{Сухарева Евгения Викторовна к.э.н., доцент}

ФГБОУ ВО «Национальный исследовательский университет «МЭИ»

Аннотация: В работе рассмотрены теоретические аспекты анализа финансовой деятельности предприятия, которые касаются проведения финансового анализа деятельности коммерческой организации, раскрыта экономическая сущность показателей и коэффициентов, применяемых при проведении анализа финансового состояния организации. Было обозначено, какие преимущества даёт финансовый анализ, какова цель финансового анализа, предмет, виды и методы анализа финансово-хозяйственной деятельности.

Ключевые слова: финансовый анализ, оценка финансового положения, факторный анализ, анализ отчетности, управление финансовым состоянием.

\section{METHODS FOR ANALYSIS OF FINANCIAL AND ECONOMIC ACTIVITIES OF THE COMPANY}

\section{Sukhareva Evgeniya Viktorovna}

Abstract: The paper discusses the theoretical aspects of the analysis of the 325 


\section{ЧЕЛОВЕК И СОВРЕМЕННОЕ ОБЩЕСТВО В СОЦИАЛЬНОМ, ПРАВОВОМ, ЭКОНОМИЧЕСКОМ РАКУРСАХ}

financial activities of the enterprise, which relate to the financial analysis of the activities of a commercial organization, discloses the economic essence of indicators and coefficients used in the analysis of the financial condition of the organization. It was indicated what advantages financial analysis gives, what is the purpose of financial analysis, subject, types and methods of analysis of financial and economic activities.

Key words: financial analysis, assessment of financial position, factor analysis, reporting analysis, financial management.

Развитие экономики - фундамент для ее дальнейшего роста. Также, взаимно дополняемы и связаны теории экономического развития и роста. Главные двигатели экономического роста и развития - человеческий капитал и создаваемые им новшества. В настоящее время в деятельности каждого предприятия заинтересован обширный круг участников рыночных отношений - инвесторы, банки, поставщики, органы государственной власти. В частности, они заинтересованы в результатах их деятельности. Финансы неотъемлемая часть рыночных отношений, поэтому важно знать природу финансов, разбираться в особенностях их функционирования, видеть способы рационального их использования в целях достижения наиболее эффективной работы предприятия.

Тема управления финансовым состоянием предприятия актуальна на современном рынке, так как, чтобы предприятие смогло конкурировать с экономическими субъектами и не допустило наступление банкротства, важно рационально оценивать и управлять финансовым состоянием предприятия.

Актуальность выбранной темы во многом определяет поддержание устойчивого финансового состояния предприятий в стране для их стабильной и эффективной работы. Руководителям необходимо уделять особое внимание возникающим ситуациям не только в его компании, но и во внешней сфере. 
Поэтому важным аспектом внимания является макросреда, которая определяет дальнейшие пути развития.

В условиях нестабильности экономических ситуаций сложное финансовое положение имеют промышленные предприятия. Некоторые из них вынуждены останавливать своё производство и объявлять о невозможности покрытия своих обязательств.

Финансовое состояние промышленных предприятий за последние несколько лет ухудшилось. Возрастает число компаний, приближающихся к стадии банкротства. В результате чего им грозит частичная или полная ликвидация. Поэтому следует уделять особое внимание экономическим и политическим ситуациям, происходящим на территории РФ в данной отрасли, при принятии финансовых решений в своей организации.

В рыночных условиях современной экономики стабильным положением для предприятия служит финансовая устойчивость, которая отражает такое состояние экономических ресурсов, при котором предприятие может легко управлять денежным потоком, а с помощью эффективного использования денежных средств, способно гарантировать непрерывный процесс производства и реализацию продукции.

Финансовое положение компании представляет собой совокупные показатели, которые отражают наличие и применение ресурсов. В процессе анализа хозяйственные процессы изучают в комплексе, что считается преимущественно значимым фактором анализа. Причинные связи, которой опосредуют все хозяйственные факты, явления, процессы.

Анализ финансового состояния нужен не только высшему руководству компании, а также многим другим заинтересованным лицам:

- инвестор, который принимает решение о создании, формировании портфеля ценных бумаг. 
- кредитор, который обязан предоставить при потребности предприятию кредит и быть уверенным, что предприятие вернет сумму кредита совместно с процентами ранее, чем обанкротится.

- аудитор, которому следует проконтролировать отчётность и хозяйственную деятельность организации, а также предоставить надлежащие рекомендации согласно ведению бухгалтерского учёта.

- руководители рекламного, а также маркетингового отделов, которые на базе данной информации разрабатывают стратегию продвижения продукции на рынке.

- менеджеры, в особенности финансовые менеджеры, для которых важна оценка эффективности управленческих решений, направленных на получения финансовых результатов и хозяйственной деятельности ресурсов.

- собственники, которые анализируют прибыль от вложенных средств в предприятие, доходность предприятия.

- поставщики оценивают оплату за выполненную работу, услуги и за поставленную продукцию.

- прочие стейкхолдеры, которые пользуются данным инструментом для прогнозирования возможности возврата кредитов и оценивают возможности предприятия по реализации инвестиционной программы.

Финансовый анализ определяет и изучает изменения финансово хозяйственной деятельности с целью оценки результата финансового состояния на начало и конец года, с целью раскрытия эффективной деятельности хозяйствующей компании, её финансовой стабильности, а также последующего повышения рыночной стоимости.

Для улучшения результатов деятельности хозяйствующего субъекта необходимо рассмотреть финансовые результаты, проанализировать финансовое положение компании. Стоит дать оценку динамики показателей, описать влияние объема прибыли на структуру активов, капитала, 
ликвидность, задолженность и т.д. При анализе полученной прибыли и рентабельности необходимо уделить внимание не только доходной части бюджета компании, но его расходной части.

Качество анализа зависит от исходной информации, используемой методики и организации бухгалтерского учета и учетной политики предприятия при проведении аудита. Он заключается в установлении законности организации бухгалтерского учета и определении соответствия положений учетной политики требованиям нормативных документов и положений по бухгалтерскому учету.

Для эффективного управления финансовым состоянием необходимо обладать навыками анализа различных финансовых отчетностей для определения текущего финансового состояния. Это состояние представляет собой совокупность финансовых и экономических показателей, отражающих наличие, использование и размещение финансовых ресурсов.

Анализ финансового состояния позволяет определить, насколько эффективно предприятие управляет своими средствами, анализировать ошибки прошлых лет, делать выводы и действовать исходя из опыта.

Любая наука обладает собственным предметом, объектом и субъектом изучения, которые она исследует с надлежащей целью свойственными ей способами.

Предметом финансовой оценки являются хозяйственные процессы организации, экономические ресурсы и их потоки, а также конечный финансовый результат деятельности.

Основная цель финансовой оценки - это получение методом вычисления небольшого количества основных, но более информативных параметров, передающих объективный и точный анализ финансового состояния организации, а также прибыли или убытка, изменения в структуре активов или пассивов, в расчётах с дебиторами или кредиторами. 
Чаще всего используются методы финансового анализа, экономические методы анализа, сравнительные методы. Основной принцип изучения финансовых отчётов: дедуктивный метод (то есть переход от общих положений к частным).

Анализ выступает инструментом, при помощи которого происходит познания явлений и предметов внешней и внутренней среды. Он основывается на исследовании разделения целого на составные части во взаимозависимости и взаимосвязи [1].

Экономический анализ является системой специализированных знаний, основанных на исследованиях взаимосвязей между экономическими явлениями и процессами, которые формируются под влиянием субъективных и объективных факторов [2].

Для корректировки и выбора направлений инвестирования капитала, для прогнозирования отдельных экономический показателей, для поиска и устранения проблем в управлении финансово-хозяйственной деятельностью используют такой инструмент как анализ финансовой отчетности [3].

Финансовый анализ вылился в отдельное направление из анализа финансово-хозяйственной деятельности и экономического анализа [4].

Под финансовым анализом подразумевают метод познания различных финансовых механизмов организации для успешного формирования и использования финансовых ресурсов в оперативной и инвестиционной деятельности. Финансовый анализ занимает одно из главенствующих позиций для исследования бизнес-процессов компании [5].

Для выявления дополнительных ресурсов на повышения рыночной стоимости компании организуют процесс исследования результатов финансовой деятельности и состоянии организации, процесс исследования является финансовым анализом. 
Успех управления и развития компании зависит от анализа финансового состояния, под которым подразумевается система экономических показателей, показывающие какими финансовыми ресурсами располагает компания, как она ведет распределение и их использует [6].

Если организация достаточно обеспеченна собственными оборотными средствами, которые используются эффективно и целесообразно, имея четкие организационные расчеты, при наличии устойчивой финансовой базы, то это хорошее финансовое состояние компании [7].

Неудовлетворительным финансовым состоянием характеризуется напротив неэффективным распределением и использованием финансовых ресурсов организации, которые обуславливаются:

- плохой платежной готовностью;

- неэффективном использованием средств и ресурсов;

- просроченной задолженностью бюджета, поставщиками, банками;

- неблагоприятной тенденцией в производстве;

- неустойчивой текущей или потенциальной финансовой базой [8].

Таким образом, ключевой характеристикой надежности и активности организации являются финансовые показатели (состояние) предприятия, так как финансовое состояние отражает не только потенциал и конкурентоспособность в системе взаимодействия между субъектами рынка, но и является гарантом экономических интересов предприятия и его партнеров [9].

Эффективное и грамотное управление организацией основанным на совокупности производственных и хозяйственных факторов, при помощи которых оцениваются результаты деятельности организации и является устойчивым финансовым положением предприятия.

Конечные результаты деятельности предприятия в рыночной экономике отражаются в финансовом состоянии предприятия, данные результаты 
представляют интерес не только для высшего менеджмента и работников организации, но и для партнеров, государственных, финансовых и налоговых учреждений [9].

Вышеприведенные факты наглядно показывают важность анализа финансового состояния организации в экономическом процессе. Данный анализ представляет собой систему изучения данных компании о финансовом состоянии и результатах деятельности в прошлом для того, чтобы оценить возможности и перспективы развития организации [8].

Снизить неопределенности принятия экономических решений менеджментом организации является главной задачей финансового анализа [6].

Финансовый анализ компании помогает руководству оценить его состояние, а инвесторам сведения, для суждения о рациональности вложенных средств.

Финансовое положение организации необходимо для изучения, поскольку на основе аналитических данных осуществляется планирование и прогнозирование, так как важной составляющей финансового положения предприятия является сбор и анализ информации для последующего планирования, обоснованности плановых показателей и объективной оценке выполнения планов.

Одна из функций управления деятельностью организации выступает экономический анализ хозяйственной деятельности, и как составная его составная часть финансовый анализ [Error! Reference source not found.]. Управление плотно связано с финансовым анализом, так как “Управлять значит принимать решения”, а одним из инструментов для принятия решения является финансовый анализ [Error! Reference source not found.]. 
Уровень информационного обеспечения и организационного управления предприятием является ключевым фактором в результативности управления предприятием. Бухгалтерские данные являются основой в системе информационного обеспечения организации для принятия решений.

Для получения точной оценки финансового положения организаций, их руководители прибегают к данной методике.

Нет предмета исследования - нет науки, поэтому каждая наука имеет предмет исследования и в соответствии с целью проводит изучение предмета исследования при помощи присущими ей методами. Важное значение имеет определение предмета для самостоятельности любой отрасли знаний [2].

Специфика науки, которая является отличительной от других, называется предметом науки. Философия трактует под предметом науки определенную сторону объективной действительности, которая изучается только данной наукой.

Методологии и методики регулируются принципы финансового анализа, к которым относятся преемственность, системность, регулярность, комплексность и другие.

Финансовый анализ рассматривают как процесс исследования финансового состояния компании, анализируя основные результаты финансовой деятельности. Это применяют для выявления резервов, что в свою очередь способствует повышению рыночной стоимость организации [Error! Reference source not found.].

Виды финансового анализа зависят от следующих признаков:

1. Внутренние и внешние финансовые анализы организации выделяются по организационным формам проведения:

- Применяется весь объем имеющейся информационных финансовых показателей для проведения собственниками или менеджерами внутреннего 
финансового анализа имущества компании, результат данного исследования в основном является корпоративной коммерческой тайной.

- Налоговые инстанции, банки, аудиторские и страховые компании производят внешний финансовый анализ выбранной компании для анализа финансовых правильностей показателей последних, его устойчивости и кредитоспособности для своих целей [Error! Reference source not found.].

2. Полный и тематический финансовые анализы предприятия выявляют по объему исследования.

- Для комплексного изучения и анализа всех аспектов финансовой деятельности применяют полный финансовый анализ организации.

- В отличие от комплексного финансового анализа, тематический финансовый анализ изучает и анализирует только отдельные аспекты, а не все аспекты финансовой деятельности компании.

3. По времени осуществления [Error! Reference source not found.]:

- До реализации хозяйственных операций - прогнозный анализ;

- Контролирующий текущую финансовую деятельность оперативный анализ;

- Финансовый анализ за отчетный период, позволяющий контролировать выполнения плановых финансовых показателей компании последующий анализ.

4. По методике проведения:

- Сравнения финансовых отчетов о результатах финансовой деятельности компании с данными прошлых периодов и плановых показателями называется сопоставительный анализ;

- Выявление взаимодействий отдельных факторов и показателей на изменения финансовой результативности организации является факторным анализом; 


\section{ЧЕЛОВЕК И СОВРЕМЕННОЕ ОБЩЕСТВО \\ В СОЦИАЛЬНОМ, ПРАВОВОМ, ЭКОНОМИЧЕСКОМ РАКУРСАХ}

- Мониторингом за отклонениями нормального хода деятельности организации называется диагностическим анализом;

- Анализ во взаимодействие объема продаж, издержек и прибыли, путем оценки и обоснования эффективности управленческих решений называется операционным анализом;

- Исследование взаимосвязей между результативными показателями и факторами деятельности компании является детерминированным анализом [Error! Reference source not found.].

5. Проводя финансовый анализ, в зависимости от целей и методов, распознают две основные системы экспресс-диагностику финансового состояния организации и углубленный (фундаментальный) анализ:

- экспресс-диагностику финансового состояния организации. Быстрый, направленный на поиск и обозначение важнейших проблем управления финансово-хозяйственной деятельности организации в текущей ситуации. Из-за отсутствия сложных расчетов и возможность провести анализ, за короткий промежуток времени. Данный вид системы финансового анализа применяется для изучения текущих аспектов деятельности организации и ставит целью дать предварительную оценку финансового состояния организации, таким образом, помогает найти проблемы и пути их решения за короткий срок.

- углубленный (фундаментальный) анализ финансово-хозяйственной деятельности организации. Определение и анализ реального экономического потенциала компании при помощи детального и углубленного оценивания финансово-хозяйственного состояния компании [Error! Reference source not found.].

Выявление взаимозависимостей и взаимосвязей между финансовыми показателями в отчетности финансово-хозяйственной деятельности организации является главной задачей анализа финансовой отчетности. 


\section{ЧЕЛОВЕК И СОВРЕМЕННОЕ ОБЩЕСТВО В СОЦИАЛЬНОМ, ПРАВОВОМ, ЭКОНОМИЧЕСКОМ РАКУРСАХ}

В зависимости от целей, методологий, информационных факторов и технического обеспечения выбирается методика анализа финансового состояния предприятия.

Фундаментальной базой для данного анализа является аналитика бухгалтерского учета и отчетности: изучение основных показателей хозяйственной деятельности и совершенных операций в общем или за определенный период времени

«Чтение» форм отечности и понимание величин в этих формах - это важнейший из навыков анализа финансовой отчетности, которое позволит узнать информацию об основных источниках привлечения средств компании, их распределения, источниках прибыли организации за отчетный период, а также поможет изучить источники оборотных активов и денежных средств [Error! Reference source not found.].

Хоть этой информации будет достаточно для принятия управленческих решений, но ее будет не хватать для оценки динамики основных показателей компании, ее места среди похожих компаний по стране и на мировом рынке.

Для этого в финансовом анализе существуют основные методологии для «чтения» финансовых отчетов организации.

Для сравнения каждой позиции отчетности с предыдущим периодом времени (месяц, квартал, год) применяется горизонтальный анализ, который заключается в создании нескольких аналитических таблиц, отражающие темпы роста (снижения). Однако данный метод теряет свою эффективность в условиях инфляции.

Для анализа влияния на целостный результат каждой позиции из отчетности используют метод вертикального анализа.

Для определения тенденций динамики показателей каждой позиции за предыдущие периоды применяют метод трендового анализа. Для более достоверной информации показатели «очищают» от случайных внешних 


\section{ЧЕЛОВЕК И СОВРЕМЕННОЕ ОБЩЕСТВО В СОЦИАЛЬНОМ, ПРАВОВОМ, ЭКОНОМИЧЕСКОМ РАКУРСАХ}

влияний и индивидуальных особенностей того или иного периода. При помощи данного метода прогнозируются значения показателей в будущем.

Сравнительный анализ состоит из внутрихозяйственного сравнения (с подразделениями внутри компании) и межхозяйственного сравнения (с показателями конкурентов и другими показателями по отрасли).

Платежеспособность и ликвидность необходимо рассматривать в совокупности по причине того, что предприятие может являться ликвидным, однако в активах имеется значительное количество неликвидов и просроченную дебиторскую задолженность.

При анализе стоит учитывать тот факт, что наличие значительной суммы средств на расчетном счете является признаком платежеспособности, если денежных средств достаточно для текущих расчетов и платежей. Но также стоит учитывать и то, что отсутствие денежных средств на расчетном счете не является неплатежеспособностью предприятия, при условии, что средства поступят в течении нескольких дней на расчетный счет организации.

Степень зависимости от внешних инвесторов и кредиторов организации определяет долгосрочные перспективы финансового состояния предприятия. По мнению многих экспертов, доля заемного капитала не должна превышать 40\%, поскольку организация с высокой оборачиваемостью денежных средств может иметь низкий уровень собственного капитала.

Заинтересованные лица в финансовой отчетности для приятия решения используют анализ баланса для изучения финансового состояния изучаемого субъекта и его перспектив развития. При изучении баланса и понимание процессов компании используется дополнительная информация, при помощи который можно проанализировать состав, риски, структуру организации. 
Чтобы точно и правильно определить положение компании на рынке, необходимо в первую очередь провести внутренний аудит, а только потом приступить к внешнему. Для этого используют управленческий и финансовый анализ, который ориентирован на исследование различной информации (открытой и закрытой). По полученным результатам формулируются вводы, на основании которых руководство предприятия принимает те или иные действия для его стабильной работы.

Для оценки взаимосвязи «затраты - выручка - прибыль» в краткосрочном планировании применяется метод CVP - анализа. Суть этого метода состоит в том, что с помощью формул и графиков устанавливается взаимосвязь затрат, выручки (дохода), объема производства и прибыли. С помощью этого метода определяется оптимальное соотношение между постоянными и переменными затратами, объемом производимой продукции и реализационной ценой на нее. Основная роль в проведении CVP-анализа принадлежит определению маржинальной прибыли, которая равна выручке от продаж за минусом переменных расходов.

Анализ соотношения затрат, выручки и прибыли позволяет определить объем производства, при котором предприятие не будет иметь убытков. Такой объем производства называется точкой безубыточности. Для ее вычисления используются три метода: метод маржинального дохода, метод уравнений и графический метод [1]. Безубыточность производственной деятельности предприятия характеризуется равенством выручки от продаж определенного количества продукции по стабильной цене и сумме постоянных и переменных затрат на производство этого же количества продукции. Разность между фактическим и безубыточным объемом продаж показывает запас финансовой прочности, чем его значение меньше, тем выше риск попадания в зону убытков. Комплексный анализ безубыточности заключается в непрерывном контроле полученных доходов и текущих издержек фирмы, определении 
соотношения точки безубыточности и фактического объема производства [2]. Производство продукции в большем объеме, чем точка безубыточности, позволяет предприятию получать прибыль. На размер прибыли влияет размер постоянных и переменных затрат предприятия, так ка при их росте происходит сокращение получаемой прибыли.

В результате полученной информации об относительной доходности руководство предприятием может координировать управленческие действия для оптимизации процессов внутри предприятия.

Когда идёт проверка внутри предприятия, соответствующие пользователи могут получать любую информацию, которая касается его текущей деятельности и перспектив развития. Внешняя проверка может ориентироваться лишь на данные, полученные из официальных источников (например, бухгалтерская отчётность) и делать выводы в пределах этой информации.

В современном мире каждое предприятие может оказаться в сложной финансовой ситуации, причём это может произойти как из-за внешних факторов, так и из-за внутренних. Но при грамотном распределении возможностей предприятия и вовремя принятых мер по устранению и оздоровлению данной ситуации, с помощью профессионализма и предыдущего опыта работы, возможно, восстановить финансовую устойчивость. Вовремя принятые меры по устранению данной ситуации, профессионализм, предыдущий опыт организации или её конкурентов - всё это поможет восстановить платёжеспособность, финансовую устойчивость и, как следствие, репутацию компании.

\section{Список литературы}

1. Анализ и диагностика финансово-хозяйственной деятельности предприятий: Учебник / под ред. Позднякова В.Я. - М.: Инфра-М, 2018. 
2. Ларионова Г.Н. Методологические подходы к оценке платежеспособности предприятий нефтехимического комплекса (на примере ОАО «Татнефть») / Г.Н. Ларионова // Научное обозрение. - 2015. - № 7.

3. Копылова Е.А. Оценка финансового состояния ПАО «Вымпелком» / Е.А. Копылова, В.С. Скворцова // Аудит и финансовый анализ. - 2017. - № 3-4.

4. Грачёв А.В. Финансовая устойчивость предприятия: анализ, оценка и управление в рыночной экономике: науч. изд. / А.В. Грачёв. - М.: Дело и Сервис, 2006.

5. Савицкая, Г.В. Анализ хозяйственной деятельности предприятия: Учебник / Г.В. Савицкая. - М.: Инфра-М, 2018

6. Абдукаримов, И.Т. Анализ финансового состояния и финансовых результатов предпринимательских структур. Учебное пособие / И.Т. Абдукаримов. - М.: ИНФРА-М, 2018.

7. Крайнова, К.А., Кулина, Е.А., Сатушкина, В.С. Методика анализа финансовой устойчивости предприятия в условиях кризиса / К.А. Крайнова, Е.А. Кулина, В.С. Сатушкина // Молодой ученый. — 2015. — №11.3.

8. Одинцов, В.А. Анализ финансово-хозяйственной деятельности предприятия: Учебное пособие / В.А. Одинцов. - М.: Академия, 2019

9. Лукасевич И.Я. Анализ денежных потоков как инструмент принятия решений в бизнесе / И.Я. Лукасевич // Финансы. - 2016. - № 7.

(C) Е.В. Сухарева, 2022 
УДК 332.1

\title{
Глава 14. \\ ЭКОНОМИЧЕСКОЕ ОБОСНОВАНИЕ \\ СОЦИАЛЬНОГО ПРОЕКТА «ПЛАТНЫЕ ПАРКОВКИ»
}

\author{
Адмаев Олег Васильевич \\ к.ф.-м.н., доцент \\ Союз журналистов Красноярского края \\ Гидзинский Евгений Витальевич \\ аспирант \\ КрИЖТ филиал ИрГУПС
}

Аннотация: Институт Уполномоченного по правам человека в Российской Федерации осуществляет постоянную и планомерную работу по укреплению правового сознания среди различных социальных групп населения, в том числе и среди подрастающего поколения.

Ключевые слова: права человека, экологическое нормотворчество, благоприятная окружающая среда, открытый урок, евклидова норма, градостроительная конфигурация, цифровая модель местности, платная парковка.

\section{ECONOMIC JUSTIFICATION OF THE SOCIAL PROJECT «PAID PARKING»}

\section{Admaev Oleg Vasilyevich Gidzinsky Evgeny Vitalievich}

\begin{abstract}
The Institute of the Commissioner for Human Rights in the Russian Federation carries out constant and systematic work to strengthen legal
\end{abstract} 341 
awareness among various social groups of the population, including among the younger generation.

Key words: human rights, environmental rulemaking, favorable environment, open lesson, euclidean norm, urban planning configuration, digital terrain model, paid parking.

«Россия должна стать не только ключевым логистическим, транспортным узлом планеты, но и одним из мировых центров хранения, обработки, передачи и надежной защчтты информационных массивов, так называемых больших данных. В полную силу должны заработать мощные научно-образовательные иентры. Они будут интегрировать возможности университетов, академических институтов, высокотехнологичных компаний. Важно нацелить их на реализащию крупных междисииплинарных проектов».

Послание Президента Российской Федерации В.В. Путина Федеральному Собранию 01.03.2018 [1].

Введение

Президент Российской Федерации В.В. Путин в Послании к Федеральному Собранию особое внимание уделил экологическим проблемам: «Позитивный эффект от перехода промышленности на наилучшие доступные технологии, на строгие природоохранные стандарты должны почувствовать 
жители крупнейших индустриальных центров страны. Решение проблем в сфере экологии - это задача для нашей промышленности и науки, ответственность каждого из нас. Призываю самым активным образом включиться в эту работу и молодёжь. Мы должны передать будущим поколениям экологически благополучную страну, сохранить природный потенциал и заповедный фонд России» [2].

Данная эколого-философская статья посвящена размещению платных парковок, как части экологических проблем крупных индустриальных центров.

Главный вопрос исследования - каким образом, изменяя географическое расположение паркоматов, стоимость одного часа, величину штрафа, другие характеристики, создавать благоприятную для населения окружающую среду? Решение данной задачи становится возможным, если разместить внутри парковочного устройства дополнительное необходимое экологическое оборудование, измеряющее атмосферные показатели городской среды в локальной окрестности каждого паркомата.

Но, наверное, будет неправильно ограничиться только технической и даже экологической составляющими в проблеме платных парковок - в настоящее время очень отчетливо проявляются еe педагогические и философско-нравственные аспекты, в связи с чем необходимо уделить пристальное внимание созданию математической модели в задаче о платных парковках.

\section{Часть I}

\section{Примеры}

В работе [3] каждая точка автомобильной дороги (линия $\mathrm{AB}$ ) имеет соответствующие координаты в экологически выбранном пространстве (рис. 1). 


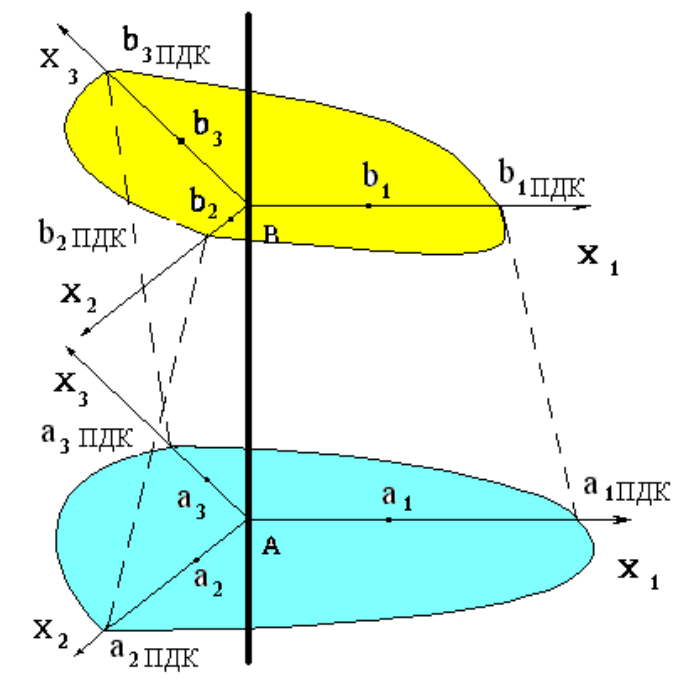

Pис. 1.

Например, пусть экспериментально установлено, что точке А соответствуют координаты $\left(\mathrm{a}_{1}, \mathrm{a}_{2}, \mathrm{a}_{3}\right)$, точке B - координаты $\left(\mathrm{b}_{1}, \mathrm{~b}_{2}, \mathrm{~b}_{3}\right)$. Пусть по оси $\mathrm{X}_{1}$ измеряются значения формальдегида, по оси $\mathrm{X}_{2}$ - диоксид азота, по оси $\mathrm{X}_{3}$ - взвешенные вещества. Полученные результаты каждый раз необходимо сравнивать с контрольными величинами ПДК, которые

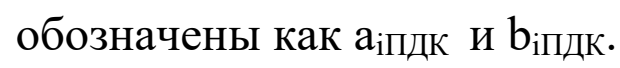

Примечание. Уровень загрязнения городской среды предполагает число $n$ - количество измеряемых компонент, поэтому при математическом моделировании очень важно учитывать особенности нормирования в соответствующих $n$-мерных пространствах.

ПДК - предельная допустимая концентрация загрязняющего вещества в атмосферном воздухе - концентрация, не оказывающая в течение всей жизни прямого или косвенного неблагоприятного действия на настоящее или будущее поколение, не снижающая работоспособности человека, не ухудшающая его самочувствия и санитарно-бытовых условий жизни.

ПДКсс - предельно допустимая среднесуточная концентрация химического вещества в воздухе населенных мест, мг/м³. Эта концентрация не 
должна оказывать на человека прямого или косвенного вредного воздействия при неопределенно долгом (годы) вдыхании.

В экологической практике распространена следующая формула расчета ограничений ПДК в воздухе, когда на организм действует несколько вредных веществ:

$$
\frac{C_{1}}{\Pi Д K_{1}}+\frac{C_{2}}{\Pi Д K_{2}}+\ldots+\frac{C_{n}}{\Pi Д K_{n}} \leq 1
$$

где $C_{1}, C_{2}, \ldots, C_{n}-$ фактические концентрации вредных веществ в атмосферном воздухе: ПДК $, ~ П Д K_{2}, \ldots, \quad \Pi Д K_{n}-$ предельно допустимые концентрации этих веществ.

Авторы предлагают другой расчетный вариант оценки загрязнения атмосферы города. Пусть вектор $\vec{X}$ имеет компоненты, приведенные к ПДКсс по трем выбранным загрязнителям с произвольными значениями в точке A, вектор $\vec{Y}$ - соответственно в точке В.

Таблица 1

\begin{tabular}{|c|c|c|c|c|c|}
\hline Загрязнитель & $\begin{array}{c}\text { ПДКсс } \\
\left(\mathrm{мг} / \mathrm{M}^{3}\right)\end{array}$ & $\begin{array}{c}\mathrm{A} \\
\left(\mathrm{мг} / \mathrm{M}^{3}\right)\end{array}$ & $\begin{array}{c}\mathrm{B} \\
\left(\mathrm{мг} / \mathrm{M}^{3}\right)\end{array}$ & $\begin{array}{c}\vec{X} \\
(П Д К с с)\end{array}$ & $\begin{array}{c}\vec{Y} \\
(П Д К с с)\end{array}$ \\
\hline Формальдегид & 0,01 & $\mathrm{a}_{1}=0,04$ & $\mathrm{~b}_{1}=0,02$ & 4 & 2 \\
\hline Диоксид азота & 0,04 & $\mathrm{a}_{2}=0,12$ & $\mathrm{~b}_{2}=0,2$ & 3 & 5 \\
\hline Взвешенные вещества & 0,15 & $\mathrm{a}_{3}=0,9$ & $\mathrm{~b}_{3}=6$ & 6 & 4 \\
\hline
\end{tabular}

Корень квадратный из скалярного произведения вектора на самого себя - это его длина или евклидова норма в вещественном конечномерном линейном пространстве со скалярным произведением.

Для рассматриваемых двух векторов $\vec{X}$ и $\vec{Y}$ евклидова норма каждого из них рассчитывается следующим образом:

$$
\begin{gathered}
\|X\|=\sqrt{(X, X)}=(4 * 4+3 * 3+6 * 6)^{0,5}= \\
(16+9+36)^{0,5}=\sqrt{61}=7,8
\end{gathered}
$$




$$
\begin{gathered}
\|Y\|=\sqrt{(Y, Y)}=(2 * 2+5 * 5+4 * 4)^{0,5}= \\
(4+25+16)^{0,5}=\sqrt{45}=6,7
\end{gathered}
$$

Поскольку евклидова норма в трехмерном пространстве для точки А больше, чем для точки $\mathrm{B}$, то будем считать, что экологическое состояние в точке А хуже, чем в точке В.

Такие же рассуждения можно провести для $m=192$ перекрестков Красноярска с количеством $n=7$ измеряемых компонент (Таблица 2). Затем к полученным данным для дальнейшего анализа можно применить методы математической статистики.

Таблица 2

\begin{tabular}{|c|c|c|c|c|c|c|c|}
\hline $\begin{array}{c}\text { Загряз- } \\
\text { нитель }\end{array}$ & $\begin{array}{c}\text { Формаль- } \\
\text { дегид }\end{array}$ & $\begin{array}{c}\text { Диоксид } \\
\text { азота }\end{array}$ & $\begin{array}{c}\text { Бенз/a/- } \\
\text { пирен }\end{array}$ & $\begin{array}{c}\text { Сера } \\
\text { диоксид }\end{array}$ & $\begin{array}{c}\text { Углерода } \\
\text { оксид }\end{array}$ & $\begin{array}{c}\text { Углерод } \\
\text { (сажа) }\end{array}$ & Бензин \\
\hline $\begin{array}{c}\text { ПКксс } \\
\left(м г / \mathbf{m}^{3}\right)\end{array}$ & 0,01 & 0,04 & $10^{-6}$ & 0,05 & 3 & 0,05 & 1,5 \\
\hline
\end{tabular}

Примечание. Поскольку полученные расчетные данные для загрязнителей атмосферного воздуха измерялись в [г/сек], то возникла необходимость ввести такую единицу измерения, как [ПДК* ${ }^{3} /$ сек]. Поэтому значения на рисунке 2 соответствуют не значениям ПДК в общепринятом понимании, а значениям ПДК в единице объема за единицу времени.

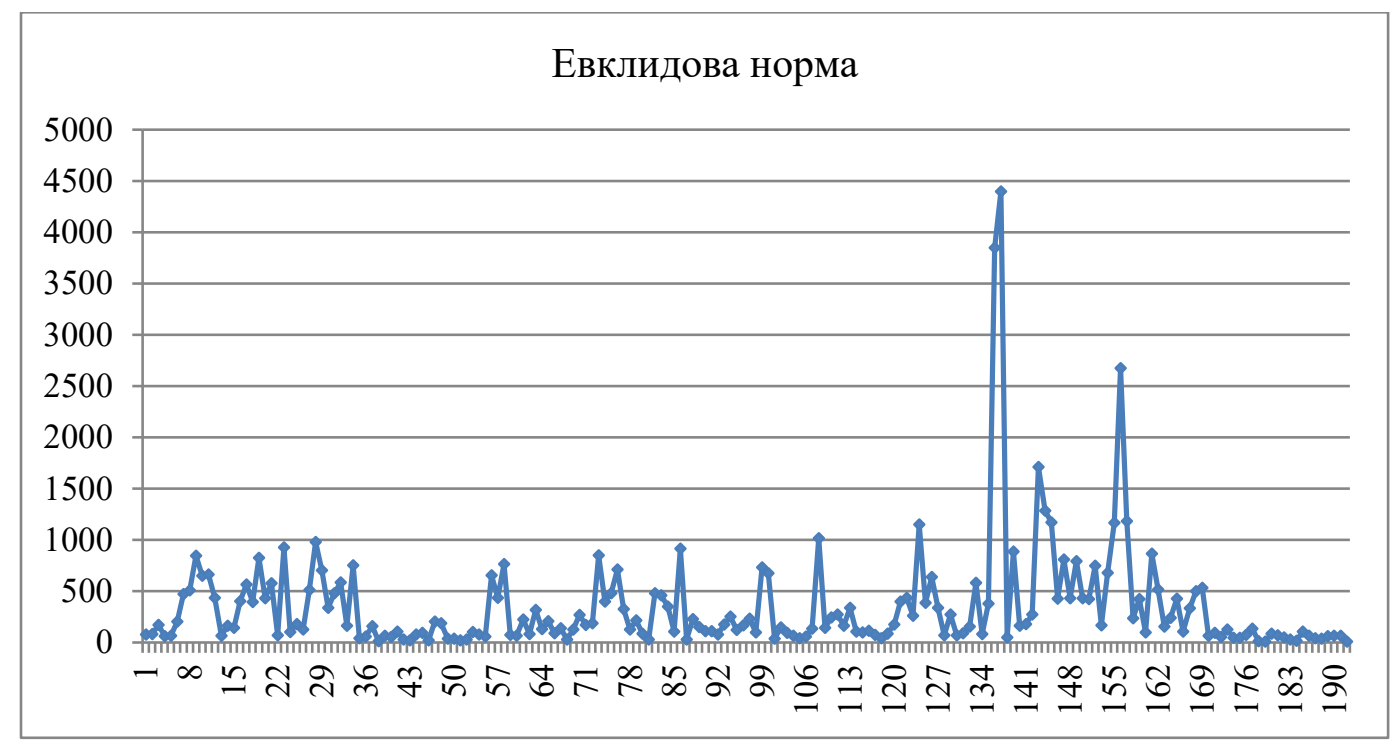

Рис. 2. По оси X приведены перекрестки Красноярска 
Можно выделить основные группы значений, например, для использования в кластерном анализе и в дифференциальных уравнениях [4]: менее 300; от 400 до 600; от 900 до 1200; более 2000.

Три точки на Рис. 2 с максимальными значениями соответствуют перекресткам 136 и 137 на участке объездной дороги вблизи Гайдашовки и кольцевому перекрестку 156 на правобережной Предмостной площади [5].

\section{Часть II}

\section{Институт Уполномоченного по правам человека в Российской Федерации}

Право на благоприятную окружающую среду является одной из важнейших социальных проблем в регионах и федеральных округах Российской Федерации. Экспертный совет при Уполномоченном по правам человека в Российской Федерации, Координационные советы уделяют экологическим правам граждан большое внимание $[6,7,8]$.

Информация о деятельности Уполномоченного по правам человека в Российской Федерации, его региональных коллег размещена на сайтах https://ombudsmanrf.org/, https://map.ombudsmanrf.org/.

Ежегодно в Международный день прав человека проходит церемония награждения медалью Уполномоченного по правам человека в Российской Федерации «Спешите делать добро». Ею награждаются граждане, внесшие значительный вклад в защиту прав человека: право на защиту семьи, материнства, отцовства и детства занимает особое место [6], ведь изменения в Конституцию Российской Федерации, внесенные по итогам всероссийского голосования, определили семью и молодое поколение главной ценностью нашего общества [9].

Институт Уполномоченного по правам человека в Российской Федерации осуществляет сотрудничество с вузами и академическим сообществом, поддерживает научные исследования $[10,11]$. 


\section{Экология и экономика}

Право на благоприятную окружающую среду - одно из основополагающих прав человека, определяющих качество жизни граждан. От обеспечения экологического благополучия зависит будущее человечества.

Одной из форм работы Уполномоченного по правам человека в Российской Федерации с учащейся молодежью являются открытые уроки по правам человека. В данной статье рассмотрено индивидуальное задание для самостоятельной работы, выполняемое в процессе экологического урока его участниками (Таблица 3). Правовые экологические уроки могут быть посвящены различным природоохранным мероприятиям, в том числе и размещению платных парковок в г. Красноярске.

\section{Таблица 3}

\section{Индивидуальная карточка для открытого урока}

\section{Задание: необходимо выбрать место размещения платной парковки}

\begin{tabular}{|c|c|c|c|c|c|}
\hline Объекты & $\begin{array}{c}\text { Характерис- } \\
\text { тика } 1 \\
\text { Евклидова } \\
\text { норма для } \\
\text { перекрестков }\end{array}$ & $\begin{array}{c}\text { Характерис- } \\
\text { тика } 2 \\
\text { Тип } \\
\text { градострои- } \\
\text { тельной } \\
\text { конфигу- } \\
\text { рации }\end{array}$ & $\begin{array}{c}\text { Характерис- } \\
\text { тика } 3 \\
\text { Высота h, м, } \\
\text { углы наклона, } \\
\text { промилле, \%o } \\
\text { H= } \mathrm{H}(\mathrm{h}, \text { alfa, } \\
\text { beta) }\end{array}$ & $\begin{array}{c}\text { Характерис- } \\
\text { тика } 4 \\
\text { Евклидова } \\
\text { норма для } \\
\text { промышлен- } \\
\text { ных } \\
\text { выбросов }\end{array}$ & $\begin{array}{c}\text { Характерис- } \\
\text { тика } 5 \\
\text { Доля } \\
\text { территории } \\
\text { для } \\
\text { водителей- } \\
\text { инвалидов, \% }\end{array}$ \\
\hline Городской парк & $100-200$ & I & $(330,0,-40)$ & $100-200$ & 10 \\
\hline Торговый центр & $300-400$ & IV & $(150,10,0)$ & $300-400$ & 15 \\
\hline Деловой квартал & $500-900$ & III & $(200,20,-30)$ & $500-900$ & 15 \\
\hline Жилой массив & $100-200$ & VI & $(270,40,-20)$ & $100-200$ & 10 \\
\hline
\end{tabular}

В теоретической части открытого урока предусмотрено раскрытие темы обеспечения экологической безопасности и ликвидации накопленного вреда окружающей среде: разработаны новые законы, реализуется федеральный проект «Чистая страна», подготовлен проект «Генеральная уборка» 
фронтальной стратегии социально-экономического развития Российской Федерации до 2030 года [12, 13].

\section{1. Нормирование в 7-мерном пространстве}

Для $m=192$ перекрестков Красноярска с количеством $n=7$ измеряемых компонент (формальдегид, диоксид азота, бенз/а/-пирен, серы диоксид, углерода оксид, углерод, бензин) была посчитана Евклидова норма в вещественном конечномерном линейном пространстве со скалярным произведением (Рис. 2).

\section{2. Основные типы градостроительных конфигураций}

В «черном небе» над Красноярском частично «виноваты» объекты городского строительства. В диссертациях $[14,15]$ рассмотрены основные типы городской застройки:
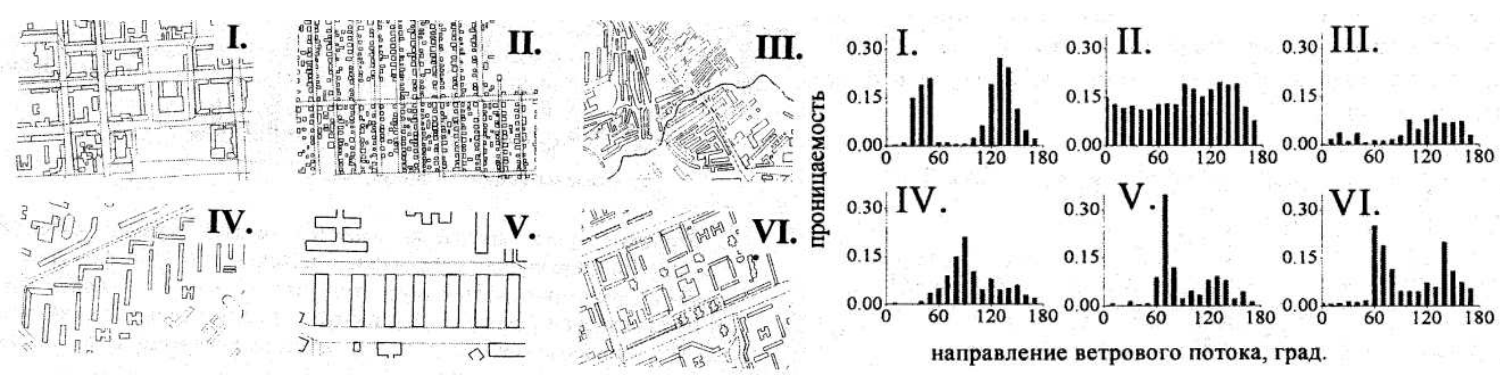

Pис. 3.

I - тип застройки периметральный, пятиэтажный

II - тип застройки свободный, одноэтажный

III - тип застройки смешанный, девятиэтажный

IV - тип застройки продольно-поперечный, четырехэтажный

V - тип застройки поперечный, девятиэтажный

VI - тип застройки периметрально-продольный, четырехэтажный 


\section{3. Интерактивная карта загрязнений воздуха}

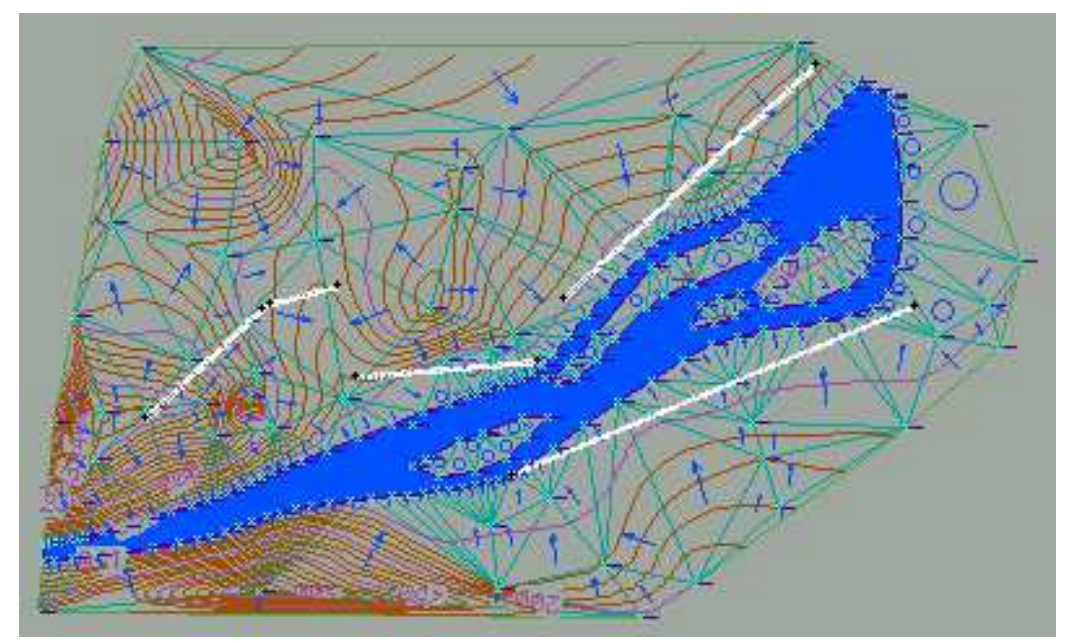

\section{Рис. 4. Цифровая модель местности Красноярска} с обозначенными автомагистралями

Орографические характеристики территории являются важнейшими и фактически постоянными составляющими любой экологической экспертной системы [16]. Добавление высотной координаты к двум плоскостным позволяет построить триангуляционную сеть как элемент цифровой модели местности Красноярска (Рис. 4), которая была выбрана в качестве основы для построения интерактивной карты загрязнения воздуха.

Рассмотрим высотную характеристику $H=H(h, a l f a$, beta $)$ для цифровой модели местности, где $h$ - собственно высота выбранной точки над уровнем моря в метрах, alfa - значение угла наклона в промилле в максимальном положительном направлении вверх, beta - значение угла наклона в промилле в максимальном отрицательном направлении вниз.

У парковок в историческом центре Красноярска значение переменной beta будет равно нулю. Для парковок на городских вершинах значение alfa также нулевое. Единственность гарантируется выбором максимального значения. 


\section{4. Промышленные выбросы}

Аналогично работе [5], определим Евклидову норму для промышленных выбросов, учитываемых с помощью сайта http://www.krasecology.ru/, в том же 7-мерном пространстве (формальдегид, диоксид азота, бенз/а/-пирен, серы диоксид, углерода оксид, углерод, бензин):

Таблица 4

Среднесуточные концентрации зВ, измеряемые в режиме on-line, за прошедшие сутки 16 января 2022 с 00:00 по 23:59 (в долях ПдКсс)

- содержание 3В превышает ПдКсс.

\begin{tabular}{|c|c|c|c|c|c|c|c|}
\hline $\begin{array}{c}\text { Автоматизированный } \\
\text { пост наблюдения }\end{array}$ & $\begin{array}{l}\text { Оксид } \\
\text { углерода }\end{array}$ & $\begin{array}{l}\text { Диоксид } \\
\text { серы }\end{array}$ & $\begin{array}{l}\text { Оксид } \\
\text { азота, } \\
\text { мг/м3 }\end{array}$ & $\begin{array}{l}\text { Диоксид } \\
\text { азота }\end{array}$ & $\begin{array}{c}\text { Сероводород, } \\
\text { мr/m3 }\end{array}$ & Аммиак & $\begin{array}{c}\text { Bзвешенные } \\
\text { частицы } \\
\text { (до 2,5 мкм) }\end{array}$ \\
\hline $\begin{array}{l}\text { «Красноярск } \\
\text { Покровка» }\end{array}$ & $\begin{array}{c}0.24 \\
16.01\end{array}$ & $\begin{array}{c}0.01 \\
16.01\end{array}$ & $\begin{array}{l}0.021 \\
16.01\end{array}$ & $\begin{array}{c}0.81 \\
16.01\end{array}$ & $\begin{array}{c}0 \\
16.01\end{array}$ & $\begin{array}{c}0 \\
16.01\end{array}$ & $\begin{array}{c}1.07 \\
16.01\end{array}$ \\
\hline $\begin{array}{l}\text { «Красноярск- } \\
\text { Березовка» }\end{array}$ & $\begin{array}{c}0.77 \\
16.01\end{array}$ & $\begin{array}{c}0.17 \\
16.01\end{array}$ & $\begin{array}{l}0.035 \\
16.01\end{array}$ & $\begin{array}{c}0.62 \\
16.01\end{array}$ & - & - & \\
\hline $\begin{array}{l}\text { «Красноярск- } \\
\text { Кировский }\end{array}$ & $\begin{array}{c}0.53 \\
16.01\end{array}$ & $\begin{array}{c}0.1 \\
16.01\end{array}$ & $\begin{array}{l}0.176 \\
16.01\end{array}$ & $\begin{array}{c}0.2 \\
16.01\end{array}$ & & $\begin{array}{c}0.06 \\
16.01\end{array}$ & \\
\hline $\begin{array}{l}\text { «Красноярск- } \\
\text { Кубеково» }\end{array}$ & $\begin{array}{c}0.25 \\
16.01\end{array}$ & $\begin{array}{c}1.14 \\
16.01\end{array}$ & $\begin{array}{l}0.013 \\
16.01\end{array}$ & $\begin{array}{c}0.14 \\
16.01\end{array}$ & - & - & $\begin{array}{c}1.1 \\
16.01\end{array}$ \\
\hline $\begin{array}{c}\text { «Красноярск- } \\
\text { Свердловский }\end{array}$ & $\begin{array}{c}0.16 \\
16.01\end{array}$ & $\begin{array}{c}0.16 \\
16.01\end{array}$ & $\begin{array}{l}0.117 \\
16.01\end{array}$ & $\begin{array}{c}0.28 \\
16.01\end{array}$ & $\begin{array}{c}0.0019 \\
16.01\end{array}$ & $\begin{array}{c}0.02 \\
16.01\end{array}$ & $\begin{array}{c}1.32 \\
16.01\end{array}$ \\
\hline $\begin{array}{l}\text { «Красноярск- } \\
\text { Солнечныйж }\end{array}$ & $\begin{array}{c}0.24 \\
16.01\end{array}$ & $\begin{array}{c}0.1 \\
16.01\end{array}$ & $\begin{array}{l}0.003 \\
16.01\end{array}$ & $\begin{array}{c}0.17 \\
16.01\end{array}$ & $\begin{array}{c}0.0007 \\
16.01\end{array}$ & $\begin{array}{c}0 \\
16.01\end{array}$ & $\begin{array}{c}0.42 \\
16.01\end{array}$ \\
\hline $\begin{array}{l}\text { «Красноярск- } \\
\text { Черемушки }\end{array}$ & $\begin{array}{c}0.66 \\
16.01\end{array}$ & $\begin{array}{c}0.14 \\
16.01\end{array}$ & $\begin{array}{l}0.075 \\
16.01\end{array}$ & $\begin{array}{c}0.83 \\
16.01\end{array}$ & & $\begin{array}{c}0.05 \\
16.01\end{array}$ & $\begin{array}{c}2.22 \\
16.01\end{array}$ \\
\hline
\end{tabular}

Таблица 5

\begin{tabular}{|c|c|c|c|c|c|c|c|c|}
\hline $\begin{array}{c}\text { Автоматизированный } \\
\text { пост наблюдения }\end{array}$ & Бензол & $\begin{array}{c}\text { Смесь м-, п- } \\
\text { ксилолов, } \\
\text { мг/м3 }\end{array}$ & $\begin{array}{l}\text { О-ксилол, } \\
\text { мг/м3 }\end{array}$ & $\begin{array}{l}\text { Стирол, } \\
\text { мг/м3 }\end{array}$ & $\begin{array}{l}\text { Толуол, } \\
\text { мг/м3 }\end{array}$ & Фенол & $\begin{array}{c}\text { Хлорбензол, } \\
\text { мг/м3 }\end{array}$ & $\begin{array}{c}\text { Этилбензол, } \\
\text { мг/м3 }\end{array}$ \\
\hline $\begin{array}{l}\text { «Красноярск } \\
\text { Покровка» }\end{array}$ & $\begin{array}{c}0 \\
16.01 \\
\end{array}$ & $\begin{array}{c}0 \\
16.01 \\
\end{array}$ & $\begin{array}{c}0 \\
16.01 \\
\end{array}$ & $\begin{array}{c}0 \\
16.01 \\
\end{array}$ & $\begin{array}{c}0 \\
16.01\end{array}$ & $\begin{array}{c}0 \\
16.01 \\
\end{array}$ & $\stackrel{0}{0} 16.01$ & $\begin{array}{c}0 \\
16.01 \\
\end{array}$ \\
\hline $\begin{array}{l}\text { «Красноярск- } \\
\text { Кировский» }\end{array}$ & $\begin{array}{c}0 \\
16.01\end{array}$ & $\begin{array}{c}0 \\
16.01\end{array}$ & $\begin{array}{c}0 \\
16.01\end{array}$ & $\begin{array}{c}0 \\
16.01\end{array}$ & $\begin{array}{c}0 \\
16.01\end{array}$ & $\stackrel{0}{0} 16.01$ & $\begin{array}{c}0 \\
16.01\end{array}$ & $\begin{array}{c}0 \\
16.01\end{array}$ \\
\hline $\begin{array}{l}\text { «Красноярск- } \\
\text { Свердловский» } \\
\end{array}$ & $\begin{array}{c}0 \\
16.01 \\
\end{array}$ & $\begin{array}{c}0 \\
16.01 \\
\end{array}$ & $\begin{array}{c}0 \\
16.01 \\
\end{array}$ & $\begin{array}{c}0 \\
16.01 \\
\end{array}$ & $\begin{array}{c}0 \\
16.01 \\
\end{array}$ & $\begin{array}{c}0 \\
16.01 \\
\end{array}$ & $\begin{array}{c}0 \\
16.01 \\
\end{array}$ & $\begin{array}{c}0 \\
16.01 \\
\end{array}$ \\
\hline $\begin{array}{l}\text { «Красноярск- } \\
\text { Северный» }\end{array}$ & $\begin{array}{c}0 \\
16.01\end{array}$ & $\stackrel{0}{0}$ & $\begin{array}{c}0 \\
16.01\end{array}$ & $\begin{array}{c}0 \\
16.01\end{array}$ & $\begin{array}{c}0 \\
16.01\end{array}$ & $\stackrel{0}{0}$ & $\stackrel{0}{16.01}$ & $\stackrel{0}{0}$ \\
\hline $\begin{array}{l}\text { «Красноярск- } \\
\text { Солнечный" }\end{array}$ & $\stackrel{0}{0} 16.01$ & $\stackrel{0}{0}$ & $\stackrel{0}{0} 16.01$ & $\stackrel{0}{0} 16.01$ & $\stackrel{0}{16.01}$ & $\stackrel{0}{0}$ & $\stackrel{0}{16.01}$ & $\begin{array}{c}0 \\
16.01\end{array}$ \\
\hline $\begin{array}{l}\text { «Красноярск- } \\
\text { Черемушки» }\end{array}$ & $\begin{array}{c}0 \\
16.01\end{array}$ & $\begin{array}{c}0 \\
16.01\end{array}$ & $\begin{array}{c}0 \\
16.01\end{array}$ & $\begin{array}{c}0 \\
16.01\end{array}$ & $\begin{array}{c}0 \\
16.01\end{array}$ & $\begin{array}{c}0 \\
16.01\end{array}$ & $\begin{array}{c}0 \\
16.01\end{array}$ & $\begin{array}{c}0 \\
16.01\end{array}$ \\
\hline
\end{tabular}


Таблица 6

Среднесуточные концентрации зВ (в долях ПдКсс)

\begin{tabular}{|c|c|c|c|c|c|c|}
\hline $\begin{array}{c}\text { Автоматизированный } \\
\text { пост наблюдения }\end{array}$ & $\begin{array}{l}\text { Фториды } \\
\text { твердые }\end{array}$ & $\begin{array}{c}\text { Гидрофторид (в } \\
\text { пересчете на } \\
\text { фтор) }\end{array}$ & Гидрохлорид & Формальдегид & Бенз(а)пирен & Свинец \\
\hline Период & \multicolumn{5}{|c|}{13.01 .2022} & $\begin{array}{r}13.12 .2021 \\
28.12 .2021\end{array}$ \\
\hline $\begin{array}{l}\text { «Красноярск- } \\
\text { Покровкаะ }\end{array}$ & $\begin{array}{c}0 \\
13.01\end{array}$ & $\begin{array}{c}0.08 \\
13.01\end{array}$ & $\begin{array}{c}0.35 \\
13.01\end{array}$ & $\begin{array}{c}1.48 \\
13.01\end{array}$ & & $\begin{array}{c}0 \\
28.12\end{array}$ \\
\hline $\begin{array}{l}\text { жКрасноярск- } \\
\text { Северный }\end{array}$ & $\begin{array}{c}0.11 \\
13.01\end{array}$ & $\begin{array}{c}0.09 \\
13.01\end{array}$ & $\begin{array}{c}0.46 \\
13.01\end{array}$ & - & & $\begin{array}{c}0 \\
28.12\end{array}$ \\
\hline $\begin{array}{l}\text { «Красноярск- } \\
\text { Солнечный» }\end{array}$ & $\begin{array}{c}0.12 \\
13.01\end{array}$ & $\begin{array}{c}0.11 \\
13.01\end{array}$ & $\begin{array}{c}0.28 \\
13.01\end{array}$ & - & & $\begin{array}{c}0 \\
28.12\end{array}$ \\
\hline $\begin{array}{l}\text { «Красноярск- } \\
\text { Черемушки» }\end{array}$ & $\begin{array}{c}0 \\
13.01\end{array}$ & $\begin{array}{c}0.23 \\
13.01\end{array}$ & $\begin{array}{c}0.13 \\
13.01\end{array}$ & $\begin{array}{c}1.38 \\
13.01\end{array}$ & & - \\
\hline
\end{tabular}

Поскольку в них уже «находятся» выбросы от автомобилей, то перед авторами данной статьи стоит задача выделения экологического «влияния» промышленности в Красноярске с помощью методов математического моделирования, изложенных, например, в монографии [17]. Для этого можно воспользоваться годовыми отчетными докладами Министерства экологии и рационального природопользования Красноярского края, в которых приведены данные промышленных предприятий краевого центра.

Для выделения влияния промышленности в Красноярске необходимо сравнить полученные данные и сформировать следующую колонку в таблице «Характеристика 4. Евклидова норма для промышленных выбросов».

Сформированные четыре колонки Таблицы 1 посвящены экологическим проблемам. В качестве близкого по содержанию примера можно привести работу [18], в которой рассмотрено влияние многофакторных антропогенных воздействий на пресноводные экологические системы, а также работы $[19,20]$.

Экологические исследования городских территорий имеют большое практическое значение в связи с высоким уровнем урбанизации территории Российской Федерации и возрастающим числом населения, проживающего в условиях высокоплотной застройки. Исследования состояния воздушной среды территорий с высокой экологической нагрузкой свидетельствуют о 
сложных процессах накопления и трансформации потоков загрязняющих веществ в приземном слое атмосферы.

Оценке влияния антропогенного загрязнения на состояние окружающей среды, разработке математических моделей экологических процессов посвящены публикации [21-27].

\section{5. Социальная сфера}

В пятой колонке «Характеристика 5» представлена социальная сфера например, доля парковочной территории для водителей-инвалидов в процентах.

\section{Часть III}

\section{Цепная линия и расчеты}

Право на труд является одним из наиболее значимых для института Уполномоченного по правам человека в Российской Федерации, поскольку количество и характер нарушения трудовых прав граждан прямо пропорционально зависит от развития производительных сил и производственных отношений в стране. Одним из экономических показателей в качестве индикатора трудового права может служить индекс производства по виду экономической деятельности (Рис. 5) для федеральных округов, регионов и различных отраслей народного хозяйства.

На Рис. 5 проведем аппроксимационную кривую (оранжевая линия) и сделаем предположение, что данная кривая является ц̧епной линией.

Цепная линия - линия, форму которой принимает гибкая однородная нерастяжимая тяжёлая нить или иеепь с закреплённыли конццами в однородном гравитацуионном поле. Является плоской трансцендентной кривой. Уравнение линии в декартовых координатах: $y=\frac{a}{2}\left(e^{x / a}+e^{-x / a}\right)=a \cdot \operatorname{ch} \frac{x}{a}$. 


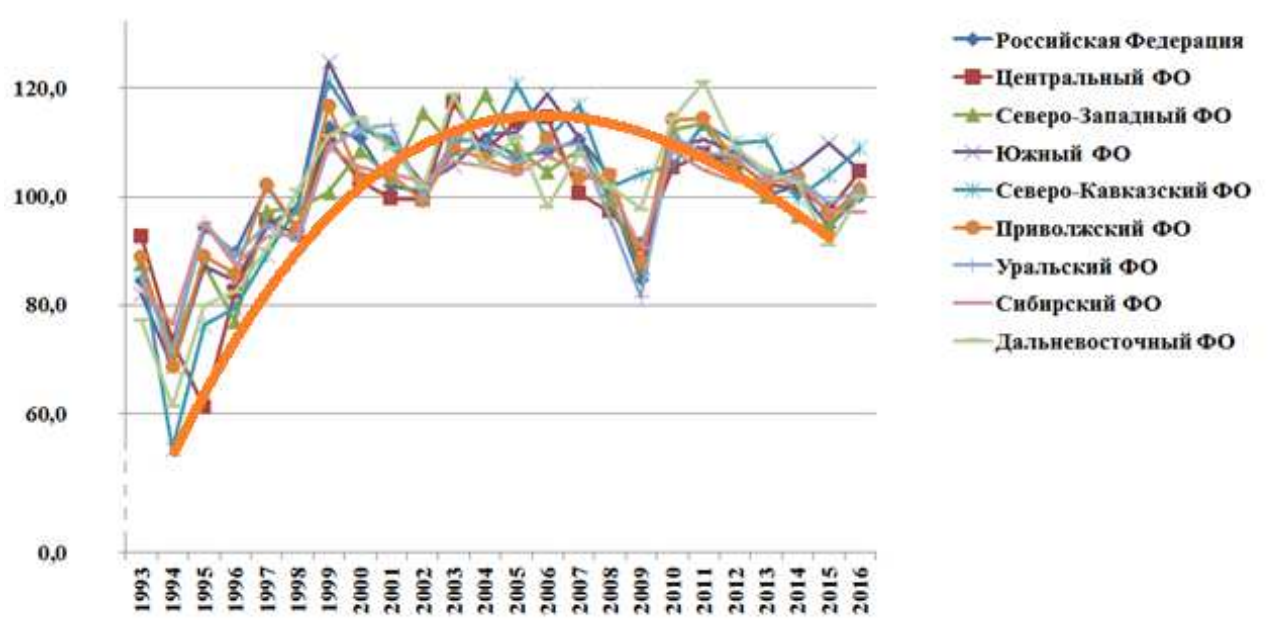

Рис. 5. Индекс производства по виду экономической деятельности «Обрабатывающие производства» по федеральным округам Российской Федерации (в \% к предыдущему году)

Аналогичные рассуждения проведем относительно представленных ниже индексов для отраслей народного хозяйства.

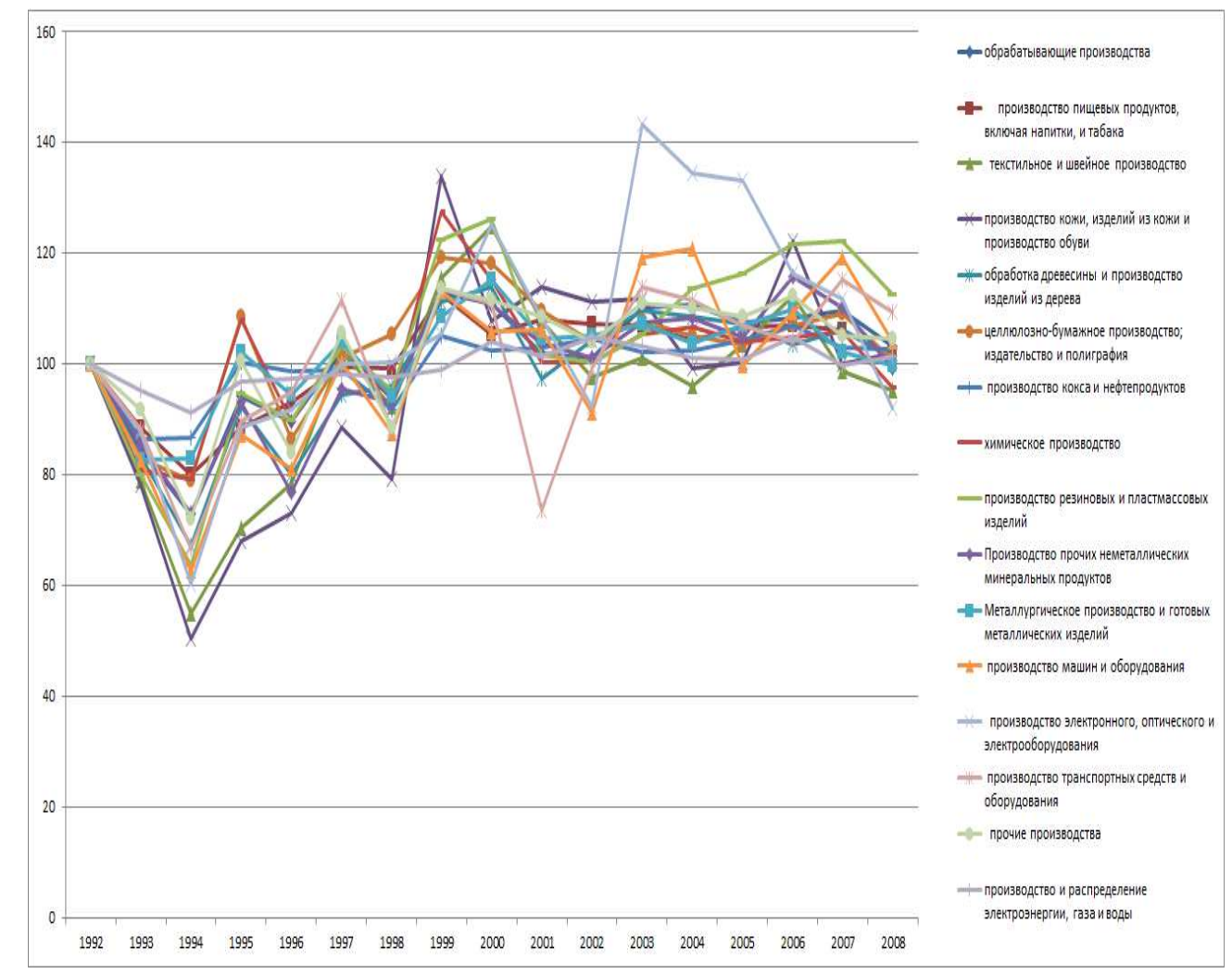

Рис. 6. Графики индексов для отраслей народного хозяйства 354 


\section{ЧЕЛОВЕК И СОВРЕМЕННОЕ ОБЩЕСТВО \\ В СОЦИАЛЬНОМ, ПРАВОВОМ, ЭКОНОМИЧЕСКОМ РАКУРСАХ}

Гипотеза: Построенная таким образом цепная линия есть не просто решение гидродинамической системы уравнений для ее общественного аналога в период с 1993 по 2015 годы - она является аналогом неизвестной свободной поверхности $\Gamma_{t}$, определяемой, например, в процессе решения задачи конвекции [17, глава 2], и на которой с заданной точностью выполнены соответствующие граничные и начальные условия для аналогов функций социальной политики, пенсионного обеспечения, здравоохранения.

Рассмотрим дифференциальное уравнение цепной линии http://www.math24.ru/:

$$
T_{0} y^{\prime \prime}=\rho g A \sqrt{1+\left(y^{\prime}\right)^{2}}
$$

где $\rho$ - объемная плотность материала нити, g - ускорение свободного падения, А - площадь поперечного сечения нити, и силы натяжения $\mathrm{T}(\mathrm{x})$ и $\mathrm{T}(\mathrm{x}+\Delta \mathrm{x})$, соответственно, в точках $\mathrm{x}$ и $\mathrm{x}+\Delta \mathrm{x}$. Примем константу $a$ равной $\mathrm{T}_{0} /(\rho \mathrm{gA})$.

Проведем численное исследование задачи Коши для данного обыкновенного дифференциального уравнения второго порядка методом Рунге-Кутта четвертого порядка точности.

Изменяя значение тангенса угла наклона касательной в начальной точке, удалось достигнуть совпадения численного и точного решения в четвертом знаке для точки $\mathrm{x}=3,55$.

Таблица 7

\begin{tabular}{|c|c|c|c|c|c|c|c|c|c|c|c|c|c|}
\hline $\mathrm{n}$ & $x$ & $\overline{\mathrm{G} 1}$ & $\overline{\mathrm{G}} 2$ & $\overline{\mathrm{G} 3}$ & $\overline{\mathrm{G} 4}$ & $\overline{F 1}$ & $\bar{F} 2$ & F3 & $\overline{\mathrm{F} 4}$ & учислен & производ & $\bar{h}$ & уточное \\
\hline 1 & $-3,55$ & & & & & & & & & 6,06976 & $-2,8655$ & 0,355 & 6,06976 \\
\hline 2 & $-3,195$ & $-2,8655$ & $-2,59615$ & $-2,61859$ & $-2,36796$ & 1,51749 & 1,39104 & 1,40152 & 1,28523 & 5,14304 & $-2,36922$ & & 5,14307 \\
\hline 3 & $-2,84$ & $-2,36922$ & $-2,14099$ & $-2,1595$ & $-1,94681$ & 1,28581 & 1,18151 & 1,1899 & 1,09431 & 4,37878 & $-1,94778$ & & 4,37883 \\
\hline 4 & $-2,485$ & $-1,94778$ & $-1,75346$ & $-1,76863$ & $-1,58714$ & 1,09474 & 1,00929 & 1,01588 & 0,93795 & 3,75285 & $-1,58787$ & & 3,75292 \\
\hline 5 & $-2,13$ & $-1,58787$ & $-1,42133$ & $-1,43363$ & $-1,27761$ & 0,93826 & 0,86893 & 0,87397 & 0,81122 & 3,24548 & $-1,27811$ & & 3,24557 \\
\hline 6 & $-1,775$ & $-1,27811$ & $-1,13409$ & $-1,14392$ & $-1,00842$ & 0,81141 & 0,756 & 0,7597 & 0,71009 & 2,84063 & $-1,00873$ & & 2,84073 \\
\hline 7 & $-1,42$ & $-1,00873$ & $-0,88267$ & $-0,89036$ & $-0,77107$ & 0,7102 & 0,66692 & 0,66946 & 0,63138 & 2,52551 & $-0,77122$ & & 2,52564 \\
\hline 8 & $-1,065$ & $-0,77122$ & $-0,65914$ & $-0,66492$ & $-0,55806$ & 0,63142 & 0,59885 & 0,60044 & 0,57259 & 2,29018 & $-0,55806$ & & 2,29032 \\
\hline 9 & $-0,71$ & $-0,55806$ & $-0,45643$ & $-0,46051$ & $-0,36265$ & 0,57259 & 0,54962 & 0,55047 & 0,53186 & 2,1272 & $-0,36254$ & & 2,12735 \\
\hline 10 & $-0,355$ & $-0,36254$ & $-0,26814$ & $-0,27066$ & $-0,17865$ & 0,53184 & 0,51766 & 0,51799 & 0,50792 & 2,03142 & $-0,17847$ & & 2,03159 \\
\hline 11 & 0 & $-0,17847$ & $-0,08832$ & $-0,08937$ & $-0,00026$ & 0,5079 & 0,50195 & 0,50199 & 0,5 & 1,99982 & $-3,6 \mathrm{E}-05$ & & 2 \\
\hline 12 & 0,355 & $-3,6 \mathrm{E}-05$ & 0,08871 & 0,08906 & 0,17817 & 0,5 & 0,50196 & 0,50198 & 0,50787 & 2,0314 & 0,1784 & & 2,03159 \\
\hline 13 & 0,71 & 0,1784 & 0,26855 & 0,27029 & 0,36227 & 0,50789 & 0,51772 & 0,51794 & 0,5318 & 2,12715 & 0,36246 & & 2,12735 \\
\hline 14 & 1,065 & 0,36246 & 0,45686 & 0,46004 & 0,55785 & 0,53183 & 0,54971 & 0,55037 & 0,57254 & 2,2901 & 0,55798 & & 2,29032 \\
\hline 15 & 1,42 & 0,55798 & 0,65961 & 0,6643 & 0,77108 & 0,57257 & 0,59898 & 0,60027 & 0,63138 & 2,5254 & 0,77113 & & 2,52564 \\
\hline 16 & 1,775 & 0,77113 & 0,8832 & 0,88954 & 1,00869 & 0,63139 & 0,66709 & 0,66919 & 0,71019 & 2,84048 & 1,00863 & & 2,84073 \\
\hline 17 & 2,13 & 1,00863 & 1,13469 & 1,14286 & 1,27818 & 0,71016 & 0,75623 & 0,7593 & 0,81144 & 3,24529 & 1,278 & & 3,24557 \\
\hline 18 & 2,485 & 1,278 & 1,42201 & 1,43228 & 1,58806 & 0,81137 & 0,86921 & 0,87342 & 0,93834 & 3,75263 & 1,58773 & & 3,75292 \\
\hline 19 & 2,84 & 1,58773 & 1,75426 & 1,76694 & \begin{tabular}{|l|}
1,94811 \\
\end{tabular} & 0,9382 & 1,00963 & 1,01515 & 1,09489 & 4,37851 & 1,94762 & & 4,37883 \\
\hline 20 & 3,195 & 1,94762 & 2,14193 & 2,15742 & 2,3697 & 1,09467 & 1,18193 & 1,18895 & 1,28603 & 5,14271 & 2,36904 & & 5,14307 \\
\hline 21 & 3,55 & 2,36904 & 2,59725 & 2,61604 & 2,86615 & 1,28572 & 1,39156 & 1,40033 & 1,5178 & 6,06936 & 2,86528 & & 6,06976 \\
\hline
\end{tabular}




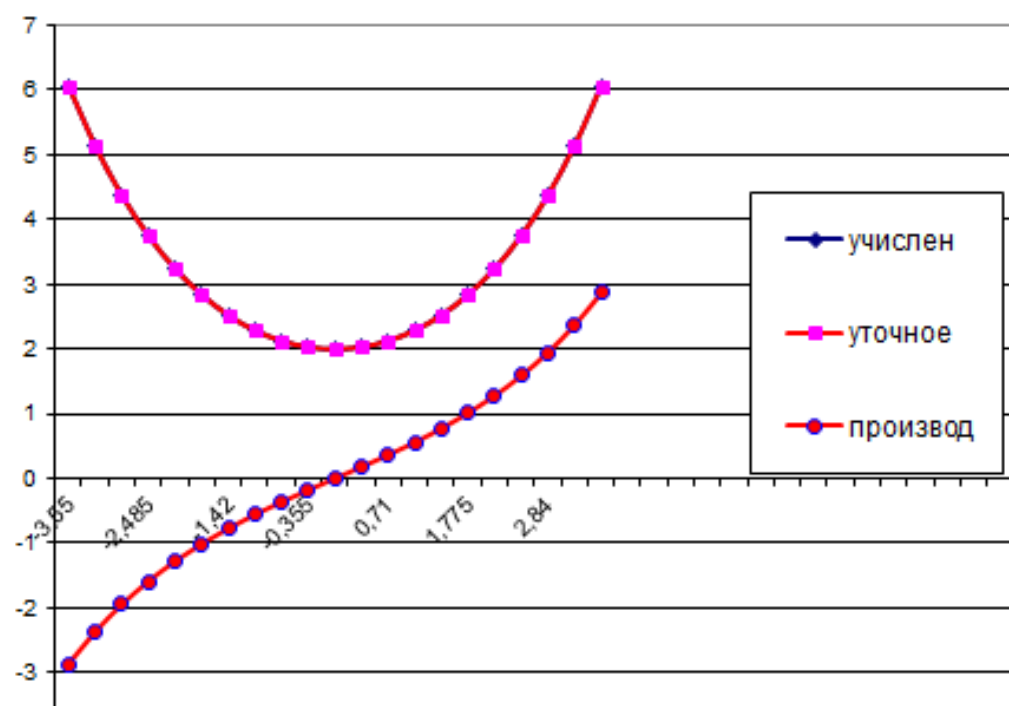

Рис. 7. Графическое совпадение для численного и точного решений

\section{Выводы \\ Подготовка и проведение Конкурсов профессионального мастерства}

Комплексное применение технологических, экономических и правовых средств может быть использовано в процессе подготовки и проведения Конкурсов профессионального мастерства в трудовых коллективах Красноярска и прилегающих к краевому центру районах, например, в сфере экологии.

С помощью всех участников экологического процесса может быть создан информационный массив больших данных, работа с которым позволит определить пути улучшения экологической ситуации на территории краевого центра.

В процессе работы научно-исследовательского семинара-вебинара «Информационные технологии и открытое образование», проходящего на базовой кафедре «Информатика и информационные технологии в образовании» Красноярского государственного педагогического университета имени В.П. Астафьева под руководством доктора педагогических наук, 
профессора Н.И. Пака, получили развитие методики нелинейной организации различных форм обучения [28].

Они содержат конкретные рекомендации: как организовать работу в парах сменного состава, как определить уровень своих знаний и умений, как выбрать оптимальный порядок изучения учебного материала, к повторению каких вопросов следует вернуться для успешного усвоения изучаемого материала.

Очень важны задания для Конкурса профессионального мастерства, призванные уменьшить негативные последствия образовательного разрыва уже сегодня нужно применять знания, которые обучающиеся получат позже.

Среди разрабатываемых тем можно назвать следующие темы: «Основания и фундаменты», «Металловедение», «Теплофизика», «Робототехника и программирование», «Базы данных». Все они могут быть использованы в экологических приложениях.

Интернет-обучение, на взгляд авторов статьи, позволит уменьшить боль и тревогу родителей, близких людей детей-инвалидов, стать им сопричастным. Хочется выразить надежду, что такая сопричастность создаст соответствующую комфортную среду, в которой решение производственных задач будет наиболее эффективным при имеющихся и всегда ограниченных pecypcax $[29,30]$.

Можно не сомневаться, что поставленные Президентом Российской Федерации В.В. Путиным социальные задачи будут решены в полной мере, и мы все при этом будем постоянно учиться доброте у своих предшественников, как отечественных, так и зарубежных. 


\section{Список литературы}

1. Послание Президента Федеральному Собранию. 01.03.2018. http://kremlin.ru/events/president/news/56957

2. Послание Президента Федеральному Собранию. 20.02.2019. http://www.kremlin.ru/events/president/news/59863

3. С.Ф. Зяблов, В.В. Серватинский, О.В. Адмаев. Расчет комплексного показателя экологической безопасности на автомобильных дорогах // Труды Второй Всероссийской ФАМ'2003 конференции. Часть вторая. (Под ред. Олега Воробьёва). Красноярск: ИВМ СО РАН, 2003, - с.85-89.

4. С.Г. Журавлев. Дифференциальные уравнения: Сборник задач: примеры и задачи экономики, экологии и других социальных наук: Учебное пособие для вузов / С.Г. Журавлев, В.В. Аниковский. - М.: Издательство: Экзамен, 2005. - 128 с. (Серия: «Учебник для вузов»).

5. Гидзинский Е.В. Экологическое нормотворчество как социальнофилософский аспект проблемы платных парковок. Сборник публикаций по материалам XXXX международной научно-практической конференции: «Достижения и проблемы современной науки». С-П.: Научный журнал «Globus», 04.04.2019. Стр. 85-91.

6. Доклад Уполномоченного по правам человека в Российской Федерации. 2020. http://ombudsmanrf.org/content/doclad2020.

7. Правозащитная карта России. Информационно-просветительский проект Уполномоченного по правам человека в Российской Федерации. https://map.ombudsmanrf.org/

8. Т.Н. Москалькова, В.В. Черников: Нормотворчество. Научнопрактическое пособие. Изд-во: Проспект, 2010.

9. Конституция Российской Федерации. http://constitution.kremlin.ru

10. Указ Президента Российской Федерации от 21 июля 2020 г. № 474 «О национальных целях развития Российской Федерации на период до 2030 года» 
11. Владимир Путин: Будет правильно, если Год науки и технологий станет началом целого научного десятилетия. 24.12.2021. https://minobrnauki.gov.ru/

12. Итоги 2021 года: экологическая безопасность. 30.12.2021. http://mnr.gov.ru/

13. Минэкономразвития России подготовило обзор международных подходов по экономике замкнутого цикла. 29.12.2021. https://economy.gov.ru/

14. С.В. Михайлюта. Особенности пространственно-временной динамики загрязнения атмосферы в условиях города: На примере г. Красноярска. Диссертация по специальности ВАК РФ 05.13.01, кандидат технических наук. Красноярск, 2005. - 134 с.

15. Тасейко О.В. Моделирование локальных условий рассеивания загрязнителей в городской застройке Диссертация по специальности ВАК РФ 05.13.18, кандидат физ.-мат. наук. Красноярск, 2005. - 125 с.

16. Адмаев О.В. Экологическое нормотворчество как часть экспертной системы транспортного комплекса для урбанизированных территорий (на примере г. Красноярска). Сборник публикаций по материалам XII международной научно-практической конференции: «Естественные и технические науки в современном мире». Москва: Научный журнал «Chronos», 10.02.2017. Стр. 17-22.

17. Андреев В.К., Гапоненко Ю.А., Гончарова О.Н., Пухначев В.В. Современные математические модели конвекции. - М.: Физматлит, 2008. $368 \mathrm{c}$.

18. Шуйский В.Ф., Максимова Т.В., Петров Д.С. Изоболический метод оценки и нормирования многофакторных антропогенных воздействий на пресноводные экосистемы по состоянию макрозообентоса. СПб., Изд-во МАНЭБ: 2004. 304 c. 
19. О.В. Тарасова, А.В. Ковалев, В.Г. Суховольский, Р.Г. Хлебопрос. Насекомые-филлофаги зеленых насаждений городов: Видовой состав и особенности динамики численности. - Новосибирск: Наука, 2004. - 180 с.

20. М.Д. Уфимцева Н.В. Терехина. Фотоиндикация экологического состояния урбогеосистем Санкт-Петербурга. - СПб.: Наука, 2005. - 339 с.

21. Алоян А.Е. Моделирование динамики и кинетики газовых примесей и аэрозолей в атмосфере. Институт вычислительной математики РАН. М.: Наука, 2008. - 416 с.

22. Реттер Э.И. Архитектурно-строительная аэродинамика. Москва, Стройиздат, 1984. - 294 с.

23. И.К. Лифанов, В.А. Гутников, А.С. Скотченко. Моделирование аэрации в городе. М.: Диалог-МГУ, 1998. - 134 с.

24. Атмосферная диффузия и загрянения воздуха. Под редакцией д-ра физ.-мат. наук М.Е. Берлянда. Труды Главной геофизической обсерватории им. А.И. Воейкова, выпуск 234. Л.: Гидрометеоиздат. 1968. - 161 с.

25. М.Е. Берлянд. Современные проблемы атмосферной диффузии и загрязнения атмосферы. Л.: Гидрометеоиздат. 1975. - 418 с.

26. Климат Красноярска / [Подгот. Н.С. Богдановой, Н.В. Буриной, Г.А. Кругловой и др.]; Под ред. Ц.А. Швер, А.С. Герасимовой. - Л.: Гидрометеоиздат, 1982. - 231 с.: ил.

27. Бояршинов М.Г. Математическое моделирование переноса и рассеяния газообразных примесей в растительных массивах. Диссертация по специальности ВАК РФ 05.13.18, д-р техн. наук. Пермь, 2000. - 324 с.

28. Пак Н.И. Нелинейные технологии обучения в условиях информатизации. Красноярск, 2004. 224 с.

29. Адмаев О.В. Развитие Красноярской городской агломерации конкурсы профессионального мастерства. Сборник публикаций научного журнала «Chronos» со статьями. «Актуальные вопросы общественных наук» 
Выпуск 2 (19). 03.09.2020 г. - М: Научный журнал «Chronos», 2020. Стр. 12-18.

30. Адмаев О.В. Конкурсы профессионального мастерства среди различных групп населения как фактор развития красноярской городской агломерации. «История, современное состояние и перспективы инновационного развития общества»: сборник статей Национальной (Всероссийской) научно-практической конференции (22 октября 2020 г, г. Калуга). - Уфа: OMEGA SCIENCE, 2020. Стр. 9-12.

(C) О.В. Адмаев, Е.В. Гидзинский, 2022 
РАЗДЕЛ ІІІ.

\title{
АКТУАЛЬНЫЕ ВОПРОСЫ ВЗАИМОДЕЙСТВИЯ ЧЕЛОВЕКА, ОБЩЕСТВА И ГОСУДАРСТВА
}

\author{
УДК 159.99
}

Глава 15.

ПРОГРАММА ПЕРСОНИФИЦИРОВАННОГО МЕНЕДЖМЕНТА

В ПСИХОЛОГИЧЕСКОЙ РЕАБИЛИТАЦИИ ЧЛЕНОВ СЕМЕЙ ЛИЦ ОПАСНЫХ ПРОФЕССИЙ

\section{Киворкова Александра Юрьевна к.биол. н.} Соловьев Андрей Горгоньевич д.м.н., профессор

ФГБОУ ВО «Северный государственный медицинский университет Минздрава России»

Аннотация: В статье обобщены результаты исследований, посвященных изучению влияния последствий хронической стрессовой ситуации, как на представителей экстремального профиля служебной деятельности, так и их микросоциальное окружение. Показана роль членов семей лиц опасных профессий в обеспечении нормального профессионального функционирования; систематизированы данные о проявлении социально-психологической дезадаптации членов семей лиц опасных профессий. На основании предложенных всех этапов обоснована программа персонифицированного менеджмента в психологической реабилитации членов семей лиц опасных профессий. 
Ключевые слова: лица опасных профессий, семья, психодиагностика, биологическая обратная связь, социально-стрессовая ситуация, психологическая реабилитация.

\title{
PERSONALIZED MANAGEMENT PROGRAM IN PSYCHOLOGICAL REHABILITATION OF FAMILY MEMBERS PERSONS OF DANGEROUS PROFESSIONS
}

\section{Kivorkova Alexandra Yrevna Soloviev Andrey Gorgonevich}

\begin{abstract}
The studies results devoted to the effects evaluation of the chronic stressful situation consequences on both extreme profile representatives on extreme profile professional activity and their micro-social environment are summarized. The family members role of dangerous professions persons in ensuring normal professional functioning is shown; data on the manifestation of socio-psychological family members maladaptation of dangerous professions persons are systematized. Based on the proposed all stages, the personalized management program in the family members psychological rehabilitation of dangerous professions persons is justified.
\end{abstract}

Key words: dangerous professions persons, family, psycho-diagnostics, biofeedback, socio-stressful situation, psychological rehabilitation.

Профессиональная деятельность лиц т.н. «опасных профессий» осуществляется в неблагоприятных условиях продолжительного рабочего дня, нагрузок высокой интенсивности, воздействия ряда вредных факторов. Экстремальные условия (арктического региона, пустыни, длительного морского похода, любой продолжительной изоляции, нахождения в 


\section{ЧЕЛОВЕК И СОВРЕМЕННОЕ ОБЩЕСТВО В СОЦИАЛЬНОМ, ПРАВОВОМ, ЭКОНОМИЧЕСКОМ РАКУРСАХ}

невесомости или под водой, высотной болезни летчиков-испытателей и горных спасателей, периодического или постоянного интенсивного шумового и/или светового воздействия, депривации сна, длительной операторской деятельности) резко отличаются от обычных и воздействуют на психику, не адаптированную к ним, как стрессоры [1, 2]. Лица опасных профессий, участвующие в специальных мероприятиях, испытывают интенсивное воздействие целого ряда стрессогенных факторов, отличающихся по своему содержанию от факторов привычной жизни, порой сверхсильных по своему воздействию [3].

Предъявляемые требования к лицам опасных профессий (уровню профессиональной подготовки, психического, соматического здоровья, личностным качествам) более высоки, чем к представителям других профессиональных групп, а проблема постстрессовых нарушений имеет особое медико-социальное значение [4]. В свою очередь, экстремальные факторы службы в подавляющем большинстве случаев оказывают отрицательное влияние на состояние здоровья лиц, выполняющих оперативные задачи. Наиболее наглядные проявления этого воздействия обнаруживаются в виде нервно-психических дезадаптивных расстройств [5]. Под влиянием психотравмирующих факторов экстремальных ситуаций у лиц опасных профессий существует риск формирования психической дезадаптации [6] с формированием психологического барьера, препятствующего их социальной адаптации уже в мирной жизни.

Современное здравоохранение ориентировано преимущественно на выявление, лечение и профилактику заболеваний, что недостаточно эффективно для профессиональных контингентов, относящихся к категории опасных профессий. Напряженная деятельность, как в условиях аварийноспасательных работ, так и процессе длительных дежурств, в различной степени затрагивает компенсаторные механизмы организма, снижает 
резервные возможности человека, что в последствие может привести к формированию нарушений здоровья, а в условиях профессиональной деятельности - к снижению работоспособности, профессиональной надежности, увеличению числа ошибок при проведении работ, которые могут повлечь усложнение аварийных ситуаций, человеческие потери (травматизм, потерю здоровья, гибель) [7]. Формирующиеся изменения в функциональных системах организма зависят не только от влияния внешних факторов (их интенсивности и качественных характеристик) но и от индивидуальнопсихологических факторов, предопределяющих особенности функционирования основных систем организма. При появлении рассогласования между внутренними и внешними факторами возникает напряжение регуляторных функций, приводящее к нарушению гомеостаза, адаптационных возможностей организма и возникновению функциональных нарушений, психовегетативных проявлений, психосоматических заболеваний $[8 ; 9 ; 10]$.

Разработка мероприятий, направленных на формирование резерва адаптации у специалистов опасных профессий, является актуальной научной задачей, комплексная межведомственная реализация которой позволит укрепить здоровье специалистов, обеспечить рост показателей индивидуальной профессиональной работоспособности, рост производительности труда организованных коллективов, что, в конечном итоге, обеспечит высокую готовность к профилактике чрезвычайных ситуаций, связанных с боевыми действиями и оперативной ликвидации их последствий [11].

Современные медико-психологические исследования свидетельствуют, что негативное эмоциональное состояние, возникающее у специалистов экстремального профиля служебной деятельности при выполнении служебных обязанностей, зачастую приводит к напряжению адаптационных 


\section{ЧЕЛОВЕК И СОВРЕМЕННОЕ ОБЩЕСТВО В СОЦИАЛЬНОМ, ПРАВОВОМ, ЭКОНОМИЧЕСКОМ РАКУРСАХ}

механизмов организма [12]. Специфика профессиональной деятельности лиц опасных профессий характеризуется высоким напряжением адаптационноприспособительных механизмов психики, ригидизацией личности, снижением нервно-психической устойчивости [13]. Неадаптивное поведение в таких случаях приводит к развитию профессиональной дезадаптации, нервнопсихических и психосоматических нарушений [14]. Так, 12-25\% возвратившихся с мест несения службы военнослужащих армии США страдали посттравматическим стрессовым расстройством, а 20-45\% имели проблемы с употреблением алкоголя [15; 16].

Учитывая, что даже легкая степень опьянения приводит у указанного контингента к значительным расстройствам сознания, протекая практически всегда по эпилептиформному типу, бывшие участники боевых конфликтов в состоянии алкогольного и других видов опьянения становятся крайне опасными для окружающих и оказывают мощное психотравмирующее действие на членов их семей [17]. В связи с этим отмечается возрастание интереса к формированию у лиц опасных профессий дифференцированных стратегий адаптивного поведения, направленных на предотвращение эпизодов дезадаптации, психосоматических расстройств, а также на профилактику нарушений функционирования в сфере социальных контактов, связанных с деструктивным влиянием боевого стресса [18].

Немаловажным аспектом социальной реабилитации является психоэмоциональная поддержка со стороны семьи и руководителей, нежели сослуживцев и друзей [19].

Следует отметить, что если психологическое состояние и социальное самочувствие лиц опасных профессий привлекает все большее внимание, то аналогичные аспекты состояния членов их семей, как в нашей стране, так и за рубежом, не столь часто становятся предметом целенаправленных научных исследований [20]. 


\section{ЧЕЛОВЕК И СОВРЕМЕННОЕ ОБЩЕСТВО В СОЦИАЛЬНОМ, ПРАВОВОМ, ЭКОНОМИЧЕСКОМ РАКУРСАХ}

В связи с тем, что хорошая адаптационная устойчивость представителей экстремальных профессий обусловливается такими психосоциальными характеристиками, как семейная стабильность, социально-позитивный круг интересов, психосоматическое благополучие и своевременная медикопсихологическая реабилитация, с каждым годом все больше актуализируется необходимость в организации и совершенствовании восстановительных мероприятий, направленных на поиск и совершенствование подходов к выявлению и коррекции дезадаптационных нарушений с учетом личностных и психосоциальных характеристик [21].

Лица опасных профессий создают вокруг себя хроническую стрессовую ситуацию, которая вторично оказывает влияние на психическое и психосоматическое здоровье микросоциального окружения, формируя замкнутый круг процесса индуцирования. Необходимо признать, что особенностями функционирования их семьи является непосредственная или опосредованная причастность к экстремальным обстоятельствам профессиональной деятельности, которая как стимулирует, так и дестабилизирует психолого-педагогические функции, сказывается в повышенной чувствительности их истощения и дефиците общения, формируя «дистантный» стиль общения [22].

Специфика профессиональной деятельности оказывает большое влияние на их близких родственников, что объясняется опосредованным влиянием участников боевых действий на родных [23; 24; 25], а насыщенная стрессовыми событиями жизнь отражается и на психическом здоровье их детей [26]. Так, у детей сотрудников силовых ведомств среди личностных особенностей описывается наличие очень высокой тревожности, что связано с ожиданием опасности, со страхом потери кормильца или его увечья [27; 28]. Воздействие посттравматического стресса и семейной системы является реципрокным: семейная поддержка помогает справиться с последствиями 
травмирующих ситуаций, но личность, страдающая от посттравматического стресса, может привносить собственные негативные переживания в межличностное общение, оказывая влияние на семейную систему, в целом [29]. Подобные симптомы оказывают пагубное влияние на межличностные взаимосвязи и ведут к супружеским конфликтам, разводу или потере работы [30].

Жена представителя опасных профессий находится в состоянии постоянного стресса, зная, что его жизни угрожает опасность [31]. В дополнение к этим стресс-факторам возникает потеря эмоциональной поддержки, перераспределение обязанностей, трудности в общении с детьми, финансовые ограничения, и как следствие - ощущение острого одиночества. У жен, наряду со значительными психологическими проблемами, такими, как тревога и нарушения взаимоотношений, могут возникнуть и сопутствующие нарушения соматического здоровья. У женщин, чьи мужья проходят службу дома, такого всплеска не замечено. Кроме того, сочетание определенных личностных особенностей с длительными командировками может выявить чувство ревности, что также является предпосылкой к возникновению конфликтов в семье [32].

Возвращение лиц опасных профессий домой сопряжено с переживанием напряженного для жены периода, так как она должна приложить максимум усилий для создания внутри семьи благоприятного психологического климата. Требуется время и терпение, чтобы после возвращения из командировки восстановить сексуальные отношения [33]. После завершения психотравмирующей ситуации необходим комплекс патогенетически обусловленных мероприятий, объединенных понятием «реабилитация» [17]. На всех этапах реабилитации важно, чтобы жена применяла поведенческие стратегии, направленные на уменьшение или сведение к минимуму стресс- 


\section{ЧЕЛОВЕК И СОВРЕМЕННОЕ ОБЩЕСТВО В СОЦИАЛЬНОМ, ПРАВОВОМ, ЭКОНОМИЧЕСКОМ РАКУРСАХ}

факторов, и способствующие сохранению здоровья и благополучия членов семьи.

Однако, несмотря на широкий интерес к данной проблеме, наблюдается дефицит в разработке программ персонифицированного менеджмента в реабилитации членов семей лиц опасных профессий, хотя выявляемые у них расстройства нередко имеют психогенно-индуктивную природу и требуют проведения целенаправленных восстановительных мероприятий. Различные исследования, проводимые в ряде силовых министерств и ведомств по изучению функции семей представителей опасных профессий, показывают, что последняя продолжает играть заметную роль в обеспечении нормального функционирования представителей подразделений силовых структур. Семейные проблемы и неурядицы зачастую непосредственно наносят ущерб служебной активности сотрудников и, как следствие, отрицательно сказываются на морально-психологическом состоянии коллектива, в целом [34]. Учитывая, что семейные отношения могут стабилизировать или дестабилизировать работоспособность и уровень адекватности самосознания лиц опасных профессий, необходимо разрабатывать и внедрять программы персонифицированного менеджмента отдельно для членов семьи, в частности, для жен лиц опасных профессий. Это обосновывает необходимость разработки и внедрения реабилитационных методик, минимизирующих последствия нахождения членов семей в стрессовых ситуациях и улучшающих качество жизни сотрудников экстремальных профессий.

Реабилитационные мероприятия позволяют повысить эффективность процесса диагностики, прогнозирования и психологической коррекции последствий пребывания членов семей в ситуациях социального стрессирования. Практическая реализация комплексного реабилитационного процесса начинается с проведения психодиагностического обследования в индивидуальном интерактивном формате. Включение в стандарт 
диагностического обследования психофизиологических методик дает возможность не только оценить степень влияния деструктивных экзогенных факторов и экстремальных ситуаций на структуру личности, но и составить персонифицированную реабилитационную программу в зависимости от психотравмирующих условий, стажа семейной жизни и гендерно-возрастных характеристик [35]. Систематизация комплекса информативных психодиагностических тестов для прогноза оценки типов поведенческих стратегий и личностных характеристик способствует профилактике дезадаптивных нервно-психических состояний у представителей опасных профессий и членов их семей [36], а также позволяет определять алгоритм восстановления и развития адаптивных способностей с учетом специфических особенностей социально-психологической структуры поведения, характерных для экстремального профиля служебной деятельности. Это имеет большое практическое значение при разработке программ персонифицированного менеджмента. В настоящее время отмечен отчетливый интерес к исследованиям, направленным на выявление эффективности биологической обратной связи (БОС) в изучении психофизиологических изменений под действием экстремальных факторов окружающей среды. Диагностический комплекс включает в себя оценку динамики психофизиологического состояния в процессе проведения программы медико-психологической реабилитации (МПР) на основе саморегуляции сердечного ритма, периферической температуры, мышечного напряжения.

Систематизация литературных данных и многолетние комплексные исследования авторов по выявлению факторов риска социальнопсихологической дезадаптации и психофизиологических показателей членов семей представителей опасных профессий, находящихся в условиях длительной социально-психотравмирующей ситуации [37], позволили разработать комплексную программу персонифицированного менеджмента 
[38], направленную на активизацию психофизологических механизмов саморегулируемого поведения, включающую несколько взаимосвязанных этапов - скринирующего, диагностического, коррекционного и заключительного - для оценки эффективности реабилитационных мероприятий (рис.1).

На этапе скрининга невротических состояний делается акцент на выявление параметров и степени выраженности нарушений психологического состояния членов семей опасных профессий. Особое внимание уделяется лицам с признаками психологической изменчивости, а именно: имеющим невротические расстройства, алекситимические особенности, в анамнезе частые психотравмы или заболевания психосоматической природы, переживания психотравмирующей ситуации, связанной со спецификой профессиональной деятельности мужа, пребывающим в ситуации семейного кризиса, а также предъявляющим жалобы на постоянные внутрисемейные конфликты. Клинико-анамнестическое исследование включает скринингдиагностику уровня невротизации и оценку невротических синдромов.

Диагностический этап заключается в углубленном определении индивидуальных психотипологических особенностей на основании психологической и психофизиологической диагностики с применением аппаратно-программных психодиагностических комплексов биологической обратной связи [39]. Специфика службы в экстремальных условиях формирует своеобразную совокупность психологических и психофизиологических особенностей, характеризующих членов семей лиц опасных профессий в условиях перманентной внутрисемейной стрессовой ситуации. Личностные характеристики (мотивация, профессиональная подготовленность, стрессоустойчивость, защитные механизмы, прошлый опыт) детерминируют характер восприятия той или иной ситуации, 
определяют степень ее экстремальности, оказывают влияние на поведение и течение адаптационных процессов [40; 41]. Индивидуально-типологические свойства - уровни концентрации и устойчивости внимания, скорость изменения знака возбуждения в двигательных центрах, также как и уровни работоспособности, тревоги, десинхронизация ритмов электроэнцефалограммы (ЭЭГ), вегетативный коэффициент - отражают реакцию личности на восприятие стресса. В диагностический этап включена и оценка основных составляющих функционального психоэмоционального состояния: степени физиологической и психологической комфортности, физической и психической активности, эмоционального фона и мониторирование психофизиологических параметров с использованием технологии многопараметрического биоуправления.

Коррекционный этап разработан для дифференцированного подхода в реабилитации с учетом психологических особенностей и включает мероприятия, являющиеся условием активизации психологических механизмов, направленных на повышение их стрессоустойчивости. Основной задачей данного этапа является изменение отношения к доминирующим проблемам для сохранения и укрепления семейного микроклимата. В качестве форм коррекционной работы рекомендуется организация мероприятий по усилению регулирующих функций психики, совершенствование психических процессов, состояний и личностных особенностей. Программа включает сеансы индивидуальной психотерапии (рациональной, когнитивноповеденческой, позитивной); a также групповую психотерапию (гетеротренинг) с дополнительным включением БОС-тренингов и сеансов кататимно-имагинативной психотерапии (символдрамы). 
На заключительном этапе осуществляется динамическая оценка эффективности психокоррекционных мероприятий по поддержанию психического здоровья членов семей опасных профессий, как непосредственно после завершения МПР, так и в процессе катамнестического наблюдения.

Повышение эффективности создания программ персонифицированного менеджмента в реабилитации членов семей лиц опасных профессий основано на включении: психофизиологического обследования, контроля функционального состояния, расширенного психологического обследования, психологического консультирования, психологической коррекции и психотерапии.

Реабилитационные мероприятия, реализуемые для членов семей представителей опасных профессий, должны быть построены по принципам:

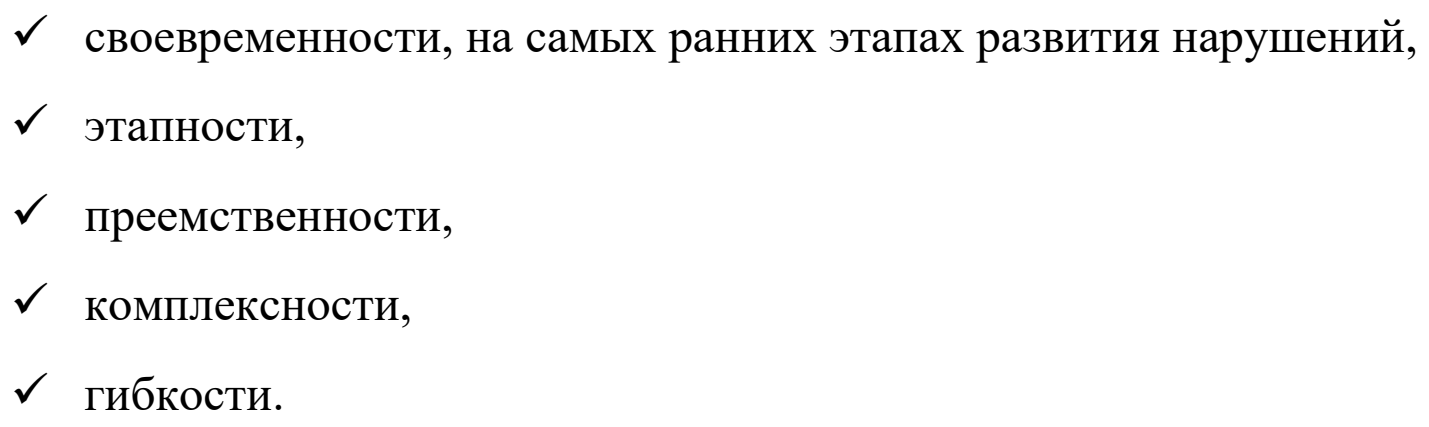

Содержание и объем мероприятий должны соотноситься с характером и глубиной неблагоприятных изменений. К числу таких мероприятий следует отнести работу реабилитационных центров, осуществляющих амбулаторную психологическую помощь. Особое внимание необходимо уделять разработке методов, с помощью которых осуществляется динамический контроль и расширенное психофизиологическое обследование членов семей представителей опасных профессий. Это позволяет активно выявлять скрытые 


\section{ЧЕЛОВЕК И СОВРЕМЕННОЕ ОБЩЕСТВО В СОЦИАЛЬНОМ, ПРАВОВОМ, ЭКОНОМИЧЕСКОМ РАКУРСАХ}

нарушения до возникновения патологических состояний и заболеваний, своевременно проводить реабилитационные мероприятия.

В систему курсов повышения квалификации специалистов психологического профиля, участвующих в проведении реабилитации, целесообразно включать следующие направления:

- обучение углубленной психофизиологической диагностики, позволяющей оценить степень влияния деструктивных экзогенных факторов и экстремальных ситуаций на структуру личности и составить индивидуальную реабилитационную программу;

- обучение дифференцированной психологической коррекции и психотерапии, с углублением знаний в области специфических психологических особенностей, характерных для экстремального профиля служебной деятельности;

- обучение алгоритму мероприятий психологического сопровождения, с разработкой индивидуальных рекомендаций по оптимизации образа жизни и профессиональной деятельности представителей опасных профессий.

Таким образом, реализация предложенного подхода дает возможность проводить динамическую оценку личностных особенностей, процессов и состояния членов семей опасных профессий в рамках проведения психокоррекционных мероприятий, являясь информативным методом, направленным на улучшение внутрисемейных взаимоотношений лиц, подвергающихся стрессовому воздействию различных экстремальных ситуаций. Внедрение описанных мероприятий в систему комплексной реабилитации позволит разрабатывать индивидуальные психокоррекционные программы для членов семей представителей экстремального профиля служебной деятельности. 


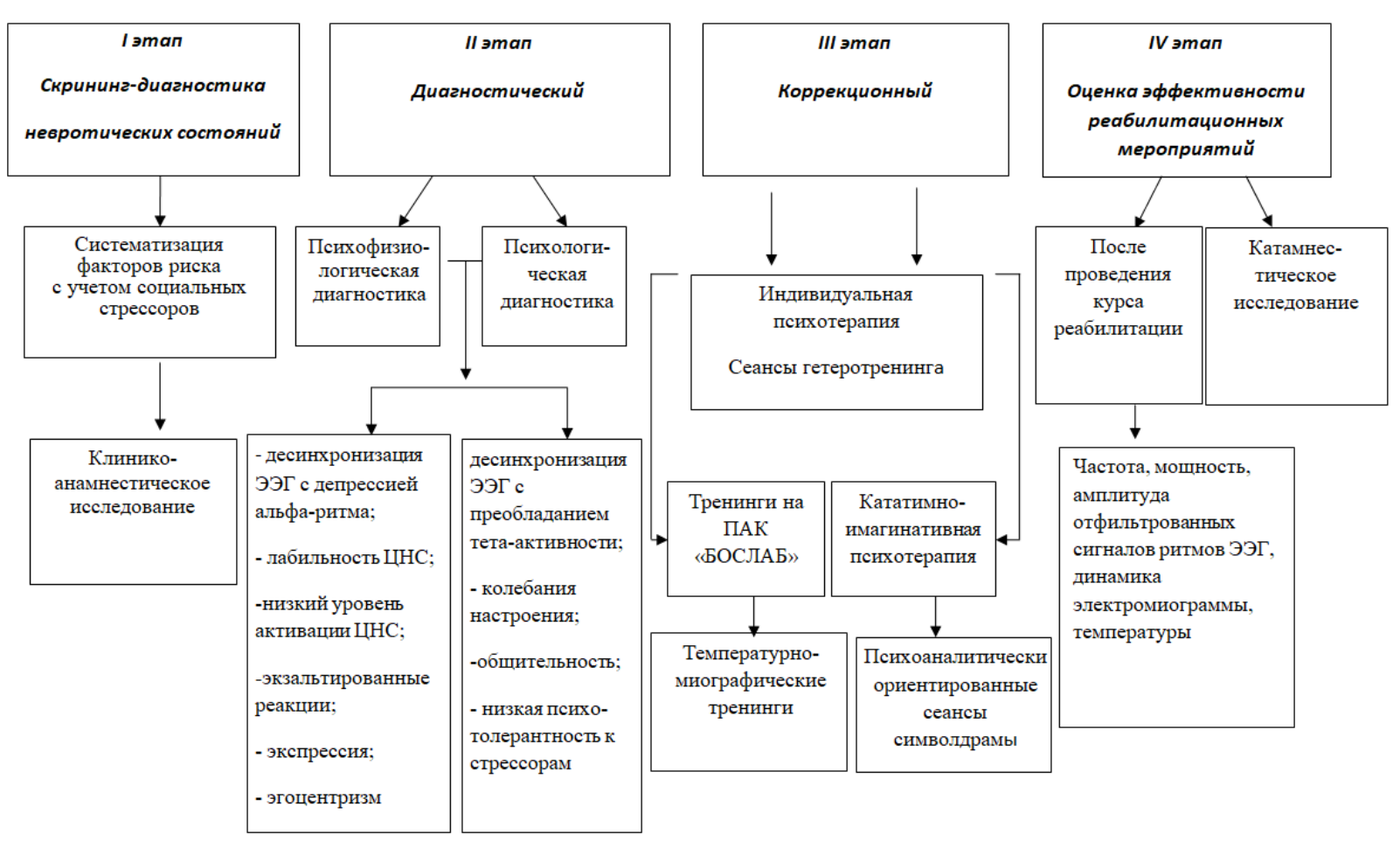

Рис. 1. Программа персонифицированного менеджмента в психологической реабилитации членов семей лиц опасных профессий

\section{Список литературы}

1. Прокопович Л.С. Адаптация клинических рекомендаций (протоколов лечения) для стоматологического приема при отборе и ежегодном профилактическом обследовании по инициативе работодателя лиц опасных профессий // Российская стоматология. 2019. Т. 12. № 1. С. 36-41.

2. Психология экстремальных ситуаций для спасателей и пожарных / Ю.С. Шойгу, И.Н. Елисеева, М.В. Павлова, и др. - М.: Изд-во «Смысл», 2008. $-319 \mathrm{c}$.

3. Александровский Ю.А. Пограничные психические расстройства: руководство для врачей / Ю.А. Александровский и др. - 5-е изд., перераб. и доп. - Москва: ГЭОТАР-Медиа, 2021. - 552 с. 
4. Бокова И.А., Агасаров Л.Г. Инновационный комплекс коррекции постстрессовых нарушений // Лечащий Врач. 2021; 5 (24): 14-16.

5. Погодин Ю.И. Психологические особенности врачей, принимавших участие в боевых действиях // Медицина катастроф. - 2010. - № 4. - С. 38-40.

6. Корехова М.В., Соловьев А.Г., Новикова И.А. Психическая дезадаптация специалистов в экстремальных условиях деятельности: монография. -Архангельск: Изд-во СГМУ, 2014. - 139 с.

7. Крупнова А.Б., Звоников В.М. Психофизиологическое сопровождение деятельности пожарных и спасателей как система профилактики возникновения нарушения функциональных состояний и психосоматических заболеваний // Мир науки. 2018. №6, https://mirnauki.com/PDF/109PSMN618.pdf.

8. Рыбников В.Ю., Санников М.В., Рогалев К.К., Жернакова С.Г. Оценка состояния здоровья и профилактика заболеваний у руководящего состава МЧС России // Медико-биологические и социально психологические проблемы безопасности в чрезвычайных ситуациях. - 2016. - № 4. - С. 67-72.

9. Алексанин С.С. Анализ профессиональной нагрузки спасателей МЧС России, гигиеническая оценка тяжести и напряженности их труда // Медико-биологические и социально-психологические проблемы безопасности в чрезвычайных ситуациях. - 2007. - № 1. - С. 58-63.

10. Склярова Т.П., Петрова А.В., Тарасов Д.А., Механтьева Л.Е.Успешность адаптации и особенности формирования синдрома эмоционального выгорания у специалистов с экстремальными условиями трудовой деятельности // Научно-медицинский вестник Центрального Черноземья, 2015. № 59. - С. 110-116.

11. Жигалин, А.Д., Николаев А.В. Чрезвычайные ситуации как отдаленные последствия локальных военных конфликтов // ГЕОРИСК-2012 : 
материалы Междунар.науч.-практ. конф. - Москва : РУДН, 2012. - Т. 2. C. 241-245.

12. Гизатуллин Т.Р., Катаев А.В., Зинатуллин Р.М. Взаимосвязь психологических и физиологических показателей здоровья сотрудников спецподразделений МВД // Медицинский вестник Башкортостана. - 2014. Т.9 - № 2. - С. 200-203.

13. Шевченко Т.И., Макарова Н.В., Бохан Т.Г. Стрессоустойчивость специалистов опасных профессий МЧС России // Вестник Томского государственного университета. - 2013. - № 369. - С. 164-167.

14. Рыбников В.Ю., Матыцина Е.Н., Кобозев И.Ю. Личностные и средовые копинг-ресурсы в профессиональной деятельности представителей профессий экстремального профиля // Медико-биологические и социальнопсихологические проблемы безопасности в чрезвычайных ситуациях. - 2012. - № 3. - С. 73-75.

15. Hoge C. W. Mild traumatic brain injury in US soldiers returning from Iraq // N Engl J Med. - 2008. - Vol. 358, N 5. - P. 453-463.

16. Returning Home From Iraq and Afghanistan: Preliminary Assessment of Adjustments Needs of Veterans, Service Members, and Their Families / Institute of Medicine of the National Academies. - Washington, DC : The National Academies Press, 2010. - P. 41-54.

17. Погодина Т.Г., Зуйкова А.А, Балчугов В.А. Основы медикопсихологической реабилитации лиц опасных профессий - Н.Новгород. 2007.$99 \mathrm{c}$.

18. Барачевский Ю.Е., Сидоров П.И., Соловьев А.Г. Медицина катастроф. - Архангельск: Издательский центр СГМУ, 2007. - 176 с.

19. Склярова Т.П., Склярова А.В., Плотникова В.И. Роль мониторинга в профилактике нарушений здоровья среди организованных профессиональных групп с экстремальными условиями деятельности. - Материалы Всероссийской научно-практической конференции «Актуальные проблемы 
формирования высококвалифицированного кадрового состава правоохранительной службы». - Воронеж, 2010г.

20. Андрюшин И.И. Психологический механизм преодоления семейных трудностей у офицеров вооруженных сил РФ (психоаналитический подход): автореф. дис. ... канд. психол. наук / И.И. Андрюшин. - М., 2009. - 27 с.

21. Ичитовкина Е.Г., Злоказова М.В., Соловьев А.Г. Влияние личностных и психосоциальных характеристик на развитие пограничных психических расстройств у комбатантов Министерства внутренних дел //Вестник психотерапии. 2011. - Т. 42. - № 37. - С. 56-68

22. Солохина Л.В., Акимов И.В. Современные проблемы ведомственной медицины и их влияние на военную семью // Дальневосточный медицинский журнал. - 2011. - № 3. - С. 113-117.

23. Решетников M.M. Психопатология героического прошлого и будущие поколения. Всерос. конф.: тез.докл. М. 1997. С. 32-35.

24. Bray R.M. Substance abuse and mental health trends among US military active duty personnel: key findings from the 2008 DoD health behavior // Mil Med. - 2010. - Vol. 175, N 6. - P. 390-399.

25. Rachel Dekel. Being a Wife of a Veteran with Posttraumatic Stress Disorder // Family Relations. - 2005. - Vol. 54, N 1. - P. 24-36.

26. Sogomonyan F., Cooper J.L. Trauma faced by children of military families. Brief report. NCCP Mailman School of Public Health at Columbia University, 2010.

27. Киворкова А.Ю., Соловьев А.Г. Игровое биоуправление и стратегии совладающего поведения детей в семьях лиц опасных профессий // МедиАль. - 2018. - № 2(22). - C. 95-98.

28. Локтаева С.А. Проявление личностных свойств детей при различных типах детско-родительских отношений в семьях профессиональных 


\section{ЧЕЛОВЕК И СОВРЕМЕННОЕ ОБЩЕСТВО В СОЦИАЛЬНОМ, ПРАВОВОМ, ЭКОНОМИЧЕСКОМ РАКУРСАХ}

военнослужащих // Вестник Российского университета дружбы народов. Серия: Психология и педагогика. - 2010. - № 4. - С. 47-51

29. Пермогорская Е.М., Падун М.А. Посттравматический стресс и семейные отношения у сотрудников ОВД - участников контртеррористических операций на Северном Кавказе [Электронный ресурс] // Психологические исследования: электрон.науч. журн. 2011. N 3(17). URL: http://psystudy.ru (дата обращения: 16.01.2022).

30. Генгер M.A. Результаты исследования психологических особенностей детско-родительских отношений в семьях военнослужащих, участвовавших в боевых действиях // Проблемы безопасности: электрон.науч. журн. - 2012. - N 4(18). - C.13-14.

31. Warner C.H., Appenzeller G.N., Warner C.M, Grieger T. Psychological effects of deployments on military families // Psychiatric Annals. - 2009. - N. 2. P. 56-63.

32. Кащенко Е.А. Сексуальная культура военнослужащих. - М.: Изд-во УPCC, 2003. $-272 \mathrm{c}$.

33. Сергеев М.Ю., Артифексов С.Б., Бородачева И.В. Прикладные аспекты оценки семейно-сексуального статуса у лиц опасных профессий // Медицинский альманах. - 2011. - №3. - С. 35-37.

34. Солохина Л.В., Акимов И.В. Современные проблемы ведомственной медицины и их влияние на военную семью // Дальневосточный медицинский журнал. - 2011. - № 3. - С. 113-117.

35. Соловьев А.Г., Киворкова А.Ю. Применение биоповеденческой терапии в медико-психологической реабилитации членов семей лиц опасных профессий // Медицина катастроф. - 2017. - № 4 (100). - С. 26-30.

36. Свечников Д.В., Баурова Н.Н., Ушакова Т.М., Курасов Е.С. Объективная диагностика расстройств адаптации у военнослужащих // Медико-биологические и социально-психологические проблемы безопасности в чрезвычайных ситуациях. - 2014. - № 4. - С. 40-44. 
37. Киворкова А.Ю., Соловьев А.Г., Боев И.В. Применение биологической обратной связи в медико-психологической реабилитации членов семей представителей опасных профессий // Экология человека -2015. №9.-С. 3-7.

38. Руководство пользователя программно-аппаратным комплексом «БОСЛАБ». - Новосибирск, 2011.

39. Дмитриева Т.Б., Василевский Г.В., Фастовцов Г.А. Боевой стресс и посттравматическая адаптация участников боевых действий - М.: ГНИИИ ВМ MO, 2003. - 32 c.

40. Калюжный А.С. Психология личности военнослужащего. - Нижний Новгород: НГТУ, 2004. - 39 с.

(C) Киворкова А.Ю., Соловьев А.Г., 2022 
УДК 007.51:316.622+614.8

Глава 16.

АКТУАЛЬНЫЕ ВОПРОСЫ СОЗДАНИЯ БАЗ ДАННЫХ

О БЕЗОПАСНОМ ПОВЕДЕНИИ ЛЮДЕЙ В ЭКСТРЕМАЛЬНЫХ УСЛОВИЯХ И ЧРЕЗВЫЧАЙНЫХ СИТУАЦИЯХ

\author{
Талалаева Галина Владленовна \\ д.м.н., доцент, профессор \\ ФГБОУ ВО «Уральский институт ГПС МЧС России», \\ Уральский федеральный университет \\ Иванов Игорь Владимирович \\ аспирант \\ ФГБОУ ВО «Уральский институт ГПС МЧС России»
}

Аннотация: В работе осуществлен литературный обзор нормативноправовых и психофизиологических алгоритмов создания баз данных, нацеленных на формирование безопасного поведения людей в экстремальных условиях и чрезвычайных ситуациях. Наукометрический анализ выполнен с глубиной поиска 10 лет. Представлены результаты авторских исследований реакции уральцев на цифровую информацию, представляемую службами спасения. Установлено, что фиксация внимания на тревожной информации, получаемой по индивидуальным гаджетам, характерна для небольшой части посетителей торговых центров $(24,5 \%)$. Затухание интереса целевой аудитории к информации, предъявляемой через Интернет, соответствует среднесрочным (недельным) биологическим ритмам человека и равняется семи дням. 
Ключевые слова: безопасное поведение, базы данных, поведенческий анализ, восприятие информации, цифровые технологии.

\title{
CURRENT ISSUES OF CREATING DATABASES ON SAFE BEHAVIOR OF PEOPLE IN EXTREME CONDITIONS AND EMERGENCY SITUATIONS
}

\section{Talalaeva Galina Vladlenovna Ivanov Igor Vladimirovich}

\begin{abstract}
A literary review of regulatory and psychophysiological algorithms for creating databases aimed at the formation of safe behavior of people in extreme conditions and emergency situations has been carried out. Scientometric analysis was performed with a search depth of 10 years. The results of the author's research on the reaction of the Urals residents to the digital information provided by the rescue services are presented. It was found that fixation of attention on alarming information received from individual gadgets is typical for a small part of visitors to shopping centers (24.5\%). The attenuation of the target audience's interest in information presented via the Internet corresponds to the medium-term (weekly) biological rhythms of a person and is equal to seven days.
\end{abstract}

Key words: safe behavior, databases, behavioral analysis, information perception, digital technologies.

Переход от индустриального общества к информационному, стремительный прогресс четвертой промышленной революции, повсеместное проникновение цифровых технологий приводит к трансформации коммуникативных технологий, вызывает разрушение (диссипацию) ранее эффективных социальных связей, формирует новые алгоритмы общественных 


\section{ЧЕЛОВЕК И СОВРЕМЕННОЕ ОБЩЕСТВО В СОЦИАЛЬНОМ, ПРАВОВОМ, ЭКОНОМИЧЕСКОМ РАКУРСАХ}

отношений. Масштабные инновации, пронизывающие все сферы жизни человека оказывают двоякое влияние на формирование безопасных моделей поведения людей. С одной стороны, они предоставляют новые возможности защиты, с другой, создают новые угрозы жизнедеятельности человека. Особую роль в дисбалансе положительных и отрицательных влияний четвертой промышленной революции на модели безопасного поведения людей сыграла пандемия COVID-19. Волнообразное длительное течение этой пандемии негативно сказалось на коммуникативные, когнитивные, психофизиологические и поведенческие паттерны общественных отношений.

Для точного обозначения комплекса негативных последствий четвертой промышленной революции, происходящей на фоне мировой пандемии и глобальной цифровизации специалистами в области комплексной безопасности, социальной психологии и генной инженерии предложен ряд специальных терминов, среди них такие, как: постковидный синдром, санитарные, гибридные, генетические войны.

В описанные условиях, которые многими жителями планеты воспринимаются как экстремальные, выходящие за рамки обычного жизненного опыта и/или чрезвычайные, т.е. несущие ущерб, угрожающие жизни и здоровью. Поиск новых алгоритмов формирования безопасного стиля поведения в цифровой среде в условиях высокой неопределенности личного, профессионального, финансового и социального будущего сегодня стал актуальной задачей специалистов в области комплексной безопасности. Совершенствование системы информирования и оповещения населения в современных условиях является одной из приоритетных задач МЧС России и в связи с программой цифровизации приобретает новые очертания по сравнению с предыдущим десятилетием.

Дополнительным стимулом к поиску оптимальных форм информирования и оповещения населения о новых угрозах цифрового 
общества стали несколько причин. К ним, на наш взгляд, относится появление новых знаний о психофизиологии восприятия цифровой информации; выяснение закономерностей передачи значимой информации членам релевантной группы в социальных сетях с помощью мобильных гаджетов; установление факта трансформация моделей коммуникативной активности людей во время длительной самоизоляцией в условиях пандемии COVID-19; a также широкое распространение мобильных информационнокоммуникационных устройств среди населения всех возрастов и социальных групп. Перечисленные причины создали технологическую основу для модернизации процесса обучения населения безопасному стилю поведения и трансформации этого процесса из унифицированной системы информирования и оповещения населения в таргетированную коучинговую технологию формирования отсроченного поведения с заранее заданными качествами.

\section{І. НОРМАТИВНО-МЕТОДОЛОГИЧЕСКИЕ АСПЕКТЫ ПОВЕДЕНЧЕСКОГО АНАЛИЗА}

\section{1. Нормативно-методическая основа внедрения информационно-коммуникативных технологий в систему информирования населения}

Глубокий анализ современных требований к методике, организации и оценке эффективности к системе информирования населения об угрозах и рисках чрезвычайных ситуаций представлен в монографии «Информационнокоммуникативные технологии обеспечения безопасности жизнедеятельности» [1]. Авторами книги являются сотрудники Федерального государственного учреждения «Всероссийский научно-исследовательский институт по 
проблема гражданской обороны и чрезвычайных ситуаций МЧС России» (федерального центра науки и высоких технологий). Отдельный раздел книги посвящен закономерностям влияния информационно-коммуникативных технологий на население. Особое внимание в этом разделе уделяется характеристике функционирования информационно-коммуникационных технологий в условиях цифровизации страны и широкого распространения во всех сферах жизнедеятельности средств массовой информации и коммуникации. В цитируемой монографии процесс система информирования и оповещения населения о возможных угрозах, рисках ЧС и рекомендуемых правилах безопасного поведения рассматривается с точки зрения кибернетики, а именного того его раздела, который описывает закономерности передачи информации в сложно организованных системах, когда конечный результат передачи информации - поведение человека определяется тремя составляющими: наличием внешней угрозы (риском ЧС), характеристикой канала связи, алгоритмом восприятия принятой информации (вариантом декодирования информации человеком в зависимости от его текущих психо-физиологических особенностей).

Описанный подход к совершенствованию системы информирования и оповещения населения является инновационным, т.к. в нем впервые акцент делается не на содержании передаваемой информации и не на технических характеристиках транслирующих устройств, а на соответствии этих компонентов, объективных по своим качествам, субъективным возможностям человека принять, интерпретировать (декодировать) полученную информацию и трансформировать ее в свою поведенческую активность.

Такая постановка вопроса стала возможной, практически значимой и актуальной только последние несколько лет. Объективной основой необходимости перехода системы информирования и оповещения населения от технически-содержательной методики к поведенческой стало активное 
внедрение информационно-коммуникационных технологий в повседневную жизнь подавляющего большинства жителей России.

Этот процесс стимулируется и поддерживается нормативно-правовыми актами, принятыми в последнее время. Ряд из них имеет особое значение для цифровизации процесса взаимодействия сотрудников МЧС России с гражданским населением. Формированию у населения навыков восприятия информации с помощью информационных технологий относятся законы и подзаконные акты, которые регламентируют широкое внедрение электронных технологий в образовательную деятельность общего, среднего, высшего и дополнительного образования. Это:

- Федеральный закон от 27 июля 2006 г. № 149-Ф3 «Об информации, информационных технологиях и о защите информации» [2];

- Федеральный закон от 29 декабря 2012 г. № 273-Ф3 «Об образовании в Российской Федерации [3];

- Стратегия развития отрасли информационных технологий в Российской Федерации на 2014-2020 годы и на перспективу до 2025 года, утвержденная распоряжением Правительства Российской Федерации от 1 ноября 2013 г. № 2036-р [4];

- Порядок применения организациями, осуществляющими образовательную деятельность, электронного обучения, дистанционных образовательных технологий при реализации образовательных программ, утвержденный приказом Минобрнауки России от 23 августа 2017 г. № 816 [5].

Процесс модернизации и перехода на «цифру» системы информирования и оповещения населения ускоряется положениями, изложенными в Послании Президента Федеральному собранию от 15 января 2020 г. [6], сформулированными в паспорте национальной программы «Цифровая экономика Российской Федерации» [7], включающей в себя шесть 
проектов, в т.ч. проекты «Информационная инфраструктура», «Информационная безопасность», «Цифровые технологии».

Проект «Цифровые технологии» в свою очередь включает в себя 9 дорожных карт по запланированным направлениям деятельности, которые будут реализовываться в приоритетном порядке с 2020 по 2024 гг. [8].

Дорожные карты по двум из девяти направлений деятельности если не прямо, то косвенно предъявляют новые требования к совершенствованию информационно-коммуникационного взаимодействия сотрудников МЧС России с населением в области информирования и оповещения об угрозах и рисках ЧС [9]. Так, дорожная карта «Искусственный интеллект» предусматривает развитие информационных технологий, направленных на совершенствование процесса передачи и восприятия информации в виде технологий компьютерного зрения, обработки естественного языка, распознавания и синтеза речи. А дорожная карта «Технологии беспроводной связи» включает в себя задачи по наращиванию сетевых технологий связи, выстроенных по принципу «вокруг» человека, т.е. ориентированных на интерфейс, комфортный для пользователя в рамках его повседневной активности. Более подробно структура указанных дорожных карт и запланированный объем их финансирования указан в сканах презентации «Дорожные карты развития «сквозных» цифровых технологий», представленных в Приложении 1.

Как следует из цитируемых правовых актов, интерес к кибернетическим аспектам анализа потоков информации, сосредоточенной в сфере жизнедеятельности всего населения России, сегодня является государственной задачей, направленной на обеспечение национальной безопасности страны.

Деятельность МЧС России по совершенствованию системы информирования и оповещения населения гармонично вписывается в решение 
задач цифровизации страны как важный элемент обеспечения ее национальной безопасности. Об этом свидетельствуют перспективные планы развития деятельности МЧС России [10].

На заседании Коллеги МЧС России 6 февраля 2019 г. отмечено, что в министерство с 2018 г. вошло в национальную программу «Цифровая экономика Российской Федерации», начата работа по созданию единого информационного пространства, в области защиты населения и территорий от ЧС [11]. Объем финансирования, выделенный на эти цели до 2024 г. составляет 3,8 млрд рублей. Согласно цитируемым источникам, взаимодействие с населением в условиях цифровизации осуществляется нарастающими темпами; только в 2018 г. органами МЧС России было рассмотрено около 100 тысяч обращений граждан: более 20 тысяч центральным аппаратом и организациями МЧС центрального подчинения и 76 тысяч - региональными органами МЧС России.

Нарастающая актуальность применения цифровых технологий для обеспечения безопасности населения зафиксирована в «Основах государственной политики Российской Федерации в области пожарной безопасности на период до 2030 года», утвержденных Указом Президента Российской Федерации от 01 января 2018 г. № 2 [12].

За последние несколько лет значимость взаимодействия сотрудников МЧС России с населением значительно возросла в своей значимости. Об этом свидетельствуют результаты заседания научно-технического совета МЧС России, которое состоялось 26 августа 2020 г., и на котором были рассмотрены приоритетных направлениях развития науки, техники и технологий, обозначенных МЧС России на период 2021-2023 гг. и на перспективу до 2030 г. В информационном сообщении по итогам заседания было подчеркнуто, что «цифровизация и совершенствование системы прогнозирования ЧС станут приоритетными направлениями в деятельности 
МЧС России» [13]. Согласно данному плану перспективных научноисследовательских разработок МЧС России в число приоритетных направлений деятельности министерства входят:

- Совершенствование автоматизированных систем поддержки принятия управленческих решений, обеспечения общественной безопасности, правопорядка и безопасности среды жизнедеятельности,

- Взаимодействие с федеральными органами исполнительной власти, органами власти субъектов Российской Федерации в области гражданской обороны, защиты населения и территорий от чрезвычайных ситуаций,

- Обеспечение пожарной безопасности и безопасности людей на водных объектах, в том числе обучение населения правилам безопасного поведения и подготовка волонтеров к действию в чрезвычайных ситуациях.

В условиях массовой цифровизации и активного внедрения онлайн технологий в сферу государственных услуг и дополнительного образования эффективное совершенствование перечисленных направлений взаимодействия сотрудников МЧС России с населением невозможно без углубленного исследования моделей коммуникативного поведения целевых аудиторий населения в информационной среде. Одной из таких целевых аудиторий являются волонтеры. Формы внедрения информационнокоммуникационных технологий в процесс подготовки волонтеров и добровольцев в сфере безопасности регламентирует Приказ МЧС России от 25 декабря 2020 г. № 995 «Об утверждении Плана мероприятий (дорожной карты) МЧС России по реализации в 2021 году Концепции содействия развитию добровольчества (волонтерства) в Российской Федерации до 2025 года» [14]. Раздел 2.2. «Развитие механизмов поддержки добровольческой деятельности в области образования» предполагает разработку программ профессиональной подготовки и повышения квалификации добровольных пожарных, участие работников 


\section{ЧЕЛОВЕК И СОВРЕМЕННОЕ ОБЩЕСТВО В СОЦИАЛЬНОМ, ПРАВОВОМ, ЭКОНОМИЧЕСКОМ РАКУРСАХ}

профессиональной пожарной охраны в развитии системы наставничества и обучения спасателей-добровольцев и добровольных пожарных, а также выполнение перечисленных направлений работ с активным использованием цифровых технологий, а именно: подготовкой соответствующих онлайнкурсов для добровольцев (волонтеров) и размещением этих курсов на официальном сайте МЧС России и в единой информационной системе в сфере развития добровольчества (волонтерства) «Добровольцы России» (приказ, пункты 7, 8, 9). Раздел 5 данного приказа «Поддержка добровольчества (волонтерства) в субъектах Российской Федерации» гласит, что МЧС России планирует принимать участие в проведении мониторинга результатов работы в субъектах Российской Федерации добровольческих организаций в части развития взаимодействия $\mathrm{c}$ органами власти и государственными учреждениями, включая предоставление субсидий, установление пониженных налоговых ставок по налогу на прибыль и налогу на имущество, имущественной поддержки, организации подготовки добровольцев, применения новых цифровых информационно-коммуникационных технологий (приказ, пункт 18).

Ответственными исполнителями по реализации названных пунктов назначены ведущие структуры министерства МЧС России:

- Главное управление пожарной охраны (ГУПО);

- Департамент образования и научно-практической деятельности (ДОН);

- Департамент кадровой политики (ДКП);

- Департамент спасательных формирований (ДСФ);

- Департамент надзорной деятельности и профилактической работы (ДНПР);

- Управление безопасности людей на водных объектах (УБВО);

- Департамент информационной политики (ДИП); 
- ФКУ «Центр экстренной психологической помощи МЧС России (ЦЭПП).

Еще более значимым по масштабам практического внедрения цифровых технологий в процесс взаимодействия МЧС России с населением является Приказ МЧС России от 20.07.2020 № 536 «О плане мероприятий на 2020-2024 годы (I этап) по реализации Министерством Российской Федерации по делам гражданской обороны, чрезвычайным ситуациям и ликвидации последствий стихийных бедствий Стратегии в области развития гражданской обороны, защиты населения и территорий от чрезвычайных ситуаций, обеспечения пожарной безопасности и безопасности людей на водных объектах на период до 2030 года» [15]. В примечании к Плану мероприятий МЧС России на 2020-2024 гг. отмечено, что «Приоритетные направления, предусмотренные к реализации в Основах государственной политики Российской Федерации в области гражданской обороны на период до 2030 г., в Основах государственной политики Российской Федерации в области защиты населения и территорий от чрезвычайных ситуаций на период до 2030 г. и в Основах государственной политики Российской Федерации в области пожарной безопасности на период до 2030 г. выполняются в соответствии с утвержденными планами мероприятий по реализации Основ государственной политики Российской Федерации в области гражданской обороны на период до 2030 г. (от 20 июня 2017 г. № 4210п-П4), планом мероприятий на 2018 - 2024 гг. (І этап) по реализации Основ государственной политики Российской Федерации в области защиты населения и территорий от чрезвычайных ситуаций на период до 2030 г. (от 20 августа 2018 г. № 6664п-П4) и планом мероприятий на 2018 - 2024 гг. (І этап) по реализации Основ государственной политики Российской Федерации в области пожарной безопасности на период до 2030 г. (от 24 августа 2018 г. № 6791п-П4)». Данным примечанием задачи внедрения современных информационно- 
коммуникационных технологий в процесс взаимодействия МЧС России с населением распространяется на всех предыдущие планы работы, включая те, которые были приняты с 2017 г., т.е. еще до вхождения министерства в национальную программу цифровизации.

Раздел II Приказа МЧС России от 20.07.2020 № 536 называется «Внедрение новых технологий обеспечения безопасности жизнедеятельности населения». Пункты 5 и 10 данного раздела расширяют сферу применения информационно-коммуникативных технологий при взаимодействии с населением за пределы работы по информированию, оповещению и подготовки добровольцев (волонтеров). Указанные пункты распространяют применение цифровых технологий на все формы обучения населения безопасному поведению. Так, пункт 5 раздела II Плана мероприятий МЧС России на 2020-2024 гг. предусматривает «Совершенствование методов, средств и способов проведения мероприятий по гражданской обороне, защите населения и территорий от чрезвычайных ситуаций, обеспечению пожарной безопасности и безопасности людей на водных объектах», а пункт 10 прямо закрепляет «Внедрение новых форм подготовки населения к выполнению мероприятий по гражданской обороне и к действиям в чрезвычайных ситуациях, в том числе с использованием современных технических средств обучения» [16].

В качестве примера расширения сферы применения цифровых информационно-коммуникативных технологий при работе с населением отметим, что среди задач, которые запланированы до IV квартала 2024 г., предусмотрено «Создание и внедрение интерактивного Атласа природных и техногенных опасностей и рисков в Российской Федерации» (пункт 3.2. Плана деятельности МЧС России до 2030 г.). Ответственными за выполнение этой задачи назначены ведущие структурные подразделения МЧС России федерального уровня, а именно: 
- Департамент гражданской обороны и защиты населения (ДГО);

- Департамент информационных технологий и связи (ДИТС);

- Главное управление «Национальный центр управления в кризисных ситуациях» (ГУ НЦУКС);

- Федеральное государственное бюджетное учреждение «Информационно-аналитический центр МЧС России» (ФГБУ "ИАЦ МЧС России»).

Таким образом, последние годы в деятельности МЧС России наметился отчетливый тренд на взаимодействие с населением по вопросам безопасности в новом информационно-коммуникационном формате. Это происходит на фоне ускоренной цифровизации всех сфер жизни страны, которые включают в себя сферу безопасности, государственных услуг, образование, волонтерскую деятельность.

Усилия МЧС России в этом направлении реализуются в рамках национальной программы «Цифровизация экономики Российской Федерации», в которую министерство включено с 2018 г. с бюджетом до 2024 г. в объеме 3,8 млрд рублей. Указанную деятельность координируют восемь структурных подразделений МЧС России федерального уровня. План развития взаимодействия сотрудников МЧС России с населением, включая добровольцев (волонтеров), предполагает участие в этой работе региональных подразделений и организаций МЧС России. Настоящая НКР вносит свой посильный вклад в решение обозначенных задач.

\section{2. Наукометрический анализ публикационной активности по запросу «ОКСИОН» на основе базы РИНЦ}

Эмпирической базой для настоящего анализа послужили данные, полученные по поисковому запросу «ОКСИОН» из числа публикаций, включенных в Российский индекс научного цитирования - РИНЦ. 
Было осуществлено два формата поиска данных. Первый формат (полный) был ориентирован на подсчет общего количества публикаций, включенных в базу РИНЦ в искомом году вне зависимости от типа публикации. Второй формат поиска включал учитывал тип публикаций и включал в себя только статьи, опубликованные в научных журналах.

Глубина наукометрического поиска составила 10 лет, с 2010 по 2019 гг. включительно. В результате поиска обнаружено 471 публикация, в том числе 263 статьи в научных журналах.

Итоги поиска по первому формату (количество публикаций вне зависимости от типа публикации) представлены графически на рисунке 1 .

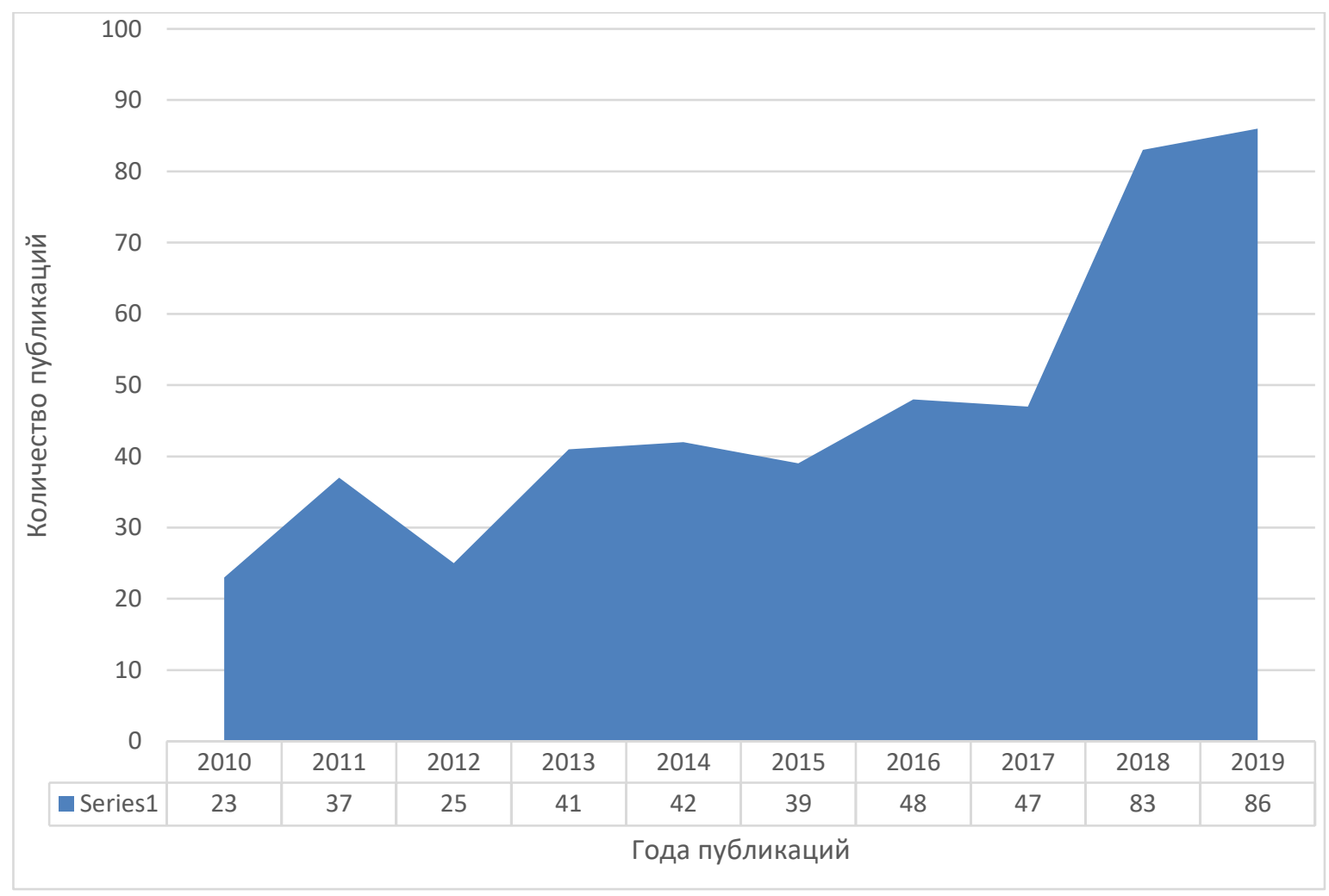

Рис. 1. Динамика количества публикаций по запросу «ОКСИОН», включенных в РИНЦ вне зависимости от типа публикации за период с 2010 по 2019 гг. 
Как следует из графика на рисунке 1 , интерес к теме «ОКСИОН» в среде научной общественности был относительно стабильным с незначительным трендом к росту в период с 2010 по 2017 гг. и демонстрирует качественный скачок в 2018 г. Можно предположить, что скачкообразный рост интереса научного сообщества к теме «ОКСИОН» в этот период связан с наработкой новых технологий информационно-коммуникативной передачи информации населению, которые представлены в литературном обзоре и внедрение которых в практику МЧС России стало актуальной задачей совершенствования системы информирования и оповещения населения. Результаты поиска данных по второму формату (статьи, опубликованные в научных журналах) представлены ниже (рис. 2).

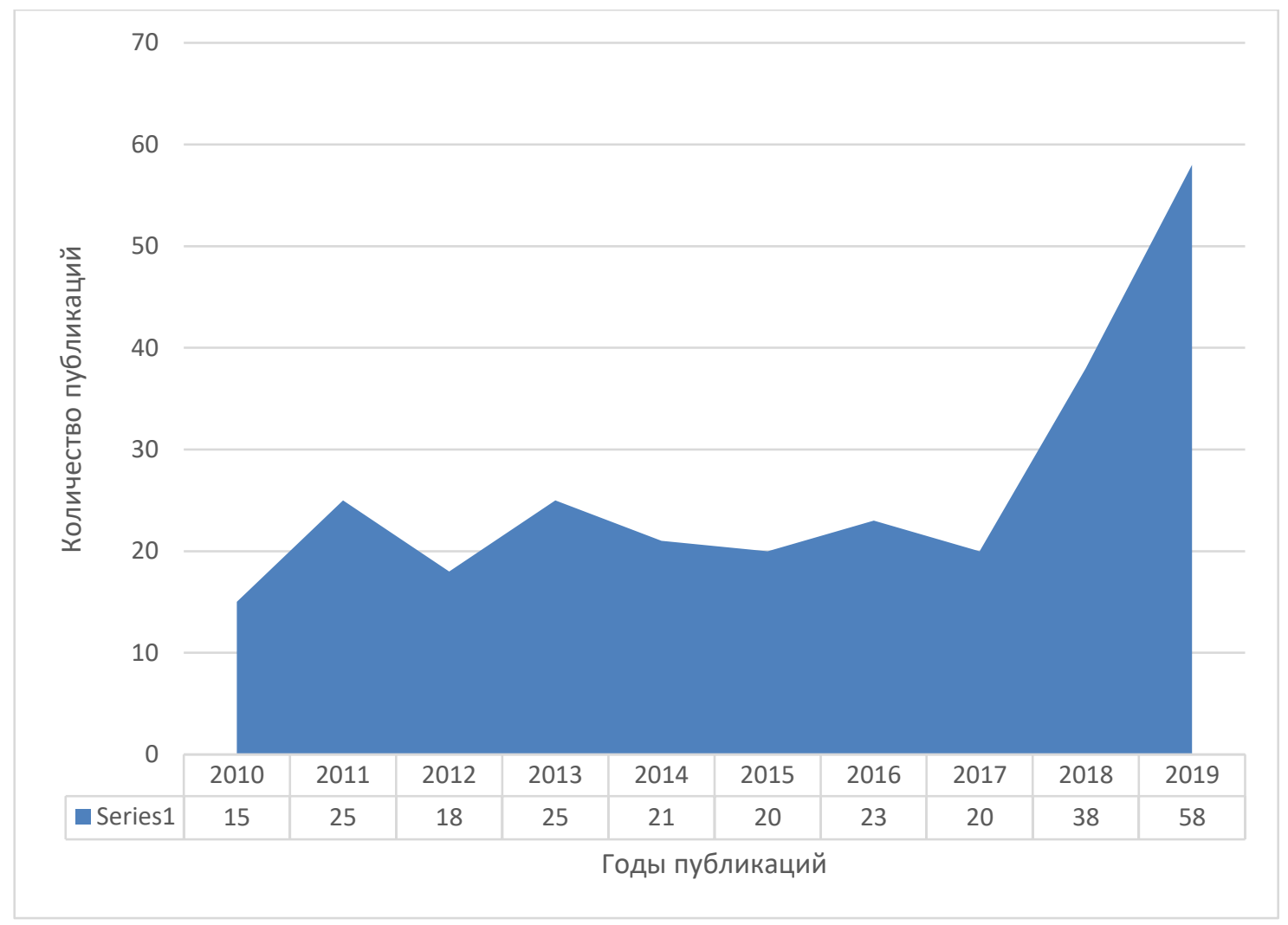

Рис. 2. Динамика количества статей в научных журналах по запросу «ОКСИОН», включенных в базу РИНЦ за десятилетний период с 2010 по 2019 гг. 


\section{ЧЕЛОВЕК И СОВРЕМЕННОЕ ОБЩЕСТВО В СОЦИАЛЬНОМ, ПРАВОВОМ, ЭКОНОМИЧЕСКОМ РАКУРСАХ}

График, приведенный на рисунке 2 , демонстрирует волнообразную динамику интереса исследователей к теме «ОКСИОН» в интервале с 2010 по 2017 гг. с периодом равным трем-четырем годам. С 2017 г. характер динамики интереса к теме «ОКСИОН» изменился качественно, зафиксирован непрерывный рост академических статей по этой теме в научных журналах.

Коэффициент корреляции между количеством статей в журналах ВАК и общим количеством публикаций, включенных в базу РИНЦ равно 0,90, что указывает на высокую степень зависимости этих двух показателей и позволяет сделать вывод о том, что и академический и научно-популярный интерес к данной тематике заметно актуализировался в последние три года, что, как указано в первой главе, идет в параллель с широким внедрением новых информационно-коммуникативных технологий в систему Интернет.

В связи с изменением динамики количества публикаций по теме «ОКСИОН» для углубленного понимания содержания происходящих перемен был осуществлен контент-анализ статей, опубликованных в научных журналах и включенных в базу РИНЦ за период с 2010 по 2019 гг.

Установлено, что в 2015 г. была системно обоснована необходимость применения современных информационных технологий для развития системы ОКСИОН МЧС России как базового инструмента информирования и оповещения населения.

В 2018 г. публикации по данной теме были посвящены анализу структуры ОКСИОН и выработке предложений по ее оптимизации. В 2018 г. анализ организационных аспектов деятельности системы ОКСИОН был дополнен новым направлением исследований, а именно, изучением эффективности восприятия населением информации, транслируемой с помощью системы ОКСИОН.

Суммируя изложенное, можно констатировать, что до 2015 г. предметом исследований в области информационно-коммуникационных технологий был 
в основном процесс передачи информации населению, а после 2015 г. им стал процесс восприятия информации населением. Наукометрический и хронологический анализ публикаций показал, что переключение внимания исследователей с технологических характеристик передачи информации населению на когнитивно-психологические параметры восприятия информации пользователем произошло сравнительно недавно, а именно в интервале с 2015 по 2017 гг. Таким образом, в научных статьях специалистов в области безопасности обнаружена та же тенденция, что и в работах экспертов в сфере социальной и коммерческой рекламы. Этот тренд заключается в смещение фокуса исследований с технико-технологических аспектов информационно-коммуникационных технологий на биокибернетические и когнитивно-психологические.

Установленный факт, на наш взгляд, означает, что совершенствование системы информирования и оповещения населения с помощью современных технологий не изучено полностью, но подлежит дальнейшему совершенствованию с использованием современных подходов и принципов, в т.ч. принципов таргетированной социальной рекламы, показавшей свои прорывные достижения в форме технологий LSI-копирантинга.

Готовность научного сообщества к внедрению новых информационнокоммуникативных технологий в систему безопасности и мероприятия по информированию и оповещению населения проанализирована по данным базы РИНЦ на примере статей, опубликованных в научных журналах 2019 г. В этом блоке исследования был проанализирован перечень журналов перечня ВАК, в которых были опубликованы статьи на интересующую нас тему, определена доля статей, содержание которых было нацелено на внедрение LSI-копирантинга. Эмпирические результаты данного блока исследования представлены в таблице 1. 
Таблица 1

Статистика статей по запросу «ОКИОН», опубликованных в 2019 г. в научных журналах базы РИНЦ

\begin{tabular}{|c|c|c|}
\hline Название журнала & $\begin{array}{c}\text { Включение журнала } \\
\text { в перечень ВАК }\end{array}$ & $\begin{array}{l}\text { Число } \\
\text { статей }\end{array}$ \\
\hline Проблемы анализа риска & Да & 1 \\
\hline $\begin{array}{l}\text { Научные и образовательные проблемы гражданской } \\
\text { защиты }\end{array}$ & Да & 1 \\
\hline Технологии гражданской безопасности & Да & 1 \\
\hline $\begin{array}{l}\text { Пожары и чрезвычайные ситуации: предотвращение, } \\
\text { ликвидация }\end{array}$ & Да & 1 \\
\hline Системы контроля окружающей среды & Да & 1 \\
\hline Актуальные проблемы российского права & Да & 1 \\
\hline Пожарное дело & Нет & 31 \\
\hline Гражданская защита & Нет & 10 \\
\hline Пожарная и аварийная безопасность & Нет & 1 \\
\hline Интернаука & Нет & 1 \\
\hline Вестник современных исследований & Нет & 1 \\
\hline Природные и техногенные риски & Нет & 1 \\
\hline $\begin{array}{l}\text { Вестник университета гражданской защиты МЧС } \\
\text { Беларусь }\end{array}$ & Нет & 1 \\
\hline Пожарная и аварийная безопасность & Нет & 1 \\
\hline $\begin{array}{l}\text { Наука и современное общество: взаимодействие и } \\
\text { развитие }\end{array}$ & Нет & 1 \\
\hline $\begin{array}{l}\text { ГосРег: государственное регулирование } \\
\text { общественных отношений }\end{array}$ & Нет & 2 \\
\hline $\begin{array}{l}\text { Современные технологии обеспечения гражданской } \\
\text { обороны и ликвидации последствий чрезвычайных } \\
\text { ситуаций }\end{array}$ & Нет & 1 \\
\hline ВСЕГО: & 6 позиций из 17 & 57 \\
\hline
\end{tabular}


Как следует из таблицы 1, в 2019 г. в базу РИНЦ в качестве статей, опубликованных в научных журналах и имеющих в своих выходных данных указания на ключевое слово «ОКСИОН», было включено 57 публикаций. Только 6 из них или 10,5 \% от общего числа найденных статей, были опубликованы в высокорейтинговых журналах перечня ВАК. Большинство статей, отражающих деятельность системы «ОКСИОН» и включенных в 2019 г. в базу РИНЦ как опубликованные в научных журналах, были представлены публикациями в двух ведомственных журналах: «Пожарное дело» «Гражданская защита». Число статей в этих двух журналах составило 40 или 70,2 \% от общего числа статей, опубликованных в научных журналах 2019 г. по теме «ОКСИОН».При ознакомлении с содержанием статей, включенных в таблицу 1, установлено, что ни в одной из них не исследована проблема внедрения технологий LSI-копирантинга в деятельность системы «ОКСИОН» МЧС России.

На основе установленных фактов сделано заключение, что проблема повышения эффективности информационно-коммуникационных технологий информирования и оповещения населения до сих пор еще не стала предметом глубокого академического исследования и представлена в основном научнопопулярными публикациями; а значит, нуждается в дополнительной методологической, методической и эмпирической проработке.

\section{ІІ. ПСИХОФИЗИОЛОГИЧЕСКИЕ АСПЕКТЫ ПОВЕДЕНЧЕСКОГО АНАЛИЗА}

\section{1. Закономерности восприятия информации населением при использовании информационно-коммуникативных технологий}

На данный момент информирование и оповещение населения ведется как по традиционным каналам оповещения (сирены, телефония, подворовые 


\section{ЧЕЛОВЕК И СОВРЕМЕННОЕ ОБЩЕСТВО В СОЦИАЛЬНОМ, ПРАВОВОМ, ЭКОНОМИЧЕСКОМ РАКУРСАХ}

обходы, телевидение, радио и т.д.), так и с использованием современных информационно-коммуникативных цифровых технологий, пример мобильных телефонов. Современные темпы развития информационных технологий и связи значительно расширяют возможности доведения до населения о потенциальных угрозах и рисках ЧС. Наряду с традиционными системами реализованы относительно новые системы ОКСИОН, СЗИОНТ, СМСинформирование, оповещение посредством социальных сетей, рассматриваются варианты информирования и оповещения посредством мессенджеров WhatsApp, Viber, Telegram.

При использовании современных цифровых технологий, также как и при проведении групповых аудиторных занятий, процесс передачи информации включает в себя три основных звена: 1) создание информационного сообщения, 2) передача его по каналам связи, 3) восприятие информации пользователем с последующей интерпретацией и трансформацией в совершаемые поступки и модели поведения.

Однако, при использовании современных гаджетов этап восприятия информации пользователями имеет существенные отличия по сравнению с восприятием той же информации в обычных условиях аудиторного обучения.

Именно поэтому специалисты в области информационнокоммуникационных технологий рассматривают восприятие информации при ее передаче через мобильные устройства как особый процесс, подчиненный своим специфическим закономерностям.

Закономерности влияния информационно-коммуникационных технологий на население подробно описаны в монографии [1]. Параграф 3.1. цитируемой книги посвящен актуальному вопросу - общей характеристике функционирования информационно-коммуникационных технологий в условиях массовой информации и коммуникации. В нем авторы монографии, специалисты ФГУ «Всероссийский научно-исследовательский институт по 


\section{ЧЕЛОВЕК И СОВРЕМЕННОЕ ОБЩЕСТВО В СОЦИАЛЬНОМ, ПРАВОВОМ, ЭКОНОМИЧЕСКОМ РАКУРСАХ}

проблема гражданской обороны и чрезвычайных ситуаций МЧС России» (федерального центра науки и высоких технологий) особо подчеркивают, что в современном обществе информационные потоки «представляют собой чрезвычайно сложный и мало изученный процесс» [1, с. 109]. Этот процесс одновременно является отражением субъективных характеристик лиц, принимающих участие в обмене информации, но и объективных обстоятельств, в рамках которых осуществляется передача информации. К значимым факторам, влияющим на процесс создания и передачи информации, по мнению авторов монографии, относятся: структура человеческой памяти и интеллекта; индивидуально-психические явления пользователя на момент поступления информации; актуальные особенности инфраструктуры общества, в котором осуществляется передача данного информационного сообщения, включая характер связи между социальными институтами и территориальными группами людей, между большими общностями людей и каждым индивидом. Авторы отмечают многоуровневость взаимосвязей, их структурное многообразие, возможную динамику во времени и пространстве, а также неизбежность трехступенчатой кодировки передаваемой информации. Последнее качество наиболее значимым становится при передаче информации, которая несет в себе сигнал тревоги и должна вызвать у ее получателя правильный алгоритм безопасного поведения. По мнению авторов монографии, «Сначала переживание является чистой психикой, затем превращается в психическую форму, символ, раздражитель и, наконец, снова обретает психическое бытие в воспринявшем объекте» [1, с. 109]. «Тексты, образы, знаково-символьные средства, выступающие в роли сигналов, содержат социально-психологические коды, которые расшифровываются в коммуникативном процессе» [1, с. 110].

Коммуникативный процесс, осуществляемый онлайн или с помощью мобильных устройств, принципиально отличается от коммуникативного 
процесса, происходящего при очной беседе сотрудниками МЧС России с пострадавшими от ЧС. При использовании современных устройств процесс общения является опосредованным, может искажаться на этапе передачи информации в связи с различными техническими помехами, может неадекватно восприниматься получателем из-за неготовности последнего к приему тревожной информации.

В отличии от учебной информации, передаваемой от учителя к ученику в аудиторных занятиях и осуществляемой в формате межсубъектной коммуникации, при которой восприятие информации учеником отслеживается учителем и подача ее варьирует в зависимости от реакции обучаемого, процесс передачи и восприятия информации в режиме онлайн и/или по мобильной связи осуществляется по другим алгоритмам. В них отсутствует эффект обратной связи, коммуникация осуществляется опосредованно без учета текущего психофизиологического состояния получателя информации, прием информации может быть разорвана пользователем в любой момент до завершения передачи значимой информации, продолжительность сеанса коммуникации также регламентируется получателем в одностороннем порядке. Все перечисленное в совокупности не позволяет гарантировать точного и полного восприятия переданной информации и, тем более, не позволяет надеяться, что принятая информация послужит адекватным стимулом для безопасного поведения людей в экстремальных ситуациях. Именно поэтому закономерностям восприятия информации, передаваемой опосредованно с использованием современных технологий, сегодня придается большое практическое значение.

Отмечено, что восприятие информации индивидуальным пользователем информационно-коммуникационных технологий осуществляется в иных временных алгоритмах, чем это происходит в учебной аудитории, когда внимание обучающегося на учебном предмете искусственно поддерживается 
и активизируется преподавателем, присутствующими в аудитории участниками группового занятия, самой обстановкой и атмосферой учебного процесса. Традиционно учебные занятия длятся 45 минут. Этот временной интервал соответствует средней продолжительности произвольного внимания человека. Именно такая продолжительность учебного занятия установлена нормативными документами РФ, регламентирующими организацию учебного процесса в общеобразовательных учреждениях страны [17, пункт 10.9]. Продолжительность удержания произвольного внимания обладает межиндивидуальными различиями, тем не менее существуют некоторые общегрупповые закономерности. Эти закономерности ограничивают количество информации, которое способен воспринять и проанализировать человек. Они имеют возрастные колебания и обусловлены такими свойствами внимания, как:

- Концентрация;

- Объем;

- Устойчивость;

- Переключаемость;

- Распределение.

Согласно пункту 10.10 «Санитарно-эпидемиологические требования к условиям и организации обучения в общеобразовательных учреждениях» СанПиН 2.4.2.2821-10 (Постановление Главного государственного санитарного врача Российской Федерации от 29 декабря 2010 г. № 189) плотность учебной работы обучающихся на уроках по основным предметам не должна превышать 60-80 \%. Пункт 10.18 цитируемого документа в таблице 5 детализирует характер учебной нагрузки по время учебного занятия в зависимости от класса обучения (таблица приведена в Приложении). С учетом темы настоящей ВКР важно отметить, что даже в старших классах работы продолжительность непрерывной работы с информационно403 
коммуникационными технологиями составляет не продолжительности учебного занятия и ограничена 25 минутами для прослушивания аудиозаписи в наушниках и без них, а также для работы с изображениями на индивидуальном мониторе компьютера и клавиатурой.

Из приведенных данных следует, что на уровне законодательства Российской Федерации признаны различия в восприятии информации, передаваемой при очном общении и с помощью дистанционных IT-технологий. Во втором случае произвольное внимание, осознанно поддерживаемое самим обучающимся и педагогом уступает место непроизвольному вниманию, которое реализуется по своим специфическим законам. К ним относятся:

- Модель ранней селекции Бродбента;

- Модель аттенюатора Э. Трисмана;

- Модель поздней селекции Дойчей и Нормана;

- Ресурсная модель внимания Д. Канемана;

- Модель простой последовательной обработки;

- Модель последовательного выбора (селекции);

- Простая параллельная модель Ч. Эриксена;

- Параллельная модель с ограниченной пропускной способностью Т. Таунседа;

- Соревновательная модель выборов;

- Коннектионистская модель;

- Переднеассоциативная и заднеассоциативная модель М. Познера;

Особенности восприятия информации человеком, использующим информационно-коммуникативные технологии отчетливо осознается методистами, разрабатывающими современные технологии информирования, оповещения и обучения. Примером этого являются исследования сотрудников ВНИИ ГОЧС МЧС России по оптимальной продолжительности видеороликов 404 
по вопросам безопасности; практика построения онлайн-курсов на национальной платформе «Открытое образование», в том числе по вопросам, относящимся к безопасности жизнедеятельности, структура печатных изданий, нацеленных на восприятие людей, привыкших к использованию различных мобильных устройств. Далее приводится детализации некоторых из этих примеров.

В монографии [1] сотрудники НИИ ГОЧС МЧС России рассматривают следующие виды информационно-коммуникационных технологий: сотовую связь, Интернет, телевидение, радиовещание. Авторы характеризуют принципиальные отличия данных технологий в двух случаях их применения: 1) как носителей информации, транслируемой СМИ (средствами массовой информации) и 2) как технологий информирования и оповещения населения, используемых службами спасения. В первом случае имеет место односторонняя передача информации, население рассматривается в роли объекта воздействия, обратная связь между источником информации и ее получатель не является самоцелью, реакция получателя информации не значима для процесса передачи информации. Во втором случае, наоборот, приоритет отдается коммуникативной составляющей передачи информации; главной задачей коммуникатора, в роли которого выступают сотрудники МЧС России, является результат информационно-коммуникационного взаимодействия, а именно: «формирование паттернов (устойчивых образцов) безопасного поведения в повседневных условиях и условиях опасных и чрезвычайных ситуаций» [1, с. 113]. По мнению экспертов НИИ ГОЧС МЧС России, существуют пять групп факторов, которые существенно влияют на формирование деятельного поведения у населения в результате информационно-коммуникативного взаимодействия с сотрудниками служб спасения. К этим факторам относятся следующие [1, с. 115]: 
1. Медиаметрические (длительность, частота предъявляемой информации, количество текста и графики, акустическое сопровождение и др.);

2. Психофизиологические (тембр звука, цветовые решения, фон, перспектива изображения и т.п.);

3. Социальные (пол, возраст, этническая принадлежность, образование и т.д.);

4. Технологические (разрешение экранов, их линейный размер и площадь, яркость, размер пикселя, величина звукового давления, возможность просмотра при нахождении в движущемся транспортном средстве и другие параметры технического устройства);

5. Информационно-содержательные (содержательность, краткость, полнота, достоверность, логика сюжетной линии, использование привлекательных персонажей).

К основе анализа материалов, представленных в проекте ОКСИОН МЧС России на мультимедийных экранах, расположенных в м, естах массового пребывания людей, эксперты ВНИИ ГОЧС МЧС России выделили основные медиаметрические факторы, влияющие на восприятие информации населением. В их число вошли:

- Продолжительность доведения информации;

- Количество предъявляемой информации;

- Время, прошедшее после получения информации;

- Количество повторов информации;

- Доля от общей площади поверхности, одновременно доступной для восприятия (для статичных объектов);

- Доля от общей площади поверхности, на которой располагаются текстовые фрагменты (для статичных объектов). 
Для видеоинформации цитируемой публикацией были установлены численные и графические закономерности, которые связывают запоминание информации с продолжительностью показа видеоролика и числом его повторений. Данные графики приведены в приложении. Важно отметить, что устойчивое запоминание предъявленной информации формируется после 6-го повторения, вероятность запоминания падает до незначительного уровня в 0,3 на второй день после предъявления информации при однократном информировании, на пятый день при получении второго сообщения и сохраняется в течении недели на уровне в 0,7 после третьего получения сообщения.

Интересна зависимость между долей людей в процентах, способных вспомнить содержание транслируемой видеоинформации, в зависимости от социальных обстоятельств, в которых происходит это воспоминание. Доля людей, вспомнивших содержание видеоролика по подсказке в 2,5 раза превышает долю тех, кто пытается вспомнить содержание ролика самостоятельно. Эта зависимость распространяется на видеоролики любой продолжительности в диапазоне от 10 до 60 секунд. В указанном диапазоне продолжительности видеоролика вероятность воспроизведения содержания оказывается наибольшей, если продолжительность видеосюжета составляет 40-50 секунд. При этом рекомендуемая продолжительность электронного плаката, видеозаставки, видеооткрытки, текстового сообщения в области безопасности жизнедеятельности, соседствующих с видеороликом, не должна превышать 15 секунд.

Названные временные параметры оказывается универсальными. Они не зависят от условий воспроизводства информации, т.е. справедливы и при самостоятельном вспоминании содержании сюжета, и при попытке, реализуемой с помощью подсказки. 


\section{ЧЕЛОВЕК И СОВРЕМЕННОЕ ОБЩЕСТВО В СОЦИАЛЬНОМ, ПРАВОВОМ, ЭКОНОМИЧЕСКОМ РАКУРСАХ}

Из приведенных фактов для целей настоящей ВКР важен следующий вывод: для эффективного запоминании и успешного воплощения в паттерны безопасного поведения информационно-коммуникативные сообщения, реализуемые в рамках информирования и оповещения населения, должны быть краткими и повторяющимися. Этот вывод базируется на психофизиологических особенностях восприятия человеком аудио- и видеоинформации, поэтому он приложим не только оформления билбордов и плазменных панелей в местах массового пребывания людей, но и для массовой рассылки индивидуальных сообщений лицам, которые предпочитают пользоваться современными моделями сотовых телефонов, планшетов и ноутбуков.

Анализ данных Интернета позволяет заключить, что описанные выше закономерности восприятия информации активно и успешно используются многими вузами Российской Федерации при переходе на дистанционное обучение в условиях пандемии COVID-19 и при совершенствовании своих текущих учебных программ, реализуемых в формате онлайн-обучения. Доказательством этого является временной формат выложенных в Интернет учебных материалов. Известно, что продолжительность онлайн-сообщений существенно отличается от таковых при очном обучении: вместо полуторачасовой аудиторной лекции видеолекция в формате онлайн длится в среднем около 10 минут [18]. Именно так организуют свои онлайн-курсы семнадцать ведущих вузов страны, объединивших свои усилия по внедрению цифровых технологий в систему образования и представивших в бесплатном доступе свои лучшие курсы в проекте «Национальная платформа открытого образования». В начале 2021 г. партнерами проекта «Национальная платформа открытого образования» являются 16 ведущих вузов страны, через год пандемии COVID-19 число возросло до 18. Основными разработчиками онлайн-курсов платформы являются: 
- МГУ - Московский государственный университет имени М.В. Ломоносова;

- МГТУ - Московский государственный технический университет имени Н.Э. Баумана (национальный исследовательский университет);

- МФТИ -Московский физико-технический институт (национальный исследовательский университет);

- НИТУ «МИСиС» - Национальный исследовательский технологический университет «МИСиС» (ранее - Московский институт стали и сплавов);

- НИУ «ВШЭ» - Национальный исследовательский университет «Высшая школа экономики»;

- НИЯУ «МИФИ» - Национальный исследовательский ядерный университет «МИФИ» (Московский инженерно-физический институт);

- Политех - Санкт-Петербургский политехнический университет Петра Великого;

- СПбГУ - Санкт-Петербургский государственный университет;

- РУТ (МИИТ) - Российский университет транспорта (Московский институт инженеров транспорта);

- СПбГЭТУ «ЛЭТИ» - Санкт-Петербургский государственный электротехнический университет «ЛЭТИ» им. В.И. Ульянова (Ленина);

- Самарский национальный исследовательский университет имени академика С. П. Королёва;

- СевГУ - Севастопольский государственный университет;

- ТюмГУ - Тюменский государственный университет;

- ТИУ - Тюменский индустриальный университет;

- Университет ИТМО - Национальный исследовательский университет ИТМО (ранее - Ленинградский институт точной механики и оптики); 
- УрФУ - Уральский федеральный университет имени первого Президента России Б.Н. Ельцина.

- В начале 2021 г. на платформе Открытого образования по адресу https://openedu.ru было представлено 683 онлайн-курса по различным направлениям подготовки; к началу 2022 г. их число увеличилось почт на 100 и стало равным 781.

Среди указанных курсов есть несколько, посвященных вопросам безопасности жизнедеятельности. В 2019 г. их было 5, в 2021 сократилось до 3. Авторами-разработчиками этих курсов являются три университета страны Национальный исследовательский технологический университет «МИСиС», Санкт-Петербургский государственный университет, Уральский федеральный университет имени первого Президента России Б.Н. Ельцина. Каждый из названных курсов обладает своей спецификой. Для обоснования приведенного суждения приведем описание курсов БЖД, предлагаемых в 2021 г. программой открытого образования.

Согласно аннотации, представленной на платформе Отрытого образования, онлайн-курс по безопасности жизнедеятельности СанктПетербургского государственного университета нацелен на усвоение обучающимися классификации антропогенных опасностей, которые нарушают нормальную жизнедеятельность людей, вызывают аварии, приводящие к чрезвычайным ситуациям (ЧС) и катастрофам, в том числе экологическим; ориентирован на анализ региональных особенностей ЧС, связанных с характеристиками народонаселения, концентрацией материальных богатств на сравнительно ограниченных территориях, т.е. на тех факторах, которые формируют техносферу во всем ее многообразии. Курс уделяет внимание неопределенности информации о функционировании техносферы, энтропийности протекающих в ней процессов, механизмам возникновения технологических крупномасштабных аварий и катастроф в 


\section{ЧЕЛОВЕК И СОВРЕМЕННОЕ ОБЩЕСТВО В СОЦИАЛЬНОМ, ПРАВОВОМ, ЭКОНОМИЧЕСКОМ РАКУРСАХ}

промышленности, энергетике, на транспорте, загрязнению биосферы высокотоксичными и радиоактивными отходами производства.

Онлайн-курс по безопасности жизнедеятельности Уральский федеральный университет имени первого Президента России Б.Н. Ельцина характеризуется иной направленностью. Он предназначен для студентов первого или второго курса бакалавриата всех направлений и специализаций. Концентрирует внимание обучающихся на современных проблемах и угрозах развития цивилизации, медико-биологических и психологических основах безопасности жизнедеятельности, охране труда, приемах оказания первой медицинской помощи при авариях, чрезвычайных ситуациях и резком ухудшении здоровья.

Национальный исследовательский технологический университет «МИСиС» в своем авторском онлайн-курсе делает акцент на вопросах безопасного взаимодействия человека со средой обитания (производственной, бытовой, городской, природной), рассматривает опасные и вредные факторы и защиту человека от них в штатных и нештатных ситуациях, характеризует методы создания среды обитания допустимого качества.

Как следует из приведенных аннотаций курсов, все три курса сосредоточены на рисках техносферы, сформированных в рамках индустриального общества и уделяют недостаточно внимания проблемам информационного стресса, который возникает у большинства людей при переходе к цифровым технологиям; обходят молчанием такую важную часть формирования культуры безопасного поведения людей в постиндустриальном пространстве, как восприятие человеком информации, передаваемой в информационно-коммуникационном пространстве с помощью социальных сетей и современных гаджетов. Наверное, не случайно за последние два года число онлайн-курсов по безопасности жизнедеятельности, содержащих классические данные по вопросам безопасности техносферы на сайте 
https://openedu.ru сократилось почти в 2 раза, с 5 до 3; но при этом появились новые курсы, посвященные отдельным аспектам профессиональной деятельности человека в условиях цифровизации.

На наш взгляд, быстрое обновление перечня онлайн-курсов на платформе Открытого образования указывает на признание специалистами высшей школы того факта, что вопросы безопасного восприятия человеком цифровой информации в условиях повсеместного проникновения IT-технологий в быт, бизнес и сферу развлечений стали актуальными и практически значимыми.

Сотрудничество с проектом «Национальная платформа открытого образования» осуществляют десятки вузов страны; их число резко возросло во время пандемии COVID-19, стимулировано переходом высшего образования к дистанционноой форме обучения. Перечень вузов-партнеров представлен на официальном сайте проекта по адресу https://openedu.ru/partners. Онлайнкурсы, размещенные на платформе, общедоступны, бесплатны, не имеют ограничений по базовому образованию, по желанию пользователя могут быть использованы в трех форматах: как элемент основной образовательной программы с зачетом в диплом выпускающего вуза, как самостоятельный курс повышения квалификации, как инструмент общеобразовательной активности любого пользователя.

Одним из результатов работы данного проекта является накопление сведений о закономерностях восприятия значимой информации пользователями информационно-коммуникационных технологий.

Другим ярким примером учета закономерностей психофизиологического восприятия современной учебной информации является учебник «Генетика» [19]. Он относится к учебникам нового поколения, в русскоязычном варианте издан 2018 г. Учебник составлен коллективом авторов под редакцией Д. Вайцмана и М. Вайцмана. Материал 
учебника ориентирован на алгоритм ускоренного восприятия информации обучающимися. Полное название учебника, вынесенное на титульный лист, гласит: «Генетика за 30 секунд: 50 фундаментальных открытий генетики, описанные за 30 секунд». Структура учебника необычно и настроена на клиповое мышление лиц, привычных к поиску информации в системе Интернет с помощью гаджетов. Каждой теме отведена одна страница текста. Она разделена на три части, отличающиеся друг от друга объемом, детализацией информации и, как следствием, временем, необходимым для их прочтения. В центре страницы - научное описание открытия; на левом поле страницы - одно под другим, два кратких изложения сути открытия с подзаголовками: «3-секундный обзор» и «3-минутный обзор». На правом поле страницы - краткое перечисление двух-трех смежных тем с указанием страниц, где можно при желании получить дополнительную информацию, и две-три «3-секундные биографии» исследователей, сделавших научное открытие, а также имя автора, подготовившего данную статью. Расположение текста на странице не типично для классических учебников и полностью копирует схему расположения информации на Интернет-сайтах. На развороте книги каждая текстовая страница соседствует со страницей цветных иллюстраций, в которой таланливо сталкиваются в одном контексте уже известные знания и нешаблонные результаты новых инновационных исследований. Такое соотношение текста и визуальных цветных иллюстраций полностью соответствует рекомендациям, которые сформулированы специалистами ВНИИ ГОЧС МЧС России для информирования населения в формате «межсубъектной коммуникации» [1]. Каждый тематический разворот сопровождается следующим разворотом - биографическим. На нем представлен какой-либо интересный драматический факт из жизни ученого, имеющего отношение к обсуждаемому открытию в области генетики и приводится его портрет (фотографический или рисованный). Включение 


\section{ЧЕЛОВЕК И СОВРЕМЕННОЕ ОБЩЕСТВО В СОЦИАЛЬНОМ, ПРАВОВОМ, ЭКОНОМИЧЕСКОМ РАКУРСАХ}

кейсов из жизни первооткрывателей придает рассказу об истории генетики незабываемый колорит, делает рассказ о научный открытиях увлекательным и легко запоминающимся.

Современному алгоритму представления научно-публицистического материала с учетом индивидуальной скорости потребления контента и применением цифровых технологий соответствуют новые версии печатных журналов «Популярная механика». В них краткое занимательное печатное изложение темы сопровождается рядом расположенным QR-кодом. Используя этот код, читатель, заинтересованный обозначенной темой и располагающий соответствующими техническими возможностями, в удобное для него время и оптимальной для себя скоростью может через приложение в мобильном телефоне получить расширенную, детальную информацию. Очевидно, что соединение в одной й технологии бумажных и виртуальных носителей информации создает качественно новую коммуникативную среду. Эта среда позволяет осуществлять мониторинг скорости, объема потребляемого контента, формировать перечень и рейтинг тем, интересующий пользователя, а также создавать профайлинг отдельного читателя и/или целевой аудитории.

Перечисленные алгоритмы структурирования и организации учебного и научно-популярного контента в современном информационном пространстве достиг уровня технологии, т.е. четко прописанной процедуры, направленной на достижение заранее обозначенного результата. Описанные приемы достаточно широко и довольно часто используется в коммерческой, политической, социальной рекламе. В русскоязычном варианте одну из подобных технологий принято называть сторителлингом [20], в англоязычных переводах данная технология также фигурирует под названием «сториномика» [21]. Последние годы эта технология начинает успешно внедряться в информационно-коммуникативные системы и в систему обучения. 


\section{ЧЕЛОВЕК И СОВРЕМЕННОЕ ОБЩЕСТВО В СОЦИАЛЬНОМ, ПРАВОВОМ, ЭКОНОМИЧЕСКОМ РАКУРСАХ}

Однако, даже такие разнообразные и выверенные с точки зрения нейропсихологии технологии подачи информационного материала не всегда гарантируют факт успешного восприятия сообщения и включение его содержания в паттерны безопасного поведения различных групп населения. Поэтому кроме исследования особенностей восприятия информации пользователями IT-технологий важно изучать особенности социального поведения людей, вовлеченных в информационную среду.

\section{2. Особенности социального поведения лиц, активно использующих информационно-коммуникативные технологии}

В коллективной монографии сотрудников ФГУ «Всероссийский научноисследовательский институт по проблема гражданской обороны и чрезвычайных ситуаций МЧС России» (федерального центра науки и высоких технологий) подчеркивается, что при прогнозировании эффективности информирования и оповещения населения с использованием информационнокоммуникационных технологий необходимо учитывать роль «человеческого фактора в процессе эксплуатации технических систем», объясняют причины, по которым доведенная до пользователя информация не гарантирует его адекватного поведения в чрезвычайной ситуации и предлагают формулу расчета показателя эффективности влияния на население информационнокоммуникационных технологий [1, с. 115].

По мнению авторов монографии, на эффективность усвоения принятой информации влияют несколько групп факторов. Это технические, когнитивнопсихологические и поведенческие факторы. Они включают в себя восприятие сигнала оповещения каждым отдельно взятым человеком, возможную недостоверность переданной информации, неоптимальную форму передачи информации, из-за которой выполнение безопасных действий по спасению в 
реальных условиях нахождения человека затруднено и/или вступает в противоречие с условиями его труда, стечения обстоятельств и т.д.

Формула расчета показателя эффективности культурноинформационных воздействий (вероятности безопасных действий человека) при получении им информации об опасности включает в себя следующие переменные: число допустимых решений, вероятность усвоения информации, вероятность правильных действий при получении информации, зависящая от качества информационных материалов (их содержания, полноты, достоверности) и оперативности (времени) доведения информации до потребителя.

Эксперты ВНИИ МЧС России особо подчеркивают тот факт, что значения показателя числа допустимых решений не является постоянной величиной и может варьировать в зависимости от культурноинформационных воздействий, образовательной системы, условий труда и быта человека и группы людей. В результате сложного взаимодействия субъективных и объективных обстоятельств процесс восприятия информации человеком и последующей ее трансформации в определенные действия и поступки не является гарантированным и детерминированным. Он не предопределен исключительно содержанием и формой передаваемой информации. Результативность передаваемой населению информации в любом случае является вероятностной величиной и лишь с определенным уровнем допущения может быть просчитана заранее. Эффективность передачи информации возрастает, если при ее создании наиболее полно учитываются индивидуальные и групповые характеристики актуального психофизиологического и когнитивного состояния пользователей IT-устройств, с помощью которых им транслируется та или иная информация.

Именно поэтому изучение закономерностей восприятия информации у пользователей IT-устройств становится актуальным, теоретически и 


\section{ЧЕЛОВЕК И СОВРЕМЕННОЕ ОБЩЕСТВО В СОЦИАЛЬНОМ, ПРАВОВОМ, ЭКОНОМИЧЕСКОМ РАКУРСАХ}

практически значимым для повышения эффективности информирования и оповещения населения в условиях массовой цифровизации и повсеместного распространения онлайн-коммуникации.

В книге [22] описаны следующие особенности восприятия информации у пользователей информационно-коммуникационными технологиями. По мнению автора книги Р. Уотсона, распространение гаджетов, цифровых технологий и дистанционного общения способствует распространению в обществе состояния тревоги, потребности в признании, самоутверждении и повышении самооценки; при этом большая часть населения теряет веру в будущее, соглашаясь с тем, что современная жизнь характеризуется высоким уровнем риска и неопределенности, и «что уровень жизни родителей для них недостижим» [18, с. 39]. На этом фоне у значительной части населения происходит «размывание правил, ролей и обязанностей» и возникают «опасные попытки вернуться к прошлому» [18, с. 41]. По моделям предпочитаемого поведения общество разделяется на несколько групп, одни становятся сторонниками экстремальных решений, другие проявляют сентиментальную ностальгию, третьи демонстрируют растущее самодовольство. Важно, что все перечисленные тенденции ставят под вопрос способность справляться с объективной реальностью, преодолевать трудности и находить оптимальный выход из чрезвычайных ситуаций. Как пишет Р. Уотсон, ссылаясь на мнение М. Этвуд, «нет прошлого, нет будущего, нет мозга, нет боли» [18, с. 42]. В доказательство выше приведенных тезисов Р. Уотсон обращается к данным статистики, согласно которым внедрение информационно-коммуникационных технологий в повседневную жизнь, бизнес и образование происходит в параллель с ростом нарушений психического здоровья людей. Так, в Великобритании в 2009 г. было выдано около 500 тысяч больничных листов в связи с психическими расстройствами, а через 4 года, в 2013 - уже около 1 миллиона; в США в 1980 г. психическое 
расстройство по типу невроза было диагностировано у 4 \% населения, а в 2014 - у 20 \%. Эксперты Всемирной организации здравоохранения - ВОЗ полагают, что в течение жизни диагноз невроза ставится каждому четвертому жителю планеты, т.е. 25\% населения.

По нашему мнению, приведенные выше факты важны для оптимизации процессов информирования и оповещения населения, т.к. повсеместная цифровизация приводят к увеличению числа «оцифрованных» людей (термин, предложенный Р. Уотсоном), а это, в свою очередь, снижает способность людей эффективно воспринимать информацию и трансформировать ее в осознанные активные действия, направленные на формирование безопасного поведения. В связи с данными обстоятельствами определенный интерес представляют технологии передачи информации населению в условиях, когда активные социально направленные действия осуществляются импульсивно, носят характер автоматизированных действий, которые протекают без контроля сознания [23]. Большой и успешный опыт инициирования таких действий накоплен публичной социологией и маркетингом. Основные положения технологий формирования автоматизированных действий $\mathrm{y}$ целевых групп населения приведены в следующем параграфе.

\section{3. Технологии формирования автоматизированных действий у представителей целевых аудиторий}

Как известно [24], под автоматизацией действий понимают такую активность человека, когда отдельные, достаточно сложные поведенческие акты для своего осуществления перестают требовать предварительного анализа, осмысления, критической переработки, сравнения альтернативных вариантов решений и выбора оптимальной стратегии индивидуального и/или группового поведения. Автоматизация поведения достигается многократным 
повторным предварительным повторением либо самих программируемых действий, либо напоминанием о них. Первый вариант автоматизации действий чаще всего используется в спорте и в профессиональной подготовке специалистов опасных профессий. Второй вариант широко применяется в политических технологиях при работе с электоратом и в маркетинговых технологиях при работе с потенциальными покупателями. В отечественной науке термин автоматизации поведения ассоциируется с именем П.Я. Гальперина, советского психолога, заслуженного деятеля науки РСФСР, доктора педагогических наук, профессора, который в годы Великой отечественной войны (1941-1943 гг.) был начальником лечебной части Кауровского восстановительного эвакогоспиталя в Свердловской области. В середине прошлого века П.Я. Гальперин $[25,26]$ создал деятельную теорию усвоения, а также теорию поэтапного формирования умственных действий, на основе которых разработал методику ориентировки к будущему действию и разграничил две части осваиваемого предметного действия: понимания (ориентировочная часть) и навыков по выполнению (исполнительная часть). Особое значение П.Я. Гальперин придавал первой части ориентировки к будущему действию, считая ее «управляющей инстанцией».

Однако, в последние годы, в условиях турбулентности, неопределенности и длительных стрессовых ситуаций внимание многих специалистов в области социальной психологии и безопасности привлекает сам факт сложной структуры такого феномена как ориентировка к будущему действию и возможность изолированного целенаправленного внешнего воздействия на его отдельные части. Результаты этих исследований интегрированы в целостном научном направлении, которое в зарубежной практике носит название бихевиоризм, а в отечественной системе образования чаще обозначается как копинг-стратегии или практико-ориентированное обучение. 


\section{ЧЕЛОВЕК И СОВРЕМЕННОЕ ОБЩЕСТВО В СОЦИАЛЬНОМ, ПРАВОВОМ, ЭКОНОМИЧЕСКОМ РАКУРСАХ}

Применение технологий автоматизации будущих действий могут завершаться двумя неодинаковыми результатами и приводить к образованию либо автоматического поведения, либо автоматизированного поведения. Эти два вида поведения отличаются друг от друга жесткостью закрепления в стереотипах поведения индивида и возможностью их перепрограммирования с помощью внешних стимулов. Автоматическое поведение по сравнению с автоматизированным поведением менее гибко и ситуативно, более тесно связано с глубинными неосознаваемыми потребностями индивида, и поэтому труднее поддается перепрограммированию с помощью внешних информационно-коммуникативных воздействий.

Различия между автоматическим и автоматизированным поведением можно сопоставить с теми различиями, которые описаны Г. Лебоном для психологии народов и психологии масс [27]. Для психологии народов характерна прочность и не подверженность изменениям, общность чувств и интересов ее представителей в противоположность представителям других народов, тогда как для психологии масс типичным является импульсивность, изменчивость и раздражительность, податливость внушению и легковерие, преувеличенная чувствительность и односторонность чувств, нетерпимость к альтернативному мнению, авторитетность суждений и консерватизм, а также заразительность, т.е. способность тиражировать свое поведение в поведении окружающих.

По мнению Г. Лебона, «современная эпоха представляет собой один из таких критических моментов, когда человеческая мысль готовится к изменению. ...Это разрушение религиозных, политических и социальных верований, ...возникновение новых условий существования и совершенно новых идей, явившихся следствием современных открытий и событий в области наук и промышленности» [27, с. 18]. На воображение толпы «очень легко действовать, в особенности образами. ...их можно вызывать 


\section{ЧЕЛОВЕК И СОВРЕМЕННОЕ ОБЩЕСТВО В СОЦИАЛЬНОМ, ПРАВОВОМ, ЭКОНОМИЧЕСКОМ РАКУРСАХ}

посредством умелого применения слов и формул. ...Могущество слов находится в тесной связи с вызываемыми ими образами и совершенно не зависит от их реального смысла» [27, с. 111]. «Ни рассудок, ни ни убеждение не в состоянии бороться против известных слов и известных формул. ... Они вызывают в душе грандиозные и смутные образы, а окружающая их неопределенность только увеличивает их таинственное могущество» [27, с. 112]. Единственная польза этих слов, по мнению цитируемого автора, заключается в том, что «они избавляют тех, кто их употребляет, от обязанности думать» [27, с. 112]. Согласно представлениям Г. Лебона, «толпа никогда не стремилась в правде; она отворачивается от очевидности, не нравящейся ей, и предпочитает поклоняться заблуждению, если только заблуждение это прельщает ее. Кто умеет вводить толпу в заблуждение, тот легко становится ее повелителем; кто же стремиться образумить ее, тот всегда бывает ее жертвой» [27, с. 120].

Приведенные выше теоретические концепции имеют прямое отношение к практической работе по организации мероприятий по информированию и оповещению населения об угрозах ЧС. Они показывают, что диалог специалиста в области безопасности с целевыми группами населения, не имеющих специальной подготовки в области ликвидации ЧС, должен проводиться с учетом знаний по социальной и экстремальной психологии. В диалоге должны быть представлены легко запоминающиеся образы, имеющие широкие ассоциативные связи с актуальными чувствами представителей целевой аудитории. Сообщения должны быть лаконичными, простыми для восприятия, не требующими критического осмысления и/или осмысленного выбора из нескольких моделей поведения.

Данное заключение подтверждается правилами организации общения с потенциальными покупателями, которые, по мнению экспертов, повышают эффективность так называемой целевой «таргетированной» рекламы. В книге 
[28] подчеркивается, что обеспечение гарантии желаемого поведения человека в будущем при осуществлении с ним диалога специалиста через социальные сети возможен лишь в том случае, если диалог ведется с соблюдением определенных языковых норм. Эти нормы с водятся к совпадению лексического, семантического и эмоционально-коммуникативного контекста участников диалога. Для достижения полного созвучия в диалоге, по мнению специалистов в области IT-коммуникаций, необходимо выверять каждое сообщение на предмет «грамматики, сленга, сокращений, «вторых смыслов», аллюзий, игры слов, фигур умалчивания и т.д.» [28, с. 346$]$.

В последние же годы до уровня технологии доведены приемы оптимизации текста социальной и коммерческой рекламы, которые выстроены по принципам целевого (таргетированного) обращения к пользователю. К ним, в первую очередь, относятся такие технологии написания текста, как SEO- и LSI-копирайтинг. SEO-копирайтинг (от англ. аббревиатура search engine optimization, двигатель (локомотив) поисковой оптимизации) базируется на ключевых словах и выражениях, типичных для целевой аудитории, созвучных ее эмоциональному состоянию и чувственноассоциативному опыту. LSI-копирайтинг (от англ. аббревиатура latent semantic indexing, латентно-семантическое индексирование) - дальнейшее развития SEO-метода написания и подачи текстов, который кратно увеличивает привлекательность и значимость сообщения для пользователя. В технологии LSI не только используются ключевые слова, характерные для той или иной целевой аудитории, но и применяются дополнительные приемы, направленные на формирование первичного положительного восприятия текста. К таким приемам относится прием домысливания, «эффект ореола», создание у пользователя ощущения, что он сам принимает решение как действовать, и что он делает правильный выбор [29]. 
Опыт применения социальных сетей для диалога с потребителями услуг, к которым все чаще последние годы стали относить услуги в области безопасности, показывает, что интерес к предъявляемым сообщениям имеет четкие хронологические закономерности. Он угасает с течением времени, если нет соответствующих повторений. Как правило, чтобы обеспечить высокий уровень информационно-коммуникативной эффективности повторяемость сообщений не должна быть меньше, чем 2 раза в неделю [28].

Необходимость учета хронологических закономерностей распространения информации в социальных сетях и системе Интернета для обеспечения эффективной информационно-коммуникационной деятельности отмечают и другие специалисты. В книге [30] как успешный предлагается следующий алгоритм мониторинга и коррекции сообщений социальной рекламы, выкладываемой для Интернет пользователей: «Раз в две недели мы формируем список задач, которые делятся на тактические, операционные и стратегические, закрепляем зоны ответственности по этим задачам, прописываем сроки решения» [30, с. 376]; аналитика по выполнению составленного перечня задач выполняется в режиме онлайн. Автор цитируемой книги особо подчеркивает, важность форимирования диалога и наличие эффективной обратной связи между источником информации и ее потребителем. Используя терминологию маркетинга, он приводит одно из главных правил таргетированной рекламы: «Знай своего клиента и сделай его счастливым» [30, с. 107] и расшифровывается свою мысль следующим образом:

- Будьте представителем клиента в своем ведомстве;

- Будьте одним целым с клиентом;

- Исследуйте предпочтения клиентов;

- Изучайте обратную связь; 
- Делайте людей счастливыми (от себя добавим, и защищенными) с выгодой для себя.

Обратим внимание, что современные технологии таргетированной рекламы и социального менеджмента ориентируются по удовлетворение внутренних потребностей пользователя информации и на создание у него позитивного эмоционального состояния. Этот методический подход прямо противоположен тому, который традиционно применяется специалистами МЧС России в информировании и оповещении населения, а именно: аргументирование неотвратимости ущерба и актуализацию чувство тревоги и страха. Таким образом, обращение к опыту современной таргетированной рекламы открывает перед специалистами МЧС России новые методические приемы активного влияния на ожидаемое поведение населения.

На сегодняшний день среди экспертов в области информационнокоммуникационных технологий сложилось единодушное мнение, согласно которому результативная ориентировка на будущее поведение людей и/или группы людей с помощью информационных технологий требует повторного и достаточно частого (до нескольких раз в неделю) повторения ключевой информации с обязательным условием донесения ее до целевой аудитории в нужном формате и с необходимой ситуационной модификацией.

Признавая значение своевременных повторов для целенаправленного и адресного формирования будущего поведения получателей сообщения, ряд компьютерных программ в сети Интернет предлагают опции, которые позволяют в режиме обратной связи оптимизировать информационнокоммуникационный процесс в онлайн-среде. Эти программы отслеживают информационную активность получателей сообщений, в автоматическом режиме фиксируют рост и/или падение интереса пользователей социальных сетей к выложенным сообщениям в горизонте 7-ми и 14-дневного трафика, предлагают варианты модификации сообщений в случае, если падает 
охватность этими сообщениями целевой аудитории. Такие автоматизированную оптимизацию сообщений предлагает Facebook, Google. На 2019 г. такими программами не располагал рекламный кабинет «ВКонтакте», однако он предлагал так называемые парсинговые сервисы, то есть программные продукты, которые п позволяют решать уникальные задачи. Уникальность этих задач заключается в автоматическом поиске среди пользователей Интернета тех людей, которые проявляют наибольшую коммуникативную активность в социальных сетях, авторитетны для множества участников сетевого сообщества, являются аттракторами их внимания и могут быть источником успешного тиражирования полученной информации. Поиск таких лиц осуществляется в таргетированном (целевом) формате по заранее заданным критериям. Популярность данные сервисы начали набирать недавно: по свидетельству автора книги [28] всего лишь последние три года.

Из представленного обзора литературы следует целесообразность и назревшая необходимость экстраполировать в сферу информирования населения высокоэффективные технологии информационнокоммуникативного общения с целевыми аудиториями, хорошо зарекомендовавшие себя в сфере социальной и коммерческой рекламы, дополнив ими уже сформировавшуюся систему «ОКСИОН» МЧС России.

\section{III. РЕЗУЛЬТАТЫ АВТОРСКИХ ЭМПИРИЧЕСКИХ ИССЛЕДОВАНИЙ НА ПРИМЕРЕ ЖИТЕЛЕЙ ПРОМЫШЛЕННОГО МЕГАПОЛИСА}

\section{1. Оценка возможности использования социальных сетей для информирования и оповешения студенческой молодежи Урала}

Поведение молодежи в социальных сетях является важной составной частью комплексной безопасности страны. МЧС России разрабатывает 


\section{ЧЕЛОВЕК И СОВРЕМЕННОЕ ОБЩЕСТВО В СОЦИАЛЬНОМ, ПРАВОВОМ, ЭКОНОМИЧЕСКОМ РАКУРСАХ}

проекты использования социальных сетей и мобильных оповещений для информирования населения об угрозах ЧС. В условиях информационного общества обмен информацией в социальных сетях и с помощью мобильных устройств становится повсеместной практикой и превращается в инструмент реализации мероприятий комплексной безопасности [31-33]. Актуальность для целевой аудитории молодежи использования социальных сетей и мобильных устройств при реализации чрезвычайных ситуаций подтверждает трагедия в политехническом колледже г. Керчи [34].

Нами по специально разработанной анкете опрошено 32 студента ведомственного вуза (30 юношей и 2 девушки) в возрасте от 19 до 21 года. С четырьмя из них опрос проведен в формате углубленного интервью.

1. Перечень основных задаваемых вопросов приведен ниже.

2. Какие социальные сети используете и как часто?

3. Как давно начали использовать социальные сети?

4. Почему ваш выбор остановился на конкретной социальной сети?

5. Как лучше использовать социальные сети для оперативного оповещения населения?

6. Что вы думаете о мобильных рассылках МЧС России?

7. Что вы знаете о системе ОКСИОН?

8. Каким устройством пользуетесь в процессе использования социальной сети?

Полученные данные состоят в следующем. Социальную сеть ВКонтакте используют все опрошенные, Facebook - 4 человека (есть аккаунты для регистрации в других сетях и использования различных приложений), Telegram - 10 человек (для переписок и различных закрытых чатов), Instagram - 29 (для обмена фото и видео). Таким образом, рейтинг популярности социальных сетей среди респондентов сформировал следующий убывающий ряд: ВКонтакте, Instagram, Telegram, Facebook. 
Отдельно было изучено присутствие респондентов в нескольких социальных сетях. Установлено, что 90\% опрошенных используют две социальные сети одновременно для своих повседневных контактов, 31\% используют три социальных сети, 12,5\% регулярно присутствуют во всех четырех выше перечисленных социальных сетях.

Проанализированы причины, по которым респонденты выбрали для коммуникации именно эти Интернет ресурсы:

ВКонтакте - удобство использования, широкий круг применения приложения, высокая скорость обмена информацией путем создания «бесед» на большое количество человек, одна из первых отечественных социальных сетей;

Facebook - используется в основном для регистрации на сторонних pecyрсах и использования различных приложений; В России мало используется для обмена информацией на постоянной основе.

- Telegram - относительная молодая зарубежная социальная сеть, по большей части используемая для чатов и различных переписок, возможность использования «закрытых» от посторонних рассылок информации. Попытки правительства заблокировать телеграм не увенчались успехом.

- Instagram - возможность быстрого обмена фото и видео материалов с возможность в режиме реального времени вести собственную трансляцию на большое количество зрителей. Возможно, закрыть свои материалы от посторонних. Геолокация опубликованного материала с точным указание места и времени публикации.

Наиболее вариабельными были ответы респондентов на вопрос о продолжительности присутствия их в социальных сетях. Разброс ответов колебался от 1,5 до 7 лет.

Ниже приведены дословные ответы четырех респондентов, которые являются типичными для всей выборки. 
Респондент №1.

1. ВКонтакте и Instagram, используются постоянно.

2. Около 7 лет ВК и 4 года в Instagram.

3. Так как большинство используют именно эти социальные сети.

4. Создавать чаты для групп и организаций

5. Прислушиваюсь к информации из мобильных рассылок и полностью поддерживаю это направление

6. Знаю только, что это система оповещения населения

7. Смартфон

Респондент №2

1. ВКонтакте - постоянно, Instagram- реже, чем вконтакте

2. Начал использовать много лет назад

3. Удобно в плане общения с друзьями

4. Всплывающие баннеры с сообщением

5. Положительно отношусь

6. Система оповещения населения о ЧС

7. Смартфон

Респондент №3

1. ВКонтакте. Instagram

2. Вконтакте с 2013 года, инстаграм 1,5 года назад

3. Наиболее удобные для общения

4. Автоматическая рассылка сообщений с расчетом на большую аудиторию

5. Положительно, потому что мобильная рассылка не требует доступа в мобильный интернет и более широкий круг устройств поддерживает SMS

6. Не знаю, что это

7. Смартфон 


\section{Респондент №4}

1. ВКонтакте, Instagram

2. $4-5$ лет

3. Удобно поддерживать связь с друзьями и знакомыми

4. Личными сообщениями или всплывающими окнами доводить информацию

5. Полезная вещь, но бывает, не видишь сообщения

6. Не знаю, что это

7. Смартфон

На вопрос о целесообразности использования мобильных телефонов и социальных сетей для рассылки экстренных оповещений МЧС России о ЧС подавляющее большинство респондентов высказалось в пользу мобильных телефонов перед социальными сетями, потому что телефоны не требуют дополнительного доступа в Интернет, гарантируют широкий круг рассылок SMS и обеспечиваются более широким кругом устройств, позволяющих использовать SMS.

Особый интерес для авторов настоящей статьи представлял вопрос о знакомстве респондентов с системой «ОКСИОН». Система «ОКСИОН» является одним из примеров использования Интернет-ресурсов для оповещения населения о ЧС и информирования разных групп населения о правилах безопасного поведения [35]. Первоначально, при создании системы «ОКСИОН» в 2007 г. [36], ее миссия была сосредоточена на информационной деятельности, в настоящее время спектр задач системы значительно расширился, и существенную роль в нем играет издательская деятельность.

Опрос, проведенный в ходе настоящего исследования, показал, что ни один из респондентов не был лично знаком с рекламными материалами системы «ОКСИОН», не встречал их ни в Интернете, ни на телевидении, ни в виде социальной рекламы в общественных зданиях, на улице и/или в места 
массового пребывания людей. Из ответов респондентов можно сделать вывод, что система «ОКСИОН», созданная десять лет назад, не пользуется достаточной популярностью в среде современной студенческой молодежи.

С точки зрения оценки потенциальной эффективности информационнокоммуникационной работы сотрудников МЧС России с гражданским населением при осуществлении мероприятий по противопожарной безопасности и формирования безопасного поведения у населения имеет значение сравнительный анализ сетевых предпочтений курсантов и гражданских лиц.

При поиске оптимальных подходов к организации профилактической работы с населением нами были в сравнительном плане проанализированы ответы респондентов на вопрос «Какие социальные сети вы используете?» (при ответе можно было выбрать несколько вариантов). Проведено авторское сопоставление результатов опроса выше названной группы курсантов Уральского института ГПС МЧС России (n=32 чел., основная группа) и результатов пилотного исследования, проведенного сотрудниками и курсантами института [33] среди анонимных пользователей Интернета без разделения респондентов по возрасту ( $\mathrm{n}=200$ чел., группа сравнения). Результаты компаративного анализа приведены в таблице 2.

Таблица 2

\section{Предпочтение пользователей Интернет в зависимости от степени} организованности групп (\% от численности группы)

\begin{tabular}{|l|c|c|}
\hline \multicolumn{1}{|c|}{ Социальная сеть } & Курсанты & Анонимные пользователи \\
\hline YuоTube & - & 86,0 \\
\hline ВКонтакте & - & 64,0 \\
\hline Одноклассники & 100 & 48,0 \\
\hline Facebook & 12,5 & - \\
\hline Telegram & 31,3 & - \\
\hline Instagram & 90,6 & 59,0 \\
\hline
\end{tabular}




\section{ЧЕЛОВЕК И СОВРЕМЕННОЕ ОБЩЕСТВО В СОЦИАЛЬНОМ, ПРАВОВОМ, ЭКОНОМИЧЕСКОМ РАКУРСАХ}

Из данных, приведенных в таблице, следует два вывода:

- Популярность социальных сетей среди пользователей Интернета широко варьирует в зависимости от характеристик групп респондентов;

- Интернет-предпочтения организованных курсантов, находящихся на казарменном положении, существенно отличаются от аналогичных предпочтений респондентов, опрошенных в анонимном формате.

Из сформулированных выводов следует, что в выборе мессенджеров при организации информационно-коммуникационной работы с населением в области информирования и оповещения сотрудники МЧС России должны опираться не только на личные предпочтения в выборе социальных сетей, сколько на изучение этих предпочтений у целевой группы населения, на которую ориентирована проводимая информационно-коммуникационная деятельность.

Суммируя полученные данные, можно сделать заключение, что социальные сети являются неотъемлемой частью жизни уральских студентов, активно использующих возможности социальных сетей и мобильных телефонов. Однако, в их повседневной коммуникативной практике темы безопасности занимают незначительный объем получаемой информации.

В данных условиях совершенствование технологий информирования и оповещения молодежи о ЧС и безопасном поведении с помощью мобильных телефонов представляется целесообразным и оправданным мероприятием. При этом одним из ключевых факторов успешного диалога между сотрудниками МЧС России и целевыми группами населения является их взаимопонимание и совпадение моделей восприятия будущего. Последнее качество может быть количественно оценено с помощью известного метода Зимбардо. В нашем исследовании мы применили этот метод для оценки конгруэнтности моделей восприятия будущего у двух групп студенческой молодежи: курсантов и студентов мегаполиса Екатеринбурга. 


\section{2. Сравнительный анализ восприятия будущего у разных групा студенческой молодежи Екатеринбурга}

Пандемия COVID-19 стала вызовов социальным устоям современных государств вне зависимости от их географического расположения, национальных границ и форм государственного управления. Большинство прогнозов отсроченных последствий пандемии сосредоточено на анализе экономических показателей: оценки снижения валового внутреннего продукта; доли предприятий среднего и малого бизнеса, безвозвратно ушедших с рынка товаров и услуг; расчета сроков возвращения доходов населения и бюджетов на докризисный уровень; составление возможных сценариев перераспределения глобальных рынков сбыта продукции, переформатирования структуры международных финансовых, корпоративных и коммуникативных связей. При этом социальным последствиям длительной пандемии уделяется меньшее внимание.

Вместе с тем очевидно, что пандемия может трансформировать модели экономического, социального, коммуникативного и демографического поведения жителей планеты. Объективным основанием для этого является длительная самоизоляция отдельных когорт населения, повсеместное ограничение межличностного и группового общения, переход на коммуникацию онлайн, имеющую иной баланс вербальных и невербальных компонентов, чем это было характерно для непосредственного общения людей до пандемии.

Прогнозируя социальные последствия пандемии, на наш взгляд, необходимо принять во внимание сложность феномена общения. Как постулируется в справочной литературе [37, с. 213], «общение - сложный многоплановый процесс установления и развития контактов между людьми, порождаемый потребностями совместной деятельности и включающий в себя 
обмен информацией, выработку единой стратегии взаимодействия, восприятие и понимание другого человека». Многоплановость общения включает характеризуется целым рядом важных аспектов (коммуникативным, интерактивным, перцептивным, мотивационным, деятельностным) и, как процесс, состоящий из перемежающихся поведенческих актов, действий и взаимодействий участников, неизбежно разворачивается во времени, и реализуясь на микро-, мезо- и макроуровнях [38], формируя рисунок будущего.

Известно, что восприятие времени отдельным индивидом как человеком, так и группами людей социально и ситуативно обусловлено. Показана неоднородность скорости социального времени сообществами жителей мегаполиса [39], ускорение и/или замедление биологического времени индивида в результате перенесения им витальной угрозы, продемонстрирована тесная взаимосвязь между хронотипом человека и трансформацией его социальных ролей [40].

Установлен факт существования бифуркационных феноменов в структуре социального поведения людей под воздействием внешних угроз [41]. Возможна как консолидации участников событий для координации совместных усилий по преодолению трудностей, так и психотическая трансформация личности с появлением вновь и/или усилением ранее скрыто присутствовавших признаков макиавеллизма, нарциссизма, психопатии.

Важно особо подчеркнуть дозозависимый эффект деструкции личности: частота и выраженность психопатических проявлений более выражена при интенсивном и продолжительном стрессе по сравнению со стрессом менее интенсивным и менее продолжительном [42, 43].

Данное обстоятельство, на наш взгляд, чрезвычайно значимо для прогнозирования социальных последствий в условиях длительной пандемии, продолжительность которой значительно превышает сроки защитного 


\section{ЧЕЛОВЕК И СОВРЕМЕННОЕ ОБЩЕСТВО В СОЦИАЛЬНОМ, ПРАВОВОМ, ЭКОНОМИЧЕСКОМ РАКУРСАХ}

действия краткосрочных механизмов психофизиологической адаптации, и когда на первый план в социальной адаптации выходят механизмы копингстратегий, при которых трансформация биосоциального времени индивида и когорт стрессированных людей становится неизбежным элементом приспособления к новым, устойчиво изменившимся условиям жизнедеятельности.

В условиях повторных волн пандемии коронавируса достаточна высока вероятность того, что активизация механизмов долгосрочной адаптации, сопровождающаяся трансформацией биосоциального времени жителей планеты, станет массовым явлением.

В обычных условиях стабильность и повторяемость в поколениях алгоритмов организации биосоциального времени людей осуществляется путем их социализации внутри референтных групп. В условиях текущей пандемии привычные социальные отношения нарушены; ранее сложившиеся связи и стереотипы организации социальной и личной жизни не находят подтверждения текущими событиями; значимые межличностные контакты, служившие таймерами и точками отсчета времени, заменены случайным общением с представителями социальных служб и волонтерами.

Новый формат социальных контактов создает объективную, субъективно окрашенную, основу для иного, чем раньше алгоритма восприятия текущего времени и схем формирования личного и группового будущего.

В связи с изложенными соображениями нам представляется теоретически важным и практически значимым оценить вариабельность восприятия будущего волонтерами, а также охарактеризовать те модели восприятия будущего, которые имеют место у потенциальных наставников волонтеров, их тьюторов. В сложившейся практике наставниками потенциальных волонтеров, ориентированных на участие в социальной работе 
во время пандемии, являются сотрудники органов государственного и муниципального управления, а также сотрудники служб безопасности и спасения, в частности, МЧС России.

Можно предположить, что алгоритм восприятия будущего именно этими категориями людей будет наиболее широко тиражироваться в населении во время и после пандемии. Следовательно, изучение алгоритмов восприятия и конструирования своего будущего представителями гражданских служб социальной помощи и силовых служб спасения может стать эмпирической основой для прогнозирования базовых очертаний облика социума после пандемии.

В связи с изложенной выше гипотезой целью нашего исследования стало сравнительное изучение алгоритмов восприятия будущего у двух групп лиц, представителей гражданских и силовых служб спасения. В формате пилотного исследования изучены модели восприятия будущего у студентов Уральского федерального университета имени первого Президента России Б.Н. Ельцина, обучающихся по специальности «Государственное и муниципальное управление» и курсантов Уральского института государственной противопожарной службы МЧС России, проходящих обучение по направлению подготовки «Техносферная безопасность» $(\mathrm{n}=45 ; 13$ и 31 респондент соответственно).

В качестве инструмента исследования алгоритмов социального времени респондентов был использован опросник временной перспективы Зимбардо (Zimbardo Time Perspective Inventory, ZTPI). Тест был разработан Ф. Зимбардо в 1997 г., адаптирован к этнолингвистическим особенностям россиян на примере студентов вузов Москвы и Санкт-Петербурга, содержит 56 пунктов, ответы по которым распределяются по 5-балльной шкале. В русскоязычном варианте результаты теста проверены на корреляцию с другими психодиагностическими методиками (шкалой депрессии Бека, шкалой 
самооценки Розенберга, шкалой тревоги Спилберга, пятифакторным опросником личности, опросником «Импульсивность», опросником уровня агрессивности Басс-Дарки).

Результаты теста группируются в пять шкал: восприятия негативного и позитивного прошлого, гедонистического и фаталистического настоящего, степени ориентации на будущее. По мнению экспертов, наиболее согласованными являются шкалы «негативное прошлое» и «гедонистическое настоящее». Фактор восприятия негативного прошлого выражает степень неприятия собственного прошлого, вызывающего отвращение, полного боли и разочарований; позитивного - степень принятия собственного прошлого, при котором любой опыт воспринимается как отправная точка, приведшая к сегодняшнему состоянию и стимул для дальнейшего развития. Фактор восприятия гедонистического настоящего указывает на разрыв хронологической связи между прошлых и будущим и свидетельствует о том, что единственной целью настоящего является наслаждение текущим моментом. Фактор восприятия фаталистического настоящего указывает на то, что респондент отчужден от происходящего и воспринимает свое настоящее вне зависимости от собственного волеизъявления как изначально предопределённым. Фактор степени ориентации на будущее отражает наличие у респондента целей и планов на перспективу.

Респонденты выполняли данный тест онлайн по ссылке [44]. Статистическая обработка результатов теста проведена с помощью инструмента комплексного статистического анализа «Описательная статистика» программы Excel, различия между группами на достоверность проверены с помощью критерия Стьюдента и непараметрического критерия хи-квадрат. Результаты теста представлены в таблице 3. 
Таблица 3

Результаты теста Зимбардо (M \pm m)

\begin{tabular}{|c|c|c|c|c|c|}
\hline \multirow{2}{*}{ Группы } & \multicolumn{5}{|c|}{ Факторы теста } \\
\cline { 2 - 6 } & $\begin{array}{c}\text { Негатив- } \\
\text { ного про- } \\
\text { шлого }\end{array}$ & $\begin{array}{c}\text { Позитивного } \\
\text { прошлого }\end{array}$ & $\begin{array}{c}\text { Гедонистиче- } \\
\text { ского насто- } \\
\text { ящего }\end{array}$ & $\begin{array}{c}\text { Фаталистиче- } \\
\text { ского настоя- } \\
\text { щего }\end{array}$ & $\begin{array}{c}\text { Ориента- } \\
\text { ция на } \\
\text { будущее }\end{array}$ \\
\hline $\begin{array}{c}\text { Суденты } \\
(\mathrm{n}=13)\end{array}$ & $3,17 \pm 0,22$ & $3,73 \pm 0,13$ & $3,53 \pm 0,15$ & $2,69 \pm 0,15$ & $3,94 \pm 0,15$ \\
\hline $\begin{array}{c}\text { Курсанты } \\
(\mathrm{n}=31)\end{array}$ & $2,60 \pm 0,09^{*}$ & $3,95 \pm 0,08$ & $3,39 \pm 0,05$ & $2,56 \pm 0,10$ & $3,61 \pm 0,08^{*}$ \\
\hline
\end{tabular}
статистически значимы.

Статистический анализ полученных результатов показал, что по трем из пяти факторов данные теста гражданских студентов совпадали с данными теста курсантов ведомственного вуза. В число этих факторов вошли: восприятие позитивного прошлого, гедонизма и фатализма в настоящем. Достоверные различия между группами касались восприятия негативного прошлого и степени ориентации на будущее. Значения обоих этих факторов были выше в группе студентов (по фактору негативного прошлого критерий Стьюдента $\mathrm{t}=2,38$, что соответствует уровню достоверности различий $\mathrm{p}<0,05$; по фактору ориентации на будущее встречаемость высоких значений 4 балла и выше в группе студентов по критерию хи-квадрат была выше с высокой степенью достоверности $\left.\chi^{2}=5,23, \mathrm{p}<0,05\right)$.

Полученные данные подтвердили сформулированную в начале статьи гипотезу о том, что тьюторы волонтеров по социальной помощи населению в условиях пандемии из числа гражданских лиц, относящихся к службам социальной защиты, и из числа представителей силовых структур, обеспечивающих безопасность граждан, характеризуются не одинаковым 


\section{ЧЕЛОВЕК И СОВРЕМЕННОЕ ОБЩЕСТВО В СОЦИАЛЬНОМ, ПРАВОВОМ, ЭКОНОМИЧЕСКОМ РАКУРСАХ}

восприятием времени и будут тиражировать в социуме различные модели построения будущего.

Для гражданских студентов, участвующих в подготовке волонтеров для работы в пандемии, по сравнению с их сверстниками из числа курсантов силового вуза, также занимающимися наставничеством волонтеров, характерен более богатый социальный опыт, включающий негативные эпизоды в прошлом, и более активная работа по постановке личных целей на будущее и построению планов на перспективу. Когнитивный, мотивационный, эмоциональный, мировоззренческий и деятельностный смысл выявленных различий подлежит детальному и углубленному изучению. Однако, на основе приведенных данных пилотного исследования можно заключить, что для сохранения устойчивости, надежности и управляемости социума после пандемии уже сегодня целесообразно продумать акмеологическую модель подготовки волонтеров, а также разработать алгоритм формирования команд тьюторов, которые через взаимодействие с волонтерами и дальше, по цепочке, с населением будет создавать новую конфигурацию социальных отношений в ближайшем будущем.

\section{3. Анализ устойчивости интереса интернет-пользователей к информации, выложенной на сайте Уральского института ГПС МЧС России}

Анализ устойчивости интереса интернет-пользователей к информации, выложенной на официальном сайте Уральского института ГПС МЧС России осуществлен нами на примере мониторинг интереса к видеоролику «Парад Победы», созданного сотрудниками уральского института. Создание видеоролика и его представление в Интернет-пространстве выполнено в соответствии с Распоряжением Правительства Российской Федерации 
от 29 мая 2015 г. № 996-р «Стратегия развития воспитания в Российской Федерации на период до 2025 года» [45].

Эмпирические данные получены с помощью интернет ресурса https://www.yuotube.com/analytics. Предметом исследования является география пользователей, предпочитаемые ими формы доступа к информации, хронология числа обращений, продолжительность просмотра. В сборе эмпирического материала приняли активное участие начальник отдела связей с общественностью майор внутренней службы А.А. Крылов и курсант третьего курса факультета техносферной безопасности [46]. Аналитическая программа, доступная авторам видеороликов, выкладываемых на Yuotube, позволила собрать следующие эмпирические данные относительно географии и поведения интернет-пользователей.

В формате инфографики авторам видеоматериалов по запросу представляется краткая характеристика пользовательской аудитории:

1. Самые популярные регионы просмотров,

2. Самые популярные источники трафика;

3. Половой состав аудитории пользователей,

4. Место воспроизведения видеоматериалов.

По дополнительным запросам авторов аналитическая программа Yuotube представляет расширенные сведения об аудитории пользователей. Видеоролик, созданный в Уральском институте ГПС МЧС России, вызвал интерес в 17 странах мира. В порядке убывания продолжительности просмотров рейтинг этих стран выглядит следующим образом: Россия Казахстан Украина Германия Соединенные Штаты Беларусь Чехия Греция Франция Азербайджан Дания Киргизия Литва Таиланд Узбекистан Нидерланды Великобритания. Программа аналитического сопровождения авторских видеороликов Yuotube дает описательное, табличное и картографическое представление интереса пользователей к материалам сайта. 
Раздел «Местоположение» позволяет авторам видеоматериалов по их дополнительному запросу детализировать поведение лиц, просмотревших видеоролик. Данная информация представляется в табличном виде отдельным файлом формата Excel и включает в себя следующие сведения:

1. Местоположение ID,

2. Время просмотра (минуты),

3. Количество просмотров,

4. Средний просмотр (в минутах) (minutes),

5. Средний просмотр (в процентах),

6. Клики по подсказке,

7. Количество показов,

8. Отношение количества кликов по подсказкам к общему числу их показов,

9. Клики по тизеру подсказки,

10. Показы тизеров,

11. Количество кликов на показ тизера,

12. Показы элементов конечной заставки,

13. Клики по элементам конечной заставки,

14. Кликов на число показов элемента конечной заставки,

15. Просмотры подписчиками,

16. Время просмотра подписчиками,

17. Время просмотра по подписке YouTube Red (минуты),

18. Просмотры по подписке YouTube Red,

19. Время просмотра по подписке YouTube Red (часы),

20. Клики по аннотациям,

21. Показы аннотаций со ссылками,

22. Количество кликов на показ аннотации,

23. Закрытия аннотаций, 
24. Показы аннотаций с кнопкой "Закрыть",

25. Закрытые аннотации,

26. Показы аннотаций,

27. Оценки "Нравится",

28. Добавленные оценки "Нравится",

29. Удаленные оценки "Нравится",

30. Оценки "Не нравится",

31. Добавленные оценки "Не нравится",

32. Удаленные оценки "Не нравится",

33. Поделились,

34. Комментарии,

35. Видео в плейлистах,

36. Добавлено в плейлисты,

37. Удалено из плейлистов,

38. Подписчики,

39. Новые подписчики,

40. Отказались от подписки,

41. Время просмотра (часы).

В аналогичном формате хронометрах просмотра видеоролика для его авторов по отдельному запросу детализируется по следующей схеме:

1. Дата,

2. Время просмотра (минуты),

3. Число просмотров,

4. Средний просмотр (в минутах),

5. Средний просмотр (в процентах),

6. Клики по подсказке,

7. Количество показов, 
8. Отношение количества кликов по подсказкам к общему числу их показов,

9. Клики по тизеру подсказки,

10. Показы тизеров,

11. Количество кликов на показ тизеров,

12. Показы элементов конечной заставки,

13. Клики по элементам конечной заставки,

14. Кликов на число показов элемента конечной заставки,

15. Просмотры подписчиками,

16. Время просмотра подписчиками,

17. Время просмотра по подписке YouTube Red (минуты),

18. Просмотры по подписке YouTube Red,

19. Время просмотра по подписке YouTube Red (часы),

20. Клики по аннотациям,

21. Показы аннотаций со ссылками,

22. Количество кликов на показ аннотации,

23. Закрытия аннотаций,

24. Показы аннотаций с кнопкой "Закрыть",

25. Закрытые аннотации,

26. Показы аннотаций,

27. Оценки "Нравится",

28. Добавленные оценки "Нравится",

29. Удаленные оценки "Нравится",

30. Оценки "Не нравится",

31. Добавленные оценки "Не нравится",

32. Удаленные оценки "Не нравится",

33. Поделились,

34. Комментарии, 
35. Видео в плейлистах,

36. Добавлено в плейлисты,

37. Удалено из плейлистов,

38. Подписчики,

39. Новые подписчики,

40. Отказались от подписки,

41. Время просмотра (часы),

42. Уникальные файлы cookie (только браузер).

Приведенная информация показывает, насколько полно, объемно и масштабно платформа Yuotube отслеживает географию, поведение пользователей и тиражирование ими полученной информации, а также мониторит реакцию пользователей на дополнительно предъявляемую попутную информацию.

По отдельному запросу указанная программа выводит на экран графическое и табличное отображение информации о предпочитаемых источниках трафика пользователей, доли каждого источника в общем трафике просмотра, а также абсолютную продолжительность трафика каждого источника в минутах. Анализ статистических данных, почерпнутых из отчета платформы Yuotube, позволил сделать следующие выводы. Внимание аудитории пользователей к видеоматериалам обладает двумя важными чертами: носит волнообразный характер и быстро угасает без дополнительного стимулирования в первую неделю просмотра.

На основании представленных данных можно сделать вывод о том, что информация, посвященная вопросам безопасности и выкладываемая в систему Интернет, требует неоднократного и достаточно частого повторения для того, что удержать внимание пользовательской аудитории.

Именно поэтому алгоритмы информирования и оповещения с использованием технологий Интернета не соответствуют тем форматам 
обучения и информирования, которые в предыдущие годы разработаны для системы ОКСИОН, наоборот, они все больше приближаются к тем алгоритмам работы с населением, котрые успешно апробированы социальной психологией и маркетингом.

\section{4. Оценка возможности использования}

информационно-коммуникационных технологий ритейла

\section{информирования населения по вопросам безопасности}

В соответствии с определением, приведенным в Википедии, под термином «ритейл» понимается система розничных продаж товаров и услуг, предназначенных для личного или семейного использования (т.е. не связанного с предпринимательской деятельностью), непосредственно конечному потребителю. Из данного определения следует, что информация, передаваемая в сети ритейла, характеризуется ориентацией на широкий круг пользователей, относящийся к среднему классу по уровню своего личного и семейного достатка, обладает высоким уровнем адресности, большинством пользователей воспринимается не личная (частная, семейная, приватной) в отличие от противовес публичной и официальной информации, распространяемой представителями власти и силовыми структурами через СМИ.

С учетом указанных обстоятельств, информация от МЧС России, транслируемая покупателям сети ритейла, по определению воспринимается последними доверительно и эмоционально, минуя барьеры социальной критики, скепсиса и настороженности. Данный факт давно используется специалистами МЧС России при организации профилактической работы с населением, в частности при размещении противопожарной информации и информации о правилах поведения в ЧС на билбордах и больших экранах, 
размещенных на территориях торгово-развлекательных центров, супермаркетов, других мест массового пребывания людей.

В ранее процитированной книге [1] изложены методические рекомендации по размещению, времени трансляции и структурированию информации, передаваемой от МЧС России населению в местах массового пребывания людей с помощью статичных информационных объектов, таких как электронные плакаты, видеозаставки, видеооткрытки, текстовые сообщения и др. Как отмечается в цитируемых методических рекомендациях, названные статичные информационные объекты размещаются в зданиях аэропортов, вокзалов, у входов в метрополитен, на рынки, гипермаркеты, где время нахождения людей возле них не превышает 30-40 с. В связи с этим продолжительность показа значимой информации рекомендуется соотносить со временем колебаний внимания посетителей мест массового пребывания людей, и делать ее достаточно кратковременной, не превышающей интервала в 15 с, а при движении людей в потоке - не более 5с. Выбор максимального размера экрана рекомендуют выбирать расчетным способом, принимая во внимание протяженность и ширину места массового пребывания людей.

Для удержания внимания потребителей информации рекомендуется обновлять форму и содержание информации каждые 5 дней, соединяя в равной пропорции новую и уже увиденную информацию.

Для активного привлечения внимания потенциальных пользователей использовать два способа: с акцентом на логическую составляющую и с акцентом на эмоциональную составляющую. При этом выбор способа подачи материала выбирать в зависимости от возраста, пола и этнических характеристик целевой аудитории, помня, что наличие циклических повторов с различными акцентами увеличивает интерес и внимание представителей различных целевых групп и аудиторий. При составлении информационных материалов для разнородной аудитории особо отмечается необходимость 
консультаций с экспертами в области медиапродукции, психологии, педагогики и др. [1, с. 143].

При разделении потоков людей по возрастным категориям специалисты НИИ ГОЧС МЧС России рекомендуют [1, с. 140-141] придерживаться следующих правил (табл. 4).

\section{Таблица 4}

\section{Характеристика приоритетных интересов аудитории ритейла по возрастам}

\begin{tabular}{|c|l|}
\hline \multicolumn{1}{|c|}{$\begin{array}{c}\text { Возраст } \\
\text { аудитории, лет }\end{array}$} & \multicolumn{1}{|c|}{ Характер приоритетной информации } \\
\hline $10-15$ & $\begin{array}{l}\text { Сюжеты, основанные на известных компьютерных играх, персонажах } \\
\text { мультсериалов, молодежных фильмов }\end{array}$ \\
\hline $16-21$ & $\begin{array}{l}\text { Сюжеты, основанные на межличностных отношениях в условиях } \\
\text { проведения спортивных, сценических, эстрадных мероприятий }\end{array}$ \\
\hline $22-30$ & $\begin{array}{l}\text { Сюжеты, связанные с созданием семьи, родительскими } \\
\text { обязанностями, социально-политическими событиями в стране, } \\
\text { выбором престижной, стабильной и высокооплачиваемой работы }\end{array}$ \\
\hline $30-60$ & $\begin{array}{l}\text { Сюжеты, основанные на страховых способах решения проблем, } \\
\text { связанными с потерей и ущербом, гарантиях государства в области } \\
\text { безопасности, действенности государственных мер, направленных на } \\
\text { защиту населения и территорий от ЧС }\end{array}$ \\
\hline Старше 60 & $\begin{array}{l}\text { Сюжеты, связанные с описанием реальных угроз для их близких, } \\
\text { родственников, детей и внуков }\end{array}$ \\
\hline
\end{tabular}

Приведенные методические рекомендации, опубликованные в 2009 г., имеют большое теоретическое и практическое значение и сегодня, однако, не учитывают того прогресса в развитии IT-технологий, которые произошли последние десять лет, особенно в сфере распространения индивидуальных мобильных телефонов и широкого внедрения цифровых технологий в 


\section{ЧЕЛОВЕК И СОВРЕМЕННОЕ ОБЩЕСТВО В СОЦИАЛЬНОМ, ПРАВОВОМ, ЭКОНОМИЧЕСКОМ РАКУРСАХ}

кассовую деятельность ритейла. Поэтому следующий параграф данной работы посвящен описанию авторских наработок в плане использования сетей ритейла для информирования и оповещения населения.

Рассмотрим два авторских предложения по использованию уже реализованных коммерческих информационно-коммуникационных площадок для информирования и оповещения населения об угрозе ЧС: информирования и оповещение населения в кинотеатрах посредством выведения информации, через кинопроектора, вначале и в конце сеансов, и оповещение посредством печати на кассовой ленте в розничной торговле.

Ежедневно миллионы людей посещают кинотеатры России, большинство кинотеатров подключены к единым центрам мониторинга состояния кинооборудования (например, система NOC системного интегратора «МагнаТек Россия», к которой подключено онлайн более 200 кинозалов разных частей страны). С помощью дооснащения каждого кинопроектора управляющим устройством вывода информации можно было бы интегрировать экраны кинотеатров в сеть ОКСИОН, и по соглашению с собственниками кинозалов информировать и оповещать население, в конце либо перед сеансом.

На развитие кинозалов в небольших муниципальных образованиях Российской Федерации в период с 2015 по 2016 годы в рамках бюджетного финансирования было полностью модернизировано 434 залов в 395 населенных пунктах 70 субъектов Российской Федерации. Все кинотеатры, модернизированные в рамках вышеуказанных мероприятий, имеют техническую возможность, для интеграции в сеть ОКСИОН, по приведенной схеме. При этом находятся зачастую в небольших городах и поселках, где строительство терминальных комплексов ОКСИОН неоправданно дорого. Поиск более рентабельных способов информирования населения с использованием цифровых технологий ритейла изучен автором на 


\section{ЧЕЛОВЕК И СОВРЕМЕННОЕ ОБЩЕСТВО В СОЦИАЛЬНОМ, ПРАВОВОМ, ЭКОНОМИЧЕСКОМ РАКУРСАХ}

примере включения информации МЧС России в чеки сети магазинов «Монетка». Основанием для такого пилотного исследования послужили следующие факты.

Ежедневно каждая касса в крупных торговых сетях на территории Российской федерации отбивает порядка 283 чеков, таким образом, держателями бумажных чеков потенциально являются 283 человека. В среднем в каждом магазине торговой сети 3-6 касс, таким образом, проходит в сутки более тысячи человек. В настоящее время большинство касс сосредоточено в руках крупных торговых сетей и подключены в единую сеть, имеют единый центр управления шаблонами чеков - обладают возможностью вывода оперативной информации в чек. Только торговая сеть «Монетка» отбивает в сутки более 850 тысяч чеков, в 1000 магазинов, расположенных на территории 3 федеральных округов (Уральского, Приволжского и Сибирского). Подобных по количеству касс торговых сетей в Российской Федерации десятки, каждая из таких сетей по сути является площадкой для информирования и оповещения населения об угрозе ЧС.

Острота данной проблемы усиливается в связи с изменением коммуникативного поведения населения в условиях пандемии COVID-19. В связи режимом карантина и самоизоляцией, нарушением ранее сложившихся социальных связей экспертами в области социальной психологии зафиксировано нарастание тревожно-депрессивных и агрессивных настроений населения. Такие тенденции отмечены специалистами в области безопасности многих стран мира. В складывающейся ситуации практически значимым становится вопрос поиска инновационных форм донесения до населения актуальных рекомендаций по безопасному поведению, в том числе в онлайн формате с использованием цифровых технологий коммуникации. 


\section{ЧЕЛОВЕК И СОВРЕМЕННОЕ ОБЩЕСТВО В СОЦИАЛЬНОМ, ПРАВОВОМ, ЭКОНОМИЧЕСКОМ РАКУРСАХ}

Актуальность, а также теоретическая и практическая востребованность указанных научных исследований подтверждается их соответствием приоритетным научным исследованиям, утвержденным нормативной базой Российской Федерации. Поиск новых технологий коммуникации специалистов спасательных служб с целевыми социально значимыми аудиториями населения соответствует:

- Пункту 3 «Информационно-телекоммуникативные системы» приоритетных направлений развития науки, технологий и техники в Российской Федерации и пункту 21 перечня критических технологий Российской Федерации, обозначенных в Указе Президента Российской Федерации от 07.07.2011 г. № 899 «Об утверждении приоритетных направлений развития науки, технологий и техники в Российской Федерации и перечня критических технологий Российской Федерации» [47];

- Пункту 4 «Развитие и внедрение передовых технологий и средств предупреждения и ликвидации чрезвычайных ситуаций» и пункту 5 «Научнометодическое сопровождение мероприятий, направленных на повышение эффективности повседневной деятельности МЧС России» приоритетных направлений научно-технической деятельности МЧС России [48];

- Пункту (д) «Противодействие техногенным, биогенным, социокультурным угрозам ...и иным источникам опасности для общества. Экономики и государства» списка приоритетных направлений научноисследовательских проектов, поддерживаемых Российским фондом фундаментальных исследований [49].

Исследование внимания покупателей к информации МЧС России, включенной в чек, проверено на примере сведений о предстоящем ухудшении погоды (резком усилении ветра). Регистрация случаев обращения внимания покупателей на необычную форму чека осуществлена И.В. Ивановым в формате включенного наблюдения по согласованию с руководством ЦУКС 
ГУ МЧС по Свердловской области и администрацией торговой сети «Монетка» в Екатеринбурге.

Схема передачи информации от источника до приемника включала в себя 6 звеньев: АРМ ЦУКС ГУ МЧС России по Свердловской области ServiceDesk торговой сети - кассы магазинов - чек покупателя (в бумажном варианте) - система лояльности - мобильное приложение покупателя (в электронном варианте).

Эмпирическая проверка внимания покупателей к информации МЧС России, включенной дополнительно в чеки, осуществлена в пиковое время продаж на одной из касс торговой сети «Монетка» г. Екатеринбурга. За 90 минут рабочего времени на кассе было обслужено 53 покупателя, 13 из них обратили внимание на необычную форму чека и на дополнительную информацию о предстоящем ухудшении погоды, включенную в чек со ссылкой на МЧС России.

Таким образом, информация от МЧС Росси, включенная в чек, привлекла внимание четверти покупателей, проходящих через магазин торговой сети «Монетка» в часы пиковой нагрузки (24,5%).

В наблюдениях, проведенных ранее (И.В. Иванов, 2019) также в торговых залах сети «Монетка», но с выведением информации об усилении ветра на экраны терминалов комплекса «ОКСИОН», было обнаружено, что лишь 5 \% проходящих мимо покупателей обращают внимание на тревожное сообщение.

Сравнение результатов двух представленных включенных наблюдений позволяет сделать заключение, что адресная информация, представленная в мобильном приложении в системе лояльности постоянного клиента торговой сети, привлекает внимание покупателей товаров повседневного спроса эконом-сегмента в пять раз чаще, чем аналогичная публичная информация, 
представленная в формате уличной рекламы с использованием терминалов комплекса «ОКСИОН» на территории того же торгового центра.

Полученные результаты позволяют рекомендовать специалистам в области безопасности оптимизировать технологии коммуникации с населением: шире использовать лично адресованные сообщения представителям целевой аудитории взамен безличной уличной социальной рекламы. Указанный алгоритм взаимодействия сотрудников служб спасения с населением, находящемся в условиях дефицита межличностного общения, ограничения социальных контактов и самоизоляции, на наш взгляд, может обладать не только информационным, но и положительным психологическим эффектом.

Разумеется, эффективное использование механизмов государственночастного партнерства возможно только посредством внесения соответствующих изменений в нормативно-правовую базу. Простая разъяснительная работа с представителями бизнеса по интеграции их медиа мощностей велась, начиная с 2012 года территориальными органами МЧС России и не принесла должных результатов. Необходимо на законодательном уровне определить обязанность по информированию и оповещению населения посредством ресурсов, которыми обладают коммерческие структуры, у которых существует непосредственное общение с населением.

\section{ЗАКЛЮЧЕНИЕ}

В представленных результатах исследования описаны современные тренды развития системы информирования и оповещения населения, наметившиеся в стране за последние десять лет и модифицированные активным внедрением цифровых технологий в повседневную жизнь россиян в связи с цифровизацией ритейла, широким распространением гаджетов среди населения всех возрастов, сокращением времени нахождения большинства 


\section{ЧЕЛОВЕК И СОВРЕМЕННОЕ ОБЩЕСТВО В СОЦИАЛЬНОМ, ПРАВОВОМ, ЭКОНОМИЧЕСКОМ РАКУРСАХ}

граждан России в местах массового пребывания людей в период пандемии COVID-19. Материалы исследования стали основой для написания и успешной защиты аспирантской научно-исследовательской работы, выполненной И.В. Ивановым под руководством доктора медицинских наук, доцента, профессора кафедры «Сервис безопасности» Г.В. Талалаевой. Основные выводы, сделанные в результате выполнения данного исследования, заключаются в следующем.

Система информирования и оповещения населения последние десять лет активно модернизируется и совершенствуется. Совершенствование системы информирования населения осуществляется специалистами МЧС России по трем основным направлениям: организационном, методическом, технологическом.

Согласно результатам наукометрического анализа публикаций по теме «ОКСИОН», включенных в базу данных РИНЦ, в 2015 г. произошло качественное изменение основных направлений исследований по данной теме. До 2015 г. приоритетным направлением научных исследований по теме «ОКСИОН» был поиск оптимальной модели представления информации населению со стороны специалистов МЧС России. После 2015 г. и по настоящее время приоритетным направлением научных исследований по теме «ОКСИОН» является изучение алгоритмов восприятия предъявляемой информации целевыми группами населения.

Проект «Национальная платформа открытого образования» оперативно реагирует на появление новых угроз безопасности жизнедеятельности человека в связи с цифровизацией информационно-коммуникационного пространства: меняя в соответствии с новыми вызовами структуру, содержание и названия онлайн-курсов.

Интерес пользователей Интернета к видео продукции, создаваемой сотрудниками МЧС России представляет собой динамичный процесс, 
развивающийся по определенным закономерностям. $\mathrm{Ha}$ примере видеопродукции Уральского института ГПС МЧС России установлено, что средняя продолжительность одного просмотра видеоролика весьма коротка и составляет менее двух минут (1,99 мин.), интерес целевой аудитории к предъявляемой информации без дополнительного стимула является относительно кратковременным и затухает в течение 7 дней.

Авторская попытка укрепить интерес пользователей к информации, предъявляемой сотрудниками МЧС России, с помощью технологий таргетированной рекламы показала ее недостаточно высокую эффективность. Так, информация об угрозах ЧС природного (метеорологического) характера, представленная на чеках магазинов сети «Монетка», вызывала интерес лишь у четверти покупателей $(24,5$ \%), проходящих через магазин торговой сети «Монетка» в часы пиковой нагрузки.

На наш взгляд, проведенные исследования и полученные результаты являются достаточно оптимистичными по своей сути. Они свидетельствуют о том, что лишь у одной четверти протестированных респондентов, жителей промышленного мегаполиса, зарегистрирована фиксация внимания на тревожной информации, угрожающей безопасности жизнедеятельности, полученной ими через индивидуальные гаджеты. Остальные три четверти респондентов данную информацию проигнорировали. Таким образом, у большинства уральцев, участвовавших в тестировании, восприятие цифровой информации через индивидуальные гаджеты характеризовалось буферным эффектом, при котором потенциальная угроза жизнедеятельности не воспринималась как реальная. Индивидуальное игнорирование потенциальной угрозы, информация о которой передавалась с помощью цифровых технологий, на групповом уровне дополнилось эффектом затухания интереса к озвученной теме, реализация которого завершалась в течение недели. 


\section{ЧЕЛОВЕК И СОВРЕМЕННОЕ ОБЩЕСТВО В СОЦИАЛЬНОМ, ПРАВОВОМ, ЭКОНОМИЧЕСКОМ РАКУРСАХ}

C точки зрения поведенческого анализа изложенная интерпретация полученных результатов исследования имеет определенное практическое и теоретическое значение. Она позволяет объяснить относительную устойчивость (ригидность) общности уральцев к возмущающим воздействиям негативных новостей, периодически появляющихся в средствах массовой информации. Избирательное восприятие тревожной информации, получаемой через личные гаджеты и отмеченное в нашем исследовании у большинства протестированных респондентов $(75,5 \%)$, на наш взгляд, можно рассматривать как противовес групповому эффекту, возникающему при стрессе в неорганизованных контингентах и способного инициировать возникновение паники среди покупателей торговых центров при публичном объявлении информации о ЧС.

Следовательно, обнаруженные нами два эффекта, эффект избирательного восприятия сведений об опасности, передаваемые с помощью цифровых технологий, также как и эффект группового затухания интереса к информации, исходящей от сотрудников спасательных служб, можно рассматривать как базовый психофизиологический механизм защиты от потенциальных угроз в условиях распространения цифровых технологий.

\section{Список литературы}

1. Информационно-коммуникативные технологии обеспечения безопасности жизнедеятельности: монография / под общ. ред. П.А. Попова, МЧС России. - М.: ФГУ ВНИИ ГОЧС (ФЦ), 2009. - 272 с. [Электронный pecypc]. - Режим доступа: URL: https://www.elibrary.ru/download/elibrary_ 15017754_18466012.pdf (20.12.2021)

2. Федеральный закон от 27 июля 2006 г. № 149-Ф3 «Об информации, информационных технологиях и о защите информации» [Электронный 
pecypc]. - Режим доступа: URL: http://www.consultant.ru/document/cons_doc_ LAW_61798/(20.12.2021)

3. Федеральный закон от 29 декабря 2012 г. № 273-Ф3 «Об образовании в Российской Федерации» [Электронный ресурс]. - Режим доступа: URL: http://www.consultant.ru/document/cons_doc_LAW_140174/ (20.12.2021)

4. Распоряжение Правительства РФ от 01.11.2013 N 2036-р (ред. от 18.10.2018) «Об утверждении «Стратегии развития отрасли информационных технологий в Российской Федерации на 2014-2020 годы и на перспективу до 2025 года» [Электронный pecypc]. - Режим доступа: URL: http://www.consultant.ru/document/cons_doc_LAW_154161/ (20.12.2021)

5. Порядок применения организациями, осуществляющими образовательную деятельность, электронного обучения, дистанционных образовательных технологий при реализации образовательных программ, утвержденный приказом Минобрнауки России от 23 августа 2017 г. № 816 [Электронный ресурс]. - Режим доступа: URL: http://www.consultant.ru/ document/cons_doc_LAW_278297/(20.12.2021)

6. Послании Президента Федеральному собранию от 15 января 2020 г. [Электронный ресурс]. - Режим доступа: URL: http://www.kremlin.ru/events/ president/news/62582 (20.12.2021)

7. Опубликован паспорт национальной программы «Цифровая экономика Российской Федерации» [Электронный ресурс]. - Режим доступа: URL: http://government.ru/info/35568/ (20.12.2021)

8. «Цифровые технологии». Последнее обновление: 21 декабря 2020. Описание [Электронный ресурс]. -Режим доступа: URL: https://igital.gov.ru/ ru/activity/directions/878/ (20.12.2021)

9. Дорожные карты развития «сквозных» цифровых технологий [Электронный ресурс]. -Режим доступа: URL: https://digital.gov.ru/uploaded/ 
presentations/20191127adorozhnaya-karta-razvitiya-skvoznoi-tsifrovoi-tehnologii15.pdf(20.12.2021).

10. МЧС России: определены направления развития [Электронный peсурс]. -Режим доступа: URL: https://www.to-inform.ru/index.php/arkhiv/item/ mchs-opredeleni-napravleniya-razvitiya (20.12.2021).

11. В системе МЧС России определены приоритетные направления развития науки, техники и технологий [Электронный ресурс]. - Режим доступа: URL: https://www.mchs.gov.ru/deyatelnost/press-centr/novosti/4241538 (20.12.2021).

12. Указ Президента Российской Федерации «Об утверждении Основ государственной политики Российской Федерации в области пожарной безопасности на период до 2030 года» от 1 января 2018 г. № 2 [Электронный pecypc]. - Режим доступа: URL: http://docs.cntd.ru/document/556185311 (20.12.2021).

13. Цифровизация и совершенствование системы прогнозирования ЧС станут приоритетными направлениями в деятельности МЧС России [Электронный ресурс]. - Режим доступа: URL: https://news.rambler.ru/fire/ 44732117-tsifrovizatsiya-i-sovershenstvovanie-sistemy-prognozirovaniya-chsstanut-prioritetnymi-napravleniyami-v-deyatelnosti-mchs-rossii/ (20.12.2021).

14. Приказ МЧС России от 25 декабря 2020 г. № 995 «Об утверждении Плана мероприятий (дорожной карты) МЧС России по реализации в 2021 году Концепции содействия развитию добровольчества (волонтерства) в Российской Федерации до 2025 года» [Электронный ресурс]. -Режим доступа: URL: https://www.mchs.gov.ru/dokumenty/normativnye-pravovye-akty-mchsrossii/5093 (20.12.2021).

15. Приказ МЧС России от 20.07.2020 № 536 «О плане мероприятий на 2020 - 2024 годы (I этап) по реализации Министерством Российской Федерации по делам гражданской обороны, чрезвычайным ситуациям и ликвидации последствий стихийных бедствий Стратегии в области развития 456 
гражданской обороны, защиты населения и территорий от чрезвычайных ситуаций, обеспечения пожарной безопасности и безопасности людей на водных объектах на период до 2030 года» [Электронный ресурс]. - Режим доступа: URL: http://www.consultant.ru/document/cons_doc_LAW_361701/ (20.12.2021).

16. Внедрение новых форм подготовки населения к выполнению мероприятий по гражданской обороне и к действиям в чрезвычайных ситуациях, в том числе с использованием современных технических средств обучения [Электронный ресурс]. - Режим доступа: URL: http://www.consultant.ru/document/cons_doc_LAW_361701/8d48834beb119b7300 f86fb94bcb4e4e525b48d3/ (20.12.2021)

17. СанПиН 2.4.2.2821-10 «Санитарно-эпидемиологические требования к условиям и организации обучения в общеобразовательных учреждениях» (Постановление Главного государственного санитарного врача Российской Федерации от 29 декабря 2010 г. № 189) [Электронный ресурс]. - Режим доступа: URL: https://rg.ru/2011/03/16/sanpin-dok.html (20.12.2021)

18. Открытое образование [Электронный ресурс]. - Режим доступа: URL: https://openedu.ru/ (20.12.2021)

19. Вайцман Джонатан. Генетика / Д. Вайцман, М. Вайцман; [пер. с англ. М. Нижарадзе]. - М.: РИПОЛ классик, 2018.- 160 с.

20. Топ 7 онлайн-курсов по сторителлингу [Электронный ресурс]. Режим доступа: URL: https://martrending.ru/smm/onlayn-kursy-po-storitellingu (20.12.2021).

21. Макки Р. Сториномика: Маркетинг, основанный на историях, в пострекламном мире / Роберт Макки, Том Джерас; пер. с англ. - М.: Альпина нонфикшн, 2019.- 280 с. 
22. Уотсон Ричард. Технологии против Человека : как мы будем жить, любить и думать в следующие 50 лет? / Ричард Уотсон; [перевод с английского Л.И. Степановой]. - М.: Эксмо, 2020.- 320 с.

23. Автоматизированные действия [Электронный ресурс]. - Режим доступа: URL: https://онлайн-словарь.рф/avtomatizirovannie-dejstviya.html (20.12.2021).

24. Автоматизация действий [Электронный ресурс]. - Режим доступа: URL: https://www.psychologos.ru/articles/view/avtomatizaciya-deystviy (20.12.2021)

25. Гальперин П.Я. Основные результаты исследований по проблеме «формирование умственных действий и понятий»: Доклад на соискание учен. степени д-ра пед. наук (по психологии). — М., 1965.—51 с.

26. Гальперин П.Я. Психология мышления и учение о поэтапном формировании умственных действий. - Исследования мышления в советской психологии. М., 1966.

27. Лебон Г. Психология масс. С предисловием Николая Старикова. СПб.: Питер, 2016. - 224 с.

28. Щербаков С. Таргетированная реклама. Точно в яблочко. - СПб.: Питер, 2019. - 352 с.

29. Панда Петр. Копирайтинг: Сила убеждения. - СПб.: Питер, 2021. $304 \mathrm{c}$.

30. Хусаинов И. «Этажи»: Сила управления / Ильдар Хусаинов. - М.: Интеллектуальная Литература, 2019. - 377 с.

31. Информационная культура жителей Свердловской области: поселенческий и социально-демографический аспекты: монография / Г.А. Банных, Е.Н. Заборова, С.Н. Костина, А.И. Кузьмин, Д.Л. Сивоволов / под общ. ред. проф. А.И. Кузьмина, доц. С.Н. Костиной; М-во образования и 
науки Рос. Федерации, Урал. федерал. ун-т. - Екатеринбург: Изд-во Урал. ун-та, 2016. - $222 \mathrm{c.}$

32. Воробьев Ю.Л., Акимов В.А., Соколов Ю.И. Комплексная безопасность человека. - М.: Всероссийский научно-исследовательский институт по проблемам гражданской обороны и чрезвычайных ситуаций МЧС России. Москва, 2011. - 346 с.

33. Кошкаров В.С., Архипова Ю.А., Рыбакова Н.И., Буданов Б.В. Информационная безопасность в социальных сетях // XXI век: итоги прошлого и проблемы настоящего плюс. - 2019. - Т. 8. - № 1 (45). С. 186-190.

34. Путин о трагедии в Керчи [Электронный ресурс] // Режим доступа: URL: http://plainnews.ru/video-channel-369438.html (20.12.2021).

35. ФАУ «ИЦ ОКСИОН» [Электронный ресурс] // Режим доступа: URL: http://www.mchs.gov.ru/document/375628 (20.12.2021).

36. ОКСИОН: Общероссийская комплексная система информирования и оповещения населения [Электронный ресурс] // Режим доступа: URL: http://www.tadviser.ru/index.php (20.12.2021).

37. Краткий психологический словарь / Сост. Л.А. Карпенко; Под общ. Ред. А.В. Петровского, М.Г. Ярошевского. М., 1985.- 431 с.

38. Горбунова М.Ю. Социальная психология / М.Ю. Горбунова. - М.: Изд-во ВЛАДОС-ПРЕСС, 2006.- 223 с.

39. Амбарова П.А. Управление временем в зеркале темпоральных стратегий поведения социальных общностей. Монография. - Екатеринбург, 2015.-252 с. [Электронный ресурс]. -Режим доступа: URL: https:/elibrary.ru/ item.asp?id=25256630 (20.12.2021).

40. Талалаева Г.В. Время, радиация и техногенез: биологические ритмы у жителей промышленных территорий. - Екатеринбург: Изд-во УрГУ, 2005. - 
206 с. [Электронный ресурс]. -Режим доступа: URL: http://ecoradmod.narod.ru/ rus/publication2/Talalaeva_2006.pdf (20.12.2021).

41. De Clercq, Dirk, Haq, Inam Ul and Azeem, Muhammad Umer. Threatened but involved : key conditions for stimulating employee helping behavior. Journal of Leadership \& Organizational Studies, 2020, 27(3), pp. 271285. [Электронный ресурс]. - Режим доступа: URL: https://doi.org/10.1177/ $1548051819857741(20.12 .2021)$.

42. Dirk De Clercq, Inam U1 Haq, Muhammad Umer Azeem. Time-related work stress and counterproductive work behaviour: Invigorating roles of deviant personality traits [Электронный pecypc]. - Режим доступа: URL: https://eprints.kingston.ac.uk/id/eprint/43128/6/De\%20Clercq-D-43128-AAM.pdf (20.12.2021).

43. Табидзе А.А. Психотическая организация личности [Электронный pecypc]. -Режим доступа: URL: https://www.b17.ru/article/274334/ (28.12.2020).

44. Опросник временной перспективы Зимбардо (ZTPI) [Электронный pecypc]. -Режим доступа: URL: https://socialmatrix.net/zimbardo/ (20.12.2021).

45. Распоряжение Правительства Российской Федерации от 29 мая 2015 г. № 996-р «Стратегия развития воспитания в Российской Федерации на период до 2025 года» [Электронный ресурс]. Российская газета Федеральный выпуск № 6693 (122) [Электронный ресурс]. -Режим доступа: URL: http://rg.ru/2015/06/08/vospitanie-dok.html (20.12.2021).

46. Талалаева Г.В., Крылов А.А., Колодкина Н.А. Мониторинг интереса интернет-пользователей к видеоролику «Парад Победы», созданному сотрудниками Уральского института ГПС МЧС России // Социология и общество: социальное неравенство и социальная справедливость (Екатеринбург, 19-21 октября 2016 года) [Электронный ресурс] Материалы V Всероссийского социологического конгресса / отв. ред. В.А. Мансуров. - 
Электрон. дан. - М.: Российское общество социологов, 2016. - С. 8270-8274. - (DVD ROM).

47. Указ Президента Российской Федерации от 07.07.2011 г. № 899 «Об утверждении приоритетных направлений развития науки, технологий и техники в Российской Федерации и перечня критических технологий Российской Федерации» (B редакции Указа Президента Российской Федерации от 16.12.2015 г. № 63) [Электронный ресурс]. -Режим доступа: URL: http://www.kremlin.ru/acts/bank/33514 (20.12.2021).

48. Приоритетные направления научно-технической деятельности МЧС России [Электронный ресурс]. - Режим доступа: URL: https://www.mchs.gov.ru/deyatelnost/vedomstvennaya-nauka/nauchnotehnicheskaya-deyatelnost-mchs-rossii (20.12.2021).

49. Справочник для пункта 4.2.1.Формы 4 «Содержание Проекта» «Направления из Стратегии научно-технологического развития Российской Федерации» [Электронный ресурс]. - Режим доступа: URL: http://www.sseu.ru/sites/default/files/2017/06/spravochnik.pdf (20.12.2021).

(C) Г.В. Талалаева, И.В. Иванов, 2022 
УДК 343

Глава 17.

НАПРАВЛЕНИЯ ОБЕСПЕЧЕНИЯ КОНСТИТУЦИОННЫХ

ПРАВ ГРАЖДАН ПРИ ПРИМЕНЕНИИ ИНСТИТУТА АДМИНИСТРАТИВНОЙ ПРЕЮДИЦИИ

\begin{abstract}
Скорев Василий Александрович
старший преподаватель

Омский государственный аграрный университет им П.А. Столыпина

Скорева Валерия Васильевна

магистрант

ФГАОУВО «Тюменский государственный университет»
\end{abstract}

Аннотация: Институт административной преюдиции является достаточно сложным правовым явлением. Криминализируя некоторые общественно опасные деяния, российский законодатель установил в качестве необходимого и обязательного условия его повторность после привлечения к административной ответственности за подобное правонарушение. В работе обосновывается вывод, что на современном периоде своего развития институт административной преюдиции затрагивает конституционные права человека и гражданина. В связи с этим необходимо усиление средств государственного надзора за правоприменением в данном межотраслевом и межведомственном феномене.

Ключевые слова: конституционные права граждан, уголовный закон, преступление, предупреждение, преюдиция, прокурорский надзор, участие, защита. 


\title{
DIRECTIONS OF ENSURING THE CONSTITUTIONAL RIGHTS OF CITIZENS IN THE APPLICATION OF THE INSTITUTE OF ADMINISTRATIVE PREJUDICE
}

\section{Skorev Vasily Alexandrovich Skoreva Valeria Vasilyevna}

\begin{abstract}
The institution of administrative prejudice is a rather complex legal phenomenon. Criminalizing some socially dangerous acts, the Russian legislator established as a necessary and mandatory condition its repetition after being brought to administrative responsibility for such an offense. The paper substantiates the conclusion that in the modern period of its development, the institution of administrative prejudice affects the constitutional rights of man and citizen. In this regard, it is necessary to strengthen the means of state supervision over law enforcement in this intersectoral and interdepartmental phenomenon.
\end{abstract}

Key words: constitutional rights of citizens, criminal law, crime, prevention, prejudice, prosecutorial supervision, participation, protection.

Феномен административной преюдиции в юриспруденции является комплексным, так как находится на стыке конституционного, уголовного и административного отраслей права.

13 июня 2021 года исполнилось 25 лет со дня принятия действующего УК РФ. Изначально в Уголовном кодексе РФ было 360 статей, сегодня же их фактически, включая статьи с «хвостиками» - 470, с учетом 14 утративших силу. Рядом ученых и видных практических деятелей Уголовный кодекс России сравнивается с «лоскутным одеялом»; не завершающиеся процессы внесения в него изменений и дополнений сравнивают с инфляционным процессом и девальвацией, необузданными «кройкой и шитьем». Признаками 
современного уголовного закона называют его бессистемность, фрагментарность, внутреннюю разбалансированность и внешнюю аморфность [11, c. 247-250; 8, c. 1399-1408].

Видоизменяется определенным образом и структура уголовного закона, появляются новые способы и техники изменения уголовно-правовых правоотношений и норм. Продолжающийся процесс трансформации уголовной отрасли права можно назвать определенной закономерностью. Одной из тенденций современного уголовного законодательства является включение в правовую материю уголовно-правовых запретов, которые конструируются с помощью механизмов административной преюдиции. В последние годы такая деятельность стала очевидно активной.

Наметившаяся в первой четверти XXI в. тенденция гуманизации российского уголовного законодательства не обошла стороной и институт административной преюдиции, он стал явно востребован. Как отмечено Президентом Российской Федерации в Послании Федеральному Собранию Российской Федерации от 12 ноября 2009 года: «в уголовном законе следует шире использовать так называемую административную преюдицию, то есть привлекать к уголовной ответственности только в случае неоднократного совершения административного правонарушения» [15]. По сути президентский вариант определения административной преюдиции лег в основу последующего ее 10 -летнего развития.

В УК РФ уголовно-правовая норма, устанавливающая ответственность за розничную продажу несовершеннолетним алкогольной продукции, совершенную неоднократно (ст. 151.1 УК РФ) появилась в 2011 году; в 2014 году - еще четыре уголовно-правовых нормы (ст.ст. 212.1, 264.1, 284.1, 314.1 (ч.2) УК РФ), в 2015 году криминализировано незаконное проникновение на охраняемый объект лицом, подвергнутым административному наказанию за аналогичное деяние (ст. 215.4 УК РФ), 
в 2016 - 2018 гг. административная преюдиция появляется в составах преступлений ст.ст. 116.1, 157, 158.1, 171.4, 264.1, 282 и др. Уголовного Кодекса Российской Федерации. На 2021 год в семнадцати составах преступлений фигурирует административная преюдиция.

Учитывая вышеуказанные обстоятельства, соблюдение конституционных прав граждан при применении административной преюдиции, бесспорно.

В среднем ежегодно в России регистрируется порядка 2,5 млн преступлений [16].

За обезличенными цифрами - обширная сфера жизнедеятельности и правоприменения. Игнорирование присущих праву закономерностей может обернуться не меньшими, а может даже большими негативными последствиями, нежели игнорирование естественнонаучных закономерностей. В отличие от собственно философских работ, в юридической литературе понятия «закономерность» и «закон» обычно существенно не различаются, а порой и отождествляются или используются в одном значении.

Действующий УК РФ присущие ему закономерности формулирует как задачи. Задачами Уголовного кодекса Российской Федерации являются: охрана прав и свобод человека и гражданина, собственности, общественного порядка и общественной безопасности, окружающей среды, конституционного строя Российской Федерации от преступных посягательств, обеспечение мира и безопасности человечества, а также предупреждение преступлений [3, ст. 2].

Время рождения Уголовного кодекса России - сложные 90-е гг. ХХ в., время крушения надежд, ломки прежних ценностей, первых проявлений геополитических катастроф. Новый УК РФ рожден, когда преступность была беспрецедентно высокой, организованной, насильственной, профессиональной и корыстной. Как отмечается в исследованиях 
Н.Ф. Кузнецовой, проект УК РСФСР, опубликованный 19 октября 1992 г., обсуждался в 35 Верховных, краевых и областных судах, в 7 школах МВД, 5 государственных университетах, в 7 научно-исследовательских институтах, на трех научно-практических конференциях, отрецензирован в Гарвардской школе права США [12]. Принятию УК РФ предшествовал 4-летний период обсуждений [13, с. 23].

Рассматривая современный Уголовный кодекс как текст, мы замечаем признаки его нелинейности и многозначности.

Традиционная линейная форма представления текста в виде журналов, книг, кодексов утрачивает свое доминирующее положение, приобретая новое свойство, которого раньше не было - становится интерактивной, в том числе за счет гипертекста и мультимедийности. Текст становится нелинейным. Как отмечено Ж. Деррида, «линейное фонетическое письмо постепенно одержало верх над всеми другими видами письма. Эпоха господства линейного письма и соответствующей ему модели мысли заканчивается повсюду - в литературе, философии, науке, а это, в свою очередь, предполагает новую организацию пространства и времени» [9, с. 37].

И.М. Клейменовым отмечено, что «совершенно очевидным является то, что в эпоху постмодерна понять и описать определенные процессы и явления современности, не прибегая к постмодернистской мысли, представляется задачей достаточно затруднительной» [10, с. 198-202].

Уголовный кодекс эпохи постмодерна отличается все большей интерактивностью, где мы видим обилие примечаний, отсылок, в целом гипертекстуальности и выхода за линейность.

В Уголовном кодексе существует несколько видов предписаний, в числе которых бланкетные, отсылочные, расширение инструментария в виде примечаний к отдельным статьям УК РФ. Например, исследование А.И. Бойко и К.К. Панько показывает, что на момент принятия УК РФ почти каждая 
восьмая статья Кодекса была снабжена ими (имелось 43 примечания), а на сегодняшний день в структуре Закона имеется уже 185 примечаний (более 50 \% статей Особенной части дополнены оговорками) [7].

Уголовный кодекс как самостоятельная система переживает период обновления и приспособления к новым вызовам. Не исключено, что непоследовательность и хаотичность вносимых в УК РФ изменений являются признаком не мутации, а преобразования отрасли уголовного права в экологоинформационную правовую систему, способом самосохранения для реализации своих имманентных задач.

Одним из новых механизмов правового регулирования в уголовном законе выступил институт административной преюдиции, усиливающий свое влияние.

Административно-правовая преюдиция является приемом юридической техники, при котором повторно совершенное административное правонарушение в случае, если лицо ранее привлекалось за подобное административное правонарушение к административному наказанию, рассматривается уже как преступление.

Общими чертами для всех видов преступлений с административной преюдицией являются:

1) умышленная форма вины;

2) высокая первоначальная латентность;

3) бланкетный характер специальных правил поведения;

По способу установления административной преюдиции составы можно разделить на несколько основных видов.

Первый вид - это статьи, где неоднократное совершение административного правонарушения либо указывается в примечании (ст. ст. 151.1, 157, 264.1, 314.1 УК РФ), либо содержатся в диспозиции нормы (ст. ст. 116.1, 158.1, 154, 180, 212.1, 215.4, 284.1 УК РФ). 


\section{ЧЕЛОВЕК И СОВРЕМЕННОЕ ОБЩЕСТВО В СОЦИАЛЬНОМ, ПРАВОВОМ, ЭКОНОМИЧЕСКОМ РАКУРСАХ}

Например, ст. 157 УК РФ - неуплата средств на содержание детей или нетрудоспособных родителей.

1. Неуплата родителем без уважительных причин в нарушение решения суда или нотариально удостоверенного соглашения средств на содержание несовершеннолетних детей, а равно нетрудоспособных детей, достигших восемнадцатилетнего возраста, если это деяние совершено неоднократно, наказывается исправительными работами на срок до одного года, либо принудительными работами на тот же срок, либо арестом на срок до трех месяцев, либо лишением свободы на срок до одного года.

2. Неуплата совершеннолетними трудоспособными детьми без уважительных причин в нарушение решения суда или нотариально удостоверенного соглашения средств на содержание нетрудоспособных родителей, если это деяние совершено неоднократно, - наказывается исправительными работами на срок до одного года, либо принудительными работами на тот же срок, либо арестом на срок до трех месяцев, либо лишением свободы на срок до одного года.

Примечания. 1. Неуплатой родителем без уважительных причин в нарушение решения суда или нотариально удостоверенного соглашения средств на содержание несовершеннолетних детей, а равно нетрудоспособных детей, достигших восемнадцатилетнего возраста, если это деяние совершено неоднократно, признается неуплата родителем без уважительных причин в нарушение решения суда или нотариально удостоверенного соглашения средств на содержание несовершеннолетних детей, а равно нетрудоспособных детей, достигших восемнадцатилетнего возраста, подвергнутым административному наказанию за аналогичное деяние, в период, когда лицо считается подвергнутым административному наказанию.

2. Неуплатой совершеннолетними трудоспособными детьми без уважительных причин в нарушение решения суда или нотариально удостоверенного соглашения средств на содержание нетрудоспособных родителей, если это деяние совершено неоднократно, признается неуплата 
совершеннолетними трудоспособными детьми без уважительных причин в нарушение решения суда или нотариально удостоверенного соглашения средств на содержание нетрудоспособных родителей, подвергнутыми административному наказанию за аналогичное деяние, в период, когда лицо считается подвергнутым административному наказанию [3].

Именно в данной статье изложен первый способ указания на наличие административной преюдиции - в примечании к конкретной статье УК РФ.

Второй способ выгладит так: статья 116.1 УК РФ (нанесение побоев лицом, подвергнутым административному наказанию).

Нанесение побоев или совершение иных насильственных действий, причинивших физическую боль, но не повлекших последствий, указанных в статье 115 настоящего Кодекса, и не содержащих признаков состава преступления, предусмотренного статьей 116 настоящего Кодекса, лицом, подвергнутым административному наказанию за аналогичное деяние, наказывается штрафом в размере до сорока тысяч рублей или в размере заработной платы или иного дохода осужденного за период до трех месяцев, либо обязательными работами на срок до двухсот сорока часов, либо исправительными работами на срок до шести месяцев, либо арестом на срок до трех месяцев.

Второе вид - составы, где повторяемость закреплена в уголовном законе, а именно: без указания на совершение предыдущего административного правонарушения (ст. ст. 154, 180 УК РФ); с указанием на то, что ранее лицо должно быть подвергнуто административному наказанию (ст. ст. 116.1, 151.1, 157, 158.1, 215.4, 264.1 УК РФ); с указанием на то, что ранее лицо должно быть привлечено к административной ответственности (ст. ст. 212.1, 284.1, 314.1 УК РФ).

Третий вид связан с количеством предыдущих административных деликтов и сроков действия, а именно: второе правонарушение в течение одного года (ст. ст. 116, 151.1, 157, 158.1, 154, 180, 215.4, 264.1 УК РФ); третий административный деликт в течение 180 дней (ст. 212.1 УК РФ); 


\section{ЧЕЛОВЕК И СОВРЕМЕННОЕ ОБЩЕСТВО \\ В СОЦИАЛЬНОМ, ПРАВОВОМ, ЭКОНОМИЧЕСКОМ РАКУРСАХ}

третий административный деликт в течение одного года (ст. 284.1, 314.1 УК РФ).

Форму предварительного расследования по составам преступлений с административной преюдицией, их подследственность и подсудность можно представить в виде следующей таблицы.

\section{Таблица 1}

\section{Составы преступлений административной преюдиции;} формы расследования/подсудность

\begin{tabular}{|c|c|c|c|c|}
\hline $\begin{array}{c}\text { № } \\
\text { ПI/II }\end{array}$ & Ст. УК РФ & $\begin{array}{c}\text { Форма предварительного } \\
\text { расследования (ст. } 150 \text { УПК РФ } \\
\text { общие правила) }\end{array}$ & $\begin{array}{c}\text { Подследственность } \\
\text { (ст. } 151 \text { УПК РФ } \\
\text { общие правила) }\end{array}$ & Подсудность \\
\hline 1. & 116.1 & дознание & дознание ОВД & районный суд \\
\hline 2. & 151.1 & дознание & дознание ОВД & районный суд \\
\hline 3. & 157 & дознание & дознаватели ФССП & районный суд \\
\hline 4. & 158.1 & дознание & дознание ОВД & районный суд \\
\hline 5. & 171.4 & дознание & дознание ОВД & районный суд \\
\hline 6. & 191 & следствие & СО ОВД & районный суд \\
\hline 7. & 193 & следствие & СО ОВД & районный суд \\
\hline 8. & 212.1 & следствие & СК РФ & районный суд \\
\hline 9. & 215.3 & дознание ч. 1 & дознание ОВД & районный суд \\
\hline 10. & 215.4 & дознание ч. 1 & дознание ОВД & районный суд \\
\hline 11. & 255 & следствие & ч. 1 СК РФ & районный суд \\
\hline 12. & 264.1 & дознание & дознание ОВД & районный суд \\
\hline 13. & 280.1 & следствие & СО ФСБ & районный суд \\
\hline 14. & 282 & следствие & $\begin{array}{c}\text { Следственный } \\
\text { комитет РФ }\end{array}$ & районный суд \\
\hline 15. & 284.1 & следствие & $\begin{array}{c}\text { Следственный } \\
\text { комитет РФ }\end{array}$ & районный суд \\
\hline 16. & 314.1 ч. 2 & дознание & Дознание ОВД & районный суд \\
\hline 17. & 315 & дознание & дознаватели ФССП & $\begin{array}{l}\text { районный суд ч. } 1, \\
\text { мировой судья ч. } 2\end{array}$ \\
\hline
\end{tabular}

Из содержания таблицы очевидно, что вопросы подследственности составов преступлений с административной преюдицией носят межведомственный характер. Производство предварительного расследования по ним возможно не только в форме дознания, но и в форме предварительного следствия. Органами, осуществляющими расследования являются как следственные подразделения МВД, так и следственные подразделения ФСБ 
РФ, Следственный комитет РФ. Органами, осуществляющими дознание по делам с административной преюдицией являются дознаватели органов внутренних дел и дознаватели органа принудительного исполнения.

Криминализация деяний и существо преступлений с административной преюдицией свидетельствуют о том, что мы имеем дело с межотраслевым явлением.

Поскольку происходит определенным образом объединение механизмов ответственности, стоит обратить внимание на необходимость повышения уровня защиты конституционных прав граждан.

Административная преюдиция безусловно непосредственно касается таких конституционных прав граждан, как право на гарантированную судебную защиту его прав и свобод, равенство всех перед законом и судом, право на рассмотрение его дела в том суде и тем судьей, к подсудности которых оно отнесено законом, презумпцию невиновности и недопустимости осуждения за одно и тоже преступление, права потерпевших от преступлений, указанные в статьях 19, 46-50 Конституции Российской Федерации [1].

Более того, административная преюдиция касается не только конституционных, но и универсальных, международных прав человека. Так, положения статьи 4 Протокола № 7 к Конвенции о защите прав человека и основных свобод, посвященные защите от двойного судебного преследования и двойной ответственности; Протокол № 7 к Конвенции формулируют один из аспектов административной преюдиции как право не быть судимым или наказанным дважды: «никто не должен быть повторно судим или наказан в уголовном порядке в рамках юрисдикции одного и того же государства за преступление, за которое уже был оправдан или осужден в соответствии с законом и уголовно-процессуальными нормами этого государства» [5].

Таким образом, эти нормы устанавливают, что основаниями для повторного рассмотрения дела могут быть лишь вновь открывшиеся 


\section{ЧЕЛОВЕК И СОВРЕМЕННОЕ ОБЩЕСТВО В СОЦИАЛЬНОМ, ПРАВОВОМ, ЭКОНОМИЧЕСКОМ РАКУРСАХ}

обстоятельства или существенные нарушения, повлиявшие на исход дела, допущенные в ходе предыдущего разбирательства. Этот принцип фактически содержит в себе и требование о преюдиции, поскольку при ее отсутствии не будет препятствий для повторного юридического преследования гражданина в рамках иного (смежного) процесса. Основной аргумент сводится к следующему: повторное административное правонарушение более общественно опасно в силу того, что общественно опасной становится личность правонарушителя.

\section{Пути обеспечения конституционных прав граждан в условиях} применения административной преюдиции

Какими же видятся пути обеспечения эффективной защиты прав граждан в условиях применения административной преюдиции.

Приоритетное направление связано с совершенствованием надзорной деятельности органов прокуратуры.

Так, в соответствии со ст. 8 Федерального Закона «О прокуратуре Российской Федерации» прокурор способен не только координировать деятельность по борьбе с преступностью, но и координировать усилия правоохранительные органов различных ведомств по анализу состояния преступности и прогнозирование тенденций ее развития. Таким образом, при межотраслевом характере преступлений с административной преюдицией и межведомственном характере борьбы с ними, роль прокуратуры как специализированного координатора актуальна.

Это направление - некий внешний контур совместных усилий. Не менее актуален и внутренний компонент такой деятельности.

В соответствии со ст. 37 Уголовно-процессуального Кодекса Российской Федерации должностным лицом, уполномоченным в пределах компетенции осуществлять от имени государства уголовное преследование в ходе уголовного судопроизводства, а также надзор за процессуальной 
деятельностью органов дознания и органов предварительного следствия, является прокурор [4, ст. 3].

В ходе досудебного производства по уголовному делу прокурор наделен обширными надзорными полномочиями и правами требованиями.

Схожими, но более усеченными компетенциями обладает прокурор в ходе производства по делам об административных правонарушениях.

В соответствии со ст. 28.4 КоАП РФ прокурор обладает полномочием возбуждать дело об административном правонарушении по отдельным составам, перечисленным в КоАП РФ, принимать участие при рассмотрении таких дел и обжаловать принимаемое решение. Кроме того, прокурор вправе возбудить дело о любом другом административном правонарушении, предусмотренном КоАП РФ [2].

Таким образом, реализация полномочий прокурора в производстве по делам об административных правонарушениях осуществляется путем:

возбуждения дела об административном правонарушении, проведения административного расследования;

участия в рассмотрении дела об административном правонарушении;

принесения протеста на постановление по делу об административном правонарушении и (или) последующие решения вышестоящих инстанций по жалобам на это постановление независимо от участия в деле, в том числе по результатам рассмотрения поступивших обращений;

совершения иных предусмотренных федеральным законодательством действий [6, с. 19-24].

Как же представлены эти надзорные функции прокурора через призму дел, связанным с административной преюдицией. Здесь нет функционально комплексного подхода.

Так, ч. 2 ст. 25.11 КоАП РФ указывает на необходимость извещения прокурора о рассмотрении дела, возбужденного по инициативе прокурора 


\section{ЧЕЛОВЕК И СОВРЕМЕННОЕ ОБЩЕСТВО В СОЦИАЛЬНОМ, ПРАВОВОМ, ЭКОНОМИЧЕСКОМ РАКУРСАХ}

либо же дела в отношении несовершеннолетнего. По таким делам прокурор наделен правом участвовать в рассмотрении дела об административном правонарушении, заявлять ходатайства, предоставлять доказательства и пользоваться иными правами, предусмотренными законодательством об административных правонарушениях (п. 2 ч. 1 ст. 25.11 КоАП РФ). Кроме того, прокуроры обязаны участвовать в рассмотрении судами дел в отношении, так называемых специальных субъектов (в отношении судей, сенаторов Совета Федерации, депутатов Государственной Думы Федерального Собрания РФ, кандидатов в Президенты Российской Федерации, кандидатов в депутаты Государственной Думы РФ, кандидатов в депутаты представительных органов власти субъектов РФ и высших должностных лиц муниципальных образований и др.), независимо от того, кем возбуждено дело.

Здесь мы видим особый статус субъектов административной ответственности (несовершеннолетних и специальных публичных лиц), за порядком привлечения которых исключительно прокурор наделен особыми полномочиями.

Административная ответственность и уголовная ответственность являются разновидностями публично-правовой ответственности. У них общая цель и прежде всего защита конституционных прав и свобод человека и гражданина. Они имеют сходные задачи и принципы.

Исходя из анализа норм закона, на наш взгляд, следует распространить обязательное участие прокурора в рассмотрении дел административной преюдиции. В частности, по всем делам об административных правонарушениях, вступление в законную силу решений по которым впоследствии может иметь и имеет преюдициальное значение, может являться основанием для уголовного преследования, необходимо обязательное участие прокурора если не на стадии возбуждения такого дела, но на стадии его 474 
рассмотрения соответствующим юрисдикционным органом, с правом принесения соответствующих жалоб.

На первоначальном этапе это необходимо реализовать по делам, наиболее распространенным и приближенным к населению, в частности по делам, где потерпевшими являются несовершеннолетние или нетрудоспособные лица, те случаи, отмеченные в ст. 5.35.1 КоАП РФ (неуплата средств на содержание детей или нетрудоспособных родителей). Необходимо законодательно возложить на прокурора обязанность участвовать в рассмотрении дел данной категории, поскольку в последующем он будет выступать по таким делам уже в качестве государственного обвинителя.

Данное положение об участии прокурора в рассмотрении дел об административных правонарушениях по указанной категории дел будет способствовать эффективной защите конституционных прав человека и гражданина. Участие прокурора в рассмотрении дел об административных правонарушениях, являющихся первой ступенью потенциального уголовного преследования будет способствовать состоянию законности в анализируемой cфepe.

\section{Список литературы}

\section{Нормативные правовые акты}

1. Конституция Российской Федерации (принята всенародным голосованием 12.12.1993) (с учетом поправок, внесенных Законами РФ о поправках к Конституции РФ от 21.07.2014 N 11-ФКЗ, от 01.03.2020г. № 1-ФКЗ) // [Электронный ресурс] Доступ из справочно-правовой системы «Консультант Плюс». 
2. Кодекс Российской Федерации об административных правонарушениях от 30.12.2001 N 195-Ф3 (ред. от 18.02.2021) [Электронный pecyрc] // Первоначальный текст документа опубликован в изданиях "Собрание законодательства РФ", 07.01.2002, N 1 (ч. 1), ст. 1. - Доступ из справочно-правовой системы «Консультант Плюс».

3. Уголовный кодекс Российской Федерации федеральный закон РФ: от 13.06.1996 N 63-Ф3 (ред. от 18.02.2021) [Электронный ресурс] // Первоначальный текст документа опубликован: «Собрание законодательства РФ», 17.06.1996, N 25, ст. 2954. - Доступ из справочно-правовой системы «Консультант Плюс»;

4. Уголовно-процессуальный кодекс Российской Федерации от 18.12.2001 N 174-Ф3 (ред. от 05.04.2021, с изм. от 13.04.2021)// СПС Консультант Плюс

5. ПРОТОКОЛ N 7 к Конвенции о защите прав человека и основных свобод. Ратифицирован Федеральным законом РФ от 30 марта 1998 года № 54-Ф3 // Бюллетень международных договоров, 1998 год, N 12).

\section{Учебная и научная литература, сетевые ресурсы}

6. Багаутдинов, Ф.Н. Актуальные вопросы участия прокурора в производстве по делам об административных правонарушениях / Ф.Н. Багаутдинов // Законность. - 2019. - № 1(1011).

7. Бойко А.И., Панько К. К. Примечания в УК РФ как особое средство уголовно-правового регулирования // ЮП. 2020. № 1(92). URL: https://cyberleninka.ru/article/n/primechaniya-v-uk-rf-kak-osoboe-sredstvougolovno-pravovogo-regulirovaniya (дата обращения: 03.10.2021).

8. Голик Ю.В., Коробеев А.И. Реформа уголовного законодательства России: быть или не быть? // Lex Russia. № 12. Том XCVII, декабрь. 2014.

9. Деррида Ж.О грамматологии. М. : Изд-во “Ad Marginem”, 2000. 
10. Клейменов И.М. Идеи постмодернизма в системе правовой реальности // Вестник Омского университета. Сер. Право. 2016. № 2(47).

11. Коробеев А.И. Уголовная политика современной России: состояние и перспективы // Юридическая наука и практика: Вестник Нижегородской академии МВД России. 2016. №3 (35). URL: https://cyberleninka.ru/article/n/ ugolovnaya-politika-sovremennoy-rossii-sostoyanie-i-perspektivy (дата обращения: 03.10.2021).

12. Кузнецова Н.Ф. К истории проектов Уголовных кодексов Российской Федерации // Вестник Московского университета. 1995. № 2.

13. Курс уголовного права : В 5-ти т. / Моск. гос. ун-т им. М.В. Ломоносова. Юрид. фак.; Под ред. Н.Ф. Кузнецовой, И.М. Тяжковой; Т. 1: Общая часть. Учение о преступлении / [Борзенков Г.Н., Комиссаров В.С., Крылова Н.Е. и др.]. - 2002. - ХІІ, 611 с.

14. Некрасов С.И., Некрасова Н.А. Философия науки и техники: тематический словарь. Орёл: ОГУ, 2010. 289 с.

15. Послание Президента Российской Федерации от 12.11.2009 г. б/н// URL: http://www.kremlin.ru/acts/bank/31381

16. Преступность по данным Росстат. URL: Статистика преступности Росстат: по полу, возрасту и виду (rosinfostat.ru) 
Глава 18.

СОВЕТСКАЯ МОДЕЛЬ СОЦИАЛЬНОГО ГОСУДАРСТВА:

СУЩНОСТЬ, ОСНОВНЫЕ ЭТАПЫ СТАНОВЛЕНИЯ

\title{
Осокина Юлия Юрьевна
}

старший преподаватель

Вологодский государственный университет

Аннотация: Попытки сформировать демократическую систему социального обеспечения были предприняты уже в первые месяцы советской власти, создавалась правовая база, регулирующая данные отношения. Постепенно социальная функция стала предполагать не только социальное обеспечение, но и образование и здравоохранение. К концу рассматриваемого периода была сформирована цельная система социального обеспечения, которая охватывала все население страны, существующая система была доступна для всех потенциальных получателей.

Ключевые слова: социальное государство; социальная функция; социальная политика; система образования; система здравоохранения.

\author{
THE SOVIET MODEL OF THE WELFARE STATE: \\ THE ESSENCE, THE MAIN STAGES OF FORMATION
}

\section{Osokina Yulia Yurievna}

\begin{abstract}
Attempts to form a democratic social security system were made already in the first months of Soviet power, a legal framework regulating these


relations was being created. Gradually, the social function began to assume not only social security, but also education and health care. By the end of the period under review, an integral social security system was formed that covered the entire population of the country, the existing system was available to all potential recipients.

Key words: social state; social function; social policy; education system; health care system.

Определённой вехой в генезисе социальной функции российского государства стали революционные события февраля, а особенно октября 1917 года. Однако идея социального государства получила совершенно иное прочтение, что в большей или меньшей степени было реализовано на практике. Данный период имел существенные отличия от рассмотренных выше этапов формирования социальной функции в дореволюционной России, но, вместе с тем, советская модель социального государства имела определенные прогрессивные черты и положительно повлияла на современное сосотяние социальной функции в России. В Декларации 1918 года идеологическим обоснованием нового типа социально-экономических отношений стали принципы искоренения всех форм эксплуатации, передачи власти рабочим и крестьянам[1].

Однако история становления социальной функции советского государства и формирование его специфической социалистической модели вовсе не определялось первыми месяцами функционирования советской власти. Генезис социальной функции был обусловлен многими внешне- и внутриполитическими факторами, вследствие чего историю развития социальной функции советского государства можно подвергнуть конституционной периодизации: 
1. Конституция 1918 года: отражает социальную политику государства первых месяцев советской власти и в период военного коммунизма (1918 - начало 1920-х). В данной Конституции предпринимаются первые шаги по реализации социальной функции государством, специфика которой была обусловлена социально-экономическими и политическими потрясениями периода гражданской войны. Классовость советской демократии не исключала, a, наоборот, предполагала фиксацию, то есть закрепление прав каждого представителя класса, каждого трудящегося как личности [2, с. 16]. Характерная черта Конституции - преобразование всех форм собственности в государственную и закрепление господства диктатуры пролетариата. Весь Основной Закон пронизан духом диктатуры пролетариата, хотя в нем нет прямой формулировки этой диктатуры [2, с. 15].

2. Конституция 1924 года: отражает развитие социальной функции государства в период проведения новой экономической политики, индустриализации и коллективизации (1920-1930-е гг.). На основе норм данной Конституции формируются основы социальной политики советского государства. Особенностью Конституции явилось создание союзного государства и, как следствие, распределение полномочий между республиками и Союзом. В частности, регулирование социально-трудовой сферы находилось в компетенции Союза.

3. Конституция 1936 года: отражает социальную политику государства в период построения основ социализма. Особенность данного конституционного периода была обусловлена нормативным закреплением в Конституции комплекса прав и свобод социальной направленности. Конституция означала расширение советской демократии не только в сфере укрепления основ народовластия, но и в сфере других демократических прав и свобод, круг которых по сравнению с предыдущими конституциями существенно расширялся: ст. 118 провозглашала право на труд; ст. 119 


\section{ЧЕЛОВЕК И СОВРЕМЕННОЕ ОБЩЕСТВО В СОЦИАЛЬНОМ, ПРАВОВОМ, ЭКОНОМИЧЕСКОМ РАКУРСАХ}

закрепляла право на отдых; также закреплялось право трудящихся на материальное обеспечение в старости и в случае потери трудоспособности [2, c. 165-166].

- Конституция 1977 года: отражает реализацию социальной функции государства в период господства социализма. В данный период модель социального государства, складывающаяся в СССР приобрела законченный вид, сформировались все ее существенные черты, социальная политика достигает своего расцвета. Одной из главных задач социалистического общенародного государства Преамбула Конституции провозглашает повышение материального уровня жизни трудящихся [2,с 197]. Конституция систематизирует правовые нормы в области социального обеспечения и социальной поддержки населения. В Конституции выделяется целый блок социальных прав, подробно регламентирующих реализацию таких прав, как право на труд и отдых, социальное обеспечение, охрану здоровья, жилище и образование.

В первые же месяцы советской власти политика государства коснулась и обеспечения неимущих. Поскольку благотворительная деятельность стала рассматриваться идеологами марксизма как буржуазное явление, в первые же месяцы она стала сворачиваться. Так, нормативными актами были упразднены благотворительные учреждения и общества помощи инвалидам (увечным воинам) и их семьям, а также духовные благотворительные учреждения [3]. А в декабре все дело помощи увечным воинам и их семьям передается в ведение общественной организации - Всероссийского союза увечных воинов, а инвалидные дома - в ведение Народного комиссариата государственного призрения (созданного вместо Министерства государственного призрения). Седьмого августа 1918 г. издается Декрет СНК «О пенсионном обеспечении солдат Рабоче-Крестьянской Красной Армии и их семейств» [4, с. 180-182], гарантировавший назначение и выплату пенсий солдатам, лишившимся 


\section{ЧЕЛОВЕК И СОВРЕМЕННОЕ ОБЩЕСТВО В СОЦИАЛЬНОМ, ПРАВОВОМ, ЭКОНОМИЧЕСКОМ РАКУРСАХ}

полностью или частично трудоспособности в результате повреждений, ран или болезней, полученных вследствие прохождения военной службы. В нем также гарантировалось получение пенсий для семей солдат Красной Армии, убитых, умерших от ран или пропавших без вести на войне. Позднее его действия было распространено и на военно-морской флот, то есть частично использовался дореволюционный опыт пенсионного обеспечения лиц по ведомственному признаку [5, с. 19-20]. Принятие данного декрета показывало огромное значение для Советской России такой категории населения, как военнослужащие.

- Параллельно с системой социального страхования и социальной помощи предпринимается попытка создать ориентированную на трудящихся систему медицинского обеспечения. В соответствии с Декретом СНК от 14 ноября 1917 г. «О бесплатной передаче больничным кассам всех лечебных учреждений и предприятий или, в случае неимения таковых, о выдаче денежных сумм на оборудование их»[6] предприниматели передали указанные учреждения в ведение больничных касс. Это было шагом к построению бюджетной системы здравоохранения, который был реализован в дальнейшем.

Условия тяжелого экономического положения государства периода гражданской войны и идеологические установки большевиков на быстрое построение коммунизма обусловили практику натурализации социального обеспечения, а главный источник существования населения лежал уже вне заработной платы [7, с. 23-25]. При военном коммунизме была введена карточная система распределения продуктов питания в городе и деревне, Декретом от 30 октября 1918 года наиболее обеспеченная часть трудового крестьянства облагалась натуральной повинностью, продукты питания распределялись среди рабочих и служащих советских предприятий и учреждений, сельскохозяйственного населения, рабочих частных 
«неэксплутаторских» предприятий [8]. Это свидетельство того, что государство пыталось переложить часть взятых на себя социальных обязательств перед населением на одну из категорий этого населения крестьянство.

Таким образом, содержанием данного этапа была попытка создания демократической системы социального обеспечения населения посредством организации социального страхования трудящихся, социальной защиты отдельных категорий населения, реформирования здравоохранения, образования. Правительство вынужденно сворачивало указанные начинания, ставило систему социального обеспечения под контроль государства, в итоге социальная политика приобрела патерналистский характер. Основными причинами было не только отсутствие средств для реализации данной политики, но также не соответствие создаваемой социальной системы политическим реалиям в стране.

Впоследствии политика социального страхования была распространена и на другие категории трудящихся. В 1925 году в систему социального страхования включены лица, занятие во найму в домашнем хозяйстве (няни, кормилицы, кухарки и т.п.), за них наниматели обязаны уплачивать взносы на социальное страхование в размере 10\% заработной платы, в том числе 7,5\% в фонды, состоящие в распоряжении страховых органов, и 2,5\% в фонд лечебной помощи [9].

Государственным социальным обеспечением пользовались лишь те крестьяне - участники войны, инвалиды и жертвы террора военного времени, которых было невозможно обеспечить посредством крестьянской взаимопомощи или трудоустройства в артелях или кооперациях инвалидов.

Помимо социального страхования трудящихся советское государство развивает и социальное обеспечение для отдельных категорий лиц. Декретом от 8 декабря 1921 года закреплялось, что правом на социальное обеспечение 
пользовались: а) все лица, работавшие по найму и потерявшие трудоспособность вследствие: увечья, профессионального заболевания или иных причин (старческая дряхлость и пр.), но в последнем случае проработавшие по найму в различных предприятиях и учреждениях не менее 8-ми лет, б) военнослужащие старой и Красной Армии, лишившиеся трудоспособности вследствие увечья или заболевания, полученных на войне или во время нахождения их на военной службе [10]. Инвалидам, не имеющим дохода, назначалась пенсия с полной или частичной натурализацией, инвалидам, имеющим доходное хозяйство предписывалось оказывать хозяйственную, трудовую и иную помощь через органы общественной взаимопомощи, действующей под организационным руководством и контролем органов НКСО.

Существенно меняется в указанный период и трудовое законодательство [11]. Практически все вопросы, служившие предметом борьбы рабочего движения в дореволюционный период были урегулированы: КЗоТ содержит положения об индивидуальных и коллективных трудовых договорах, устанавливает 8-часовой рабочий день, ограничение рабочего времени для несовершеннолетних, закрепляет важные положения о времени отдыха, профессиональных союзах, охране труда, а также содержит основные положения о социальном страховании. Вместе с тем возможность трудится рассматривается не сколько как право, сколько как обязанность, что сохранится и последующие периоды советской эпохи. Нетрудовые «элементы» фактически исключались из адресатов социальной поддержки государства, подвергались моральному осуждению и несли юридическую ответственность.

В сфере образования государство пока не могло обеспечить должный уровень мероприятий по содержанию системы образования, поэтому в качестве временной меры в области образования вводилась плата за обучение 
(в школах I и II ступени, в техникумах, практических институтах и высших учебных заведениях) [12]. От платы освобождались военные, инвалиды, степендиаты, государственные пенсионеры, работники просвещения, малообеспеченные рабочие и служащие.

Развитие системы здравоохранения в период НЭПа детерминировано со следующими обстоятельствами: во-первых, недостаточным количеством средств государственного бюджета на развитие системы медицинских учреждений, что частично нивелировало наличие медицинского страхования; во-вторых, преодолением последствий гражданской войны, борьбой с последствиями голода, эпидемиями и обеспечением минимального уровня санитарно-эпидемологического благополучия населения. Постепенно ситема здравоохранения восстанавливается, расширяется сеть лечебных и санаторнокурортных заведений. С 1937 г. государство полностью возлагает на себя финансирование здравоохранения. В соответствии с Постановлением СНК СССР от 23 марта 1937 г. [13] медицинская помощь и лечение предоставляются бесплатно всем гражданам независимо от их правового положения. В соответствии с указанным Постановлением государство берет на себя расходы и на содержание детских яслей и садов. Это было шагом к построению единой, всеохватывающей системы социального обеспечения.

Развитие социальной функции государства в 1930-е годы было обусловлено политическими и социально-экономическими процессами данного периода: централизация власти, индустриализация, коллективизация и т.П. Государство предпринимает шаги по увеличению пенсий и пособий, систематизирует нормативно-правовое регулирование данной области. Важной вехой стало принятие положения о пенсиях и пособиях по социальному страхованию [14], которое упорядочило правовое регулирование в данной сфере. Положение предусматривало 3 вида пенсий (по инвалидности, потере кормильца, старости) и 4 вида пособий (по безработице, временной 
нетрудоспособности, рождению ребенка и на погребение), а также регулировало организационные вопросы.

Таким образом, содержанием данного этапа являлось формирование социальной функции советского государства на основе сочетания социального обеспечения и социального страхования. Социальная функция уже понимается шире, государство озаботилось не только материальным обеспечением населения, но и развитием системы образования и здравоохранения. Конечно, социальная политика государства носила ярко выраженный идеологический окрас: в первую очередь социальные блага гарантировались рабочим и крестьянам, «эксплуататорские элементы» не имели права на получение социального обеспечения. Отметим также и то, что адресаты социальной политики государства изначально не были равноправны в получении социальной поддержки: в первую очередь она гарантировалась рабочим и служащим, лишь во вторую - крестьянству, и существенно позднее творческой интеллигенции (писатели, работники культуры и искусства). Если в отношении рабочих и служащих государство выступает основным, а работодатель вспомогательным (посредством социального страхования) субъектом социальной помощи, то в сельской местности по-прежнему опора идет на коллектив крестьян: организация касс взаимопомощи, натуральной помощи инвалидам и т.д., впоследствии эти функции переложены на колхозы. Причиной тому послужила недооценка роли сельского населения в формировании экономики страны и возможном участии в ее развитии.

Основным содержанием послевоенного периода являлось расширение системы социального обеспечения и реабилитации военнослужащих, увольняемых с военной службы, инвалидов и членов семей военнослужащих, что обусловлено было политическими событиями периода. Не менее важной целью государства в послевоенный период было и восстановление экономики, с целью привлечения трудящихся и усиления кадрового потенциала, 
в 1947-1956 гг. устанавливаются повышенные размеры пенсий для работников металлургической, угольной, строительной, химической и ряда других отраслей промышленности.

Спустя несколько лет государственным пенсионным обеспечением охватывается и крестьянство. Закон о пенсиях и пособиях членам колхозов 1964 года устанавливал пенсии по старости и инвалидности, а нетрудоспособным членам семей умерших колхозников, если они находились у них на иждивении, закреплял право на пенсию по случаю потери кормильца [15]. Закон также закреплял право женщин - членов колхозов на пособие по беременности и родам. Финансовые средства на указанные выплаты формировались за счет денежных отчислений колхозов в централизованный союзный фонд социального обеспечения колхозников в размерах, определяемых Советом Министров СССР.

Следовательно, в указанный период социальная поддержка населения состояла из трех основных элементов:

1) государственное социальное обеспечение военнослужащих, членов творческих союзов, учащихся, инвалидов и ряда других категорий граждан за счет государственных, республиканских и местных бюджетов;

2) государственное социальное страхование, распространявшееся на рабочих и служащих, находившееся в ведении профессиональных союзов, осуществлявшееся за счет финансовых средств полученных путем взносов предприятий, учреждений и организаций;

социальное обеспечение членов колхозов, средства на которое формировались за счет взносов колхозов и бюджетных дотаций.

Существовавшая пенсионная система и политика оплаты труда не создавала стимулов к труду и стремление повысить свой уровень жизни. Как отмечают М.Л. Захаров и Э.Г. Тучкова, на протяжении многих десятилетий советское государство фактически «экономило» на старшем поколении, 


\section{ЧЕЛОВЕК И СОВРЕМЕННОЕ ОБЩЕСТВО В СОЦИАЛЬНОМ, ПРАВОВОМ, ЭКОНОМИЧЕСКОМ РАКУРСАХ}

финансируя расходы на пенсионное обеспечение по принципу «разумной достаточности», что позволяло сознательно замораживать уровень пенсионного обеспечения на длительные периоды, не гарантируя пенсионерам непрерывного улучшения жизни по мере роста оплаты труда в стране, повышения уровня жизни, появления у государства дополнительных экономических возможностей [16]. Соглашаясь в целом с мнением М.Л. Захарова и Э.Г. Тучковой, считаем необходимым отметить достаточно высокий уровень обеспеченности пенсионеров в советский период, отсутствие резких различий в размерах пенсий и отсутствие дифицита средств для выплаты пенсий.

Помимо социального обеспечения развитие социальной функции государства шло по пути предоставления населению основных социальных услуг в области образования, здравоохранения. Обеспечение достойного уровня жизни невозможно без возможности пользоваться качественной и доступной медицинской помощью.

Развитие системы образования шло по пути расширения количества лиц, охваченных данной системой и повышения уровня образованности. Законом СССР 1958 года вводится обязательное основное 8-летнее образование, закрепляет, что полное среднее образование можно получить в следующих типах образовательных учреждений: школы рабочей и сельской молодежи, средние общеобразовательные, трудовые политехнические школы с производственным обучением, техникумы и другие средние специальные учебные заведения. Расширяется сеть школ-интернатов, групп продленного дня с целью «усиления роли общества в оказании помощи семье» [17].

Политика в области образования считалась одним из наиболее важных направлений государственной политики, сферой подготовки необходимых для государства кадров. В основе образовательных программ лежал тот же самый классовый принцип, само содержание было идеологизированым. Конечной 
целью образования считалась подготовка кадров для государства, воспитание трудящихся в духе коммунизма, отсюда и широкая доступность образовательных учреждений.

Разумеется, в советский период были определенные «перегибы» социальной политики в отношении некоторых категорий населения: уже упоминавшееся «отставание» социального обеспечения колхозников, или, напротив, материальное обеспечение номенклатуры посредством распределения материальных благ сверх установленного для основной массы населения уровня. Однако в отношении обычных граждан государством обеспечивался достойный уровень существования, при этом категория «достойный» была относительной, в СССР не брались за основу такие показатели как минимальный прожиточный уровень, «черта бедности», нормирование расходов на социальное обеспечение велось по принципу «разумной достаточности», что в итоге приводило к замораживанию на долгие годы размеры минимальных и максимальных пенсий, пособий, норм расходов на содержание детей, престарелых и инвалидов в учреждениях социального обеспечения.

Таким образом, попытки сформировать демократическую систему социального обеспечения были предприняты уже в первые месяцы советской власти, создавалась правовая база, регулирующая данные отношения. Постепенно социальная функция стала предполагать не только социальное обеспечение, но и образование и здравоохранение. К концу рассматриваемого периода была сформирована цельная система социального обеспечения, которая охватывала все население страны, существующая система была доступна для всех потенциальных получателей. 


\section{Список литературы}

1. Декларация о правах трудящегося и эксплуатируемого народа (принята III Всероссийским съездом Советов 13.01.1918) // СУ РСФСР. 1918. № 15. Ст. 215.

2. Кукушкин Ю.С., Чистяков О.И. Очерк истории Советской Конституции. - 2-е изд., доп. - М.: Политиздат, 1987. - 367 с.

3. Приказ Народного Комиссариата Государственного Призрения РСФСР № 68 «Об упразднении благотворительных учреждений и обществ помощи инвалидам и о передаче их дел и денежных сумм Исполнительному Комитету увечных воинов» от 19 ноября 1917 г. // СУ РСФСР. 1917. № 4. Ст. 61.; Постановление Народного Комиссариата Имуществ Республики «Об упразднении придворного духовенства, о передаче благотворительных учреждений придворного духовенства со всеми принадлежащими им капиталами в ведение Народного Комиссариата Государственного Призрения и о передаче учебных заведений придворного духовенства в ведение Народного Комиссариата по Просвещению» от 14 января 1918 г. // СУ РСФСР. 1918. № 28. Ст. 369. (утратил силу).

4. Декрет от 7 августа 1918 г. «О пенсионном обеспечении солдат Рабоче-крестьянской Красной Армии и их семейств» // Декреты Советской власти. М.: Политиздат, 1964. Т. 2. С. $180-182$. (утратил силу).

5. Кинашенко И.А., Корякин В.М. Становление и развитие военнопенсионных органов России // Военно-юридический журнал. 2021. № 10. C. 19-29.

6. Декрет СНК РСФСР «О безплатной передаче больничнымъ кассамъ всехъ лечебныхъ учрежденій и предпріятій или, въ случае неименія таковыхъ, о выдаче денежныхъ суммъ на оборудованіе ихъ» от 14 ноября 1917 г. // СУ РСФСР. 1917. № 3. Ст. 34.(утратил силу). 
7. Игольникова В.А. Реализация элементов социального государства в Советской России (1917 - 1920 гг.) // История государства и права. 2021. № 6. C. 23-25.

8. Декрет ВЦИК «Об обложении сельских хозяев натуральным налогом, в виде отчисления части сельско-хозяйственных продуктов» от 30 октября 1918 г. // СУ РСФСР. 1918. № 82. Ст. 864.(утратил силу).

9. Постановление ЦИК СССР, СНК СССР«О социальном страховании лиц, занятых по найму в домашнем хозяйстве» от 25 сентября 1925 г. // С3 СССР. 1925. № 66. Ст. 491.(утратило силу).

10. Декрет СНК РСФСР «О социальном обеспечении инвалидов» от 08 декабря 1921 г. // СУ РСФСР. 1921. № 79. Ст. 672. (утратил силу).

11. Кодекс Законов о Труде Р.С.Ф.С.Р.: утв. Постановление ВЦИК «О введении в действие Кодекса Законов о Труде Р.С.Ф.С.Р. От 09 ноября 1922 г. // СУ РСФСР. 1922. № 70. Ст. 903.(утратил силу).

12. Декрет ВЦИК, СНК РСФСР «О порядке взимания платы за обучение в учреждениях Народного Комиссариата Просвещения» от 22 марта 1923 г. //СУ РСФСР. 1923. № 24. Ст. 279.(утратил силу).

13. Постановление СНК СССР «О снятии некоторых расходов с бюджета государственного социального страхования и изменении тарифа страховых взносов» от 23 марта 1937 г. // СЗ СССР. 1937. № 22. Ст. 88. (утратило силу).

14. Положение о пенсиях и пособиях по социальному страхованию (утв. Постановлением ЦИК СССР, СНК СССР от 13.02.1930) // СЗ СССР. 1930. № 11. Ст. 132. (утратило силу).

15. Закон СССР № 2688-VI «О пенсиях и пособиях членам колхозов» от 15 июля 1964 г. // Свод законов СССР. Т. 2. С. 616. 1990. (утратил силу).

16. Четыркин Е., Кабалкин С. Мировой опыт реформирования пенсионных систем: уроки для России. М.: Изд-во Дело, 2020. -423 с. 
17. Закон СССР «Об укреплении связи школы с жизнью и о дальнейшем развитии системы народного образования в СССР» от 24 декабря 1958 г. // «Ведомости ВС СССР», 1959, № 1, ст. 5.(утратил силу).

(C) Ю.Ю. Осокина, 2022 


\title{
Коллектив авторов:
}

Адмаев О.В., Арсеньев Ю.Н., Барцаева Е.В., Березина Е.С., Богданов И.В., Большаков С.Н., Гидзинский Е.В., Горшкова В.В., Грязнова Е.Р., Давыдова Т.Ю., Иванов И.В., Катаева Л.Ю., Киворкова А.Ю., Ким О.Л., Корзун О.О., Миляева Л.Г., Неволина В.В., Низамбиева И.И., Осокина Ю.Ю., Разумовская Т.И., Рябышева В.В., Сабитова А.М., Савкина Е.А., Скорев В.А.,

Скорева В.В., Соловьев А.Г., Сухарева Е.В., Талалаева Г.В., Ушакова Н.В.

НАУЧНОЕ ИЗДАНИЕ

\section{ЧЕЛОВЕК И СОВРЕМЕННОЕ ОБЩЕСТВО В СОЦИАЛЬНОМ, ПРАВОВОМ, ЭКОНОМИЧЕСКОМ РАКУРСАХ}

\author{
Монография \\ Подписано в печать 24.01.2022. \\ Формат 60x84 1/16. Усл. печ. л. 28.6. \\ Тираж 500 экз. \\ МЦНП «Новая наука» \\ 185002, г. Петрозаводск \\ ул. С. Ковалевской д.16Б помещ. 35 \\ office@sciencen.org \\ www.sciencen.org
}




\section{НОВАЯ НАУКА \\ Международный центр \\ научного партнерства

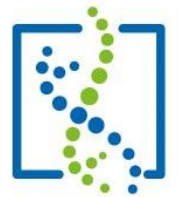 \\ NEW SCIENCE \\ International Center for Scientific Partnership}

МЦНП «НОВАЯ НАУКА» - член Международной ассоциации издателей научной литературы «Publishers International Linking Association»

\section{ПРИГЛАШАЕМ К ПУБЛИКАЦИИ}

1. в сборниках статей Международных

и Всероссийских научно-практических конференций

https://www.sciencen.org/konferencii/grafik-konferencij/

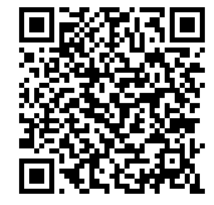

2. в сборниках статей Международных

и Всероссийских научно-исследовательских, профессионально-исследовательских конкурсов

https://www.sciencen.org/novaja-nauka-konkursy/ grafik-konkursov/

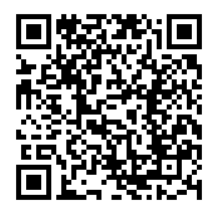

3. в составе коллективных монографий

https://www.sciencen.org/novaja-nauka-monografii/ grafik-monografij/

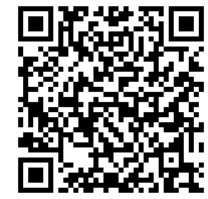

\section{4. авторских изданий}

(учебных пособий, учебников, методических рекомендаций, сборников статей, словарей, справочников, брошюр и т.п.) https://www.sciencen.org/avtorskie-izdanija/apply/

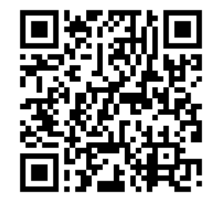

https://sciencen.org/ 